\title{
FAMILIAR LESSONS
}

IN

\section{BOTANY}

WITE

\section{FLORA \\ OF TEXAS,}

ADAPTED TO GENERAL USE IN

THE SOUTHERN STATES.

BY

M. J. YOUNG.

NEW YORK :

A. S. BARNES \& CO., PUBLISHERS. HOUSTON, TEXAS : E. H. CUSHING. 


\section{QK156 \\ Y 65}

Entered according to Act of Congress, in the year 1872, by A. S. BARNES \& CO., In the Office of the Librarian of Congress, at Washington. 


\section{PREFACE.}

Is presenting this volume to the public, the author feels compelled to explain its design. The book is an outgrowth of the wants of her own class-room, and was first used there, without any thought of publication. Finding the primary works too primary, and, therefore, not awakening the proper interest-the more advanced too scientific, thus at the very outset disheartening the pupil-she prepared these Lessons, endeavoring to combine simplicity of diction with some degree of technical and scientific knowledge, thereby leading the pupil gradually on to where he should get such glimpses of the wonders and beauties of Vegetable Physiology, and all the cognate subjects that make up the science of Botany, as to become willing to go with earnest zeal into the advanced works of Woop and GraY.

And here she would express her indebtedness to Professor Woon for some admirable cuts, the perfection of which is unrivaled, being prepared by himself, who is at the same time botanist and artist. No student should be without WooD's "Plant Record," a most valuable aid in his study of Plant Analysis. 
The Flora appended is the Flora of the Southwest. As there has never been any report of consequence made of the Flora of Texas, she has in many instances stated where certain flowers are found in that young and growing empire. But the Flora is equally applicable and useful to the students of all the Gulf States-Arkansas, Kansas, and Missouri-as the flowers described are found there: also in Southern Illinois and Indiana. 


\section{CONTENTS.}

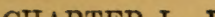

CHAPTER I.-Introduction...................... 5

CHAPTER II.-Root......................... 6

Section 1.-Duration of Roots................... 10

SECTION 2.-Form of Roots .................. 12

CHAPTER III.-The Stem . . . . . . . . . . .

Section 1.-Kinds of Stem .................... 17

Section 2.-Cuticle....................... 21

CHAPTER IV.-Buds and Leaves................... 23

Secrion 1.-Buds ........................... 23

Section 2.-Leaves ........................ 27

SECtion 3.-Appendages....................... 38

CHAPTER V.-The Flower . . . . . . . . . . . . . . . . 40

Section $1 .-$ Calyx ......................... 41

SECtion 2.-Corolla ......................... 44

Section 3.-Stamens....................... 49

Section 4.-Pistils ......................... 51

Section 5.--Inflorescence...................... 53

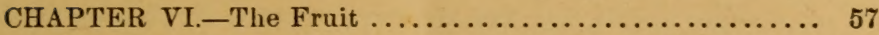

Section 1.-Pericarp......................... 57

Section 2.-Seed............................ 62

CHAPTER VII.-Germination $\ldots \ldots \ldots \ldots \ldots \ldots \ldots \ldots \ldots \ldots, 67$

CHAPTER VIII.-Simple Organs................... 70

CHAPTER IX.-Miscellaneous Vegetable Phenomena........ 75

CHAPTER X.-Food $\ldots \ldots \ldots \ldots \ldots \ldots \ldots \ldots \ldots \ldots \ldots \ldots \ldots \ldots \ldots \ldots \ldots \ldots$

CHAPTER XI.-Metamorphosis .................. 88

CHAPTER XII._Phænogamia................... 92

SECtion 1.-Cryptogamia......................... 92

CHAPTER XIII._SECTION 1.-Recapitulation ........... 99

Section 2.-General Remarks.................... 101

CH.PTER XIV.-Classification................... 102

SEction 1.-Artificial System ..................... 102

SeCtion 2.-Natural System.................... 105

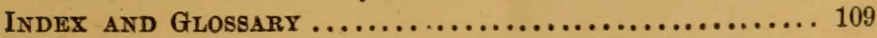




\section{FAMillar LEssons in BOTANy.}

\section{CHAPTER I.}

\section{Introduction.}

1. That science which treats of the regetable kingdom we call Botany. The name is derived from a Greek word, botane, which signifies plant. It tells us not only the names of grasses, herbs, flowers, and trees, but also how they grow and where; what they feed upon, and what they produce.

2. You will at once perceive the importance of this study and its intimate connection with agriculture, manufactures, chemistry, and the arts. A moment's reflection will also suggest the names of many well-known food-plants, as Indian corn, wheat, rye, oats, pease, beans, potatoes, coffee, tea, cocoa, and sugar-cane; clothing-plants, as cotton, ramie, flax, and hemp; dye-plants, as indigo, madder, woad, logwood, saffron, alkanet, etc.; medical plants, as poppy, aloes, jalap, Peruvian bark, etc.

3. To this kingdom the chemist turns as the great laboratory in which are the products that challenge his researches, and at the same time verify the truth of his speculations. Here he sees Nature quietly transforming

1. What is that ecience called which treats of the vegetable kingdom? From what is the word derived? What does botany tell us?

2. Mention the names of some clothing-plants. Food-plants. Medicine. Dyeplants.

3. What does the chemist see? 
minerals and metals, acids and alkalies, solids and gases into pleasant and agreeable food for the animal creation; while he stands awed at beholding in the humble grass of the field a power and capability of chemical analysis and combination that all his wisdom, with the best-contrived laboratory, cannot essay to imitate.

I have given you a glimpse into the world whose wonders, beauties, and uses I wish you to investigate. I shall endeavor to divest your study of all difficulties by plain and familiar conversations, avoiding learned technicalities as much as possible, and aiming to make you thoroughly acquainted with the groundwork of the science, that you may be prepared to study with pleasure and profit the more elaborate works of Wood, Darby, Gray, and others. As I take it for granted that you are beginners, I will commence where Nature commences, with the plant.

\section{CHAPTER II.}

\section{Root.}

\section{Section I.-Kinds of Roots.}

4. THE root is that part of the plant which supports it in an upright position and supplies it with nourishment for its growth. The large body of the root, the descending axis of the plant, called the tap, serves the first-named purpose; but it is only the small fibrous rootlets that are furnished with mouths, by which nourishment is taken up from the soil and carried to the other parts of the plant. These mouths appear in the form of small sponge-like bodies on the sides and at the extreme ends of the fibers.

4. What is the root? What are its uses? What is the tap root? What of the fibrous roots? How and where do these mouths appear? 
5. Their botanical name, spongioles, comes from their resemblance to a sponge, and their office of sucking up or imbibing moisture. Under the microscope, they do not exhibit a different organization from the minute radicles, but appear only as expansions of them.

6. Radicle is the name given to little roots or rootlets, and comes from the Latiu radix, which signifies root.

7. Roots, when found penetrating the soil, and performing the offices of support and sustentation to the plants, are denominated ground-roots.

8. There are several varieties of air-roots: First, those which strike from the sides of the stem, but grow downward, ultimately entering the soil. A familiar example of these is seen in the Indian corn. Here you will perceive roots springing from the second and third joints of the stalk, and proceeding downward until they penetrate the soil to a depth equal to the ground-roots. These are found generally on the plants whose stems are tall and slender, where they perform the twofold work of fixing the plant more securely to the soil, and of drawing up nourishment for its growth. 'This additional support is very necessary to the Indian corn, whose slender stalk, laden with such a weight of leaves and ears, is unusually liable to be prostrated by both wind and rain; and even with all the precaution of this double stay and prop, it is not uncommon to see whole fields of it leveled to the ground after a heavy rain-storm.

9. Secondly, plants throw out aerial roots, which do not

5. What is the botanical name of these mouths? From what derived? Do they, nnder a microscope, exhibit a different organization from the fibrons root?

6. What is a radicle? From whence is the word derived? Its signification ?

7. Roots that penetrate the soil, and support and nourish the plant, are called what?

8. Are there several varieties of air-roots? What is the first? What purpose do the air-roots of Indian corn serve?

9. What is the second kind of air-root? What is their use? The work they periorm is similar to what? What plant has the second kind of air-root? What proof that these roots are not feeders? 
seek the soil, but attach themselves to other plants, to the sides of buildings, etc. They are more useful to support the plant in its place than to nourish it, and they thus perform the work of tendrils. Of this class is the Virginia creeper, Bignonia grandiflora. A proof that its aerial roots are not feeders is, that it never injures the tree to which it attaches itself, any more than the grape or any other air-rootless creeper.

10. The third class of air-roots do not attach themselres to anything, but hang from the plant like seemingly useless threads. These roots draw nourishment from the air, and a plant so fed will continue to grow for years in a suitable atmosphere, merely suspended in a room. These are called Epiphytes, from the Greek word epi, upon, and phuein, to grow. I have seen a leaf of this kind transfixed to the side of a plastered wall, pretty much as an entomologist would secure a bug. There it threw out roots from the terminal point of each primary vein, and in a few weeks the whole margin of the leaf was adorued with tiny plants, fed by these air-rootlets. Spanish moss, Trulandsia usneoides, is an epiphyte.

11. In the mistletoe (VIscus flavescens) we have an example of roots that fix their abode upon and draw nourishment from other plants. These are called parasites, from the Greek parasitos, which means an eater at the table of another, that is, to be fed or nourished by another. These plants often destroy the tree upon which they fix themselves.

12. Roots when found growing in water are called aquatic (radix aquatica). I gave you the derivation of root from radix. I will now tell you that aquatic comes from aqua, which signifies water. Some of the aquatic roots

10. Is there still another class of roots? Their names? What is the name Epiphytes derived from?

11. How does the mistletoe grow? What are these kinds of plants called? Its signification? Do they injure the tree upon which they grow ?

12. Roots, when growing in water, are called what? Derivation of aquatic? 
serve no other purpose than to supply the plant with nourishment, having no fixed place, but drifting hither and thither with the waves.

13. 'The little miniature plant, duck-meat (LExrs minor), that covers the surface of so many of our ponds and bayous, is a familiar example of the unfixed, floating aquatic plant, while the NYMPH AEA odorat, common pondlily, though often found in water from ten to fifteen feet in depth, is ever anchored firm and strong. Thus moored, it sways upon the tide like some fairy barque laden with beauty and perfume.

14. A plant called by our Mexican neighbors the siempre viva belongs to the Lycopodium tribe, and seems to be the connecting link between all the other mentioned roots. It possesses the extraordinary porver of lying dormant and apparently dead for an indefinite period, months or years, in an atmosphere however dry and unfarorable to vegetable life, and then to be called into perfect and active existence again by the application of water. A dead, crisp, unsightly thing was brought to me by an officer of the army, who had found it, during a hard wind, lown like a dry bur through a mountain-pass in Arizona. It lay in his haversack over a year, and when he brought it to me it was literally "a root out of dry ground, without form or comeliness." Following his directions, I placed it in a shallow saucer of water, and what was my astonishment to see it commence in a few minutes to expand and grow green, its black, crisp roots becoming flexible and golden, and soon a plant not unlike a rose in shape, with imbricated leaves, expanded its living green cup to my delighted gaze, and the Resurrection Rose, as it has been happily called, in all its mysterious beauty stood before me. I have been told by those who have had the opportunity of observing its habits, that this plant has no fixed place of abode;

13. What can you tell of the root of the Lemna minor? Nymphoce odsrata?

14. What of the siempre viva? Why is it called the Resurrection Rose? 
that for eight or nine months it lies coiled up like a hedgehog, its crisp, brown leaves presenting no more appearance of life than the empty bur of last year's chestnut. In this condition it becomes the foot-ball of the winds, and is taken up hill and down dale, orer the heated rocks and through the arid sands, but called into life and beauty when the hollows and crevices of the rocks become filled with water during the rainy season. Then its roots strike downward, its leaves expand, and countless young plants spring up around the parent stem, to be broken asunder during their future wanderings in wind and weather.

15. I have now told you that roots are -1 st. Those growing under-ground, and nourishing the plant. $2 d$. Those commencing their growth above, but finally penetrating the soil. $3 \mathrm{~d}$. Those plants that are supplied with ground-roots for nourishment, and air-roots for support. 4th. Those roots which are simply air-roots for nourishment. 5th. Those roots growing upon other plants for support and nourishment. 6th. Those growing in water, not fixed to the soil. 7th. Those growing in water, fixed to the soil. 8th. Those fixed in water and soil part of the year, dry and unfixed the rest of the time. 'These, however, are all placed under three general heads: the ordinary ground-root, air-root, aquatic root.

\section{Section II.-Duration of Roots.}

16. Roots have different durations, and are classed under names expressive of their term of life. Annual roots belong to those plants which come from seed in the spring, bloom in summer, bear seed in autumn, and perish with the year. This word we also owe to the Latin annus, a

15. Please tell me, in regular succession, the different kinds of roots. These eight are placed under how many heads? Their names?

16. Have roots different durations? What is the first mentioned? From whence is the word derived? Signification? 
year. It means anything that returns every year. Balsams, China aster, Indian corn, wheat, etc., are annuals. If you wish to have these things in your gardens and fields, you must sow them every year.

17. Biennial roots (Latin, bis, twice, and annus, year) are those plants which live two years, as the name suggests. The seed is sown in spring, but the plant does not bloom until the next year. That is, it comes up in the spring, lives through the summer, fall, and winter, blooms the next spring, bears seed in summer, and dies in autumn. It will perhaps not be out of place to mention here a peculiarity of many of the biennial family; that is, their care for the future, storing up food in root, stem, and leaf, the first summer, for the development of flower and seed the next. The turnip, beet, and potato are familiar examples of the food stored in roots. The cabbage and spinach in leaves, and the banana and potato-cabbage in the stem. During the first summer these organs are juicy and succulent, cellular tissue predominating, and forming a very important part of the food for man and beast. The second summer, when the flower-bud springs, this food is drawn up to support the growing shoot and perfecting seed. When the latter are fully matured, the root, stem, or leaf, as the case may be, is found to consist entirely of woody tissue, the cellular all having been exhansted for the growth and development of bud, flower, and seed. The GiLIa coronopifolia, known to the children of the Southwest as the Texas plume, the Euchroma coccinea called the Mexican blanket, mustard, and cabbage are biennials. Perennial roots (perennis, through the year) are plants whose term of life is indefinite. We therefore find

17. From what is biennial derived ? What remarkable provision for the future do many of this family exhibit? When do they store their food ? For what purpose? Examples of food-storing plants? What kind of tissue predominates the first summer? What the second? What has become of the cellular? Do biennials constitute an important article of food? Mention some. Some noted for their flowers. 
in botany that the oak, cedar, orange, mezquit, retamma, grasses, etc., are called perennials.

\section{SeCtion III.-Form.}

18. You will find a distinguishing feature of botany to be that it calls for a close and marked observation of seemingly unimportant particulars. Frequently the identification and separation of a plant from all its congeners will hinge upon what a casual observer would consider a trifle quite unworthy of notice. This is as true of the study of the root as any other organ. We have talked about the situation, uses, and duration of roots, but still a rery

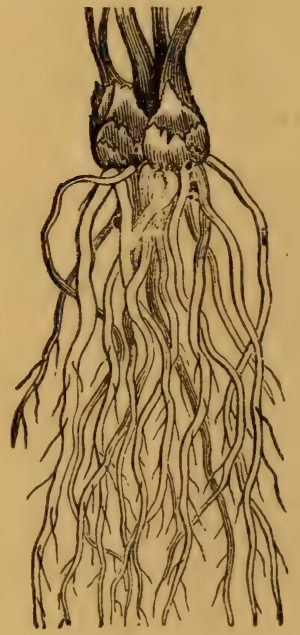

Fig. 1. important part of the study is yet before us; that is, the different forms under which roots present themselves.

19. Perhaps we see the fibrous (Radix fibrosa-fibra, thread) as often as any other. Most of the grasses and many annuals have this form of root, resembling a bunch of threads tied together. Plants that frequent dry, sterile sands are furnished with fibrous roots, these having a greater number of spongioles by which to absorb the scanty nourishment.

20. Creeping roots (Radix repens - repens, creeping) send out branches that do not penetrate downward, but run horizontally along the surface, sending down fibers here and there along the stem. On the Mexican Gulf coast we find almost all the plants with these

18. What is a peculiar feature of botanical investigation? "What do we now proceeci to talk about ?

19. Describe the fibrous root. Where are they generally found?

20. What of creeping roots? What does repens mean? What of IIolland? What lesson should we learn from the radix repens? 
roots; in fact, wherever the soil is loose and yielding, Providence stations these guardians, whose apparently feeble

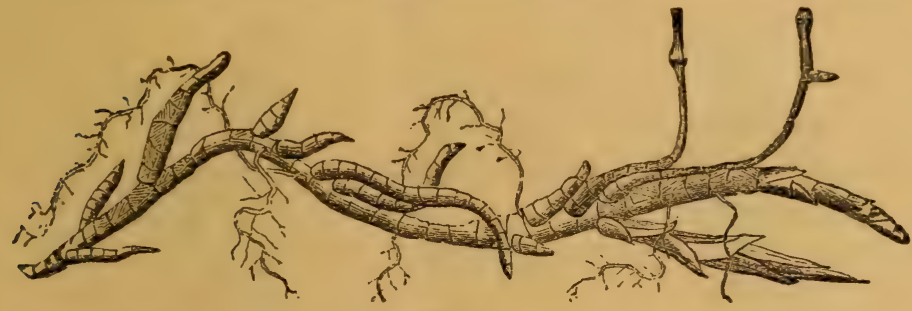

FIG. 2.

threads effectually bind the gliding feet of the sands. Holland would have long ago, in spite of all the mechanical skill of her engineers, been swept into the sea, but for these seemingly insignificant roots that meander like life-veins through her soil. We should learn a lesson of wisdom from the Radix repens, when we see them accomplishing what blocks of granite and walls of iron could not do. With the small things of earth God often confounds the mighty, and it would be well for us to remember this oftener than we do. Examples of creeping roots are found in the violet, strawberry, and many grasses.

21. Fusiform root (Radix fusiformisfusus, spindle, and forma, shape). This root is large above, but gradually diminishes to a point. Many garden vegetables possess this form of root, as the beet, radish, and parsnip.

22. NAPIFORM воOт (napus, turnip) is large at the upper part, and becomes suddenly small.

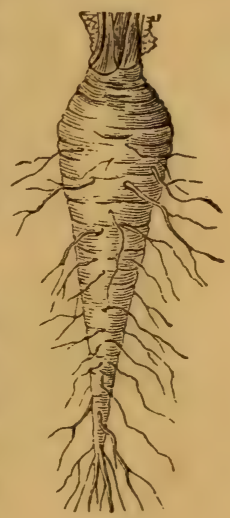

Fig. 3.

23. Branching Root (Radix ramosa-ramus, a branch)

21. What is a fusiform root? From what is the name derived?

22. Napiform? Its derivation? Examples of napiform root?

23. Branching? 
(Fig. 5) presents much the same appearance as the stem and branches would if stripped of the leaves, and is recog-

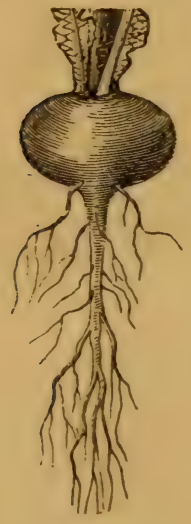

Fig. 4.

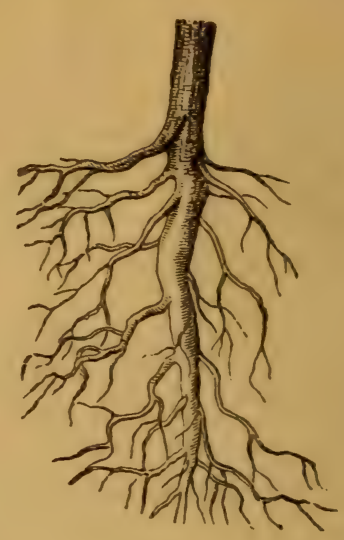

Fig. 5.

nized by botanists as the true type of roots. Examples are seen in all shrubs and trees.

24. Trberous roots (Radix tuberosa-tuber, a knob)

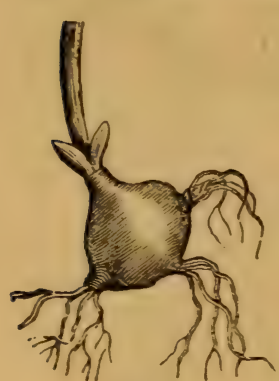

Fig. 6. are hard, fleshy bodies, growing sometimes at the ends of the fibers, and again strung irregularly along upon them. The potato, ground artichoke, and the Mexican rine are tuberous roots.

25. Bulbous roots (Radix bulbosa -bulbus, bulb) (Figs. 7, 8, 9) are divided into corms, or solid bulbs, as the gladiolus; tunicated, or coated, as the onion ; squamous, or scaly, like the lily.

26. The RHizowa grows horizontally, throwing ont fibers and putting forth leares only at one end. These

24. Describe a tuberons root.

25. Bulbous. Derivation of bulbous? Corm? Tunicated? Sqnamous bulb?

26. Describe the rhizoma. Examples. Are there other subdivisions of roots? What have you now learned? 
leaves, as they fall off, leave scars, as seen in the cut. As this root grows at one end, it gradually dies at the other.

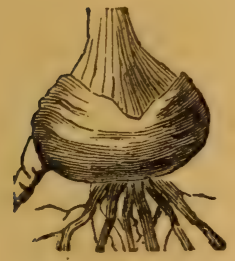

Fig. 7.-Conм.

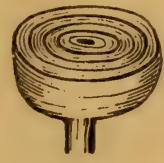

Frg. 8.-Tunicated.

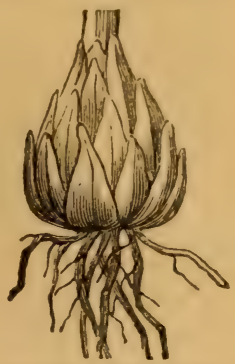

Fig. 9.-Squamous.

Iris, calamus, day-lily, and ginger are examples of the rhizoma. There are many other subdivisions, but I have mentioned enough to enable you to classify pretty accu-

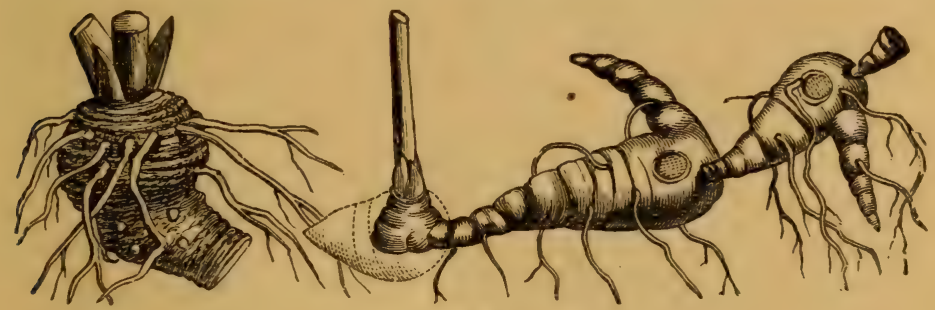

Fig. 10.

rately the most important varieties. You have now learned the uses of the root, its places of growth, duration, and form.

27. You will now repeat what I have told you: That there are-1. Ground roots; 2. Air roots; 3 . Water roots; 4. Fixed roots; 5. Floating roots; 6. Roots for support and nourishment; $\%$. Roots merely for support; 8 . Roots simply for nourishment; 9. Roots fixed upon and nourished by other plants; 10. Annual; 11. Biennial; 12. Perennial. 
That they are-1. Fibrous; 2. Creeping; 3. Fusiform; 4. Napiform; 5. Branching; 6. Tuberous; \%. Bulbous; 8. Rhizoma.

28. The work of supplying the plant with nourishment has merely been stated. The process by which this is done shall be more fully explained in a future chapter, when, after the description of other organs, you will be more fully able to comprehend the higher functions of this. I hare now finished what I purpose to tell you about roots; and as this is the first organ we have had under consideration, I will now explain to you, before we go any further, what an organ is.

29. Webster says, "An organ is an instrument or medium by which an important action is performed, or an important object is accomplished; a natural part of a living existence, capable of special functions that are essential to the life and well-being of the whole." For instance, your heart is an instrument that performs the rery important action of sending the blood through every artery in your body; it is a natural part of your living existence ; that is, it is no artificial addition made after you had come into existence. It performs the office I mentioned above, receiring and propelling the blood; it does it independently, that is its special function, no other part of you can do it, and it is so entirely essential to your life that should it cease to beat ten minutes, you would cease to lire.

30. We have seen that the root is an instrument by which an important action is performed, an important object accomplished, imbibing moisture and food from the soil, nourishing the plant, and fixing it in its place of abode. We furthermore have seen that no other part of the plant could do this work; and as the plant would per-

25. Has the process by which plants are nourished been explained? Why not?

29. Give Webster's definition of an organ.

30. What have we seen concerning the reot? Shall we therefore call it an organ? 
ish without it, we find that the root is essential to the life and well-being of the plant. Consequently we see that the root is an organ.

\section{CHA P TER III.}

\section{The Stem.}

\section{- Section I.-Kinds of Stem.}

31. THE stem is that part of the plant which supports the leaves, flowers, and fruit. The three great classes of Exogens, Endogens, and Acrogens constitute the first grand divisions of stems. These names express their different manner of growth, and mean simply outside growth, inside growth, and increasing in growth from the extremity.

32. Exogenous plants grow by successive additions to the outside of the wood, a ring being formed each year, between the previous year's growth and the bark. They are furthermore distinguished by a light elastic substance occupying the centre of the stem, and well known under the familiar name of pith.

33. Medulla is its botanical name. This is large in young plants, but becomes partly absorbed by the growth of the plant, and partly compressed into thin plates that are found to extend through the woody portions, terminating in the bark, and dividing the wood into wedge-shaped portions. These divisions are called medullary rays. They

31. What is the stem? What is the first division of stems? What do their names imply?

32. How do exogenons plants grow? What furthermore distinguishes them ?

33. Is this medulla larger in young plants? What becomes of it? What are the transverse lines of pith called ? 
are very plain to be seen in a transverse section of any exogenous stem, particularly some varieties of the oak. It will generally be found that the larger the space occupied by the medulla or pith, the harder is the surrounding wood, a wise provision of Providence to compensate for the weakness of the interior. For instance, the cane (Arundinaria macrosperma), three-fifths of whose diameter is occupied by pith, has its surrounding wood almost as hard as a bone.

34. The Exdogerous plants increase by internal growth and elongation at the summit, the wood growing in bundles and irregular distribution through the whole mass; the outside presenting more the appearance of scales and scars from the falling off of the leares, than the bark proper, as seen in the exogenous family.

35. A botanist needs only a bit of stem of each of these to determine immediately the family to which it belongs. The first, exogen, will present a series of rings; in the centre will be the pith-surrounding this, concentric layers of wood, and then the bark; while the latter, endogen, has no pith, and the rood consists of fibrous bundles distributed in irregular masses through the cellular tissne of the stem, and with no true bark. You may be surprised to learn that from these same bits of stem he can tell you how the embryo, the first rudiments of the plant of each, appeared; the exogenous embryo having two seed-leares (only a few have several in a whorl), with their true leaves net-veined, as in Fig. 11; while the embryo of the endogen plant has one cotyledon, and its true leaves are parallelveined, as in Fig. 12.

36. Acrogenous means increasing in growth from the extremity. They are plants which grow taller, but do not

34. How cloes the outside appear ?

35. What does a botanist only need, to determine one of these families? How will the exogenous stem appear? The endogenous? What further can he tell? What kiud of leaf has the exogen? The endogen?

36. What plants are found in the exogen? Endogen? Acrogen? 
increase in diameter. In the first class we find the oak, pine, pride of China, etc. In the second, the palm, yucca, banana. In the third, the ferns, mosses, etc.

37. Now, after examining the three primary or grand

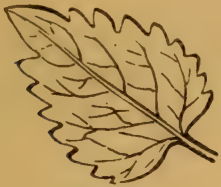

Fro. 11.

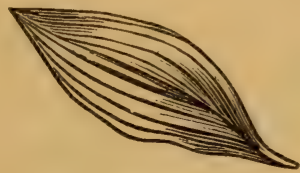

Fig. 12.

divisions of stems, we will observe that the stems of some plants are soft and watery, and others tough and hard. The first are herbaceous, as mint, poke-weed, etc.; the second we call woody, as lilac, rose, and althea.

38. The main stem of a shrub or plant is called the caulis; the stem that supports the flower, the peduncle. When the peduncle is subdivided it is a pedicel. If a plant has one single stem, as the lily, it is said to be simple; if branching, as in the dahlia, it is compound; if the stalk springs from the root and bears the flower, but no leaf, it is called a scape. A jointed hollow stem is called a culm. The grasses, bamboo, cane, etc., have this kind of stem. When the flower is set down upon the main stem without any peduncle or flower-stalk, it is said to be sessile. A leaf also is sessile if it has no petiole or leaf-stalk.

39. There are some plants that present no division of stem and leaf; they appear as part of each other, and bear the flower and fruit upon the edges and under surface of

37. What further is to be observed respecting stems? What are soft stems called? Hard stems?

38. What is the main stem of a plant called? What the stem that supports the leaf? What the flower? When the peduncle is divided? If a plant has a single stem, what is it called? If branching? If the stalks spring from the root, supporting only the flower? What is a culm? Example. When is a flower sessile? When is a leaf sessile?

39. When plants present no division of stem and leaf, where do they bear the flower and fruit? Explain the cat (Fig. 13), and tell me what a stipe is. 
the leaf. These are called fronds. Ferns are called fronds. The leafless part of a fern, the stem of a mushroom, the

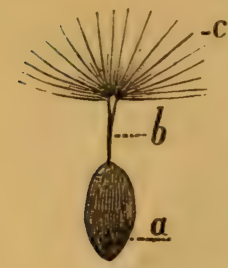

FIG. 13. little thread that supports some winged and downy seeds, are called stipes. Here is a dandelion seed (Fig. 13); $a$ is the seed, $b$ the stipe, and $c$ the down. You are familiar with the mushroom. It looks like a tiny umbrella, the stem or handle being the stipe.

40. Now I have told you that the first grand division of stems is into Exogenous, Endogenous, and Acrogenous, and that exogenous tems are divided into herbaceous and woody; these are either simple or compound: if compound, the divisions are called branches, and if again subdivided, they are called boughs.

41. Herbaceous plants are soft and watery. Annuals are herbaceous; perennial plants are woody, though all woody plants are not perennial, yet they are longer lived generally than the soft-stem plants. Geologists tell us that acrogens, plants with stipe stems and fronds, were first formed. They call the carboniferous era, the period when coal-plants grew, the age of acrogens. Carboniferous means bearing or producing coal. What a singular appearance our globe must hare presented when nothing but feathery fronds, from the tiny leaf soft as down to the gigantic treefern, waved their feathery foliage in the primeval air, we can form some faint idea when looking upon the wild wilderness of ferns growing in rank luxuriance as they do in the allurial "bottoms" of the rivers and bayous of the South and West. We learn also from geology, that after the acrogenous came the cauline or branching variety of

40. Repeat what you have learned respecting the divisions of stems.

41. Are anuuals herbaceous? Are all woody plants perenuial? What class of plants do geologists tell us was first formed? What do they call this period? Meaning of carboniferous?

Note.-The teacher will explain this a little further. 
stems. Before closing this chapter on stems, let me tell you something of the Cuticle, Epidermis, and Bark.

\section{Section II.-Cuticle.}

42. The cuticle is a membranous substance covering the whole plant from root to anther-box, with the exception of the spongioles and the stigmatic surface of the pistil.

43. The epidermis is the exterior layer of the true bark; it also underlies the cuticle of the leaves, etc. Under the microscope it is seen to consist of layers of flattened cells, sometimes of one layer only, again of many. This membrane is full of pores on the under side of the leaf. These mouths are very eridently designed to carry off all superfluous moisture and unnecessary gases elaborated by the assimilation of sap. Upon the epidermis are found various organs, as Hairs, Stings, Prickles, Glandular hairs, SCURF, and LENTICELS.

44. Hairs are formed of cells proceeding from the epidermis. They are covered with the cuticle.

45. Stings differ from hairs in the fact that they spring not immediately from the epidermis, but from cells rising above it, which cells contain an active poisonous fluid which is sent up the hollow hair and through the orifice at the top by the slightest pressure. Prickles are from the cuticle, and are hooked and stiff. They fall off as the stem increases, and are therefore found upon new wood, and very rarely upon old.

46. Scurf is a scaly substance, caused, as some botanists suppose, by the cohesion of many minute hairs.

42. What is the cuticle? Where found?

43. What is the epidermis? Its appearance under the microscope? What is this membrane full of? How are these pores formed? Their use? Mention the names of the organs found in the epidermis.

44. What are hairs? With what are they covered?

45. What are etings? How do they differ from hairs? What are prickles? Do they adhere permanently?

46. Scurf? 
47. Lenticels are the spots, mostly of brownish color, found on the surface of cherry and other trees.

48. The BARK is beneath the epidermis, and consists of several layers.

49. During its early stages it presents a uniform structure, and is entirely cellular; but as the tree advances, lactiferous vessels and woody fiber are introduced into the inner portion, which is called liber. Here is obtained the fiber of flax, hemp, and ramie, which furnish to the manufacturer materials for the gossamer laces of Brussels and Valenciennes, as well as all the gradations from these down to carpets, sail-cloth, and bagging. From the liber of some plants a beautiful paper is obtained, and the natives of the South Pacific isles procure a lace of exquisite texture from the inner bark of one of their forest-trees. Before leaving the subject of the inner bark, I will mention the fact that the substance of which it is composed, woody fiber, is remarkable for its indestructibility by decay. You may take the linen that has lain in a Theban tomb three thousand years, grind it to a powder, and boil it to a pulp, and the manufacturer will present it to you again, in a week, in the form of paper for your letters, or bound in a volume to become the custodian of the mental labors of a Humboldt or the songs of a Tennyson.

50. The outer layer of the bark is called cellular integument. It varies in thickness in different plants. The QUERCUS suber, cork-tree, has it prodigiously developed, and furnishes thereby the cork of commerce. It is not so useful to man as the liber or inner layer, yet, besides the very important contribution already mentioned, we are indebted to it for many esculent roots, which by cultiva-

47. What are lenticels? Where seen?

48. Where is the bark situated ? of what does it consist?

49. Where is the liber? What is obtained from it? What is the outer layer called?

50. What tree has this integument largely developed? What are the offices of the bark? Tell me some of the substances found in the bark. 
tion have increased their cellular integument, and thereby, from being totally worthless, have become food for man and beast. The bark seems to perform several functions, as the protection of the new wood, forming a channel for the descending elaborated sap, and for the secretion of various products, such as cinchona in the Peruvian bark, tannin in the oak, and what is more familiar to you, sweet-gum in the liquid-amber or sweet-gum tree.

\section{CHAPTER IV.}

\section{Buds and Leaves.}

\section{Section I.-Buds.}

51. If in the summer you will observe a branch of hickory, oak, or almost any other tree belonging to the exogenous family, you will perceive in the axil of the leaf and at the extremities of the branches, little round or oval bodies; watch them as the season advances, and you will perceive them slightly increasing, and scales forming over them. When autumn robs the tree of its leaves, the protuberances will be found to be arranged along the tree at regular intervals, either alternate, opposite, spiral, or in whorls. These points of situation of the buds are called nodes.

52. In some cases these are covered with a substance not unlike varnish. The object of these scales and this varnish will be very evident when you are told that in the little bud is wrapped the infant leaf or flower of the coming spring. Cut the bud of the hickory (I mention this be-

51. What is the subject of the fourth chapter? What changes occur in a branch of oak or hickory? When are the buds formed?

52. How are buds protected from the cold ? 
cause it is one of the largest and best-developed scale-buds found in our forests), and you will find a tiny bundle of soft, moist, colorless leaves, folded so compactly together that the most delicate instrument cannot lift one fold without wounding the other. Over this is a roll or envelope of thick substances, around these a tunic of felt-lined leaves, over this still another set of leaves covered with a delicate varnish, and finally scales complete the external wrappings. Now the Empress of all the Russias never laid her babe into a more carefully prepared cradle, for Mother Nature is determined that neither rain nor dew nor chilling blasts shall disturb the winter slumber of her little ones.

53. When spring comes with its sunshine, balmy breezes, and soft showers, it sets the sap, the blood of the regetable world, coursing through a million veins. These buds, warmed by the sunshine and fed by the sap, awake, and burst one dry scale after another, till soon little eyes are peeping forth from every node to bid the spring good-day. The sap still rises and goes rushing through the boughs, the buds push on and out, and soon young branches are stretching their limbs to the air, while the leaves are clapping their hands to the merry breezes that are singing along. Thus you see these buds are the rudiments of future branches and flowers.

54. Various theories have been offered as to their origin, and I don't believe that the now generally accepted theory of their being an outgrowth of the medullary process is any nearer the truth than many hypotheses long since discarded. The microscope reveals the fact that the sap takes up molecules of regular form, but whose tenuity and transparency have heretofore baffled the investigation of the most powerful lens. I believe them to be germs which,

53. Repeat the changes wrought by the coming of spring. Buds are rudiments of what?

54. Is their origin satisfactorily explained ? What theory is here suggested? 
by the action of elements drawn from the atmosphere and the earth, become elaborated into a perfectly organized embryo. This is taken by the descending sap in the fall and deposited at each node, where it remains until the warmtl of spring quickens it into life. To make it plainer, we will say that a little egg is placed by the sap into these nests, the scaly buds, and when the sunshine hatches them they push through the scales and come forth as leaves, branches, and flowers. That simple process known to every practical gardener, called budding, goes to confirm this hypothesis relative to the original and independent existence of the bud germ. If, while the bud is yet in its normal condition, disconnected from the medullary process and the woody fiber, that is, before development commences, you take a sharp knife and remove it carefully from the parent stem, you can deposit it as safely and successfully in another, where it will grow and flourish, as the poulterer can remove an egg from one nest to be hatched in another, and under a different hen.

55. It is evident that if this bud was a development of some other part of the plant, an outgrowth of the medullary process or the woody fiber as some maintain, and consequently vitally connected therewith, a removal in its earliest stage would be more fatal to its life and growth than were that operation postponed until higher development should make its power more self-sustaining and independent. But this is not the case; it is only when the embryo bud lies an independent atom in the scale-bud that it can be removed at all. You understand that this is offered as a mere theoretic speculation, not an established fact.

56. Buds are arranged at regular intervals along the stem, and the points from which they spring are called nodes; the spaces between, internodes; and the bud

55. What is evident? When only can a bud be removed ?

56. How are buds arranged? What are those points called? What the spaces? Bud on the extremities? 
upon the extremity of the branch is called the terminal bud.

57. There are three kinds of buds: flower buds, leaf buds, and mixed buds. The flower bud is generally roundish, and contains the rudiments of one or more flowers. The leaf bud is longer than the flower bud, and contains not only the leaf, but the rudiments of the future branch. Consequently, the arrangement of the branches on the tree must be identical with the situation of the leaves. Mixed buds contain both leaves and flowers. The lilac bud, if cut longitudinally, and placed under a magnifying glass, will exhibit a beautiful example of this kind of bud; its leaves and flowers will be seen compactly inclosed together.

58. I have now told you where to find the buds, how they were protected during the winter, and that there were three kinds of buds. But there are a great many trees that have no scale buds at all. The young buds make their appearance and push out from the node at all seasons of the year, seemingly in the most reckless and disorderly manner. 'These trees, however, are not so improvident and foolish as you might suppose. The fact is, they are all natives of warm climates, where such precautions as extra coverings, felt-lined leaves, varnished coats, and dry scales are totally unnecessary. The men and women of tropical countries do not dress in woolens and furs, neither do the plants put on extra covering. Nature does no unnecessary work; we always find everything properly adjusted to the circumstances that surround it. Some trees, when taken from the tropics to more northern climates, form scales for their buds, and are thus enabled to contend successfully with the rigors of climate, while others

5\%. How many kinds of buds are there? What of flower buds? Leaf buds? Mixed buds? Example of mixed buds?

58. What have you now been told? Are there trees that have no scales? Why do not the trees of tropical climates form scale buds? Do they ever learn to do It? Mention some. 
never do. The horse-chestnut, owing to this accommodating faculty, has become one of the most prized ormaments of our avenues and gardens; while the orange, after years and years of endeavor on the part of horticulturists, thrusts its young buds into the chilly air to perish at the first breath of Jack Frost.

\section{Section II.-The Leaf.}

59. The leaf next claims our attention. All leaves are not packed up alike. Each species of tree differs as much in that respect as in any other. In fact, there is nothing which charms a botanist more than this endless variety. From the infinitesimally small grain of pollen to leaves, boughs, and roots, each tree has its own undeviating form, its characteristic peculiarity that never varies.

60. Thus the rose family invariably fold their leaves upon themselves, and hence their leaves are said to be conduplicated, from the Latin conduplicare, to double, to fold up.

61. When the surface of the leaves are applied to each other without being rolled up, they are said to be appressed (Latin, appressum, pressed to). When they lie over each other, like tiles on a roof, they are called imbricated (imbricatus, corered with tiles). When the margin of the leares roll inward they are involute; when outward, revolute; when one leaf incloses the margin of the opposite leaf it is obvolute; when they overlap, or ride each other, they are called equitant (Latin, equitare, to ride). When they are rolled from the apex downward they are circinate.

62. This arrangement of leaves within their buds is called vernation or perfoliation.

59. What is the Eubject of this section? Are all leaves packed up in their buds alike?

60. How is the rose family folded?

61. What are their leaves said to be? What is appressed? Involute? Revolute? Obvolute? Equitant? Circinate?

62. What is this arrangement of leaves within their buds called : 
63. You have now learned that leares spring at regular intervals along the branches, and that these points are called nodes; that their different manner of folding themselves in the bud is called their rernation. You see from

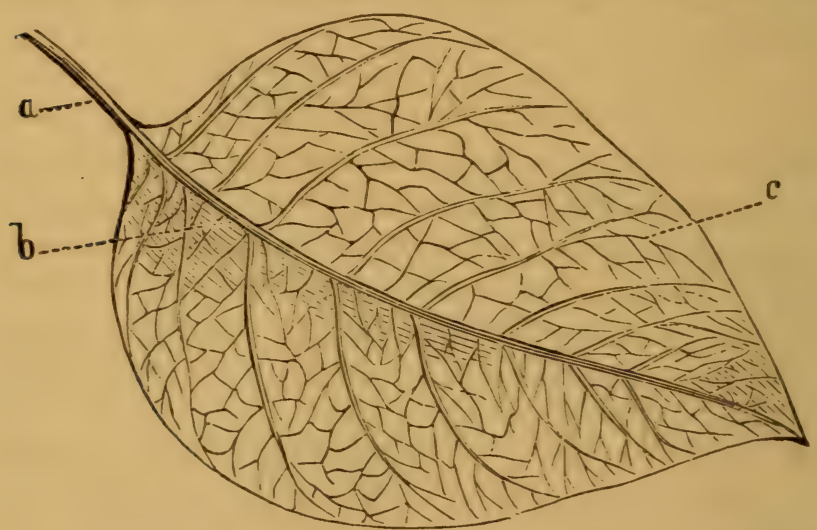

FIG. 14 .

this cut that the leaf is divided into three parts: $a$ is the petiole or leaf stalk, $b$ the midrein, and $c$ the lamina. The petiole, if you will observe, seems to run through the entire length of the leaf, and is called the midrib. It supports the leaf, and from it the reins which form the netted framework of the leaf springs. Those veins which spring from the midvein are called primary, those branching from the primary are called secondary, and the smallest are reinlets. The midrib is nerer wanting, though the petiole is. I have before told you that a leaf destitute of a petiole was said to be sessile.*

* Prof. McCosh, some years ngo, presented to the British Association for the Advancemcnt of Scicnce a paper upon the venation of exogenous plants, in which he asserts that the leaf is the type of the whole piant, that the distribution of the branches along the axis and the distri-

63. What have you now learned? What does the ent represent? How many parts has a leaf? What are they? How does the petiole run? What is it called? Veins springing from the midrib are called what? Have all leaves a midrib ? Have all a petiole? When the petiole is absent, what is the leaf said to be? 
64. The substance that constitutes the lamina (a word that means plates or scales, hence the term as applied to the blade of a leaf, that is, the thin expanded portion of the green leaf, the petiole of the flower, or the sepal of the calyx) is called cellular tissue, and the thin green skin which covers the whole is the cuticle.

65. If you take any thick fleshy leaf, as the Madeira-vine (Basellacece baselloides), pond-lily, or cabbage, you can with a delicate penknife or a needle-point lift this covering or cuticlè, and discover beneath the very different texture of the cellular tissue. Cellular tissue, when magnified by a strong glass, presents the appearance of an immense number of little sacks or cells cohering together, and are in reality tiny bladders or sacks in a greater or less degree of cohesion.

66. The cuticle, under the microscope, exhibits hundreds of minute pores, especially that from the outside of the leaf. These mouths or breathing-places are called stomata.

67. In my remarks upon the epidermis, I told you something about the breathing-pores. Those in the cuticle are the same in their appearance and office. Leaves are furnished with these mouths to inhale such things as are necessary for the plant, and exhale all superfluous or unnecessary gases, moisture, etc., elaborated by the process

bution of the veins in the leaf always correspond. When the branches are whorled the leaves are also whorled, as in the rhododendron, or the veins of the individual leaf, as in the common sycamore and lady's-mantle. When the leaf his a petiole, the tree has its trunk unbranched near the base, as is the case in the sycamore, cottonwood, etc.; and when the leaf has no petiole, the truuk is branched from the root, as in the common ornamentul low shrubs, laurel, holly. lagaerstremia, box, etc. I mention Prof. McC.'s thenry that you may in your own observations verify the endless variety that is brought out by the Great Creator from one type. Everything in the whole round of scientific facts goes to prove that the idea of creation was conceived upon one broad, comprehensive, unified thought; each detail being worked out from the great central original type.

64. What is the lamina? What does the word lamina mean? To what applied? What is the substance called that constitutes the lamina of the leaf? What is the thin green covering called?

65. When this is removed, what is found beneath? Of what does this cellular tissue consist?

66. How does the cuticle appear under a strong glass?

67. The offices of these pores? 
of assimilation. You see, therefore, that leaves perform the threefold function of mouth, lungs, and stomach.

68. What I told you concerning the root is equally applicable to the leaf; great care is to be observed concerning its shape, etc. Often a species is determined entirely by the leaf. Thus the violet family is divided into several species, the difference in the leaf constituting their basis, as the violet sagittata, violet rotundifolia, that is, arrowshaped and round leaves.

69. When plants are destitute of leaves, which is sometimes the case, they are said to be aphyllous. Mushrooms, some seaweeds, garlic, rushes, etc., are all aphyllous, without leares.

70. The first leaves that appear are seminal, from semina, seed, and are named cotyladons, or seed lobes. Those that appear first after the seed leaves are called primordial. Those upon the fully matured plant are styled characteristic. When the leaf springs from the root, like the dock and plantain, it is said to be radical; when from the stem, cauline; when on the stem, sessile. And we describe their position further by the terms alternate and opposite, as they may be situated, thus:

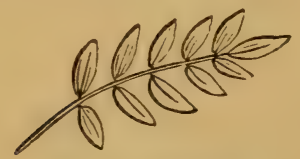

FrG. 15.-Opposite.

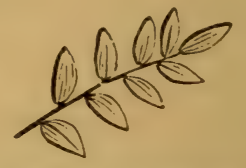

Fig. 16.-Alteriate.

71. The duration of all leaves is not the same. Some fall off as soon as they expand, and are then said to be

68. Why must care be observed relative to the form of the leaf?

69. When a plant is destitute of leaves, what is it called?

70. What are the first leaves called? Have they any other name? What is seminal derived from? Those that succeed them? Those on the mature plant? When a leaf springs from the root? When from the stem? How are they further described?

71. Is the duration of the leaves the same? If they fall off as soon as they expand, what are they? What are deciduous leaves? What persistent? 
caducous; others remain until autumn, and are called deciduous; others live through the winter, and are called persistent, or evergreen.

72. I have told you that a leaf consists of a petiole and lamina; that the lamina is composed of cellular tissue and the cuticle; that the midrib is but a continuation of the woody fiber of the petiole, and that the branches that spring from it are primary reins, and they again are subdivided into secondary and veinlets. You have heard that the minute pores on the under surface are mouths by which the plant performs the operation of breathing and feeding. You have been taught how to distinguish between seminal, primordial, and characteristic leaves, and the situation of cauline, radical, and sessile leaves. We will now look at some pictures of the rarious leaves, and learn their names.

73. Leaves are divided into simple and compound. Simple hare but one blade, as the violet, cottonwood, crape myrtle. Here are pictures of some of the various forms of simple leaves:

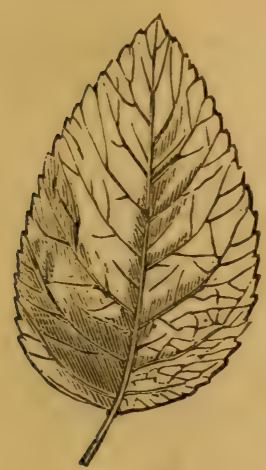

Fig. 17.

Ovate, (Quince.)

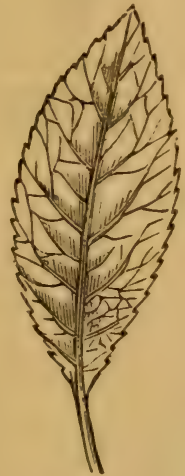

FIG. 18. Elliptical,

(Black Haw.)

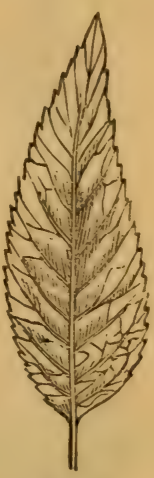

FIG. 19.

Lancoleate, (Flowering Almond.)

72. Repeat all that you have now learned concerning the leaf.

73. The teacher should make the pupil not only describe each leaf, but identify cach by specimens, and also draw them on the blackboard. 


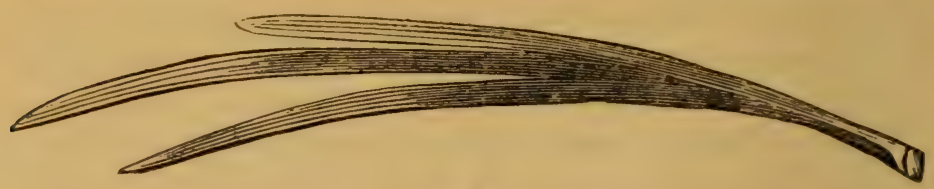

Fig. 20.

Enstform, (Sword-shaped.)

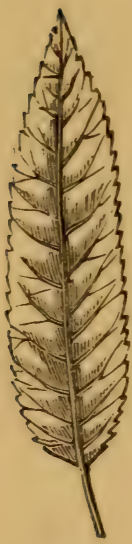

Fig. 21.

Oblong, (Willow.)

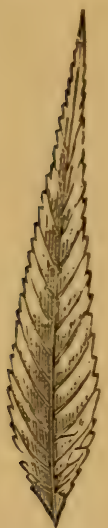

Fig. 22.

Narrow lanceolate, (Weeping Willow.)

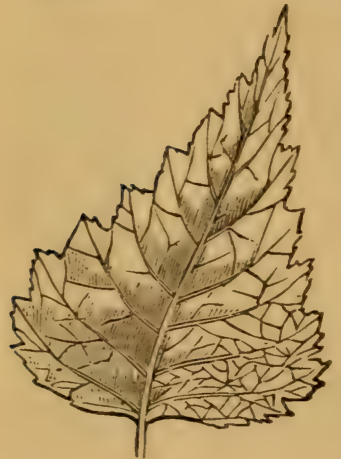

Frg. 24.

Delloid,

(Cottonivood.)

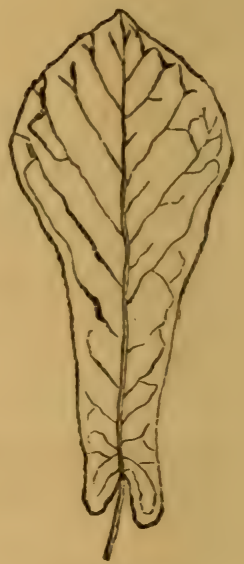

Fig. 23.

Spatulate,

(Fraser's Magnolia.)

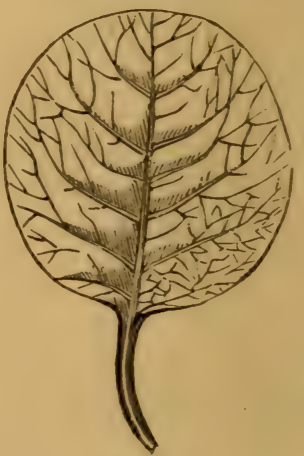

Fig. 25.

Orbicular,

(Winter-green.) 


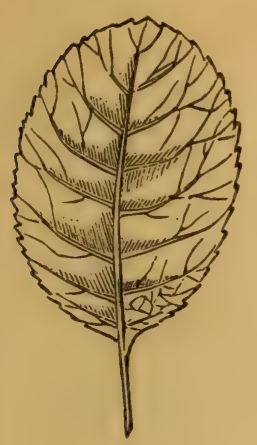

Fie. 26.

Oval,

(Crape Myrtle.)

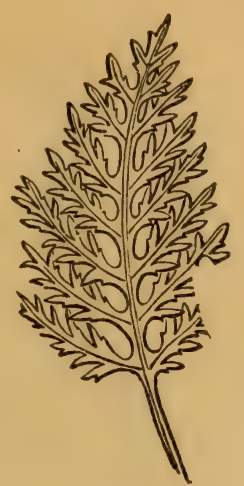

Frg. 27.

Bi-pinnatafi,

(Pigweed.)

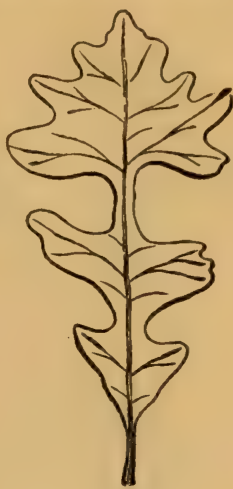

FIG. 28.

Lyrate,

(Moss-cup Oak.)

Fig. 29.

Acerose when short, as in the Pine. Linear when Jong, as in the Grasses.

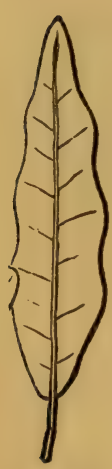

Fia. 30.

Undulate, (Jack Oak.)

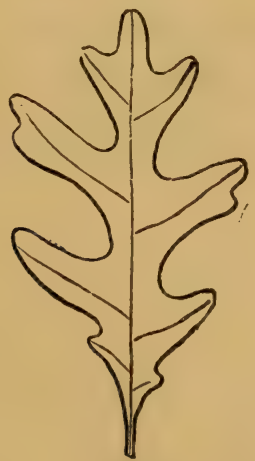

Fiя. 31.

Sinuate,

(White Oak.)

$2 *$

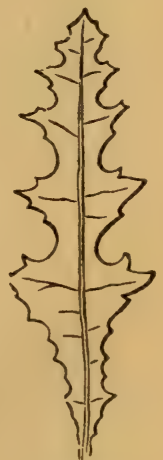

Fro. 32.

Lobed leaf, (Horned Poppy.) 


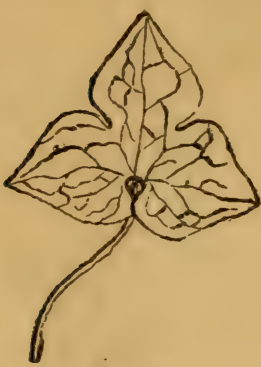

Fig. 33.

Three-lobed, (Wild Violet.)

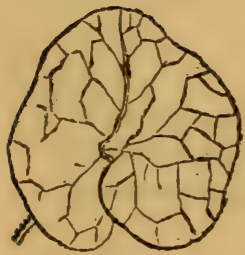

Fig. 36. Reniform, (Wild Ginger.)

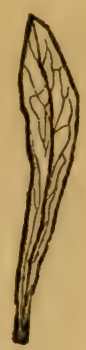

Fig. 34.

Oblong lanceolate, (Silene Virginica.)

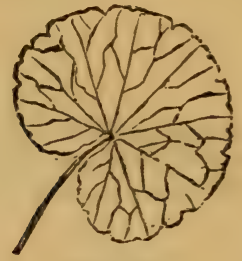

Fig. 37.

Reniform, (Pennyworth.)

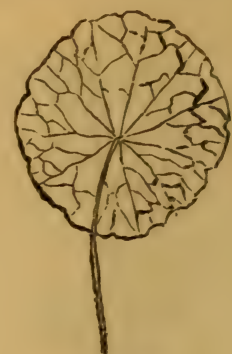

Fre. 35. Peltate, (Nasturtion.)

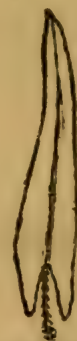

Fig. 38.

Sagittate, (Water Plantain.)

74. A compound leaf consists of several distinct blades on one petiole; each blade is a leaflet. When these leaflets have each a little foot-stalk, those foot-stalks are called petiolules, as in the rose-leaf, which is a pinnate leaf. 


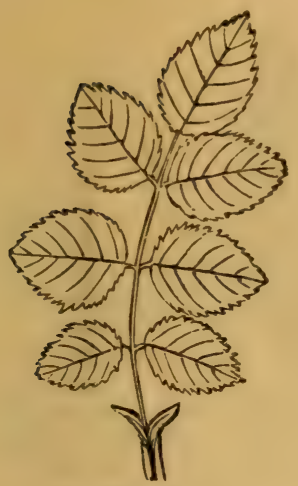

F1G. 39.

Pinnate Leaf.

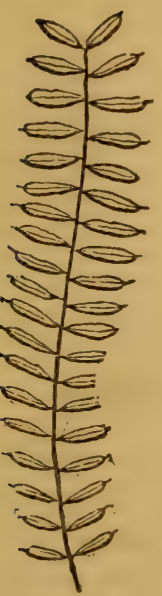

F1G. 42. Equally Pinnate.

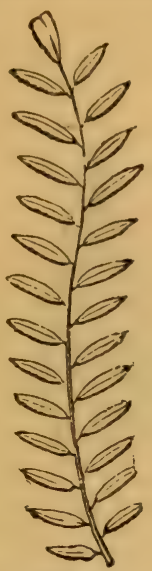

FIG. 40. Odd Pinnate.

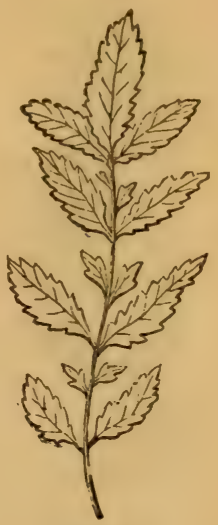

Frg. 41. Intermuptedly Pinnate.

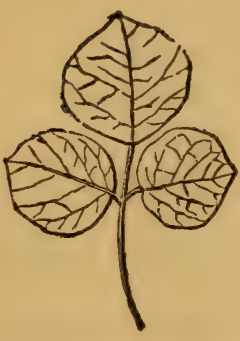

FIG. 43.

Pinnately Ternate.

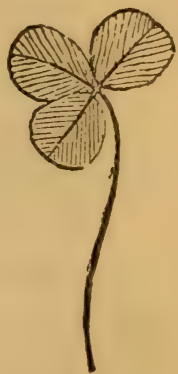

Frg. 44.

Palmately Ternate.

75. The parallel-veined leaves have figures resembling the net-veined, and you distinguish them by saying cordate, parallel-veined, sagittate, etc., etc. 


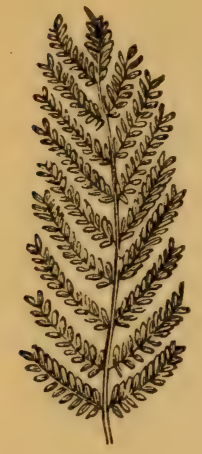

Fig. 45.

Bipinnate.

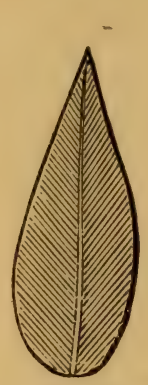

FIG. 46.

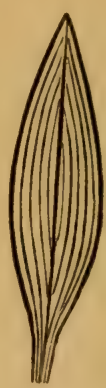

Frg. 47.

Parallel-veined Leaves.

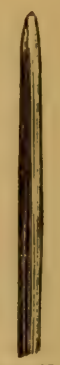

FIG. 48 .

The Onion Leaf is tubular.

\section{DEFINITION OF TERMS.}

Cordate, heart-shaped.

Deltoid, from the Greek letter delta, $\Delta$.

Lanceolate, lance-shaped.

Linear, thread or line.

Orbicular, round.

Oval, longer than broad.

Peltate, shield-shaped.

Pinnate, feather-shaped.

Reniform, kidney-shaped.

Sagittate, arrow-shaped.

Spatulate, spatula, a thin knife used by druggists.

77. Leaves are further distinguished by their margins and their apex. The margin, when indented like a saw (Fig. 49), is serrate, as the chestnut and chinquapin ; dentate (Fig. 50), when the teeth are perpendicular to the edges, as the viburnum; bidentate (Fig. 51), larger teeth with small ones between them (elm); repand (Fig. 52),

77. What are serrate leaves? Dentate? Bidentate? Repand? Lobed? Entire? What is an accuminate apex? Acute? Obtuse? Emaeginate? Cordate, ctc. ? Have you learned all about the different forms of leavcs ? 
hollowed out between the teeth (nightshade); lobed serrate (Fig. 53), geranium; entire, magnolia. The apex is divided

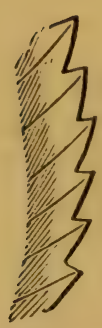

Fic. 49.

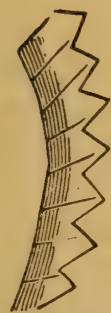

Fig. 50.

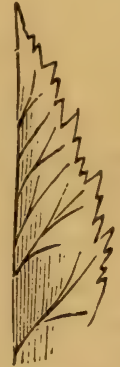

FIg. 51.

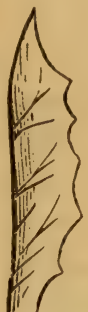

FIG. 52.

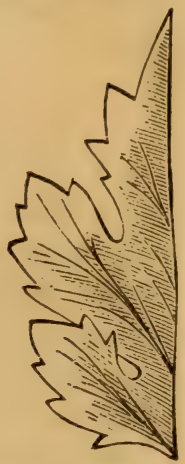

Fig. 53.

into $a$, Mucronate ; $b$, Cuspidate; $c$, Acuminate; $d$, Acute ; $e$, Obtuse ; $f$, Emarginate; $g$, Cordate; $h$, 'Truncate; $i$, Retuse.

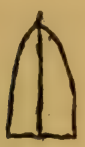

a.

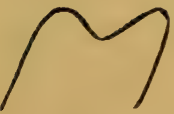

$s$,

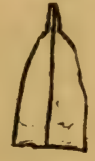

b.

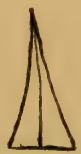

c.

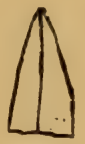

d.

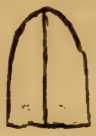

$\epsilon$.

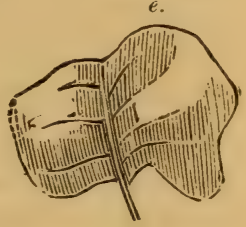

i.

The base is divided into $A$, Hastate; $B$, Sagittate, and $C$, Sagittate; $D$, Auriculate (ear) ; $E$, Cordate ; $F$, Reniform.

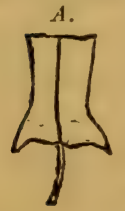

$B$.

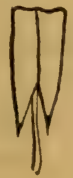

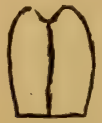

g.

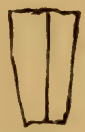

$h$.
D.

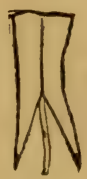

E.

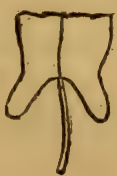

F.
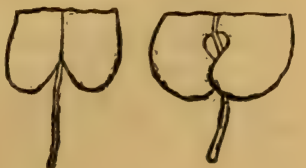

These are not all, but sufficient has been said to accom- 
plish the intention of this volume; that is, to introduce you to the study of botany, leaving it to the larger works of Wood and Darby to unfold still other wonderful forms of beauty.

\section{Section III.-A PPENDAges.}

78. Many leares are furnished at their base with little appendages or organs, separated by the substance of the base of the petiole, called stipules. 'These frequently fall off as soon as the leaf is developed, and they are said to be caducous ; others remain as long as the leaf, and are termed persistent. The rose, hop, and hickory have stipules.

79. Those little thread-like organs, by which plants attach themselves to other objects, are called tendrils. Every child is fumiliar with these, as the grape-vine, melon, etc., are liberally supplied with them.

80. There is a form of leaf that seems in its relation to the true luaf and flower to be a kind of joint property of the two. In many cases, it is hardly to be distinguished from the true leaf; again, hardly distinguished from the proper flower. Its situation, however, determines it, as it is always found on the peduncle, and never on the petiole. These we call bracts. In the Mexican blanket, Euchromes coccinea, and the Salvia splendissima, the bracts are highly colored, and constitute the whole beanty of the flower; while in the sage, and many other plants, being green, it is with difficulty that the botanist can discriminate as to where the leares cease to be and the bracts begin.

81. Many leaves are largely furnished with glands for the secretion of various products. These are found both upon the upper and under surface of the lamina, as well as

79. What are those little thread-like organs called by which plants cling and climb?

80. What can you tell me about bracts? Are they ever colored? How can they be distinguished ?

81. What are glands?. Where found? Office? 
npon the petiole and midrib. 'They yield fluids that are oily, saccharine, and acid, as their peculiar secretions may develop. In the orange and lemon these glands are imbedded in the lamina, presenting the appearance of small yellow grains: if they are pricked with a needle, the oil will be seen with the naked eye rising from the orifice.

82. Other leares are covered with a coating rarying in softness from the velvet down of the mouse-ear, through all the gradations of woolly mullein, to the sharp prickles of the thistle. They are described under the various names of hairy, villous (Latin, villus, hairy), pubescent (which also means hairy), ciliate (Latin, cilia), muricate (Latin, murex, sharp-pointed), etc.; all of which, being new words to you, must be found in the Glossary and committed to memory.

83. Our lesson upon leaves is now closed, and I hope you will remember all that has been said concerning this organ, so necessary to the beauty, growth, and life of the tree. Did you ever think how this world would look if all the leaves were gone? You have scen them fade and fall in autumn, but it was when the chill air drove you within doors, when birds, flowers, and leaves were all gone; and, besides, you knew they would all come again. But think of the blazing sun of the long summer days shining on barren hills and scorched plains, without a green leaf anywhere! They seem rery insignificant and unimportant, but summer would not be summer without them. And, moreover, if they were all destroyed, the whole earth would perish for lack of their sustaining care; for they not only feed the tree and plant, but no animal life could exist without them. The whole atmosphere would become so noxious without their regulating power, that death to all animal life would ensue. As the sun regulates the boundary between day and night, so do these seemingly insignificant

82. What of the down upon plants? The different terms ?

83. What would be the consequence of universal death to the leaves? What if leaves were to reverse their actions? Can you hope to understand all this now ? 
things hold in their hands the issues of life and death. If they were to invert their processes, reverse their actions one month, the earth would be one vast charnel-house. You cannot understand all this now, but I want you to think about it, and when we come to the chapter upon how plants live and what they feed upon, you will see for yourself that what $I$ have just told you is true.

81. To recapitulate: Leaves are sometimes supplied with tendrils, stipules, bracts, thorns, prickles, hairs, scales, and glands. Stipules are immediately below the leaf. Bracts are upon the flower-stalk; tendrils are from the extremities and sides of the stem, sometimes from the apex of the leaves. These, you remember, were spoken of in our talk about the epidermis.

\section{CHAPTER V.}

\section{The Flower.}

85. The flower is the crowning grace of Nature. It is this organ, or rather combination of organs, which is distinguished by its color, form, and odor from the other parts of the plant, and in whose production Nature seems to have emptied her store-house of beauty and variety. These "voiceless preachers" silence by a look those extreme utilitarians who declare that the merely beantiful is unnecessary waste. They answer, in language more potent than words, that loveliness has high and holy uses, and teach lessons which could never be enforced without them. They cause gratitude and love to spring eternal in the human breast, and suggest to the weary wanderer consol-

84. Tell me again the varions appendages of leaves. Where are they found ? Where did we leart of them before?

85. What is the subject of Chapter V.? By what is the flower distinguished ? 
ing dreams of the matchless glories of the infinite world, that land of pure heart's-ease, where fadeless flowers and sweet perfumes delight the garden of the Lord.

86. Their profusion, their fragility too, united with the important offices that many of them accomplish, the early fading away of their young lives, and the good they leave behind them in fruit, food, and seed, all teach us useful and beautiful lessons, that we should strive to remember.

87. A glance will show us that the flower is not a single organ, like the root, the stem, or the leaf, but a combination of several organs, distinguished by their names, calyx, corolla, stamens, pistil, anther, stigma, etc.

\section{Section I.-CALYX.}

88. Calyx signifies a cup, and is the outer covering of the flower. It is generally green, sometimes entire, that is, without divisions, sometimes divided into leaves, which are called sepals. When the calyx is entire we call it monosepalous (from the Greek monos, one, and English sepal, from the Latin sepio, to inclose). If divided into many sepals it is polysepalous (poly, from the Greek pollus, many). Sometimes there is but one row of leaves, and they are colored. We say then that the plant has no corolla, for in all cases the outer row is the calyx. Sometimes there are many rows, all colored, and we say that the calyx and the corolla are confounded, that is, they cannot be distinguished. We simply call it then a perianth (Greek, peri, around, and anthos, flower).

89. In the monosepalous calyx, that portion formed by

86. What lessons do flowers teach?

87. Is the flower a single organ or a combination of several ? What are their several names?

88. What does calyx signify? Describe it. When withont divisions. Wher divided. When there is but one row of leaves, what do we call it ? When many, and colored? What is the word perianth derived from? What does it mean ?

89. In a monosepalous calyx, what is that portion called formed by the union of sepals? What the upper division? If the calyx takes its rise from below the ovary? What is strictly true regarding the true position of the calyx ? 
the union of the sepals is called the tube. The divisions of the upper margin we call limbs. In this cut, $a$ is the

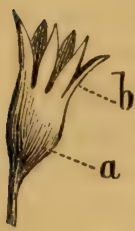
tube, $b$ the limb. If the calyx takes its rise below the ovary or seed-vessel, it is said to be inferior; if above, superior. These distinctions, however, are merely nominal, for the origin is in all cases the same, beneath. But in some plants the calyx adheres to the ovary, uniting with it

Fia. 54. so as to become a part of it, as the haw, apple, etc.

90. You have now been told that the calyx is the corering of the flower, that it is generally green and leaf-like, that it may be monosepalous, that its divisions are called sepals, and that it may be inferior or superior. It fails off in some cases as soon as the flower expands; it is then said to be caducous. The calyx of the magnolia is caducous. If it remains as long as the corolla it is deciduous. The virgin-bower has this kind of calyx. If it remains until the seed is perfect it is said to be persistent. The rose has a persistent calyx.

91. There are several kinds of calyx. Linnæus divides them into seven classes: the ament, calyptra, glume, invo-

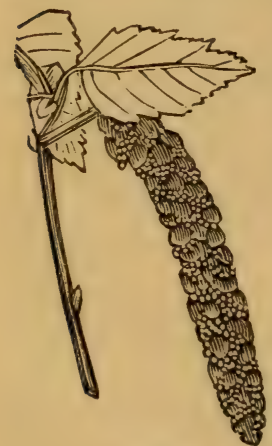

Fra. 55. lucrum, perianth, spatha, and volva.

Ament, or catkin, consists of chaffy scales on a thread-like stalk. Each scale is the receptacle of stamens and pistils, and we call the whole aggregate a flower, and consequently it is classed as a mode of inflorescence, as in cottonwood and banana.

92. Calyptra (from the Greek, to cover or conceal) is the name given to the little hood or cap that covers the pistil of the Fig. 56.

90. State the period of the falling of the eepals, and the names given to each.

91. How many kinds of calys did Linnæus arrange? Their names? Describe the ament.

92. What of calyptra ? 
mosses, which resembles in form and position the extinguisher of a candle.

93. Glume (from the Latin gluma, a husk) is seen in the calyx of grasses, and plants of that family. It is known when separated from the ripened seed of oats, barley, etc., as husk or

chaff. Those long thread-like appendages Fro.5\%. called the beard of wheat and barley are parts of the calyx.

not

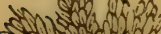

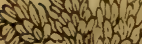

(1) V.

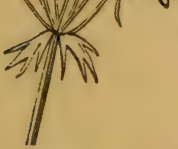

Frg. 58

94. InvoluCRE (from involvere, to wrap) is generally found in the umbelliferous family. When inclosing a cluster, it is said to be universal; when but a single flower, partial.

95. Perianth, when applied to a distinct calyx, means those cuplike calyces in which the corolla may properly be said to be placed. The long tubular calyx of the pink and the graceful urnshaped calyx of the rose are examples.

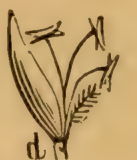

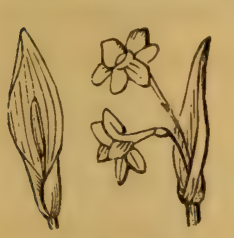

FIG. 60 .

96. Spatha, or sheath. 'This form is very common among the bulbous-root families, as in the narcissus and daffodil. These frequently wither and fall off in the early stage of bloom. In others they are beautifully colored, and remain, consticalla tribe. tuting what we call the flower, as in the

97. Volva. The curtain or ring that incloses the head of the mushroom, and which, after it bursts, remains on the stem, is called the volva. Fig. 61 shows you a mush-

93. Describe glume.

94. What of involucre?

95. What can you say of perianth ?

96. Describe apatha.

97. Volva. 
room with its head still inclosed, while Fig. 62 represents the volva bursted and clinging to the stem.

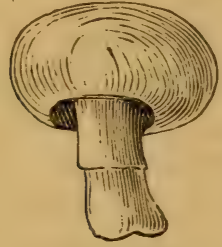

Fig. 61.-EntiRe.

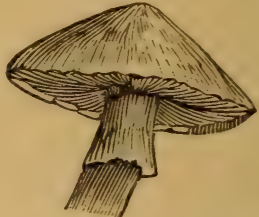

Fig. 62.-Bunsted.

98. The calyx is rarely wanting in delicate fragile flowers, where its evident use, the protection and support of the other organs, is so much needed. Bouncing Bet, pinks, and all those flowers whose petals are long and slender at their base, would be blown to pieces by the first breeze but for the sustaining office of this organ.

99. In the amaryllis, tulip, and hyacinth tribe, we find but one covering for the stamens and pistils, the strong, firm, well-seated petals requiring no aid from the calyx; and here we find none, or at least what would properly be considered none. I have explained that in botanical analysis, if there is but one envelope, it is called a calyx, not a corolla.

\section{SECTION II.-CoRoLla.}

100. Corolla (from the Latin corona, a crown) is the interior envelope, and exhibits every variety of color, form, and texture. Under the subject of calyx I explained to you that sometimes the distinction between the corolla and calyx was not plainly marked; these are exceptional cases, however, as generally they present a very marked and

98. In what kind of flowers is the calyx seldom wanting ?

99. What of the amaryllis? If there is but one envelope, is it proper to call it a corolla ?

100. What is the corolla? What does it signify? Is the difference between the calyx and corolla ever difficult to determine? What is generally the cuse : What do vegetable physiologists tell us ? 
striking difference, both texture and color presenting a decided contrast. Vegetable physiologists tell us that the calyx is a continuation of the outer bark; the corolla, of the inner cellular integument. Hence the corolla is clistinguished by the exquisite delicacy of its texture, the soft and flexible character of its petals, the brilliancy of its color, the fleeting character of its existence.

101. Each part of the corolla is called a petal. Like the calyx the corolla is frequently entire, and then it bears a name analogous to that of the calyx under the same circumstances, monopetalous; and when divided, polypetalous. The monopetalous corolla presents us with a great variety, to which names have been applied indicative of their characteristic differences.

102. When the throat is short, and the limbs or petalous divisions, short and spreading, it is called rotate. When the border is like the rotate, but with a long tube, we call it salver-shaped. When the throat is shorter, but wide in proportion, and the margin separated into limbs, it is campanulate, Canterbury bell.

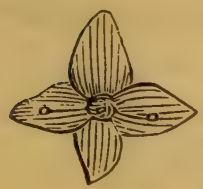

FIG. 63.

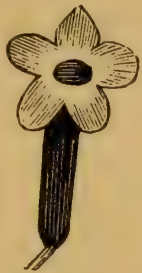

Fra. 64 .

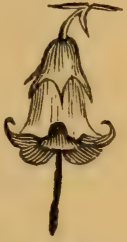

FIG. 65.

103. When the corolla is separated into unequal divisions, called the upper and lower lips, it is called labiate, posterior and anterior. These when open, as in Fig. 66, are said to personate; when closed, as in Fig. 6\%, are

101. What is each part of the corolla called ? When entire, what is it called ? When divided ?

102. What is a rotate corolla? Salver-form? Campanulate? Describe a campauulate corolla.

103. Describe a labiate. Funnel-form. 
ringent. When the throat spreads into an expanded tube, we call it funnel-form, as Fig. 68, morning glory and Jamestown weed.

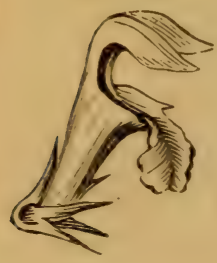

FIG. 66 .

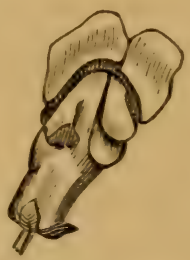

Fig. 67 .

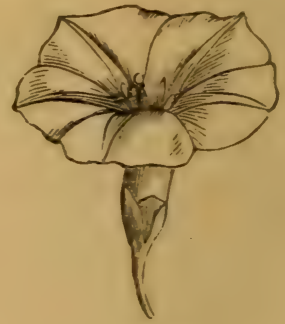

Fiต. 68.

104. In polspetalous corollas each leaf or petal consists of two parts, a limb or lamina, and a claw or unguis. The claw $(b)$ is the narrow part, generally supported by the calyx. The limb $(a)$ is the spreading part, generally supa manvy ported by the claw. The unguis or claw corresponds to the petiole, while the limb agrees with the lamina of the leaf.

105. When there are several abruptly spreadb... ing petals with short claws as (Fig. r0), it is rosaceous, rose. When the claws gradually

Fig. 69. expand into laminæ and the petals are upright and

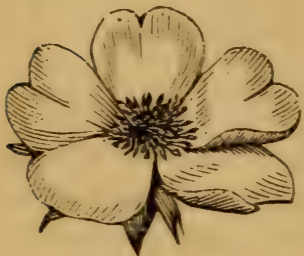

Fig. 70.

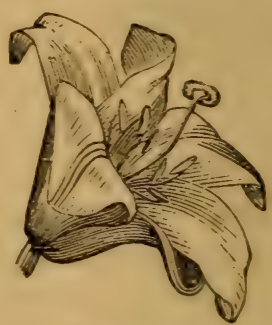

Frg. 71.

spreading, as Fig. 71, it is liliaceous, lily. Flowers like

104. In polypetalous corollas, each leaf consists of how many parts? What is the limb? What is the claw?

105. Describe a rosaceous corolla. Liliaceous. Caryophyllous. Papilionaceous. 
the pink (Fig. 72), with long, slender claws inserted into a tubular calyx, are called caryophyllous (Fig. 73); with four petals at right angles, cruciform, mustard. Papilionaceous corollas have five petals (Fig. 74), the upper one erect and

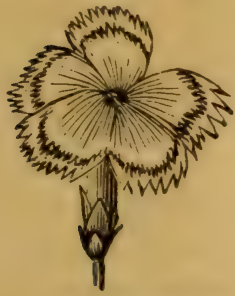

FIG. 72.

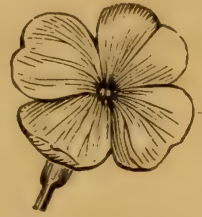

Fre. 73.

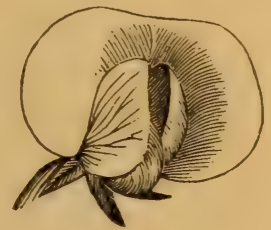

Fra. 74.

more dilated than the others, the two lateral at right angles with the upper, and parallel with the other. We call the exterior petal the banner, or vexillum, and taken apart it looks thus (Fig. 75); the two half exterior are wings, or alce (Fig. 76) ; the two lower are the keel, or carina (Fig. ${ }^{\text {Mry }}$ ). These are frequently united (pea clover).

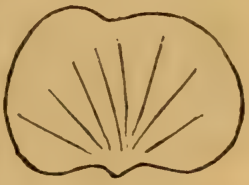

Fic. 75.

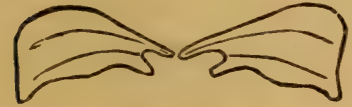

FIG. 76 .

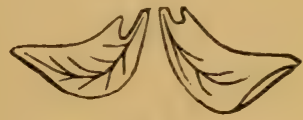

FIG. \%7.

106. Various flowers are furnished with different appendages, differing from the other organs, though situated among them. Their uses have never been discovered, though ancient botanists supposed their peculiar functions to be the secretion of honey, and hence styled them nectaries. But subsequent investigation has proved this to be untrue, as they rarely if ever exhibit any such product.

106. What are varions flowers furnished with? Are their functions known? What did ancient botanists think? Is this true? Mention flowers that have no appendages. Mention the varions forms of nectaries. 
The larkspur, violet, columbine, monk's hood, horned poppy, etc., present us with a variety of nectaries in the form of hoods, spurs, horns, scales, cavities, etc.

107. A little more talk about the corolla, and we are done. Some flowers have stamens and pistils, but no calyx or corolla. Sometimes they have the two latter and only stamens, and again no stamens, only pistils. However, if the stamens and pistils are present it is said to be a perfect flower, as they alone are indispensable for the reproduction of the plant. If all the organs are present we say it is entire. When the calyx and corolla are absent, the flower is said to be achlamydeous (from the Greek, signifying without a cloak); when only the calyx is present, monochlamydeous (one garment or covering); dichlamydeous (two) when the two floral envelopes are present. In this case we say it has calyx and corolla. The Crinum Americanum, found upon Buffalo Bayou, near Houston, and in some parts of Louisiana, familiar to you all, is monochlamydeous; also the common white lily. The rose isdicllamydeous. The sweet gum (liquid amber) is achlamydeous.

108. The most important office of the corolla seems to be the protection of the stamens and pistils from injury. We thus frequently find the corolla using the greatest care to insure this. Many of them close up at night, or at the approach of rain-storms and high winds; others droop their heads at evening, evidently to prevent too great an accumulation of dew in their cups at night. When you learn the important office of the stamen and pistil, you will more readily perceive the necessity of this protecting care. It is the corolla that also elaborates the volatile oils that give such delicious fragrance to the flower, making

107. Have all flowers a calyx and corolla? Have all pistils? Stamens? When is a flower perfect? Entire? Achlamydeous? Monochlamydeous? Dichlamydeous? Examples?

108. What is the most apparent use of the corolla? Mention the coverings with which it protects the other organs. What is elaborated by the corolla? What of poisonous plants? 
the rose, pink, jasmine, and heliotrope the very synonym of all that is pleasant. Poisonous flowers are often distinguished by their disagreeable fotid odor, and by the dull color of their corolla.

\section{Section III.-Stamens.}

109. You have been told that the flower generally consists of two sets of envelopes, the outer termed the calyx, the inner the corolla.

110. Now within the corolla are a set of thread-like organs called stamens. They consist of three parts, the filament, anther, and the pollen. The filament (Latin, filum, a thread) is the slender part of the stamen supporting the anther--the little knob or box on the top of the filamentand which is generally divided into two lobes, sometimes more. This box contains the pollen, which is a fine dust that is ejected from the anther-box when it is fully matured, and is necessary for the fertilization of the ovary. Fig. 78 is

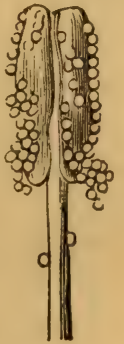

FIg. 78. an anther with pollen grains enlarged.

111. To the naked eye, pollen appears only as a mass of fine dust, but under the microscope the grains present us with forms as various as the flowers on which they are found. Here again we perceive the richness of God's treasure-house of beauty, its infinite diversity, marshaled into fixed rank and order by His undeviating laws, making each flower to differ from the others, but each to bear pollen after its kind. The magnolia bears pollen grains which look like long needle-shaped crystals of translucent white-

109. How many envelopes has a flower generally ?

110. What within the corolla? Their names? How many parts have they? What is the filament? Anther? Pollen? Its uses?

111. How do pollen grains appear under the microscope? The magnolia? Crapo myrtle? Mallow ? 
ness; the crape myrtle has light-brown, egg-shaped grains; the mallow has a white opaque sphere, covered with elongated projections (papillæ), and looks just like an infinitesimally small gherkin. The crimson Texas-star (Sabbatia brachiata) has golden-colored grains shaped like rice. These forms are as fixed and uniform as any other peculiar characteristic distinguishing one family of flowers from another.

112. The microscope shows us also that these grains consist of a delicate tube of great tenuity, surrounded by a thin liquid, which is inclosed in a thin sack or skin. When the pollen falls upon the stigmatic surface of the pistil, this sack bursts and the pollen tube issues therefrom, penetrating the stigma, descends the hollow tube of the style, and finally reaches and fertilizes the ovules in the germ below. As insignificant as this dust may appear to you, it is just as important as the root, the stem, or the leaf. If for a few years the corn and wheat blossoms should fail to perfect pollen, starvation to millions would be the consequence. Reproduction depends on this, and no seed can mature without it.

113. Observation will teach you that the stamens are sometimes below the pistil, sometimes around it, and again upon it. When they arise from the calyx, they are said to be perigynous; from the pistil, epigynous; under the pistil, hypogynous. When the stamens are longer than the corolla's depth, so that they project beyond, as in the honeysuckle, they are said to be exserted (Latin, exserere, to stretch out); when shorter than the corolla, included (Iatin, includere, to shut up, to confine within). When they bend down in a curve, they are said to be declinate (Latin, declinare, to lean, to bend).

112. What does the pollen grain consist of? When it falls on the stigma, what takes place? What if the pollen of grain-bearing plants should all fail for years to perfect their pollen?

113. When the stamens rise out of the calyx, what are they called? When npon the pistil? Under the pistil? When longer than the corolla? When shorter? When they bend downward? 
114. There are some plants, that you shall have described to you in the future, whose stamens and pistils are in separate flowers, and others again on separate plants. And as the pollen of these plants is very light and very abundant, the winds and the insect world easily transport it from plant to plant, and from tree to tree, and thus secure the fertilization of the pistillate blooms. 'The palm, olive, mulberry, Indian corn, pumpkin, and strawberry, are all members of these families.

\section{Section IV.-Pistils.}

115. In the center of the flower we find the pistil. It

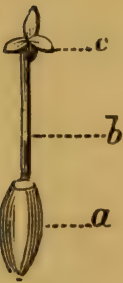

Fig. 79.

Pistil. a-Ovary.

b-Style.

$c-$ Stigma. also consists of three parts, the germ or ovary, the style, and the stigma. This organ has not been inaptly compared to a column Capital. $b$ in architecture; the germ corresponding to the base or pedestal, the style to the shaft, and the stigma to the capital. The germ is the

Shaft.

Base.

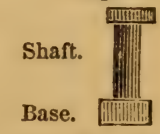

FIG. 80. base of the style, and on fertilization develops into ovules, ovary, and receptacle. The style is the hollow thread-like tube springing from the times so short as to appear entirely wanting. It is then said to be sessile, that is, having no stalk.

116. It is through the style that the pollen tube is transmitted to the germ. Upon the top of the style rests the stigma, which is properly only its development, just as I

114. Are the stamens and pistils ever in separate flowers? How is the pollen transported? Mention some plants whose stamens and pistlls are in separate flowers.

115. Where is the pistil found? Of what does it consist? What is the germ? The style? When sessile?

116. Through what is the pollen transmitted ? Where is the etigma, and what is its usc? To what is it compared? Has it an epidermis? What is said of a secreted fluid? With what is the stigmatic surface flled? 
told you that the spongioles are the development of the fibrous roots; and like these spongioles, the stigma has no epidermis. They are the only parts of the entire plant not furnished with that covering. It secretes a viscid fluid whose office is to secure the adhesion of the pollen grains, and also to furnish sufficient moisture to cause the sack to burst, and the consequent expulsion of the pollen tubes. Its surface is also filled with cells, through which these tubes find easy entrance to the style, and thence downward to the ovules in the germ, ovary.

117. After these ovules become fertilized by the pollen tubes, they begin to mature into perfect seeds, and the ovary enlarges and undergoes very remarkable changes. As the other parts of the flower within die, and fall off, it becomes the future pericarp (peri, around, and carpos, fruit). The apple, peach, pumpkin, acorn, in fact all that part of fruit, nut, or berry which is not the seed, is the pericarp, and has once been the ovary.

118. You have now had explained to you the three parts constituting the stamens, the filament, anther, and pollen, and their uses. The pistil also consists of three parts; the germ, the style, and stigma, and also their offices. If you will take the ovary of the okra, which is unusually large, and can be examined without a glass, and cut it longitudinally or transversly, you can plainly see the orules arranged just as the ripened seed appear in the perfected pod. These ovules have the form of seed, but present a color and texture differing but little from the ovary in which they are inclosed.

119. You have now been told that the flower has a

117. What of the fertilized ovules? Of the ovary? What does it become? What is a pericarp?

118. Of what does the stamen consist? The pistil? What experiment is suggested with the okra? What of the color and texture of the ovules?

119. What have you learned about the calyx ? The corolla? What is each division called? How is the stamen divided? What does the pollen contain? How is the pistil divided? What about the germ ? 
CALYX, which when entire is called monosepalous; divided, polypetalous; and that each division is called a sepal ; - a COROLLA, which when entire is monopetalous; when divided, polypetalous; each division being called a petal ; - STAMENS, which are formed of a filament, to support the anther; anther, which is divided into two lobes; pollen, a fluid and a tube;-PISTILS, which are formed of a germ, which is the base of the style; style, which is the channel from the stigma to the germ; stigma, which receives the pollen;GERI, which, on being fertilized, is a receptacle for the pericarp; ovary, which develops into the pericarp; ovules, which become the seed.

120. You have been told that the calyx is to protect and support the corolla; that the corolla is to protect the stamens and pistils; that the stamens are designed to fertilize the orules in the germ of the pistil, and that thus the stamens and pistils are the necessary organs of reproduction.

\section{SeCtion V.-InfLoRESCENCE.}

121. In walking over the prairies of the Southwest, the pupil must have noticed that the buffalo clover grows on its stem very unlike the Texas star, that the Mexican blanket puts out blossoms quite differently from the Houstonia, and that the Elder bears no sort of resemblance in its flat clusters of blossoms to the long tassel-like senna or fringe-like retama. The peculiar style of each is called its manner of INFLoRESCENCE, and it furnishes another very striking distinction to aid us in classifying plants. When the flower springs from a terminal branch and bears a flat-topped cluster, as the mustard and cabbage, we call it a cyme (Fig. 81). When they grow in clusters and spread out regularly

120. What are the indispensable organs of reproduction?

121. What is the subject of Section V.? What is inflorescence ? What is a cyme? Example? 
from a common plane or convex surface, as in the carrot, we call it an umbel (Fig. 8z).

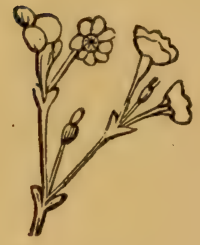

Fig. 81.

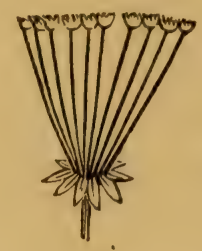

Fig. 82.

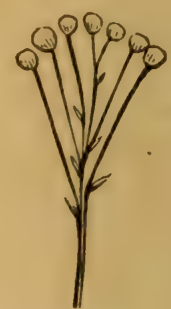

FIG. 83.

122. When the flower stalks spring from the different points along the main stem, but form a level top, as in yarrow, we call it a corymb (Fig. 83).

123. When the cyme is clustered closely together, forming a compact group, as in sweet william, it is a fascicle (Fig. $84)$.

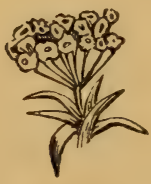

Fig. 84.

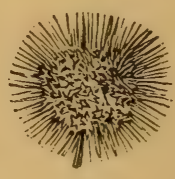

FIG. 85.

124. When the flowers are more closely grouped, and the foot-stalk or peduncles are entirely wanting, that is, a cluster of sessile flowers arranged in a globular form on the stalk, as in the bachelor's button, it is called head (Fig. $85)$.

125. When they have short stems, but clustered together on the main stalk, they are glomerate (Fig. 86).

126. The ament or catkin has already been described to

122. What is a corymb?

123. A fascicle?

124. A head?

125. What is a glomerate flower?

126. A spadix? 
you in the chapter on the calyx. When an assemblage of flowers grows upon a common receptacle surrounded by a spatha, as in the Ethiopian lily, it is a spadix (Fig. 87).

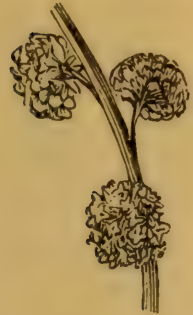

Fig. 86.

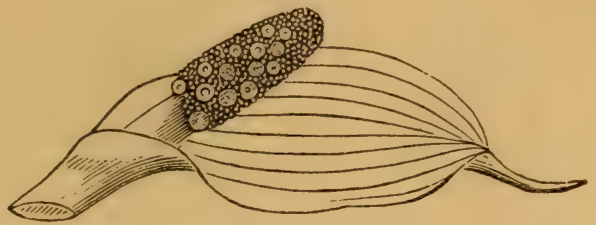

Fig. 87.

127. When the flowers arise along the common stem, supported by short peduncles, as in some grasses, they form a spike (Fig. 88). A compound spike (Fig. 89), water oats.

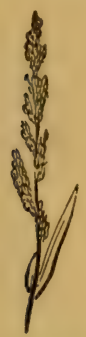

Fia. 88

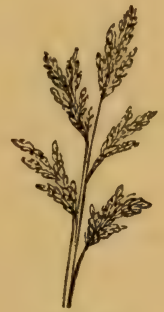

Fig. 89.

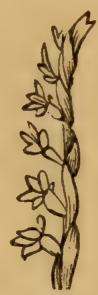

FIG. 90.

128. When the peduncles are arranged regularly and equally around the stem, as in the hyacinth and hare-bell, they form a raceme (Fig. 90).

129. When the peduncles are divided and subdivided, as in grasses, they form a panicle (Fig. 91). When the panicles are very dense, as in lilac, it is a thyrse (Fig. 92).

127. A spike? Compound spike?

12S. A raceme?

129. Describe a panicle. A thyrse. A whorl. 
When the flowers grow around the stem, as in mint and pennyroyal, they are called a whorl (Fig. 93). When the

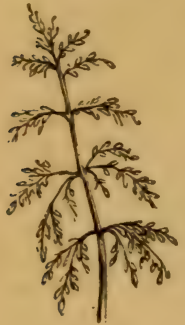

Fig. 91.

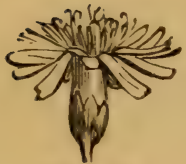

Frg. 94.

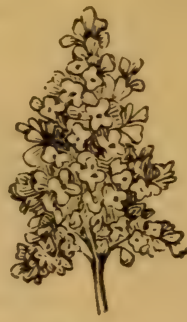

Fig. 92.

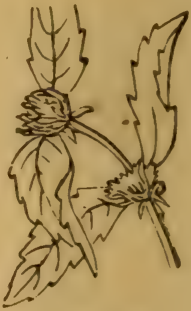

Fig. 93.

receptacle is dilated, bearing flowers above and scale bracts around, as in the sunflower, it is a capitulum (Fig. 94), as seen in composite flowers. The flowers are called florets; those on the outer circle, ray florets; those in the center, disk florets.

130. You have now had described to you several forms of inflorescence: the cyme, umbel, corymb, fascicle, head, ament, glomerate, spadix, spike, raceme, panicle, thyrse, whorl, and capitulum.

131. You have now watched the plant in its growth from root to flower. You have seen the flower withering away, but you have learner that the fertilizing germ always remains. 'This is supported upon what is called the receptctcle, on the extremity of the peduncle.

132. The receptacle supports the fruit and flower, and the fact that it is a separate organ, and not merely the apex of the peduncle, is more obvious in compound flowers than in any other.

133. Take, for instance, the sunflower. Its receptacle

130. Recapitulate the various kinds of inflorescence that you have had described to you.

131. What is the extreme end of the peduncle called?

132. Is the receptacle a separate organ from the peduncle?

133. In what family of plants do we see this particularly plain? 
expands into a broad saucer-like flower containing the aggregate flowers and seeds of that well-known plant. This form of the receptacle is called common, indicating its office to numerous flowers and florets.

134. In the Indian corn it is a pillar or center column, upon which the staminate flower's and afterward the ripened grains are arranged. It is familiarly known to you as the $c o b$. This sort of receptacle is called columella.

135. In the nelumbium we have the receptacle extraordinarily developed, and filled with cavities in which the seeds are lodged.

136. In some plants the receptacle is hairy, as the thistle, or chaffy, as in the helichrysum (everlasting). Sometimes it is convex, sometimes conical, concave, spherical, etc.

\section{CHAPTER VI.}

\section{The Fruit.}

\section{Section I.-Pericarp.}

137. Is the description of the pistil you were told that the orary became the pericarp, and that all the innumerable forms of fruits, berries, nuts, etc., were the results of the changes that this organ undergoes in arriving at maturity. The pericarp always incloses the seed. It may be dry and thin, as the mustard; or thick and fleshy, as the pumpkin ; soft and juicy, as the tomato ; or hard and flinty, as the ivory plant.

134. Describe the colnmella. Where do you find this?

135. What of the receptacle of the nelumbium or water-lily?

136. Mention some of the appearances of the receptacle.

137. A matured germ consists of how many parts? Examples of the dry, thin, and fleshy? 
138. The pericarp is divided into three parts, the epicarp,

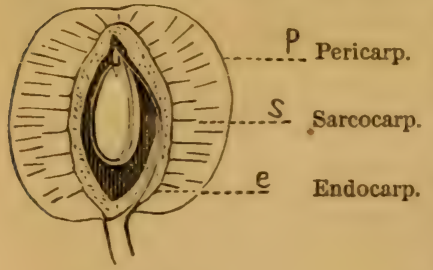

Fia. 95. or outer part, which in a fully ripe peach can be remored with your finger, as it separates easily from the next larger or midcle portion, which you eat, the sarcocurp. In the interior lies the endocarp, the stony seed.

139. When the ripened fruit remains closed after full maturity, it is said to be indehiscent, and when it bursts, dehiscent. Acorns, persimmons, haws, etc., are indehiscent, while peas, beans, okra, balsams, etc., are dehiscent.

140. The ralres of a pericarp are the dirisions or sides of the seed ressels. A pericarp without these dirisions is univalred, as the chinquapin, buckeye, olive, etc. If it is separated into two, it is a biralve (Fig. 96). If it separates into three, like the violet, it is trivalved (Fig. 97). The

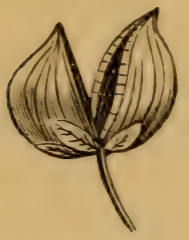

Fig. 96.

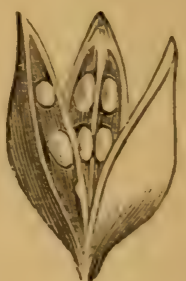

FIG. 97.

Jamestown weed has four, and therefore is said to be quadrivalved. Before the fruit is fully ripe, the ralres are joined together, and the line of union is called a suture or seam.

138. How many parts has the pericarp? That is the epicarp? The sarcocarp? The endocarp? In the peach, which is the first? Second? Third?

139. When the ripened fruit remains closed, what is it said to be? Then it opens?

140. What are the valves? When divided into three cells? Into four? How are the valves in partially ripe fruit? What are the lines of connection called? 
141. The column is the axis. In the orange it can be seen like a tough string of fresh pith running through the center, or like the core in an apple. When divisions, as in the orange, extend from the suture to the column, they are called dissepiments, and form the cells in which the seed are found; when they run lengthwise, they are called longitudinal, and when across from side to side, transverse.

142. Pericarps are further distinguished into drupe

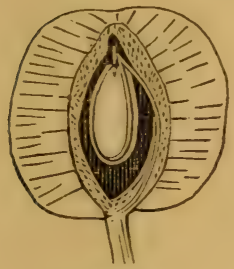

Fiต. 98.

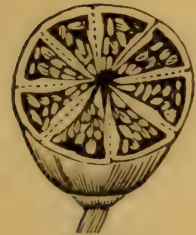

Fre. 101.

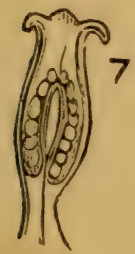

Fra. 104.

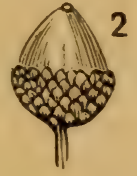

Fir. 99.

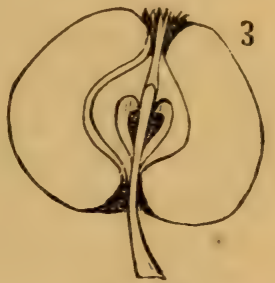

Fig. 100.

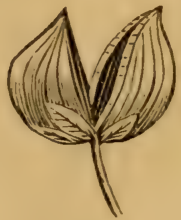

Frg. 103.

FiG. 102.

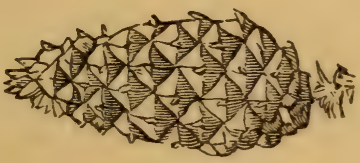

Fig. 105.

(Fig. 98), nut or glans (Fig. 99), pome (Fig. 100), berry (Fig. 101), pod or legume (Fig. 102), follicle (Fig. 103),

141. What is the colnmn? How in the orange? Apple? What are the sepa. rating walls called? When lengthwise? When crosswise?

142. How are pericarps further distinguished? What is a drupe? 
capsule (Fig. 104), strobilium (Fig. 105). The drupe is a juicy fruit, composed, as you have been told the peach was, of three parts, an epicarp, sarcocarp, and an endocarp.

143. The cocoa-nut is also called a drupe, because it possesses three divisions, though the middle one is not succulent, but a dry mass of woody fiber. The walnut and hickory-nut, though you know them under the name of nuts, are, properly speaking, drupes.

144. A nut or glans has a hard pericarp, one-celled, surrounded by bracts. The acorn is a nut. You perceive it has a hard shell-like skin or covering, that it has no dirision, and the cup of the acorn is covered with scales or bracts. The chestnut is a nut, and the bur is composed of bracts. You will thus perceive the difference, and will remember hereafter to distinguish between drupes and nuts.

145. The epicarp, sarcocarp, and calyx form the edible part of the fruit, while the endocarp forms the cells for the

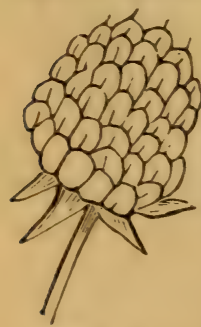

FIG. 106. seed; altogether they are called a pome. The apple, quince, and pear are pomes. The thickened and juicy calyx is the most important part of the apple. It is quite curious to observe this fruit maintaining the form of this organ, even presenting us the claws of the calyx at the top of the full-grown fruit. When the seeds are imbedded in a mass of juicy pulp, as in the whortleberry, gooseberry, tomato, grape, etc., it is called a berry. When single berries are clustered in a head, they are called compound, as the blackberry (Fig. 106).

146. The strawberry reverses the situation of seeds, and is not a berry at all, but seeds on a juicy receptacle. You

143. What is the cocos-nut? Hickory-nut? And why?

144. What is a nut? Example? What is the chestnut? What the bur?

145. What is a pome? Example? A berry?

146. What is a strawberry? 
will, perhaps, be surprised to hear that the orange and citron are berries; but if you will remember what constitutes a berry, seeds imbedded in a pulpy mass, you will immediately recognize them as berries, gigantic though they be.

147. A pericarp of two valves, that is, having

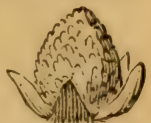

Fig. 107. only one suture, one cell, and one row of seeds, is called leguminous (Fig. 108): peas and beans are leguminous. A silique has two valves, two cells, and two rows of seeds arranged upon the membrane forming the divisions of the cells: mustard seed-pods are siliques. When this pod is very short and broad, as in the cat-bell, it is called a silicle (Fig. 110). A follicle is a pericarp of one valve, opening lon-

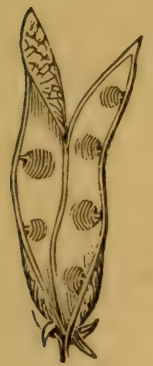

FIG. 108.

LEGUME.

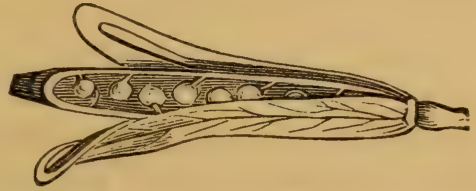

Fig. 109.-SEeds IN A Pod.

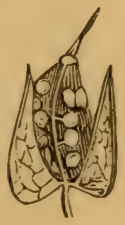

Fig. 110.

SuICLx.

gitudinally, with seeds lying loose within. The follicle may be simply one pod, or compound, two or many.

148. When the fully ripe pericarp opens by pores, it is called a capsule, as the poppy and hollyhock. The word capsule means box or chest.

149. The strobilium pericarp (Fig. 111) is a cone or spike with seeds inclosed by scales, each scale having covered a flower. A strobile may be regarded as an exaggerated ament or catkin, hardened into almost woody scales. The cedar,

147. What are leguminous sceds? What is a silique? A silicle? A follicle? 148. What is a capsule? Examples?

149. A strobilium? Examples? 
pine, fir, hop, cypress, etc., are examples. They are long in the pine, small in the birch, chaffy in the hop, round in

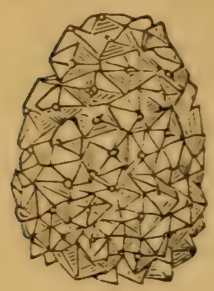

Fig. 111. the fir and cypress.

150. You will certainly be able to designate all the different rarieties of seed-ressels in the future. Botanists make other divisions, but we have considered those made by Linnæus a sufficient tax upon your memory at present, and you will please now repeat them: Drupe, nut or glans, pome, berry, Sтвовитум. pod or legume, follicle, capsule, strobilium. You will pause now a moment, and arrange in your minds the different organs in succession, and their various functions. The root, stem, bud, petiole, pedicel, leaf, peduncle, calyx, corolla, stamens, pistils, anther, pollen, germ, orule, ovary, receptacle, and the pericarp.

\section{Section II.-Seed.}

151. $\pi$ now come to the last and connecting link in the graud chain, the perfect orule, the seed. Here we see that "extremes meet;" for this crowning work, the product of all the other organs, holds within its narrow casket the root and germ of the future plant. Though it was born and bred in the sunshine, the rery child of light and air, yet, strangely incomprehensible, it has to go under the dark earth, and there in darkness and insstery the imprisoned plant is freed, and mounts in beauty to the upper air again, to perform the work alloted by the Divine hand that formed it.

152. Does not the language of St. Paul, in the sti 'ime

150. Hare botanists made other divisions? That of Linnæus' divisions? Name the different organs in succession.

151. What does this chain of organs now bring us to? And what axiom does the seed confirm? What mysterious change incomprehensible to the human mind now takes place ?

152. What use does St. Paul make of the seed in illustrating a more mysterious change? 
and beautiful comparison he makes between the mortal body and the seed, and the immortal body and the springing plant, occur with startling emphasis to your memory?

"'That which thou sowest is not quickened except it die: and that which thou sowest, thou sowest not that body that shall be, but bare grain, it may chance of wheat, or some other grain." So of the body: "It is sown in dishonor, it is raised in glory ; it is sown in weakness, it is raised in power; it is sown a natural body, it is raised a spiritual body."

Some of the sublimest lessons of truth and wisdom were taught by the Saviour and his apostles through the silent ministry of flowers, the lilies of the valley, the grasses of the field, corn and olives, figs and grapes. In these latter days, we find these "voiceless preachers" conveying promises and assurances that the wisest men have failed sometimes to enforce. There are limits to our inrestigations, points where we hear the voice that controls the waves, saying, "Thus far shalt thou come and no farther." We can talk much about the seed, and may feel wise and puffed up with our learning, until we come where mystery guards the principle of life. At this door we knock in vain for admission. Here human knowledge falters. However, with chastened, humble hearts, let us endeavor to learn all that science can teach us; and, remembering that revelation declares that every soul is responsible to God for every talent, strive to use our time conscientiously and profitably.

153. We already know that the seed is the perfected ovule, and in our conversations about the stamen and pistil, we described the fertilization of the ovule by the pollen tubes. When this is effected a marked change takes place, the ovule enlarges and changes from a semi-flnid into a solid body called the seed; and now, if cut into two

153. Under the microscope how does the ovule appear? What is this called? How many parts has the embryo? 
parts, and placed under a microscope, it will disclose the rudiments of the plant. This is called the embryo (Fig.

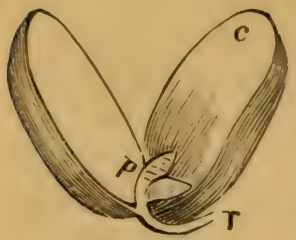

FIG. 112.

112). This embryo will be found to consist of three parts, the $(v)$ radicle, the $(p)$ plumule, and the $(c)$ cotyledon.

154. The radicle descends and becomes the root, the plumule ascends and develops into the plant (Fig. 113). The cotyledons are the first leares, and serve to nourish the young plant until the radicle has dereloped sufficiently to assume its duties of drawing nourishment from the soil for the growth of the

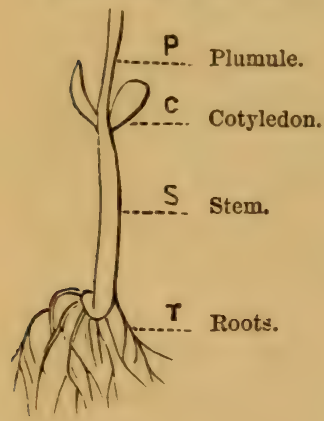

Fig. 113. plumule or plant.

155. Before proceeding farther, you must be told that the seed has three parts: the outer covering, coat, skin, or husk; the hilum or scar, made by the separation of the thread that fastened the seed to the seedressel or pericarp; and the kernel.

156. These parts can be plainly seen in the bean. In boiling, the skin or husk falls off; the hilum is what we call the eye, and the kernel

is the part we eat.

15\%. Albumen constitutes the greater part of the seed, and it is deposited around the embryo. In germination it becomes food for the young plant. It is the nutritious part of all seed, being flour in corn and wheat, the fleshy part of the cocoa-nut, oil in the palma Christi, and hard and bone-like in the regetable irory.

154. That is the radicle? The plumule? The cotyledon? Their growth, development, and uses?

155. How many parts has the seed? What is the husk? Hilum? Kernel?

156. In the bean how do these appear?

157. What constitutes the greater part of the seed? Where is the albumen deposited? Under what form does it appear in corn? Cocoa-nut ? Palma Christi? 
158. All young plants are supplied with this albumen either around the embryo or in the fleshy leaves of the cotyledons. When around the embryo, we say the seed is albuminous; when not there, that the seed is exalbuminous. We learned something about seed leaves in our talk about the stem, and you were told that endogenous plants had one cotyledon, exogenous two.

159. Now, when observing the embryo of these different classes, we find they are divided into plants having no seed leaves, and are therefore termed acotyledonous; those having one, monocotyledonous; those having two, dicotyledonous.

160. The acotyledonous are seen in ferns and mosses; monocotyledonous in grasses, yucca, sarsaparilla, pine, spruce, etc. ; dicotyledonous, oak, orange, beans, peas, etc. ; polycotyledonous, pine, spruce, arbor vitæ, etc.

161. Seeds, like stems and leares, are sometimes furnished with appendages that constitute very marked characteristics, and should always receive our careful attention in observing them for classification. Some seeds are inclosed in a thin, dry, indehiscent covering; and these, to distinguish them from other forms of indehiscent pericarps, are called achenium (plural, achenia). The achenia are more frequently furnished with these appendages. Sunflower, lettuce, maple, elm, blue milkweed, are all achenia. In the clematis we find this organ adorned with a soft fringelike plume. The dandelion has a pappus, or feather crown, connected to the achenium containing the seed by a stipe. This is also called an aigret.

162. When the aigret springs from the seed or achenium

158. What are all young plants supplied with? Where?

159. How are embryos divided ?

160. What is an acotyleclon? Monocotyledon? Dicotyledon?

161. Are seeds ever furnished with appendages? Clematis? Dandelion? What is a pappus ?

162. When the aigret springs from the seed without a style or stem, what is it said to be? When the hairs are not branched? When hairs are branched, that is, other hairs arranged on the primaries, what do we call it? 
without a stipe or stem, it is said to be sessile. If the hairs are without branches they are simple, if other hairs are ar-

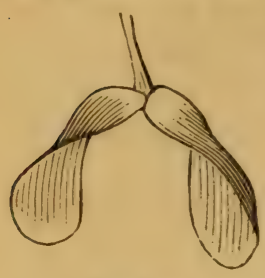

FIG. 114 . ranged on the primary ones they are plumose. Pine and maple have a scalelike appendage called a wing (Fig. 114).

163. The seed of the cotton plant is entirely covered with long hairs called coma. Willow and poplar are also covered with coma, but it differs from that of the cotton plant in being short and brittle.

164. These appendages are not placed upon seed accidentally or for no obvious use-far from it. These wings,

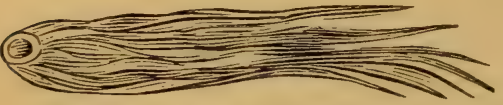

Fig. 115.-Coma of Cotton Plant.

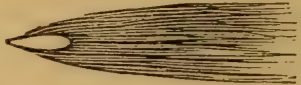

Frg. 116.-Coma of Cotton Tres.

plumes, trains, coma, scales, and aigrets, are so many balloons, ships, carriages, or expresses, for the safe transportation of seed through the air, down the rivers, over the mountains, and across oceans, dispersing vegetation over the face of the earth. Have you not often seen our rivers white with the soft down of the cottonwood seed, and in a few weeks after beheld a barren sandbar or a "new bank" come out in a dress of green verdure that rivaled in beauty and freshness the grassy prairies of the upper table-land?. Well, in a few years you may find those same spots groves of stately cotton-trees! Those sandbars would never have received their garments of green without the friendly office of these traveling seeds. Well, what you have seen one kind of winged seed doing for one spot, is what the myriad seeds are doing for the whole globe, causing the barren places to rejoice and the desert to bloom

163. What is the appendage of the cotton seed called?

164. Are these things accidental? What are their uses ? 
like a garden, dispersing plants that would otherwise remain only in certain localities, leaving other places poorer for their absence.

\section{CHAPTER VII.}

\section{Germination.}

165. Although nearly all that you shall learn in this chapter has been detailed to you in the previous chapters, yet for the sake of clearness, and your perfect understanding of the process of germination, we will dwell a little more upon how the principle of life seems to awaken into activity; and the result, as exhibited in the various transformations and developments of the parts of the seed.

166. There are three things necessary for germination, and these three are heat, water, and air. If a seed is exposed to moisture without heat, it decays; if you give it heat without moisture, no change takes place unless the temperature be very high or long continued, when it loses its vitality. You may give it all the other requirements, and yet without the proper quantity of air, or, more properly speaking, oxygen, the result will be the same-no germination takes place.

167. When the requisite agents are present the seed swells, bursts the outer covering or coat; the radicle first makes its appearance and strikes downward; the cotyledons arise and expand; the plumule next is seen issuing from between the cotyledons, and arising upward.

165. Subject of this lesson?

166. How many things are necessary for germination? What if a seed has moisture without heat? Heat without moisture? Heat and moisture without air, or rather oxygen?

167. When all are present? Describe the change that takes place. What appears first? The next, etc. ? 
168. It is during the earliest stage of germination that we discern the important office of oxygen. It unites with the carbon of the plant and passes off as carbonic acid gas, diminishing the carbon and leaving an excess of oxygen, which now busily employs itself converting the amylaceous (starch) contents of the seed leaves into sugar, food for the future plant. When this is prepared the plant develops into life.

169. It is not by the direct agency of oxygen, though it is the leading power, if we may so express it, that converts the starch into sugar. Neither is this conversion confined to seed leaves, but is performed in tubers, as in the potato, etc. The agent for this transformation is originally oxygen, but that, uniting with the nitrogen and carbon of the plant, creates another substance, a sub-agent, known in chemistry as diastase. It seems to have no office save this, and is found only in one situation, immediately in the passage between the cotyledon and the germ; and in tubers, only at the very base of the eye or sprout.

170. It exercises no influence other than that above mentioned; but chemistry has revealed to us few more powerful agents, converting as it does two or three thousand times its own weight of starch into sugar, for the growing plant. If you have not studied chemistry, I hope you will very soon, for you will thereby gain a more perfect knowledge of this important agent and its offices to the plant, and also of what I shall further relate to you concerning the chemical process of germination.

171. Carbon, of which the greater part of all the sub-

168. What do we discover in the earliest stages of germination? With what does the oxygen unite? Forming what? What becomes of the excess of oxygen resulting from the diminution of carbon? What does amylaceous mean?

169. Is it by the direct agency of oxygen that sugar is formed? What is this sub-agent called ? Where is it found? Has it any other office or situation?

1 70. Give me a proof of its power. What study is necessary for the perfect comprehension of this subject?

171. Of what is the greater part of seeds composed? To what is carbon opposed? Why does a bousekeeper put up her vegetables in salt ? 
stance of the seed is composed, is the great principle in nature opposed to putrefaction. In common parlance, it is antiseptic. When the housekeeper wishes to preserve green cucumbers, etc., she packs them down in salt. Salt is antiseptic, and prevents these things from fermenting and decaying. When she is ready to make them into pickles or sweetmeats, she soaks them in water to remove the salt, preparatory to converting them into agreeable articles for the table.

172. Thus is given you a very homely but familiar comparison to make you understand that carbon is the strong anti-putrefactive principle in nature, and that the seed, being almost all carbon, is on this account preserved from decay; and that nature, like the housekeeper soaking her fruits in water to remove the salt, must put her seed into some situation where this superfluous carbon shall be removed.

173. You know seeds differ greatly in the duration of time they observe between perfecting and germinating. Some actually sprout while yet in the pericarp, as the wellknown epiphyte, love-vine. Some retain the living principle only a few months; others years, as the olive, peach, etc.; and some varieties of the grasses and grains will continue centuries without losing it. Chemistry informs us that these differences are due to the quantity, greater or less, of carbon in the seed.

174. You will now perceive how indispensable is oxygen, as it alone has power to combine with the carbon. It thus forms carbonic acid gas, which is immediately conducted. off. But after life is awakened it forms diastase for the nourishment of the plant. This diastase converts the

172. Why does Nature pack seeds in carbon? What then becomes necessary for their germination?

173. Do seeds differ in time of germination? These differences are due to what ?

174. What does oxygen do? The remaining oxygen unites with what to form diastase? And diastase does what? What becomes of the sugar? 
starch into sugar, upon which the young plumule feeds until the root has become long enough and strong enough to draw up nourishment from the soil for the growth of the plant. It is not necessary that you should be told more about this subject now, as you would need preparatory studies to understand it.

\section{CHAPTER VIII.}

\section{Simple Organs.}

175. We will now take a peep into Nature's workshop, and see of what materials she forms those compound organs, roots, stems, leaves, and flowers, of which we have been learning.

176. You know of your own observation that vegetables are composed of fluids and solids. You can take a young sprout of pokeweed and crush it in your hand, or watch the sugar-cane as it goes under the crush-wheel, and you will perceive that a quantity of fluid will be pressed out, leaving a mass of pulp and fibrous substance. A tree, when first felled, will be found to contain much moisture. This may be seen exuding from the pores in drops eren in winter, and in the spring flowing almost in a stream. Thus practical every-day obserration will teach you the first lesson on this subject, that is, that vegetables are composed of solids and fluids.

177. For the next step, however, the microscope must be called into requisition. By its magical power we shall

175. What do we now take under consideration?

176. What does common observation teach us?

177. What does the microscope terch us ? The solid parts of vegetables are composed of what? 
see that the solid parts of vegetables are composed of a substance called by the common name of tissue.

178. Tissue is divided into three kinds: cellular, woody, and vascular. Cellular tissue is the fleshy part of fruits, leaves, etc. It is composed of little cells, which adhere together in very different degrees of closeness, sometimes so loosely as to be easily separated from other parts, as in very ripe fruits, the orange, for instance; and sometimes cohering so firmly as to resist even the powers of an ordinary magnifying-glass to demonstrate that it is not simple membrane.

179. Each cell is a little bag containing a liquid in the early stage of its formation, but, changing with the growth of the plant, it becomes firm, as in the wood of trees; dry and inelastic, as in the lamina of the leaf; hard, as in the shell of nuts; sweet in the watermelon and sugar-cane, acid in the lemon. Coloring matter is also deposited here, and we have the blue violet, the red rose, the golden sumflower, and the many-colored morning-glories. Here, too, is deposited the material for the food of man, the amylaceous material that makes the edible roots; the substance for bread, as found in corn, wheat, etc.; the flour-like deposit in the leguminous tribes.

180. If you cook an Irish potato over steam until it bursts open, you will see a mealy mass, which under the microscope comes out into regular bags or starch grains. This is simply the cellular tissue distended to an unusual size by the action of heat.

181. In the quince and guava, little grains, hard like seed, are found in the cellular tissue of the fruit. These

178. This tissue is divided into how many kinds? Where is cellular tissue found?

179. What is each cell? How does it change with growth? What is deposited here? Where is coloring matter deposited? Where food material ?

180. What causes a cooked potato to appear mealy?

181. What are those hard particles found in the quince and guava? What elsa does sclerogen form ? 
are produced by the deposit of sclerogen, and this is the substance that forms the peach-stone, cherry-seed, etc. Professor Lindley demonstrated concerning cellular tissue that it has the power of reproducing itself. He estimated the production of mushroom cells to be at the rate of four billions per hour.

182. These cells are not always the same shape or size. Sometimes they are like honeycomb. You find leaves, pith, and most kinds of fruits presenting this form of cell. Again they are arranged in parallelogram form, like bricks in a wall, and are therefore called muriform; they are also egg-shaped, and sometimes round, looking like a pile of balls.

183. Among those cells other little organs or cells are sometimes found. They are called receptacles of secretion. Here are found oil, as in olive, myrtle, and orange; turpentine, as in the pine and fir; coloring matter, as in woad, logwood, and madder.

184. You were told just now that these cells looked sometimes like balls piled one upon another, as you see cannon-balls in forts and arsenals. In these the interstices, or openings between, can be easily enough seen. These cells, whatever their shape, have cavities, which are called intercellular passages, and are filled with fluids. They communicate with the open air through the pores that you have been told cover the epidermis.

185. Cellular tissue decays early, as you will perceire in fruits and the lamina of the leaves; while the seed of the fruit and the veins of the leaves, being formed of a firmer

182. Are these cells always shaped alike? Where do you find them shaped like honeycomb cells?

183. What is found among these cells? What are they called? What is found here?

1 S4. Are there cavities in the cells? What are they filled with? How do they communicate with the outer air?

185. Does cellular tissue decay early? What of woody tissue ? What of the bundles of tubes? With what were they a long time confounded? What has the microscope demonstrated? What are they? 
texture, resist decay for a much longer period. This firmer part is called woody tissue, and consists of bundles of cylindrical tubes or cells, of great length and toughness, tapering at both ends. 'These are so minute that for a long time they were confounded with fiber, but microscopic investigation has demonstrated that beyoud a certain point they cannot be divided, and that each of them is a perfect and complete cylindrical tube, tapering at both ends, and overlapping and adhering to each other.

186. Here sclerogen is deposited, giving durability, hardness, and elasticity to the plant or tree. Woody fiber is as indispensable to trees as bones are to the bodies of animals.

187. In their early stage these woody fibers serve as channels for the ascending sap; but as their cavities become filled with solid matter, and are rendered dense and firm, their developed uses unfit them for any secondary work. They then only give strength and durability to the plant. There is a third tissue, called vascular tissue, which consists of hair-like tubes coiled spirally, and inclosed in an external membrane.

188. In their normal condition they are coiled up like a corkscrew, but they may be drawn out to a great length. If you take a young shoot of hop-vine or pokeweed, and bend it down first on one side and then on the other, until the outer skin is broken, and then draw the pieces gently asunder, these spiral vessels may be plainly seen with the naked eye. Such spiral vessels abound where great elasticity is needed, as in the tender shoots of young plants, the leaves and flowers, the petioles and peduncles.

186. What is deposited here? Its uses? Is woody fiber indispensable to trees?

187. What do they serve in their earlier stages? Does it continue this office? What is the third tissue called? Its constitution? Its appearance?

188. What of its normal condition? What is it capable of? Example? Where do spiral vessels abound ? 
189. Some botanists style them air vessels, because they contain air; but as investigation has proven them to contain fluids also, this term cannot be considered strictly correct. Their offices have been as much a matter of discussion as their name. Some affirm that they are breathingtubes; others, that they conrey fluids to recently developed tissues. Darby believes that both these theories are true, that in their earliest stage they contain fluids, and in more adranced age, air. Chemical analysis has proved this air to contain seven or eight times more oxygen than the air we breathe.

190. If you cut a stem of water-lily under water, air will be seen rushing up in great bubbles to the surface. The most important functions that these ressels thus far are known to serve is the protection of the plant in the earliest stage of development. No other form of vessel could so preserve the plant from the injurious effects of wind and rain as this spiral tube, which abore all other forms combines the great requisites of strength and elasticity. There is another tissue which consists of minute tubes connected with each other, forming a network of branching veins. It extends throughout the plant, but is more abundantly developed in the liber of the bark. It is called lactiferous tissue, from the Latin lac, milk, because it contains the mucilagenous substance called latex, the milky juice of the plant.

191. Botanists disagree as to the character of this fluid, some consider it highly elaborated sap; others, that so far from being sap fit for the use of the plant, it is a substance eliminated totally unfit for use. It is this fluid that exudes from fig stems when you pluck the unripe fruit, and is seen in abundance in the euphorbia on our prairies.

189. What do some botanists call these vessels? Why? What are the theories respecting them? What does Darby say?

190. If you cut a stem of the water-lily, what will you see? What has an analysis of this air shown? What is the most important function of these tubes? Is there another tissne? Describe it.

191. Do botanists disagree concerning this flnid also ? 


\section{CHAPTER IX.}

\section{Miscellaneous Vegetable Phenomena.}

192. You would, perhaps, if asked what constitutes the difference between regetables and animals, say boldly that they differ every way, that there is no resemblance; but you would commit a grave error by such a declaration, for in some particulars there are points of great resemblance, which resemblances increase to such a degree as you descend the scale of vegetable and animal existence, that at last you arrive at a point where the greatest wisdom and discrimination is necessary to say correctly to which organism the thing under examination belongs, vegetable or animal.

193. But higher up in the scale of complete vegetable development we also see these wonderful analogies. Thus we say in general that plants have no stomach, and yet that wonderful flower, the catchfly (Dioncea muscipula), not only catches flies, but digests them, as it will bits of meat. In fact, animal food is necessary for its nourishment. This is proved by placing a net over it so as to shut off its insect dinner. The poor, starred plant will soon sicken and die. We again say that plants are fixed and have not the power of motion, but the duck-meat and the fresh-water sailor rise from the muddy soil below to float upon the surface, and again sink when their health or comfort require the change.

194. The mimosa is very sensitive, shrinking from the slightest touch. Darwin, in his beautiful yet absurd poem

192. Is there any resemblance between vegetable and animal life? How as you descend the scale?

193. What can you say respecting the phenomena of the catchfly? Are there plants endowed with powers of locomotion?

194. What of the mimosa? Repeat Darwin's lines. 
of the "Lores of the Flowers," claims that the mimosa knows even the approach of rough weather:

"Weak with nice sense the chaste mimosa stands, From each rude touch withdraws her timid hands; Oft as light clouds o'erpass the summer glade, Alarmed, she trembles at the morning shade, And feels alive through all her tender form The whispered murmurs of the gathering storm."

195. If you but touch the pericarp of the balsam it bursts, scattering its contents in the most irritable manner. The Desmodium gyrans possesses the most remarkable powers of spontaneous morement. Its branchlets sometimes moving together, then again one solitary leaf, then two or more, then perfect quiet will reign, perhaps to be broken by every leaf from base to apex putting themselres into the most diverse and fantastic motions. Plants also sleep, particularly those belonging to the pinnate leaf tribe so common in Louisiana and Texas. Some exhibit this peculiarity much more than others. The retama and weesachie, for instance, seem to sink to rest at night, and arouse to life again with the morning sun.

196. In witnessing these various phenomena so analogous to similar exhibitions of animal life, we sometimes feel almost inclined to fall into Darwin's theory, that plants hare a nerrous system similar to that in the animal economy. He goes farther, and compares the sap to the blood, pores to lungs, spongioles to mouths, woody tissue to bone, cellular tissue to fiber, pith to marrow, etc. But this is fauciful and overstrained. Botanists of later days have rejected all such theories, and place these regetable phenomena under the general head of irritability. This they refer to three heads, as it is produced by the atmosphere,

195. What of the pericarp of the balsam? The Desmodium gyrans? Of other plants?

196. In witnessing these phenomena, what are we inclined to do ? Where do botanists place these phenomena ? How divided? 
by the touch, or by some unobserved force. We know of no satisfactory theory to account for these demonstrations.

197. Linnæus formed what he called a floral time-piece. It was made of those flowers which open and close their petals under atmospheric influence. Each hour was represented by a flower that expanded or shut up at that particular time.

198. We have many flowers in our gardens that are thus affected. The portulaca opens at sunrise and closes at $12 \mathrm{M}$; the marvel of Peru at 4 o'clock P.Mr.; the nightjasmine at 8 P.M., and is deliciously fragrant until sunrise, when it closes and is entirely scentless. The nightblooming cereus is another well-known night-bloomer.

199. De Candolle, noting the time that flowers bloom in Paris, arranged a floral clock, which you can take a hint from and arrange one of Southwestern flowers. We have a number of those that you will find in this "clock." Here is the list, and their hours of expanding:

Between 3 and 4 A.x. Bindweed of the hedgerows.

At 5 A.M. Naked-stalked poppy and most of the cichoracæ.

Between 5 and 6 A.x. Nipplewort and Day-lily.

At 6 A.M. Many of the Solanaceæ (nightshade family).

Between 6 and 7 A.r. Snow-thistle and spurry.

At 7 A.M. Water-lilies and lettuces.

At ' 7 and 8 A.r. Venus' looking-glass.

At 8 A.M. Wild pimpernel.

At 9 A.M. Wild marigold.

At 9 to 10 A.M. Ice plant.

At 11 A.M. Purslain, star of Bethlehem.

At 12 M. Most of the mesembryanthemum family.

197. What did Linnæus form from a knowledge of the atmospheric effects upon the expansion of fluwers?

198. What flowers in our gardens are thus affected?

199. What did De Candolle arrange with flowers ? 


\section{At 2 P.м. Scilla pomeridiana.}

Between 5 and 6 P. M. Silene noctiflora.

Between 6 and $\%$ P.M. Marvel of Peru.

Between 7 and 8 P.x. Cereus grandiflorus, night-blooming cereus.

At 10 P.s. Purple convolvulus.

You will be interested in noting the fact that the same flower expands at different hours here and in Paris. Owing to the excess of light and heat enjoyed on the Western Continent, they expand an hour or two earlier than the time noted by De Candolle. But to resume the subject of vegetable phenomena:

200. The color of plants is supposed to be owing to a substance called chromule, and that the variety of hues is formed by the action of alkalies and acids on this chromule. This substance is pure carbon, and is deposited in minute grains in the resicles of cellular tissue. Light being necessary for the deposition of this substance, plants growing in dark places are nearly colorless.

201. Plants have been formd in deep mines, howerer, that were green, though they had never seen the light. A great many theories have been adranced to account for the variety of hues in leaf, stem, and flower.

202. "Macquart supposed it was owing to the rarious modifications of chlorophyle being converted into two distinct substances on the addition or abstraction of water." -Darby.

203. 'The coloring matter obtained from rarious plants is of the greatest value in arts and manufactures. Madder, saffron, oak, logwood, woad, indigo, give us the red, yellow, brown, black, and blue dyes of commerce. These in all

200. To what is the color of plants ascribed? What is this chromule? Where deposited ? What of plants growing in dark places?

201. What of some plants fonnd in mines?

202. What did Macquart suppose?

203. Of what value is the coloring matter found in plants? Examples? What do they require? What is a mordant? 
cases require a mordant to fix them, that they may not be removed by washing. A mordant is any substance that will unite with the coloring matter and with the fabric that is to be dyed, and hold them united. We speak of it in common conversation as setting the dye, to prevent its fading.

204. Besides the exquisite beauty of form and color, Nature has furnished plants with perfume as raried as the forms and hues of the corolla. The rose, violet, mignonnette, lemon, verbena, weesachie, and a thousand others of the flower garden and the lawn, owe their chief attraction to the odor that distinguishes them.

205. These perfumes proceed from oily or resinous matter contained in the receptacles of secretions. But how they are liberated baffles investigation.

206. Odors are of three kinds, permanent, fugitive, and intermittent. Permanent odors are such as give out slowly, and not only when living, but when separated from the plant. They are more generally present in the wood and bark, as the sandalwood, sassafras, etc.; also in some flowers and plants, as the rose, lavender, sweet clover, etc. Fugitive odors are those that belong to transient organs, such as leaves and flowers. These odors vary also with the hour of the day, being generally stronger in the morning and erening than at midday. This of course is easily explained. The heat dissipates the odor by excessire eraporation; this being suspended in the evening, the perfume accumulates, and when again rising is of course stronger. Also at midday the current of air being upward, the odors are wafted rapidly beyond us, while in the evening the vapors settle, preventing their escape.

207. Intermittent odors are more difficult of explanation.

204. Have plants any other attraction besides form and color ? Odors proceed from what?

205. Where is the oil and resin deposited? Is the process of liberation known?

206. How many kinds of odors are there? Describe them.

$\mathbf{2 0 7}$. What of intermittent odors? 
It seems evident that their generation must be like their emission, periodical ; but further than this no satisfactory theory has been given. The law that controls them is hid from us. Of course, various theories have been suggested. The effects of solar light and heat, or its absence, and certain atmospheric conditions, have been referred to as causes. Some have supposed that intervals of fragrance were caused by the respiration of plants.

208. We heard of the night-jasmine and its periodic odor in our conversation about night-blooming flowers. The day-jasmine, an equally familiar plant, noted also for its intermittent odor, is quite scentless at night, but deliciously fragrant in the day. The magnolia glauca gives out great waves of perfume at irregular intervals.

209. No satisfactory theory has yet been presented to account for these phenomena. To account for the other properties, taste, texture, etc., is a much easier task. You know that the flavor of vegetables raries with the modes of culture. Not that cultivation will make a tomato pungent like a pepper, the aloe sweet, or camomile sour. The nature of the plant is fixed as to taste or odor, but the manner of culture very materially governs quantity. Every child who has cultivated his little "patch" of sugar-cane knows that if he wants sweet cane he must have it grow in the sunshine.

210. The influence of light and heat, then, is to intensify the peculiar properties of plants. Consequently the absence of these two solar influences will diminish them. Celery, when perfectly dereloped, is a pungent, disagreeable plant. When its pungency is decreased by the absence of light, the aromatic property is subdued into a delicate flaror that makes the plant an agreeable salad.

208. What is said of the night and day jasmine? Magnolia glanca ? 209. Has any satisfactory theory been given of these phenomena?

210. What is the effect of light and heat on plants? Example? 
211. The peculiar property of the cane is sweetness; if grown in the shade it is insipid and watery, and not much better than a corn-stalk. By the influence of light and heat its saccharine properties are fully developed. Thus we see that the sunlight makes the aloe more bitter, the cane sweeter, the lemon sourer, the melon more juicy, the pepper more pungent, the vanilla more fragrant, the grass greener, the wood harder. I have told you that cellular tissue decays rapidly; so does the timber when this predominates.

212. As light increases the growth of woody tissue, so darkness develops cellular; consequently the mushroom, which is composed entirely of cellular tissue, grows only in the night; though it will never develop spores, or seed vessels, without the agency of light.*

\section{CHAPTER X.}

\section{Food.}

213. You have been told that the organs of nutrition were the spongioles and leaves. The former take up food from the earth, converting solids into fluids, which, mixing with the sap, is conveyed to all parts of the plant, while the leaves take in through their pores gases and

- What influence this fact has in the common practice of planting certain crops in the in: crease of the moon, and others in the decrease, may possibly be worth investigation.

211. Give some examples of the effect of sunshine in developing peculiar properties.

212. What tissue grows best in darkness? Will mushrooms develop sporee (seeds) in the dark?

213. What have you been told of the organs of nutrition ? 
moisture from the atmosphere. These meet and combine with the various substances brought up by the ascending sap, and are assimilated for the growth of the plant.

214. There are four elements necessary for vegetable life, carbon, oxygen, hydrogen, and nitrogen. Being a solid, carbon has first to be united with oxygen and converted into carbonic acid gas, before it can be taken up by the plant. Oxygen is also absorbed from the atmosphere in combination with nitrogen. Hydrogen is obtained in the same way from the atmosphere, and also in combination with water from the soil, or in union with ammonia.

215. You were told, in our conversation upon the stomata, how those breathing pores enable a plant to get rid of its superfluous gases and moisture. It is in this way a plant disposes of an excess of oxygen. You were also informed that a great deal of oxygen was required to convert carbon into such a form that the plant could use it. Now, when it has assimilated the carbon, the oxygen is liberated and finds its way again to the atmosphere through the spiral vessels which conduct it to the stomata, and through them to the air.

216. An excess of carbon is deleterious to animal life, while oxygen is necessary to it; and we see the wisdom of the great God in making these two great supporters of life mutually balancing and counteracting each other, the vegetable kingdom throwing out just what will promote animal life, and absorbing all that would be deleterious, while the animal kingdom throws off what the plant needs. As light is necessary for the decomposition of carbonic

214. How many elements necessary for vegetable life? What are they? How is carbon rendered fit for vegetable food? How is oxygen absorbed? How is hydrogen?

215. What are the nses of the stomata? Why is oxygen in such an excess in plants?

216. How do the two kingdoms, regetable and animal, balance each other? What is necessary for the proper analysis and assimilation of carbonic acid gas? When does this take place then? 
acid gas, and the plant's healthy assimilation of carbon, it is during the day that carbon is absorbed and oxygen liberated. There is no chemical action of plants at night. Sunshine is necessary for their work. The night, therefore, brings to them that rest which it does to almost all animated nature.

21\%. Besides these four primary organic elements, plants absorb various substances from the soil, as sulphuric acid, magnesia, potash, lime, alumina, chlorine, iron, etc. These are converted into liquids by the action of spongioles, so as to enable the plant to draw them up in the shape of sap.

218. The process by which the plant then assimilates this food thus prepared is called chemical action, differing, however, very materially from inorganic chemical union, inasmuch as no art has been able to imitate it, requiring as it does the action of life.

219. A chemist can analyze a glass of water, and show you the two gases, hydrogen and oxygen, in their original elementary form; he then can recombine them and present them to you again under the form of water. The same chemist can take a plant, and in his laboratory reduce it to its component elements, and tell you to a fraction what gases, liquids, solids, acids, alkalies, etc., and in what quantities, enter into its composition. But this is all he can do. He cannot convert them back into a plant. This can only be accomplished through the mysterious agency of what we call the principle of life, the secret of which is hid from us in a cloud of impenetrable mystery. You see that organic chemistry requires the action of living organs, while inorganic chemistry combines its elements by a

217. Besides the four elements, carbon, oxygen, hydrogen, and nitrogen, what other substances do plants absorb ? and how ?

21 8. How does organic chemistry differ from inorganic?

219. Tell me what a chemist can do with a glass of water. Can he do the same with a plant? Why cannot he make a plant if he has all the component parts ? 
power we call chemical affinity. Perhaps I should explain to you the meaning of the word assimilation.

220. It is a term used to express that process by which different substances are converted into a common substance suitable to the organism of the individual. Thus food assimilated by a plant becomes a part of the plant; just as the food you eat is assimilated or converted into the material that makes blood, which replaces the wasted tissues of your body. You now understand a little of the difference between organic and inorganic chemistry, and how the assimilation of food is performed by what we term organic chemical action, that is, it is accomplished by living organs, the spongioles, as before explained, having the power of converting inorganic substances, such as lime, potash, iron, magnesia, ammonia, etc., into liquids, combining them with the organic elements, oxygen, hydrogen, carbon, and nitrogen, and assimilating the whole into food necessary for the growth and perfection of the plant.

221. If you are curious to know how much inorganic matter is taken up by a plant, sweep your hearth clean, and burn upon it a log of oak or a branch of ash, or simply a bunch of grass: the organic substances will escape in the form of smoke, vapor, and invisible gases into the open air, while the inorganic earthy substances will remain upon the hearth in the form of ashes.

222. If you burn rushes or reeds, you will probably find quite a quantity of small shining particles in the ashes; this is silica. These little roots, you think, must possess astonishing power to be able to convert silica into a liquid, carrying it up, and covering the whole stem with it. When you have studied chemistry, you will learn that silica is an acid, and thus combines with the alkalies, soda and potash,

220. What is the meaning of assimilation? How is this performed?

221. How can you form some idea of the quantity of inorganic substances in \& plant? What do you find in the ashes? What has become of the gases and vapors?

222. What of silica? Raphides? Where found? 
in the soil, and, being dissolved by the rain, is taken up in a fluid state by the plant as silicate of potash or silicate of soda. The microseope has discovered it in the form of a perfect wall of exquisite masonry of crystals or raphicles, from the Greek, raphis, a needle. 'This gives the graceful cane its strength, and enables the slender wheat and barley stems to bear upright heary heads of grain.

223. The Dutch rush contains such an amount of these raphides, that before the invention of sand-paper, it was extensively used in the arts for polishing purposes. It is stated on good authority, that reeds, during hurricanes in tropical regions, have been set on fire by the friction of the stems striking and lashing each other, owing to the superabundance of silica (flint) in them.

224. You have been told of the food of plants, how absorbed, and how assimilated. The sup is the medium by which this food is conveyed, in spring-time, through the wood to the remotest branches of the trees, and continues to rise until the leaves fed by it are developed into organs competent to perform the functions of absorption, elaboration, and exhalation. Then the sap descends slowly and through another set of vessels to the root again, taking out of the plant all extraneous and useless matter not expelled through the epidermis of the bark and leaf.

225. It is called, in its first morement, ascending sap or lymph; when flowing downward, descending sap or juice. 'The lymph is thin and watery, possessing no peculiar characteristics, being perfectly innoxious even in poisonous plants. There is a plant in the Canary Islands whose copious ascending sap is freely drunk by the thirsty traveler, while the descending sap of the same plant is a deadly poison. The ascending sap goes up with wonderful force.

223. What of the Dutch rush? What of reeds in tropical countries?

224. What is the medium through which food is conveyed?

225. What is the ascending sap called? and through what vessels does it go? What course does the descending sap take? and what is it called? Does lymph possess any peculiar properties? 
226. The experiment made so often by school-boys on mustang grape-vines will give you some idea of the quantity of sap and the power with which it is propelled upward. A branch is chosen, say an inch in diameter, and cut off four feet from the ground; over this the neck of a bladder is stretched and secured firmly by a rosined thread. In a few hours this bladder will be full of sap, and soon it will burst into shreds with an explosion like that of a pistol.

22\%. The force with which sap ascends has been estimated to be five times greater than that which impels the blood in the great crural artery of the horse. After rising to the leaves, exhaling through them superfluous moisture, exchanging gaseous compounds, yielding up some, receiving others, it commences its downward motion, and is now true sap, containing all the peculiar products of the plant, gums, resins, oil, milk, and mucus.

228. Its principal flow is now through the bark, though it spreads horizontally also. It makes a deposit of tissue for a new laver of wood, and continues downward, hardening the root by deposits of various matter. It adds fresh cellular tissue to the extremities to form new spongioles, converting them into epidermis.

229. We thus see each year a new layer of wood and bark deposited; the soft wood of the year previous becoming harder and firmer from the deposit of sclerogen and other substances left by the descending sap. Some approximation may be made to the age of a tree by counting the number of rings the yearly sap deposits in a transverse section of its trunk.

226. What of the grape-vine experiment?

227. What is the ascending force computed to be equal to? Describe its action after it reaches the leaves.

228. Where is the principal flow of the sap after it reaches the leaf? Is it confined entirely to the bark? Describe its further downward flow.

229. How does soft wood become hard? How can you judge the age of a tree? 
230. Many theories have been advanced to account for the motion of the sap, all of about equal consideration. Some attribute it to evaporation through the leaves, others to capillary attraction, others to vital action. I confess that no theory that I have ever seen satisfactory explains this circulation. All are plausible up to a certain point, when some stubbon fact intervenes and checks one's pride of opinion as effectually as a frosty night does the flow of sap. To the one mysterious power, vital action, must the phenomenon be ascribed.

231. You have now been told of the sap and its offices. Let us take a hasty glimpse at some of the substances elaborated by it. The first in importance is starch. How important can be imagined when I tell you that more than one-half of the human family live entirely upon it in its various forms. Here we also find sugar, gum, oil, wax, resin, mucilage, alkaloids, narcotine, morphine, cinchona, iodine, potash, soda, and poisons, both narcotic and acrid.

232. The sap elaborates all these, but certain cells are formed which secrete from it some of these substances; others seem to be thrown out from the sap as excessive; and hence we divide them into two classes, calling the first secretions, and the latter excretions. Sweet-gum (Liquidamber, styracifua) is an excretion of the sweet-gum tree, while tannin in the red-oak (Quercus ruba) bark is a secretion.

233. We have now in discursire chapters learned of various vegetable phenomena: such as the irritability of plants; their color; their permanent, fugitive, and intermittent odors; the influence of light upon tissue; the properties and longevity of plants; of their food, organic and inorganic,

230. Has any satisfactory theory been advanced to account for the upward flow of sap? To what must we ascribe it?

231. Tell some of the substances eliminated by the sap. Where are these found?

232. What are the two kinds of cells called? Sweet-gum ? Tannin?

233. What have you now learned? 
its assimilation; of ascending and descending sap, and its elaboration and deposit of secreted and excreted substances. We will now take up a subject that will give a long name to the next chapter.

\section{CHAPTER XI.}

\section{Metamorphosis.}

234. THE metamorphoses of plants may be explained to be the changes that take place in the organs during growth, in respect to form, color, size, etc., and the incidental changes from exceptional circumstances, as culture, excessive or deficient nourishment, etc., that may arise in the organs. In their normal state all flowers are single, and are made otherwise by cultivation. This is effected by the conversion of stamens into petals.

235. You sometimes see a full-blown rose with a perfectly green unexpanded flower-bud in the center where the stamens and pistils should be. The common honeylocust in an early season will put out fresh young branches. If the season is invaded by the return of cold winds and frosts, followed by drought, these tiny rudimentary branches lose their leaves and become thorns. It may be, in a year or two the reverse of all this will be the case-a warm, wet season, when vegetation becomes extremely rank and vigorous, and these thorns may be seen adorning themselves with tufts of green leaves. That well-known floral ugliness, the green rose, is a development of the sepals of the calyx, to the utter extinction of all the other floral organs. Thus we see sometimes a stamen, and the next year a petal,

234. What does this chapter treat of? What does metamorphosis mean ? 235. Tell me of the rose. The honey-locust. Mention some changes in the flower caused by exceptional or incidental circumstances. What are they called? 
one season a thorn, the next a branch, one year the rose is double, full, and perfect as to petals, the next year a bud usurps the stamens and pistils; now these are all irregular metamorphoses.

236. Regular metamorphosis is the change we see going on in regular sequence, governed by laws that act with precision, unless controlled directly by some of those agents just alluded to as producing irregular metamorphoses.

237. This change botanists pronounce to be the result of two forces, expansion and contraction. The plumula expands into a stem, the radicle into root, the stem into branches, and the branches into leaves; the leaf contracts into bracts, the bracts into calyx, the calyx into the corolla, which expands into fruit or contracts into seed. Irregular metamorphosis can be easily demonstrated by experiment; the single poppy, for instance, can be made perfectly double in two or three years by proper cultivation. To witness regular metamorphosis you have but to follow any plant throngh its different stages of germination, growth, flowering, and seeding.

238. The expansion into leaves and contraction into flowers is prettily shown in the hoya, common wax-vine. Take two slips, put one in a large pot with plenty of rich soil, and supply it abundantly with water, and you will have a large vigorous vine, with a superabundance of green leares, but no flowers ; place the other in a small jar, scantily supplied with nourishment, and you will have a small vine, few leaves, and large and beautiful clusters of flowers. You will, perhaps, be surprised to hear that it was a poet and not a philosopher that made this discovery. Goethe has embodied his history of metamorphosis in a poem, the beauty of which will make you excuse its length. So,

236. What is regular metamorphosis?

23\%. To what are these changes due? Explain the process. What of irregular metamorphosis ?

238. Illustrate the expansion into leaves and contraction into flowers. Who made this discovery? 
without even craving your patience, we will venture to give it to you, in Mr. Dwight's admirable translation:

\section{The Metamorphosis of Plants.}

Thee perplexes, beloved, the intertangled confusion Of this flowery throng, which in the garden thou seest; Many the names you must hear, and ever one after another With its barbarous clang crowds itself into your ear. All in their forms are kindred, and yet no one like another; So this wonderful choir points to a half-hidden lawYes, to a holy enigma. Oh, could I teach thee, beloved, Happily teach thee the word, which will unriddle it all! Study it now as it grows, and see how the plant, ever changing, Step by step carried up, forms into blossoms and fruit. Out of the seed it unfolds itself, so soon as the fruitful Earth's still fostering lap letteth it forth into life, And to the soft-wooing light, the holy, eternally moving, Quick the opening leaves' delicate structure commits. Singly slept the germ in the seed; an embryo fore-type Lay enwrapped in itself, curling up under the shell; Leaf, and root, and bud, half-formed, and all without color, Thus the kernel so dry safely protects the still life; Then it flowers strivingly upwards, turning the delicate moisture, And soon lifteth itself out of its mantle of night. But what shows itself first is always a simple formation; Thus may we among plants always distinguish the child. Soon a following impulse lifts itself upward repeating, Joint upon joint built up, ever the earliest form ; Yet not always the same; for, constantly changing its figure, Opens out, as you see, ever the following leaf, More spread out and indented, and cut into points and divisions, Which, half-grown, heretofore slept in the organ below, Aud so reaches its first, its highest determined completion, Which in many a tribe thee to astonishment moves. Variously ribbed and jagged, on the juicy exuberant surface Seems the fullness of life free and unbounded to be. But here Nature holds with powerful hands the formation Back, and to perfecter shape softly inclines it to grow. Now more sparingly leads the sap through slenderer ressels, And the delicate plant's finer formations begin.

Now the forth-putting edges draw themselves quietly backward, 
While the rib of the stalk builds itself solidly out.

Leafless, however, and swift, upsprings the delicate flower-stem, And a miraculous sight fills the beholder with joy.

Round in a circle there place them, in number exact or uncounted,

Leaflets, the smallest one first, next to that likest itself.

Gathered close round the axle, now opens the sheltering calyx, And to full beauty and height lets out the gay-colored crown.

So shines Nature complete in all her fullness and glory, As in regular rise, limb upon limb she displays.

Ever thou marvelest anew, so soon as the stem with its blossom Over the changing leaves' delicate scaffolding rocks.

But this beateous show now a new creation announces;

Yes, the soft-colored leaf feeleth the hand of the God, And together draws itself quick; the tenderest forms now Lean together in pairs, seemingly made to unite.

Lovingly now they stand, the beautiful couples, together. See, in numerous crowd, ranged round the altar they wait! Hymen hovers this way, and streams of exquisite odors, Borne on the generous breeze, breathe a new life in all around. Now distinctly swell at once the germs without number, Germs of the swelling fruit, soft in the motherly lap. And here Nature concludes the ring of her infinite powers ; Yet a new one at once links itself on to the last, That unbroken the chain through endless time may be lengthened, And the whole made alive, like the one part we have seen. Turn thee now, beloved, and look at the motley confusion; Now, no longer perplexed, you may look as it waves. Every plant but announces to thee some law everlasting • Every blossom, it speaks plainer and plainer to thee.

239. You thus see in the beautiful garb of poesy the same thing presented to you in the talk about leaves, that Nature works from one type-the leaf being the embodiment of the idea which she varies and elaborates through all her marvelous derelopment of vegetable structure. This development and contraction you are again told is known by botanists under the general name of regular metamorphosis.

239. What is presented to you in the talk about leaves? Under what name is it known by botanists? 


\section{CHA P'TER XII. \\ Section I.-Phenogamia.}

210. Is the course of these conversations you have been told of monocotyledonous plants, with one cotyledon or seedleaf, stems growing by inner deposition, and called, therefore, also, endogens; dicotyledonous, having two seed-leaves, the sap making external deposits, and hence styled exogens; polycotyledonous, having several seminal leaves, as seen in the coniferous family, the pine, hemlock, etc. All these have been described, and yet you have not been told that there is another classification made, by which the vegetable world is divided into two classes, styled par excellence the two grand divisions, phenogamous and cryptogamous.

241. Phenogamous (Greek, phaino, appear, and gamos, marriage) are plants which have their stamens and pistils visible. To make this division clear we will present a table:

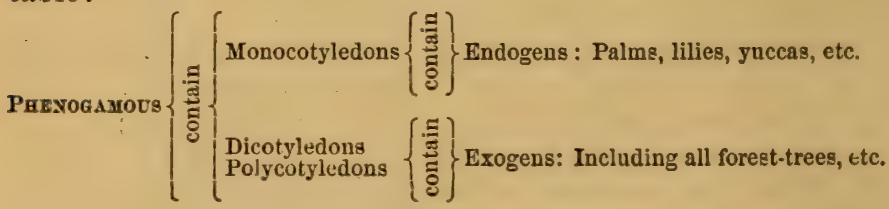

\section{SeCtion II.-CRy ptogaMia.}

242. Cryptogamous (Greek, krypto, to conceal, and gamos, marriage) are plants with stamens and pistils invisible. They are divided into:

1. Felices, ferns.

2. Equisetacece, horse-tails.

3. Musi, mosses.

240. What are the grand divisions ?

211. What does phenogamous mean? Phenogamous plants include what ?

242. What does cryptogamous mean? Give the botanical name of ferns. Horse-tail. Mosses. Mushrooms, Lichens, Lycopodium. Algæ. 
4. Hepaticae, liverworts.

5. Fungi, mushrooms.

6. Lichens, rock-mosses.

\%. Lycopodiums, club-mosses.

8. Alga, water-weeds, mosses, etc.

243. We will now take up the cryptogamous plants, but in describing them we use different terms from those describing analagous organs in the phenogamous tribe; and before proceeding farther you must be told some of them, and their meanings explained, so as to assist you as much as possible in your future studies of the natural specimens.

244. Calyptra means a cap or vail, and is the covering that incloses the theca or capsule before the sporules or seeds are yet ripe. It is shaped much like an extinguisher, and bursts longitudinally (Fig. 117), leaving the theca (Fig.

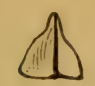

F16. 117.

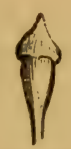

Fra. 118.

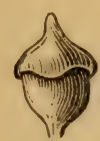

Fig. 119.

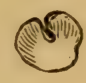

FiG. 120.

118). The little cap on the theca is called operculum (Fig. 119).

245. Indusium is the shield or scale covering the capsule or seed-cases of ferns (Fig. 120). - Sori are the fruit-dots on the back of the fronds (Fig. 121). The cap is the head or expanded part of the mushroom (Fig. 122). Gills or lamellae are the laminated divisions of the under side (Fig. 123). Volva is the membranous covering protecting the gills; it is attached to the margin of the cap and to the stipe. When the cap is fully grown the volva bursts at the margin, but, retaining its connection with the stipe, falls over it like a curtain (Fig. 12t). When the plant is fully

243. What can you say of the cryptogamous plants?

244. What is a calyptra? A theca?

245. What is an indusium? Sori? Cap ? Volva ? 
matured, this, partly absorbed and partly thrown off by decay, becomes simply a ring, called annulus (Fig. 125).

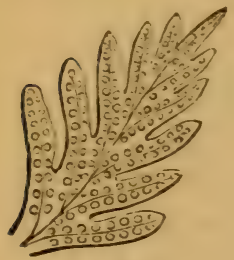

FIG. 121.

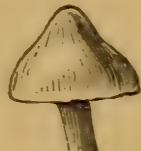

FiG. 122.

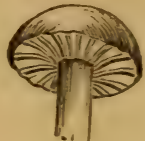

Fig. 123.

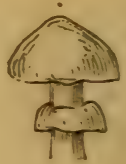

FIG. 124.

246. Ferns have light graceful leaves which we call fronds. When young they are curled, circinate (Fig. 126), and expand by unrolling. Their spore-cases or seed-res-

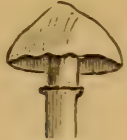

Fig. 125.

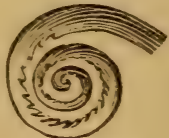

FIG. 126.

sels are situated on the back of the fronds, as you saw in the cut showing sori, and are arranged differently in different species.

247. The genus equisetaceæ, horse-tail, contains numerous species. They consist of leafless, jointed stems, erect, hollow, and ridged. The spores of the equisetaceæ are contained in scales forming the inflorescence, which appears in the form of a terminal spike (Fig. 12\%).

248. The mosses are composed of cellular tissue entirelr, and are furnished with a theca supported on a slender stalk called seta (Fig. 128). The tuft of leares from which the seta or stem springs is called a perichretium (Fig. 129): $a$

246. What are ferns? Fronds? Spores? Sori?

247. What are equisetacex? Describe them. Where are their spores

218. What is the seta? Per ihretium? 
represents the theca, $b$ the seta, and $c$ the perichcetium. You have before been told that the theca contains the

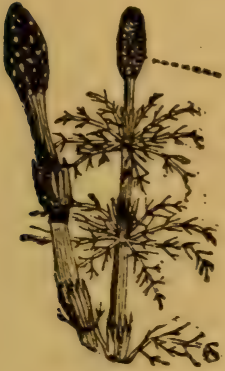

Fig. 127.

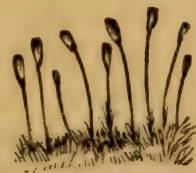

FIG. 128

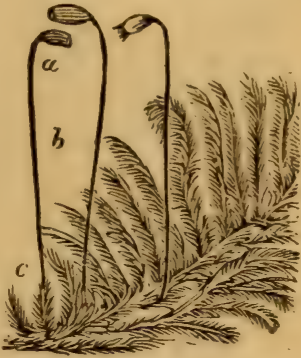

Fig. 129.

spores or seeds, and is covered by a lid or operculum. An enlarged theca with its lid would look like an old-fashioned sugar-bowl (Fig. 130). Moss seeds are first seen in the theca, then covered over with operculum. These are then all wrapped up in a calyptra.

249. Hepatica, or liverworts, are small creeping plants.

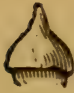

FrG. 130

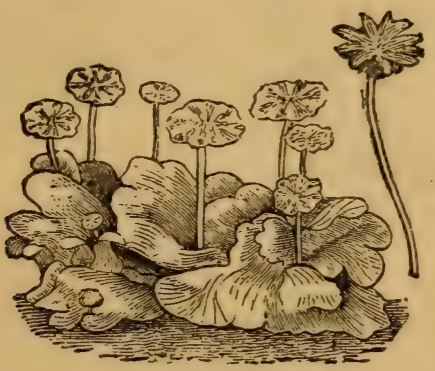

Fig. 131.

Their leaves lap over each other like scales (Fig. 131), and are hence said to be imbricated. They generally have no lid to their capsule, and are by that distinguished from the mosses. They grow upon old walls, rock, bark of trees, and are sometimes found in damp places, but never under

249. Describe hepaticæ. How do you distinguish bepatice from alge? 
water. By that circumstance they are never confounded with algæ.

250. Fungi or mushrooms have already been fully explained in giving you the techuical names of their several parts. You were told, when learning of tissues, of the effect of light upon vegetation, and that mushrooms are composed of cellular tissue, and therefore grow during the night, though unable to perfect spores without the agency of light. We are indebted to the microscope for our knowledge of several varieties of fungi. The rust upon wheat, the mold upon paper-hangings, old cheese, etc.; the mildews that at some seasons so disfigure the orange-trees and oleanders along our coast, are all plants, and are all fungi.

251. Lichens (Fig. 132) are those scaly wood-colored plants found on trees, old buildings, fences, felled forest-trees,

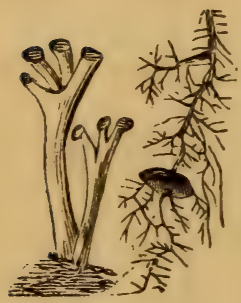

Fig. 132.

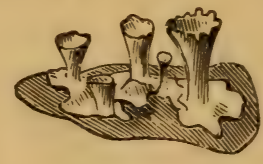

Fig. 133.

etc. Though generally of gray color, they are often found brown, green, and yellow. The sporules are in cup-shaped receptacles (Fig. 133). Sometimes these cups are upon stalks, called podita (Fig. 134); again these cups sit down upon the thallus, which is the leaf-like expansion of the plant (Fig. 135). You will have some idea of the research and industry of botanists when you hear that they have described over two thousand species of this one genus. 
252. Lycopodiums or club-mosses, better known as ground-pines (Fig. 136), seem to be a connecting link be-
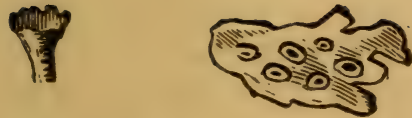

Frg. 194.

Fro. 135.

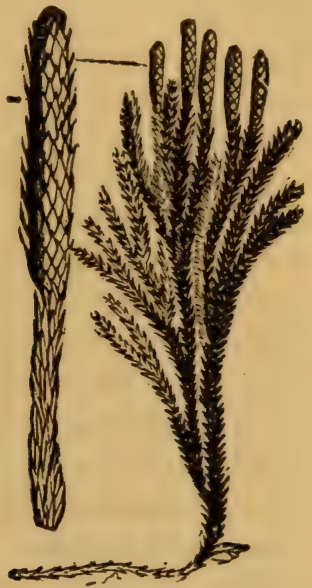

FiG. 136.

tween mosses and ferns. They have imbricated leaves growing close down upon the stem, like the arbor-vitæ. Their erect branching stems are surmounted by a terminal conelike spike, containing its sporules at the base of these scales. These sporules are seen in the form of yellow dust, very much resembling the pollen-grain of the pine. There are a few species without stems, having awl-shaped leaves. The resurrection rose is a lycopodium.

253. Algæ are water-plants, found either in salt or fresh water. They are cellular, some having the distinction of fronds and stems. Some have merely stems, simple or branching. The sporules are imbedded in the substance of the frond, or in the tubercles, variously situated. They are generally entirely submerged. The salt-water algæ

252. What of lycopodinms ?

253. What can you say of the algre plants? Describe their growth and organs of reproduction. 
comprise an immense family of exceeding beauty, varied and curious in construction, and presenting us every variety of form, color, and condition. Some are fixed to the rocks and sands below, some floating. In many, roots are perfectly developed; again, a mere expansion of the stem attaches them to the rocks; others again show no sign of either root or expansion, but spread into vast laminæ, thin and delicate, like yards of finest Florence silk, green, purple, and crimson, or they appear like bundles of irregular tubes; while others present themselves as masses of tangled threads. Here vast frond fans wave to and fro in the waters, fastened by foot-stalks to the rocks, while above them the gulf-weed, buoyed by its air-bubbles, goes floating along from Honduras to the Hebrides, dallying with the rosy coral of the tropical seas, and anon weaving a shroud for the adventurous sailor lost amid the icy waters of the Northwest Passage.

254. In contemplating these wonders of the land and water, we can but exclaim, " $O$ Lord, how manifold are thy works; in wisdom hast thou made them all; the earth is full of thy riches; so is the great and wide sea."

255. We cannot dismiss the subject of the cryptogams without speaking of the important work that these pioneers of the regetable world perform. Geologists inform us that they were the origin of all vegetable life. Making their appearance upon the rocks that first emerged from the bosom of the waters, they disintegrated these rocks, and by this process and their own decay furnished soil for more complex organization. Thus we see cryptogamous plants preparing the way for endogenous, and they in their turn for exogenous plants.

256. Here we see a new cause for wonder and admira-

254. What are we forced to exclaim in contemplating these wonders of the land and sea?

25.5. What can you say of the important work of the cryptogamous plant?

256. What new cause have we for adoration of the Almighty? 
tion of the great God, who works with means so simple and apparently so weak for so great accomplishments, making the very existence of the gigantic oak, that braves the tempests of a thousand years, the result of the life and labors of the lowly cryptogams.

\section{CHAPTER XIII.}

\section{Section I.-Recapitulation.}

HAVING now completed so much of the study of regetable physiology as the limited plan of this introductory work will admit, for the sake of impressing several divisions of the subject upon your mind, I will now make a brief recapitulation of the whole. We first took up the root and its three divisions, ground-roots, air-roots, waterroots, and found these again divided into branching, fibrous, bulbous, tuberous, running, and fusiform; and that these were either annual, biennial, or perennial.

From the roots springs the stem. It is either ligneous, hard, woody, and perennial; herbaceous, succulent, green, and annual; suffruticose, partly woody and partly herbaceors. Ligneous stems are subdivided into endogenous, inward growth ; exogenous, outward growth; acrogenous, growing from the apex only.

At regular intervals upon the branches are nodes; the spaces between are internodes. From the nodes spring the leaf. The leaf consists of two parts, lamina and petiole. The first leares are called seminal, the next primordial. Those on the perfect stem, characteristic. When the leaf springs from the root, it is radical ; from the stem, cauline ; when on the stem, sessile. If the leaf falls off early after unfolding, it is caducous; if in autumu, it is deciduous; remaining all winter, persistent or evergreen. 
The arrangement of the veins, venation, is either reticulate or parallel. The first is divided into palm renation, lobed venation, etc.; the second, into forked venation, etc.

Leaves are simple or compound. They are cordate, lanceolate, deltoid, needle-shaped, ovate, reniform, palmate, pedate, pinnate, unequal, alternate, regular and irregular, bipinnate, tripinuate, etc. Leaves have stipules, stings, scales, pubescence.

The complete flower consists of calyx, corolla, stamens, and pistils. The first two are called floral envelopes; the last, essential organs. When the calyx and corolla are both present, the flower is dichlamydeous; when one is wanting, monochlamydeous; when both are wanting, achlamydeous.

The manner in which the petals are situated in the bud is called their æstivation or præfloration. When they fit by their edges, they are called volvate; when the outermost pieces cover the margin of the inner, imbricate; when each overlaps the other in a spiral manner, contorted or twisted. Each division of the corolla is called a petal; when the corolla is entire, monopetalous ; when divided, polypetalous. A monopetalous corolla may be salver-shaped, funnel-form, campanulate, trumpet, etc. Polypetalous corollas may be liliaceous, cruciform, rosaceous, and caryophyllaceous. Irregular corollas are labiate, lingulate, and papilionaceous.

The essential organs are the stamens and pistils. The stamens consist of filiment, anther, and pollen. If the stamens are inserted upon the pistil, it is epigynous; under the germ, hypogynous; if around, perigynous.

In the center of the flower is the pistil. This consists of the germ, style, stigma. The ovary, if placed above the calyx, is said to be superior; if below, inferior. When the style is wanting, the stigma is said to be sessile. The arrangement of the flower upon the branches and stems is called their manner of inflorescence, and may be a spike, head, raceme, corymb, umbel, ament, panicle, spadix, ver- 
ticillate. The termination of the peduncle upon which the flower sits has several names, receptacle, torus, etc. When it supports but one flower, it is proper; when a cluster, it is common.

The germ is the base of the style, and the stigma its apex; the rudimentary seeds, the ovules. When the germ is fully developed it becomes fruit. This consists of pericarp and seed. The pericarp may be a shell, pod, or pulp.

Fruits are divided into dehiscent and indehiscent. Indehiscent are those which do not open when matured, and are subdivided into drupe, berry, pepo, and pome. Dehiscent are those which do open when matured, and are subdivided into legume, follicle, silicle, silique, capsule, and pyxis.

Seeds are sometimes furnished with appendages, as down, aigret, wings, and scales. A seed consists of three parts, embryo, albumen, epidermis. The embryo contains the cotyledon, plumula, and radicle.

We commenced at the root, and-like the mariner, who, sailing west, if he sails long enough and far enough, will reach the port he left-we have, by continually traveling upward, found ourselves where we started from, at the bottom of the plant again, the radicle or root.

\section{Section II.-General Remarks.}

You have been told that plants consist of solids and fluids, that these constitute various tissues, cellular, vascular, woody, and lactiferous. These are made from inorganic substances held in solution by the water drawn from the soil by the spongioles, by gases taken from the earth by the roots, and from the air by the leaves. That by the process of assimilation they are converted into material identical with the plant, and that this material is deposited by the sap in its descending flow. 
You have seen how the well-being of both the vegetable and animal kingdom depends on the seeming discord of their forces; that they are

"Formed for one another, though dissimilar,"

and work together for the good of man with a beneficence and wisdom that fills the Christian heart with profound awe and adoration.

\section{CHAPTER XIV.}

\section{Classification.}

\section{Section I-Antificial System.}

To classify plants is to arrange into groups and families those that bear the closest resemblance to each other. Botanists have taken different circumstances as the grounds for this resemblance, and consequently we have several systems of classification. You should make yourselves familiar with both the Linnæan or artificial, and the natural system. The first named is founded upon the number, length, and situation of the stamens and pistils. This first division is into phenogamous, with stamens and pistils visible; and cryptogamous, stamens and pistils invisible. The phenogamous plants include the first twenty classes.

As a knowledge of Latin and Greek numerals is necessary in order to understand the names of the classes and orders, you will commit the following to memory:

Latin.

Greek.

Unus,

Duo,
1. Monos,

2. Duo,
1.

2. 


\section{Latin.}

Tres,

Quatuor,

Quinque,

Sex,

Septem,

Octo,

Novem,

Decem,

Undecim,

Duodecim,

Tredecim,

Quatuordecim,

Quindecim,

Sexdecim,

Septendecim,

Octodecim,

Novemdecim,

Viginti,

Multus,

Bis,

\begin{tabular}{r|lr}
3. & Treis, & 3. \\
4. & Tettares, & 4. \\
5. & Pente, & 5. \\
6. & Hex, & 6. \\
$\%$ & Hepta, & 7. \\
8. & Okto, & 8. \\
9. & Ennea, & 9. \\
10. & Deka, & 10. \\
11. & Endeka, & 11. \\
12. & Dodeka, & 12. \\
13. & Dekatreis, & 13. \\
14. & Dodekatreis, & 14. \\
15. & Dekapente, & 15. \\
16. & Dekaex, & 16. \\
17. & Dekaepta, & 17. \\
18. & Dekaokto, & 18. \\
19. & Dekaenna, & 19. \\
20. & Eikosi, & 20. \\
many. & Polus, & many. \\
twice. & Bis, & twice.
\end{tabular}

Andria signifies stamen. Instead of saying monos andria, one stamen, we make a compound word, and write it thus:

\begin{tabular}{|c|c|c|c|}
\hline 1st class & Monandria, & one st & amen. \\
\hline $2 \mathrm{~d} \quad "$ & Diandria, & two & " \\
\hline $3 \mathrm{~d} \quad$ “ & Triandria, & three & “ \\
\hline 4 th “ & Tetrandia, & four & 6 \\
\hline 5 th “ & Pentandria, & five & $“$ \\
\hline 6 th “ & Hexandria, & $\operatorname{six}$ & " \\
\hline yth " & Heptandria, & seven & “ \\
\hline 8 th $"$ & Octandria, & eight & " \\
\hline 9 th $\approx$ & Enneaudria, & nine & “ \\
\hline h $"$ & Decandria, & ten & $"$ \\
\hline " & Icosandria, & twenty & \\
\hline
\end{tabular}


'This last class, the eleventh, has twenty or more stamens inserted on the calyx.

Twelfth class, polyandria, has twenty or more inserted on the receptacle.

The orders of the first twelve classes depend on the number of pistils, and are named by prefixing the Greek numerals to the word gynia:

1. Monogynia.

2. Diagynia.

3. Triagynia.

4. Tetragynia.

5. Pentagynia.

6. Hexagynia.
\%. Heptagynia.

8. Octogynia.

9. Enneagynia.

10. Decagynia.

11. Dodecagynia.

12. Polygynia.

When the filaments are united, making a little tube in which the pistil stands, we call it monadelphia (from monos, alone, and adelphos, brother): this makes the fifteenth class. Sixteenth class, diadelphia (dis, two, adelphos, brother), has stamens united by their filaments, forming two sets. In these classes the orders depend upon the number of pistils, and are named in the first twelve classes only, adding gynia (pistil), monogynia, diagynia, etc.

Seventeenth class have their anthers united, and hence are called syngenesia, which means growing together (flowers compound). This class has these orders:

1st. Equalis, flowers perfect; that is, each flower having a stamen, pistil, and seed.

2d. Superflua, disk florets perfect, ray florets containing neither stamens nor pistils.

3d. Necessaria, florets of the disk, staminate; rays, pistillate.

4th. Segregata, florets each furnished with a perianth or calyx.

The eighteenth class, gynandria, stamens growing on the pistil. 
Ninteenth, stamens and pistils in separate corollas on the same plant, and is called monocia: cocia signifies house ; hence, mono, one; recia, house.

Twentieth class, dicecia, two houses; stamens and pistils in separate corollas upon different plants or houses.

The orders of these three last classes, like those of monodelphia and diadelphia, depend upon the number of stamens. The cryptogamous family, stamens and pistils invisible to the naked eye, form the twenty-first class. The orders of this class are six-filices, musi, hepaticæ, algæ, lichens, and fungi.

\section{Section II.-Natural System.}

The natural system differs totally from the artificial, paying but little attention to any one organ, but, regarding the plant as a whole, takes the collective resemblances and groups them by their natural relationships. On this basis it forms them first into classes; these classes are separated into orders, orders are subdivided into genera, and genera into species.

We say that exoyenous plants constitute one class, endogenous another, acrogenous a third. The first class is divided into two sub-classes:

1st. Angiosperms, which hare pistils of the common kind, in which seed are formed. This includes nearly the whole of the exogens, except the conifers, such as the pine, yew, cedar, etc. These belong to the sub-class number.

2d. Gymnosperms, with ovules and seeds naked, there being no pistils, or, if any, a mere scale, as in the conifers.

The cryptogamous plants are subdivided into three classes:

Class 3. Acrogens, including ferns, horse-tail, and clubmoss.

Class 4. Anophytes, containing mosses and liverworts.

Class 5. Thallophytes, including lichens, algæ, mushrooms. 
Thus we see the regetable kingdom is divided into two sub-kingdoms :

1st. Phenogamia are distinguished by peculiarities:

$a$. Consists of regular axis of growth and with leares.

b. They have a woody and spiro-vascular construction.

c. They have stamens and pistils.

d. They produce seeds containing an embryo.

2d. The cryptogamia:

a. Are destitute of regular axis and true leares.

b. They are of vascular structure.

c. Their flowers are invisible to the naked eye.

d. They produce spores instead of seed.

The phenogamia are divided into two great classes, whose characteristics are distinct and palpable

Exogens (outside growers) or dicotyledons :

a. Growing by layers external to the wood, internal to the bark.

b. Leares net-veined.

c. Flowers, 4- or 5-parted, rarely 3.

d. Seeds with two cotyledons.

$e$. The radicle producing an axial root.

Endogens (inside growers) or monocotyledonous plants: a. Growing by internal bundles of cellular and woody tissue.

b. Pistils complete, inclosing the orules.

c. Seeds inclosed in a pericarp.

d. Embryo with one cotyledon.

'The third division is into sub-classes. The exogens form two:

ANgiospery (seed corered) :

a. Flowers generally perfect and complete.

b. Pistils complete, inclosing the orules.

c. Seeds in a pericarp.

d. Embryo with two cotyledons.

Gruxosperus (seed naked):

a. Flowers imperfect and incomplete. 
b. Pistils scale-like or wanting.

$c$. Seeds naked, destitute of a pericarp.

d. Embryo polycotyledonous.

The exogens form two sub-classes:

Petaliferous. Plants of the endogenous structure, with flowers constructed on the usual plan; perianth of one or more whorls of petals.

Glumiferous. Plants of the endogenous structure, the flowers in imbricated glumes, instead of petals and sepals.

Angiosperms are further divided into

Apetalous, which have calyx, but no corolla.

Monopetalous, corolla entire.

Polypetalous, calyx and corolla.

Endogens, or monocotyledonous, are divided into

Flowers on a spadix.

Flowers not spadicious.

With simple or double perianth, regular or irregular.

FLOWERS imbricated or with glumaceous bracts.

These are again grouped into herbaceous, or trees and plants, terrestrial or aquatic.

Anthers, introrse or extrorse.

Glumes, single or in pairs.

In this division we find the palm, yucca, banana.

You will now recapitulate what you have learned of the natural system:

That it is first divided into phenogamous and cryptogamous plants.

That the phenogamia are further divided into

1. Exogens.

2. Endogens.

That exogens are subdivided into

1. Angiosperms.

2. Gymnosperms.

That the cryptogamia have three divisions:

1. ACrogens, woody and vascular tissue. 
2. ANophytes, cellular tissue only.

3. 'Thallophytes, with no distinction of stem foliage, but all confounded in a thallus.

Our task is now accomplished. In our conversations upon classification we have only done as we did in previous talks upon vegetable physiology-given you an easy and pleasant introduction to the subject; hoping that the stronger hands of the many botanists of whom America is so proud-Darby, Wood, Gray-may lead you through this glorious kingdom, showing you its great and mighty, its useful and beautiful, its mysterious and awe-inspiring possessions. 


\section{INDEX AND GLOSSARY}

\section{TO PART I.}

Achlamydeous .............107

Acotyledonous ..............159

Acrozenous .............. 36

Aigret..................16!

Air Roots............... 8

Air Vessels................189

Albumen.................157

Algæ...................253

Alternate ............... 70

Ament ................ 91

Annual Roots............. 16

Annulus...............245

Anther .................110

Aphyllous............. 69

Appressed..............6. 61

Aquatic Roots............. 12

Assimilation ...........219,220

Bark.................... 48

Berry ................... 145

Biennial Roots............. 17

Bivalved..................140

Botany ...................

Branching Root ............. 23

Bracts ................... 80

Buds...................... 51

Bulbous Roots............ 25

Caducous................ 71

Calyptra.....................244

Calyx.................88 -99

Campanulate...............102

Cap ...................245

Capsule.....................148

Carbon .....................

Carina....................... 105

Caryophylious.................. 105

Catkin.................... 91

Canlis ..................... 38

Cellular ..................6.

Cellular Tissue.................178

Characteristic ................. 70

Chromule ...................200

Ciliate.................., 82
Circinate paragraph

Circinate ...............246

Claw..................... 104

Color .............179, 200

Columella.................134

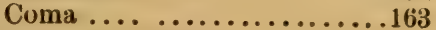

Compound Organs..........175

Conduplicate.............60 60

Confounded.............. 88

Contraction.............237

Corms................25

Corolla....................

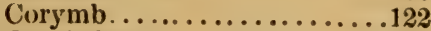

Cotyledons...............154

Creeping Roots............20

Cruciform..................

Cryptogamia.............242

Culm.................... 38

Cuticle................... 42

Cyme ..................121

Deciduous............... 71

Declinate.......................

Dehiscent.................139

Diastase..................169

Dichlamydeous .................

Dicotyledons...............159

Dissepiment................141

Drupe...................143

Embryo....................

Endocarp.................. 138

Endogenous.................34

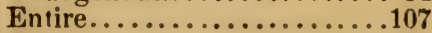

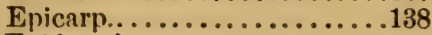

Epidermis.................43

Epigynous...................113

Epiphyte................... 10

Equisetaceæ.............242

Equitant................61

Excretion .................231

Exogenous ................ 32

Expansion..............237

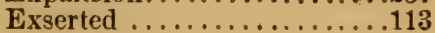


Fascicle ............... Panagraph

Ferns ........................246

Fibrous Roots............... 19

Filament................110

Flower............... 85

Flower Buds.............. 57

Form of Leaves..........6 68

Form of Root............ 18

Follicle................147

Fronds..................246

Germ..................115

Germination ................165

Gills .....................245

Glands..................... 81

Glandular Hairs.............. 43

Glans......................... 144

Glomerate.....................124

Ground Root $\ldots \ldots \ldots \ldots \ldots \ldots, 7$

Hairs. ................... 44

Head......................124

Hepaticæ .................249

Herbaceous Plants.......... 37

Hilum....................155

Hydrogen ................214

Imbricate $1 . \ldots \ldots \ldots \ldots \ldots \ldots 249$

Included ......................113

Indehiscent ................139

Indusium.................245

Inferior ................... 89

Inflorescence .................121

Inorganic Matter...........221

Intercellular Passages.........184

Intermittent Odors ..........207

Internodes................ 56

Introduction .............. 1

Irritability..............192

Keel .....................105

Kernel.................. 155

Labiate...................103

Lactiferous Tissue............190

Lamina .................. 63

Leaf.................... 59

Ieaf Bud................ 51

Legume..................147

Lenticels. ..............47

Liber................... 49

Lichens ................251

Liliaceous..................105
PARAGRAPR

Limb.................... 89

Lymph................225

Medulla.................. 33

Metamorphosis.............234

Midrib.................6. 6

Mixed Buds............... 57

Monochlamydeous............107

Monocotyledonous............159

Monopetalous................101

Monosepalous............. 88

Mordant...............203

Mosses..................252

Muricate.............. 82

Napiform...............22

Nectaries ................. 106

Nodes................. 51

Obvolute................61

Odors......................206

Opposite ................. 70

Organ...................29

Ovary ....................115

Ovules................... 151

Oxygen ....................168

Panicle..................129

Papilionaceous.............105

Pappus ...................161

Parasites.................. 11

Pedicel.................... 38

Peduncle................. 38

Perennial................. 17

Perfect Flower............107

Perfoliation.............62

Perianth ................. 88

Pericarp …............117, 137

Perichætium...............248

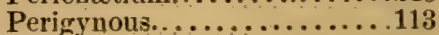

Permanent Odors............206

Persistent . ................ 71

Petal.........................

Petiole...................63

Phenogamous...............240

Pistil......................115

Polycotyledonous............. 160

Polypetalous................... 101

Polysepalous............. 88

Pollen.....................110

Prickles ................ 82 


\begin{tabular}{|c|c|}
\hline & \\
\hline Primordial................. 70 & Stipes............ \\
\hline Pubescent............... 82 & $\begin{array}{l}\text { Stipules } \ldots \ldots \ldots \ldots \ldots \ldots \ldots \ldots \ldots \ldots \\
\text { Stomata.............. }\end{array}$ \\
\hline Radicle. & Style $\ldots \ldots \ldots \ldots \ldots$ \\
\hline Receptacle. & Superior. \\
\hline Receptacles of Secretion... & Suture.... \\
\hline & Tap .: \\
\hline Sagittata.. & Tendril. \\
\hline Salver-shaped........ & Terminal Bud......... \\
\hline Sap................ & Thallus............... \\
\hline Sarcocarp ............... & Theca.... \\
\hline Sicape.................... 38 & Thyrsus. . \\
\hline Sclerogen................181 & Tuberous Root...... \\
\hline Scurf...................46 & Tunicated .......... \\
\hline Seta..................248 & \\
\hline Silicle.................147 & Umbel. \\
\hline 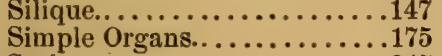 & Unguis. . \\
\hline $\begin{array}{l}\text { Simple Organs.............175 } \\
\text { Sori } \ldots \ldots \ldots \ldots \ldots \ldots \ldots \ldots \ldots \ldots \ldots\end{array}$ & \\
\hline 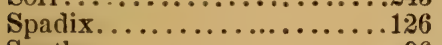 & Vascular Tissue........... \\
\hline patha..................96 & Vegetable Phenomena... \\
\hline Spike.: & Vernation .......... \\
\hline Spongiole............... 5 & Vexillum............... \\
\hline Spore Cases.......... & Villous............ \\
\hline 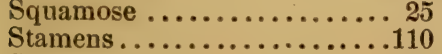 & Volva... \\
\hline 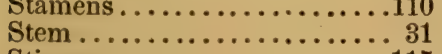 & Wi \\
\hline$\ldots 115$ & Whorl. . \\
\hline tings... & Woody ? \\
\hline
\end{tabular}

PAGE

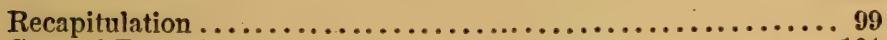

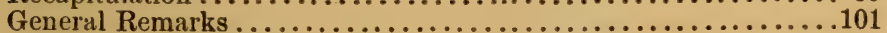

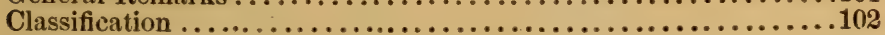

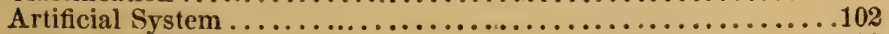

Latin and Greek Numerals ................................. 102

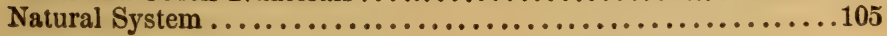



PART II. 



\section{NOTE.}

The Author must explain that, from the fact that she is indebted to "Chapman's Southern Flora" for a large proportion of Texas plants (identified for her by her kind and learned friend, Professor S. D. Buckley, formerly Assistant Geologist and Botanist of 'Texas), and being compelled to use Dr. Chapman's descriptions of many that she has never seen either growing or in herbarium, that she has copied verbatim his arrangement of the Orders (he himself following Gray), and, in the great majority of cases, his description of the same.

Her indebtedness to Professor Buckley is beyond all expression of thanks; suffice it to say, that without his generous aid, her Flora could not have attained a fourth of its present fullness.

Also, to Dr. Watson, of the "Botanic Gardens, Cambridge, Mass.," her thanks are gratefully made for his kind assistance in her prosecution of the study of Natural Classification.

She claims no merit for original work: for the most part she has been but a gleaner on others' lands, gathering into one garner, as far as she could, sheares cut by Chapman, Buckley, Gray, Drummond, Torrey, and others; but left lying bound on their own individual fields. 
Neither does she claim to have made an exhaustive collection. Like the instructions given to the learner, this is only to introduce children to the works of the "great masters," Gray and others; also to try and induce some more able one to tell to the outside world of the treasures of beauty, usefulness, wealth, and the curious that abound in the Vegetable Kingdom of the great Southwest.

M. J. Y. 


\section{NATURAL CLASSIFICATION. \\ FLORA OF TEXAS.}

\section{CHA P TER I.}

Is the first part of this volume you have been told something of Vegetable Physiology, and are now in a degree prepared for the next step in the study of the science of Botany, viz., Classification. You will have to receive a little more instruction concerning some of the organs, and learn a few more technical terms.

\section{Section I.-Pistil.}

We will first consider the essential organs, the stamens and pistils. The former in their collective character are termed the (1) andracium (as you call the petals collectively the corolla). Opposed to these is the pistil or (2) GYNeCIUM. This organ (the pistil) presents the most extraordinary application of the theory of vegetable metamorphosis, of which you were told in the first part of this rolume. You will easily understand the structure and origin of the gynæcium by considering it as the development of a leaf, or the combination of several leaves. The elementary organs, the junction of which form the pistils, were called by De Candolle (3) crrpels.

A single pistil is a single leaf-a double pistil, two or more leares. The botanist considers the pistil as consisting of the blade of the leaf curved inward until its mar- 
gins meet and adhere, forming in this way a tube or pod. This is the (4) varry. Now the inner surface of the ovary answers to the upper surface of the leaf, while the outer surface is the lower surface of the leaf. The united surface of the leaf bears the (5) ovules. The summit or apex of the leaf prolonged into a thread-like summit makes the style; while the edges of the leaf turned outward, either at the apex or along the edges of the style, form the stigma. The style, you will at once pereeive, answers to the midrib of the leaf.

The seam made by the union of the margin of the leaves is called the (6) ventral (or inner) suture (seam), while that of the midrib, or opposite line, is called the (7) dorsal (or onter) suture. Now you have the orary, the style, and the stigma.

You have already been told that the ovary contains the ovules, which when fertilized and developed become the seed. The line which supports the ovules is called the (8) placenta; this is usually rather thicker than the surrounding parts, being frequently a cellular growth from the inner suture; and as it is a growth from each margin of the leaf, it consists of two parts, and this accounts for the fact of the ovules being often found occupying two longitudinal rows in a simple pistil, as in the pea. A single pistil can have only one style and one stigma; but can have, and most generally does have, a double row of ovules. When a pistil is thus distinct, it is said to be (9) apocarpous. When there are several pistils united, they are (10) syncarpous.

The carpels do not always effect their junction in the same way. It may either be by the ovaries alone, or by the ovaries, styles, and stigmas, or by the stigmas alone. When the styles are united, there is found a style which in appearance is single, but, in reality, is a compound of as many partial styles as there are carpels. When the carpels are united by means of the ovaries, an orary is 
formed with as many cells as the ovary. In this compound ovary, the placentre will all be brought together in the axis of the compound pistil. These cells you at once see are made by the union of the walls of the carpels. These divisions or partition walls are called (11) dissepiments. As these are made by the union of two carpels, they consist, in consequence, of two partitions, and often split into two parts. In consequence of abnormal growth from the dorsal suture, these divisions sometimes become greater than the number of the carpels, and are then called (12) false dissepiments.

You have been told that a single carpel produces a single cell, two or more carpels two or more cells. In some plants, compound pistils or carpels frequently produce single cells. These are further distinguished as (13) axile and parietal placentæ. In the first the ovule occupies the center or axis of the pistil; in the second it is borne on the walls.

An ovary that can be seen by looking into the bottom of the flower, is said to be (14) superior. When only the summit can be seen at the bottom of the flower, and is united with the receptacle, so as to be looked for underneath the flower, it is (15) inferior.

\section{Section II.-Ovule.}

The ovule consists of three parts: a small central body called the (16) nucleus; this is enveloped in a double covering, the inner, called the (1\%) secundine, the outer (18) primine. The nucleus adheres to this sac by its base, its summit being free. This double covering has an aperture corresponding to the free summit of the nucleus, which aperture is called the (19) micropyle. The point or base where the nucleus adheres to the double covering, is called the (20) chalaza. The point where the ovule is attached to the placenta, by the thread or (21) funiculus, is termed the (22) hilum. 
Ovules vary greatly in number: when one in a cell, they are said to be solitary; when of an uniform number, definite; when more than are easily counted, indefinite.

Also as to situation: they are erect when they arise from the bottom of the cell, ascending when fixed above its base and rising obliquely upward; when they project from the side of the cell straight out, neither turning upward nor downward, they are horizontal; pendulous when they hang obliquely downward, and suspended when hanging perpendicularly from the top of the cell.

The (23) Gymnosperms have no ovary or seed-covering, in fact, no pistil except the ovule, which is borne on the upper surface of a carpillary leaf or scale. When the staminate flowers are in bloom these conelike pistil-leaves open, and the pollen is showered down in great quantities upon the uncovered ovules. These scales gradually close and remain so during their growing state. When fully matured, the cone again opens, allowing the ripened seed to escape.

The Coniferæ (firs, pines, cypress, arbor vitæ, etc.) and the Cycadaceæ (zamia, etc.) are the two orders of this subclass.

All ovules are not of the same form. Some are shaped like an egg, with the hilum exactly opposite to the micropyle; they are then said to be (24) orthotropal. When the ovule has its point of attachment near the micropyle, with a cordlike swelling on one of its sides (which reaches all along it and is called a (25) raphe), it is said to be (26) anatropal. When it has no raphe, but is bent, and has its point of attachment near the micropyle, it is (27) campylotropal.

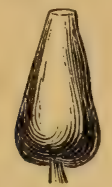

ORTHOTROPOUS.

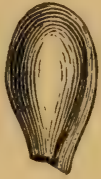

ANATROPOUs.

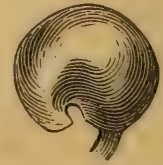

CAMPYLOTROPOUS. 


\section{SECTION III.-Fruit.}

In our talk about the fruit, we forbore crowding your attention with too many divisions; but for your better learning to properly classify, there are one or two things concerning indehiscent fruits that deserve further mention.

You understand that the dry indehiscent fruit of the Ranunculus, which contains a single seed adhering to the pericarp, is called an (28) achenium. Some achenæ have a membranous appendage, like wings, as in the elmit is then called a (29) key or samara; others adhere to the pericarp so as to form one body with it-it is then called a (30) caryopsis, as in wheat.

The dehiscent fruits are distinguished by their manner of opening-some longitudinally, as peas and beans; some horizontally, as in the cypress-vine and portulaca; some open by the severance of the partitions, each valve corresponding with a carpel-it is then called (31) septicidal dehiscence. Others again open by the dorsal suture, and then the dehiscence is said to be (32) loculicidal, the splitting opening into the cells.

When the sutures of the pericarp open for a short distance down from the apex, the dehiscence is said to be (35) circumscissile.

\section{SECTION IV.-SEed.}

In our talk about the seed, you were told of the embryo, plumule, etc. The outer covering of the seed is called the integument or (34) testa. It varies greatly. In some seeds it is long, in others membranaceous, and again it is papery. This is closely adherent to the nucleus, and again expanded into wings, as in the seed of the trumpetcreeper. Some seeds, besides this integument, are furnished with a covering, partial or entire, made by an 
expansion of the apex of the funiculus; this is called an (35) aril. Some seeds are formed entirely by the embryo, as in the bean; others again have the embryo packed away with a mass of albumen, as in the four-o'clock. The former seed are said to be (36) exalbuminous, the latter (37) albuminous.

You were merely told of the three rudimentary parts of the plant as forming the embryo: cotyledons, plumule, and radicle. The radicle of the embryo always points toward and is near to the micropyle of the seed: if the embryo is straight, or merely partakes of the curvature of the seeds, the cotyledons point to the opposite extremity; that is, to the chalaza.

The position of the radicle varies in respect to the hilum. In orthotropous seeds the radicle points away from the hilum: in the anatropous form, the extremity of the radicle is brought to the immediate vicinity of the hilum; and this is the case, though in a different way, in the campylotropous seed.

The embryo and the albumen do not always occupy the same relative parts of all seeds. For instance, in wheat, as in all cereal grains, and grasses, the embryo is placed laterally at the base of the albumen; then again, it surrounds it; in other cases, is surrounded by it. When the embryo is external, and curved circularly round the albumen, it is said to be (38) peripheric; when bent in such a way that the radicle lies along the edges of the cotyledons, the latter are said to be (39) acumbent; when the radicle rests against the back of one of them, or near to it, they are (40) incumbent.

The direction of the embryo with respect to the pericarp is also of importance to the student of natural classification. The terms (41) ascending, or radicle superior, are employed when the latter points to the apex of the fruit; descending, or radicle inferior, when pointing to the base; (42) centripetal, when the radicle is turned toward the 
axis of the fruit; (43) centrifugal, when turned toward the sides; and vague, when it bears no uniform relation to the pericarp.

\section{CHAPTER II.}

\section{Classification.}

Is classification we commence at the concrete and descend to the individual. Placing all vegetable life in a KINGDOM, this is divided into two grades or series, the Phanogamous or flowering plants, and Cryptogamous or flowerless plants. The first (Phænogamous) is further subdivided, according to their manner of growth, into CLASSES-outside growers, inside growers, and growing at the apex of the plant; termed in botany, Exogenous, Endogenous, and Acrogenous.

Exogens are further divided into sub-Classes: Angiosperms (seeds covered) and Gymnosperms (seeds naked). Also into Divisions: Polypetalous, Monopetalous, and Apetalous.

Endogens are distinguished into Spadiceous and Glumaceous.

These are all further divided into oRDERs, based upon the greatest number of general resemblances. Orders are subdivided into TRIBES, grouped together upon more particular relationship. Those with closer resemblances into GENERA ; and the differences in color, form of leaves, etc., etc., divide the genus into SPECIES. 
You now can see the scale of arrangement:

Kingdom.

Series.

\section{Class.}

\section{Sub-class.}

Division.

Order.

Tribe.

Section I.-Botanical Names.

Genus.

Species.

Series, you have been told, are named from their flowers being visible or invisible.

Classes, from their manner of growth.

Sub-classes, from their seeds being covered or naked.

Divisions, from the corolla being divided, undivided, or none.

Orders are Latin adjectives (feminine plural to agree with plantre, plants, understood), named generally from some leading genus, as Rosacece, the rose family; Euphnrbiacea, euphorbia family.

Generic names are Latin substantires, as ranunculus (from rana, a frog, in consequence of the aquatic habit of some of the species).

Specific names are Latin adjectires, and are generally descriptive of some distinguishing character of the plant, as Ranunculus repens, creeping ranunculus, Magnolia grandiflora.

\section{CHAPTER III.}

\section{How to Study a Plant.}

For this purpose we will take a little flower found everywhere throughout our State, familiarly known to you as crowfoot. 
Our first care shall be to determine what series it is inflowers visible or invisible. These are visible, and therefore it belongs to the first series, Phænogamous or flowering plants.

Is it destitute of true bark, without pith, and with stem composed of cellular tissue and scattered bundles of woody fiber? or, has it a stem with pith in the center, a bark (or skin) on the outside, with a ring of wood between the bark and the pith? It has pith, a ring of wood and bark, and leaves with netted veins; therefore we must place it in the first class, Exogenous.

Our next step is to find the sub-class. Removing the petals and stamens, we find in the center of the flower a number of one-seeded pistils - the naked eye can plainly see the ovary containing the young seed, or ovule; therefore this plant bearing seed that are covered must belong to the first sub-class, Angiosperm.

We have no trouble in determining the division. Its calyx and corolla of five petals place it in the first division, Polypetalous.

We find in this division orders that are identified by different characteristics-first those with

* stamens and pistils free from the calyx, hypogymous, or nearly 80.

Split the flower through the middle; you find the stamens inserted on the receptacle, free from the calyx. Our flower goes under this description.

Next we find

+ Stamens more than twice as many as the petals.

We have five petals and any number of stamens; therefore we are evidently thus far on the right road in search of our plant.

Now carefully follow down this list; and first we find a description of leaves :

Leaves "opposite.

- dotted.

- alternate." 
Ours are alternate. Continuing down the page of orders we find "Herbs;" our plant is an herb. Then we find Ovaries: "Ovaries embedded in the top of the large receptacle." Our ovaries are not embedded, neither is our receptacle very large. The next:

"Ovaries borno on the receptacle. Sepals and petals deciduous."

That is it. The ovaries of our plant were found growing on the receptacle, when we were studying the seed to learn if they were covered or uncovered. But the second part? Sepals and petals deciduous? Yes, here are one or two flowers whose petals have already fallen. We now have the order, RanunCUlaces. Turning to this order, we find five tribes.

In the first the sepals are valvate in the bud; ours are imbricate; so we will pass on. Tribe II., the sepals agree with ours, but there are no petals. Tribe III. contains three genera, the very first of which answers to our flower exactly. So placing it with the Ranunculaceæ, we turn to that, and proceed to find its specific name.

The first paragraph marked §says, "Petals white, with a yellow pit at the base." Ours are yellow; so we go to the next.

"§ Petals yellow, with a small scale at the base."

"* Achenia muricate." That is enough; ours is not muricate, it has no wartlike excrescence.

"** Achenia smooth. † Leaves undivided." Ours are divided.

" $+\dagger$ Leaves divided. It Petals small, not exceeding the calyx." Ours are not very small, and are larger than the calyx. To the next:

" $+\dagger$ Petals much larger than the calyx. Achenia in globose heads." Under this description we find the Ranunculus repens, which agrees with our plant in erery particular. And we feel as much delighted as if the flower had just been created under our very eye. 
In this way you proceed with any flower that you may have in hand. Practice will soon enable you to classify with readiness and precision. And nothing but practice can.

\section{Series I. Phenogamous or Flowering Plants.}

Plants with flowers, consisting of stamens and pistils; seeds containing an embryo.

\section{Class I. Dicotyledonots or Exogenous Plants.}

Stem consisting of bark, pith, increasing by annual deposition of a new layer between the old wood and the bark. Netted-veined leaves. Floral envelopes in fours or fives. Cotyledons two (sometimes whorled).

\section{Sub-class I. Angiospermous Exogenous Plants.}

Ovules in an ovary, fertilized by the action of pollen through the stigma. Two cotyledons.

\section{Division I. Polypetalous Exogenous Plants.}

Floral envelopes double; both calyx and corolla present. Corolla with petals separated.

* Stamens and petals free from the calyx, hypogenous or nearly 80.

+ Stamens more than twice as many as the petals.

Leaves opposite entire.

— dotted. Stamens separate. Stigma small..............HYPEricace

- dotless. Stamens nnited below. Stigma radiate-pellate...... ChusiackA. alternate.

Ovaries more than one, each 1-celled.

Stems woody. Petals six or more, in two or more rows.

Petals imbricated in the bud.

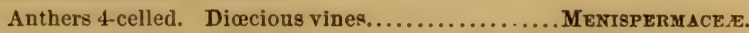

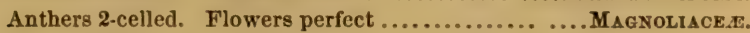

Petals valvate in the bud. Fruit pulpy. Albumen ru-

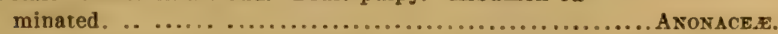

Herbs. Ovaries embedded in the top of the large receptacle...... NeluMbiace 
Ovaries borne on the receptacle. Sepals and petals decidu-

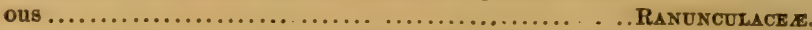

Ovary solitary, 1-celled.

Sepals and petals persistent.. САвомвасE天.

Placenta central. Sepals 2, deciduous. Anthers intorse.........Portulacaces. Placentæ parietal.

Sepals 5, persistent. Anthers extorse.......... Droserace $\mathbb{E}$.

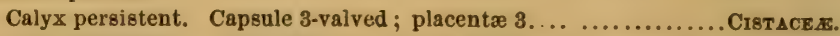

Calyx deciduous. Juice colored. Leaves simple, lobed ...... PAPAveraceA.

Juice watery. Placenta 1. Leaves $2-3$, ternate.............. Cimicifuges.

Juice watery. Placentæ 2. Leaves simple or trifoliolate. CAPPARIDACEE.

Ovary solitary, 2-many-celled.

Stamens connected with the base of the petals.

Stamens united in a column. Sepals valvate..

Malvacez.

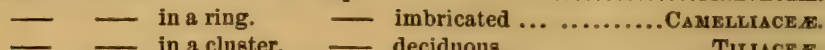

— separate. Ovary 5-celled. Leaves tubular.................. TiLiACEACENIACE.

Ovary many-celled. Leaves flat............NY MPH

+† Stamens twice as many as the petals.

Ovary more than one.

Flowers diœcious. Fruit a drupe. Trees with pinnate leaves......SrMarubace $\overline{\text { s. }}$.

perfect. — dry, indehiscent, 1-3-seeded, aquatic herbs.

Cabombacex.

_ a many-seeded follicle. Fleshy herbs.... Crassurace

Ovary solitary, 1-celled.

Leaves alternate. Fruit a legume. Leaves stipulate...........LEGumose.

- opposite.

Fruit a capsule, with parietal placentæ. Leaves entire, dotted.

_ - with a free central placenta. Leaves dotless.

HY PERICACE E.

CARYophyllaceE.

- a drupe. Shrubs with trifoliolate dotted leaves.... Burserace E.

- a berry. Herbs with two peltate lobed leaves... BERBRRIDACE

Ovary solitary, 2-celled.

Flowers irregular: stamens monadelphous. Capsule 2-seeded..... Polyoulacex. - regular; _ separate. _ _ long, many-seeded. TILIACERE.

Ovary solitary, 3-celled. Shrubs, with alternate leaves.

Flowers monœcious. Fruit 3-seeded, 3-valved. Stamens united.. EupHonbiacE E.

_ perfect. _- 3-seeded, 3-winged. indehiscent..... Crrillace $\mathbb{E}_{\text {. }}$

- many-seeded, 3-valved...............ERICACE.E.

Ovary solitary, 4-celled. Stamens 8.

Style single. Low, fleshy root-parasites, with scale-like leaves..Monotropes.

A shrub, with alternate leaves and bractless

flowers............................... CYRILLACE $E$.

Styles 4. Flowers cymose. Capsule 4-lobed, spreading.......Crassulacese.

Cvary solitary, 5-celled. Stamens 10.

Style single. Stamens separate. Leaves alternate, simple......... Prrouex.

Styles 5. Cells of the fruit separating into 1-seeded nutlets......Geraniace.F.

- united. Leaves trifoliate............ OxALmACE.

Ovary solitary, 7-celled. Anthers opening by terminal pores...........Ericace. 
t+t Stamens exceeding the petals in number, but not twice as many.

Ovary 1-celled. Petals 4; stamens 6.

Sepals 2. Flowers irregular. Embryo minute in fleshy al-

bumen .............................. FuMARIACER.

4. Flowers regular. Embryo large. Albumen none..CAPPARIDACER.

Ovary 2-celled.

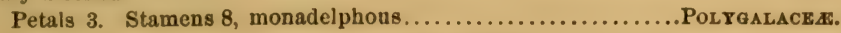

Ovary 3-celled. Leaves opposite.

Petals 5. Stamens 9. Leaves simple, dotted................ Hypericacex.

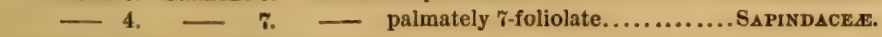

Ovary 3-4-celled. Leaves alternate.

Petals 5-8. Stamens 10. Fruit indehiscent, 3-4-winged ........ Crmillaces.

t+t+ Stamens (the fertile ones) as many as the petals.

Ovaries more than one.

Flowers monœeious. Stamens united into a 5-lobed disk..... ScHIzANDREe.

- diœcious. Anthers 4-celled. Leaves simple...... Menispermacex. - 2-celled. — pinnate, dotted.....RUTACE.E.

Ovary solitary, 1-celled.

Flowers irregular. Fruit a legume. Albumen none..........LEGUMnNosE.

Flowers regular.

Capsule 3-valved. Albumen fleshy............. Violaces.

- monœcious, the fertile ones apetalous. Fruit utricular. EupHorbiace w. $_{\text {- }}$

- perfect.

Stamens opposite the petals.

Anthers opening by uplifted valves

BERBERIDACEN.

- opening lengthwise.

Stamens and petals 3. Stigma many-parted

. Cistace ze.

Leaves a pair, opposite. Capsule 3-valved, few-seeded.......Porturacacez.

Leaves alternate, numerous. Capsule 2-valved............. Brtrneriace $\bar{E}$.

Leaves at the base of a naked stem. Fruit a utricle.

Plumbaginaces.

Stamens alternate with the petals.

Leaves opposite, dotted, exstipulate. Albumen

none

HTPERICACE As.

Leaves opposite or whorled, dotless, stipulate.

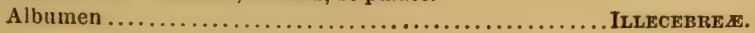

Leaves alternate. Capsule 1-celled.

- componnd. Fruit a legume.

Mimose.

Sterile stamens none.

Droserace.

Ovary solitary, 2-celled. Trees or shrubs.

Fruit a double samara. Leaves simple, opposite...............ACERACE.

— single samara. _ trifoliolate. alternate.............RUTACE $\approx$.

- a berry. $\quad$ palmately 5-foliolate..............VITACE $\mathbb{E}$.

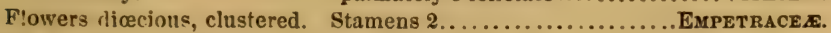

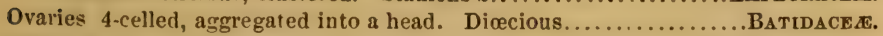

Ovary 5-celled. Style single. Petals stalked................... Butrneriace.

Ovary 5-celled, or falsely 10-celled. Styles 5. Petals sessile.......... LiNaces. 
$+\dagger+t+$ Stamens fewer than the petals.

Stamens 2. Petals 4, cruciform. Fruit a silicle Crucifere.

- 2-3. — 5. Flowers regular. Leaves opposite..... CARYophyllaces. - 4. 5 . — irregular. - alternate......... KRAMERIACEF.

** Stamens and petals inserted on the calyx or on a more or less perigynous disk.

+ Calyx not adherent to the ovary.

t+ Stamens as many as the petals.

Stamens monadelphous around the stalk of the ovary...........PASSIFLORACEE. - separate opposite the petals.

Calyx truncate. Ovules 2 in each cell. Woody vines.............. Vitaces. - valvate. _ single in the cells. Trees, shrubs...... Rhamnace.s. Stamens separate, alternate with the petals.

Leaves opposite. Calyx persistent. Capsule 2-4-celled......... LYTHRAcE... Trees or shrubs.

Fruit a double samara. Leaves opposite. Styles 2................ ACEraced.

- a drupe. Ovary 1-celled. Albumen none. ANACARDIACE $\mathbb{R}$.

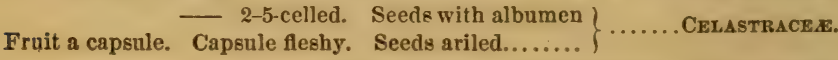
- ㄴ. 2-elled, 2-beaked. Leaves simple... .EscalloniE.X.

\section{t+ + Stamens more numerous than the petals.}

Oraries more than one.

Leaves alternate, stipulate. ROSACE E.

exstipulate. Succulent herbs Crassulaces.

- opposite, exstipulate. Sepals and petals numerous......... CXCANTHACEx. Ovary solitary, 1-celled.

Fruit a drupe. Style arising from the base of ovary ......... ChrysobalaNE Style terminal. Ovules pendulons ............. Ax YGDALEX.

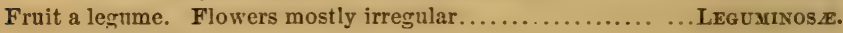
Ovary solitary, 2-celled.

Style single. Leaves simple, opposite or whorled LTTHRACER. - compound, dotless. Petals imbricated..... SAPINDACE.s.

Styles 2. Leaves alternate. Fruit a capsule.............. SAXIFRAGACE $\mathbb{x}$. - opposite. Fruit a double samara . .............. Acerace. Style 2-3, each 2-3-parted. Capsule 2-3-celled.............. Euphorbiace.s.

t+ Calyx adherent to the ovary.

Ilerbs.

Orary 1-celled. Capsule and 2-lobed calyx, circnmscissile.... PORTULACACEA. 3-valved. Calyx 5-parted. Leaves rough.

LOASACEx.

Ovary 2-6-celled.

Style single. Anthers opening by a terminal pore. Leaves ribbed.

Melastomacese.

Styles or stigmas 2 or more.

-_ lengthwise. Leaves ribless...... ONogracex.

Flowers umbelled. Fruit dry, separating into two pieces..... Umeellifer.t. - a berry-like, of $2-5$ nutlets.............ArALIACE\&. 
Flowers not umbelled.

- perfect. Fruit capsular. Leaves alternate.......... SAxifragaces. Shrubs or trees.

Leaves opposite.

Fruit dry, variously dehiscent, many-seeded

HYDRANGEE.

— indehiscent, 1-2 seeded.

Stipules none. Leaves dotted. Stamens numerons..............Mrntace.E.

Ieaves alternate.

Fluwers umbelled. Leaves compound ...................... AraLIACE not umbelled.

Leaves stipulate. Fruit fleshy or baccate indehiscent PoMex.

Leaves exstipulate. dry, woody, 2-valved.

HAMAMELACEA.

Flowers diœcions. Drupe baccate. Sterile flowers apetalous.

Cormaceer.

Flowers perfect. Ovary 3-celled. Fruit a 2-winged nut.

— 2-5-celled. — a 1-5-seeded berry. $\}$... STrRACACE

- 1-celled, with two parietal placentæ....Grosstrace.

- 1-celled, with numerous placenta......... CACTACE $\bar{~}$

\section{Division II. Monopeitalous Exogenous Plants.}

Floral envelopes double, consisting of both calyx and corolla; the latter of more or less united petals.

* Calyx free from the ovary.

+ Flowers regular.

t+ Fertile stamens fewer than the lobes of the corolla.

Fruit a 1-seeded fleshy drupe. Evergreen trees................... OLesces.

- separating into $2-4$ nntlets.

Ovary 4-lobed; the style rising from between the lobes............... LAIATE.

- not lobed; the style terminal...................... VerBENACE.

Fruit a 2 celled capsule.

Capsule circumscissile. Leaves alternate, radicle.......... PLANTAgrnace.

- 2-valved. Corolla-lobes imbricated in the bud.... ScropHulamiace.s.

- twisted in bud................ ACANTHACE.E.

t+ ++ Fer tile stamens as many as the lobes of the corolla and opposite them.

Herbs. Capsule 1-celled, many-seeded.

Prtaulaces.

Trees or shrubs, rarely herbs.

Anthers intorse. Calyx plaited, glandular. Fruit a atricle..Plumbagrnaceze.

++++++ Fertile stamens as many as the lobes of the corolla and alternate with them.

Ovaries 2, separate.

Juice milky.

Stamens united with the stigmas into a mass.............. AsCLEPIADACE.玉.

- separate and free from the stigma................. A POCY NACE 8. 
Ovary solitary.

Fruit indehiscent.

Leaves opposite.

Ovary 2-celled. Drupe 1-seeded, Corolla-lobes long. OLEACER - 4-celled. - 4-seeded - - short VerbeNaCese Leaves alternate.

Flowers diœcious. Fruit baccate, 4-9-seeded AQUTPOLACE - perfect

Ovary 2-celled. Corolla plaited or valvate. SOLANACER. Fruit a capsule.

Capsule circumscissile. Flowers on a scape.............. Plantaginace. _ dehiscent by valves.

Ovary 1-celled, Leaves lobed, hairy or pubescent ........ HYDROPHYLACE.

Ovary 2-5-celled.

Stipules membranous or annular between opposite leaves.... LoGANIER. Stipules none.

Capsule few-seeded.

Stem twining. Leaves alternate

Leaves none.

Contolvulacese.

_ not twining. Leaves opposite or alternate

POLIE MONTACEE.

Capsule many-seeded.

Style single.

Capsule 2-celled. Corolla plaited in the bud

SolanaC EE.

- — imbricated in the bad ........... ScropHULARIACEE.

- 5-celled. Stamens elongated ........................ERICACE

Style 2. Capsule 2-celled.............................. Hrdrolesce.

$++t++t$ Stamens more numerous than the lobes of the corolla.

Leaves compound, stipulate. Fruit a legume .........................

- simple.

Flowers diœcious. Ovary 8 celled. Fruit a berry

Ebenace.

- perfect. Stamens numerous.

Stamens united into a column. Anthers 1-celled .................MALraces.

- united into a ring or in clusters at the base.......... CAMELLACE.

Flowers perfect. Stamens twice as many as the corolla-lobes.

Corolla-lobes imbricated in the bud. Capsule many-seeded ........... Enicaces.

_ valvate in the bud. Drupe 1-seeded.

Olacacese.

\section{+t Flowers irregular.}

Stamens 6. Calyx of 2 sepals. Capsule 1-celled................. FuMARIACE Stamens (the fertile ones) 2 or 4.

Ovary 1-celled. Stamens 2. Corolla epurred...................entibulacex.

- 4. Fruits 1-seeded, reflezed........... PHRYME...

- 4. - many-reeded. Leaves scaly............ OROBANCHACE.

Ovary 2-celled.

Albumen copious. Corolla imbricated in the bud........ Scroprulariacex. - none.

Placenta with hooked appendages. Corolla twisted in bud..... ACANTHACE. _- not appendaged. Capsule large................ Bignoniace. 
Ovary 4-celled.

4-lubed; the style rising from between the lobes

LABIATE.

not lobed. VERBENACE

Anthers united.

** Calyx more or less adherent to the ovary.

Anthers contorted. Vines climbing by tendrils........... Cucorbitace.e.

_ straight. Flowers in a raceme. Fruit a many-seeded

capsule.............................. LOBELUCEA.

Flowers in a raceme. Fruit a $1-4$-seeded

drupe................................. RubIACE

Flowers in a head. Fruit a dry achenium ...... CoMposite.

Anthers separate. Leaves opposite or whorled.

Leaves connected by stipules or whorled...................RUBtAcE.

Stipules none. Stamens as many as the lobes of the corolla.. CAPRIFoliace $\boldsymbol{x}$.

Anthers separate. Leaves alternate.

Herbs.

Corolla-lobes valvate in the bud. Capsule opening at the sides.CAMPANULACFR.

- imbricate in bud. — valvate............. PRI MULACE E.

Flowers regular. Anthers opening by a terminal chink......... VACCINIE

STriracaces.

\section{Division III. Apetalous Exogenous Plants.}

Floral envelopes single, consisting of a calyx, or altogether wanting.
* Amentaceous trees or shrubs. Flowers monocious and dicecious.
+ Sterile fowers only in aments.

Leaves simple, stipulate. Involucre scaly. Seed entire......... CupUurFer. - pinnate, exstipulate. — none. - 4-lobed.......JUGLANDACE.

t+ Both the sterile and fertile flowers in aments.

Ament globose. Calyx uone.

Fruit 2-beaked, 2-valved, many-seeded. Sterile aments spiked.HAMA MELACE. Aments oblong or linear.

Ovary 1-celled. Drupe 1-8eeded. Stipules none............... Mrricace.

Capsule 2-valved, many-seeded. Seed comose..... SALICAC.E.

Ovary 2-celled. Fruit dry, angled or winged................ Betclace - enclosed in the confluent berry-like calyx....Morace E.

** Flonvers not in aments.

t+ Calyx and corolla none.

Ovaries 3-4 united below. Flowers perfect, spiked SAURURACEN.

Ovaries single.

Involucre spathe-like. Styles 2. Leaves alternate, parted....Podostemacex. - 8-12-parted. — 1. - whorled, forked.CeratopHYLLACE.

- 4-5-toothed, cup-like, containing one fertile flower and several sterile ones, each reduced to $a$. single stamen ........................ EupHorBIACE $\boldsymbol{x}$. 
t+ Calyx herbaceous or corolla-like.

Ovaries more than one.

Stamens inserted on the calyx. Leaves stipulate..............RosAcE $\boldsymbol{x}$.

- hypogynous. Stipules none.

Embryo minute............................ Ranunculacex.

Ovary solitary.

MENISPERMACEX.

Calyx adherent to the ovary.

Ovary 1-celled.

Fruit a 2-valved, many-seeded capsule

SAXIFRAGACEA.

indehiscent, 1-seeded.

Anthers (and stigma) sessile. Tree-parasites

LORANTHACE E.

- on filaments.

Drupe berry-like. Stigma decurrent

Corsace.

- dry. Albumen copious

SANTALACEA.

Ovary 4-celled, many-ovuled. Stigma capitate

- 3-celled, 3-ovuled.

3. Leaves dissected $\}$

ONAGRACEA.

- 2-3-celled.

Capsule 2-valved. Leaves alternate....... HAMA MELACF . $_{\text {. }}$

Fruit a berry. Leaves opposite...............MrRTACEAs.

Calyx free from the ovary.

Ovary 1-celled.

Ovules and seeds numerous.

Vines. Fruit berry-like Pasgiflorace

Stems erect. Capsule circumscissile Celosiez.

Ovule and seed solitary. Leaves stipulate.

Stipules sheathing.

- alternate................. PoLygonace

- scarious. $\quad-$ opposite .................. ILLECEBRE.A.

_ not sheathing nor scarions.

Flowers perfect. Achenium 2-lobed, spiny .................... Petiverize.

- imperfect.

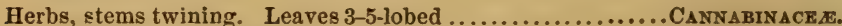

Trees or shrubs.

not twining. — serrate or entire

.. URTICACEE.

Juice watery. Flowers single or clustered............... ULMACE.s.

— milky. —_ included in a fleshy receptacle .........Morace.

Ovule and seed solitary. Leaves without stipules.

Stamens more numerous than the calyx-lobes.

Anthers opening by valves.

LAURACEe.

- opening lengthwise.

Calyx 5-6-parted

Polygonace $x$.

- entire. Berry oval

ThyMeleaces.

Stamens equaling in number or fewer than the calyz-lobes.

Flowers with scarious bracts......................... AMARANTACE

- without scarions bracts.

Caly x corolla-like, plaited.

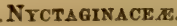

Ovary 2-12-celled.

herbaceous. Styles 2 .

Chenopodiace.s.

Leaves whorled.

A heath-like shrub. Calyx of imbricated scales..............EMPETrACE.

A prostrate annual. _- corolla-like .....................MOLLUGINE.

Leaves opposite. 
Fruit a single samara. Calyx minute, persistent............ F RAXINE $\mathbb{E}$

- a double samara. - deciduous...................... ACERACE

- a drupe.

Flowers perfect. Stamens on the calyx...............Rrumace.s.

Fruit a many-seeded capsule. Herbs....................... LYthrace.E.

Leaves alternate.

Ovules and seeds 1-2 in each cell.

Flowers monodiceious. Fruit a drupe or capsule ........ EUPHORBLACE.

_ polygamous. Capsule 3-4-winged ............. SAPINDACE.A.

- perfect or polygamous.

Fruit a berry. Caly x colored.................. Phytolaccaceze.

- a samara. Leaves stipulate ................. Ulmacke.

Ovules and seeds numerous in the cells. Capsnle circumscissile.

Capsule 3-celled. Flowers solitary.................. Pontulacace $\boldsymbol{E}_{\text {. }}$

- 5-celled. - cymose............................

\section{Sub-class II. Gymnospermous Exogenous Plants.}

Ovules naked (not contained in an ovary), supported by an open scale or leaf, or else terminating a branch, and fertilized by the direct application of the pollen.

Stem branching. Leaves simple.................................... Stem simple, palm-like. Leaves pinnate .................... CYCADACER.

\section{Class II. Monocotyledonous or Endogenous Plants.}

Stem composed of cellular tissue and scattered bundles of woody fiber and vessels, destitute of pith, proper bark or concentric layers, and increasing in diameter by the deposition of new fibrous bundles. Leaves mostly alternate, entire, and parallel-veined, commonly sheathing at the base, seldom falling off by articulation. Floral envelopes usually in threes. . Cotyledon single.

\section{* Floral envelopes none. Flowers on a spadix.}

Stemless, floating herbs.

Plants frond-like, with no distinction of stem and leaves......... LEMNACEE.

Leaves clustered, epreading. Flowers axillary............ Pistia in Aracex. Caulescent, leafy, rooting herbs.

Fruit a berry. Spadix enclosed in a spathe. ARACEX.

— an achenium. Stem immersed, floating ............... NATADACE.E. — not immersed, erect TYPHACEX.

** Floral envelopes (perianth) single or double, not glumaceous.

Ovary arlherent to the perianth.

Stamens and pisti's united into a column. Flowers irregular... Onchmaces. - _ separate.

Flowers monœcious or diœcions.

- enclosed in a spathe in the bud. Aquatics...... Hrorocuaridacex. 
Flowers without a spathe. Leaves reticulate. Terrestrial

vines................................. DIOSCORRACE. perfect.

Ovary 1-celled. Stamens 3. Leaves minute.

BCrmanniaces.

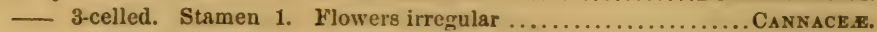

Stamens 3. Anthers extorse.

IRIDACE $A$.

Stamens 6. Perianth smooth or hairy ........ AMARYLLIDACE $\mathbb{x}$.

Ovary free from the perianth.

Perianth single (calyx).

Flowers on a spadix. Ovary solitary

ARACE.E.

Ovaries 4. Stem leafy

NaIADACER.

Flowers on a scape, spiked. Leaves rush-like JUNCAGINEX.

Perianth double (caly $x$ and corolla).

Calyx and corulla alike, or nearly so, and glume-like..........Juxcaces..

\section{- - - and not glume-like.}

Leaves ribbed and netted-veined. Fruit a berry.

Smracez.

- parallel veined.

Capsule 1-celled. Stamens, or the fertile ones, 3.........Pontederiace. - or berry 3- (rarely 4 or 6-) celled.

Anthers intorse (except Lilium) Style single

Stigmas 3, nearly sessile $\}$ LHiacz.s.

Anthers extorse (exc. Tofieldia). $\left.\begin{array}{l}\text { Styles } 3 \\ \text { Styles } 3 \text { or } 1\end{array}\right\}$........Melanthacex.

Calyx and corolla unlike.

Ovaries few or numerous, forming acheniæ in fruit..............ssucEs.

Ovary solitary.

Palms. Calyx tubular. Leaves fan-shaped.................... PALM $\boldsymbol{E}$.

Herbs.

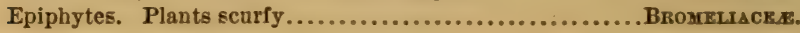

Stamens 6. Leares in a whorl. Flower single............. Trilliaces.

_ alternate, sheathing................ CoMmely NackA.

Stamens 3 or 4. Flowers monœcious capitate. Scape leafless.

Eriocaulonace.

*** Flowers glumaceous, i. e., with scale-like bracts, in place of proper floral envelopes.

Bracts single. Sheaths closed. Fruit an achenium............... CrPERACER.

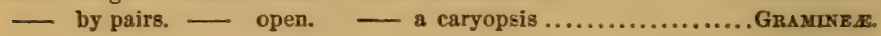

\section{Series II. Cryptogajous or Flowerless Plants.}

Plants destitute of proper flowers, and producing, in place of seeds, minute bodies (spores) which do not contain an embryo.

\section{Class III. Acrogens.}

Plants with a distinct stem, containing woody and rascular tissue, growing from the apex only.

Fructification borne on the under side of a peltate scale.......... EQUISETACE $\boldsymbol{x}$.

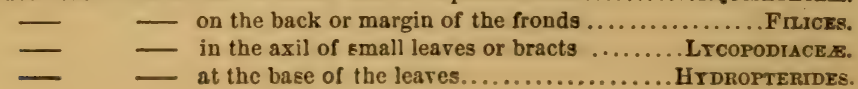




\section{FLORA OF TEXAS.}

SERIES I.

PHANOGAMOUS OR FLOWERING PLANTS.

Class I. Dicotyledons.

Sub-Class I. ANgiosperms.

\section{Division I.-Polypetalous Exogenous Plants.}

1. Crowfoot Family. Order, Ranunculaceæ.

Herbs, sometimes woody climbing plants, with colorless juice, sharp or acrid to the taste. Leaves mostly divided, exstipulate, with half-clasping petioles. Parts of the flower all separate and distinct, and inserted on the receptacle. Petals often wanting. Stamens more than 12 . Pistils more than one (except in larkspur, baneberry, and bugbane), and entirely separate, except in fennel-flower, in fruit becoming akenes or pods, or sometimes berries.

SYNOPSIS OF THE GENERA.

Tribe I. Clematideæ. Sepals valvate in the bud, colored. Petals stamen-like or none. Style elongated, persistent. Fruit an achenium.-Chiefly vines. Leaves opposite.

1. Atragene. Petals small and stamen-like.

2. Clematis. Petals none.

Tribe II. Anemoneæ. Sepals imbricated in the bud, colored. Petals none. Ovules solitary. Fruit an achenium.-Herbs. Floral leaves often whorled, forming an involucre.

3. ANEMONe. Involucre leaf-like and distant from the long peduncled flowers.

4. Hepatica. Involucre calyx-like and close to the flower.

5. Thacictrum. Flowers panicled and without an involucre. Achenia ribbed or inflated. Leaves compound.

6. Trautvetteria. Flowers corymbed. Involucre 
none. Achenia 4-angled. Seed erect. Leaves simple, lobed.

Tribe III. Ranunculeæ. Sepals imbricated in the bud, mostly herbaceous. Petals manifest. Ovules solitary. Fruit an achenium. Herbs. Leaves alternate.

\%. Mrosurus. Sepals spurred at the base. Achenia spiked. Leaves radical, linear.

8. Ranunculus. Sepals spurless. Achenia capitate. Stems leafy.

Tribe IV. Helleborineæ. Sepals imbricated in the bud, colored. Petals of various forms or none. Fruit a 1-many-seeded follicle. Leaves alternate.

9. Caltha. Petals none. Follicle many-seeded. Sepals yellow. Leaves simple.

10. Isopyruy. Petals none. Follicle few-seeded. Sepals white. Leaves compound.

11. Aquilegia. Sepals 5, regular. Petals 5, spur-shaped, hollow. Follicle many-seeded. Leaves compound.

12. Delphinum. Sepals 5, irregular; the outer one spurred. Petals 4, small; two of them spurred, the others stalked. Follicle many-seeded. Leaves lobed.

13. Aconitum. Sepals 5, irregular; the outer one large, hooded, and enclosing two long-stalked, hooked petals; the other petals stamen-like or wanting. Follicle many-seeded. Leaves lobed.

14. Zanthorhiza. Flower's regular. Sepals and petals 5 ; the latter 2-lobed. Follicle 1-2-seeded. Shrubby. Leaves compound.

Tribe V. Cimicifugeæ. Sepals imbricated in the bud, colored. Petals small and flat, or none. Fruit a follicle or berry. Herbs. Leaves alternate.

15. Hydrastis. Petals none. Ovaries numerous, forming a head of 1-2-seeded berries. Stems 1-flowered. Leaves simple, lobed. 
16. AстæA. Petals 4-8, entire. Ovary solitary, forming a many-seeded berry. Flower's in short oblong racemes. Leaves compound.

17. Cimicifuga. Petals 3-5, cleft. Ovaries 1-8, forming many-seeded follicles. Racemes elongated. Leaves compound.

\section{ATRAGENE.}

Sepals 4, colored, membranaceous, spreading, valvate in the bud, deciduous. Petals numerous, stamen-like. Stamens indefinite. Ovaries numerous, 1-ovuled. Achenia capitate, bearing the persistent styles in the form of long plumose-bearded tails. Seeds suspended. Shrubby vine, climbing by the petioles. Leaves opposite, componnd, from scaly buds. Flowers solitary, showy.

A. Alpina. New Mexico; April. Bigelow.

\section{CLEMATIS, L. VIRGIN'S Bower.}

Petals none. Persistent styles, naked or plumose. Otherwise as Atragene. Herbs or shrubby rines. Leaves simple or compound, opposite. Buds not scaly. Flowers solitary or panicled, often polygamous or diœcious.

* Flowers solitary, nodding; calyx thick or leathery.

+ Stems erect, mostly simple, herbaceous.

t+ Stems climbing, herbaceous.

C. VIorNa, L. Smoothish; leaves pinnate; leaflets 5-7, oval or oblong-ovate, mostly acute, somewhat membranaceous, entire or 2-3-lobed, the lowest pair often ternate; calyx ovate; sepals ovate, tapering into a short recurred point, not margined, rather longer than the stamen; tails of the achenia ( $1 \frac{1}{2}^{\prime}$ long) plumose. River banks. MayAugust. Flowers nodding. Sepals thick, reddish purple, 1 ' long.

C. Reticulata, Walt. Smooth; leaves pinnate; leaf- 
lets 7-9, oval, entire or 2-3-lobed, obtuse or mucronate, coriaceous, strongly reticulated ; calyx ovate; sepals ovatelanceolate, with spreading tips, not margined, longer than the stamens; tails of the achenia ( $1 \frac{1}{2}^{\prime}$ long) slender, plumose. Dry sandy soil. May-July. Calyx downy, dull purple.

C. Pitcheri. Leaflets rough with prominent veins, coriaceous. Sepals lanceolate, thick, achenia with short pubescent tails. Leaves pinnate, those of the peduncles simple, subsessile. Leaflets ovate, acute or obtuse, often subcordate at base. Sepals of the nodding flower ovatelanceolate, dull purple, $8-10^{\prime \prime}$ in length, the cuspidate point reflexed. Hills in W. Texas. June. Bigelow.

C. Texensis, Buckley. Stem climbing; leaves pedunculate, entire, broad-ovate, acuminate, mucronate, shortly petiolate; cauline leaves unequally pinnate, long petioled, leaflets 1-3-lobed, segments lanceolate, acute, peduncles one-flowered, sepals coriaceous, at the apex a little reflexed. Leaves thin, not coriaceous, whole plant smooth;

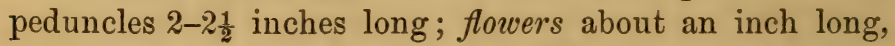
subconical, purple, floral leaves 2-4, near the junction of the peduncle with the stem, large, crowded, and on petioles 2-3 lines long, at the base of which are 2-4 spathular bracts. The unequally pinnated stem-leaflets small, 1-3-lobed, segments lanceolate and acute; part of these stem-leaflets are on long tendril-like petioles. Flowers in May. Near the Colorado River, above Austin.

* * Floners panicled; calyx thin, spreading, white ; stems woody.

C. Virginiana, L. Smooth; leaves ternate; leaflets ovate or cordate-ovate, lobed or toothed; panicle trichotomous, many-flowered, leafy; flowers diœcious or polygamous; sepals obovate, smoothish; tails of the achenia long, plumose. Swamps and meadows. July. Leaflets $2^{\prime}-3^{\prime}$ long.

C. Drummondi. Flowers in paniculate corymbs, diœcious; leaves pinnate, silky-villous beneath, sparingly. hir- 
sute on the upper surface; leaflets rhombic-ovate, incisely 3 -lobed, the lobes acute; sepals 4, oblong; carpels villous, with very long capillary plumose tails. Along the tributaries of the Rio Grande. Torr. and Gray. Drummond describes one closely allied to C. serica of Central America. Stem slender, angular, somewhat hairy. Leaflets mostly 5 , about an inch long; the lateral lobes sometimes a little toothed. Panicles about as long as the leaves, trichotomously divided. Sepals white, villous externally. Tails of the carpels very slender, more than two inches in length, densely plumose.

\section{ANEMONE, L. WIND-FLOWER.}

Sepals 4-20, colored, imbricated in the bud, deciduous. Petals none. Stamens indefinite. Filaments filiform. Ovaries numerous. Ovule solitary. Achenia capitate, compressed, pointed by a short, naked or woolly, straight or hooked persistent style. Seed suspended. Perennial herbs with naked stems, bearing at the summit 2-3 opposite or whorled and divided leaves, which form an involucre remote from the flower. Radical leaves lobed or divided.

A. Caroliniana, Walt. (Carolina Anemone). Stem slender, 1-flowered; penduncle many times longer than the small, sessile, 3-leaved, 3-toothed involucre ; radical leaves 2-3, long-petioled, ternate, deeply parted, lobed and toothed; sepals 14-20, oblong, white; achenia numerous in a cylindrical-oblong head, woolly. March. W. Texas.

A. Heterophylla. Leaves roundish-oval, crenate segments; involucre linear-cleft to the base. Sepals acute, $5-13$; head of carpels cylindrical. Radical leaves one or few, long-stalked (3-5) ternate, the segments stalked, simple, or incisely 3 -lobed or parted. Scape 8-16' high, silky pubescent above. Leaves of the involucre totally unlike the others, the segments $1-1 \frac{1^{\prime}}{2}$ by $1^{\prime}$, placed (in flower) above the middle of the scape. Flowers greenish, scentless; se- 
pals commonly 8 , all linear-oblong, $5-6^{\prime \prime}$ long, soon falling. Achenia flattened.

\section{HePatica, Dill. Liver-leaf.}

Flowers and fruit as Anemone. Involucre close to the flower, 3-leaved, resembling a calyx; its leaves sessile, ovate, entire. A low, perennial herb, with scape-like, 1-flowered?

\section{THALICTRUM, Tourn. Meadow Rue.}

Sepals 4-10, imbricated in the bud, colored, spreading, deciduous. Petals none. Stamens numerous. Filaments filiform, clavate or flattened. Ovaries 3-15, 1-ovuled. Achenia sessile or stalked, furrowed or inflated, pointed by the sessile persistent stigma or short style. Seed suspended. Perennial herbs. Leaves compound.

* Flowers polyganous or dicecious; sepals shorter than the stamens; stigma elongated; achenia nearly sessile, ribbed; leaves alternate, decompound ; involucre none; flowers small, panicled.

T. Dioicux, L. Stems erect; leaves long-petioled; leaflets thin, roundish, crenately 5-\%-lobed, smooth; flowers numerous; sepals greenish; stamens and stigma filiform; achenia sessile or distinctly stalked.

T. DEBILE, Buckley. Stems low $\left(8^{\prime}-12^{\prime}\right)$, procumbent or ascending, much branched; leaves long-petioled; leaflets small, stalked, rounded, crenately lobed, smooth ; flowers few on axillary or terminal peduncles; achenia oblong, strongly ribbed, short-stalked, as long as the slender style. Stems branching at the base, slender. March-April.

T. CORNuTr, L. Radical leaves long-petioled; stemleaves sessile (the common petiole wanting); leaflets thick, oval or oblong, 3-lobed or entire, often cordate, smooth, or pubescent beneath; sepals white; stamens and stigma slightly clavate; achenia short-stalked. Meadows and woods. June-August. Stems $3^{\prime}-40^{\prime}$ high. Radical leaves very large. 
* Flowers peifect; sepals longer than the stamens; stigma depressed; acheria sessile, ribbed; stem-leaves whorled, flowers umbelled.

T. anemonordes, Michx. Radical leaves biternate, long-petioled; leaflets oval or roundish, cordate, 3-5-lobed; stem-leares $2-3$, sessile, ternate; the long-stalked leaflets forming an involucre apparently of 6-9 simple leaves; umbel 3-6-flowered; sepals 6-10, white; roots tuberous, stem $6^{\prime}-10^{\prime}$ high. Flowers $\frac{1^{\prime}}{2}-\frac{3^{\prime}}{4}$ in diameter. Woods. April-May.

\section{TRAUTVETTERIA, Fisch. and Mey.}

Sepals 3-5, orbiculæ imbricated in the bud, colored, caducous. Petals none. Stamens indefinite; filaments clavate; ovaries numerous, 1-ovuled. Stigma recurved. Achenia capitate, gibbous, 4 -sided, beaked by the hooked persistent stigma. Seed erect. Erect, perennial herbs, with alternate, palmately-lobed leaves and corymbose flowers.

\section{\%. MyOSURUS, L. Mouse-tail.}

Sepals 5-\%, imbricated in the bud, spurred at the base. Petals 5-\%, linear, spatulate. Stamens 5-10; filaments filiform. Ovaries numerous, 1-ovuled, style subulate. Achenia 3-angled, imbricated on the filiform, elongated receptacle. Seeds suspended. Small annuals, with linear radical leaves, and small solitary yellowish flowers on a naked scape.

M. Mrnimus, L. Scapes $2^{\prime}-6^{\prime}$ long, longer than the leaves; achenia beakless. Fruiting-spike linear, 1'-2' long. April. Flower pale-yellow; prairies and bottom-lands.

\section{RANUNCULUS, L. BetTercup.}

Calyx of 5 ovate sepals; corolla of 5 roundish shining petals, each with a nectariferous scale or pore at the base inside; filaments indefinite. Achenia flattened, beaked, with the smooth persistent style--Herbs. Leaves alter- 
nate, the radical ones long-petioled. Flowers axillary or somewhat corymbed, white or yellow.

\$1. Petals white, with yellow pit at the base; achenia mugose.

R. aquatilis, L. Stems 1-2 feet or more in length, slender, weak, round, smooth, jointed. Leaves petioled, divided into an indefinite number of capillary segments, in outline roundish, and $\frac{1}{2}^{\prime}-1^{\prime}$ diameter. Flowers axillary, remote, long peduncled. Sluggish streams and ponds. July, August.

§2. Petals yellow, with a small scale at the base.

* Achenia muricate; annuals.

R. PARVIflorus. Silky-pubescent; leaves small, the lower ones circular, 3-lobed, acutely toothed; the upper 3 -parted or entire; flowers quite small, the yellow petals $3-5$, as long as the reflexed sepals; achenia narrowly margined, pointed with the short, recurved style. Waste places. March-May. Stem $6{ }^{\prime}-12^{\prime}$ high, erect, branching. Leaves rarely $1^{\prime}$ wide.

\section{** Achenia smooth ; chiefly perennials. \\ + Leaves undivided.}

R. oblongifolius. Leaves petiolate, denticulate, lower ones oblong-oval, upper ones linear-lanceolate; petals a little longer than the calyx ; carpels globose, not pointed, smooth.-Drummond.

R. Texensis. Stems erect, diffuse, branching. Leaves lanceolate and lance-ovate. Flowers minute, numerous. Stamens about 20. Petals yellow, less than $1^{\prime \prime}$ long. Carpel minute, pointless, in round heads.-Engl.

++ Leaves (at least those of the stem) alternately lobed or divided.

t+ Petals small, not exceeding the calyx.

R. AfFinis. Radical leaves petioled, pedately multifid; cauline ones subsessile, digitate, with linear lobes; stem erect, few-flowered; calyx and ovary pubescent; carpels with recurved beak, disposed in oblong-cylindrical heads. June-August. New Mexico.-Bigelow. 
+ Petals much larger than the calyx; achenia in globase heads.

R. REPENS, L. Smooth or hairy; leaves ternate, or the earliest ones 3-lobed; leaflets 3-lobed, toothed; achenia strongly margined, pointed with the broad and straight or slightly curved beak; stenis erect or prostrate, often bearing long runners. Rich soil. Varieties to be found in river swamps. March, April.

R. Bulbosus. Hairy; stem erect $\left(1^{\circ}-1 \frac{1}{2}^{\circ}\right.$ high) from a bulbous base. Radical leaves petioled, 3-parted, and somewhat pinnately divided; leaflets 3 -cleft, incisely toothed; those of the upper leaves lanceolate, entire. Flowers large ( $1^{\prime}$ wide) ; achenia pointed with a short recurved beak. Low grounds. May.

\section{CALTHA. Marsh Marigold.}

Calyx colored, of 5-9 sepals, resembling petals; corolla wanting; stamens indefinite, shorter than the sepals ; follicles 5-10, capitate or whorled, sessile, spreading, manyseeded. Aquatic, and very glabrous.

\section{ISOPYRUM, L. False Rue, Anemone.}

Sepals 5-6, regular, ovate, colored, imbricated in the bud, deciduous. Petals 5, small, tubular, sometimes wanting. Stamens numerous. Ovaries 2-20. Style short, subulate. Follicles subsessile, acuminate with the style, membranacenus, 2-several-seeded. Delicate herbs, perennial, smooth. Leaves compound, alternate. Flowers pedunculate, axillary and terminal, white.-Torr. and $G r$.

I. Biternatum. Stem $\left(6^{\prime}-12^{\prime}\right.$ high $)$ slender, sparingly branched; radical leaves biternate, on long petioles; stemleaves ternate, nearly sessile; leaflets ovate and obovate, obtusely 3 -lobed; petals none; ovaries 1-5; follicle 2 -seeded. Shady woods. April.-Torr. and $G r$. 


\section{AQUILEGIA, L. Columbine.}

Sepals 5, equal, ovate, colored, spreading, caducous. Petals 5, tubular, dilated at the mouth, the outer margin erect, the inner attached to the torus, extending behind into a long spurred nectary ; stamens indefinite, the inner ones longer and sterile; styles 5; follicles 5, many-seeded. Leaves 2-3, ternate. Flowers nodding.

A. LePToCERA. Found among the Organ Mountains, near Doña Ana, New Mexico. - No description given.Bigelow.

\section{DELPHINUM, L. LARKSPUR.}

Sepals 5, colored, irregular, the upper one spurred behind. Petals 4, very irregular, the 2 upper ones protracted in to a tubular nectariferous spur, enclosed in the spur of the calyx; styles 1-5; follicles 1-5. Showy herbs. Leaves pinnately divided. Flowers of the cyanic series never yellow.

D. AzUREuM. Stem mostly simple, downy; leaves $3-5$ parted, the divisions cleft 3-5, linear, toothed or entire, acute lobes; racemes many-flowered; pedicels and follicles erect; spur slightly curved, twice as long as the calyx. Sepals sky-blue or sometimes whitish, tipped with brown. Lower petals 2-cleft, bearded, stem $\left(1^{\circ}-2^{\circ}\right)$ high. Rich soil. April, May.-Michx., Buckley.

D. viMINEUM. Leaves flat, 3-parted, segments cuneiform, obtuse, 3-lobed, mucronulate, uppermost ones linear, undivided or 3-parted; petioles scarcely dilated at the base; racemes loose, velvety; limb of the inferior petals bifid at the summit, spur straight, as long as the sepals; ovaries silky. Flowers middle-sized, bright azure. Blooms in July, August. Velasco (and all the coast prairies).-Drummond. 


\section{ACONITUM. Monkshood, Wolfsbane.}

Sepals 5, irregular, colored, upper one vaulted; petals 5 , the 3 lower minute, the 2 upper on long claws concealed beneath the upper sepal, recurved and nectariferous at the apex; styles 3-5; follicles 3-5. Leaves digitate or palmate.

\section{ZANTHORHIZA. YELLOW RoOT.}

Sepals 5 ; petals 5 , of 2 roundish lobes raised on a peciicel; stamens 5-10; ovaries 5-10, beaked with the styles, 2-3-ovuled; follicles mostly 1-seeded, seed suspended. Smooth trailing shrub, yellow root. Leaves pinnately divided. Racemes axillary compound. Flowers small, dark purple.

Z. APIIFolia. Shady banks. Stem short, woody, leafy above. Leaves glabrous, about $8^{\prime}$ long, including the long petiole. Leaflets $5,2^{\prime}-3^{\prime}$ long, sessile, incisely lobed and dentate. March and April.-L'Her.

The 15th, 16th, and 1\%th genera, Hydrastis, Actææ, Cimicifuga, have not yet been reported (if found) by botanists, as growing in Texas.

\section{MAgNolia Family. Order, Magnoliacex.}

Trees or shrubs, with aromatic or strong-scented and bitter bark, and alternate simple leaves, which are never toothed; large, thin stipules form the covering of the buds; fall off early. Flowers large, single at the ends of the branches, their leaves in threes, viz., 3 sepals colored like petals, and 6 petals in two rows or 9 in three rows, their margins overlapping in the bud. Stamens very many on the receptacle, with long anthers occupying, as it were, 
the side of the filament. Pistils many, packed and partly grown to make a sort of cone in fruit.

\section{SYNOPSIS.}

Suborder I. WINTEREA.

1. Illicum.

Suborder II. Schizandre.e.

2. Schizandra.

Suborder III. Magnolies. Flowers perfect. Stamens numerous, separate. Ovaries imbricated in a head, 2-ovuled. Fruit fleshy or somewhat woody, in conelike heads or spikes. Chiefly trees. Leaves entire. Stipules large.

3. Magnolia. Fruit fleshy, dehiscent, persistent on the receptacle. Anthers intorse.

4. Liriodendrou.

\section{MAGNOLIA, L.}

Sepals 3, caducous; petals $6-9$; anthers longer than the filaments, opening inward; carpels 2-ralved, 1-2-seeded, aggregated into a hard, conelike fruit; seeds berry-like, and suspended from the opening carpels by a long funiculus. Trees and shrubs with large fragrant flowers. Leaves conduplicate in the bud, embracing and embraced by sheathing stipules.

\section{* Leaves perennial.}

M. GRANDiflora (Magnolia). Leaves coriaceous, oblong or obovate, smooth and glossy above, rusty-pubescent beneath, flat or concave; petals mostly 9, obovate, concare, clawed. Light, fertile soil, in the Gulf counties of Texas. A very large tree. Leares 6'-12' long. Flou'ers $6^{\prime}-9$ ' wide, white, changing to brown. Cone of the fruit oral, seed crimson, remaining suspended by a white thread for several days after ripening.

M. GLAtCA (Sweet Bay). Leaves coriaceous, lanceolate and oblong, silky-pubescent, at length smooth abore, glancous beneath; petals 9, obovate, concave. Swamps. A 
shrub or small tree. Leaves partly deciduous. Flowers $2^{\prime}$ wide, white, very fragrant; cone of fruit oval, $1^{\prime}-1 \frac{1}{2}{ }^{\prime}$ long.

** Leaves deciduous, acute at the base.

M. acuminata, L. Leaves scattered, oval acuminate, downy beneath; petals $6-9$, oblong orate, obtuse. Upper districts, in rich, shaded soil. June, July. Large tree. Leaves $66^{\prime}-9^{\prime}$ long. Flowers $3^{\prime}-4^{\prime}$ wide, dull yellow and greenish. Cone of fruit cylindrical, $2^{\prime}-3^{\prime}$ long.

\section{CUSTARD-APPLE FAMILY. Order, Anonaces.}

Tiees or shrubs, resembling the Magnolia family, but the three petals of each not overlapping each other in the bud; the bark and foliage not aromatic, but disagreeable tasted. Seeds with variegated albumen, large, bony. Leaves exstipulate, entire, pubescent when young. Flowers axillary, mostly solitary.

Petals, and commonly the leares, minutely punctate with pellucid dots.

\section{asimina, Adams. Papaw, Custard Apple.}

Petals thick; the outer ones larger and spreading. Stamens very numerous, crowded on the globular receptacle. Ovaries 3-15, sessile, 1-celled, few-many-ovuled; baccate in fruit. Seeds horizontal, enclosed in a thin succulent aril. Shrubs or small trees. Leaves deciduous. Flowers nodding.

* Flowers appearing with or before the flowers.

A. TRILoba, Dunal. Leaves oblong-obovate, acuminate, corered with a rusty pubescence, as also the branches when young, at length glabrous; outer petals round-ovate, dark purple, 3-4 times as long as the hairy sepals. A shrub or small tree. Leaves $8^{\prime}-12^{\prime}$ long. Flowers $1^{\prime}-12^{\prime}$ wide. Fruit oblong, yellow, and pulpy when mature; edible. 


\section{MOONSEED FAMIIX. Order, MeNispermaCex.}

Climbing shrubs. Flower's diœcious, small, in panicles or racemes. Sepals and petals often confounded, 4 or 6 . Stamens monadelphous, or separate, generally of the same number as the petals, opposite them, sometimes four times as many. Anthers adnate or innate, 4-lobed. Ovaries several. Drupes baccate, 1 -seeded, incurved. Leaves alternate, simple, palmately veined, exstipulate.

This order contains, according to Gray and Darby, only 2 genera. Wood has 3.

1. Stamens 12 to 20. Pistils 2 to 4 . Flowers white; leaves rounded and angled, shield-shaped.
Fruit blue-black.
Menispermum. MooNseED.

2. Stamens 6, one before each petal. Flowers greenish; leaves heart-shaped.

Cocculus. Cocculus.

3. Stamens 12 in staminate flowers.

Stamens 6 in pistillate flowers, abortive.

Anthers 2-celled.

Ovaries 3.

Sepals 6, petals none.

Calycocarpum. CUPSEED.

\section{MENISPERMUM, L. MooNSEED.}

Flowers diccious. Sepals and petals 4-8. Stamens 12-14. Anthers 4-celled. Ovaries 2-4. Stigma dilated, spreading.

Leaves rounded, angular or lobed, slightly cordate and pellate at the base. Flower's white, panicled.

M. Canadense, L. Stem twining. Sterile panicles elongated. Drupe black. July. Banks of streams.

\section{COCCULUS, L.}

Flowers diœcious or polygamous. Sepals and petals 6, each in two rows. Stamens 6, anthers 4-celled, abortive in 
the fertile flower. Ovaries 3-6, 1-celled, 1-ovuled. Stigma subulate, recurved. Drupe baccate, campylotropus. Nut reniform, rugose. Seed conformed to the cavity of the nut. Embryo semicircular.

Leaves ovate or slightly cordate, entire or angularly lobed.

C. Caroliniana, DC. Pubescent. Stem twining, $10^{\circ}-15^{\circ}$ long. Leaves very acute, rather rigid. Racemes of the fertile flowers simple; of the sterile, compound. Flowers white. Drupe red. Wet ravines. Valley of the Picos and Rio Grande.

\section{BARBERRY FAMILY. Order, Berberidacex.}

Herbs or shrubs, with alternate, usually exstipulate, simple or compound leaves.

Sepals and petals in fours, sixes, or eights. Stamens the same number as petals, one before each petal (on the receptacle). Anthers opening by recurved valves.

Pistil one. Style short or none. Fruit a berry or capsule, seeds several, albuminous.

\section{SYNOPSIS.}

* Anthers opening by uplifted valves.

Stamens 6. Leaves bristly-serrate. Shrubs................BERERIs.

6. - compound. Herbs.

Caulophrllum.

- 6. - peltate, deeply two-cleft, and lobed. Herb.Diphylueia.

** Anthers opening longitudinally.

Stamens 12 or more. Flowers solitary in the fertile, of two peltate, lobed leaves................ PoDophyLum.

\section{BERBERIS. BARBERRY.}

Sepals 6, orbicular. Petals 6, obovate, often biglandular near the base. Stamens 6, irritable. Stigma circular, depressed. Fruit a 1-9-seeded berry. Seeds erect. Shrubs 
with yellow wood. Leaves bristly serrate, often reduced to branching spines. Flowers racemose, yellow. Berries acid.

B. TRIFoliata. Leaves coriaceous and rigid; leaflets $1^{\prime}-2$ ' long, the middle one larger and longer than the other two; petiole short, leaves terminating in a spiny apex. Racemes short, berries red. Austin, thence west to New Mexico.-Bigelow.

B. Swaserin, Buckley. Leaflets 5-9, smooth, lightgreen above, glaucous below, sessile, the basal smallest, veins irregular, much branched, and reticular, repand, dentate, teeth large and spinose, leaves alternate, leaflets opposite, fasciculated at the base of the smaller branches, but rather scattered on the terminal growing ones; leaf $2-3$ inches long, width 1-1 $\frac{1}{2}$ inches, leaflets $\frac{1}{2}-1$ inch long and about $\frac{1}{2}$ inch wide, terminal leaflet sometimes petiolate, fruit stems 1-2 inches long and 2-3 branched, near the summit bractose, bracts clasping and acute, mucronate, fruit nearly round, about $\frac{1}{2}$ an inch in diameter, juicy, and of a slightly acid agreeable taste, 6-9-seeded, seeds smooth, oblong and blunt at both ends, fruit subtransparent, yellowish-white tinged with red. Shrub, evergreen, $2-3$ feet high, branches small, smooth, and reddish brown; large stems rough and grayish brown. Flowers February and March. Fruit ripe about the first part of June. Western Texas on the Perdinales River. In honor of Dr. Swasey, of Mobile, Ala.

B. TRIfoliolata, Torr. Leaves ternate, smooth, rigid, and spinose, petiolate, evergreen, blnish green, with reins of a paler and whitish color. Flowers yellow, last of February and first of March. Pedicels aggregated in 2's and 5's, 4-6 lines long, berries small, red, and edible. Grows in dense clumps 4-6 feet high. Limestone hills, Austin and vicinity. 


\section{Nelumbo FAmily. Order, Nelumbiace 2 .}

$H e r b s$ aquatic, prostrate rootstock, leaves radical, $1^{\circ}-2^{\circ}$ in diameter, peltate orbicular. Flowers large, pale yellow, solitary, on long upright scapes, 4-5 sepaled; petals numerous, arranged in many rows, as are also the stamens; ovaries separate, each with a simple style and stigma, becoming in fruit 1-seeded nuts half sunk in the hollows of the large torus, the seeds with largely developed embryo and no albumen.

N. Luteum (Water Chinquepin). Aquatic herbs, with peltate leaves depressed in the center, and solitary, hypogynous flowers, $5^{\prime}-8^{\prime}$ wide, pale yellow. Eagle Lake, near Columbus.

\section{\%. WA'TER-ShIELD FAMILY. Order, Cabombacez.}

Sepals and petals $3-4$. Stamens $6-18$. Ovaries $2-\infty$. Capsule 1-3 seeded, indehiscent. Stems filiform, branching. Submerged leaves opposite, divided into numerous filiform flattened segments; floating ones peltate, entire. Flowers small, in the axils of the floating leares.

C. Caroliniana. Floating leaves oblong linear; flowers white. Ponds and still water. Stem $2^{\circ}-4^{\circ}$ long. JuneAugust.

\section{BRASENIA. WATER-SHIELD.}

Sepals and petals 3-4. Stamens 12-18, anthers exserted. Ovaries 4-18. Leaves all peltate and entire, alternate oval, on long petioles. Flower's axillary on elongated peduncles, dull purple.

B. Peltata, Pursh. Stem, petioles, and lower surface of the leaves coated with a gelatinous exudation. Ponds and slow-flowing streams. 


\section{WA'TER-LILY FAMILY. Order, NyM- PH IACE.E.}

Aquatic herbs. Leaves peltate or cordate from a rhizome. Sepals, petals, and stamens numerous, imbricated and gradually passing into each other. Anthers adnate, and intorse. Pistils many, and united into a many-celled, many-seeded compound ovary.

\section{NYMPHEA, Tourn. WATER-LiLy.}

Sepals 4, green outside. Petals oblong, inserted into the thin torus which enrelops the ovary, the inner one passing into stamens. Stamens numerous, inserted above the petals, the outer ones petal-like. Anthers adnate, intorse. Ovary many-celled. Stigmas as many as the cells, linear, radiating around a globular central gland. Berry globose. Seed enclosed in a membranaceous aril. Leaves orbicular, cleft at the base to the center, floating. Flowers on elongated, often spiral peduncles.

N. odorata, Ait. (Pond Lily). Rhizoma large, creeping; leares $6{ }^{\prime}-12^{\prime}$ wide, entire, the sinus narrow and the lobes acute, or else with an open sinus and obtuse lobes. Ponds and still waters. May.

\section{NUPHAR. Order, Yellow Water-Lily.}

Sepals 5-6, oborate, vellow. Petals 10-20, stamen-like, hypogynous. Stamens numerons, at length recurved, persistent. Orary cylindrical, many-celled. Stigma sessile, circular. Berry oblong. Seeds smooth, without arils. Leares cordate or sagittate, floating or erect. Flowers yellow, erect.

N. advena, Ait. (Boxwets. Spatter-Dock). Leares thickish cordate, smooth or downy beneath, often emersed 
and erect on stout petioles. Sepuls 6, the outer ones rounded; petals numerous, thick and fleshy, truncate. In still water; flowers through the summer. In Devil's River, West Texas.-Bigelow.

10. SIDESADDLE-FLOWER FAMILY. Order, SARRACENIACEA.

Leaves radical, urn-shaped or trumpet-shaped. Flowers large, on scapes. Sepals 5, colored, persistent; below the calyx are three bractlets.

Petals 5, incurved, deciduous. Stamens numerons, situated on the receptacle. Styles 5. Stigmas united, forming a five-angled peltate-persistent membrane covering the ovary and stamens. Capsule 5-celled, seeds many. Leaves holding water, with a wing on the front side and a hood at top.

This order contains nine genera.

\section{POPPY FAMILY. Order, Papaveraced.}

Herbs with alternate, exstipulate, leaves, and generally a milky or colored juice. Flowers solitary, on long peduncles, never blue, hypogynous. Sepals 2 , rarely 3, cadncous, and petals 4, rarely 6, all imbricated. Stamens indefinite, but some multiple of 4. Anthers 2-celled, innate. Ovary compound. Style short or none. Stigmas 2 or more, stellate upon the flat apex of ovary. Fruit either pod-shaped with two parietal placentæ, or capsular with several. Seeds indefinite, minute.

\section{aRgemone. Mexican Poppy.}

Sepals 2-3, horned or hooded. Petals 4-8. Stigmas 4-7, free, radiate. Capsule oblong-obovate, hispid, opening 
at the summit by $3-6$ valves, which separate from the filiform persistent placentæ. Seeds globular, crested, pitted. Glaucous herbs with yellow juice, sessile, pinnatifid, bristly leaves, and showy white or yellow flowers.

A. Mexicana, L. Annual. Leaves pinnatifid-lobed, bristly and prickly, blotched with white, spinous on the margin, and veins beneath. Stem $2^{\circ}-3^{\circ}$ high, branching, armed with prickly spines. Flowers axillary and terminal on short peduncles 2 ' -3 ' in diameter, white or yellow. All through Southern Texas and West to the Rio Grande.

\section{ESCHSCHOLTZIA, Cham.}

Sepals 2, cohering by their edge, caducous. Petals 4 . Stamens indefinite, adhering to the claws of the petals. Stigmas 4-7, sessile, 2-3 of them abortive. Capsule podshaped, cylindric, 10-striate, many-seeded. Leaves pinnatifid, glaucons. The juice colorless and exhales an odor of hydrochloric acid.

E. Douglasir, Hood. Stem branching, leafy; torus obconic; calyx ovoid, with a very short abrupt acumination; petals, bright yellow, with an orange spot at base. Ravines along the Rio Grande from Frontera to Eagle Pass.-Torr.

\section{FUMitory FAMily. Order, Fumariacex.}

Herbs smooth, delicate, with bristle stems, colorless juice. Leaves alternate, multifid, often furnished with tendrils.

Flowers irregular, purple, white, or yellow.

Sepals 2, very small; petals 4, hypogynous, more or less grown together, the two outside ones larger with small spreading tips; the two inner small, with spoon-shaped tips sticking together face to face, over the anthers and stigma. 
Stamens 6, diadelphous, each bundle opposite the larger petals; sometimes all joined in one tube below; the two outer anthers are 1-celled, the two inner 2-celled, of each bundle. Pistil 1, like the Poppy family. Fruit either an indehiscent nut 1 -2-seeded, or a pod-shaped capsule many-seeded; seeds ariled and glossy.

\section{CORYDALIS.}

Sepals minute. Petals separate, deciduous; one of the outer ones saclike at the base. Filaments united nearly to the summit, with gland at the base. Stigma 2-lobed. Capsule many-seeded. Seed crested. Caulescent, annual or biennial herbs, with bipinnate dissected leaves, and flowers in lateral and terminal racemes.

C. AUREA, Willd. Stems diffuse; racemes simple; capsule knotted, drooping ; crest of the seeds scalloped; flowers yellow. March. Hueco Mountains.-Thurber.

C. GLAUCA, Pursh. Stems erect; racemes compound; capsule even, erect; crest of the seeds eatire; flowers whitish, tinged with yellow, and reddish. Plant glaucous, $1^{\circ}-2^{\circ}$ high, leaves finely dissected as in $C$. aurea, but coarser.

\section{CRUCIFEROUS OR CRESS FAMILY. Order, Crucifer e.}

Herbs with watery, pungent juice. Leaves alternate, exstipulate. Flowers cruciferous, generally in racemes and without bracts. Sepals 4, deciduous; petals 4, hypogynous, with long claws and spreading limbs.

Stamens 6, the 2 outer opposite ones shorter than the 4 interior. The pistil makes a pod which is 2-celled by a false partition, with parietal placenta. When the pod opens, the valves fall away, leaving the seeds attached to the edges of the frame. The whole kernel of the seed is 
an embryo. It is always bent and folded up in various ways. 'I'he genera of this whole fumily is distinguished by the pod.

\section{SYNOPSIS.}

I. Siliquose. Fruit a silique, few-many-seeded.

* Cotyledons flattened, parallel with the partition, one edge applied to the ascending radicle (accumbent).

* Valves of the fruit nerveless.

Silique short, nearly terete. Seeds in two rows in each cell...... NasturTIUM. - linear, compressed. Seeds wingless in a single row...... CARDAMINE.

\section{t+ Valves of the fruit 1-nerved.}

** Cotyledons flat, with one edge turned toward the partition, and the back of one of them applied to the ascending radicle.

Silique sessile, nearly terete. SISYMBRIUM.

\section{Siliculosex.}

Silicle compressed, parallel with the broad partition, or globular.

Silicle oval or oblong, many-seeded........................... DraBA. — orbicular, few-seeded............................ Vesicania.

** Silicle cumpressed contrary to the narrow partition.

Vaives of the silicle boat-shaped. Seeds solitary............... LEridrum.

\section{NASTURTIUM, R. Br. WATERCRESS.}

Silique nearly terete, linear or oblong, or short and siliclelike, usually curved upward; the valves nerveless. Seeds numerous, small, in two rows in each cell, not margined. Cotyledons accumbent.-Herbs. Leaves pinnately lobed. Flowers white or yellow, small.

N. Tanacetifolium, Hook and Arn. Smooth; stems diffuse; leaves pinnately divided, with pinnatifid or toothed lobes; silique oblong-linear, pointed with the short style, twice as long as the pedicel. Damp soil. March, April. Stems $66^{\prime}-12^{\prime}$ long. Flowers minute, yellow.

N. Sessiliflorum, Nutt. Smooth; stem stout, erect, 
branching; leaves oblong-obovate, pinnatifid toward the base, toothed above, obtuse; silique linear-oblong, pointed with the very short and thick style $4-5$ times as long as the pedicel. Flowers small and yellow.

\section{CARDAMiNE, L. Bitter Cress.}

Silique linear, flattened; the valves nerveless, usually opening elastioally from the base. Seeds several, wingless, disposed in a single row in each cell, suspended by filiform stalks. Cotyledons accumbent.-Herbs. Leaves often undivided. Flowers purple or white.

\section{* Perennials.}

C. Rotundifolia, DC. Smooth. Leaves oval, or orbicular or cordate petiolate; root fibrous; stem erect, simple, bearing from the root or upper axils long and leafy runners. The lowest leaves are very long petioled, and sometimes sparingly pinnatifid. Silique subulate, spreading; seeds oval. Cool springs. May and June. Stem $6^{\prime}-12^{\prime}$ high. Runners $2^{\circ}-3^{\circ}$ long. Flowers white.

\section{** Annuals.}

C. Ludoviciana, Hook. Low ; stems branching and hairy at the base; leaves lanceolate pinnatifid, with numerous. oblong sparingly-toothed lobes, those of the root tufted; silique broadly linear, erect, spreading, pointed with the sessile stigma; seeds orbicular, margined. Stems 4'-6' high. Flowers small and white.

C. HIRsuta. Stem hairy or smooth, erect, $1^{\circ}-2^{\circ}$ high, branching. Leaves pinnatifid, with numerous oval or oblong sparingly-toothed lobes, those of the upper leaves linear and entire; silique narrow, linear, erect, pointed with the nearly sessile stigma; seeds oval, minute, and marginless. Wet soil. March, April. Flowers small and white. 


\section{SISYMBRIUM. Hedge Mustard.}

Silique linear or oblong, terete or somewhat angled, with 1-3 nerved valves. Seeds in a single row in each cell, oblong, marginless. Cotyledons linear-oblong, incumbent. Herbs with simple or pinnately divided leaves. Flowers in racemes, small, white or yellow.

S. Canescens, Nutt. Pubescent and somewhat hoary; stem simple or sparingly branched; leaves bipinnatifid, with small mostly toothed lobes; racemes at length elongated; silique shorter than the spreading pedicel. March, April. Stem $1^{\circ}-2^{\circ}$ high. Flowers small, greenish white.

\section{DRABA, L. WhItLOW Grass.}

Silicle oblong or oval, flattened parallel with the broad partition. Seeds numerous in two rows in each cell, compressed, wingless. Cotyledons accumbent. Small herbs, with entire or toothed leaves, and yellow or white flowers in terminal racemes.

\section{$\$$ Petals entire. \\ $\S$ Petals 2-cleft.}

D. Brachycarpa, Nutt. Annual ; minutely downy; stem leafy, simple or branched; radical leaves round-ovate, stalked; those of the stem oblong-linear; silicle oval, as long as the pedicel. Stem $1^{\prime}-3^{\prime}$ high. Silicle $4^{\prime \prime}-6^{\prime \prime}$ long. Flowers white. March, April.

D. Caroliniana, Walt. Annual; stems leafy and hispid at the base, smooth above; leaves tufted, spatulate-obovate, hispid; silicle linear-oblong, two or three times as long as the pedicel. February-April. Stems $1^{\prime}-3$ ' high; silicle $4^{\prime \prime}-6$ " long. Flowers white.

D. cuneifolia, Nutt. Annual. Leaves obovate, wedgeshaped, or the lowest spatulate, toothed; raceme somewhat elongated, in fruit $1^{\prime}-3^{\prime}$ long, and at length equaling the 
naked peduncle; petals emarginate, much longer than the calyx; silicles oblong-linear, minutely hairy, longer than the horizontal pedicels. March, April.

\section{LEPIDIUM, L。 Pepper Grass.}

Silicle rounded or obcordate, compressed contrary to the narrow partition; valves carinate; cells 1-seeded. Cotyledons accumbent and incumbent. Petals sometimes wanting. Stamens 2, 4, or 6. Leaves entire, toothed, or pinnately divided. Flowers minute. Very common. March-June. $1^{\circ}-2^{\circ}$ high.

\section{STREPTANTHUS.}

Silique very long, compressed or somewhat quadrangular. Style short or none. Seeds in a single series, flat, marginal. Sepals erect, colored. Claws of the petals canaliculate, usually twisted. Filaments subulate, those of each pair of the longer stamens sometimes united; anthers linear; annual or biennial, rarely perennial herbs, with purple, rarely white or yellow flowers.

* Petals narrow, calyx closed.

S. HYACINTHOIDES, Hook. Glabrous; leaves oblong, linear, acuminate, petals spatulate-linear, the limb reflexed; filaments of the longer stamens united by pairs. Near San Felipe de Austin._Drummonel.

** Limb of pelals broad, calyx slightly spreading.

S. Macclatus. Leaves ovate-oblong, broad, clasping, entire, or minutely and remotely repand-denticulate; petals obovate, purple; siliques somewhat four-sided. Stem $1 \frac{1}{2}^{\circ}-2^{\circ}$ high, sometimes much taller, usually simple, sometimes branched, glabrous, glancous terete. Leares $3^{\prime}-66^{\prime}$ long, $1 \frac{1}{2}^{\prime}$ broad, glancous, rather acute. Flowers in simple or paniculate racemes, very showy. Petals deep purple, 
lighter toward the crenulate edge; claws longer than the limb. Near San Antonio.-Dr. Leavenworth.

\section{CAPER FAMily. Order, Capparidacex.}

Herbs, shrubs, and trees destitute of true stipules. Leaves alternate, petiolate, either undivided or palmately lobed. Flowers solitary or in racemes, cruciform, hypogynous. Sepals 4. Petals 4, unguiculate (that is, with long claws). Stamens 6 to 12, or some multiple of 4 , never tetradynamous, on a disk or separated firom the corolla by an internode of the torus. Germ with a style of two united carpels. Style united into one. Stigma discoid. Fruit either pod-shaped and dehiscent, or fleshy and indehiscent.

Cleome. Stamens 6, not separated from the petals.

Polanisia. Stamens 8-32; torus not developed.

\section{CLEOME, L. SPIDER Flower.}

Petals long-clawed, 4. Sepals sometimes united at base, torus not developed between the petals and stamens, which are 6-4; pod stipulate more or less. Herbs or shrubs. Leaves simple or digitate. Flowers racemed or solitary.

C. Pungens. Glandular pubescent; stem simple and with the petioles aculeate. Leaves 5-9, lobate, on long petioles, leaflet elliptic-lanceolate, acute at each end, obscurely denticulate; bracts simple; flowers racemed; sepals distinct; petals on filiform claws; stamens 6, twice longer than the petals. Plant tall and showy, flowers purple. In prairies of South Texas, from May to September.

POLANISIA.

Petals clawed. Stamens 8-32, filaments free, unequal, 
filiform. Torus short, bearing a truncated or emarginate gland on the upper side. Ovary sessile or short-stipitate. Style filiform. Capsule silique-like, many-seeded. Annual clammy herbs with palmately trifoliate petioled leaves and racemose flowers.

P. TRACHYSPERMa. Viscidly pubescent; leaves 3 , foliate; leaflets lanceolate, alternate-acuminate, shorter than the capillary claws of the emarginate petals. Stamens usually 16 ; the filaments deep purple, twice or thrice the length of the petals; style about the length of the glabrous ovary; pods linear-oblong, turgid, abruptly attenuate at the base, reticulate, glandular-scabrous; seeds turgid, verrucose, muricate.-Drummond.

\section{VIOLET FAMILY. Order, Violacex.}

Herbs with stipulate, alternate, simple, often cleft leaf. Flowers irregular, spurred at base. Sepals, petals, stamens 5. Filaments prolonged beyond the anthers. Pistil 1, with 1 style. Pod 1-celled, with three rows of seeds on its walls. Roots and juice rather acrid. The common plants of the family belong to the genus.

\section{VIOLET. Viola, Tourn. Heart's Ease.}

Flower nodding on the summit of the flower-stalk. Style club-shaped; stigma bent over to one side. Flowering in spring, and some species continuing to bloom all summer.

$\$$ Leaves and peduncles arising from a subterranean rhizoma, without apparent stems ; perennials, flowering in early spring, the later flower's apetalous.

\section{* Flowers blue.}

V. cucullata, Ait. Smooth or pubescent; leaves longpetioled; all undivided, rarying from cordate-ovate to reniform, serrate, the sides at the base involute when young; the later ones acutish ; lateral petals bearded, stig- 
ma beakless. Low ground. Flowers blue, often variegated with white.

\section{** Flowers while.}

V. primulefolia, L. Smooth or hairy; leaves oblong, mostly acute, crenate, cordate or abruptly decurrent on the winged petiole; petals often acute, the lower ones bearded and striped with purple. Low grounds. Rhizoma slender and commonly bearing long leafy runners. Flowers small.

\section{Cistus Family. Order, Cistacee.}

Herbs or low shrubs with opposite, entire, simple leaves. Flowers perfect, hypogynous, on 1 -sided racemes. Petals 5 or 3 , all alike, overlapping each other in the bud, each with one edge covering the one before it, but covered by that behind it. Calyx remaining after blossoming, of 5 sepals, three of them larger and two smaller, often very small, the latter entirely outside in the bud and looking like bracts. Stamens from 3 to 20 or more, all separate and borne on the receptacle. Pistil 1, making a 1-celled capsule, with the seeds borne on 3 parietal placentæ, which divide the capsule into three valves.

\section{SYNOPSIS.}

Helianthemum. Style none. Stigma capitate. Embryo nearly annular. Lechea. Style none, stigma plumose. Embryo straight.

Hudsonia. Style filiform. Stigma minute. Embryo coiled.

\section{HELIANTHEMUM. Rock Rose.}

Petals 5, corrugated in the bud, sometimes wanting. Stigma sessile or nearly so, capitate,-3-lobed. Capsule 3-valved. Embryo curved nearly into a ring. Low herbs or partly shrubby plants, with fugacious yellow flowers.

\footnotetext{
* Flowers perfect; ; petals conspicuous; stamens indefinile; capsule many-seeded.
} 
H. Carolinianum, Michx. Hirsute; leaves lanceolate, denticulate, acute, short-petioled, the lowest oborate, crowded; flowers large, solitary, borne above the axils. Dry, sandy soil. March and April. Stem $66^{\prime}-12^{\prime}$ high, ascending from a shrubby base. Flowers $1^{\prime}$ wide.

H. POLIFOLIUM ; primary or petaliferous flowers, small, terminating the slender stem and numerous short branches on filiform peduncles many times larger than the flower. The broadly cuneiform petals exceeding the calyx. Secondary flowers very small, apetalous, 3-6-androus, clustered in lateral cymules on the floriferous branches.Drummond.

\section{LECHEA, L.}

Petals 3, persistent, not longer than the sepals. Stamens 3-12. Stigmas 3, sessile, plumose. Capsule globose, 3-valved, incompletely 3-celled, 6-seeded. Embryo slightly curved. Perennial herbs, with small greenish flowers in racemes or panicles.

L. MAJOR. Michx. Villous; leaves alternate, opposite, or whorled, elliptical, those on the prostrate radical branches roundish; flowers on short pedicels, densely crowded in short simple or compound axillary racemes. July, August. Stem $2^{\circ}$ high, branching toward the summit. Capsule as large as a pin's head.

L. MINoR, Lam. Rough, with appressed scattered hairs; the young branches and calyx more or less hoary; stems paniculately branched above; leaves scattered, linear; flower's loosely racemose on distinct, often appressed pedicels. Stems $\frac{1^{\circ}}{2}-2^{\circ}$ high. Capsule larger than in L. minor. Radical branches often wanting.

L. Drumondi. Decumbent and much branched at the base, slightly pubescent; leaves linear-subulate, scattered; racemes filiform, terminating the numerous branches, loosely flowered ; flowers unilateral on capillary spread- 
ing and at length reflexed pedicels; capsule globose, 3 -seeded. Dry places in small prairies. June and July. Petals purple.-Dr. Drummond.

\section{HUDSONIA, L.}

Petals 5, larger than the sepals, fugacious. Stamens 9-30. Style filiform. Stigma minute. Capsule oblong, 1-celled, 3 -valved, with $2-6$ erect seeds attached near the base. Embryo coiled. Low tufted shrubs, with minute, hoary, subulate, imbricated leares. Flowers yellow.

\section{1\%. SUNDEW FAMILY. Order, Droseracee.}

Low glandular-hairy marsh herbs, with circinate tufted radical leaves.

Sepals and petals 5. Stamens 5-15. Ovary 1-celled, many-ovuled, with 3 or 5 parietal placentæ. Styles separate or united. Capsule loculicidally 3-5-valved. Seeds anatropous. Flowers white or purple, hypogynous, borne on a naked scape.

\section{DROSERA, L. SUNDEW.}

Stamens 5. Styles 3-5, deeply 2-parted; the divisions 2-many-lobed. Capsule 3-valved, many-seeded. Leaves dewy and glandular. Scape often forking. Flowers racemose.

D. Rotundifolia, Pursh. Leaves orbicular, abruptly contracted into the hairy petiole; scape erect, smooth, 6-10-flowered. Calyx ovoid; - seeds covered with a loose membranaceous coat. Rhizoma none. Leaves $2^{\prime}$ long. Scapes 6'-9' high. Flowers white.

18. Parnassia family. Order, Parnassiacee.

Perennial smooth herbs, with ovate or reniform chiefly 
radical leaves, entire, on long petioles, and large solitary flowers terminating the scape-like 1-leaved stem. Sepals 5, persistent. Petals 5, ovate or obovate, veiny imbricated in the bud, deciduous. Fertile stamens 5, alternating with the petals. Ovary 1-celled, with 3-4 parietal placentæ. Stigmas 3-4, sessile, placed over the placentæ. Capsule loculicidally 3-4-valved at the apex, many-seeded. Seeds anatropous winged, without albumen. Embryo straight, cylindrical.

\section{ST. JOHN'S-WORT FAMILY. Order, HYPERI-}

\section{CACE无.}

Herbs or low shrubs with entire opposite, exstipulate, dotted leaves, as if punctured with transparent or darkcolored dots, one or both. Flowers hypogynous, perfect, regular, 4 or 5 persistent sepals; as many petals. Stamens few or many, in 3 or 5 clusters, and therefore said to be polydelphous, borne on the receptacle. Petals mostly oblique or convoluted in bud. Styles $2-5$, commonly separate, or sometimes all united into one. Ovary a onecelled fruit with parietal placenta, or as many cells when the dissepiments reach the center.

\section{GENERA.}

Ascrrom. Sepals 4. Petals 4, convolute in the bud, yellon.

HYPERICUM. Sepals 5. Petals 5, convolute in the bud, yellono.

Flodea. Sepals 5. Petals 5, imbricated in the bud, rose-colored.

ASCYRUM, L. St. Peter's-wort.

Sepals 4, the two outer ones much larger. Petals 4, convolute in the bud, oblique. Stamens numerous. Styles 2-4, distinct or united. Capsules 2-4-valved, 1-celled, with 2-4 parietal placentæ. Smooth shrubs with 2-edged branches, Flower's mostly solitary, yellow. 


\section{HYPERICUM, L. ST. JoHN's-WORT.}

Sepals 5, similar. Petals 5, oblique, convolute in the bud. Stamens mostly numerous, and commonly collected in 3-5 sets without intervening glands. Styles 3-5, distinct or united. Capsule 1-5-celled. Herbs or shrubs. Flowers mostly cymous, yellow.

Stamens numerous. C'apsule 3-celled; styles united: shrubs.

H. PROLIfICUM, L. Branches 2-edged, the barren ones elongated; leaves lance-oblong, obtuse or mucronate at the base; cymes axillary and terminal, often few-flowered; capsule oblong, rarely 4-5-celled. Varies with a more branching stem, smaller and narrower leaves and smaller and more numerons flowers. Shrub $2^{\circ}-3^{\circ}$ high. Leaves $1^{\prime}-2^{\prime}$ long, paler beneath. Swamps and river banks.-Dr. Veatch. July, Angust.

Stamens 5-20; capsule strictly 1-celled; styles separate: annuals. Flowers in cymes.

H. мutilus, L. Stems slender, branching above, 4-angled; leaves oblong or rounded, obtuse, clasping, 5-nerved; cymes leafy at the base; sepals lanceolate, mostly longer than the small petals, and equaling the (green) ovoid capsule; stamens $6-12$. Stem $1^{\circ}$ high, with the branches of the cyme filiform. Flowers very small, remote. Ditches and low grounds. June-August.-Drummond.

H. Canadense, L. Stems simple or branched, 4 -angled; leaves linear or linear-lanceolate, the upper ones acute, sessile; sepals lanceolate, acute, longer than the petals, shorter than the oblong (brown) capsule. Wet, sandy soil. Stem $4^{\prime}-12^{\prime}$ high, with the branches erect. Flowers small, copper-yellow. Stamens 5-10. June-October.

Flowers scattered on the slender branches; flowers minute.

H. Drummondi, Torr. and Gr. Stem much branched; leaves linear or the lower ones oblong, acute, appressed; sepals barely shorter than the ovate capsule; flowers pedi- 
celed. Dry soil. Stems and branches stouter than the last. Stamens 10-20. July-August.

\section{Elodea.}

Sepals 5. Petals 5, equal-sided, imbricated in the bud. Stamens mostly 9, and united in sets of three, with a scalelike between each set; styles 3 distinct. Capsule 3-celled, 3-valved, many-seeded. Smooth perennial herbs. Flowers rose-colored, in contracted lateral and terminal cymes.

\section{BALSAM-TREe FAMily. Order, Clusiacex.}

Trees or shrubs, with resinous yellow juice; opposite, coriaceous, entire, dotless leaves articulated with the stem, and regular hypogynous flowers. Sepals 3-6. Petals 4-9. Stamens mostly numerous, distinct or variously united. Ovary 1-many-celled, few-many-ovuled. Style single, often none. Fruit capsular, baccate or drupaceous. Seeds without albumen. Embryo straight. Cotyledons thick, distinct or united.

\section{Clusia.}

Calyx 2-bracted, of 6 imbricated, colored sepdls. Petals 4-9. Stamens numerous, the filaments united at the base into a thick and fleshy tube. Ovary 5-15-celled. Ovules numerous, fixed to a central column. Stigma large, radiatepeltate. Capsule coriaceous, globose-angled, 5-15-celled; the valves separating from the central column at maturity. Seeds numerous, ovate. Parasitical tropical trees, with thick opposite, entire and shining leaves, and chiefly polygamous cymose showy flowers.

\section{Canelia, P. Brown.}

Sepals 3, rounded, concave, imbricated in the bud, persistent. Petals 5, hypogynous, oblong, convolute in the 
bud, deciduous. Stamens united into a tube. Anthers 15, aduate linear. Ovary 3 -celled. Style cylindrical. Stigmas 3. Berry globose, 1-3-celled, mostly 2 -seeded. Seeds globose renifurm. Embryo minute, in fleshy albumen. Large tree, leares alternate, near the ends of the branches, obovate, emarginate, glabrous, on short petioles. Racemes compound, shorter than the leaves, terminal. Pedicels 1-flowered. Flowers small, purple.

\section{PURSlane family. Order, Portulacacex.}

Succulent plants, with entire leaves and regular hypogynous or perigynous flowers. Sepals 2-5. Petals 3-6, imbricated in the bud, sometimes wanting. Stamens as many as the petals and opposite them, or indefinite. Styles 3-6, mostly united below, stigmatic along the inside. Capsule 1-5̃-celled, few-many-seeded. Seeds campylotropous, erect from the base of the cell, or attached to a central placenta. Embryo slender, curved around mealy albumen.

\section{GENERA.}

* Sepals 2. Petals 5-6.

Cratronu. Petais and stamens 5. Capsule 3-valved, 3-6-seeded. TALnuar. Petals 5. Stamens 10-30. Capsule 3-valved, many-seeded.

Portouscs. Petals 5-6. Stamens 8-20. Capoule circumscissile.

* Sepals 5. Petals none.

Sesurvur. Stamens 5-60, inserted on the calyx. Capsule circumscissile.

\section{CLAYTONIA, L. Sprixg Beatty.}

Sepals 2, free, persistent. Petals hypogynous. Stamens 5 , inserted on the claws of the petals. Style 3-cleft. Capsule 1-celled, 3-ralred, 3-6-seeded. Smooth herbs, with a simple stem bearing two opposite leares, and terminating with a loose raceme of pale rose-colored, reiny flowers.

C. VirginicA, L. Leaves 3 '-6' long, linear, acutish; 
petals mostly emarginate, but sometimes acute. Damp rich soil. March. Plant $4^{\prime}-10^{\prime}$ long.

C. Caroliniana, Michx. Leaves 1'-2' long, ovatelanceolate or oblong, tapering at the base; petals obtuse. Mountains. March, April.

\section{TALINUM.}

Sepals 2, free, deciduous. Petals 5, hypogynous. Stamens 10-20. Style 3-lobed. Capsule 3-celled at the base, 3-valved, many-seeded. Smooth and fleshy herbs, with alternate leaves and cymose flowers.

T. teretifolius, Pursh. Stem thick, leafy; leaves linear-cylindrical ; cymes on long peduncles; petals purple, fugacious. Stems $2^{\prime}-4^{\prime}$ long, perennial.

\section{PORTulaca, Tourn. Purslane.}

Sepals 2, united and cohering with the ovary below, the upper portion circumscissile and deciduous with the upper part of the capsule. Petals 4-6, inserted with the 8-20 stamens. Styles 3-8 parted. Capsule globose, 1-celled, and many-seeded. Low, fleshy herbs, with terete or flat, mostly alternate leaves, and fugacious yellow or purple flowers.

P. oleracea, L. Leaves flat, cuneate, naked in the axils; flowers yellow; stamens 10-12. Stem prostrate. Cultivated grounds.

\section{PINK FAMily. Order, Caryophyllacee.}

Herbs with swollen joints, opposite entire leaves and regular flowers. Sepals 4 or 5, persistent. Stamens never more than twice as many as the petals or sepals and often fewer. Petals 4 or 5, unguiculate or not, bifid or entire, mostly removed from the calyx by a short internode of the receptacle, sometimes wanting. Style 2 to 5, stigmat- 
ous along the whole length of the inner surface. Fruit a capsule, which is 1-celled (or imperfectly 2-or 5-celled), with seed from the bottom or on the central column, opening at the top or loculicidal. Seeds numerous, with the embryo coiled round the albumen.

Tribe I. Illecebreæ. Sepals distinct or united below. Petals often stamen-like or wanting. Leaves with scarious stipules.

* Fruit indehiscent, 1-seeded (utricle).

Paronychia. Sepals united at the base. Stamens inserted on the base of the sepals. Style long. Utricle united.

ANychia. Sepals distinct. Stamens inserted on the base of the sepals. Style very short. Utricle partly exserted.

SipHonrchia. Sepals united into a tube below the middle. Stamens inserted on the tube of the calyx. Style long.

** Fruit valvate, few, many-seeded.

+ Leaves opposite.

STIPULICIDA. Stem-leaves minute; the lowest spatulate.

SPERGUlaria. Leaves all linear. F'lowers solitary, axillary.

t+ Leaves whorled.

Spergula. Styles 5. Stamens 5-10. Capsule 5-valved.

Polycarpon. Styles 3. Stamens 3-15. Capsule 3valved.

Tribe II. Mollugineæ. Stamens alternate with the sepals, when of the same namber; when three, allernate with the cells of the ovary. Stipules none.

MoLlcgo. Capsule 3-celled. Leaves whorled.

Tribe III. Alsineæ. Sepals separate or nearly so. Stamens opposite the sepals, when of the same number. Ovary sessile, Stipules none.

* Valves of the capsule as many as the styles, 
SAGINA. Styles and valves 4-5.

Alsine. " " 3.

** Valves of the capsule twice as many as the styles.

Arenaria. Valves of the capsule 2-4 each, soon 2-cleft. Petals entire.

Stellaria. Valves of the capsule 6-10. Petals 2-cleft.

Cerastium. " " 8-10, toothed.

Tribe IV. Sileneæ. Sepals united into a tube. Petals and stamens inserted on the stipe of the ovarg. Stipules none.

Silene. Styles 3. Capsule 6-toothed.

Saponaria. Styles 2. Capsule 4-toothed.

Agrostemma. Styles 5. Capsule 5-toothed.

\section{PARONYCHIA, Tourn.}

P. Dichотома, Nutt. Smooth; stems slender, erect; leaves linear, subulate-those of the barren stems imbricated; cymes fastigiate, diffuse; sepals linear, 3-ribbed, slender, pointed; petals minute, bristle-like. July-November. Stems $6^{\prime}-12^{\prime}$ high.

P. DRummondi. Minutely pubescent; stem erect, branching above into numerous cymes; leaves (of the branches) linear-oblong, short, the uppermost mucronate ; calyx turbinate at the base, with a ring of hooked hairs; sepals broadly scarious and dilated above, the back produced into a somewhat recurved horn; sterile setæ very minute; stem about 10 inches high; sepals reddish-brown, the scarious margins and horns white. Annual.-Drummond.

\section{ANYCHIA.}

Sepals 5, distinct, slightly mucronate at the apex. Petals none. Stamens 2-3, inserted on the base of the calyx. Style very short. Stigmas spreading. Utricle exserted. Seed erect. Radicle inferior. An erect, slender annual, 
with forking, setaceous, spreading branches. Leaves thin, oblong, obtuse, narrowed at the base. Flowers minute, solitary or clustered in the forks of the branches, greenish. A. Dichotoma, Michx. Stem 4'-10' high.

\section{SIPHONYCHIA, Torr. and Gray.}

Sepals 5, united to the middle, concave and petal-like above, obtuse or mucronate. Petals 5, bristle-like, inserted with the 5 stamens on the throat of the calyx. Style slender, 2-cleft. Utricle included. Seeds resupinate. Radicle superior. Erect or diffusely prostrate herbs. Cyme denseflowered. Flowers white.

S. Anericara, Torr. and Gray. Stems prostrate, diffuse, pubescent in lines; leaves lanceolate, narrowed at the base ; the radical ones larger and crowded; flowers obovate, solitary in the forks of the stem, and clustered at the end of the branches; sepals rounded and incurred at the apex, the tube bristly with hooked hairs; petals minute. Stems $1^{\circ}-3^{\circ}$ long. Leaves sometimes falcate and incrusted with brownish particles. Stipules small. June-October.

\section{STIPULICIDA, Michx.}

Sepals 5, emarginate, white-margined. Petals 5, spatulate, 2-toothed near the base, longer than the sepals, withering, persistent. Stamens 3, opposite the inner sepals. Style very short, 3-parted. Capsule 1-celled, 3-valved, many-seeded. A small perennial, with an erect forking stem. Stem-leaves minute, subulate, with adnate, pectinate stipules. Radical leaves spatulate, clustered, growing from a tuft of bristly stipules. Flowers white, in terminal clusters.

S. Setacea, Michx. Stem $3^{\prime}-6$ ' high, branches spreading and curving. Low, sandy counties. April-June. 


\section{SPERGULARIA, Pers.}

Sepals 5. Petals 5, oval, entire. Stamens 2-10. Styles 3-5. Capsule 3-5-valved; the valves, when 5, alternate with the sepals. A low maritime herb, with opposite fleshy leares and conspicuous scarious stipules. Flowers axillary, solitary, rose-colored.

S. RUBRa, Pers. Stems prostrate, much branched. Leaves linear, longer than the joints. Seeds with or without a membranaceous margin. Sands or marshes. April-May.

\section{SPERGULA, L. SPURREY.}

Sepals 5. Petals 5, entire. Stamens 5 or 10 . Styles 5. Capsule 5-valved, the valves opposite the sepals. Embryo forming a ring around the albumen. Leaves whorled. Flower's cymose, white.

S. ARvensis, L. Stem erect; leaves fleshy, narrow, linear, several in a whorl ; cymes loose, long-peduncled; fruiting pedicels reflexed; stamens 10 , seeds rongh.

\section{POLYCARPON.}

Sepals 5, carinate. Petals 5, emarginate, shorter than the sepals. Stamens 3-5. Styles 3, very short. Capsule 3 -valved. Low annuals, with whorled leaves, and minute flowers in terminal cymes.

\section{MOLLUGO, L.}

Sepals 5, petals none. Stamens 5 and alternate with the sepals, or 3 and alternate with the cells of the ovary. Styles 3, short. Capsule 3-valred, 3-celled, many-seeded. Prostrate diffusely-branched annuals. Leaves whorled. Flowers white, on slender axillary peduncles.

M. verticillata, L. Smooth; leaves spatulate-lanceolate, unequal, in whorls of $4-8$; fruiting peduncles reflexed; stamens 3. May-August. . 


\section{SAGINA, L.}

Sepals 4-5. Petals 4-5, entire or wanting. Stameri. 4-10. Styles 4-5, alternate with the sepals. Capsule 4-5valved, the valves entire, opposite the sepals. Small herbs with filiform forking stems, subulate leaves, and solitary flowers.

S. Elliotrir, Fenzl. Smooth ; stems erect or ascending, tufted; peduncles erect; petals and sepals 5, equal, obtuse; stamens 10. Stems $2{ }^{\prime}-6$ ' high. Peduncles 2-3 times as long as the sharp-pointed leaves. April-June. Annual.

\section{ALSINE, Tourn.}

Sepals 5, petals 5, stamens 10, styles 3. Capsule 1-celled, 3-valved, the valves entire, opposite the inner sepals. Low, slender herbs, with linear or subulate leaves, and white cymose or solitary flowers.

A. squarrosa, Fenzl. Stems tufted, $6^{\prime}-10^{\prime}$ high. Leaves subulate, rigid, those of the glandular flowering stems distinct, of the sterile ones imbricated with spreading tips; sepals ovate, obtuse, shorter than the capsule, cymes fewflowered. Pedicels rigid. April-May. Perennial.

A. BRevifolia. Stems smooth, 2'-4' long, not tufted, erect, filiform, simple, $2-5$-flowered ; leaves minute, $1^{\prime \prime}-2$ ", erect, lance-subulate; sepals oblong, obtuse, as long as the capsule; petals twice as long as the sepals. Flowers small, on filiform peduncles.

\section{ARENARIA, L. SANDWort.}

Petals 1-5 or none. Styles 2-4. Capsule opening above by as many valves as there are styles, each valve soon splitting into two pieces. Otherwise like Alsine.

A. DIfFusa, Ell. Downy; stem elongated, prostrate, alternately short-branched; leaves lanceolate; peduncles longer than the leaves, lateral reflexed in fruit; petals 1-5, 
shorter than the sepals, often wanting. Stem $1^{\circ}-4^{\circ}$ long. May-October. Perennial.

\section{STELLARIA, L. Chickweed, StaRwort.}

Sepals 4-5. Petals 4-5, 2-cleft, or 2-parted. Stamens 3-10. Styles 3-5, opposite the sepals. Capsule 1-celled, opening by twice as many valves as there are styles, manyseeded. Stems weak. Flowers white, on terminal peduncles, becoming lateral in fruit.

S. media, Smith. Annual ; stems prostrate, forking, pubescent in lines; leaves ovate or oblong, acute, the lower ones petioled; petals shorter than the sepals. March, April.

S. prostrata, Baldw. Smooth or nearly so. Stems forking, prostrate; leaves ovate, acute, all on slender petioles, the lower ones often cordate; petals twice as long as the sepals. Stem $1^{\circ}-2^{\circ}$ long. Petiole mostly longer than the limb. March, April. Annual.

\section{CERASTIUM, L. Mouse-EaR.}

Sepals 4-5. Petals 4-5, obcordate or 2-cleft. Stamens 10. Styles 4-5. Capsule cylindrical, 8-10-toothed, manyseeded. Flowers white, solitary or cymose, peduncled. Herbs.

C. vULGATUM, L. Villous and somewhat clammy; stems ascending; leaves oval, remote, the lowest obovate; cymes crowded in the bud, spreading in fruit; sepals lanceolate, acute, as long as the peduncles, and half as long as the slender capsule. Stems 6'-12' high. April, May. Annual.

C. viscosum, L. Hairy and clammy; stems ascending ; leaves lance-oblong, obtuse, the lowest wedge-shaped; cymes loose in the bud; sepals oblong-ovate, obtuse, shorter than the peduncles. April, May. Annual. 


\section{SILENE, L. CATChFLY.}

Sepals united into a 5-toothed tube. Petals 5, longclawed, inserted with the 10 stamens on the stipe of the ovary, commonly crowned with two scales at the base of the limb. Styles 3. Capsule 1-celled, or 3-celled at the base, opening by 6 teeth, many-seeded. Leaves mostly connate. Flowers cymose, often showy.

* Perennials ; flowers showy.

+ Petals gash-fimbriate, crownless.

S. STEllata, Ait. Leaves in whorls of four, lanceovate, acuminate, the uppermost opposite; flowers white, in a large spreading panicle; calyx inflated, bell-shaped. Stems $2^{\circ}-3^{\circ}$ high, downy, branching above. June.August.

\section{** Annuals : flowers small, expanding at night.}

S. Antirrhina, L. Stem slender, smoothish, clammy below the upper joints; leaves linear, acnte, sessile, the lowest lanceolate, narrowed in to a petiole; flowers panicled; calyx smooth; petals obcordate, rose-colored. Stem $6^{\prime}-2^{\circ}$ high, simple or branched. Flowers minute. May, June.

\section{SAPONARIA, L. SOAPWORT.}

Calyx tubular, terete, 5-toothed. Petals long-clawed. Stamens 10. Styles 2. Capsule sessile or short-stiped, 1-celled, or 2-celled at the base, 4-toothed at the apex. Cymes dense-flowered.

\section{AGROSTEMMA, L. CoRN-CockLe.}

Calyx tubular, with 5 elongated linear deciduous lobes. Petals 5, entire, crownless. Stamens 10. Styles 5. Capsule 1-celled, 5-toothed. Annual or biennial herbs, with linear leaves and showy purple flowers on elongated peduncles. 
A. Gimingo, L. Plant $1^{\circ}-2^{\circ}$ high, whitened with long appressed hairs. Stem forking; petuls obovate, emarginate, shorter than the lobes of the calyx. Peduncles $\left.4^{\prime}-6\right)^{\prime}$ long. Flowers $1^{\prime}$ wide. June and July, annual.

\section{MALLOW FAMiLY. Order, Malvacex.}

Herbs or shrubs. Leaves alternate and stipulate. Flowers with 5 sepals united at the base, valvate in bud, often subtended by an involucel. Petals 5, loypogynous, united at the bottom with the tube of the stamen. Stamens numerous, monodelphous, $i$. e. united by their tilaments into one tube. Anthers 1-celled, kidney-shaped. Pistils several distinct or united, and stigmas various.

Fruit a several-celled capsule, or a collection of 1 -seeded, indehiscent carpels.

This order contains many useful and agreeable plantsCotton (Gossypium) annong clothing plants, and Okra, a food plant; while all are mucilaginous, thus offering a cooling and safe clrink to those ill with many of the diseases incidental to our climate, while almost every member of the order is more or less beautiful.

\section{TRIBES AND GENERA.}

Tribe I. Malveæ. Carpels as many as the stigmas, 1-few-seeded, disposed in a circle around a central axis, separating at maturity from the axis and from each other. Anthers borne at the apex of the column.

* Carpels 1-seeded.

+ Stigmas occupying the inner face of the style.

Malva. Carpels leafless. No process within.

Callirrhoe. Carpets beaked, and bearing a dorsal process above the seed within.

++ Stigmas capitate.

Malvastrum. Involucel 2-3-leaved. Ovule peritropous ascending. Radicle inferior. 
Sida. Involucel none. Ovule resupinate-pendulous. Radical superior.

** Carpels 2-fero-seeded.

AButilon. Carpels 1-celled, involucel none.

Modiola. Carpels transversely 2-celled. Involucel 3-leaved.

Tribe II. Ureneæ. Carpels half as many as the stigmas, separating at maturity. Anthers borne above the middle of the column.

Pavonia. Carpels 5, dry, 1-seeded. Involucel 3-leared.

Tribe III. Hisbisceæ. Carpels as many as the stigmas, united at maturity, and forming a loculicidal capsule. Column bearing the anthers throughout, or from above the middle.

Kosteletzky a. Cells of the depressed capsule 1-seeded.

Hibiscus. Cells of the globose or oblong capsule fewmany-seeded.

\section{MALVA, L. MALLOW.}

\section{* Leaves undivided.}

Involucel 3-leaved, persistent. Petals obcordate. Styles 9-10, filiform, stigmatic on the inner face. Carpels broadly reniform, beakless, 1-seeded, indehiscent, disposed in a circle around the central axis, from which they separate after maturity. Embryo nearly annular. Radicle inferior. Herbs. Leaves rounded. Flowers axillary, not yellow.

M. Rotuxdifolia, L. Stems sereral, prostrate; lenres long-petioled, round-cordate, crenate and crenately-lobed; flowers single or clustered, white veined with purple; carpels even. Perennial.

** Leaves divided.

M. LINeARILoba. Stem clothed with spreading hairs. 
Leaves divided nearly to the base, stellately hirsute on both surfaces. Flowers axillary in the uppermost leaves, about $1 \frac{1^{\prime}}{2}$ in diameter, scarlet; peduncle $1 \frac{1}{2}^{\prime}-2^{\prime}$ long. Sepals very hirsute, lanceolate, united only a little above the base. Ovaries 15-20. Stigmas simple. Carpels lunate, pointless.-Drummond.

M. Digitata. Glaucous and nearly glabrous; leaves deeply 6-7 parted; segments linear, entire, or 2-rarely 3-cleft, the uppermost entire; flowers few, solitary, or somewhat paniculate, on elongated peduncles; calyx naked, glabrous, roots tuberous, somewhat fusiform. Stems $2^{\circ}-4^{\circ}$ high, terete, slender, with a few branches toward the summit. Flowers $1 \frac{1}{2}^{\prime}-2^{\prime}$ in diameter, purple. Segments of the calyx ovate-lanceolate, acuminate. Petals crenulate at the summit. Perennial.-Drummond.

\section{CALLIRRHÖ̈, Nutt.}

Involucel 1-3-leaved and persistent, or none. Petals wedge-shaped, entire or crenate. Styles as in Malva. Carpels numerous, with a short and naked beak, and a ligulate dorsel process below the beak within. Embryo curved.

Radicle inferior. Perennial herbs. Leaves palmatelylobed, or angled. Flowers showy, purple or whitish.

C. TRIANgulata, Gray. Rough-pubescent. Stem ascending from a perpendicular rhizoma, branching above; leaves triangular, coarsely and unequally crenate, the lowest ones long-petioled and cordate, the upper ones 3-5lobed; flowers approximate, panicled, longer than the pedicels ; involucel 3-leaved, the leaves linear ; carpels at length 2 -valved. Stem $2^{\circ}-3^{\circ}$ high. Flowers $1^{\prime}-1 \frac{1}{2}^{\prime}$ wide, purple.

C. PAPAVER, Gray. Rough with scattered appressed and rigid hairs; stems low, simple; leaves 3-õ-parted; the lobes oblong or lanceolate, toothed or entire; flovvers few, solitary, axillary, long-peduncled; involucel 1-3-leaved, or none; petals finely crenate; carpels indehiscent. Rich open 
woods. Stems $1^{\circ}$ high. Flowers purple, $2^{\prime}$ wide, on peduncles which are sometimes $1^{\circ}$ long.

\section{MALVASTRUM, Gray.}

Involucel 1-3-leaved or none. Styles 5-20. Stigmas capitate. Carpels beaked or beakless, 1-seeded. Seed ascending. Embryo curved or annular. Radicle inferior. Herbs or shrubby plants, rough with rigid hairs. Flowers yellow.

I. ANgustur, Gray. Annual; stem erect, branching; leaves lanceolate, sparingly serrate, short-petioled; stipules bristle-like; flower's axillary, mostly solitary; involucel setaceous, 2-3-leaved; carpels 5, circular, awnless, at length 2-valved. Stem $6^{\prime}-12^{\prime}$ high. Calyx enlarged in fruit.

\section{SIDA, L.}

Involucel none. Calyx angular. Styles 5-15. Stigmas capitate. Ovaries 1-celled. Carpels erect, mostly 2-valved and 2-beaked at the apex, separating at maturity from each other, and from the central axis. Seed resupinate, suspended, 3-angled. Embryo curved. Radicle superior. Branching herbs or shrubs, with chiefly undivided leares, and small yellow or reddish flowers in their axils.

\section{* Leaves, at least the lower ones, cordate. Carpels 5.}

S. SPInosa, L. Annual; minutely pubescent; branches erect; leaves oblong-orate, acute, serrate, the slender petioles often with a tubercular spine at the base, the lower ones cordate; stipules setaceous, half as long as the petioles; flower's single or clustered, on short, erect peduncles; carpels faintly reticulated, each pointed with two erect subulate spines. Stems $1^{\circ}-2^{\circ}$ high. Flowers $\frac{1}{2}^{\prime}$ wide, yellow.

** Leaves not cordate. 
S. FASCICUlata. Stems about a span high, branching from the base. Leaves $\frac{3}{4}$ long and a line wide, mustly with a few serratures toward the apex, ncarly glabrous above, stellately hirsute beneath; petiole about $\frac{1}{4}$ the length of the lamina. Calyx hemispherical ; segments ovate-acute. Carpels short and broad, strongly roughened with projecting points. Flowers sessile terminal.-Drummond.

S. RHомвіfolia, L. Downy; stems erect, much branched; leaves rhombic-oblong, obtuse at each end, serrate, short-petioled, pale beneath; stipules setaceous, longer than the petioles, caducous; peduncles solitary, more than half as long as the leaves; carpels 10-12, even, pointed with a single subulate spine, indehiscent. Annual. Stems $2^{\circ}-3^{\circ}$ high. Leaves $2^{\prime}-3^{\prime}$ long. Flowers yellow. July to October.

S. FIlicaulis. Stems very slender, hispid; leaves ovateoblong, cordate at the base, serrate; petiole as long as the lamina; flowers axillary; solitary carpels 5, 2-beaked. Stem $2^{\circ}$ long, clothed with spreading hairs. Leaves $5^{\prime \prime}-7^{\prime \prime}$ long, $1 \frac{1}{2}{ }^{\prime \prime} 2 \frac{1}{2}$ wide, rather obtuse. Peduncles nearly an inch long, very slender. Calyx hemispherical.-Drummond.

\section{ABUTILON, Tourn. Indian MaLlow.}

Involucel none. Stigma capitate. Ovaries 5 or more, 1-celled, 2-9-ovuled. Carpels 1-6-seeded, partly 2-valved, tardily separating from each other or from the central axis. Radicle ascending. Leaves cordate. Flowers yellow, white, or purplish.

A. Texensis. Leaves cordate-ovate, acute, softly pubescent, serrate, $1^{\prime}$ long; petiole half as long as the lamina; peduncles somewhat racemose at the upper branches, 1-flowered; carpel: 8, pubescent, acute, cohering except at the summit. Capsule ovate. Rocky hills of the Cibola. 
July, August. Perennial.-Drummond, Schott, and Thurber.

A. CRISPC I, Gray. Hoary-tomentose; stem sparingly branched; leaves round-cordate, acuminate, finely crenate; peduncles axillary, 1-flowered, elongated, filiform, refracted after flowering; carpels 10, beakless, inflated, corrugated, hispid, 2-seeded. Stem slender, $1^{\circ}-2^{\circ}$ high. Leares $1^{\prime}-2^{\prime}$ long, the upper ones nearly sessile. Peduncles as long as the leaves. Flowers $4^{\prime \prime}-6^{\prime \prime}$ wide, white. Rio Grande.-Thurber.

\section{MODIOLA.}

Not represented in Texas as far as known.

\section{PAVONIA.}

Involucel 5-15-leaved, persistent. Ovaries 5, 1-celled, 1-ovuled. Stigmas 10, capitate. Carpels indehiscent or somewhat 2-valved, naked or armed at the apex with three hispid awns, separating at maturity. Embryo incurved. Radicle inferior. Chiefly shrubs with petioled stipulate leaves, and solitary flowers on axillary peduncles. $-P$. Drummondii.

\section{KOSTELETZKYA, Presl.}

Capsule depressed, the cells 1 -seeded. Otherwise as in Hibiscus.

- K. Virginica, Presl. Rough-hairy; stem erect, stout, branching; lower leaves ovate, cordate, serrate, mostly 3-lobed, the upper ones narrower and usually entire; flowers in terminal racemes, purple.-Var. Althe.efolia. Densely stellate-pubescent and somewhat hoary; leaves all undivided, ovate or ovate-lanceolate, acuminate, unequally toothed-serrate; racemes dense-flowered; capsule hirsute. -Var. symlacifolia. (Hibiscus smilacifolius._Shuttl.) 
Stem more slender, smoothish below; leaves all hastate, with lanceolate serrate lobes; racemes few-flowered. JulySeptember. Perennial. Stem $2^{\circ}-4^{\circ}$ high. Flowers $1 \frac{1}{2}^{\prime}-2^{\prime}$ wide.

\section{HIBISCUS, L. Rose Mallow.}

Involucel many-leaved or many-cleft, and, like the calyx, persistent. Stigmas 5, peltate or capitate. Capsule globose or oblong, 5-celled, loculicidally 5-valred, manyseeded. Herbs, shrubs, or trees, with petioled stipulate leaves, and large showy flowers on axillary peduncles.

* Leaves of the involucel forked.

H. ACUleatus, Walt. Muricate-hispid; leaves roundcordate, divided into 3-5 coarsely-toothed and spreading lobes, the upper ones narrower and mostly entire; flowers yellow, with a purple center, short peduncled; involucel 10-12-leaved; capsule hispid; seeds smooth. Perennial. July. Stems $2^{\circ}-3^{\circ}$ high. Flowers $4^{\prime}$ wide.

\section{** Leaves of the involucel entire.}

+ Perennial herbs; stipules deciduous.

H. Moscheutos, L. Tomentose; leaves broadly ovate, acuminate toothed-serrate, mostly 3-lobed above the middle, rounded or slightly cordate at the base, hoary beneath; peduncles often partly adnate to the petioles; flowers white or pale rose-color with a crimson center; seeds smooth. Wet places. Stem $3^{\circ}-5^{\circ}$ high. Leaves $3^{\prime}-5^{\prime}$ long. Flowers $4^{\prime}-5^{\prime}$ wide.

H. Incanus, Wendl. Leaves lanceolate and oratelanceolate, not lobed, slightly cordate-acuminate, finely serrate, hoary on both sides. Flowers pale yellow, with a crimson center. Seeds smooth. Ponds and marshes. June, July. Stem $2^{\circ}-5^{\circ}$ high. Leaves $3^{\prime}-6^{\prime}$ long. Flower's $6^{\prime}-8^{\prime}$ wide.

H. Militakis, Car. Smooth; leaves thin, on long and 
slender petioles, serrate, slightly cordate, the lower ones roundish, 3-5-lobed, the upper ovate-lanceolate, entire or somewhat hastate, with rounded lobes; peduncles shorter than the petioles; calyx inflated ; corolla tubular-campanulate, pale rose-color, with a red center; seeds silky. River banks. July, August. Stem $3^{\circ}-4^{\circ}$ high. Leaves $6^{\prime}-12^{\prime}$ long. Corolla $6^{\prime}-8^{\prime}$ wide. Column of stamens naked below.

\section{†† Trees or shrubs; stipules persistent.}

H. Drummondi. Stem and lower surface of the leaves minutely tomentose; leaves broadly cordate, $2^{\prime}-2 \frac{1^{\prime}}{2}$ long, and of nearly the same breadth. Flowers red. Column very slender, a little declined; stigmas hairy. Fruit red, subglobose, obtuse; composed of 5 closely united carpels. -Drummond.

\section{BYTTNERIA FAMiLY. Order, ByttNeriaceds.}

Chiefly trees or shrubs, differing from Malvaceæ in having definite stamens, of which those opposite the petals are usually sterile, 2-celled anthers, with smooth pollen-grains, and a straight embryo. Ovary 3-5̃-celled, rarely 1-celled.

\section{AYENIA, L.}

Involucel none. Calyx 5-parted. Petals on long capillary claws, connivent on the stigma. Fertile stamens 5, alternating with 1-2 sterile ones, their filaments united into a pedicellate cup. Style single. Stigma 5 angled. Capsule 5-lobed, 5-celled, loculicidally 5-ralved, the cells 1-seeded. Low, shrubby plants, with minute axillary flowers. Capsule rough. Albumen none.

A. Pusilla, L. Stems mostly simple prostrate, downy; leaves $\left(4^{\prime \prime}-8^{\prime \prime}\right.$ long) roundish or oblong, coarsely serrate; peduncles solitary, reflexed in fruit; capsule depressed, 
muricate. Perennial. Stems $6{ }^{\prime}-12^{\prime}$ long. Flowers purple.

\section{WALTHERIA, L.}

Involucel 3-leared, deciduous. Calyx 5-cleft. Petals 5, spatulate, convolute in the bud. Stamens 5, united below. Ovary 1-celled, 2-ovuled. Style single. Stigma penicillate or tuberculate. Capsule 2 -valved, 1-seeded. Embryo in the axis of fleshy albumen. Herbs or shrubs with alternate leaves, and small flowers in axillary clusters.

W. Americana, L. Stems erect, villous; leaves ovate or oblong, acute or obtuse, serrate, plicate, tomentose on both surfaces; heads of flowers globose, stalked or subsessile and shorter than the petioles, the upper ones often spiked. Calyx hirsute; flowers yellow. Stem $2^{\circ}-3^{\circ}$ high, rigid. Leaves $1^{\prime}-2$ ' long.

\section{MELOCHIA, Lin.}

Calyx 5-cleft, persistent, naked or with 1-3 bracteoles at the base. Petals 5, spreading. Stamens 5, opposite the petals, short, monadelphous at the base. Styles 5 ; stigmas slightly clavate. Carpels united into a 5-angled, 5-celled loculicidal capsule. Seeds 1-2 in each cell. Cotyledons flat, foliaceous, reniform. Shrubby plants, with alternate serrated leaves. Peduncles several-flowered, terminal, axillary, or opposite the leaves. Flowers violet or white.

M. PYRAMIData. Leaves ovate-lanceolate, toothed, glabrous ; peduncles 5-6-flowered, longer than the petioles; petioles and branches pubescent.-Drummond.

Between San Felipe and Brazos.

\section{LINDEN FAMILY. Order, Tiliace..}

Trees, rarely herbs. Leaves alternate, with decidnous stipules. Flowers axillary or extra-axillary, hypogynous, 
polyandrous. Sepals 4-5 valvate in the bud; deciduous. Petals 4-5 convolute or imbricated in the bud. Stamens distinct or united in clusters. Anthers 2-celled, the pollen-grains smooth. Style single; stigma 4-10 lobed. Capsule 2-5-celled, 1-many-seeded. Seeds anatropous. Embryo in the axis of fleshy albumen. Cotyledons flat, leafy.

\section{TILIA. LINDEN. BassWOOD.}

Tilia Americana, L. Leaves smooth and green on both sides, obliquely cordate or truncate at the base, sharply serrate. June. A large tree. Leaves $4^{\prime}-5^{\prime}$ wide.

\section{CORCHORUS, L.}

Sepals 5. Petals 5, convolute in bud. Stamens numerous, separate. Style slender. Stigma dilated crenulate. Capsule mostly elongated, silique-like, loculicidally 2-valved, many-seeded. Herbs or shrubs, with alternate serrate petioled leaves; flowers small, yellow, on short peduncles opposite the leaves. Stipules decidnons.

C. siliquosus, L. Stem much branched, hairy in lines. Leaves ovate and lanceolate, compressed, 2-celled, manyseeded. Stems $1^{\circ}-2^{\circ}$ high. Capsule $2^{\prime}$ long.

C. PIlolobus. Rocky hills of the Rio Grande.-Marcy.

\section{CAMELLia FAMily. Order, Camelliacex.}

Trees or shrubs. Leaves alternate, exstipulate, featherveined, simple. Flowers large and showy, regular. Calyx, 5 sepals imbricated and persistent, often unequal in size. Stamens numerous, more or less coherent at the base into two, three, or five sets, and with the base of the petals. Anthers 2-celled. Fruit, a woody pod containing few large seeds ; little or no albumen. Cotyledons large. 
Their properties are stimulating and slightly narcotic. To this order belongs the Tea Plant of China.

\section{2\%. ORANGE FAMily. Order, Aurantiacex.}

Trees or shrubs, abounding in little transparent receptacles of volatile oil. Leaves alternate, articulated with the petiole, which is frequently winged.

Flowers regular, 3 or 5. Petals and stamens inserted on a hypogynous disk. Stamens with flat filaments. Fruit a berry, thick rind, many-celled, pulpy. Seeds attached to the inner angle of each carpel. Cotyledon thick; no albumen.

Orange. The Orange, though not a native, is so constantly met with in our gardens that we give a conspectus of the order, that the student may exercise his knowledge of analysis by examining it.

\section{PRIDE OF INDIA FAMily. Order, Meliacex.}

Trees or shrubs, pinnate, exstipulate leaves.

Flowers 3 to 5 sepals and petals. Stamens 6-10, coherent into a long tube with anthers sessile. Disk hypogynous, sometimes cup-like. Style 1. Ovary compound, several-celled, 1-4 ovules. Fruit dry or fleshy. Seeds neither winged nor axillate.

China Tree. This tree is almost naturalized in many parts of our State. The writer has seen it growing in the Brazos bottom, far from any habitation; also below Harrisburg, upon Buffalo Bayou.

\section{FLAX FAMILY. Order, Linacex.}

Herbs with entire, exstipulate, simple leaves.

Flowers regular, symmetrical, and perfect, pentamerous (i. e. 5 sepals, petals, stamens, and styles). Sepals im- 
bricated. Corolla convolute in xstivation, hypogynous. Stamens definite, hypogynous, alternate with the petals; styles distinct, stigmas capitate. Pod 10-celled, and splitting when ripe in 10 pieces, with one seed in each cell. Inner bark of tough fibers. Oily seeds with a mucilaginous coat.

\section{LINUM.}

Sepa7s, petals, stamens, and styles 5. Capsule 10-celled. Cells 1-seeded; seeds oily; stem slender; leaves narrow and mostly alternate; peduncle 1-flowered, borne above or opposite the leaves.

L. Virginianox, L. (Wild Flax.) Leaves lanceolate, acute, the lower ones opposite and obtuse; flowers scattered in corymbous racemes; sepals smooth, ovate, acute; styles distinct; capsule depressed-globose, 10-celled. Varies with glandular sepals, larger globose-orate capsules, and linear leares; perenuial. Flowers yellow, stem slender, branching, $2^{\circ}$ high.

L. PERenxe, L. (Perennial Flax.) Glabrous, with virgate brances; leaves linear, acute, scattered; flowers subaxillary and terminal; sepals oval, margins membranous, shorter than the globose capsule; petals retuse, 3-4 times the length of the sepals, blue.-Torry.

\section{WOOD-SORREL FAMILY. Order, OxalidaCex.}

$H e r b s$, with alternate trifoliate leaves, with an acid juice. Flowers regular, hypogynous, and symmetrical ; 10 stamens, somewhat monadelphous, those opposite the petals being the longest. Sepals 5, persistent, imbricated. Petals 5, convolute in æstivation. Styles 5, separate. Capsule 5-celled, two or more seeds in each cell.

\section{OXALIS. WOOD-SORREL.}

Capsule 5-lobed; the cells loculicidally dehiscent on the 
back, 1-few-seeded. Seed-coat loose and separating. Leaves 3-foliate. Leaflets obcordate.

O. violaced, L. (Purple Wild Sorrel.) Stemless; root tuberous; scapes umbellately 4-6-flowered; flowers purple, nodding. Scapes and petioles $5{ }^{\prime}-9^{\prime}$ high.

O. ACetocella, L. (White Wood-Sorrel.) Stemless; root creeping, scape 1-flowered. Flowers white, veined with red: Scape and petiole hairy.

O. STRICTA. (Yellow W.-S.) Branching stem, leạfy; axillary peduncles, 2-6-flowered, longer than the leaves; flowers yellow. Capsule elongated, erect; annual and perennial.

O. VeSPERTILIONis. Stemless; bulb solitary, scaly. Leaves 3-foliate, and with the whole plant glabrous. Leaflets dilated, broadly cuneate at the base, 2-lobed; scape 5-8-flowered, longer than the leaves. Sepals linear-oblong, with 3-4 glands at the top; petals violet, narrowly oblong, entire.-Drummond.

L. RIGIDUM. Leaves erect, linear, rigid, acute. Flowers racemed on the corymbous branches. Stem angular. Sepals 3-veined, ovate-lanceolate, acuminate, with glandular fringed serrated bracts, longer than the globous capsule. Styles more or less united at the base. Stems $10^{\prime}-16^{\prime}$ high. Leaves $4^{\prime \prime}-8^{\prime \prime}$ long, scabrous on the margins. Flowers yellow, $8^{\prime \prime}$ diameter.-Torry.

L. Berlandiere. Cache Creek.-Marcy.

L. Bоотті. Wichita Mountains.-Marcy.

31. GeraniUm FAMily. Order, Geraniacez.

Herbs or shrubs, swollen, separate joints. Leaves stipulate, palmately veined. Flowers symmetrical, hypogynous, pentamerous. Sepals imbricated; petals convolute in æstivation; stamens 10 , monadelphous, the alternate ones often abortive. Pistils 5 grown into one, cohering to an 
elongated receptacle, from which when ripe they separate and twist up, carrying with them the five little one-seeded pods. There are three genera:

Stamens 10, all perfect, every other one shorter. Petals all alike. Corolla regular. Geranium. Crane's Bill.

Stamens 5, perfect; 5 alternate, imperfect. Corolla regular.

Erodiuy. Heron's Bill.

Stamens 7, perfect. Corolla irregular.

Pelargonium. Stork's Bill.

\section{GERANIUM.}

Flowers regular. Stamens perfect, the inner ones with a gland at the base. Styles at maturity separating with the 1-seeded carpels and coiled upward, the inner face naked.-Herbs. Stems forking. Leaves palmately lobed. Peduncles 1-3 flowered.

G. Macclatey. Perennial, erect, hairy; leaves 5-7parted, the divisions acutely lobed and toothed; peduncles 1-2-flowered, the terminal ones often umbellate; petals large, entire, 2-3 times longer than the oblonged awned sepals. Roots tuberous, astringent. Stem $1^{\circ}-2^{\circ}$ high. Flowers purple, 1' wide. Mount Bonnell, near Austin.

G. Carolinianci, L. Annual, prostrate, downy. Leaves obtusely lobed and toothed, 5-\%-parted. Perluncles 2 -flowered. Petals emarginate, as long as the orate awned sepals. Stems forking, $6^{\prime}-18^{\prime}$ long. Flowers pale purple.

\section{ERODIUM. HERON's BILL.}

Calyx 5-leared; petals 5 ; filaments 10 , the 5 alternate ones abortive; fruit rostrate, of 5 aggregated capsules 
tipped with the long, spiral style, bearded inside. Flowers umbellate.

E. CICUtariuMr. Diffuse hairy. Leaves pinnately divided; segments sessile, pinnatifid, acute. Peduncles several-flowered. Petals unequal. Leaves oblong in outline, with many segments. Flowers $2^{\prime}-3^{\prime}$ diameter.Torrey.

\section{BALSAM FAMILY. Order, Balsaminace.e.}

Herbs, tender annuals with succulent stems and watery juice. Flowers very irregular, and unsymmetrical. Sepals 5, deciduous, the upper two connate, the lowest spurred and gibbous. Petals 4, hypogynous, united by pairs, or rarely 5, distinct. Stamens 5, hypogynous. Filaments subulate. Anthers 2-celled. Stigma 5-lobed, sessile. Fruit, a pod, 5 -celled, bursting elastically by 5 valves. Seeds several in each cell. Leaves exstipulate, undivided.

\section{IMPATIENS, L. JEWEL WeED.}

Lowest sepal saccate and spurred. Petals 4, united in pairs. Filaments short, with a scale on the inner face. Capsule 5-celled, bursting elastically into 5 valves. Placentce central, persistent. Stems branching, somewhat pellucid. Leaves serrate. Peduncles axillary, 1-severalflowered.

I. Pallida, Nutt. (Pale Touch-me-not.) Flowers pale yellow, lower sepal slightly spotted, dilated, often tipped with a short recurved spur. Leaves oval or ovate, obtusely serrate, membranaceous. Stem $2^{\circ}-4^{\circ}$ high. 


\section{RUE FAMily. Order, Rutacex.}

Herbs, shrubs, or trees. Leaves strong-scented, sharptasted, exstipulate, dotted with transparent dots like punctures, filled with aromatic, acrid, volatile oil. Fowers regular, segments 3 or 5 , hypogynous, perfect, or polygamous. Stamens on the receptacle (hypogynous), as many or twice as many as the petals. Pistils 2 to 5, separate or combined into a compound ovary with as many cells, sessile or raised on a stipe (gynophore); styles mostly cohering. Fruit, a pod, or separating into its component 1- or 2-seeded carpels.

Trees or shrubs. Stamens 3 or 5 , only as many as the petals. Flowers diœcious, 2 to 5, making fleshy pods with two black seeds. Leaves pinnate; stems prickly.

Zanthoxylum. Prickly Ash.

Flowers pclygamous. Pistil one, making a 2-celled, 2 -seeded key, winged all round. Leaflets 3 . Stems not prickly.

Ptelea, Hop Vine.

\section{ZANTHOXYLUM. PRICKLY Ash.}

Flowers monœcious or diocœus. Sepals and petals 3-5; ovaries; 2-5 sessile or stipulate, 2-ovuled. Carpels 2-valved; 1-2-seeded. Seed smooth and shining. Trees or shrubs, commonly armed with stipular prickles. Leaves unequally pinnate, the leaflets punctate with pellucid dots. Flowers small, greenish.

Z. Carolinianum, Lam. (Toothache Tree.) Smooth, the branches armed with prickles. Leaves $7-9$ foliolate, alternate; leaflets ovate-lanceolate, crenate-serrulate, unequal-sided.

Z. Floridanum, Nutt. (Satin Wood.) Branches and petioles unarmed. Leaflets 5-\%, ovate-lanceolate on the 
fertile plant, and elliptical, obtuse, or emarginate on the sterile, slightly crenulate, and like the cymose panicle stellate-pubescent; stamens 4-5; carpels 1-2, obovate, stipulate; seed solitary, obovate, black and shining. Leaves 1'-2' long. Cyme sessile, divided into three primary branches. Flowers minute.

Z. Ргевота. Branches zigzag, armed with short curved prickles; petiole winged, jointed; leaflets $7-9$, small, obovate, coriaceous, crenate above the middle, sessile; flowers in axillary clusters, which are single or by pairs, as long as the first joint of the petiole; stamens 4 ; ovaries 2 ; carpels solitary, globose, pitted, distinctly stipitate; leaflets $\frac{1^{\prime}}{2}-3^{\prime}$ long, those on the fertile plant narrower and smaller; carpels small, dotted.

Z. HIRsutus; Buckley. Young branches and petioles prickly and strongly hirsute; leaves pinnate, 2-3-paired; leaflets ovate-lanceolate, crenate, obtuse; flowers axillary or terminal, shortly paniculate; carpels subcordate, 1-2-seeded; seeds subovate.-Tree about 25 feet high, and 8-12 inches in diameter; branches armed with stout recurved prickles; leaflets opposite or subalternate; trunk and old branches gray and smooth. Near Corpus Christi.

\section{PTELEA, L. Hop Tree.}

Flowers polygamous; sepals and petals 4-5, imbricated in the bud, deciduous; stamens 4-5; ovary 2-celled, with two ovules in each cell ; style short; stigma 2-lobed; capsule 2-celled, 2-seeded, surrounded by a broad, circular, reticulated wing. - Unarmed shrubs, with trifoliate leaves, and small greenish flowers in a terminal cyme.

P. trifoliata. Pubescent; leaves long-petioled; leaflets oral or oblong, mostly acute, obscurely crenulate, paler beneath, the lateral ones unequal-sided; filaments 
4-5, densely villous below the middle, longer than the style in the sterile flowers, shorter in the fertile ones. -Shrub $4^{\circ}-8^{\circ}$ high ; leaflets ' 2 '-4' long; fruit $1^{\prime}$ wide.

P. MoLLIs, Curtis. Lateral leaflets oval, the terminal obovate, with an abrupt, acute point, the under side with the petioles, panicles, and young branches clothed with soft, white, silky villus; cymes compact; style long ; filaments equaling the anthers; stamens 4.

P. BALDWInir. Leaves very small, glabrous; leaflets sessile, oval, obtuse, the terminal one cuneiform at the base; flowers tetrandrous; style none.-Shrub $1^{\circ}$ high, with numerous scraggy branches; leaflets $1^{\prime}$ long.

\section{SUMACH FAMILY. Order, ANaCaRdiacex.}

Trees or shrubs, with a resinous, caustic, milky juice. Leaves alternate, simple or ternate, or unequally pinnate; flowers terminal or axillary, with bracts commonly diøcions, small; sepals 3 to 5 , united at base, persistent; petals same number, sometimes wanting, imbricated; stamens as many as petals, alternate with them, distinct or cohering, and perigynous; style or stigmas 3 , on a 1-celled orary, which makes a 1-seeded little stone-fruit (drupe) with a thin flesh.

Some of this order are poisonous even to the touch, as the R. TOXICODENDRoN or Poison Oak.

\section{RHUS, L. SUMACH.}

Calyx 5-parted; petals 5, inserted with the 5 stamens on the disk which surrounds the base of the orary; stigmas 3 ; drupe dry; radicle superior, incurved.-Shrubs or small trees. Leaves pinnate or trifoliate, rarely simple. Flowers greenish, in spikes or panicles. 
- Flowers polygamous, in a close terminal panicle; drupe red, hairy; leaves pinnate. (Nol poisonous.)

R. TYPHINa, L. Branches, petioles, and drupes villous; lectlets 17-21, lanceolate, acuminate, serrate smooth, pale beneath.-Large shrub.

R. GLABra. Smooth and glaucous; leaflets 17-31, oblong-lanceolate, serrate, acuminate, white beneath. Open woods. - Shrub $6^{\circ}-10^{\circ}$ high.

R. Copallind. (Sumach.) Branches and wing-margined petioles tomentose; leaflets 9-12, lanceolate or ovatelanceolate, acute or obtuse, mostly entire, smooth above, paler and downy beneath; panicle often large and spreading. Margins of fields and open woods.-A shrub or small tree.

** Flowers diccious, in loose axillary panicles; drupe whitish, smooth; leaves pinnate and trifoliate. (Poisonous.)

R. toxicodendron, L. (Poison Oak.) Branches and petioles smonth, leaves trifoliate; leaflets $7-13$, ovate or oblong, abruptly acute or acuminate, entire ; panicles longpeduncled, narrow, erect.-Shrub, $8^{\circ}-12^{\circ}$ high.

There are four tarieties of the Toxicodendron in our State:

2d. Quercifolium. Stems low, erect, leaflets varionsly lobed.

3d. Radicans. Stems climbing by rootlets; leaflets toothed or entire, more or less pubescent.

4th. Trilobate. Found in the northern part of 'Texas.

*** Flowers dicecious, in loose panicles; drupe oblong, smooth, scarlet; nut chartaceous ; seeds arillate; leaves pinnate.

**** Flowers diocious, in short bracted spikes, appearing with the leaves: drupe red, hairy; leaves trifoliate.

R. ARomatica. Stem low, smooth; leaflets ovate, or the terminal one obovate, obtuse, pubescent when young, toothed above the middle; spikes single or clustered, 
spreading.-Shrub $1^{\circ}-2^{\circ}$ high; spikes $1^{\prime}$ long. Aromatic, not poisonous.

R. virens, Lindheimer. Smooth; leaves evergreen, pinnate; leaflets 3-4 paired with an odd one, each is naked; leaflets ovate or oblong-obtuse, acuminate with the margin subrevolute, entire, coriaceous, above shining, beneath pale and slightly tomentose; flowers white in thyrsoid panicles; panicles axillary, shorter than the leaves; drupe red, hirsute. Limestone hills, Western Texas; Mount Bonnel, Austin. -Shrub, growing in clumps 3-5 feet high.

35. GRAPE FAMILY. Order, Vitacex.

Shrubby plants with a watery and sour juice, climbing by tendrils; known by having a minute caly $x$ with scarcely any lobes; flowers growing in racemes; petals valvate in bud and falling off early; stamens 5 or 4 , one before each petal, inserted on the disk which surrounds the 2-celled, 1-styled ovary; fruit a berry, usually 4-seeded; seeds bony.

\section{VITIS, L. Grape Vine.}

Petals distinct, or remaining united at the apex and separating at the base, inserted into a 4-5-lobed or cupshaped disk which surrounds the ovary.

\section{SYNOPSIS.}

1. $\S$ Flowers perfect; petals and stamens 4-5; style conspicuous; stigma minute; leaves single or compound............................ Crssus.

2. ₹ Flowers polygamous; petals 5 , cohering at the top, free at the base; stamens 5 ; style short; disk thick, 5 -lobed; leaves simple, cordate, entire or variously lobed VITis.

* Leaves and branches voolly.

** Leaves and branches smoothish.

V. BIPINNATA, Willd. Leaves bipinnate, smoothish; leaflets small, ovate, sharply toothed; flowers some- 
what cymose on a long forking peduncle; petals 4-5, united at the apex, separating at the base; style conical; disk 4-5-lobed; berry 2-4-seeded. No tendrils. Leaflets $1^{\prime}$ long. Berry small and black.

V. ACIDA, L. Branches geniculate; leaves trifoliolate, thick and rigid; leaflets small, cuneate-obovate, sharply toothed at the apex; flowers in compound umbels; petals 4 , united at the apex, separating at the base; style slender; disk cup-shaped, entire; berry black, 1-seeded; tendrils stout and elongated. Leaflets $\frac{1^{\prime}}{2}$ long. Branches and peduncles flattened and elongated.

V. INCISA, Nutt. Smooth ; stem climbing, warty; leaves trifoliolate, very thick and fleshy; leaflets stalked, wedge-shaped, and entire near the base, the lateral ones 2-lobed, the middle 3-lobed, all mucronate-toothed or serrate; berry purple, globose-ovate, nodding, pointed with the conspicuous slender style, 1 -seeded. Stem $6^{\circ}-12^{\circ}$ long; leaflets $1^{\prime}-3$ ' long; panicles cymose.

V. INDIVISA, Willd. Leaves simple, undivided, ovate, truncate, or cordate at the base, acuminate, toothed-serrate, pubescent; peduncles forking; petals and stamens 5 ; slyle slender; clisk cup-shaped; berry 1-3-seeded; stem climbing. Berry small, black.

V. LABRCSCA, L. (Fox Grape.) Leaves broadly cordate, angularly 3-lobed, mucronate-serrate, very woolly when young, at length smoothish above; fertile panicles or racemes few-flowered; berry large; leaves 4'-6' wide. Berry $\frac{1}{2}^{\prime}$ in diameter, purple or whitish, pleasantflavored.

V. CARIBAA, DC. Leaves round-cordate, with a broad and shallow sinus, entire or 3-lobed, wavy-serrate, acute or acuminate, soon smooth above, the lower surface like the branches, petioles, and panicles, clothed with soft ash-colored down; panicles equaling or longer than the leaves; pedicels smooth ; berry $\frac{1^{\prime}}{2}$ in diameter. 
V. Astivalis. (Summer Grape.) Leaves cordate, entire or 3-5-lobed, or on young plants pinnatifid, mucrorateserrate, covered with a loose cobwebby down, at length smooth or nearly so on both sides; panicles long, manyflowered; berry small; stem climbing high; leaves $4^{\prime}-7^{\prime}$ wide; panicle 6'-12' long, compound. Berry deep blue, very austere.

V. Monticola, Buckley. Leaves broad cordate, sparingly hoary, tomentose beneath, coarsely and irregularly toothed, teeth acute and submucronate, entire or slightly 3-lobed near the apex, smooth and subcorrugated above; racemes shouldered; berries $\frac{1}{2}$ to $\frac{3}{4}$ of an inch in diameter, dull purple or green with a reddishbrown shade, often quite black; pulp white, acid, and rather agreeable to the taste; skin thin; seeds 1-4, generally 3 ; racemes 3-4 inches long. Young branches have a cottony pubescence; stem small, climbing, 8-10 feet high. Fruit ripe August and September. Leaves 2-3 inches long and about the same width. Common in the hilly region northwest of Austin, Texas. Mountain Grape.

V. Lincenduir, Buckley. Leaves very large, reniformcordate, entire or 3-lobed, crenate-dentate, teeth sub-mucronate; above smooth, beneath a rust-colored pubescence which is also on the younger branches and petioles; racemes shouldered, shorter than the leaves; berries purple, skin thin. Fruit about $\frac{3}{4}$ of an inch in diameter, juicy, and of a pleasant acid taste. This grape has larger leaves than any other American species of grape. Fruit ripens about the 18th of July. "Post-oak Grape." Stems small, climbing, rarely more than 8 or 10 feet. Sandy soils. Eastern and Central Texas. Named in honor of Dr. Lincecum, of Texas.

V. mustangensis, Buckley. Leaves cordate, entire or 3-5-lobed, above smooth, beneath covered with a white 
cottony pubescence, as is also the fruit and leaf-stems and the younger branches; slightly crenately toothed or entire, teeth mucronate; bervies large; bluish-black or green with a purple shade. It makes an excellent wine, but is little esteemed for eating on account of an acrid juice beneath the skin, which, if swallowed, gives a burning pain in the throat. Mustang Grape. Fruit ripens in July and August.

V. vulpina, Michx. (Muscadine.) Leaves broadly cordite, toothed-serrate, smooth and glossy on both sides, or rarely like the branches pubescent, the sinus at the base broild and rounded, or narrow and acute; panicle small, berry-like; stem climbing high, with pale and smooth bark. Leaves $2^{\prime}-3$ wide. Berry $\frac{1^{\prime}}{2}-\frac{3}{4}$ in diameter, purple, pleasant flavored.

V. RUPESTRIS, Scheele. Leaves cordate, smooth on both sides, unequally toothed, teeth submucronate, entire; plant smooth ; racemes small, often not shouldered; berries black or greenish purple, small, about $\frac{3}{8}$ of an inch in diameter; seeds 3-4, large. On the banks of streams. This grape often grows in thick cane-like patches, and does not climb; but on hills and uplands it climbs to the height of 8 to 15 feet. Associated with the Mountain Grape in the region northwest of Austin. Its smooth leaves, of a different shade of green, etc., enable any one at a glauce to distinguish it from the Mountain Grape.

\section{AMPELOPSIS, Michx.}

Petals distinct, spreading, concave; disk none; leaves digitate; flowers clustered in corymboso panicles.

A. QUINQUEFoliA. (American Ivy.) Leaflets 5, oblongobovate, serrate above the middle, smooth; berry small, dark blue. 
A. HePtaphylla, Buckley. Leaves petiolate, palmate, 7 -foliate; leaflets small, ovate-lanceolate, sessile, or shortly petiolate, apex mucronate-dentate, acuminate; panicles cymose, long-pedunculate; flowers small; petals distinct, oblong-lanceolate, sub-obtuse; stamens exsert; berries round, 3-4 seeded. Flowers last of April and first of May. Common on the mountains in Burnet and San Saba Counties, climbing sometimes to the height of $25-30$ feet.

\section{BUCKTHORN FAMILY. Order, RHAMNACEx.}

Woody plants, or small trees, often spiny. Leaves simple, alternate; regular flowers (sometimes apetalous or otherwise imperfect); petals 4 or 5, small; stamens same number as the petals, opposite them and alternate with the sepals. Stamens and petals both perigynous (inserted on the calyx), or on a fleshy cup which lines the tube of the calyx; calyx valvate (edge to edge) in the bud; disk fleshy. Fruit of 2 to 5 cells, and one large seed in each.

\section{SYXYOPSIS.}

* Drupe baccate, 1-2-celled. Ovary immersed on the disk. Petals 5. Drupe

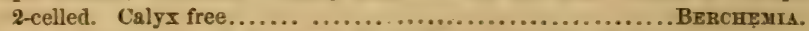

** Leaves alternate. Seeds furrowed on the back. Flowers clustered.

Leaves alternate. Sceds not furrowed on the back. Flowers clustered.

RHA.res.

Fraxgula.

*** Flowers corymbed. Calyx white. Nutlets 2-valved............. CEanothes.

Flowers cymose. Calyx green. Nutlets opening at the margin... Colubriva.

\section{BERCHEMIA.}

Calyx 5-cleft, the tube hemispherical; petals 5, sessile, as long as the calyx; ovary free, 2-celled, half immersed in the fleshy disk; styles united; stigmas 2 ; drupe oblong, 2-celled, 2-seeded.-Erect or twining shrubs, with 
alternate pinuately-veined leaves, with minute stipules, and small greenish axillary or panicled flowers.

B. volubilis. Stem twining; leaves oblong, acute, wavy on the margin, glossy above, the veins oblique; flowers in small terminal panicles; drupe purple.

\section{CEANOTHÙS, L. JERSEY Tea.}

Calyx 5-cleft, colored, tube adnate to the ovary and persistent, lobes connivent, deciduous; petals 5, longer than the calyx, hooded, long-clawed; stamens exserted; style 3-parted; drupe dry, composed of three 2-valved, 1-seeded nutlets; embryo in fleshy albumen; cotyledons flat.-Shrubby plants, with alternate, serrulate, minutely stipulate, 3-ribbed leaves, and small flowers in lateral and terminal corymbs or panicles.

C. Microphyluts, Michx. Stem erect, diffusely muchbranched; leaves perennial, small, obovate, slightly crenate, 3-ribbed, glossy above, with scattered hairs beneath, those in the axils clustered; corymbs small, terminal. Leaves $2^{\prime \prime}-3^{\prime \prime}$ long.-Shrub, $1^{\circ}-2^{\circ}$ high, yellowish. Pedicels and flowers white.

\section{RHAMNUS. BUCKTHORN.}

Calyx 4-5-cleft, the tube urceolate, lined with a thin disk; petals small, obovate, concave, often wanting; ovary free, 2-4-celled; styles united below; stigmas $2-4$; drupe baccate, composed of $2-4$ somewhat dehiscent nutlets ; seeds grooved on the back; raphe dorsal ; cotyledons leafy, revolute.-Shrubs, with alternate stipulate finely-veined leaves, and small axillary clustered polygamous or diœcious greenish flowers.

R. овтUsifolius, Gray and Torry. Somewhat thorny, glabrous. Branches whitish; leaves ovate or oblong-ovate, 
obtuse, about 3-nerred from the base, obscurely serrate, rather shining above; fascicles of flowers shorter than the petioles.

R. LANCeolates, Pursh. Leaves oblong-lanceolate, acute, or those of the flowering branches oblong and obtuse, serrulate; flowers clustered on short pedicels, with long styles, or the more fruitful ones scattered on longer pedicels and with shorter styles; petals emarginate; drupe 2-seeded. - A tall shrub. Drupes black, as large as a grain of pepper.

R. Texensis, Gray and Torry. Much-branched and straggling; branches pubescent; leaves orate or oblongovate, somewhat acute, rillous-pubescent on both sides, denticulate-serrulate, the reins prominent and very oblique; fruit broadly turbinate, $2-3$-seeded; seeds tumid, without a furrow.

R. Drumyoxdi. Branches whitish ; leaves about $\frac{3}{4}$ long, somewhat coriaceous, obtuse or a little acute at the base; petioles $1^{\prime}-2^{\prime}$ long; fruit $3^{\prime}-4^{\prime}$ in diameter, with a very thin pulp, obscurely lobed; seeds smooth and shining.

\section{FRANGULA, Tourn.}

Seeds not grooved; raphe lateral; leaves strongly parallel-reined; flowers perfect.

F. Caroliniaxa, Gray. (Carolina Buchthorn.) Leaves oblong, wavy and finely serrulate on the margins, the slender petioles and many-flowered short-stalked umbels pubescent; petals 5, minute; stigmas 3 ; drupe globose, 3-seeded._A shrub or small tree. Leares $3^{\prime}-4^{\prime}$ long.

3\%. Staff-TreE Family. Order, Celastraces.

Woody plants with simple alternate or opposite leaves; the divisions of the calyx and the petals both overlapping in 
the bud; the stamens as many as the petals ( 4 or 5 ) and alternate with them, inserted on a thick expansion of the receptacle $($ disk) which fills the bottom of the calyx. Pod colored, of 2 to 5 mostly 1 -seeded cells; showy when ripe in autumn, especially when they open and display the seeds enveloped in a pulpy scarlet aril.

\section{EUONYMUS, L. Spindle Tree.}

Flowers perfect; calyx flat, 4-5-cleft; petals 4-5, spreading; stamens 4-5, very short, inserted with the petals under the broad and fleshy disk which surrounds the ovary; ovary 3-5-celled, with 2 erect or resupinate ovules in each cell; style very short; capsule 3-5-celled, loculicidally 3-5-valved; seed enclosed in a red pulpy aril. Erect or trailing shrubs, with 4-angled branches, opposite serrate leaves, and greenish or purplish flowers in axillary peduncled cymes.

E. Americanus, L. (Strawberry Bush.) Flowers greenish, pentamerous; peduncles 1-3-flowered; capsule warty; leaves short-petioled, varying from ovate or obovate to linear-lanceolate, serrulate.-Shrub, $3^{\circ}-6^{\circ}$ high ; leaves $1^{\prime}-2$ ' long.

E. Atropurpureus, Jaq. Flowers purple, tetramerous; peduncles many-flowered; capsule smooth; leaves oblong on rather long petioles, serrulate.-Shrub, $8^{\circ}-12^{\circ}$ high ; leaves $2^{\prime}-5$ ' long; flowers dark purple.

\section{Celastrus. Staff Tree.}

Flowers somewhat diœcious; calyx cup-shaped, 5-cleft; petals 5, spreading; stamens 5, inserted with the petals into the edge of the cup-shaped fleshy disk which fills the tube of the calyx, abortive in the fertile flower; ovary 2-4-celled, the cells 2-ovuled; style thick; capsule glo- 
bose, commonly 3 -celled and 3 -ralved; seeds $1-2$ in each cell, enclosed in a fleshy scarlet aril ; embryo in the axis of copious fleshy albumen.-Climbing shrubs, with alternate leaves, and small greenish flowers in axillary or terminal racemes.

C. SCANDENS. Leaves oblong-ovate or obovate, acuminate, serrate, smooth; racemes terminating the branches, nearly simple; capsule orange-colored.

\section{MAPLE FAMILY. ACERACE.}

Trees or shrubs, with opposite lobed or pinnate exstipulate leaves and regular mostly polygamous or diøcious flowers, with an imbricated æstivation. Calyx 4-9-lobed; petals as many as the lobes of the calyx or none; stamens 4-12, inserted with the petals into a hypogynous disk; ovary 2-celled, with 2 pendulous amphitropous ovules in each cell, forming in fruit a double 2-seeded samara; styles 2 ; seeds with little or no albumen; embryo folded or spirally coiled.

* Flowers on long and drooping umbellate or comymbose pedicels, developed from lateral and terminal buds.

\section{ACER.}

A. SacCharinum. (Sugar Maple.) Leaves cordate, with 3-5 acute or acuminate sinuate-toothed lobes, paler and slightly pubescent beneath; flowers umbellate-corymbed, appearing with the leaves; calyx bell-shaped, fringed on the margin, nearly as long as the stamens; petals none.-A large tree; leaves $33^{\prime}-5^{\prime}$ wide.

** Flowers on short and erect clustered pedicels, developed from lateral budi, and appearing before the leaves; fruiting pedicels long and drooping.

A. rubruy, L. (Red or Swamp Maple.) Leaves 3-5lobed, or undirided, smooth or pubescent, either cordate or rounded, or sometimes acute at the base toothed and ser- 
rate, white beneath; petals oblong or linear; samara small, smooth. - A small tree; flowers and fruit red.

\section{NEGUNDo. Ash-leaved Maple.}

A small tree, bark green and smooth ; flowers diœcious; calyx minute; petals none; stamens $4-5$, hypogynous; leaves pinnately 3-5-foliolate, the leaflets ovate, lobed, or toothed. Flowers small, greenish; the sterile ones on long and drooping clustered pedicels; the fertile ones racemose; both from lateral buds appearing with or before the leaves.

N. ACEROIDES. On banks of streams.

39. SOAP-BERRY FAMILY. Order, SAPINDACE.

Trees, shrubs, rarely herbs. Leaves simple or compound, alternate or opposite; flowers mostly unsymmetrical and irregular, 4 or 5 divided; sepals and petals imbricated in the bud; stamens 5 to 10 , inserted on an hypogynous or perigynous disk; ovary 2-3-celled and lobed, with two, sometimes more ovules in each cell.

\section{SYNOPSIS.}

Tribe I. Dodone.e. Ovules $2-3$ in each cell. Embryo spirally coiled. Cotyledons distinct. Leaves alternate.

Tribe II. Sa Pindas. Ovules usually solitary. Embryo curved or straight. Cotyledons distinct. Leaves alternate.

Ovules solitary. Petals 5, regular. Fruit baccate............... SAPINDUs.

Ovules solitary. Petals 4, irregular. Fruit a bladder-like capsule.

Cardiospermum.

Calyx 5-lobed. Petals 4-5, unequal. Leaves digitate............ Esculus.

\section{SAPINDUS, SOAP-BERRY.}

Calyx 5-parted, deciduous; petals 5, regular, with a scale at the base of each within; stamens $8-10$, inserted on 
the hypogynous disk; styles united; stigmas 3 ; ovary 3 -celled, the cells 1-ovuled; fruit baccate, globose or 2-3loked, 1-3-seeded; seeds bony; embryo incurved.-Trees, with abruptly pinnate leaves, and small polygamous flowers in axillary or terminal racemes or panicles.

S. marginatus, Willd. (Wild China.) Petioles wingless; leaflets 9-18, opposite or alternate, ovate-lanceolate, unequal-sided, strongly veined above; panicles large, denseflowered; fruit globose; flowers white.

\section{CARDIOSPERMUM.}

Sepals 4, the two outer ones much shorter; petals 4, irregular, each with a petal-like scale at the base within, those of the two outer petals entire, the others with a crested appendage on the inner edge; stamens 8 ; disk 2-glandular; cells of the ovary 1-ovuled; style 3-cleft; capsule 3 -angled, 3 -celled, loculicidally 3 -valved, inflated; seeds furnished with a cordate aril.-Herbs, climbing by tendrils; leaves biternate.

C. Halicacabum. Leaflets ovate-lanceolate, incisely lobed and toothed; stem slender; capsule pear-shaped, $1^{\prime}$ in diameter. Annual.

\section{ÆesCUlUS, L. Buckeye, Horse Chestnut.}

Calyx 5̃-lobed, unequal; petals 4-5, unequal, clawed; stamens $\check{0}-8$, usually $\%$, inserted on the annular hypogynous disk ; style slender; ovary 3-celled, the cells 2-ovuled; capsule coriaceous, 1-3-celled, loculicidally 2-3-valved, 1-3-seeded; cotyledons very large and thick, partly united. -Trees or shrubs, with opposite long-petioled digitate leaves and showy polygamous flowers in terminal panicles.

\$ AEsculus PROPER. Fruit prickly.

$\$$ Pavu. Fruit smooth. 
Æ. Pavia. Stamens slightly exserted; claws of the two upper petals as long as the tubular calyx; panicle oblong; leaflets 5, varying from lanceolate to oval, short-acuminate, finely serrate, smooth, or nearly so, on both surfaces. A shrub or small tree; flowers red.

A. ARGUTA, Buckley. Fruit covered with prickles; stamens erect or slightly curved, much longer than the pale yellow corolla; calyx campanulate, divisions obtuse; pedicels short; whole panicle subpubescent; flowers dense; leaflets \%, glabrous, ovate-lanceolate, acute at both ends, sharply and unequally serrate.-Shrub, 3-5-feet high, with a smooth bark. Flowers in March. Panicles $4-6$ inches long. Leaflets 2-4 inches long. Hills in the vicinity of Larissa, Texas.

\section{MilKWORT FAMILY. Order, Polygalacez.}

Herbs or shrubs, with simple exstipulate leaves. Flowers irregular, unsymmetrical, hypogynous, perfect; sepals 5, very unequal, distinct, 3 exterior, 2 (wings) interior, large, petaloid; petals 3 , the anterior (keel) larger than the 2 posterior; stamens 4 to 8, distinct or cohering in a tube which is split on the upper side; ovary superior, compound, with suspended ovules; united styles and stigmas; fruit a 2-celled, 2-seeded pod. Seeds pendulous, furnished with a caruncle (a small scale entire or cleft).

\section{POLYGALIA. MILKWORT.}

§ Flowers in globose or oblong more or less compact spikes.

* Spikes corymbase ; biennials.

P. Crmosa, Walt. Stem tall, simple; leaves scattered, linear-acute, the upper bract-like, the lowest long and crowded; corymbs simple or compound; wings oblong, 
abruptly acute; seeds minute, globose-obovate, smooth; caruncle none; stems $2^{\circ}-4^{\circ}$ high; corymbs very large and compound, or small and simple; flowers yellow; plant yellowish

\footnotetext{
** Spikes solitary ; leaves alternate.

+ Flowers purple or rose-color; annuals, stems branching.
}

P. INCARNATA, L. Stem often simple, glaucus; leaves scattered, linear, fleshy, sometimes minute and subulate; spikes lanceolate, acute, dense-flowered; petals united into a tube which is twice as long as the elliptical wings, conspicuously crested; caruncle spongy, as long as the stalk of the oval hairy seed; bracts deciduous; flowers and often the rachis purple.

5 Flowers in slender racemes or spikes.

* Leaves alternate; perennials or biennials.

P. ALBA, Nutt. Stems several from a somewhat woody root, erect or ascending, angular, at length branched above; leaves linear, narrowed toward the base, acute or lowest ones obtuse ; spike long-peduncled, linear-lanceolate, acuminate; flowers short pediceled, wings oval, rather longer than the capsule; lobes of the caruncle shorter than the oblong-obovate very hairy seed. Flowers white. North Fork of Red River.-Torrey.

\section{1. rhatany family. Order, Krameriaced.}

Silky-pubescent herbs or shrubs, with diffuse stems, alternate leaves, and irregular hypogynous purplish flowers, on axillary 2-bracted and jointed peduncles. Sepals 5, colored, deciduous; petals 5, shorter than the sepals; the 3 posterior ones long-clawed, often united; the 2 anterior broad, sessile, and fleshy; stamens 4 , the posterior ones 
distinct or united; anthers 2-celled, opening by a terminal pore; ovary 1-celled, 2-ovuled; fruit 1-seeded, woody, indehiscent, armed with hispid prickles. Albumen none. Radicle concealed in the cotyledons.

\section{KRAMERIA.}

K. Lanceolata. Herbaceous. Stems slender,prostrate, mostly branching; leaves lanceolate or linear, acute; peduncles longer than the leaves, leafy-bracted above the middle claws of the posterior petals, and stamens, united; fruit globose, downy, armed with a few strong spreading spines. Root long and woody. Stems $1^{\circ}$ long.

\section{PULSE FAMILY. Order, Leguminos}

Herbs, shrubs, or trees. Leaves alternate, usually compound, margins entire; stipules 2 at the tumid base of the petioles; sepals 5, more or less united, often unequal, the odd one anterior; petals 5, either papilionaceous or regular, perigynous, the odd one, when present, posterior; stamens diadelphous, monadelphous, or distinct, inserted on the calyx; anthers versatile; ovary superior, single and simple; fruit a legume, either continuous (1-celled) or (a loment) joined into 1-seeded cells; seeds solitary, or several, destitute of albumen. The papilionaceous corolla (as seen in the pea-blossom) consists of 5 irregular petals -an upper one, generally largest and outside in the bud, called the standard or vexillum, two side petals, called wings, and two lower ones put together and commonly a little joined, forming a kind of pouch which encloses the stamens and style, and which, being shaped somewhat like the prow of an ancient ressel, is named the keel. A few flowers in the family are almost regular, or not papilionaceous. In one case all but one petal is wanting. Another set have perfectly regular blossoms; the pod and the leaves 
give them their place in Leguminosæ. The legume is of every variety of size and shape. The whole kernel of the seed in an embryo, with thick cotyledons.

\section{Sub-order, Papilionaceots.}

Tribe I. Lotere. Corolla papilionaceous ; stamens 10 (except Petalostemon) ; legume continuous (not jointed); cotyledons leafy in germination; stems (except Wistaria) not twining, nor climbing.

- Stamens monadelphous; anthers of 2 forms. Leaves simple or palmately decurrent.

Calyx 5-lobed. Legume inflated. Upper stipules decnrrent......... Crotalaria.

- 2-lipped - flattened. Stipules not decurrent............ Lupivus.

** Stamens diadelphous; anthers alike. Leaves trifoliolate, rarely palmate or pinnate, the earliest ones alternate.

Legume membranaceous, curved or coiled, many-seeded. Flowers racemed.

MEDicago.

- coriaceous, straight, rugose or veined, 1-4-seeded. Flowers racemed or Bpiked........................................ MELtuLotus.

- smooth, membranaceous, 1-4-seeded. Flowers capitate.... TrurourcM.

— straight, many-seeded. Peduncle 1-3-flowered............... Hosıckis.

\$क* Stamens monadelphous or diadelphous. Legume mnstly 1-seeded ana' indehiscent. Plants dotted with small glands. Ear'icot lecives olposite.

+ Legume included in the calyx.

Corolla papilionaceous. Stamens 10, diadelphous; half of the anthers imperfect.

Psoralea.

Stamens 5, united into a cleft tube, and adnate to the claws of four of the regular

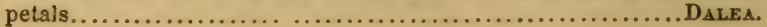

\section{++ Legnime exserted.}

Stamens 10, monadelphons. Wings and keel none. AMORPHA.

**** Stamens mostly diadelphous. Legume 1, many-seeded, 1-celled, 2-valved. Leaves pinnate.

+ Trees or shrubs.

Legume flat and thin, margined on the edge. Trees or shrubs........ Rosinu. - nearly terete, coriaceous, contracted between the seeds. Twining shrubs. 
†† Herbs.

Calyx 5-cleft. Vesillum large. Legume compressed, many-seeded. Leaves un-

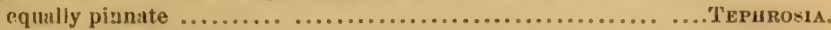

Caly x 5-clefi. Vexillum small. Legume terete or angled, 2-many-seeded. Leaves

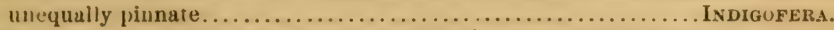

Calyx truncate. Legume oblong, 2-seeded. Leaves abruptly pinuate.

GLotTidium.

Calyx 5-toothed. Legune very long and slender, many-seeded. Leaves alnuptly

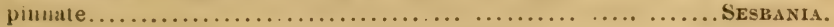

***** Stamens diadelphous. Legume 2-celled lengthwise, or 1-celled with one of the sutures turned inward. Leaves pinnate.

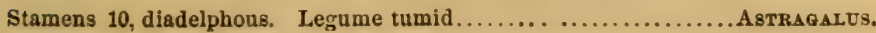

TrIBE II. Vicieæ. Stamens diadelphous, 9 and 1. Legume 2-valved, not jointed. Cotyledons thick and fleshy, remaining underground in germination. Climbing vines; the petioles of the pinnate leaves ending in tendrils.

Style fliform, bearied at the apex, or on the side of the keel........... Vrcrs. - - flattened, bearded on the side facing the vexillum........... Latuxrus.

Tribe III. Hedysareæ. Stamens monadelphous or diadelphous. Legume separating transversely into 1-seeded indehiscent reticulated joints, or 1-jointed. Stems not twining.

\section{* Flowers yellowo.}

Leaves pinnate. Stamens diadelphous, 5 and 5 . Flowers perfect. EschrNomene. - palmately compound. Legume 2-5-jointed. Flowers perfect.....Zoris.

- trifoliate. Anthers of 2 forms

- pinnate. - - alike.

** Flowers white or purple.
-_ monœcious.

Strlosanthes. monœcious.

Chapmannia.

Legume 1-jointed. Peduncles axillary .LESPEDEZA. _-_ 2-6-jointed, bristly. Racemes terminal. Desmoviux.

Tribe IV. Phaseoleæ. Stamens monadelphous or diadelphous, 9 and 1. Legume 2-valved, not jointed. Cotyledons thick and fleshy; usually raised aboveground in germination. Chiefly twining vines. 
* Ovary 1-2-ovuled.

Legume oblong. Flowers yellow. Leaves trifoliate. RHYNcosia.

** Ovary few or many oruled.

+ Keel spirally twisted.

Leaves pinnate, not stipellate.

Apros.

trifoliolate, stípellate.

Praseolus.

+† Keel straight. Leaves trifoliolate.

t+ Legume terete, tortulose.

Flowers yellow. Vexillum roundish. Stem twining VIGNA.

- scarlet. narrow, elongated. Stem erect.

ERytariNa.

t+ ++ Legume flatlened.

$=$ Bracts opposite. Vexillum very large.

Calyx tubular, 5-toothed. Vexillum spurless at the base. Clttoria.

- short, 5-cleft.

- spurred at the base.

Centrosema.

$$
==\text { Bracts alternate. }
$$

Calyx 4-5-toothed. Flowers of two kinds. Bracts persistent..... AMpHicarpar.

- 4-cleft. Bracts deciduous. Legume ïnear................. Galactia.

- bilabiate. Stamens monadelphous. Hilum linear. Legume 3-ridged on

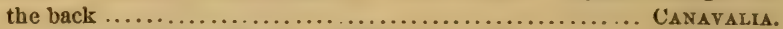

— 5-cleft. Stamens diadelphous. Hilum oval................ DoLichos.

Tribe V. Dalbergieæ. Stamens 10, monadelphous or diadelphous. Legume indehiscent. Cotyledons thick and fleshy. Trees or shrubs.

Legume compressed, 4-winged. Ltaves pinnate................... PIscrds.

Tribe VI. Sophoreæ. Stamens 10, separate. Legume not jointed. Erect herbs, shrubs, or trees.

* Legume dehiscent.

Stamens deciduous. Legume inflated, stipitate, few-seeded. Leaves simple or

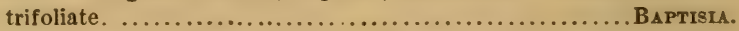

- persistent. Legume nearly sessile, flattened, many-seeded. Leaves trifoliate............................ THERMOPsIs.

_ persistent, Legumic flat, few-seeded. Leaves pinnate. Free.

Cladastris.

** Legume indehiscent.

Legume moniliform. Leaves pinnate. Shrubs SOPHORA. 
Sub-order II. Cæsalpinieæ. Corolla irregular and somewhat papilionaceous, or almost regular, imbricated in the bud; the upper petal interior. Stamens separate. Embryo straight.

Flowers perfect, somewhat papilionaceous. Calyx 5-toothed. Leaves simple.

Cercis. irregular, perfect. Calyx deeply 5-parted. Anthers dissimilar. Leaves

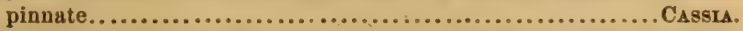
polygamous, almost regular. Calyx 8-5-parted. Leaves pinnate and

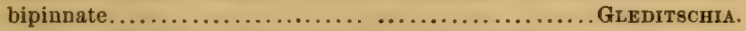
perfect, somewhat papilionaceous. Calyx 5-parted, rather unequal. Leaves bipinnate......................................

Sub-order III. Mimoseæ. Corolla regular, hypogynous, valvate in the bud. Stamens distinct or united, often very numerous, inserted with the petals. Embryo straight. Leaves pinnate or 2-4-pinnate. Flowers polygamous.

\section{* Flowers perfect and staminate. Petals uniteã.}

Filaments distinct. Legume jointed, flat .Mrmosa.

$\longrightarrow$ united in
within not jointed, echinate. SCHRANEIA. nited into a tube below. Legume broad and flat, mealy or pulpy Pithecolobium.

** Flowers perfect and neutral. Petals distinct.

Sterile filaments filiform. Legume linear, many-seeded............ Desmanthus. - flat or petal-like. Legume oblong, few-seeded........ NePtunis.

\section{PULSE FAMILY. Sub-order I., Papilionacex.}

\section{CROTALARIA, RATTLE-BOX.}

Calyx 5-lobed; vexillum cordate; keel falcate; stamens monadelphous; anthers alternately oblong and roundish; capsule inflated, oblong, many-seeded.-Low herbs, with simple leaves; the upper ones with broad decurrent inversely sagitate stipules; racemes opposite the leaves; flowers yellow; legumes dark purple.

C. Purshin, DC. Stems slender, erect, roughened with 
scattered appressed hairs; leaves thick, smooth above, the lower ones oblong, the upper linear; racemes long, $5-10$ flowered; stems $12^{\prime}-18^{\prime}$ high ; racemes $6{ }^{\prime}-12^{\prime}$ long; flowers distant. Perennial.

\section{LUPINUS. LUPINE.}

Calyx 2-lipped, 5-toothed; vexillum with the sides reflexed; keel falcate, acute; stamens monadelphous, with alternate anthers oblong and roundish; capsule oblong compressed, many-seeded; the seeds often separated by cellular partitions.-Herbs, with simple or palmately 5-many foliolate leaves, and showy flowers in terminal racemes.

L. villosus, Willd. Biennial ; villous and hoary; stems thick, prostrate or ascending ; leaves simple, lanceolate-oblong, mostly acute, long-petioled; stipules linear subulate, elongated, adnate below to the petioles; racemes erect, densely many-flowered; flowers pale red, the vexillum dark purple in the center ; legume very woolly. Stem $1^{\circ}-2^{\circ}$ long; leaves, with petiole, $6^{\prime}-8^{\prime}$ long.

\section{MEDICAGO, L.}

Calyx 5-cleft, the lobes subulate or setaceous; corolla deciduous; vexillum longer than the partly united wings and keel; stamens 10, diadelphous (9 and 1), equal; style smooth; legume woolly; stems $1^{\circ}-2^{\circ}$ high; leaves $2^{\prime}-4^{\prime}$ long.

M. LUPULiNa. Pubescent; stem procumbent; leaflets obovate, toothed; stipules nearly entire; spikes globose, many-flowered; flowers minute, legume reniform, 1-seeded, black. Annual ; stem $1^{\circ}-2^{\circ}$ long.

\section{TRIFOLIUM, L. ClOVER.}

Calyx 5-cleft, the teeth subulate or setaceous; corolla withering or persistent; the keel shorter than the wings, 
and united with them by their claws; stamens diadelphous (9 and 1) ; legume smooth, membranaceous, 1-6-seeded, oftener shorter than the calyx, scarcely dehiscent.-Tufted or diffuse herbs. Leaves trifoliolate, the leaflets mostly toothed; stipules adnate to the petioles; flowers capitate.

* Fruiting calyx erect.

T. pratense, L. (Red Clover.) Hairy; stems erect; leaflets oblong-ovate or oval, often emarginate, slightly serrulate; heads large, ovate; calyx-teeth setaceous, hairy; flowers purple. Stems $1^{\circ}-2^{\circ}$ high ; leaves usually marked with a pale 3 -angled spot above.

\section{** Fruiting calyx reflexed.}

T. Reflexum, L. (Buffalo Clover.) Pubescent; stems ascending; lenflets roundish or obcordate, toothed, the uppermost oblong; heads globose; calyx-tube very short; the subulate teeth long and hairy; standard broadly ovate, purple; the wings and keel white; legume 3-5-seeded. Annual and biennial. Stems $6^{\prime}-12^{\prime}$ long; heads large.

T. MACROCALYX, Berlander. Slightly hairy; stems ascending, slender; leaves on slender petioles; leaflets obovate-cuneiform, retuse, serrulate; stipules ovate-lanceolate; heads rather few-flowered, sub-globose, on long peduncles; flowers at length deflexed, pedicellate; calyx broad, persistent, reticulated, very deeply bilabiate; the lower lip minute, linear-subulate; the upper 4-cleft, nearly as long as the persistent and scarious corolla; vexillum sessile and broadly oval ; wings lancinate-denticulate at the apex; the keel small; legume 7-9-seeded, ciliate above. Flowers large. Near Bexar.

T. REPENS. (White Clover.) Smooth ; stems creeping; leaffets roundish or obcordate; heads globose, long peduncled; calyx-teeth short; flowers white; legume 4-seeded. Perennial ; stem $66^{\prime}-12^{\prime}$ long. 
T. Procumbens, L. Pubescent; stems slender, erect or procumbent; leaflets small, thin, obovate or obcordate, toothed, the middle one stalked; heads small ovate; flowers yellow ; legume 1-seeded. Annual ; stems $6{ }^{\prime}-12^{\prime}$ long.

T. Carolinianum, Michx. Pubescent; stems tufted, prostrate; leaflets small, obcordate, slightly toothed; heads roundish, long-peduncled; flowers white, tinged with purple; standard acute; legume 4-seeded. Perennial ; stem $6^{\prime}-10^{\prime}$ long; in shady places erect.

\section{PSORALEA, L.}

Caly $x$ campanulate, 5 -cleft, with the lobes acute; stamens diadelphous or partly monadelphous; half of the anthers often imperfect; legume often wrinkled, 1-seeded, indehiscent, included in the calyx. - Perennial, usually glandular herbs; stipules cohering with the petioles; flowers axillary or terminal, purplish or white, racemose or spiked.

\section{* Leaves 1-3-foliolate.}

P. Melilotoides, Michx. Glandular and sparingly pubescent; leaves trifoliolate; leaflets oblong-lanceolate or elliptical; stipules subulate; spikes oblong, on peduncles 3-5 times as long as the leaves; bracts ovate, acuminate, veiny; corolla violet; legume rugose; stem $1^{\circ}-2^{\circ}$ high; leaflets $1^{\prime}-2$ ' long.

** Leaves palmately 5-7-foliolate.

P. овтusiloba. Canescent; branches spreading; leaves 3 rarely 5-foliolate; leaflets oblong-oborate, obtuse or slightly emarginate, finely dotted; stipules almost none; racemes 3 times as long as the leaves, oblong, loose, 10-15-flowered; bracts minute, broadly ovate, abruptly acuminate, spreading; calyx $\frac{1}{3}$ the length of the petals; legume nearly glabrous, not wrinkled.-Drummond. 
P. CRY PTOCARPA. Stem somerhat divaricately branched, canescently hairy with an appressed pubescence; leaves 5 -foliolate; leaflets $1 \frac{1}{2}{ }^{\prime \prime}$ long; stipules subulate; peduncles longer than the leaves; spikes ovate, compact; bracts lanceolate, cuspidate, shorter than the flower; calyx somewhat inflated, gibbous at the base; legume membranaceous, slightly tipped with the base of the style, not wrinkled. -Drummond.

P. esculenta, Pursh. The whole plant hirsute; stem erect, somewhat branched; leaves 5 -foliolate; leaflets slightly dotted; spikes capitate; flowers pale blue; vexillum obovate, marked with 2 callosities toward the base; legume covered with the calyx, hirsute; root the size of a walnut, scarcely farinaceous, solid and tough. "According to Nuttall the root of this species is the Pomme de Prairie (also called Pomme Blanche) of the Canadian voyageurs." -Gray and Torrey. In Texas, Dr. Leavenworth.

*** Leaves pinnate.

P. SIMPLEX. Grayish pubescent, obscurely glandular, erect; stem simple, solitary, or two from the same root, $1^{\circ}-3^{\circ}$ high; leaves 3 -foliolate; leaflets lanceolate, acute, rugosely veined, mucronate; peduncles very long; spikes oblong, many-flowered; bracts linear-lanceolate, acuminate; teeth of calyx oblong-triangular, the lowest one longest and acuminate; legumes nearly orbicular; fllowers purplish. Calyx and petals strongly reined.-Drummond.

P. Rномвifolia. Sparingly pubescent; stem slender, decumbent, angular; leaflets $\frac{1^{\prime}}{2}-\frac{3^{\prime}}{4}$ long, dotted with scarcely visible glands; petioles $1^{\prime}-2^{\prime}$ long; spikes 6-8flowered; flowers purplish; calyx hirsute; the teeth (except the lowest one) shorter than the tube; vexillum obovate.Drummond. 


\section{PETALOSTEMON, Michx.}

Calyx nearly equally 5-toothed or 5-cleft; petals almost regular, on filiform claws, four of them united with the tube of the stamens, the fifth free, cordate or oblong, folded; stamens 5, united into a cleft tube; ovary 2-ovuled; legume indehiscent, 1-seeded, included in the calyx. Perennial, glandular herbs, with unequally pinnate leaves, and white or purple flowers in terminal spikes or heads.

\section{* Spikes solitary.}

P. Carnecm, Michx. Stems erect, much branched, very leafy; leaflets 5-7, linear, acute; spikes oblong, long-peduncled; vexillum oblong. Stem $2^{\circ}-3^{\circ}$ high; flowers white or reddish.

\section{** Spikes corymbose.}

P. corymbosum, Michx. Stems clustered, erect, very leafy; leaflets $3-7$, filiform; teeth of the calyx setaceous, plumose; vexillum oblong. Stem $2^{\circ}$ high; flowers white.

P. Gracile, Nutt. Glabrous; stem slender, $1^{\circ}-2^{\circ}$ long, decumbent or assurgent; spikes oblong-cylindrical, short; bracts acute, as long as the calyx ; leaflets 3 pairs, $\frac{1}{2}^{\prime}$ broad, linear-elliptical, slightly dotted beneath; petals ovate; vexillum broadly cordate; petals white.-Drummond.

P. MULTIFLoRUM, Nutt. Glabrous; stem erect, branches fastigiate, about $2^{\circ}$ high ; spikes roundish oblong, $\frac{1}{2}^{\prime}$ long; calyx with the tube glabrous; the teeth short, pubescent on the margin ; petals white, rounded or slightly cordate at the base ; leaflets 4-6 pairs, linear, oblong, with black dots on the surface.-Drummond.

P. Griseum, Gray and Torrey. Pubescent; stem $2^{\circ}-3^{\circ}$ high, terete, of a reddish color, usually branched in a paniculate manner, either near the summit or from the 
middle upward ; leaflets $5^{\prime \prime}-6^{\prime \prime}$ long, rather thinly pubescent on both surfaces, with soft appressed hairs; spikes about $2^{\prime}$ long; bracts subulate, as long as the flowers; corolla pale rose-color; petals scarcely acute at the base, as long as the vexillum.-Drummond.

P. A PHLEOIdEs. Stem pubescent; leaflets $4^{\prime \prime}-5^{\prime \prime}$ long, nearly linear; spikes cylindrical, about $2^{\prime}$ long, on long peduncles; bracts awned; calyx marked with large resinous glands ; petals extremely narrow, acute at the base, white; claw of the vexillum passing through the deep notch of the calyx.-Drummond.

P. obovatum, Gray and Torry. Whole plant almost woolly, with soft grayish hairs. Stem thick ; leaflets rather remote, more than $\frac{1}{2}^{\prime}$ long, $3^{\prime \prime}-4^{\prime \prime}$ wide ; bracts almost concealing the flowers, concave with a long acuminate point; vexillum pale purple, with the claw as long as the limb; teeth of the calyx subulate. Remarkable for its large and broad leaflets and very thick subsessile spike-Drummond.

P. vrolaceum, Michx. Somewhat pubescent or glabrous ; leaflets 2 pairs, linear, with a few glands beneath; spikes very dense, varying from globose-ovate to oblong-cylindrical, pedunculate; caly $x$ silky canescent; teeth about onethird the length of the tube; petals oblong, obtuse at the base, with short claws; vexillum cordate; root thick, somewhat fusiform, perennial. Leaves fascicled, leaflets $6^{\prime \prime}-10^{\prime \prime}$ long ; flowers bright purplish-violet.-Drummond.

P. emarginatum, G. and T. Annual. Stem $2^{\circ}$ high; leaves numerous, leaflets $\frac{1}{3}^{\prime}$ long, deeply emarginate; spikes compact, on peduncles $6^{\prime}-10^{\prime}$ long; bracts silky villous, lower ones much dilated; calyx very villous, deeply 5-cleft, the segments lanceolate; petals oblong with short claws. Limbs of the vexillum somewhat 4-sided.Drummond. 


\section{DALEA, L.}

Calyx 5-cleft; corolla imperfectly papilionaceous; petals clawed, four of them united with the tube of stamens below the middle, the fifth (rexillum) free, cordate, and inserted into the bottom of the calyx; stamens 10 , united into a cleft tube; legume 1-seeded, membranaceous, indehiscent, included in the calys.-Mostly glandular herbs, with spiked or capitate flowers.

D. ALOPECLROIDEs, Willd. Stem smooth, erect; leares pinnate, with numerous linear-oblong leaflets; spikes dense, cylindrical, silky-rillous; corolle small, pale riolet, the standard white. Stem $1^{\circ}-2^{\circ}$ high.

D. LAxiflora, Pursh. Stem with numerons slender somewhat spreading branches, $3^{\circ}-4^{\circ}$ high; leciflets $2^{\prime \prime}-3^{\prime \prime}$ long, and $\frac{1}{2} "$ wide, strongly dotted ; racemes $2^{\prime}-3^{\prime}$ long; bracts almost orbicular, glandular, slightly cispidate; calyx deeply cleft, beantifully plumose; corolla white, keel twice as long as the wings; rexillum cordate, rery small, sometimes with 4 approximated glands near the middle; segments of the calys remotely denticulate. Perennial.-Drummond.

D. AUREA. Stem $2^{\circ}$ high; leaves remote; leafets $t^{\prime \prime}-6^{\prime \prime}$ long, when young almost villous beneath, nearly glabrous above, rery sparingly dotted; spikes $1^{\prime}-2^{\prime}$ long. rery thick; caly $x$ deeply cleft; corolla jellow; vexillum small, shorter than the oblong wings and keel-plates.-Drummond.

\section{AMORPHA, L.}

Caly $x$ obconical, 5-toothed, persistent; vexillum straight, concare; wings and keel none; stamens monodelphous, at the base exserted; legume 1-2-seeded, oblong, curred, glandular, roughened, indehiscent or nearly so.-Shrubs, with unequally pinnate leaves and numerous leaflets which 
are punctate with pellucid dots. Flowers blue or white, in slender racemes or spikes.

A. Fruticosa, L. Pubescent; leaves petioled; leaflets 15-21, oblong, obtuse or emarginate, sparingly dotted; flowers racemed, blue; caly $x$-teeth very short, nearly equal, pubescent; legume 1-2-seeded.-Shrubs, 60-15 high; leaflets $1^{\prime}-1 \frac{1}{2}$ long; racemes mostly panicled.

A. CAnescens, Nutt. Hoary-tomentose; leaves sessile; leaflets numerons, small, elliptical, crowded; spikes short, panicled, dense-flowered; calyx-teeth acute, nearly equal; legume 1-seeded.-Shrub, $1^{\circ}-2^{\circ}$ high; flowers bright blue. -Drummond.

A. PANiculata, G. and ' $I$ '. Whole plant canescently tomentose, except the upper surface, which is shining and nearly glabrous; flowers subsessile; teeth of the glandular and tomentose calyx unequal, the 2 upper triangular-ovate and shorter, the 3 lower triangular-subulate, the middle one longest; leaves $8^{\prime}$ to $1^{\circ}$ in length; stipules short; panicle often $1^{\circ}$ or more long, compound; spikes $6^{\prime}$ in length, the flowers much crowded.-Drummond.

\section{ROBINIA.}

Calyx short, 5-toothed or 5-cleft, the two upper teeth shorter and more or less united; vexillum large, roundish; keel obtuse; stamens diadelphous (9 and 1) ; style bearded on the side facing the vexillum; legume compressed, manyseeded, the seed-bearing suture margined; seeds flat.Trees or shrubs, often with stipular spines, unequally pinnate leaves, and showy white or rose-colored flowers in axillary racemes.

R. Pseudacacia. (Locust; False Acacia.) Smoothish; spines small on the older branches, straight; leaflets 9-1\%, oblong-ovate, or elliptical; racemes pendulous, oblong, many-flowered; flowers white; legume 4-6-seeded; ra- 
cemes 3 '-5' long; calyx spotted.-A tree, $30^{\circ}-60^{\circ}$ high; legume smooth; flowers fragrant.

\section{WISTARIA, Nutt.}

Calyx campanulate, somewhat 2-lipped, the upper lip broad 2-cleft, the lower 3-cleft; vexillum large, with two parallel ridges at the base ; stamens diadelphous (9 and 1); legume coriaceous, nearly terete, contracted between the seeds, at length 2-valved.-Twining shrubs, with unequally pinuate leaces, and showy purple flowers, in a crowded raceme.

W. Frttescens, DC. Young leaves and branches silky pubescent; leaflets 9-13, orate-lanceolate or oblong; stipels none; racemes on short branches, dense-flowered, $4^{\prime}-6^{\prime}$ long; leaflets $1^{\prime}$ long; legume 1 -several-seeded; bracts large, caducous.

\section{TEPHROSIA, Pers.}

Calyx nearly equally 5-toothed or 5-cleft; vexillum large, roundish, spreading or reflexed, usually white within and reddish or purple and silky without; keel obtuse, cohering with the wings; stamens monadelphous or diadelphous; style smooth or laterally bearded; legume compressed, linear, many-seeded. - Perennial herbs, with unequally pinnate leares, with the leaflets opposite, mucronate, and straight-reined, and white or purplish flowers.

* Flowers single or by pairs in the axils of the leaves; the uppermiast of len crowded in a dense raceme.

T. Virginiana, Pers. (Goat's Rue.) Soft hairy and somewhat hoary ; stems very leafy, clustered, erect, simple; leaflets 11-25, oblong or linear-oblong, acute or obtuse, smoothish above; flowers yellowish-white tinged with 
purple; stem $1^{\circ}-2^{\circ}$ high from long and slender roots; 'flowers showy.

** Flowers in long-peduncled racemes opposite the leaves; vexillum pubescent externally.

T. spicata, Torr. and Gray. Hirsute or villous with rusty hairs; stems simple or diffusely branched; leaves scattered, short-petioled; leaflets $9-15$, oval or cuneate oblong, rounded and strongly mucronate at the apex, smoothish above; racemes $2-3$ times as long as the leaves, $6-10$ flowered; lobes of the calyx linear-subulate; flowers large, white and purple; stems $1^{\circ}-2^{\circ}$ long.

T. Hispidula, Pursh. Hoary-pubescent or smoothish; stems slender, terete, erect or procumbent; petiole shorter than the lowest leaflets; leuflets $11-15$, small ( $4^{\prime \prime}-6^{\prime \prime}$ long), oblong, acute or obtuse, often smooth abore; peduncles slender, terete, commonly longer than the leaves, 2 -4-flowered; flowers small, purple; stems $6^{\prime}-18^{\prime}$ long.

\section{INDIGOFERA, L. INDIGo.}

Calyx 5-cieft; vexillum roundish; keel with a subulate spur on each side, often elastically reflexed; strmens diadelphous (9 and 1); legume 1-many-seeded; seeds usually truncated at each end, often separated by membranaceous partitions.-Herbs, with unequally pinnate leaves, and white, brownish, or purplish axillary flowers; legumes drooping.

\section{* Racemes longer than the leaves.}

I. Caroliniana, Walt. Smoothish; stem erect, tall, branching; lenflets 10-15, obovate or oblong; racemes many-flowered; calyy-teeth short, acute; flowers yellowishbrown; legume oblong, veiny, 2 -seeded; stem $3^{\circ}-5^{\circ}$ high ; flowers small ; legume $4^{\prime \prime}-5^{\prime \prime}$ long.

I. Leptosepala, Nutt. Rough hairy ; stem decumbent; 
leaflets 7-9, obovate-oblong or cuneate; racemes 6-15-flowered; caly $x$-teeth slender, subulate; flowers pale scarlet; legume linear, even, $6-9$-seeded; stem $2^{\circ}-3^{\circ}$ long ; legume $1 \frac{1}{2}$ long, straight.

\section{GLOTTIDIUM, Desv.}

Calyx campanulate, obliquely truncate, 5-toothed; vexillum short, reniform; stamens diadelphous (9 and 1); style short, incurred at the apex; stigma acute; legume oblong stipitate, compressed; the membranaceous endocarp at length separating from the coriaceous epicarp, and enclosing the two oblong seeds.-A tall, smooth-branching annual, with abruptly pinnate leaves, and small yellow flowers in axillary often compound racemes.

G. Floridanum, DC. Stem $2^{\circ}-8^{\circ}$ high; leaflets numerous, oblong linear; legume $1^{\prime}-2^{\prime}$ long.

\section{SESBANIA.}

Calyx 2-bracted, campanulate, equally 5-toothed; vexillum roundish; keel obtuse; stamens diadelphous (9 and 1 ), the tube toothed at the base; legume slender, elongated, knotted.-Herbs or shrubs; leaves abruptly pinnate ; leaflets numerous; flowers yellowish or reddish, in axillary racemes.

S. MACROCARPA. Leaflets oblong-linear, obtuse, mucronate; racemes shorter than the leaves, 1-4-flowered; legume curved, compressed, 4-sided, many-seeded; stems $5^{\circ}-12^{\circ}$ high ; legume $8^{\prime}-12^{\prime}$. long, pendulous; flowers red and yellow, dotted with purple.

\section{ASTRAgALUS, L. Milk Vetch.}

Calyx 5-toothed; the two upper teeth separated; vexillum as long as the wings and obtuse keel; stamens 10, 
diadelphous; legume commonly turgid, few-many-seeded, usually partly or completely 2 -celled by the introversion of one or both of the sutures.-Herbs, with unequally pinnate leaves, and axillary spiked or racemose flowers.

\section{* Legume partly or completely 2-celled by introversion of the dorsal suture.}

A. obcordatus, Ell. Smoothish ; stems prostrate; leaflets small, 17-25, obcordate; peduncles as long as the leaves, loosely 8-15-flowered; legumes crescent-shaped, compressed, veiny, partly 2-celled; leaflets $3^{\prime \prime}-4^{\prime \prime}$ long; flowers pale purple; perennial.

\section{** Legume ovate, thick and fleshy.}

A. TRICHOCAlyx, G. and T. Stems numerous, decumbent, somewhat pilose with appressed hairs; stipules lanceolate; leaflets 10-16 pairs, elliptical-oblong, obtuse ; pectuncles about the length of the leares; racemes short and crowded; bracts a little longer than the pedicels; calyx dens sly villous with mostly whitish hairs; the teeth subulate, scircely half the length of the tube; legume thick and somewhat fleshy, glabrous, finely wrinkled transversely. -Dr. Leavenworth.

"Nuttall says this species is remarkable for its succulent legumes, which are filled with a sweetish and rather agreedble juice, so that they were frequently collected by the party with which he traveled, as an article of food."-Gray and Torrey.

***: Legumes curved.

A. Distortus, Gray and Torrey. Pubescent, prostrate ; leaflets 8-12 pairs, oblong or ovate, sometimes elliptical, usually emarginate; peduncles longer than the leaves; spike roundish or oblong, 10-20-flowered, loose; calyx clothed with blackish hairs; the teeth broad acuminate, 
half the length of tube; legumes oblong, somewhat inflated; abruptly curved in the middle, sessile.-Drummond.

**** Stipules cohering neither with each other nor with the petiole; flowers in dense spikes or heads ; legumes straight; root annual.

A. Leptocarpus, Gray and Torrey. Stem about a foot long, with somewhat spreading branches; lenflets $4^{\prime \prime}-5^{\prime \prime}$ long, a little hairy on the midrib beneath, glabrous above; flowers purplish blue, $\frac{1^{\prime}}{2}$ long; calyx clothed with appressed dark-colored hairs; vexillum broadly ovate; keel broad obtuse, with a narrow furrow along the back.Drummond.

A. Reflexus. Stem $1^{\circ}$ or more in height, slender, branched; leaflets $\frac{1^{\prime}}{2}$ long, usually truncate and emarginate; flowers $\frac{1}{3}^{\prime}$ long, purplish ; vexillum narrow, elongated; keel obtusely roseate, much longer than the wings; legumes $\frac{1^{\prime}}{3}$ long, somewhat triangular. (Gray and Torrey.)-Drummond.

Slipules cohering neither with each other nor the petiole; flowers purple or white; legumes curved; root annual.

A. Trichocarpus, Gray and Torrey. Stem $18^{\circ}-20^{\circ}$ high, branched from the base; leaflets $4^{\prime \prime}-5^{\prime \prime}$ long, pubescent with appressed hairs beneath; flowers $\frac{1^{\prime}}{3}$ long, blue; ovary glabrous ; legume $8^{\prime \prime}-10^{\prime \prime}$ long and $1 \frac{1^{\prime}}{2}$ wide, slightly curver toward the base, with a short abrupt point; seeds somewhat truncate.-Drummond.

\section{VICIA, Tourn. Vetch or TARE.}

Calyx tubular, 5-cleft, the two upper teeth usually shorter; style filiform, hairy at the apex or on the side facing the keel; legume 2-many-seeded. 2-valved; seeds orbicular; cotyledons thick.-Slender climbing herbs; leaves pinnate; the petiole terminating in a tendril; stipules mostly semisagittate; flowers axillary. 
* Peduncles shorter than the leaves; 1-2-flowered.

V. sativa, L. (Vetch or Tare.) Pubescent; stem simple; leaflets $10-12$, varying from obovate-oblong to linear, emarginate; flowers by pairs, nearly sessile, pale purple; legume linear; several-seeded, annual; corolla $\frac{1^{\prime}}{2}$ long; stem $1^{\circ}-2^{\circ}$ long.

V. Micrantha, Nutt. Smooth; leaflets 4-6, linear, obtuse or barely acute; peduncles 1-2-flowered; flowers minute, pale blue; legume sabre-shaped, 4-10-seeded; stem $2^{\circ}-3^{\circ}$ long; seeds black, annual.

V. Caroliniana, Walt. Smoothish; leaflets 8-12, linear or linear-oblong, obtuse or barely acute; stipules small, peduncles many-flowered; calyx-teeth shorter than the tube; flowers nearly white, the keel tipped with blue; legume oblong, several-seeded, perennial; stems $3^{\circ}-4^{\circ}$ long, branching; flowers 4 "- 6 " long.

V. Ludoviciana. Stem $2^{\circ}-3^{\circ}$ long, rather stout, strongly angled, climbing; leaflets $6^{\prime}-8^{\prime}$ long, $2^{\prime}$ wide, commonly emarginate; stipules very small; flowers blue, often 2 or 6 on a peduncle; calyx hairy; keel marked with a deep-blue spot at the summit; legumes $\frac{3}{4}^{\circ}$ long and 3 ' wide. (Gray and Torrey.) -Dr. Leavenworth.

V. Micrantha. Stem slender, $2^{\circ}-3^{\circ}$ long, annual; leaflets $1^{\prime}$ long, in the lower leaves truncate and often toothed at summit; flowers small, pale blue, the peduncles $\frac{1}{3}$ the length of the leaves; style short; legumes 1' long, slightly pubescent; seeds blackish, compressed; the hilum extending $\frac{2}{3}$ of its circumference.-Dr. Leavenworth.

\section{LATHYRUS, L.}

Style flattened, bearded on the side facing the vexillum; otherwise as in Vicia. 
L. Pusillus. Leaflets 2 , linear-lanceolate, acute ; stipules sagittate; peduncles elongated, 1-2-flowered; teeth of the calyx subulate-setaceous, nearly equal ; legume long, 10-15-seeded.-A small vine; flowers purple; annual.Leavenworth.

\section{ZORNIA.}

Calyx 2-lipped, the upper emarginate, the lower 3-cleft ; corolla inserted into the base of the calyx ; stamens monadelphous, alternately shorter; anthers alternately oblong and globose; legume compressed with 2-5 roundish hispid joints.-Herbs ; leaves palmately 2-4-foliolate ; stipules sagittate; flowers yellow, in axillary large-bracted racemes.

Z. tetraphylla, Michx. Perennial; smooth or downy; leaflets 4 , lanceolate, or oblong-obovate; racemes 3-9-flowered, much longer than the leaves; the flowers distant and almost concealed by the large ovate bracts; legume hispid, 3-4-jointed; stem $2^{\circ}$ long, prostrate.

\section{STYLOSANTHES, Swartz.}

Flowers of two kinds: one kind perfect, but sterile; the other destitute of calyx, corolla, and stamens, and fertile. Calyx 2-bracted, 2-lipped, 5-cleft, the tube long and slender ; corolla inserted on the throat of the calyx; keel entire at the apex; stamens monadelphous, with the alternate anthers linear and ovate; style of the fertile flower hooked; legume veiny, 1-2 jointed, the lower joint empty.-Low herbs; leaves trifoliolate; stipules united with the petioles; flowers in a short and dense terminal spike.

S. Elation, Swartz. Stem $6{ }^{\prime}-12^{\prime}$ high ; pubescent, erect; leaflets lanceolate, rigid, strongly veined; stipules sheathing; spike few-flowered; bracts bristly; flowers, yellow. 


\section{LESPEDEZA. Bush Clover.}

Calyx 2-bracted, 5-cleft; the teeth subulate; corolla inserted on the base of the calyx; stamens diadelphous (9 and 1); anthers alike; legume small, lenticular, indehiscent, 1-seeded.-Perennial herbs, with trifoliolate leaves, and small axillary racemes or spikes.

* Flowers of two kinds, viz., perfect, but mostly sterile, borne in spikes or racemes, and fertile, but destitute of corolla and stamens; the latter commonly in sessile clusters; corolla purple, longer than the calyx.

L. REPENS, Torrey and Gray. Stem slender, prostrate; leaflets small, oval, mostly emarginate, the petiole very short, or as long as the lateral leaflets; racemes fewflowered, on filiform penduncles much longer than the leaves; legume roundish; plant $1^{\circ}-2^{\circ}$ long, smooth or tomentose.

L. VIolaceA, Pers. Stem erect, spreading; leaflets varying from elliptical to linear; pubescent with appressed hairs beneath; fertile flowers in axillary clusters; legume ovate, smooth, or with scattered appressed hairs much longer than the calyx.

L. Steuvi, Nutt. Stem erect, branching, softly pubescent; leaflets oval or roundish, tomentose or silky on both surfaces or only beneath, longer than the petiole; $r a$ comes axillary, mostly longer than the leaves; flowers nearly all perfect; legume longer than the calyx, ovate, villous.

** Flowers all perfect and fertile; corolla as long as the calyx, yellowish-white, the vexillum spotted with purple; legume included in the calyx.

L. HIRTA. Stem erect, pubescent or villous; leaflets oval or roundish, longer than the petiole, pubescent beneath or on both sides; spikes dense on peduncles longer than the leaves; calyx-teeth linear-lanceolate, as long as the ovate pubescent legume. Stem $2^{\circ}-4^{\circ}$ high. 
L. Capitata, Michx. Stem mostly simple, softly pubescent, erect, $2^{\circ}-4^{\circ}$ high; leaves short-petioled, leciflets varying from oblong to linear, silky on both sides, or only beneath; calyx hairy, longer than the oval villous legume.

\section{DESMODIUM, DC. Hedysarum, Ell.}

Flowers all perfect; calyx bilabiate; the upper lip emarginate or entire, the lower 3-cleft; corolla inserted on the base of the calyx ; stamens diadelphous (9 and 1) or more or less monadelphous; legume flattened, 2-6-jointed.-Chiefly perennial branching herbs; leaves trifoliolate, petioled, stipulate; the leaflets petioled and stipellate; flowers small, purple or whitish, in terminal racemes or panicles; legumes hispid with hooked hairs.

* Stamens monadelphous below; legumes conspicuously stipitate, 2-4-jointed, the joints half obovate, concave on the back.

D. Nudiflorum, DC. Stem smooth, short, leafy at the summit, panicles ascending from the base of the stem, naked, or with one or two leaves near the base, much longer than the stem; leaves long-petioled, smooth; leaflets ovate, acute or obtuse, white beneath; legume long stipitate; racemes simple or compound, on peduncles $2^{\circ}-3^{\circ}$ high.

** Stamens diadelphous; legume sessile or short stipitate; stipules large. acuminate, persistent; legume 3-6-jointed, the joints convex on the upper suture, rounded on the lower one.

D. Rotundifolium, DC. Stem long, trailing, hairy; leaflets orbicular pubescent; lobes of the calyx longer than the tube; legume with 3-4 rather large obtusely 3 -angled joints. Stem $2^{\circ}-3^{\circ}$ high.

D. Paniculatum, DC. Stem slender, mostly smooth, with long and virgate branches; leaflets varying from ob- 
long to linear-lanceolate, obtuse, smooth or slightly pubescent; legume 3-5-jointed, the joints triangular. Stem $2^{\circ}-4^{\circ}$ high.

*** Stipules subulate, deciduous; legume 2-3-jointed, the joints small, oval, or obliquely obovate; flowers small.

D. Marilandicum, Boott. Stem erect, smooth, mostly simple; leaflets small, ovate or roundish, obtuse, smooth, pale beneath, commonly shorter than the petiole; panicle rough; legume mostly 2 -jointed. Stem $2^{\circ}-3^{\circ}$ high.

D. CILIARE, DC. Very much like D. Marilandicum, but the stem and leaves rough-hairy, and the leaflets longer than the petiole.

D. SEssilifolium, Gray and Torrey. Stem erect, rather stout, tomentose-pubescent; leaves sessile; leaflets linear or oblong, rather coriaceous, obtuse at each end, reticulated, scabrous above, tomentose with soft pubescence beneath; stipules subulate, somewhat persistent; racemes paniculate, much elongated; pedicels very short; bracts minute; upper lip of the calyx slightly emarginate; the lower tooth a little longer than the triangular lateral ones; legumes small, nearly sessile, of $2-3$ somewhat semi-orbicular hispid joints.

D. PUBENs. Stem puberulent, $1^{\circ}-2^{\circ}$ high ; leaves oblonglanceolate, rather rigid, pubescent; leaflets $1^{\prime}-3^{\prime}$ high, long, minutely pubescent; flowers purple; legume rather large, the joints oblong, angled on the back.-Gray and Torrey.

\section{RHYNCHOSIA, DC.}

Calyx 2-lipped, with the upper lip 2-cleft and the lower 8-parted, or nearly equally 4-parted; stamens diadelphous (9 and 1); style smooth, subulate; legume oblong or scymetar-shaped, mostly 1-2-seeded; seeds carunculate.Erect or twining herbs or shrubs, with 1- or 3-foliolate 
mostly softly pubescent and resinous-dotted leaves and axillary yellow flowers.

* Slems twining, or low and erect; flowers in axillary racemes.

+ Calyx somewhat 2-lipped, 4-cleft; the teeth subulate; shorter than the corolla, the lowest one longest; stems twining.

R. MIriss, DC. Tomentose; leaflets small, roundish or broadly rhombic, barely acute, dotted beneath; stipules subulate; racemes filiform, much longer than the leares, loosely 6-12-flowered; flowers minute, reflexed; legume scymetar-shaped. Leaflets $\frac{1^{\prime}}{2}-1^{\prime}$ long.

R. Parvifolia, DC. Velvety throughout; leaflets ovate, oblong, or obovate-oblong, obtuse, or the upper ones acute, hoary and strongly reticulate beneath, longer than the petiole; stipules small, lanceolate; racemes equaling or longer than the leaves, slender, loosely 3-5-flowered; lowest tooth of the calyx nearly twice the length of the others; legume oblong, obtuse, clothed with soft down and longer hairs intermixed, $2-3$-seeded. Stem $1^{\circ}-2^{\circ}$ long; leaflets $1^{\prime}$ long.

R. CARIB $₫ A$, DC. Velvety throughout; stem prostrate or twining; leaflets thin, ovate, acute or slightly acuminate; stipules ovate; racemes slender, shorter than the leaves, loosely $3-\tilde{\partial}$-flowered; teeth of the calyx short, nearly equal; legume scymetar-shaped, acute. Stem $2^{\circ}-3^{\circ}$ long; leaflets $1 \frac{1^{\prime}}{2}-2^{\prime}$ long, tapering at the base.

t+ Calyx 4-parted, nearly as long as the corolla, the lobes linear or lanceolate, nearly equal; stems twining or erect.

R. MENispermoidea, DC. Stems sereral from one root, prostrate or twining, downy; stipules ovate-lanceolate; leaflets solitary, reniform, tomentose; peduncles rarely as long as the petiole, with few crowded flowers at the summit; calyx deeply parted, the lanceolate acute or acuminate lobes nearly equal; legume oblong, acute, tomentose, 2 -seeded. Stem $2^{\circ}-3^{\circ}$ long; leaflets $1^{\prime}-2^{\prime}$ in diameter. 
R. romentosa, Torr. and Gray. Leaflets 1-3, roundish or ovate; racemes dense-flowered; legume oblong. Red River.-Torrey.

** Stem tall, erect, with long virgate branches; flowers solitary or by pairs, in the axils of the upper leaves; calyx deeply 4-cleft, shorter than the corolla.

R. GALACTOIDES. Stem bushy, purplish, closely pubescent; leaves very small, almost sessile; leaflets 3 , oval or obovate, rigid, reticulate, pubescent; flowers mostly longer than the leaves, yellow, the vexillum reddish externally; legume oblong, 2-seeded. Stem $2^{\circ}-4^{\circ}$ high ; leaflets $3^{\prime \prime}-9^{\prime \prime}$ long; legume $\frac{3^{\prime}}{4}$ long.

R. Texana. Minutely velvety-pubescent; stems diffuse, much branched from the base; stipules setaceous, minute; leaflets rhombic-ovate or ovate-lanceolate, obtuse, mucronulate, rounded or slightly cordate at the base, pubescent and dotted, with minute resinous glands beneath, the upper surface reticulated and nearly glabrous; peduncles axillary, mostly 1-flowered, much shorter than the petioles; teeth of the calyx attenuate-subulate, rather shorter than the corolla; legumes pubescent, oblong, narrowed at the base, nearly straight.-Drummond.

\section{APIOS, Boerh.}

Calyx somewhat 2-lipped, the lateral teeth nearly obsolete, the lowest one longest; vexillum very broad, reflexed; the keel at length twisted; stamens diadelphous (9 and 1$)$; legume nearly terete, many-seeded.-A smooth, perennial, twining herb, with unequally pinnate leaves, and brownish-purple flowers in dense axillary racemes.

A. TUberosa, Mœnch. Stem twining, high; leaflets 5-\%, ovate or ovate-lanceolate; racemes often by pairs, shorter than the leaves; root bearing small edible tubers; seeds black, separated by loose cellular tissue. 


\section{PHASEOLUS, L. KidNey BeaN.}

Caly $x$ 5-toothed, the 2 upper teeth more or less united; keel of the corolla spirally coiled or twisted; stamens diadelphous; legune linear or falcate, few-many-seeded.Twining or prostrate herbs, with trifoliolate stipellate leaves; flowers commonly large, racemed, or clustered at the summit of the axillary peduncles.

\section{* Flonvers scattered in long racemes; legumes scymetar-shaped.}

P. PEREnnis, Walt. Stem climbing, pubescent; leaflets ovate, acute, entire, membranaceous ; racemes often branching, twice as long as the leares. Perennial; flowers purple; leaflets $2^{\prime}-4^{\prime}$ long.

** Flowers clustered at the summit of the peduncle; legumes linear, nearly terete; seed scurfy.

P. HeLvolts, L. Stems prostrate; leaflets varying from ovate to oblong-linear; smooth or hairy; peduncles 3-6 times as long as the leaves; corolla purple.

\section{VIGNA, Savi.}

Calyx 4-toothed, the upper tooth broader, entire or 2-cleft; vexillum depressed-orbicular, with thickened knobs near the base; keel not twisted; stamens included in the keel, diadelphous, and with the style bent upward; style hairy above, appendaged below the stigma; legume nearly terete, somewhat torulose, the seeds separated by cellular tissue.-Twining herbs, with trifoliolate leaves and racemose ; axillary flowers.

V. GLABra, Sari. Annual, hirsute; leaflets orate or orate-lanceolate; racemes on stout peduncles longer than the leaves; flowers yellow, crowded. 


\section{ERYTHRINA, L.}

Calyx tubular-campanulate, truncate, toothless; vexillum narrow, straight, elongated; keel and wings very small; stamens and style partly exserted; legume stipitate, torulose, partly dehiscent.-Trees, shrubs, or rarely lierbs, often armed with prickles; leaves trifoliolate, the terminal leaflet loug-petiolulate; flowers showy, scarlet, in long racemes.

E. HerbaceA, L. Stems herbaceous, several from a very thick root, prickly, the flowering ones mostly leafless; leaves long-petioled; leaflets ovate or somewhat hastate; vexillum lanceolate, folded; seeds scarlet. Stems $2^{\circ}-4^{\circ}$ high; racemes $1^{\circ}-2^{\circ}$ long; flowers $2^{\prime}$ long; legume opening by one suture opposite the seeds.

\section{CLITORIA, L.}

Calyx tubular, 5-toothed; vexillum very large, spurless on the back, obovate, emarginate; keel shorter than the wings; stamens monadelphous below ; style curved, hairy; legume stipitate, linear-oblong, torulose, veinless.-Perennial herbs, with trifoliolate leaves, and very large purple flowers on axillary peduncles; bracts opposite.

C. Mariana, L. Smooth; stem erect or twining; leaflets ovate-oblong, pale beneath; peduncles shorter than the leaves, $1-3$-flowered; legume $3-4$-seeded. Stem $1^{\circ}-3^{\circ}$ long; flower's 2 'long, pale purple; bracts shorter than the calyx ; legume $1 \frac{1}{2}^{\prime}-2^{\prime}$ long.

\section{CENTROSEMA, DC.}

Calyx short, 5-cleft, the two upper lobes more or less united; vexillum very large, spurred on the back, orbicular, emarginate; keel nearly as long as wings; stamens 
monadelphous below; style smooth; legume nearly sessile, linear, compressed, the sutures thickened, the valves lined with an intramarginal vein.-Twining herbs, with trifoliolate leaves, and very large purple flowers on short axillary peduncles; bracts opposite.

C. Virginiana, Benth. Rough, with short hooked pubescence; stem very slender, much branched; leaflets oblong or linear-oblong, strongly reticulate; peduncles single or by pairs, 1-4-flowered; calyx-teeth subulate, barely exceeding the ovate bracts; vexillum adhesive; legume slender, elongated, curved, many-seeded; flowers $1 \frac{1}{2}$ long; legume $4^{\prime}-6^{\prime}$ long.

\section{AMPHICARPAA, Ell.}

Flowers of two kinds: those on the upper racemes perfect, but mostly abortive; those near the base of the stem or on the prostrate branches apetalous, but fruitful. Calyx tubular, 4-5-toothed; vexillum obovate and partly enclosing the wings and the keel ; stamens diadelphous, or in the fertile flowers distinct or wanting; fertile legume obovate, fleshy, 1-2-seeded.-Twining annual or perennial herbs, with trifoliolate leaves; flowers white or purplish, in simple or compound axillary racemes.

A. MoNorca, Nutt. Hairy; stems much branched; leaflets rhombic-ovate; sterile racemes single or by pairs, often compound, nodding; bracts striate; calyx-teeth short, triangular; fertile legumes hairy.

\section{SALACTIA, P. Browne.}

Calyx 4-parted, the upper one broadest; vexillum oblong. or ovate, reflexed in flower; stamens diadelphous; legume more or less compressed, 2-valved, few-many-seeded.-Prostrate or twining, rarely erect, perennial herbs, with chiefly 
trifoliolate leaves, and mostly small purplish or white flowers in axillary racemes; bracts alternate and deciduous; leaflets stipellate.

* Leaves trifoliolate, with the leaftets stalked; stems twining or prostrate.

G. MOLLIS, Michx. Villous and somewhat hoary; stems mostly prostrate and simple; leaflets oval or oblong, obtuse or emarginate at both ends or the upper ones acute; racemes single, about twice the length of the leaves, the short-pediceled flowers approximate near the summit of the stout peduncle, acute in bud; calyx like the straight 10 -seeded compressed legume, very villous and hoary. Stem $2^{\circ}-3^{\circ}$ long ; leaflets $1^{\prime}$ long; corolla reddish purple, onethird longer than the acute calyx-lobes.

G. Floridana, Torr. and Gray. Hoary pubescent; stem prostrate; leaflets oval or oblong, rarely acute, reticulate; racemes simple or branched, often by pairs, many-flowered, rarely longer than the leaves; flowers large, approximate; legume flat, 10-seeded; leaflets acute or emarginate, the few flowers almost sessile in axillary clusters. Stem $2^{\circ}-4^{\circ}$ long ; leaflets $1^{\prime}-2^{\prime}$ long; flowers largest of all.

G. GLABeLla, Michx. Stems prostrate, minutely pubescent; leaflets rather rigid, on short petioles, oblong, rarely acute, smooth and shining above, slightly hairy beneath; racemes seldom as long as the leaves, 3-6-flowered; style elongated; legume slightly falcate, at length smoothish, 4-6-seeded. Stems $2^{\circ}-3^{\circ}$ long; leaflets $1^{\prime}$ long; flowers large, reddish purple.

\section{DOLICHOS, L.}

Calyx campanulate, somewhat 2-lipped, the upper lip of two more or less united teeth, the lower 3-cleft; vexillum callous near the base; keel more or less falcate; stamens diadelphous, the free stamen spurred at the base; stylc bearded; legume flattened; seeds compressed, with a small 
and oval hilum.--Twining herbs, with trifoliolate leaves and axillary racemose flowers.

D. Multiflonts, Torr. and Gray. Pubescent; leaflets thin, large orbicular, abruptly acute; racemes shorter than the leaves, many and densely flowered at the summit of the stout peduncle; upper lip of the calyx entire; keel nearly straight; legume 4-5-seeded. Leaflets $3^{\prime}-6^{\prime}$ in diameter; stem $5^{\circ}-10^{\circ}$ long; flowers purple; perennial.

\section{BAPTISIA, Vent.}

Calyx campanulate, 4-cleft; the upper lobe broader and mostly emarginate; vexillum roundish, with the sides reflexed; wings and keel straight; stamens 10, distinct, shorter than the wings, deciduous; legume stipitate, oval or oblong, inflated, few-seeded, pointed with the persistent style.-Erect, widely branching, perennial herbs; leaves simple or palmately trifoliolate, withering-persistent; stipules deciduous or persistent, rarely wanting; flowers showy in terminal racemes, rarely axillary and solitary.

B. Perfoliata, Brown. Leaves perfoliate, oval, or orbicular, glaucous; stipules none; flowers axillary, solitary; legume small, ovate, coriaceous ; stem $2^{\circ}$ high ; leaves $2^{\prime}-3^{\prime}$ long; flowers small, yellow; vexillum orbicular, emarginate; ovary and style smooth.

* Leaves trifoliolate, pellate.

+ Flowers yellow.

B. Lanceolata, Ell. Pubescent when young, at length smoothish; leaves on very short petioles, the upper ones nearly sessile; leaflets varying from lanceolate to obovate, thick, obtuse, tapering at the base; stipules and bracts small and caducous; flowers large, solitary in the axils, and in short terminal racemes, short-pediceled; orary villous; legume ovate or globose, coriaceous, slender-pointed. Stem $2^{\circ}$ high; leaflets $1^{\prime}-2^{\prime}$ long. 
B. villosa, Ell. Pubescent; leaves short-petioled; leaflets oblong and obovate, tapering at the base, becoming smooth above; lower stipules and lanceolate bracts persistent; racemes many-flowered, declining; ovary villous; legume smoothish, coriaceous, oblong, strongly beaked; stem $2^{\circ}$ high. Leaves and flowers larger than B. lanceolata.

B. SPHжROCARPA, Nutt. Glabrous; leaves nearly sessile; leaflets obovate-oblong, obtuse, minutely pubescent when young; stipules and bracts minute or almost none; stem $2^{\circ}-3^{\circ}$ high, many from the same roots, with erect branches; flowers large, usually in a long strict spike, deep yellow; teeth of calyx short, very acute; the upper ones obtuse; ovary glabrous; stipe short. Near Fort Townsend.-Dr. Leavenworth.

\section{t+ Flowers white.}

B. Leucantha, Nutt., Torr. and Gray. Smooth and glaucous; branches spreading; leaves short-petioled; leaflets oblong and obovate, obtuse; stipules lanceolate, as long as the petioles, deciduous; racemes central and terminating the branches, long, many-flowered; ovary smooth; legume large, oblong, much inflated, long-stipitate. Legume $1 \frac{1}{2}^{\prime}$ long.

B. LEUCOPH $\approx$ A, Nutt. Hairy or smoothish ; stem stout, angled; leaves short-petioled; leaflets varying from oblanceolate to obovate, rigid, reticulate, soon smooth above; stipules and bracts leafy, ovate-lanceolate, persistent; racemes stout, declined, 1-sided; flowers large, yellowishwhite, on long and slender erect pedicels; ovary villous; legume ovoid, long-pointed. Stem low, with widely spreading branches; racemes $4^{\prime}-12^{\prime}$ long; flowers $1^{\prime}$ long, the vexillum spotted with brown. 


\section{SOPHORA, L.}

Calyx campanulate, obliquely truncated or 5-toothed; stamens 10, free or cohering at the base; style smooth; legume moniliform, wingless, many-seeded, indehiscent; seeds subglobose.

S. SPEciosa, Benth. Leaves evergreen, smooth, pinnate; leaflets $3-5$-paired, ovate, obtuse, or subacuminate, shining above, paler beneath; flowers racemose, blue, or yellowish-white tinged with blue, very fragrant; pods large, constricted, tough, covered with a light gray pubescence; seeds bean-like, red. Flowers in February and March. Fruit-pods adherent during the summer.-A small tree or shrub, on hills in Western Texas; Mount Bonnell, Austin; also on the shores of Matagorda Bay, where it is sometimes 30 feet high. Very ornamental.

BRASILETTO FAMILY. Sub-order II., CÆSALPINIEA.

\section{CIRCIS. RED-BUD.}

Calyx campanulate, 5-toothed; petals all distinct, the vexillum shorter than the wings; stamens 10, distinct; legume oblong, compressed, many-seeded, the upper suture winged.-Trees, with broadly-cordate, simple stipulate leaves, and reddish-purple clustered flowers appearing before the leaves.

C. Canadensis, L. Flowers very numerous from lateral buds. - Tree, $15^{\circ}-20^{\circ}$ high.

\section{HOFFMANSEGGIA.}

Sepals 5, united into a short obconic base, somewhat equal; petals 5, obovate, on short claws, somewhat un- 
equal, spreading, the upper one concave, one or more of them often glandular at the base; stamens 10 , filaments mostly hairy or glandular, and thickened or dilated toward the base, nearly equal ; anther's oval, nearly uniform; style as long as the stamens, somewhat thickened at the apex; legume oblong or linear, often falcate, compressed, dry, 2-valved, 2-seeded.-Low perennial herbs or suffrutescent plants, often dotted with black glands; leaves abruptly or unequally bipinnate; racemes opposite the leaves; flowers yellow; glands either sessile or pedicellate.

H. Drummondir. Glabrous, with a few scattered pedicellate glands; stem diffuse, suffrutescent; pinnæ 3 (digitate), abruptly 8-12 foliolate; leaflets elliptical, obtuse or retuse; legumes lunate-ovate, glabrous; plant low and much branched, with a very few subulate scarcely capitate glands on the lower side of the petioles; leaves small, upper petal with a reddish spot. In some flowers we have not observed the stipules; ovules about 5 -seeded. In some flowers the alternate filaments are almost fiilform and nearly glabrous, while those opposite the sepals are thickened and clothed with glandular hairs.-Torrey and Gray.

H. CaUdata, Gray. Shrubby; leaves bipinnate, pinnæ 2-3-paired; leaflets small, 20-30-paired, smooth, round or obliquely subcordate, veins glandular; stipules and bracts caducous; leaflets about two lines in length, thickish, obscurely mucronulate, subsessile, oblique. The terminal pinnæ are sometimes 2 and 3 inches in length, and bear many pairs of leaflets, while the lateral ones are scarcely an inch long; raceme sparsely 6-9-flowered; legume nearly 2 inches long and $\frac{2}{3}$ of an inch wide. Sandy soil, Western Texas.

H. JAMESII. Canescently pubescent; stipules subulate, entire, pinnæ 5 ( 2 pairs and a terminal one), abruptly 
10-16-foliolate; legume broadly oblong, somewhat lunate; calyx, petals, and legumes sprinkled with sessile black glands.-A low, much-branching, slirubby plant; leaves with the 3 upper pinnæ arising from the same point; leaflets oval, obtuse at both ends, nearly glabrous above; racemes elongated, opposite the leares; flowers nodding or reflexed, rather large; calyx a little oblique, the 4 upper segnents lanceolate, acute, all membranaceous ; upper petal marked with reddish spots; style subulate, dilated above, and somewhat gibbous at the apex; the stigma turned to the upper side and somewhat hooded, the membranaceous upper portion of the style being slit for some distance on that side; legumes about an inch long, scabrous, sprinkled with glands, flat, 2-3-seeded; seeds oval, compressed.

\section{CASSIA, L. SENNa.}

Calyx of 5 nearly distinct sepals; petals 5, unequal; stamens 5-10; anthers mostly of different forms, opening by two terminal pores; legume many-seeded; seeds often separated by cross partitions.-Herbs or shrubs; leaves abruptly pinnate; flower's yellow.

* Stamens 10, unequal; part of the anther's abortive; sepals obtuse; stipules deciduous.

C. occidentalis, L. Annual, smoothish; stem stont, branching; leaflets about 10 , ovate or orate-lanceolate, acute; petiole with a globular gland at the base; racemes 2-4-flowered, the upper ones crowded. - Stem $1^{\circ}-5^{\circ}$ high; legume linear erect, compressed. slightly eurved, $3^{\prime}-4^{\prime}$ long.

C. obtusifolia, L. Annual, roughish; stem slender; leaflets 6 , cuneate-obovate, with a tooth-like gland between the lowest pair; flowers by pairs; legume narrow- 
linear, 4-angled, recurved. Stem $1^{\circ}-4^{\circ}$ high; legume $6^{\prime}-10^{\prime}$ long.

C. Marilandica, L. Perennial, smoothish; leciflets 12-18, oblong, acute; petiole with a club-shaped gland near the base; racemes several-flowered, the upper ones crowded, forming a compact panicle ; legume linear, slightly curved. Stem $3^{\circ}-4^{\circ}$ high; legume $3^{\prime}-4^{\prime}$ long.

C. BIfLORA, L. Shrubby; leaflets 4-10, oblong, narrowed at the base, mucronate, with an obovoid gland between the lowest pair; racemes 2-4-flowered, often by pairs, slender, shorter than the leares; fertile anthers 5; legume linear, flat, straight or somewhat falcate, smooth, many-seeded. Leaflets $1^{\prime}$ long; legume $3^{\prime}$ long, $2^{\prime}$ wide.

** Stamens 5-10: anthers all perfect ; sepals acute ; stipules persistent.

C. CHAM hairy; leaflets small, numerous, linear-oblong, mucronate; stipules acuminate, nerved; flowers borne above the axils, large, clustered, on long pedicels; anthers 10 ; styles slender; legume linear, nearly straight; part of the petals often purple at the base. Stem $1^{\circ}-1 \frac{1}{2}^{\circ}$ high.

\section{HOOPESIA, Buckley.}

Calyx ebracteate, deeply 5-cleft or 5-parted; segments lanceolate, rather unequal, linear-acute; petals 5, subpapilionaceous, long-clawed; stamens 10, free; filaments at the base lanuginose; stipe many-oruled; style dilated at the base, filiform, a little longer than the filaments; stigma small; legume broad lanceolate, slightly compressed, $\mathrm{ob}_{\mathrm{e}}$ tuse, 8-10 seeded; seed reniform. If dehiscent, it is late in becoming so.

H. ARBOREA, Buckley. Leaves bipinnate, 1-3-paired; 
leaflets opposite, obovate, obtuse, 3-6-paired; flowers axillary, subsolitary, shortly pedunculate.-A tree, with spinose branches, 20-25 feet high and 8-12 inches in diameter; bark of trunk and branches smooth and of a pale green; branches numerous, forming a dense shade; legume 4 inches long, 10 lines wide, and 8 lines thick; seeds large, divided by septa; spines axillary, double, stipular, subulate, and small; flowers yellow, with reddish-brown lines near the base of the limb of the petals. Insects destroyed the embryo in our fruiting specimens. Grows on hills near the Gulf, about $1 \frac{1}{2}$ miles below Corpus Christi, Texas. Dedicated to Joshua Hoopes, of West Chester, Pennsylvania, a zealous botanist, who has long studied and admired trees.

\section{GLEDITSCHIA, L. Honey Locust.}

Flowers polygamous; sepals 3-5, united at the base, spreading; petals as many, or less by the union of the 2 lower ones; stamens $3-5$, distinct, inserted with the petal on the base of the calyx; legume stipitate, flat, 1-many-seeded; seeds compressed.-Thorny trees; leaves abruptly 1-2-pinnate, with oblong serrate leaflets; flowers small, greenish, in short spikes.

G. TRIACANTHU's, L. Leaflets lanceolate-oblong; thornes mostly compound ; legume very long, many-seeded, pulpy within.-A large tree; legume $12^{\prime}-18^{\prime}$ long, $1^{\prime}$ wide, twisted.

G. Morosperma, Walt. Leaflets ovate or oblong; thorns mostly simple; legume short, obliquely oval, 1-seeded, not pulpy.-A small tree; legume $1^{\prime}$ long.

mimosa family. Sub-order III., Mrmosex, L.

\section{mimosa, L. Sensitive Plant.}

Flowers polygamous; calyx minute, 4 -5-toothed; petals united into a 4-ó-cleft tubular-campanulate corolla; sta- 
mens 4-15, distinct, much exserted; legume compressed, mostly jointed, 1-many-seeded; the broad valves separating at maturity from the persistent margins.-IIerbs, shrubs, or trees; leaves bipinnate, sensitive; flowers white or rose-color, capitate or spiked, on axillary peduncles.

M. strigillosa, Torr. and Gray. Herbaceous, and rough with scattered appressed rigid hairs; stem prostrate; leaves long-petioled; pinna, ó-6 pairs ; leaflets $10-14$ pairs, oblong-linear; peduncles longer than the leaves; heads of flowers elliptical ; legume oval or oblong, 1-3-jointed, hispid. Flowers rose-rolor.

\section{SCHRANKIA, Willd.}

Flowers polygamous; calyx minute; corolla funnelformed, 5-cleft; stamens 8-10, distinct, exserted; legume not jointed, prickly, 1-celled, many-seeded; the narrow valves separating at maturity from the broad margins.Perennial prostrate prickly herbs, with bipinnate sensitive leaves, and purple flowers in globose, axillary, peduncled heads.

S. uncinata, Willd. Stem, petioles, peduncles, and legumes thickly beset with short and thick recurved prickles ; pinnoe 5-6 pairs ; leaflets $26-30$, elliptical, reticulated with elevated veins beneath ; peduncles mostly solitary, usually shorter than the leaves; legume oblong-linear, with a short acuminate point, about as long as the peduncle; seeds elliptical. Stem $2^{\circ}-4^{\circ}$ long; legume $2^{\prime}$ long.

\section{DESMANTHUS.}

Flowers polygamous; calyx 5-toothed; corolla of 5 obs long-spatulate petals, or tubular and 5-cleft; stamens 5-10; filaments of the lower flowers filiform, sterile; legume linear, continuous 2-valved.-Herbs or shrubs, with abruptly 
pinnate leaves, and heads or spikes of white flowers borne on axillary peduncles; leaves sensitive.

D. Depressus, Humb. and Bonpl. Stems slender, prostrate, sprinkled with hairs, shrubby at the base; pinnoe 2 pairs; leaflets oblong-linear, very obtuse, oblique and almost truncate at the base, hairy on the margins ; peduncles 2-4flowered, the two upper flowers (sometimes all) perfect; stamens 10; legume linear, many-seeded; seeds angular, compressed. Stem $1^{\circ}-2^{\circ}$ long ; legume $1^{\prime}-1 \frac{1}{2}^{\prime}$ long.

D. DIFfusus. Stem somewhat shrubby, prostrate; pinnce 4-5 pairs; spikes few-flowered, capitate; flowers pentandrous; legume narrowly linear, $2^{\prime}$ long.

D. LEPTоLовUs. Herbaceous; stem ascending, angled; pinnce about 10 pairs, with a small gland at the base of the lowest or two lower pairs; leaflets about 24 pairs, linear, slightly ciliate; stipules setiform; peduncles solitary, fewflowered, not bracteate, much shorter than the leaves; flowers pentandrous, all perfect; legumes usually several from each head, narrowly linear, subulate-acuminate, slightly falcate, 6-8-seeded, somewhat intercepted between the seeds, thrice the length of the peduncles; seeds linear-oblong, nearly glabrous. Stems $2^{\circ}-3^{\circ}$ high; heads usually ripening 4-6legumes, which are 2-3 inches long, and about a line in width; seeds placed lengthwise in the pod.Drummond.

D. strictus. Suffrutescent at the base; stems ascending and somewhat angled; leaves short; pinnce 3-4 pairs, with an oval concave gland at the base of the lowest pair; leaflets 6-8 pairs, linear-oblong, ciliate; stipules setiform; peduncles solitary, not bracteate, nearly the length of the leaves, few-flowered heads subglobose; flowers nearly all perfect, decandrous; legumes linear, straight or somewhat falcate, acuminate, longer than the peduncles, about 8 -seeded; seeds oval. Stem $1^{\circ}-2^{\circ}$ long; leaves small and short; legumes $1^{\prime}-1 \frac{1}{2}^{\prime}$ long.-Drummond. 
* Sterile fllaments flat or somewhat pelaloid; legumes oblong, 4-6-seeded, often stipllate; aquatic, prostrate.

D. LACUstris, Willd. Herbaceous, floating; leaves destitute of glands; pinnce 3 pairs; leaflets 20-30, alternate and opposite, linear, obtuse; heads ovate, many-flowered; peduncles 2-3-bracteate; flowers decandrous; legumes somewhat falcate, oblong, stipitate; spikes loose. Flowers small, somewhat pediceled; filaments of the lower ones antheriferous; leaflets somewhat lanceolate, broader at the base.-Drummond.

\section{ROSE FAMILY. Order, Rosacex.}

Herbs, shrubs, or trees, with alternate stipulate leaves, and regular flowers; calyx of 3-8 (mostly 5) more or less united sepals, and often with as many bracts; petals as many (rarely none), inserted with the few or numerous distinct stamens on the edge of the disk which lines the tube of the calyx, mostly imbricated in the bud; ovaries 1-several, free, or more or less united with the calyx, and with each other, 1-few ovuled; seeds anatropous, and, with few exceptions, without albumen; embryo straight, with large and thick cotyledons; fruit various.

\section{SYNOPSIS.}

SUb-order I. Chrysobalaneæ. Calyx bractless, free from the solitary ovary. Style single, arising from the base of the ovary. Ovules erect. Fruit a drupe. Trees or shrubs. Leaves simple.

1. Chrysobalanus. Calyx-limb persistent. Stone grooved. Low shrubs.

Sub-order II. Amygdaleæ. Calyx bractless, free from the solitary ovary. Style single, terminal. Ovules suspended. Fruit a drupe. Leaves simple. 
2. Prunus. Calyx-limb diciduous. Stone even, or grooved on the margins.

Stb-ORdeir III. Rosaceæ. Calyx 3-5-cleft, the lobes often alternating with as many bracts, free from the 1 -several ovaries. Style lateral or terminal. Fruit a 1-10-seeded follicle, or a 1-seeded achenium. Herbs or shrubs. Leaves mostly lobed or compound.

* Fruit a 1-10-seeded follicle.

Petals obovate or roundish, imbricated in the bud.................. SPR - linear-lanceolate, convolute in the buid...

GHLENIA.

** Fruit a 1-seeded achenium.

+ Fruiting calyx dry, the lobes mostly valvate in the bud. Achenia few, or numerous and collected in the bud.

t† Calyx-tube contracted (except Neviusis). Achenia 1-4.

Petals none. Stamens indefinite. Calyx lobes serrate.............. Nevrusu.

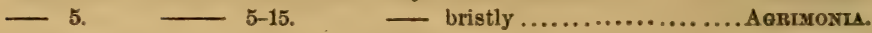

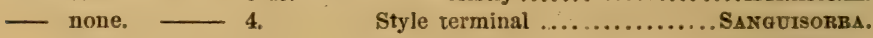

- none. - 1-4. lateral ........................

it $1+$ Calyx open, bracted. Stamens and dry achenia numerous, the latter rarely $2-4$.

$=$ Seeds erect.

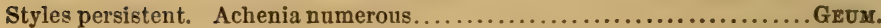

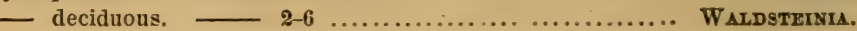

$$
==\text { Seeds suspended or ascending. }
$$

Receptacle flat or convex, dry

Potentilla.

conical, enlarged and fleshy in fruit.

Fragaria.

t† $+\dagger$ t† Calyx open, bractless. Stamens and juicy achenia numerous.

Achenia crowded on the conical receptacle...................... RUB Us.

It Calyx-tube fleshy, urn-shaped; the lobes imbricated in the bud. Achenia numerous, inserted on the receptacle which lines the inside of the calyx-tube.

Achenia dry and hairy. Prickly shrubs

RosA.

Sur-order IV. Pomeæ. Calyx including and cohering with the 1-5 ovaries, very thick and fleshy in fruit. 
Fruit of 1-5 bony 1 -seeded nutlets

. Cratequs.

- 2-5 cartilaginous or membranaceous 2-seeded cells............ Pxrus.

- 3-5 two-seeded cells; seeds separated by false partitions.. Amelanchier.

\section{PRUNUS. Plum Cherry.}

Calyx 5-cleft, deciduous; petals 5, spreading; stamens 15-30; ovary with 2 collateral suspended ovules; styles terminal; drupe fleshy ; the stone even.-Trees or shrubs; leaves simple; flowers white.

Prunus. (Plum.) Drupe glaucous; stone more or less compressed; leaves convolute in the bud; flowers in lateral clusters, appearing before the leaves; branches often spiny.

P. Americana, Marsh. Leaves thick, ovate or somewhat obovate, acuminate, rounded or slightly cordate at the base, pubescent beneath, sharply serrate, on glandular petioles; drupe large, globose.-A small tree ; leaves $2^{\prime}-3$ ' long, smooth when old; flowers very numerous; plum roundish, $\frac{1^{\prime}}{2}-1^{\prime}$ in diameter, pleasantly acid; ripening in September.

P. umbellata, Ell. Leaves thin, ovate-lanceolate or oblong, acute at both ends, or the upper ones rounded at the base, finely and sharply serrate, smooth or soft-downy beneath ; calyx-teeth emarginate, pubescent; drupe globose; stone slightly compressed; branches purple, shining; leaves $1^{\prime}-1 \frac{1}{2}^{\prime}$ long.-Tree or shrub; plum rarely $\frac{1}{2}^{\prime}$ in diameter, dark-purpled or black, sour and bitter ; ripening in August.

P. Chicasa, Michx. Leaves thin, lanceolate or oblonglanceolate, acute, smooth, minutely and sharply serrate, with the glandular and incurved flowers short-peduncled; calyx smooth; drupe yellowish-red, globose.-A shrub or small tree; leaves $1 \frac{1}{2}^{\prime}-2^{\prime}$ long; plum $\frac{1^{\prime}}{2}$ in diameter, thinskinned, and of an agreeable flavor. 
P. GLANDUlosA, Hook. Shrub about a foot high, with very crooked branches; leaves about $1^{\prime}$ in length, rather smooth above; calyx segments spreading and very glandular; umbels 1-2-flowered; ovary pubescent; style elongated. -Drummond.

LaURocerasus. (Cherry Laurel.) Drupe not glaucous ; stone globular; flowers in racemes from the axil of the evergreen leaves.

P. Caroliniana, Ait. (Mock Orange; Wild Peach.) Leaves coriaceous, smooth, and glossy, orate-lanceolate, acute, mostly entire; racemes shorter than the leaves, white; drupe ovoid, soon dry, black.-A small tree. February and March.

\section{SPIRÆA, L. Meadow Sweet.}

Calyx 5-cleft, persistent; petals 5, roundish, imbricated in the bud; stamens 10-50; follicles 3-12, 1-10-seeded; styles terminal._Shrubs or perennial herbs, with simple or compound leaves; flowers white or rose-color, sometimes diœcious.

* Shrub; flowers perfect.

+ Flowers corymbose.

S. opUlifolia, L. Leaves broadly orate or cordate, 3-lobed, doubly crenate-serrate, smooth; corymbs umbellate, terminating the short branches, mostly pubescent; follicle smooth, inflated, 2-4-seeded.-Shrub, $3^{\circ}-5^{\circ}$ high, the old bark separating into thin layers; flowers white.

\section{AGRIMONIA, Tourn. AgrIMONY.}

Calyx 5-cleft, the tube top-shaped, contracted in the throat, and armed with hooked bristles; petals 5 ; stamens $5-15$, inserted on the throat of the calyx; achenia 2 , in- 
cluded in the grooved and indurated calyx-tube.-Perennial herbs, with unequally pinnate leaves, leafy toothed stipules, and small yellow flowers in long spiked racemes; fruit nodding.

A. Eupatoria, L. Stem hairy; leaflets 3-7, with smaller ones below or intermixed, oblong-ovate, hairy, sometimes white-downy beneath, coarsely serrate; petals twice the length of the calyx. Stem $2^{\circ}-3^{\circ}$ high.

A. Parviflora, Ait. Stem and petiole hirsute; leaflets 9-15, with smaller ones between, lanceolate, coarsely serrate, roughish above, pubescent beneath ; flowers and fruit smaller than A. Eupatoria.

\section{SANGUISORBA, L.}

Calyx 4-parted, the tube 4-angled; petals none; stamens 4 , the filaments usually thickened upward; style terminal, slender; stigma pencil-form; achenia 1-2, included in the 4-winged indurated calyx-tube.-Herbs, with unequally pinnate leaves; flowers in close heads or spikes.

S. ANNUA. Glabrous; stem branching ; leaflets 4-6 pairs, oval, deeply pectinate-pinnatifid; the segments linear and very narrow; heads elliptical; bracteoles 3 , large and scarious; filaments short, not dilated; flowers all perfect, brownish-green. Stem 10-20 inches high, slender, leafy; annual.-Dr. Leavenworth.

\section{GEUM, L. Avens.}

Calyx campanulate, deeply 5-cleft, and usually with as many bracts as the sinuses; petals 5 ; stamens and achenia numerous, the latter crowded on the conical or cylindrical dry receptacle; styles terminal, long, persistent, jointed and hairy, or straight and smoothish ; seeds erect; flowers 
yellow, white, or purple.-Perennial herbs, with pinnately divided leaves.

G. ALbuM, Gmelin. Smoothish or downy ; stem slender, and spreading branches; radical leaves pinnate, or the earliest ones nearly simple and rounded; stem-leaves 3-parted, lobed or toothed; petals white, as long as the calyx ; style jointed, and bent near the middle, the smooth lower portion persistent and hooked; receptacle and ovaries bristly-hairy. Stem $2^{\circ}$ high.

G. vernuy. Stem $6^{\prime}-10^{\prime}$ high, weak, dichotomons and few-flowered at the summit; pedicels elongated in fruit; calyx-segments triangular-ovate; stipe nearly the length of the head of carpels; radicla leaves either roundish-cordate and slightly $3-5$-lobed, or pinnate, with the leaflets variously incised and lobed; the cauline mostly $3-5$-foliolate or lobed, serrate-toothed, ciliate, the uppermost leaflets lanceolate; carpels scabrous, in globose heads; receptacie glabrous.-Gray and Torrey.

\section{WALDSTEINIA, Willd.}

Calyx obconical, 5-cleft, with as many alternate bracts; petals 5 ; stamens numerous, inserted into the throat of the calyx ; achenia 2-6, dry or somewhat fleshy; style terminal, filiform, separating from the achenium by a joint; seeds erect.-Low perennial herbs, with chiefly radical and roundish lobed leaves, and yellow flowers on scape-like stems.

W. lobata, Torr. and Gray. Hairy; leaves cordate, crenately 3-5-lobed; scape filiform, bracted, 4-8-flowered; achenia mostly 2, hoary; petals rather shorter than the calyx. Scape and leaves $4^{\prime}-8^{\prime}$ high.

RUBUS, L. BRIER; Bramble.

Calyx concare or flattish, 5-parted, without bracts; 
petals 5, deciduous; stamens numerous; achenia juicy, crowded on the conical or cylindrical receptacle; style nearly terminal, deciduous.-Perennial or shrubby and nearly prickly plants, with lobed or compound petioled leaves, and white or reddish flowers.

* Heads of achenia oval or oblong, persistent; receptacle juicy.

R. villosus, Ait. Stem erect or bending, tall, shrubby, armed like petioles and peduncles with stout recurved prickles, the branches and 3-7-foliolate leaves soft-hairy or nearly smooth; leaflets ovate or oblong, doubly serrate; racemes leafy below, bracted above; sepals acuminate, much shorter than the obovate white petals; fruit large, oblong, black. Stem $4^{\circ}-10^{\circ}$ high.

R. TRIVIalis, Michx. Shrubby, and armed with stont, straight, or recurved prickles and bristly hairs; stem prostrate, slender; leaves 3-5-foliolate, partly persistent; leaflets smooth, oblong ovate or obovate, acute, sharply serrate; racemes few-flowered, leafy below, mostly longer than the leaves; flowers large, white; fruit black.

R. HISPIDUs, L. Somewhat shrubby, and armed with weak bristle-like prickles; stem slender, prostrate; leaves trifoliolate, persistent; leciflets obovate, obtuse, coarsely serrate, smooth; racemes many-flowered, slender, longer than the leaves; flowers small, white; fruit of few large and black achenia. Fruit sour.

\section{ROSA, Tourn. ROSE.}

Calyx 5-cleft, the urn-shaped tube becoming fleshy in fruit; petals 5 ; stamens numerous, inserted with the petals on the throat of the calyx; ovaries numerous, hairy, inserted on the thin receptacle that lines the inner surface of the calyx-tube; styles nearly included; achenia bony.- 
Prickly shrubs; leaves unequally pinnate; stipules united with the petioles; flowers showy.

** Styles distinct, included; flowers red or white.

R. Carolina, L. Stem erect, smooth, armed with stout recurved stipular prickles; leaflets 5-9, oblong or elliptical, acute, finely serrate, dull and smoothish above, the lower surface paler, or, like the prickly petioles and caudate calyx-lobes tomentose; flowers single or corymbose, caly $x$ tube and peduncles glandular-hispid. Stem $4^{\circ}-6^{\circ}$ high, commonly purplish ; fruit depressed-globose, glandular.

R. RUbiginosa, L. (Eglantine.) Stem erect or curving, armed with very stout prickles; leaflets $5-7$, oval or oborate, serrate, glandular beneath; flowers mostly solitary, on hispid peduncles; fruit obovate. Branches yellowish green; leaves fragrant.

R. Levigata, Michx. (Cherokee Rose.) Stem long, trailing, smooth, the branches armed with very stout and curved prickles; leaves evergreen, mostly trifoliate; leaflets smooth and shining, lanceolate, the midrib hispid; stipules deciduous; flowers large, solitary, white; calyx very bristly.

R. Foliolosa, Nutt. . Branches slender, glabrous, armed with very weak scattered deciduous prickles, and sometimes with persistent short and nearly straight stipular prickles; leaflets $7-11$, linear-oblong, glabrous, shining above, sharply serrate, crowded, the lower pair close to the narrow glandular-ciliate stipules (the species described by Leavenworth sometimes onIy $\frac{1^{\prime}}{2}$ in length); leaves much crowded on the flowering branches; petiole and midrib often setose and pubescent; flowers mostly solitary, small, and almost sessile; calyx glandular-hispid, the segments reflexed often with lateral appendages; peduncles $\frac{1}{4}-\frac{1}{2}$ in length; fruit subglobose, somewhat hispid. 


\section{CRAT AGUS, L. HAWTHORN.}

Calyx urn-shaped; the limb 5-cleft, persistent; petals 5, orbicular, concave; stamens few or many; styles 1-5, distinct; fruit fleshy, containing 1-5 bony nutlets.-Thorny shrub or tree; leaves simple, serrate or variously lobed; flowers white, axillary and solitary, or in corymbs terminating short lateral branches; stipules on the young branches linear, or lunate and serrate.

* Corymbs compound, many-flowered.

+ Fruit small, not larger than a pea.

C. spathulata, Michx. Young branches tomentose, otherwise nearly smooth and glandless throughout; leaves small, spatulate, crenate at the summit; those on the young shoots larger and incisely lobed; calyx-lobes very short; styles 5 ; fruit very small, red.-A small tree; corymbs sometimes slightly pubescent; stipules lunate on the young branches.

C. APIIfolia, Michx. Young branches, leaves, and corymbs whitened with soft hairs; leaves small, deltoid, pinnately 5-7-lobed, sharply toothed, nearly smooth when old, truncate or cordate at the base; styles 1-3, filiform; fruit globular, red.-Small tree; leaves $\frac{1^{\prime}}{2}-1^{\prime}$ long.

C. Condata, Ait. Young branches, leaves, and corymb: pubescent, soon smoothish ; leaves large, deltoid-ovate, truncate or cordate at the base, long-petioled, 3-5-lobed and serrate; spines slender; fruit globose, red.-Small tree; leaves 1 '-3' long; styles 5 .

C. A RBorescens, Ell. Smooth; leaves thin, oval or elliptical, acute at both ends, finely serrate, sometimes obscurely toothed near the apex, on slender nearly glandless petioles; corymbs very numerous; styles 5 ; fruit ovoid, red.-Small tree, with ash-colored branches; spines stout 
or wanting; leaves $1^{\prime}-2^{\prime}$ long, entire at the base, sometimes hairy in the axils of the veins beneath.

†+ Fruit large (1'-l' long); leaves, etc., mostly glandular.

C. Crus-Galli, L. Leaves thick, oblong-obovate, smooth, shining above, finely serrate from near the glandless base, those on the young branches sometimes slightly lobed; spines long and stout, or sometimes wanting; corymbs smooth or nearly so ; styles $1-3$; fruit pear-shaped or globose, red.-A small shrub or small tree.

C. Texana, Buckley. Leaves broadly ovate, cuneate at the base, unequally dentate, teeth acute, smooth abore, pubescent beneath; petioles, younger branches, and calyx densely tomentose; petals obovate, longer than the calyx; calyx laciniate, lanceolate-acuminate; fruit red, oblong. Bark of trunk and branches dark gray, furrowed and rough (resembling that of the dogwood, Cornus florida); leaves large, incisely and doubly toothed, nearly as broad as long; petioles not margined, about an inch in length; old leaves arachnoid, tomentose beneath; fruit large, red, and edible; ripe last of October.-A tree, 20-25 feet high, nearly thornless; trunk 8-10 inches in diameter. Rich soils, Central and Western Texas.

C. coccinea, L. Smooth; leaves thin, roundish-ovate, with 3-5 short and sharply serrate lobes on each side, abruptly narrowed into the slender petiole, strongly straightveined; those on the young branches often truncate or slightly cordate at the base, and more strongly lobed; spines stout; styles 3-5; fruit large, globose or pearshaped, bright red.-Small tree or shrub; leaves 1'-2' long, bright green.

C. toventosa, L. Leaves large, $3^{\prime}-5$ ' long, broadly orate or oval, finely serrate, and slightly lobed above the middle, abruptly narrowed into a short marginal petiole, pubescent, especially beneath, the veins straight and impressed; 
corymbs large, tomentose; styles 1-3; fruit pear-shaped, orange-red.

C. A Rborescens. Unarmed; leaves lanceolate, acute at each end, deeply serrate, glabrous on the upper surface, hairy underneath at the division of the veins, sometimes slightly lobed toward the summit; corymbs many-flowered; calyx hairy, the segments subulate, entire; flower's pentagynous.-Drummond.

** Corymbs simple, 1-6-flonvered.

C. Parvifolia, Ait. Leaves obovate, scarcely petioled, serrate, the lower surface, like the branchlets and calyx, pubescent; spines numerous, long and slender; flowers mostly solitary; calyx-lobes large, serrate; styles 5 ; fruit large, globose or pear-shaped, somewhat hairy.-A muchbranched shrub, $3^{\circ}-5^{\circ}$ high; leaves $1^{\prime}$ long.

\section{PYRUS, L. Pear and APple.}

Calyx urn-shaped, 5-cleft; petals 5 ; stamens numerous; styles 2-5; fruit fleshy or baccate, containing 2-5 cartilaginous 2-seeded carpels.-Trees or shrubs; flowers cymose or corymbose.

* Leaves simple, glandular; fruit depressed at the base.

P. angustifolia, Ait. Leaves lanceolate or oblong, acute at the base, serrate, short-petioled; corymbs simple, few-flowered; flowers rose-color, very fragrant; styles smooth, distinct.-A small tree; fruit very sour.

Var., MeLANOCARPA. Stem low, $2^{\circ}-4^{\circ}$; branchlets, cymes, and leaves smooth; leaves simple, small: petals white; fruit baccate, globose; berries black. 


\section{CAROLINA-ALLSPICE FAMILY. Order, Cal yCaNthaCE.⿱一.}

Shrubs, with opposite and entire leaves, without stipules or pellucid dots; sepals and petals numerous and alike, united below into an obconical fleshy cup, imbricated in the bud; stamens numerous, short, inserted within the petals, the inner ones often sterile; anthers adnate, extorse; ovaries several, enclosed in the calyx-tube, and inserted on its inner face, becoming 1-seeded achenia in fruit; seeds anatropous, without albumen; cotyledons convolute.

\section{MYrtLE FAMily. Order, Mrrtace无.}

Trees or shrubs; leaves opposite, simple, entire, dotted, and commonly with an intramarginal vein; stipules none; calyx 4-6-cleft, valrate in the bud, the tube adherent to the compound ovary; petals 4-6, inserted with numerous stamens on the throat of the calyx, sometimes wanting; filaments long, free, or variously combined ; anthers intorse, roundish, longitudinally dehiscent; styles solitary; seeds without albumen, fixed to a central placenta.

\section{Melastoma family. Order, Melastomacee.}

Herbs, shrubs, or trees, with opposite 3-9-ribbed leaves, without dots or stipules, and showy flowers; calyx urnshaped, 4-6-lobed, persistent, cohering with the ovary below or with its angles; petals 4-6, twisted in the bud, inserted with the 4-12 stamens on the throat of the calyx; anthers adnate, often appendaged, usually opening by terminal pores; ovary 3-6-celled; ovules numerous, attached to the central placentæ; style solitary; fruit baccate and indehiscent, or capsular and loculicidally dehiscent; sceds anatropous, without albumen. 


\section{RHEXIA. DeEr Grass.}

Caly $x$-tube prolonged and narrowed above the orary, 4-cleft; petals 4, roundish, deciduous; stamens 8; anthers 1-celled, opening by a terminal pore; capsule 4-celled, many-seeded.-Perennial herbs; leaves 3-5-ribbed; flower's cymose, terminal.

* Anthers long, linear, curving upward, saccate at the base, and commonly furnished with a bristle-like appendage at the insertion of the fllaments; flowers purple or whitish.

R. Glabella, Michx. Stem terete, smooth, mostly simple; leaves lanceolate, sessile, entire or slightly serrulate, thick, smooth, and glaucous; calyx smooth or bristly; flowers large, bright purple. Root spongy; stem $2^{\circ}-4^{\circ}$ high; leaves sweetish.

* Anthers short, oblong, erect, not appendaged; neck of the calyx short.

+ Flowers purple; leaves small, ovate or roundish, bristly sermilate.

R. Serrulata, Nutt. Low; stem simple, 4-angled, smooth; leaves smooth above; calyx glandular-bristly; cyme leafy, 1-6-flowered. Stem $2^{\prime}-6^{\prime}$ high; leaves and flowers smaller than in the preceding.

\section{†+ Flowers yellow.}

R. LUTEA, Walt. Stem at length much-branched, 4-angled, bristly; leaves smoothish, bristly serrulate, the lower ones obovate and obtuse, the upper lanceolate and acute; cymes numerous; calyx short and smooth; flowers small. Stem $1^{\circ}$ high; petals more persistent than those of the other species.

\section{4\%. LOOSESTRIFE FAMILY. Order, Lythracex.}

Chiefly herbs, with opposite or whorled and entire leaves, without stipules; flowers mostly axillary; calyx tubular, persistent, 4-7-toothed, free from the 2-4-celled ovary; 
petals as many as the teeth of the calyx and inserted into its throat, deciduous, sometimes wanting; stamens as many as the petals; or 2-4 times as many, inserted below the petals; anthers short, intorse; style solitary; capsule enclosed in the calyx, 1-4-celled, few or many seeded; placentoe central; seeds anatropous, without albumen; sinuses of the calyx often appendaged; stigma capitate, or rarely 2 -lobed.

\section{SYNOPSIS.}

\section{* Calyx regular.}

Calyx hemispherical. Petals none, stigma 2-lobed. Capsule 2-celled.

HYPOBRYCHIA.

- campanulate. Stigma capitate. Capsule 4-celled............. A mmannia. cylindrical, striate. Capsule oblong, 2-celled. LYTHRUM.

- short, even. Capsule globose, 3-5-celled. Stamens 10 Nesca. ** Calyx gibbous at the base.

Calyx tufular, 12-ribbed. Stamens mostly 12. Capsule early ruptured..CuPIEA.

\section{HYPOBRYCHIA.}

Calyx hemispherical or campanulate, 4-lobed; petals none; stamens 2-4; style very short; stigma 2-lobed; capsule globose, 2-celled.-A submerged aquatic herb, with long filiform stems, opposite crowded pellucid linear leaves, and minute sessile axillary flowers.

H. Nuttallit, Torr. and Gray. Stems $1^{\circ}-2^{\circ}$ long; leaves $1^{\prime}$ long, acute; flowers not larger than a pin's head. Ponds and still waters.

\section{AMMANNIA. HodsToN.}

Calyx globular or campanulate, 4-angled, 4-toothed, the sinuses commonly furnished with a small horn-shaped appendage; petals 4, small, deciduous, sometimes wanting; stamens 4, short; stigma capitate; capsule globular, 4-celled, many-seeded.-Low annual smooth herbs, with opposite leaves, and solitary or clustered flowers. 
A. Humlis, Michx. Stems branching from the base; leaves lanceolate, tapering into a petiole; flower's solitary; style very short; petals 4 , purplish. Varies, with the leaves dilated and somewhat cordate at the base, and the lower flowers clustered. Ditches and muddy places. Stems 6'-12' high.

\section{LY'THRUM, L. LOOSESTRIFE.}

Calyx cylindrical, striate, 4-7-toothed, usually with minute appendages in the sinuses; petals $4-7$; stamens as many as the petals, or twice as many, inserted on the lower part of the calyx, nearly equal; capsule oblong, 2-celled, many-seeded.-Herbs, with opposite or alternate leaves, and axillary purple or whitish flowers.

L. Alatum, Pursh. Smooth; stem and virgate branches t-angled; leaves lanceolate, acute at both ends, opposite, the uppermost alternate, and shorter than the flowers; petals and stamens 6 . Varies, with branches shorter, leaves larger, $2^{\prime}$ long, broadly lanceolate, sometimes whorled, the uppermost twice as long as the calyx. Stem $2^{\circ}-4^{\circ}$ high; flowers violet-purple.

L. LINEARE, L. Smooth; stem 4-angled, much-branched; leaves all opposite, linear; flowers small, whitish; petals and stamens 6. Brackish marshes. Stem $2^{\circ}-4^{\circ}$ high; calyx-teeth short.

\section{CUPHEA, Jacq.}

Calyx tubular, 12-ribbed, gibbous or spurred at the base on the upper side, 6-toothed, and usually with as many little appendages in the sinuses; petals 6 , unequal ; stamens 11-12; ovary with a gland at the base next the spur of the calyx; style filiform; stigma 2-lobed; capsule 1-2-celled; few-seeded.-Chiefly herbs, with branching stems, and purplish. 
C. viscosissima, Jacq. Annual, clamms-pubesceut; leaves thin, opposite, ovate-lanceolate, long-petioled, rough; flowers nearly sessile, borne between the petioles, solitary; petals riolet-purple; stamens 12. Stem $1^{\circ}$ high.

\section{EVENING-PRIMROSE FAMILY. Order, ONAGRACEE.}

Calyx adherent to the orars, and often produced into a tube beyond it, 2-6-lobed, ralrate in the bud; petals as many as the lobes of the calyx, inserted into its throat, convolute in the bud, sometimes wanting; stamens as many, or twice as many, inserted with the petals; ovary $2-4$ celled; placenta central ; style solitary; stigma capitate or 2-1-lobed; capsule loculicidally dehiscent or indehiscent; seeds anatropous, with little or no albumen.-Chiefly herbs.

Sub-order I. Onagraceæ. Styles slender. Fruit 4-ralved, indehiscent in Gaura. Seeds attached to a central placenta, without albumen.

\section{* Calyx-tube produced beyond the ovary.}

Capsule nut-like, indehiscent, 1-4-seeded. GACRA,

4-valved, many-seeded.

CENothera.

** Calyx-tube not produced beyond the ovary.

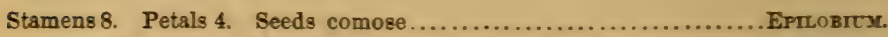

- 8-12. Petals 4-6. Capsule long. Seeds naked............. Jrsst.x.

4. - 4, or none. Capsule short, many-seeded........LtDwiGia. - 2 .

obovate, 1-2-seeded

Circasa.

SUb-ORder II. Halorageæ. Styles rery short or none. Fruit indehiscent. Seeds suspended, solitary in each cell. Albumen thin. Flowers minute, axillary.

Flower perfect. Stamens 3. Capsule 3-angled................... Proserpraca.

- monecious. Stamens 4-8. Capsule 4-angled.......... MrRophrL.t.

\section{GAURA.}

Calyx-tube much produced beyond the orary, the limb 
3-4-lobed, reflexed, deciduous; petals 3-4-clawed, unequal or turned to the upper side; stamens 6-8; styles declined; stigma 4-lobed; ovary 3 -4-celled; fruit 3-4-angled, mostly 1-celled, 1-4-seeded.-Herbs, with alternate leaves, and white or purple flowers in a long-peduncled raceme or spike.

G. BIENNIS, L. Soft-hairy; leaves oblong-lanceolate, acuminate, becoming smoothish, wavy-denticulate on the margins; petals spatulate, white; fruit obtusely 4-angled, acuminate at both ends, sessile. Biennial; stem $3^{\circ}-8^{\circ}$ high ; spikes compound.

G. FILIPES, Spach. Pubescent and somewhat hoary, becoming smoothish; stem slender, paniculately branched; leaves linear, toothed, wavy; fruit ovoid, obtuse, sharply 4 -angled, on slender pedicels. Biennial; stem $2^{\circ}-3^{\circ}$ high, very leafy.

G. Sinuata, Nutt. Stems suffruticose and branching at the base, naked above, glabrous ; leaves lanceolate, linearacute, remotely and acutely sinnate-toothed, rather thick, veinless; flowering branches slender, nearly simple, naked, flowers loose pediceled; segments of the calyx much longer than the obconic tube; petals oblong-obovate, on slender claws.-Drummond.

G. Drummondi. Stem suffruticose at the base, a little hairy below, virgately branched above; leaves somewhat canescently puberulent, lanceolate, acute, denticulate or somewhat sinuate; spikes slender, few and loosely flowered; bracts ovate, caducous, about the length of the ovary; tube of the calyx about the length of the segments and rather shorter than the ovary; and terete when mature, orate pyramidal above, acute, with 4 strong carinate angles.Drummond.

G. Parviflora, Dong. Stem tall, erect, and, with the margin of the leaves, villous with very soft white hairs; leaves ovate-lanceolate, acute or acuminate, repand-denticu- 
late, clothed with a very short velvety pubescence on both sides; spikes virgate, strict, very many-flowered, much elongated in fruit; bracts lanceolate-subulate; flower's very small; tube of the calyx shorter than the glabrous ovary and longer than the segments; fruit sessile, oblong-clavate, 4-nerved, slightly 4-angled; petals spatulate-oblong, scarcely unguiculate, shorter than the calyx-segments, rose-color.Drummond.

\section{enothera, L. Evening Primrose.}

Calyx-tube produced beyond the ovary, the limb 4-lobed, reflexed and deciduous; petals 4; stamens 8; stigma 4-lobed; capsule 4-valved, many-seeded.-Herbs, with alternate leaves and axillary or racemose chiefly yellow flowers. Pollen grains triangular, connected by cobwebby hairs.

* Capsule cylindrical, sessi'e; flowers expanding ut night; annuals or biennials.

E. BIfrons, Doug. Pubescent; stem erect, often branching above; leaves oblong or ovate, the upper ones short, closely sessile and somewhat cordate, denticulate; spikes elongated; bracts ovate-cordate; tube of the calyx very slender, much longer than the segments, and many times longer than the slightly hairy ovary; petals entire, about the length of the stamens; capsules prismatic-cylindrical, nearly glabrous.-Drummond.

E. Drummondi, Hook. Softly pubescent; stem decumbent; leaves ovate-elliptical or oblong, rather obtuse, the lower ones tapering into a petiole, somewhat sinuately toothed, the upper ones obscurely denticulate; fowers very large, axillary; tube of the calyx equaling in length the segments and the hirsute ovary; petals much longer than the slightly declined stamens, a little exceeding the calyxsegments; capsules cylindrical, elongated, hirsute-pubescent, slightly pediceled.-Drummond; Gray and Torrey. 
E. RHombipetala, Nutt. Tall, erect; leaves lancelinear, sessile, acute, spreading, lower ones petiolate, becoming somewhat pinnatifid; spike strict; flowers large, longer than the leafy bracts; caly $x$-tube very slender, $3-4$ times longer than the sessile ovary; petals rhombic-elliptical, acute or acuminate; capsule small. Flowers strawyellow.-Marcy.

E. BIEnNis, L. Hairy, hirsute, or smoothish; stem tall, often simple; leaves lanceolate and ovate-lanceolate, acute, wavy and toothed or serrate on the margins, the earliest ones sometimes pinnatifid; spikes leafy, at length elongated; calyx-tube longer than the lobes; flowers large. (E. muricata, Pursh; EE. grandiflora, Ait.) Stem $2^{\circ}-4^{\circ}$ high. Varies greatly in pubescence and size of the flower.

E. sindata, L. Hairy or downy; stems ascending or diffuse; leaves oblong, pinnately lobed, the lowest pinnatifid; flowers small, axillary; calyx and capsule hairy. Passes through several intermediate forms into Var. HUMIFUSUM, Torr. and Gray. Stems prostrate, hoary; leaves small, lanceolate, sparingly toothed or entire. Stems $2^{\prime}-4^{\circ}$ high.

** Capsule obovate or clavate, furrowed, and more or less peduncled; flowers expanding in sunshine.

E. SPeciosa, Nutt. Perennial, puberulent; stems erect or ascending, flexuous, often branching; leaves lanceolate or oblong-lanceolate, attenuate at the base, the radical and lower cauline ones pinnatifid, or pinnately toothed; flowers (large) in a loose at length elongated spike; tube of the calyx longer than the ovary, but shorter than the conspicuously acuminate segments; capsules slightly pediceled, thick and almost ligneous, clavate-obovate, rather acute, strongly 8-ribbed, the alternate ribs cristate.-Drummond.

E. Spachiana. Annual, minutely pubescent; stem simple or branching from the base; leaves lanceolate or 
linear, obtuse, entire, attenuate at the base; flowers (rather small) axillary; tube of the calyx shorter than the segments; petals nearly entire, much longer than the calyxsegments and stamens; capsules canescently pubescent, obovate-clavate, the alternate angles carinate or slightly winged toward the summit, tapering to a slender base, nearly sessile.

E. Linifolia, Nutt. Stem strict, simple or branched above; radical leaves oblong-spatulate, petioled, the cauline ones linear-filiform, crowded and fascicled; spikes slender, loosely flowered; bracts shorter than the ovary, persistent; flowers very small; tube of the calyx rather shorter than the ovary; the segments shorter than the petals; lobes of the stigma very short; capsules obovate, 4 -carinate, nearly sessile, hispidly puberulent.-Drummond.

E. FRUTicosa, L. Hairy or smoothish; stem mostly simple; leaves lanceolate, commonly wavy and remotely denticulate on the margins; raceme at first corymb-like, at length elongated; flowers large; capsule 4-winged, with intermediate ribs, oblong-clavate, longer than the pedicel; perennial. Stem $1^{\circ}-2^{\circ}$ high ; flowers $1^{\prime}-2^{\prime}$ in diameter.

E. Linifolia, Nutt. Low, smoothish ; stem at length much branched; leaves very numerous, linear-filiform, the lowest spatulate; racemes pubescent, ferw-flowered ; bracts shorter than the ovary; flowers small; lobes of the stigma coherent into a globular head; capsule obovate, 4 -angled, nearly sessile. Stem $6^{\prime}-12^{\prime}$ high ; flowers $4^{\prime \prime}-5^{\prime \prime}$ in diameter.

\section{EPILOBIUM, L. WILlow Herb.}

Calyx-tube not prolonged beyond the ovary; the limb 4-cleft, deciduous; petals 4 ; stamens 8 ; capsule elongated, many-seeded; seeds with a tuft of long hairs at the apex; perennials, with alternate and opposite denticulate leares and chiefly white or purplish flowers. 
E. Angustifolium, I. Stem tall, simple, smoothish; leaves alternate, lanceolate, entire or wavy on the margins, puler beneath; racemes elongated, bracted; flowers showy; petals obovate, purple; stigma 4-lobed; capsule and calyx hoary-tomentose.

\section{JUSSIEA, L.}

Calyx-tube long, 4-angled or cylindrical, not prolonged beyond the ovary; the limb 4-6-lobed, persistent; petals 4-6; stumens 8-12; capsule mostly elongated, 4-6-celled, many-seeded, opening irregularly at the sides. Marsh herbs, with alternate leaves, and axillary yellow flowers.

J. LEPTOCARPA, Nutt. Hairy; stem erect, at length much branched; leaves lanceolate, acute; flowers small; calyxlobes mostly 6 , as long as the petals; capsule linear, cylindrical, much longer than the pedicel. Marshes. Stem $2^{\circ}-5^{\circ}$ high ; capsule $1 \frac{1}{2}^{\prime}$ long, slightly curved; annual.

J. DECURrens, DC. Smooth; stem erect, branched, wingangled; leaves lanceolate, acute, sessile; flowers nearly sessile; calyx-lobes 4, nearly as long as the petals; stamens 8 ; capsule 4-angled, oblong-clavate. (Ludwigia decurrens, Ell.) Stem $6^{\prime}-3^{\circ}$ high ; annuals.

J. occidentalis, Nutt. Pubescent; stem erect, angled; leaves lanceolate, acute at each end, sessile or with short petioles; flowers (rather large) on very sharp mostly bracteolate pedicels; lobes of the calyx 4, ovate, acute, shorter than the obovate emarginate petals; stamens 8 ; capsules elongated, 4-sided, thrice the length of the pedicels. Drummond.

\section{LUDIVIGIA, L. SEed-Box.}

Calyx-tube 4-angled or cylindrical, mostly short, not prolonged beyond the ovary; petals 4 , roundish or obcor- 
date, often wanting; stamens 4 ; style short; stigma capitate; capsule variously dehiscent, 4 -celled, many-seeded.Perennial and mostly stoloniferous marsh herbs, with entire leaves and yellow flowers.

** Talves of the capsule separating from the concare disk, and irregularly from the persistent partitions and placenta ; calyx-lobes persistent ; petals small or none; stamens and s!yle short; stems ereet or ascending; leaves alternate; floucers sessile.

+ Petals conspicuous.

I. LINeARIs, Walt. Smooth; stem $\left(1^{\circ}-3^{\circ}\right.$ high $)$ virgately much branched; leaves linear, acute; flowers small; capsule clarate-oblong, with 4 rounded angles, $2-3$ times as long as the triangular-orate calyx-lobes. Bark at the base of the stem spongy.

L. Linifolia, Poir. Smooth ; stem low $\left(6^{\prime}-12^{\prime}\right)$, creeping at the base, branching; leaves linear or linear-spatulate, often obtuse ; capsule linear-cylindrical, rather longer than the lanceolate calyx-lobes. Swamps in the low country.

\section{+ Petals minute or wanting.}

L. CYLINDRICA, Ell. Smooth; stem angled abore, often much branched; leaves long, lanceolate, obscurely denticulate, acute, tapering into a petiole; petals none; capsu?es axillary, often clustered, cylindrical or obscurely 4-sided, many times longer than the small calyx-lobes. Swamps. Stem mostly bushy, $2^{\circ}-3^{\circ}$ high ; leares $3^{\prime}-4^{\prime}$ long.

L. PILOSA, Walt. Tomentose; stem stout, terete, much branched; leares sessile, lanceolate or oblong, acute; flowers in dense terminal spikes; petals mostly wanting; capsule giobose 4-sided, about as long as the spreading calyx-lobes. (L. mollis, Ell.) Ditches and ponds. Stem $2^{\circ}-3^{\circ}$ high, the branches spreading; capsule whitish.

L. Alata, Ell. Smooth; stem slender, simple or sparingly branched near the summit, strongly angled; leares cuneate-lanceolate, obscurely endiculate; flowers few, near 
the summit of the branches, white; petals none; capsule cubic-obeonical, with concare sides and winged angles, as long as the calyx-lobes; seeds ovoid. Stem $2{ }^{\circ}-3^{\circ}$ high.

L. Microcarpa, Michx. Smooth; stem low, creeping at the base, 3 -angled, mostly simple; leaves spatulate-obovate, petals none; capsule minute, cubic-obconical, shorter than the calyx-lobes. Stem $66^{\prime}-12^{\prime}$ high ; capsule scarcely larger than a pin's head.

*** Stems creeping; leaves opposite.
+ Petals none.

L. PALtstris, Ell. Smooth; stems diffuse; leaves obovate, tapering into a long petiole; capsule oblong or obconical, obscurely 4-sided, longer than the calyx-lobes. Stems $6{ }^{\prime}-12^{\prime}$ loug.

L. Spathulata, Torr. and Gray. Pubescent and somewhat hoary; leaves spatulate-obovate; capsule ovoid.

t+ Fetals 4.

L. Nataxs, Ell. Smooth; stems diffuse; leaves obovate, acutish, tapering into a long petiole; flowers short-pediceled; petals roundish, as long as the lobes of the calyx; capsule obtusely 4 -angled, narrowed at the base.

\section{PROSERPINACA, L.}

Calyx-tube 3-sided, 3-lobed; petals none; stamens 3; stigmas 3; fruit bony, 3-angled, 3-celled, 3-seeded.-Herbs, with pinnately dissected leaves, and minute axillary greenish flowers.

P. PAltstris, L. Leaves lanceolate, sharply serrate, the submerged ones pectinate; stem $1^{\circ}-2 \frac{1}{2}^{\circ}$ long, ascending or floating. 


\section{MYRIOPHYLLUM, Vail. WATER-MILLFoIL.}

Flowers monœcious or polygamous; calyx 4-parted in the sterile flowers, 4 -toothed in the fertile ones; petals 4 or none; stamens 4 or 8 ; stigmas 4 , recurved; fruit bony, 4-celled, 4-lobed, indehiscent.-Aquatic perennial herbs, with the submerged leaves pinnately divided into filiform or capillary segments, and commonly whorled; flowers minute in the axils of the upper leaves, the uppermost sterile.

\section{* Stamens 8 ; fruit even or warty.}

M. LAXum, Shuttl. Stem long, slender; leaves 4 in a whorl, the floral ones reduced to minute nearly entire spatulate bracts, shorter than the flowers. which thus form an interrupted almost naked spike; fruit roughened with minute warts, with the lobes obtuse. Ponds and lakes.

M. VERTiCILlatuM, L. Leaves in whorls of 3-4, the floral ones linear, pectinately toothed, much longer than the flowers; fruit smooth. Still water. Stem $2^{\circ}-4^{\circ}$ long, stouter than the last.

\section{** Stamens 4 ; fruit ridged and noughened.}

M. HETEROPHYLLUM, Michx. Stem thick ; leaves 4-6 in a whorl, the floral ones crowded, ovate or lanceolate, finely and sharply serrate; the lower ones pinnatifid; fruit slightì roughened.

\section{CACTUS FAMILY. Order, Cactaces.}

Succulent, shrubby, and commonly leafless and prickly plants, with globular, or columnar and angular, or flattened and jointed stems, and solitary sessile flowers; sepals and petals similar, imbricated in several rows, and adherent to the 1-celled ovary; stamens indefinite, with long 
filaments, inserted on the base of the petals; style single; stigmas numerous; fruit baccate; seeds numerous, campylotropous, borne on several parietal placentæ; albumen scanty or none.

\section{CEREUS, Haw.}

Sepals and petals united into an elongated tube above the ovary; stamens inserted on the tube; style filiform; stigma many-lobed; seeds without albumen; stems elongated, ribbed or angled, the angles bearing tufts of spines and showy flowers.

C. viridifLoRis. Stems $3^{\prime}-6^{\prime}$ and sometimes $8^{\prime}$ high, $1^{\prime}-2^{\prime}$ in diameter; spines usually $3^{\prime \prime}-5^{\prime \prime}$ or nearly $6^{\prime \prime}$ long; central spine, if present, $6^{\prime \prime}-10^{\prime \prime}$ long. In one specimen, on some of the areolce most of the spines are purple, the central one being curved upward, with a purple or white tip; flower $1^{\prime}$ or less below the top, $1^{\prime}-1 \frac{1}{4}^{\prime}$ long, not quite wide even when fully open; petals $2^{\prime \prime}-3$ " wide; fruit $3^{\prime \prime}-6^{\prime \prime}$ long, crowned with a withered corolla.-Dr. Engelmann.

C. Chloranthus. Stem $3^{\prime}-10^{\prime}$ long, $1 \frac{1}{2}^{\prime}-2^{\prime}$ in diameter; areola 3-4 lines apart, not so much elongated as in the last species; radial spines slender, patulous, not strictly radiating, pectinate or appressed to the plant; lower lateral ones the longest, inferior ones shorter, upper ones shortest; no central spines are present in the young plants, next 1-3 appear, and the well-developed flowerbearing plants have always 5 ; the upper darker and shorter ones are about $6^{\prime \prime}$ long, the lower ones $9^{\prime \prime}-12^{\prime \prime}$ or eren $15^{\prime \prime}$ long; the lowest one is the lon छest and regularly deflexed, so that the plant seen from above shows as many ralys formed by these spines as there are ribs. Flowers yellowish green, always low down on the plant, forming a circle round the stem; flowers an inch long, funnelshaped, not fully opening even in the bright sunshine; 
fruit $6^{\prime \prime}$ or less in thickness, crowned with the conic remains of the flower; stamens very numerous (Mr. Wright counted 400), half as long as the petals; stigmata green, much exsert.-Dr. Engelmann.

C. Dasyacanthus. Stems $5^{\prime}-12^{\prime}$ high, $2^{\prime}-4^{\prime}$ in diameter, densely covered by the innumerable ashy-gray or reddish spines; lower lateral spines somewhat bulbous and compressed at the base, $6^{\prime \prime}-7^{\prime \prime}$ long, upper ones $3^{\prime \prime}-4^{\prime \prime}$, and lower ones 5 "long; upper central spines shorter than the lower ones-these are stoutest and of about the length of the lowêr external spines, or a little longer; flowers large and numerous, from the upper axillæ of the past year's growth; flowers 3' long, and of the same diameter, very showy, externally greenish yellow, with the center of the sepals red; petals bright yellow; stanens (counted by $\mathrm{Mr}$. Wright, over 1700) with yellowish-green filaments; pistil stout; stigmata thick, erect; flower opening only in bright sunshine, about middle of the day, closing in the afternoon, but reopening the next, or even the third day; fruit subglobose, $1^{\prime}-1 \frac{1^{\prime}}{2}$ in diameter, green or greenish purple; when fully ripe, "delicious to eat, much like a gooseberry." Western Texas.-Engelmann.

C. CAsPitosus. This species has 12-18 ribs, 20-30 radial spines, rarely with 1 or 2 central ones here and there; fiowers 2 '-3' in diameter; petals sometimes though rarely curly; stigmata $12-18$; fruit $9^{\prime \prime}-10^{\prime \prime}$ long, oval, generally bursting irregularly; flower-tube covered with darkish wool and slender bristles. Western Texas.-Engelmann.

C. Dubius. Stems 5'- $8^{\prime}$ high, pale green color and soft flabby texture; ribs few, broad; grooves shallow; radial spines $6^{\prime \prime}-12^{\prime \prime}$ or $15^{\prime \prime}$ long, lower ones longer than the upper ones; flowers $2 \frac{1}{2}$ ' long, of the same diameter; petals few and only $6^{\prime \prime}$ wide, rose-color, and mostly quite obtuse and almost entire; fruit $1^{\prime}-1 \frac{1}{2}^{\prime}$ long, with $20-24$ pulvilli, 
on each of them 9-12 bristly spines $4^{\prime \prime}-9^{\prime \prime}$ long. Rio Grande.-Engelmann.

C. Patcispinus. Stem $5^{\prime}-9^{\prime}$ high, $2^{\prime}-4^{\prime}$ in diameter, not cæspitose, but either simple or with few branches from near the base; ribs few, grooves wide and shallow; areoloe $8^{\prime \prime}-10^{\prime \prime}$ apart; spines few and dark-colored, $9^{\prime \prime}-15^{\prime \prime}$ long, upper one often shorter, and central spine when present 15"-20"long; flower not described.-Engelmann.

C. Berlandieri. A spreading procumbent plant, with erect branches contracted at the base, and thereby articulated, $1 \frac{1^{\prime}}{2}-6^{\prime}$ long, $\frac{3^{\prime}}{4}-1^{\prime}$ thick, either terete with distinct spirally-disposed tubercles, or the tubercles arranged in $\mathbf{5}$ or 6 ribs; areoloe $4^{\prime \prime}-6^{\prime \prime}$ apart; radial spines bristle-like (weaker than C. procumbens), $4^{\prime \prime}-5^{\prime \prime}$ long, sometimes a stouter and darker one at the upper end of the areolæ; central spine yellowish brown, shorter on the lower part of each branch, longer toward the top, from $5^{\prime \prime}-6^{\prime \prime}$ to $10^{\prime \prime}-13^{\prime \prime}$ in length; flower $3^{\prime}-4^{\prime}$ long, or when fully open spreading 'almost 4 ', and only $2^{\prime}$ in height; bristles of the tube below $2^{\prime \prime}-3^{\prime \prime}$, upward $4^{\prime \prime}-6^{\prime \prime}$ long, the tomentum white and short; petals lorig and narrow, $3^{\prime \prime}-4^{\prime \prime}$ or rarely $5^{\prime \prime}$ wide, bright rose-purple; filaments short, pale rose-colored; stigmata long and sub-erect; berry $9^{\prime}$ long, densely covered with the elongated mottled hairlike spines. Named for Dr. J. L. Berlandier, who found it on the lower Rio Grande. Native of Southern Texas.-Emory's Reports.

C. PRocumbens. Similar to the last, but more slender; branches $\frac{1}{2}^{\prime}-3^{\prime}-4^{\prime}$ in length, $6^{\prime \prime}-8^{\prime \prime}$ in diameter; tubercles $4^{\prime \prime}-5$ " apart, in 4 rows when the branches appear quadrangular, or in 5 rows when they are more terete; radial spines $1^{\prime \prime}-2^{\prime \prime}$ long, central one or lower part of joint wanting, or hardly longer than the radial ones, on the upper part $2^{\prime \prime}-4^{\prime \prime}$ wide; fruit $6^{\prime \prime}-8^{\prime \prime}$ long; seed compressed.Engelmann.

C. Tuberosts. Stem $1^{\circ}-2^{\circ}$ high, lower part ligneous, 
scarcely as thick as a quill; young branches $4^{\prime \prime}-8^{\prime \prime}$ in diameter; ribs very little prominent; areola $1^{\prime \prime}-2{ }^{\prime \prime}$ apart ; radial spines a line long or less; central spine $2^{\prime \prime}-3$ "long; in robust plants the entire spine is brown or black, rigidly erect; flower over ' 2 ' long and of the same diameter, opening for several days, but only in bright sunshine; ovary and tube covered with very woolly pulvilli in the axils of the reddish scales, with 6-8 long white or black bristles; petals rose-color or purple, $1^{\prime}$ long; fruit corered with long wool and black and white bristles. Rio Grande.-Dr. Engelmann and Dr. Poselger.

C. vartablis, Pfeiff. Tall species, $3^{\circ}-10^{\circ}$ high ; fullgrown stems 3-4-angled, with few and stout spines; but young shoots with 8 ribs and numerous slender spines; flowers white, nocturnal ; fruit oral, about 3 ' long, spinose, crimson externally and internally; seed obliquely obovate. Southern Rio Grande.

C. GregGir. Root a dirty, large, fleshy tuber, often $4^{\prime}-6^{\prime}$ in diameter, and about $6^{\prime}-10^{\prime}$ long, generally. producing but one stem $2^{\circ}-3^{\circ}$ high, with erect branches; stem thin at base, rather terete and ligneous, upward $99^{\prime \prime}-12^{\prime \prime}$ in dianeter, usually 4-5-angled. 'The acute ribs at first sight seem crenulate, the pulvinate areolæ being separated by a slight depression, and the spines being scarcely risible without close examination ; areoloe $1^{\prime \prime}-1 \frac{1}{2}$ "long; spines remarkably short, and from a disproportionately thick base, only $1^{\prime}$ long; the 3 lowest spines are the longest, and run into a fine bristly point, often somewhat curved; ovary $9 "-12^{\prime \prime}$ long; whole flower $6^{\prime}-8^{\prime}$ long, about $2 \frac{1}{2}^{\prime}$ in diameter; bristles at base of the tube $1^{\prime \prime}-2^{\prime \prime}$, or upward $4^{\prime \prime}-6^{\prime \prime}$; berry orate, $1 \frac{1^{\prime}}{2}$ long, $1^{\prime}$ in diameter. Stem always triangular, of a reddish-brown color-Engelmann.

C. VAsMerir. Calyx-tube prolonged; three rows of sepals, the outside row greenish white, segments long and narrow, lanceolate, acuminate; stamens long, the upper 
ones much exserted, rising in a long funnel-shaped tube above the corolla ; stignia 6 -cleft; flower 9 inches long, and 6 in diameter; calyx-tube smooth, with a very few minute spines at the base, and a few imbricated scales scattered at intervals from base to summit, where they form a petallike crown supporting the pure white corolla. Stem $3^{\circ}-4^{\circ}$ high, sometimes 4-angled at the base, but upper joints 3 -angled, narrow at the base; whole plant rather recumbent; spines few, in clusters of 7 , six 4 lines long, the seventh about 1 ' long, curved upward; flower white, very fragrant, vesperine, blooming but once. On hills near La Grange. Introduced into gardens by Mrs. T. W. House; named for Mrs. Vasmer.-Author.

\section{OPUNTIA, Tourn. Prickly Pear.}

Sepals and petals not united into a tube; stamens inserted into the base of the petals; style cylindrical ; stigma 3-8-lobed; seeds with thin albumen; stems with flat or rarely cylindrical joints; leaves fleshy, with tufts of bristly hairs and commonly strong spines in their axils, deciduous.

O. VULGaRIS. Stem prostrate; joints oborate, pale; spines few and short; fruit nearly smooth.

O. STENopetala. Joints $7^{\prime}-8^{\prime}$ in diameter, pulvilli about $11^{\prime}$ or $1 \frac{1}{2}$ apart on the surface, much crowded toward the edges, with much dirty-white wool, short dark-brown bristles, and very dark, almost black spines, lighter at the tip; the stouter spines $1 \frac{1}{2}-2^{\prime}$ long, flat on the upper, rounded on the lower surface, often much covered; ovary $9^{\prime \prime}$ long; leaves or sepals on the tubercles deciduous, very slender, $2^{\prime}-2 \frac{1}{2}^{\prime}$ long; sepals and petals $4^{\prime \prime}-6^{\prime \prime}$ long, not more than $1^{\prime}$ long at the base, very slender, acuminate, fleshy; sepals greenish red, petals orange; stamens rumerous, half as long as the petals; style very much inflated in the middle, 
with a single pointed stigma. Lower Rio Grande. Dr. J. Gregg described it in 1848.

O. STrigil. Stems $2^{\circ}$ high, pale green; joints covered with numerous pulvilli, each with a bunch of bright redbrown spines, paler at the tip, which gives the plant a very showy appearance; joints $4^{\prime}$ or $5^{\prime}$ long, $3^{\prime}-4^{\prime}$ wide; spines $5-8$; flower not described; fruit $6^{\prime \prime}-7^{\prime \prime}$ long and about $6^{\prime \prime}$ thick. Around San Antonio.

O. Engelyannir. A stout coarse-looking plant, $4^{\circ}-6^{\circ}$ high; lower part of the old stems woody, with loosely reticulated ligneous fibers, and with a gray back often covered with lichens about $6^{\prime}$ in diameter; joints in larger species $1^{\circ}$ long; flowers $2^{\prime}-3^{\prime}$ in diameter; ovary short; petals comparatively narrow and not emarginate. Ovary $1 \frac{1}{4}$ ' long; fruit sub-globose, dirty purplish; pulp bright purple; insipid and even nauseous taste. New Braunfels. -Dr. Lindheimer.

O. Mricrorhiza. Roots large, tuberous; flower-bud long-acuminate, and the stigmata always 5. Austin and San Antonio.-Dr. Lindheimer.

\section{MAMMILARIA.}

'Tube of the calyx adherent to the ovary; the lobes 5-6, crowning the young fruit, colored; petals 5-6, scarcely distinct from the calyx, longer than the sepals and united with them into a tube; stamens filiform, in several series; styles filiform; stigma 5-7-cleft, radiate; berry smooth. Plant roundish or somewhat cylindrical, destitute of a woody axis, often with a somewhat milky juice, covered with conical or mammæform crowded spirally-disposed tubercles, which bear deciduons spines and tomentum at their extremity; flowers sessile among the tubercles, usually in a transverse zone.-De Canclolle. 
M. 'Texana. Heads $1^{\prime}-1 \frac{1}{2}$ in diameter, $1^{\prime}-2 \frac{1}{2}$ ' high, usually covered below with young branches, and finally densely crespitose; tubercles $3^{\prime \prime}-4^{\prime \prime}$ long, dark green; axille quite woolly, with several coarse twisted bristles mixed with the wool; exterior hairlike spines covering the whole plant as with a coarse wool, often $6^{\prime \prime}-8^{\prime \prime}$ long, whitish, with dark tops, in robust ones yellow at base, brown upward, and almost black at top; flowers " $7 "-10^{\prime \prime}$ long. Along the Rio Grande.-Dr. Poselger.

M. SPH.erica. Plants $2^{\prime}$ long, $1_{\frac{3}{4}}{ }^{\prime}$ in diameter above, narrowed below, the old tubercles withering and leaving a short clavate scaly stem; ovary exsert; flowers quite large. The tubercles soon become proliferous, and the branches increase and reproduce often in such a manner as to form large and hemispherical masses. Tubercles $6^{\prime \prime}-8^{\prime \prime}$ long; spines $3^{\prime \prime}-4^{\prime \prime}$ long; flowers $1 \frac{1}{2}-2^{\prime}$ in length, and fully as widely open in bright sunshine; tube slender, funnel-form, remarkably constricted above the oval ovary. On Gulf prairies.

\section{ECHINOCACTUS, Link and Otto.}

Sepals numerous, imbricated, adnate to the base of the ovary and united in a very short tube, the exterior involucriform, the inner petaloid; stamens numerous; style filiform, many-cleft at the apex; berry somewhat squamose with the vestiges of the sepals.-Plant simple, ovate or globose, leafless, with alternate vertical ribs and furrows, the former bearing fascicles of spines; spaclix none; flowers from the clusters of spines at the summit of the ribs, similar to those of Cerus, but with scarcely any tube.-De Candolle.

E. Texensis, Hoepf. Fruit red and juicy, drying up very soon ; seeds 1-2-1-4 lines long, somewhat reniform, with a deep indentation including the circular hilum; testa 
smooth and shining, indistinctly tuberculated; embryo curred or hooked, with the foliaceous cotyledons buried in the large albumen.-Dr. Engelmann.

E. BICOLOR. Stem 4'-6' high, 2'-3' in diameter; groores rather shallow; floral areolce close to the spiniferous one, without the intervening glands which are so conspicuous in some other species; the 4 upper radial spines about an inch long and flat; all the others rounded, red, paler at both ends; the lowest is the weakest and shortest one, and often somewhat curved; upper central spine $15^{\prime \prime}-20^{\prime \prime}$ long, the 3 others shorter; the lower one flat above, rounded below, often reddish like the lower radial spines; flower between $2^{\prime}$ and $3^{\prime}$ long; petals bright purple or rose-purple, gradually paler in fading; filaments springing from the whole tube down to its base.-Engelmann.

E. viridescens, Nutt. One foot high, $9^{\prime}-10^{\prime}$ in diameter; they are usually simple, but sometimes they branch from the base, forming quite a pile of prickly balls; flowers disposed in a circle around the rertex, greenish, $1 \frac{1}{2}$ long, $1 \frac{1^{\prime}}{4}$ in diameter, tube inside naked at the base; stamina short; style 1' long, more deeply dirided than in other species; fruit $\mathrm{S}^{\prime \prime}-10^{\prime \prime}$ long, of the shape and taste of a gooseberry, bluish green ; radial spines $18-20$, about $6 "-88^{\prime \prime}$ long; central spine about $18^{\prime}$ long.

\section{CURRANT FAMiLY. Order, Grossulacex.}

Spiny or unarmed shrubs, with alternate palmately reined and lobed leares, without stipules, and with axillary racemose or clustered flovers; calyx-tube adherent to the orary, the limb 5-lobed; petals 5, small; stamens 5 ; ovary 1-celled, with 2 parietal placentæ; styles more or less united; fruit a 1-celled, many-seeded berry; seeds anatropous, with the minute embryo at the base of hard albumen. 


\section{RIBES, L. Currant; Gooseberry.}

Character of genus same as order.

R. AUreum. Plant smooth; leaves 3-lobed, lobes divaricate, entire or with a few large teeth; petioles longer than the leaves; bracts linear, as long as the pedicels; racemes lax, with many bright-yellow flowers ; calyx tubular, longer than the pedicels, segments oblong, obtuse; petals linear; fruit smooth, oblong or globous, yellow, finally brown.A beautiful shrub, 6-10 feet high; flowers numerous, very fragrant. Red River-Marcy.

\section{LOASA FAMILY. Order, LOASACEx.}

$H e r b s$, commonly armed with bristly barbed and stinging hairs; leaves alternate, exstipulate; flowers solitary or clustered; caly $x$-tube adherent to the 1-celled ovary, the limb 5-parted and persistent; petals 5 or 10 , inserted on the throat of the calyx; stamens mostly indefinite, in several parcels, inserted with the petals; styles united; capsule irregularly dehiscent; seeds few or many, borne on 3-5 parietal placentæ, commonly with scanty albumen.

\section{MENTZELIA, Plum.}

Calyx-tube cylindrical or club-shaped; petals convolute in the bud; stamens commonly 30 or more, the exterior ones often dilated and sterile; styles 3 , united to the middle; capsule 3 -valved at the summit, with 3 parietal placentæ; cotyledons broad and flat. Stems branching; leaves toothed or sinuate-pinnatifid; flowers yellow.

M. oligosperma, Nutt. Flowers deep golden-yellow, $8^{\prime \prime}-10^{\prime \prime}$ in diameter, expanding in sunshine, evanescent; leaves lanceolate-ovate, often acuminate, on rery short petioles, cuneate at the base, incisely toothed or somewhat 
lobed; petals cuneate-oblong, cuspidate, entire, a. little longer than the numerous stamens; capsule very narrow, about 3 -seeded; seeds linear oblong.-Giray and Torrey.

M. NCDA. Rough with minute barbed pubescence; leaves somewhat lanceolate, interruptedly pinnatifid, the segments obtuse; flowers large, terminating the branches, not bracteolate; petals 10 ; stamens very numerous; the exterior filaments petaloid and often sterile, the other filiform; capsules 3-ralved at the summit; seeds numerous, winged. Witchita River.-Marcy.

\section{TURNERA FAMILY. Order, TerNerace.e.}

Sepals united into an equal 5-lobed calyx, imbricated in æstiration; petals 5, equal, inserted on the calyx, with a twisted æstivation; stamens 5, alternate with the petals and inserted below them, distinct; anthers intorse; ovary free from the calyx, 1-celled, with 3 parietal placentæ; orules numerous; styles 3 , commonly branched; capsule 3 -ralved, loculicidal; seeds numerous, anatropous, with a membranaceous arillus on one side.-Herbaceous or sometimes suffrutescent plants; peduncles 1-flowered; petals yellow.

\section{PASSION-FLOWER FAMILY. Order, PASSIFLORACEA.}

Climbing herbs or shrubs, with alternate mostly stipulate leares, and axillary often showy flowers; calyx of 4-5 more or less united sepals, commonly bearing at the throat 4-5 petals, and a crown of slender filaments in one or more rows; stamens 4-5, monadelphous below and enclosing the stipe of the ovary; ovary 1-celled, with 3-4 parietal placentre; styles $3-4$, clarate; fruit fleshy or baccate; seeds numerous, anatropous, included in a pulpy sac; embryo in the axis of fleshy albumen. 


\section{PASSIFLORA, L. Passion-Flower; May-Pop.}

Calyx-tube very short; filaments of the crown in 2 or more rows; fruit baccate; tendrils axillary; peduncles jointed, 1-flowered.

P. incarnata, L. Leaves palmately 3-lobed, acute, serrate; petioles biglandular; peduncles 3 -bracted; sepals with a hornlike point below the apex, whitish within; filaments of the crown in about 5 rows, the two outer ones as long as the sepals; berry large, oval; fruit yellowish, as large as a hen's egg; flowers purple and white; perennial.

P. LUTEA, L. Leaves cordate, broadly 3-lobed at the summit, with the lobes rounded and entire; petioles glandless; flowers small, greenish-yellow; peduincles by pairs, bractless; filaments of the crown in 3 rows, shorter than the sepals.

\section{GOURD FAMILY. Order, Cucurbitace..}

Herbs, with succulent stems, climbing by means of lateral tendrils; leaves alternate, palmately veined or lobed; flowers axillary, monœcious or diœcious; calyx 5-toothed, adnate to the ovary; corolla of 5 distinct or more or less united petals, coherent with the calyx; stamens $3-5$, free or variously united; anthers long, straight or tortuous, commonly connate; ovary 1-3-celled; stigmas 3 ; fruit (a pepo) fleshy or pulpy, 1-3-celled; seeds compressed, anatropous, without albumen; cotyledons leafy.

\section{SYNOPSIS.}

Petals 5, distinct or united at the base. Ovary 3-celled. Fruit 3-seeded, smooth.

Brronia.

Petals 5, united at the base into a flattish nearly rotate corolla. Ovary s-celled.

Fyuit fleshy, echinate, 3-6-seeded......................... Discanthera.

Petais 5, united at the base, a rotate corolla. Ovary 1-celled. Fruit 1-seeded,

hispid.............................................. Sicros. 


\section{BYRONIA, L.}

Flowers monœcious or diœcious; calyx 5-toothed; petals 5 , distinct, or united at the base; stamens 5 , triadelphous; anthers tortuous; style mostly 3-cleft; fruit ovate or globose, smooth, few-seeded.

B. Bочкіміr, Torr. and Gray. Rough pubescent; leaves broadly cordate, 3-5-lobed, the lateral lobes entire or toothed, the middle one cuspidate; sterile and fertile flowers intermixed, 3-5 in a cluster, short pediceled; styles united; fruit 3 -seeded, the seed 3 -toothed at the base; flowers greenish white; berry crimson.

\section{DISCANTHERA, Torr. and Gray.}

Flowers monœcious.-STERILE FLowers: Caly $x$ obsolete; petals 5, ovate, united at the base into a flattish nearly rotate corolla; stamens 2 ; filaments very short, connate; the anthers forming a flat peltate disk, opening all around the even continuous margin, both superior and inferior surfaces furnished with a minute ciliate fringe; disk and rudiment of the ovary none.-FERTILE FLOwERS: Calyx produced beyond the ovary into a filiform tube, the teeth obsolete; petals nearly as in the sterile flowers; rudimentary stamens none; disk none; ovary 3 -celled, with apparently about 6 erect or ascending ovules; seeds $3-4$ or 6 , large, flat.-A slender trailing or climbing herb, with pedately dissected leaves and simple tendrils; flowers white, very small; the sterile in filiform often somewhat compound racemes, the fertile ones solitary in the same axil on short peduncles.

D. Dissecta. Stems slender; leaves ternately divided, the divisions attenuated and linear at the base, or petiolnlate, the petiolules slightly margined; the terminal division 3-parted; the lobes irregularly toothed or sinuate, the 
middle one oblong, conspicuously mucronate; the lateral ones shorter, and often 2-3-lobed; lateral divisions 2-parted; the segments deeply 2-3-lobed, and sinuate-toothed; sterile racemes as long as the leaves; flowers scarcely on short pedicels ; peduncle of fertile flowers scarcely as long as the fruit; ovary 3-celled, ovules erect from near the base of the cell; the young fruit thickly clothed with long, weak, and soft smooth prickles._Drummond.

\section{SICYOS, L.}

Flowers monœcious; calyx flattish, with 5 subulate or minute teeth; petals 5 , united below in a rotate corolla; stamens 5, monadelphous or triadelphous; ovary 1-celled, 1-ovuled; style slender; stigma 3; fruit membranaceous, bristly, 1-seeded.-Annual herbs; sterile and fertile flowers mostly from the same axil.

S. ANGulatus, L. Plant hairy and clammy; leaves thin, cordate, with 3-5 acuminate denticulate lobes; sterile flowers racemose; the fertile ones in peduncled clusters, whitish.

\section{SURIANA FAMILY. Order, Surianacex.}

A downy shrub, with alternate crowded exstipulate leaves, and perfect yellow flowers, in small axillary bracted racemes; calyx 5-parted, persistent, the base filled with a fleshy torus, which bears the ovaries, petals, and stamens; petals 5, oblong-obovate; stamens 10, hairy, the alternate ones short and sterile; ovaries 5 , distinct, with 2 erect collateral orthotropous ovules in each ; styles 5 , each arising from the central angle of the ovary near the base, thickened upward; carpels 1-seeded, indehiscent; seeds without albumen; embryo hooked. 


\section{ORPine faimly. Order, Crassulacee.}

Succulent herbs, with exstipulate leaves, and regular, perfect and mostly cymose flowers; sepals 3-20, more or less united at the base, persistent; petals as many as the sepals, inserted on the base of the calyx, imbricated in the bud, rarely wanting; stamens as many or twice as many, inserted with the petals; ovaries as many as the sepals, separate or united below; carpets several-seeded, opening along the inner suture; seeds anatropous; embryo straight, in their albumen.

\section{SYNOPSIS.}

Carpels distinct. Sepals 4-5. Stamens $8-10 \ldots \ldots \ldots \ldots \ldots \ldots \ldots . . . \ldots \ldots$ SEDUM.

- united at the base. Sepals 4. Stamens $8 \ldots \ldots \ldots \ldots \ldots \ldots$ DuArorpHA.

_ united above the middle. Sepals 5. Stamens $10 \ldots \ldots \ldots . .$. Pentrorum.

\section{SEDUM, L. Orpine; Stone Crop.}

Sepals 4-5; stamens 8-10; carpels distinct, many-seeded, with an entire scale at the base of each.-Herbs, smooth and fleshy.

S. PULChELluM. Stems ascending $\left(4^{\prime}-12^{\prime}\right.$ long); leaves very numerous, alternate, linear, obtuse; cyme composed of several recurved or spreading branches; flower's pale purple; sepals much shorter than the petals; stamens 8, those of the central flowers mostly 10 ; carpels tapering into the long and slender style.

\section{PENTHORUM, Gron.}

Sepals 5; petals 5 , often wanting; stamens 10 ; carpels 5 , united into a 5-celled capsule, spreading at the summit, which falls away at maturity; seeds numerous.-Perennial herbs, with alternate serrate leaves, and yellowish flowers on one side of the revolute branches of the simple cyme. 
P. SEdordes, L. Stem erect, $1^{\circ}-2^{\circ}$ high ; leaves lanceolate; petals commonly none. Ditches and muddy places.

\section{5\%. 9AXIFRAGE FAMilY. Order, Saxifragaced.}

Calyx of 4-5 more or less united sepals, free, or more or less adherent to the ovary, persistent; petals as many as the sepals, rarely wanting; stamens as many, or 2-4 times as many, inserted with the petals on the calyx; ovaries 2 or sometimes 3-4, commonly united below, and separate at the summit; seeds few-many; embryo straight, in the axis of fleshy albumen.

\section{SYNOPSIS.}

Sub-order I. Saxifrageæ. Herbs. Petals imbricated in the bud. Stipules adnate to the petiole, or none.

* Stamens twice as many as the sepals.

+2 -celled.

Flowers perfect. Stamens 10. Leaves entire or lobed

Saxifraga. t+ Capsule 1-celled.

Stamens 10. Petals 5, entire.

TIARELLA.

10.

$\mathbf{5}$, pinnatifid

Mitella.

- 8-10.

none

Chrysoplentum.

Sub-order II. Hydrangieæ. Shrubs. Petals valvate or convolute in the bud. Leares opposite. Stipules none.

Petals valvate. Stamens 8-10. Styles distinct...................... HYDRANGEA.

- convolute. - 20 or more. Styles 4. Capsule 4-valved.... PhInAdELPHus.

\section{SAXIFRAGA, L. SAXifrage.}

Calyx free, or cohering with the base of the ovary, deeply 5-cleft; petals 5, commonly deciduous; stamens 10 ; styles 2 ; capsule 2-celled, 2-beaked, opening between the beaks; seeds numerous, smooth; lowest leaves clustered. 
Stem naked, scape-like.

S. Virginiensis, Michx. Pubescent; leaves somewhat fleshy, obovate, crenately or sharply toothed, abruptly contracted into a slender petiole; scape slender; panicle loosely flowered; sepals spreading, half as long as the lanceolateoblong, white, faintly-spotted petals ; filaments filiform.

Saxifraga (Micranthis) Texana, Buckley. Leaves all radical, glandular pubescent, obovate, entire, shortly and broadly petiolate; stem simple, slightly pubescent; bracts linear or subspathulate; flowers cymose paniculate; sepals ovate, subacute; petals spathulate-obovate, little longer than the calyx. Stems 4-6 inches high; leaves nearly sessile, and, including petiole, $\frac{3}{4}-1$ inch long, obtuse, and about an inch wide.

\section{TIARELLA, L. False Mitrewort.}

Calyx campanulate, nearly free from the ovary, 5-parted; petals 5, entire; stamens 10 ; styles 2 ; capsule membranaceous, 2-valved, the valves very unequal, 1-celled, fewseeded; seeds globular, smooth.-Perennial herbs, with scape-like stems, chiefly radical and petioled leaves, and small racemose flowers.

T. condifolia, L. Leaves round-cordate, crenately or acutely lobed and toothed, hairy above, pubescent beneath, on long hairy petioles; scape $\left(6^{\prime}-12^{\prime}\right.$ high $)$ naked, or bearing 1-2 alternate leaves above the middle; racemes simple or branched, many-flowered; petals oblong, white or purplish.

\section{Mítella, Tourn. Mitrewort.}

Calyx coherent with the base of the orary, 5 -cleft; petals 5, pinnatifid; stamens 10; styles 2; capsule 2-beaked, 1-celled, 2-valved at the apex, many-seeded; seeds smooth, 
borne on two parietal placentæ.-Perennial herbs, with broadly cordate and lobed leaves, and small flowers in a terminal raceme.

M. DIPHYLLA, L. Hairy; radical leaves cordate, acute, coarsely serrate and slightly 3 -lobed, on long petioles; stemleaves 2 , opposite, sessile; raceme slender, loosely manyflowered. Shady woods. Stem $6{ }^{\prime}-12^{\prime}$ high; flowers white.

\section{CHRYSOSPLENIUM, Tourn. Golden Saxifrage.}

Calyx-tube coherent with the ovary, 4-5-lobed, the lobes obtuse and yellow within; petals none; stamens $8-10$, very short, inserted on a conspicuous disk; styles 2; capsule very short, 2-lobed, 1-celled, with 2 parietal placentæ, 2-valved at the apex, many-seeded.-Smooth and succulent herbs, with roundish leaves, and axillary flowers.

C. Americanum, Schweinitz. Stems prostrate, forking; leaves mostly opposite, roundish, slightly lobed; flowers. solitary, greenish; perennial.

\section{HYDRANGEA.}

Calyx-tube hemispherical, 8-10-ribbed, coherent with the ovary, the limb 4-5-toothed, persistent; petals ovate, valvate in the bud; stamens 8-10, filiform; capsule crowned with the 2 diverging styles, 2-celled, many-seeded, opening at the apex between the styles.-Erect shrubs, with opposite petioled leaves, without stipules, and whitish or purplish flowers, in ample compound cymes; the marginal flowers mostly sterile, with the calyx-lobes enlarged and showy.

H. ARborescens, L. Smoothish; leaves ovate, acute or acuminate, serrate, mostly rounded or cordate at the base; cymes crowded, flat-topped; sterile flowers few or none.Shrub, $4^{\circ}-8^{\circ}$ high ; leaves $3^{\prime}-6^{\prime}$ long. 
H. radiata, Walt. Leaves ovate, acuminate, serrate, mostly cordate at the base, white-tomentose beneath; cymes flat-topped; sterile flowers few.-Shrub, $4^{\circ}-8^{\circ}$ high.

H. QUerchfolis, Bartram. Young branches and leaves densely tomentose; leaves oval, sharply 5-lobed, serrate; cymes clustered, forming a close oblong panicle; sterile flowers large, numerous. Shady banks. -Shrub, $3^{\circ}-6^{\circ}$ high; leaves $4^{\prime}-8^{\prime}$ long; sterile flowers whitish, turning purple.

\section{PHILADELPHUS, L. Syringa.}

Calyx-tube turbinate, cohering with the ovary, the limb 4-5-parted, persistent; petals 4-5, convolute in the bud; stamens 20-40, shorter than the petals; styles mostly 4, more or less united; capsule mostly 4-celled, loculicidally 4-valved, many-seeded.-Shrubs, with simple opposite 3-5ribbed leaves, without stipules, and large white solitary or cymose flowers.

P. GRANdiflorus, Willd. Branches and leaves pubescent; leaves ovate or ovate-oblong, acuminate, sharply serrate; flowers solitary, or 2 or more in a terminal cyme; calyx-lobes ovate, acuminate, much longer than the tube. Banks of streams, April and May.-Shrub, $6^{\circ}-10^{\circ}$ high, with long and slender branches.

\section{WITCH-HAZEL FAMILY. Order, Hamamelaceæ.}

Trees or shrubs, with alternate leaves, deciduous stipules, and clustered or spiked often polygamous or monœcious flowers; calyx-tube coherent with the base of the ovary; petals 4-5, long and linear, or none; stumens twice as many as the petals, with the alternate ones sterile, or numerous and perfect; styles 2; capsule woody, 2-celled, 
opening at the summit; seeds anatropous, bony, 1-2 in each cell; embryo large and straight, in scarce albumen.

\section{SYNOPSIS.}

Calyx-lobes and petals 4. Fertile stamens 4. Ovules solitary in each cell, suspended. HAMAMELIS.

Calyx and corolla none. Flower's polygamous or monocious, capitate. Slamens numerous. Ovules several............................LIQUidasBar.

\section{HAMAMELIS, L. Witch-HAZEL.}

Calyx 2-3-bracted, 4-parted; petals 4, long and linear; stamens 8 , the alternate ones short and sterile; styles 2 ; capsule loculicidally 2 -ralved at the apex, the outer coat separating from the inner one, which encloses the seed, but soon splits elastically into 2 valves; seeds large, bony.Shrubs; leaves short-petioled; flowers yellow, clustered.

H. Virginica, L. A large shrub; leaves obovate or oval, oblique, crenate-toothed, pubescent; flowers appearing when the leaves are falling.

\section{IIQUIDAMBAR, L. SWEET-GUM.}

Flowers monœcious, in globular 4-bracted spiked heads; calyx and corolla none; stamens very numerous; styles 2 ; ovary 2-celled, with numerous ovules in each cell; capsule united in a close head, woody, 2-beaked, opening between the beaks, 1-2-seeded; seeds wing-angled.-Trees; heads of sterile flowers sessile, crowded, those of the fertile flowers on long nodding peduncles.

L. STYRACIFLUA, L. Branches with corky wings; leaves roundish, with 5-\% acuminate serrate spreading lobes. $-A$ large tree. The exposed juice hardens into a fragrant gum. 


\section{PARSLEY FAMILY. Order, UMBELLIFER}

Herbs, with chiefly hollow and furrowed stems, alternate mostly compound leaves, with dilated or clasping petioles, and umbelled flowers; calyx-tube coherent with the orary, the limb 5-lobed or obsolete; petals 5, mostly incurved, inserted with the 5 stamens on the edge of the disk that crowns the ovary; styles 2 . Fruit composed of 2 indehiscent carpels (mericarps), suspended from a filiform axis (carpophore), and cohering by their inner face (commissure), each furnished with 5 primary ribs, and often with as many secondary ones, the interrening spaces (intervals) usually containing channels (vittco), which are filled with aromatic oil. Seed solitary, suspended; embryo minute, at the base of horny albumen; umbels and partial umbels (umbellets) commonly subtended by an involucre or involucel.

\section{SYNOPSIS.}

\section{\$1. Inner face of the seed flat, or nearly so.}

* Umbels simple, or one growing from the summit of another; stems creeping.

Fruit orbicnlar, flattened. Leaves rounded.................. H PDROCOTYLE.

Fruit globular. Leaves linear, fleshy...........................

** Umbels capitate; flower sessile.

Frait bristly, globular. Flowers polygamous. Involucel none... .... SAxicula.

Fruit scaly, turbinate. Flowers perfect, bracted. Heads involuceled.. Enrrarox.

**** Umbels compound; flowers pediceled.

+ Fruit with bristly ribs, the bristles in a single rono.

Fruit 9-ribbed. Leaves finely 2-3-pinnate. Davecs.

t+ Fruit smooth or slightly roughened.

$\ddagger$ Fruit wingless, laterally compressed, or twin.

Flowers white. Fruit subglobose. Calyx-limb 5-toothed............... Crcuta.

Flowers white. Fruit oblong. Calyx-limb obsolete. Dirisions of the leaves

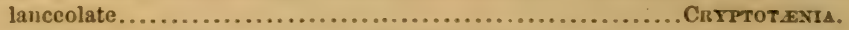

Flowers white. Fruit ovate, rough. Calyx-limb obsolete. Divisions of the leaves filiform. LEPTOCACLI8. 
Flowers white. Fruit ovoid. Calyx-limb 5-toothed. Divisions of the leaves

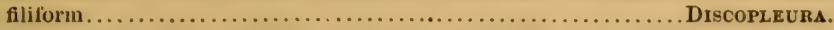

Flowers white. Fruit oblong. Calyx-limb obsolete. Involucre 1-3-leaved, or

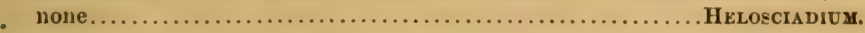

Flowers white. Fruit globose. Calyx-teeth minute or none. Involucre 5-6-leaved.

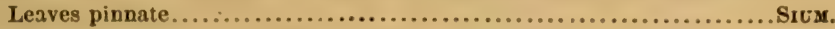

Flowers yellow. Fruit ovoid-oblong. Leaves simple............. BUPI.Eurum.

Flowers yellow. Fruit ovoid-oblong, the intervals with 3 vittæ...........Zzra.

Flowers yellow or dark purple. Fruit ovoid or oblong, the intervals with single vittæ. Thaspium.

Flowers white. Fruit elliptical, with several vittæ in each interval. .Lreustrcum.

\section{¥ Fruit dorsally compressed, winged on the margins.}

I Margins of the fruit double-winged; flowers white; leaves pinnately compound.

Carpels 3-ribbed on the back, the intervals with single vittæ. ANGELICA. Carpels 3-ribbed on the back, the intervals with 2 or more vittæ...ARchaNeELICA. Carpels 3-winged on the back, the intervals with $2-3$ vittæ....... Conioserivum.

\section{Margins of the fruit single-winged.}

Fruit broadly-winged. Marginal wings remote from the 3 dorsal ones. Leaves

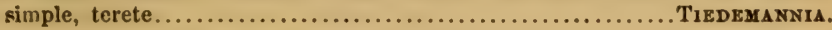

Fruit as in No. 19. Leaves pinnate or ternate. Archemora. Fruit with all the ribs equidistant. Marginal flowers sterile. Plant woolly.

Heracleum.

\section{§2. Inner face of the seed concave.}

Fruit linear-oblong, narrowed toward the apex. Cheroph YluUa. Fruit linear-clavate, narrowed toward the base Osmorrhiza.

\section{HYDROCOTYLE, Tourn. Marsh Pennywort.}

Calyx-teeth obsolete; petals not incurved; fruit laterally compressed, orbicular; carpels 5-ribbed, the dorsal and lateral ones often obsolete, the intermediate ones enlarged; vittae none.-Low marsh herbs, with slender creeping stems, and peltate or reniform leaves; umbels small, axillary; flowers white.

H. Americana, L. Smooth; leaves orbicular-reniform, crenately 7-lobed; umbels sessile, 3-5-flowered; fruit 2-ribbed; stems stoloniferous; leaves very thin, glossy. 
H. uMBELLATA, L. Smooth; leaves orbicular, peltate, obscurely lobed, crenate; umbels globose, on peduncles commonly longer than the petioles; fruit 2-ribbed on each side. Wet places. Leaves $1^{\prime}$ wide.

H. RANunculoides, L. Smooth ; leaves orbicular-reniform, crenately 3-5-lobed; umbels few-flowered, on peduncles much shorter than the petioles, mostly nodding in fruit; fruit obscurely ribbed. Springs and muddy places. Petioles $6{ }^{\prime}-12^{\prime}$ long; peduncles $1^{\prime}$ long.

H. INTerrupta, Muhl. Smooth; leaves orbicular, peltate, crenate; umbels proliferous, the nearly sessile clusters forming an interrupted spike; fruit strongly ribbed. Wet places. Petioles longer than the peduncles.

H. Repanda, Pers. Pubescent; leaves broadly ovate, truncate or slightly cordate at the base, glandular-serrate; umbels capitate, few-flowered, shorter than the petioles; fruit strongly ribbed. Low grounds.

\section{CRANTZIA, Nutt.}

Calyx-teeth obsolete; petals roundish; fruit globular; carpels 5-ribbed, the lateral ribs thickened and corky; vittce single in the intervals, with 2 on the commissure.-Small creeping marsh herbs, with fleshy linear leaves, and small whitish flowers in axillary umbels.

C. Lineata, Nutt. (Hydrocotyle lineata, Michx.) Muddy banks, near the coast. Leaves $1^{\prime}$ long, with cross partitions, narrowed toward the base, obtuse; involucre 5-6-leared.

\section{SANICULA, Tourn.}

Calyx 5-toothed, persistent; fruit globose, without ribs, armed with hooked prickles; the carpels not separating spontaneously, each with 5 vittæ.-Perennial erect branch- 
ing herbs, with palmately-divided long-petioled leaves, and polygamous flowers in small heads, disposed in a loose expanding cyme.

S. Marilandica, L. Leaves 5-7-parted, the divisions lobed and toothed; heads many-flowered; sterile flowers numerous on slender pedicels; styles long, recurved. Dry woods. Stem $2^{\circ}-3^{\circ}$ high.

S. Canadensis, L. Leaves 3-5-parted, the divisions lobed and toothed; heads few-flowered; the sterile flowers (1-3) nearly sessile ; styles short and straight. Dry woods, common. May. Stem $1^{\circ}-2^{\circ}$ high ; branches of the cyme long and spreading.

\section{ERYNGIUM, Tourn. Button Snakeroot.}

Calyx 5-toothed, persistent ; styles slender; fruit turbinate, covered with scales or tubercles, without ribs or vittæ. - Herbs, with spiny or bristly mostly lobed or toothed leaves, and white or blue bracted flowers, closely sessile, in dense heads.

\section{* Fruit scaly; stems erect.}

E. Virginianum, Lam. Leaves linear-lanceolate, flat, the lowest ones spiny-serrate with the teeth incurved, or nearly entire, veiny; the upper narrower, spiny or pinnatifid; leaves of the involucre (blue), 3-5-cleft, longer than the head; bracts 3-cleft, as long as the flowers. Perennial; stem $2^{\circ}-3^{\circ}$ high ; flowers blue.

E. VIRGatux, Lam. Leaves short, oblong or oblongovate, serrate, the upper ones toothed or divided; leaves of the involucre entire, or with $2-4$ bristly teeth, longer thian the head; bracts 3 -toothed; stem $1^{\circ}-2^{\circ}$ long; leaves $2^{\prime}-3^{\prime}$ long, sometimes cordate; flowers blue.

** Fruit granular ; stems diffuse.

E. BaLdwinit, Spreng. Small, prostrate, branching; 
leaves thin; the earliest ones orate, sharply serrate or toothed, long-petioled, the other 3-parted, with the middle segment lanceolate and commonly 3 -toothed; leares of the involucre subulate, longer or shorter than the oblong head; bracts spatulate, obtuse, barely exceeding the calyx. Annual; stems 5'-10' long; flowers blue.

E. DIFFCsLy. Leaves all sessile and palmately parted; segments oblong, incisely serrate and spinose; stem dichotomously branched, diffuse; heads subglobose, nearly sessile; leaflets of the involucre 4-6, 3-cleft, a little longer than the heads; scules lanceolate, entire. Witchita Mountains.-Marcy.

E. Coroxatem. Cauline leaves palmately 5-7-parted; dirisions pinnatifid-lancinate, with narrow spinose segments; leaflets of the involucre 9-12, lanceolate, entire, spiny at the tip, twice as long as the flowers; the terminal ones leafy and crowning the head; stem about $3^{\circ}-4^{\circ} \mathrm{high}$, with erect branches; cauline leares $2^{\prime}-4^{\prime}$ in diameter; heads $\frac{1^{\prime}}{2}$ in diameter, crowned with several foliaceous spinose-dentate scales; $\operatorname{caly} x$-tube clothed with acute resicular scales.-Drummond.

E. Leavexworthit. Stem stout, about $1^{\circ}-2^{\circ}$ high ; cauline leares palmately 5 -\%-parted, $2^{\prime}$ long; pecluncles $1^{\prime}$ long; heads, exclusive of crown, $1^{\prime}-1 \frac{1^{\prime}}{2}$ loug and nearly $1^{\prime}$ in diameter, the axis proliferous and bearing a tuft of leares at the summit resembling those of the involucre; caly $x$-lobes pinnatifidly $3-5$-cuspidate, clothed with obtuse scales; the heads and upper part of the stem usually of a bright violet-purple color.-Drummond.

E. AqLaticey, Linn. (Button Snakeroot.) Leaves broadly linear, with straight and simple parallel reins, remotely ciliate with soft spines; leaflets of the involucels mostly entire, shorter than the orate-globose pedunculate heads; scales entire. Variable in size and in breadth of 
leaves; sometimes scarcely $1^{\circ}$ high, with leaves $2^{\prime \prime}-3^{\prime \prime}$ wide; then again in farorable situations attaining the height of $4^{\circ}-6^{\circ}$, and the leaves $1^{\prime}-2^{\prime}$ in breadth; calyx-tube with acute scales.-Torrey and Gray.

E. Virginiaxum, Lam. Leaves linear-lanceolate and linear-uncinately-serrate; leaves of the involucre $7-8$, usually longer than the heads, 3-cleft or dentate-spiny; scales tricuspidate; stem $1 \frac{1}{2}^{\circ}-5^{\circ}$ high, cymosely branched, and often compound at the summit, fistulous; radical and lower cauline leaves usually $5^{\prime \prime}-10^{\prime \prime}$ wide, but sometimes rery narrow, tapering at each end; the teeth remote and indistinct; heads numerous, $\frac{3}{4}$ in diameter, pale blue or nearly white; calyx-tube imbricated with acute lanceolate vesicles.-Torrey and Gray.

\section{DAUCUS. CARROT.}

Calyx 5-toothed; corolla irregular; fruit oblong or ovate; carpels with 9 unequal bristly or prickly ribs, and a single vitta under the larger ribs.-Annual or biennial herbs, with pinnately finely-dissected leaves and involucre, and yellowish or white blossoms.

D. Pesillus, Michx. Stem rough with reflexed rigid hairs; leaves twice pinnate, with the divisions linear; bristles of the fruit barbed. Stem $1^{\circ}-3^{\circ}$ high ; umbels longpeduncled.

\section{CICUTA. WATER HEMLOCK.}

Calyx 5-toothed; carpels with 5 flattish equal ribs, the intervals with single vittæ, and 2 on the inner surface.Smooth perennial marsh herbs, with holiow stems, and twice pinnately or ternately divided leaves; involucels many-leaved; flowers white; fruit roundish. 
C. MACULATA, L. Stem large, $3^{\circ}-6^{\circ}$ high, purplish; leaflels orate-lanceolate, acute, coarsely serrate; umbels large, many-rayed. Marshes and low places. Very poisonous.

\section{LEPTOCAULIS, Nutt.}

Calyz-teeth obsolete; fruit orate, compressed on the sides, often rough or bristly; carpels 5-ribbed, the intervals with single vittæ, and 2 on the face.-Slender smooth herbs, with finely-dissected leaves and white flower's; umbels ferv-rayed; involucre none; involucel few-leaved.

L. DIVARICATCS, DC. Stem widely branched; leaves 2-3 pinnatifid, with the divisions filiform; umbel 3-4rayed; fiut very small, roughened with minute scales. Annual; stem $18^{\prime}$ high.

I. Diffeses, Nutt. Plant 8'-15' high, rery slender, with diraricate branches; rays of the umbel $1^{\prime}$ or $1 \frac{1}{2}{ }^{\prime}$ long; fruit roughened with minute tubercles, terminating in scales or branches; pecticels filiform, two-thirds as long as the rays of the umbel.-Drummond.

L. Patens, Nutt. Muricate with minute tubercles; rays of the umbel and umbellets (4-8) rery unequal, erect, spreading; stem $1^{\circ}-2^{\circ}$ high, branching abore; rays of the umbel $5^{\prime \prime}-10^{\prime \prime}$ long, of the umbellets $2^{\prime \prime}-4^{\prime \prime}$. $-D r$. Leavenworth.

L. echisatcs, Nutt. Fruit echinate with spreading nncinate bristles; rays of the umbel $\left(5^{\prime \prime}-6\right.$ " long) $4-6$, of the nmbellets $6-10$, slightly diverging.-Plant about a span high; fruit armed with stiff, whitish bristles, which are distinctly uncinate.-Drummond. 


\section{DISCOPLEURA, DC.}

Calyx-teeth subulate, persistent; petals ovate, entire, with a minute inflexed point; fruit ovate, somewhat didymous; carpels with the 3 dorsal ribs filiform, prominent, and rather acute, the 2 lateral ones united with a thin corky accessory margin; intervals with single vittæ; carpophore bifid; seed somewhat terete; leaves much dissected, with setaceous segments; leaflets of the involucre pinnately 3-5-parted, or nearly entire; flowers white-Annual, glabrous herbs.-Torrey.

D. NetTallir, DC.-Division of the leaves somewhat verticillate; involucre commonly less than half the length of the rays; the leaflets sometimes 3-cleft, those of the involucre mostly entire; umbels about 20-rayed; fruit rather broader than long. Plant erect.-Gray and Torrey.

D. CAPILlaCeA, DC. Umbels 3-10-rayed; leaves of the involucre mostly 3-5-cleft; fruit ovate. Stem $1^{\circ}-2^{\circ}$ high, much branched. Brackish marshes.

\section{THASPIUM, Nutt.}

Perennial herbs, with 1-2 ternately-divided leaves; involucre, none; flowers yellow or purple; calyx-teeth short or obsolete; fruit ovoid or oblong, somewhat flattish at the sides; carpels commonly equally and strongly 5-ribbed.

\section{Calyx-teeth obsolete.}

T. TRIFoliatuM, Gray. Stem $1^{\circ}-2^{\circ}$ high ; leaves crenate, the lowest usually simple and cordate, the others trifoliate; leaflets orate-lanceolate, obtuse at the base; fruit roundish, ribbed or winged; flowers yellow or dark purple. 


\section{TIEDEMANNIA, DC.}

Margin of calyx 5-toothed; petals broadly ovate, with a narrow, inflexed point; fruit much compressed dorsally, obovate; carpels with 5 filiform somewhat carinate approximated equal ribs, the lateral ones dilated into a membranaceous margin nearly as broad as the dorsal disk; intervals with single large vittæ; seed flat.-A glabrous biennial; fistulous stems, and leaves reduced to terete petioles; flowers white.

T. TERetifolia. Stem $2^{\circ}-6^{\circ}$ high, erect, fistulous, branching above; leaves or rather petioles $4^{\prime}-8^{\prime}$ long, $2^{\prime \prime}-4^{\prime \prime}$ in diameter, tapering to the summit, divided by numerous transverse membranous partitions; principal umbel of 10-15 slender rays; fruit about $3^{\prime \prime}$ long.-Gray and Torrey.

\section{CHAROPHYLLUM, L.}

Margin of the calyx obsolete; petals obovate, emarginate, with an inflexed point; carpels with 5 obtuse equal ribs; intervals with single vittæ.-Perennial, biennial, or annual herbs; leaves decompound, the segments toothed or many-cleft; fruit oblong or linear, tapering at the apex, contracted at the base; involucel many-leaved; involucre few-leaved or none; flowers white, rarely yellow.

C. Procumbens. Stem $6^{\prime}-18^{\prime}$ long, usually decumbent, but sometimes erect or oblique, when young more or less hairy, but often nearly glabrous, except the sheath and margin of the leaves; lobes of the leaves $1^{\prime \prime}-2^{\prime \prime}$ wide, mostly obtuse; umbels opposite the leaves, usually sessile, of 2-3-4 rays; involucre none; involucels of 4-5 ovate-oblong leaflets; fruit narrowly oblong, abruptly contracted at the summits; ribs scarcely as broad as the interrals.Gray and Torrey.

C. Thisterieri, Hook and Arn. Stem decumbent or 
erect; leaves bipinnately divided; segments pinnatifid; the lobes linear-oblong, rather acute; umbels opposite the leaves, usually sessile; umbel 2-3 rays; involucel of 4-5 ovate leaflets; fruit linear-oblong, attenuated upward; ribs very prominent, much broader than the intervals. Prairies and along rivers.-Gray and Torrey.

\section{POLYT ENIA, DC.}

Margin of the calyx 5-toothed; petals oblong, with a long inflexed emarginate point; fruit oval, lenticularly compressed on the back, glabrous, with a broad and even tumid corky margin; the dorsal disk impressed; ribs obscure, nearly immersed in the corky pericarp; intervals with 2 vittæ, the thickened corky margin filled with resiniferous tubes; carpophore free, 2-cleft; seed plano-convex. -A glabrous herb, with bipinnately-divided leaves, the uppermost opposite and often 3-cleft; umbels terminal and opposite the leaves; involucre none; involucel of several setaceous leaflets; flowers bright yellow.

P. Nuttallit. Plant $2^{\circ}-3^{\circ}$ high ; root fusiform ; stem rather stout, usually scabrous leafy; leaves on long petioles; the segments pinnately incised or toothed, those at the base of the peduncles often only 3 -cleft, with entire or sparingly-toothed lobes; rays of the umbel 12-20, about an inch in length; fruit $3^{\prime}$ long, entire at each end. Witchita Mountains._Marcy.

\section{GiNsEng Family. Order, Araliace.}

Shrubs, trees, or perennial herbs, with compound or simple exstipulate leaves; flowers mostly umbellate, the umbels often paniculate or racemed; calyx adherent to the ovary; the limb usually very small, entire or toothed; petals 5-10, valvate in rstivation, very rarely none; stamens as many as the petals and alternate with them; 
filaments short; anthers intorse; ovary crowned with an epigynous disk, 2-15-celled, with a solitary suspended ovule in each cell; styles erect and connivent, or spreading; stigmas simple; fruit drupaceous or baccate, sometimes nearly dry, but the carpels not separating; seeds solitary in each cell, anatropous.

\section{ARALIA, L.}

Calyx-limb short, 5 -toothed or entire; petals 5, spreading; stamens 5, alternate with petals; filaments short; style 5, at length divaricate; drupe baccate, 5-Jobed, 5-celled, the endocarp chartaceous. - Shrubs or herbs; leaves compound; petioles sheathing at the base.

A. RACEMosa, L. (Spikenard.) Stem herbaceous, smooth, leafy, divaricately branched; leaves ternately and quinately decompound; leaflets cordate-ovate, acuminate, doubly serrate, slightly pubescent; umbels small, numerous, disposed in large doubly-compound racemose panicles; involucre minute or almost none.-Gray and Torrey.

\section{* Shrubby or arborescent, prickly.}

A. Spinosa. Stem aborescent, prickly, as also the petioles; leaves bipinnately compound; leaflets orate, 'acuminate, serrate, mostly glabrous, glaucous beneath; umbels in very large and branched panicles, somewhat racemose on the branches; involucre small and few-leared.Gray and Torrey.

\section{DOGWOOD FAMILY. Order, CoRnacex.}

Trees or shrubs, with simple, entire or rarely toothed exstipulate leaves, and perfect or polygamous flowers; calyx coherent with the 1-2-celled ovary, 4-5-toothed; petals $4-5$, valvate in the bud, sometimes wanting; sta- 
mons $4-10$, inserted into the margin of the disk that crowns the ovary; ovules solitary, anatropous, pendulous; fruit a berry-like 1-2-celled, 1-2-seeded drupe; embryo nearly as long as the fleshy albumen; cotyledons large and foliaceous.

\section{CORNUS, Tourn. Dogwood; CoRnel.}

Flower's perfect; calyx 4 -toothed; petals and stamens 4 ; stigma capitate; drupe 2-celled, 2-seeded.-Shrubs or low trees; leaves and branches opposite; flowers in naked spreading cymes, or capitate, and subtended by a colored involucre.

* Flowers while, in a loose open cyme ; involucre none.

Alternifolia, L'Herit. Leaves oval, abruptly acute at each end, pale and pubescent beneath, long-petioled, and, like the greenish striped branches, alternate; drupes deep blue. Bauks of streams. -A widely branching shrub or small tree.

C. Stricta, Lam. Leaves ovate or oblong, abruptly acute or acuminate, smooth, whitish beneath ; cymes flat or depressed at the summit; drupes and anthers pale blue. Swamps.-A strub or small tree; branches brown.

C. Paniculata, L'Herit. Leaves smooth, ovate-lanceolate, acuminate, paler beneath; cymes convex at the summit, somewhat panicled, loose-flowered; drupes white, depressed-globose._Shrub $4^{\circ}-8^{\circ}$ high ; branches gray.

C. SERICEA, L. Leaves ovate or elliptical, smooth above, the lower surface, like the purplish branches and close depressed cyme, silky-pubescent; drupes pale blue. Low woods. - Shrub $6^{\circ}-10^{\circ}$ high.

** Flowers capitate, subtended by a white 4-leaved involucre.

C. FLORIDA, L. Leaves orate-lanceolate or ovate, at 
length smooth on both sides; flowers greenish; drupes ovoid, red. Oak woods, common.-A small tree; wood hard and close-grained; leaves of the involucre emarginate and thickened at the summit, showy.

\section{NYSSA, L. Sour GUM.}

Flowers diocio-polygamous; sterile flowers in manyflowered heads or cymes; calyx 5-parted; stamens 5-10; petals and pistil none; fertile flowers single or few in a head; calyx-limb 5-toothed or obsolete; petals 5, minute, or wanting; stamens 5-10, mostly sterile; style long, revolute; stigma decurrent; ovary 1-celled ; drupe 1-seeded.Trees or shrubs; leaves alternate, entire or rarely toothed, finely reticulated. Flowers small, greenish, on axillary or lateral peduncles.

\section{* Sterile flowers in loose clusters.}

N. MULTIFLoRA, Wang. Leaves oval or obovate, mostly acute, tomentose when young, at length shining above; fertile peduncles long and slender, 3-8-flowered; drupes ovoid, dark blue. Rich upland woods.-A tree $30^{\circ}-50^{\circ}$ high, with widely spreading branches; leaves rather thick, dark green, $2^{\prime}-5^{\prime}$ long; fertile peduncles $11_{2}^{\prime}-3^{\prime}$ long; drupe $\frac{1^{\prime}}{2}$ long,

N. Aquatica, L. Branches, leaves, etc., tomentose when young, at length nearly smooth; leaves short-petioled, varying from lanceolate to orbicular, obtuse, sometimes slightly cordate; peduncles short, the fertile ones 1-2-flowered; drupes oval, blne. Ponds and swamps.-A large tree, or in pine-barren swamps sometimes a mere shrub; leaves $1^{\prime}-2^{\prime}$ long; peduncles $\frac{1}{2}-1^{\prime}$ long; drupe smaller than in the last.

N. uniflora, Walt. Leaves large, long-petioled, ovate or oblong, acute, entire or sharply toothed, tomentose be- 
neath, the lower ones often cordate; fertile peduncles elongated, 1-flowered; drupes ovate-oblong, dark blue. (N. tomentosa, Michx.; N. grandidentata, Michx. f.) Deep swamps and ponds. - A large tree; leaves $4^{\prime}-6^{\prime}$ long; drupe $8^{\prime \prime}-12^{\prime \prime}$ long.

** Sterile flowers capitate.

N. Capitata, Walt. (Ogeechee Lime.) Leaves large, short-petioled, oblong, oval or obovate, mucronate or acute, tomentose beneath; flowers below the leaves, the fertile ones perfect, solitary, on very short peduncles; drupe oblong, red. Swamps, near the coast.-A small tree; leaves $3^{\prime}-5^{\prime}$ long; drupe $1^{\prime}$ long, agreeably acid. 


\section{Division II.-Monopetalous Exogenous Plants.}

Floral envelopes double. Calyx and corolla both present; the latter of more or less united petals.

\section{HONEYSUCKLE FAMILY. Order, CAPRIFO-}

\section{LIACE E.}

Shrubs, rarely herbs, often twining, with opposite exstipulate leaves; calyx adherent to the orary, the limb 4 or 5 -toothed or lobed; corolla tubular or rotate, 4-5-parted; flowers clustered, often fragrant; stamens inserted on the corolla-tube, as many as and alternate with the lobes of the corolla (rarely one less than the lobes) ; ovary 2-5-celled, with 1 -many pendulous orules in each cell ; style 1 ; stigmas 3-5; fruit baccate drupe, or capsule; embryo small, in the axis of fleshy albumen.

\section{SYNOPSIS.}

* Corolla tubular, with fliform siyle; capitate stigma.

Corolla campanulate. Berry 4-celled, 2-seeded. Erect shrubs..SYMPHORICARPUs. - tubular. - 1-3-celled. Chiefly woody vines..........LONICERA. Drupe bony, 3-5-seeded. Herb8............ Triostzum.

** Corolla rotate. Stigmas $3-5$, sessile. Flowers in cymes.

Leaves pinnate. Berry 3-5-seeded Sambecus. - simple.

Drupe 1-8eeded VIBURNuM.

\section{SYMPHORICARPUS, Dill. SxOW-BERRY.}

Calyx-tube globous, limb 4 to 5-toothed; corolla funnelshaped or bell-shaped, the limb in 4 to 5 subequal lobes; 
stamens inserted on the corolla, and as many as its lobes; stigma capitate ; berry globous, 4-celled, 2-seeded (2 opposite cells abortive).-Small shrubs, with entire oval leaves and small rose-colored flowers.

S. vUlgaris, Michx. Leaves roundish-oval; spikes axillary, subsessile, capitate and crowded; corolla campanulate, lobes nearly glabrous; stamens and bearded style included; berries dark red. River banks.-Shrub, $2^{\circ}$ to $3^{\circ}$ high; branches purplish and often pubescent; leaves $1^{\prime}$ to $2^{\prime}$ by $\frac{3^{\prime}}{4}$ to $1 \frac{1}{2}^{\prime}$, somewhat pubescent; corolla greenish red.

\section{LONICERA, L. WOOdBINe; HoNeysUCKLe.}

Calyx ovoid, 5-toothed; corolla tubular, 5-cleft, often bilabiate, and gibbous near the base; stamens 5 ; ovary 2-3celled, with several ovules in each cell; berry 1-3-celled, several-seeded; seeds bony.-Erect or twining shrubs, with entire, often connate leaves; flowers by pairs or in spiked whorls.

L. SeMpervirens, Ait. Stem twining; leaves oblong or lanceolate, pale and tomentose beneath, the upper pair shorter and connate; spikes terminal; whorls distinct; corolla nearly equally 5-lobed, scarlet or orange without, yellow within. Margins of swamps. Leaves perennial; corolla $2^{\prime}$ long.

L. GRATA, Ait. Stem twining; leaves obovate, glaucous beneath, the 2 or 3 upper pairs connate; whorls of flowers axillary and terminal ; corolla bilabiate, the tube long and slender; young branches often hairy; corolla $1 \frac{1^{\prime}}{2}$ long, with a red or purplish tube and a white limb, changing to yellow ; berry orange-red.

L. Flava, Sims. Smooth and somewhat glacous; stem scarcely twining; leaves oval or obovate, the upper pairs connate; whorls of flowers crowded, terminal; corolla 
slender, bilabiate. Banks of rivers; corolla 1' long, bright yellow; the 4-cleft limb nearly as long as the tube.

L. PARVIFlora, Lam. Smooth; stem twining; leaves elliptical, glaucous beneath, all more or less connate; whorls of flowers crowded, peduncled; corolla short, bilabiate, gibbous at the base; stamens hairy below. Mountains. Corolla $8^{\prime \prime}-10^{\prime \prime}$ long, yellow and purplish.

\section{TRIOSTEUM, L. FEVERWORT.}

Calyx ovoid, with 5 leafy linear-lanceolate persistent lobes ; corolla tubular, equally 5 -lobed, rather longer than the calyx ; stamens 5; ovary 3 -celled, with a single orule in each cell; fruit a dry drupe containing 3 bony nutlets. -Perennial hairy herbs, with large leaves, narrowed but connate at the base, and sessile axillary flowers.

T. PERfoliatum, L. Stem soft-hairy; leaves oral, acuminate, entire, hairy above, tomentose beneath; flowers conmonly clustered, brownish purple. Shady woods. Stem $2^{\circ}-4^{\circ}$ high ; leaves $4^{\prime}-7^{\prime}$ long.

\section{SAMBUCUS, Tourn. Elder.}

Calyx-lobes minute or none; corolla rotate, 5-lobed; stamens 5 ; fruit a globular baccate drupe, containing three 1-seeded nutlets.-Shrubs, with pinnate leaves, and white flowers, in ample terminal cymes.

S. Canadensis, L. Leaflets 7-11, oblong, serrate, smoothish, acute, the lower ones often 3-parted; cymes flat, 5-parted; fruit black. Low grounds, common. Stem $4^{\circ}-16^{\circ}$ high, the straight young shoots with large pith.

S. PUbens, Michx. Leaflets 5-\%, oblong, serrate, pubescent beneath; cymes paniculate, pyramidal; fruit red. Mountains. Shrub $6^{\circ}-10^{\circ}$ high; cymes smaller than in the last. 


\section{VIBURNUM, L. HAW; SloE.}

Calyx minute, 5-toothed; corolla rotate or somewhat campanulate, 5-lobed; stamens 5; ovary 1-3-celled, one of the cells containing a single orule, the others empty; drupe baccate, containing a single compressed bony nut.Shrubs or small trees; leaves lobed or undivided, the petioles sometimes winged; flowers in terminal cymes, small, white, the marginal ones occasionally radiant and sterile.

* Sterile and radiant flowers none.

+ Cymes sessile.

V. PRUNIFOLIUM, L. Leaves thin, obovate or roundish, mostly obtuse, finely and sharply serrate, smooth and glossy, or the veins beneath and more or less dilated petioles rusty-pubescent; cymes large, 4-5-rayed; drupe oblong-ovoid, black.-A small tree; fruit edible.

V. Lentago, L. Leaves thin, ovate, acuminate, finely and sharply serrate, smooth above, the lower surface and dilated wavy petioles roughened with minute scales when young; cymes 4-rayed; fruit oval, black. May.-A small tree.

\section{MADDER FAMILY. Order, Rubiace无.}

Trees, shrubs, and herbs; leaves opposite, somewhat verticillate, entire; stipules between the petioles, sometimes resembling the leaves; calyx-tube more or less adherent to the ovary; limb 4 to 5-cleft ; corolla regular, inserted upon the calyx-tube, and of the same number of divisions; stamens inserted upon the tube of the corolla, equal in number and alternate with its segments; ovaries 2- (rarely more) -celled; style single or partly divided; fruit rarions; seeds one, few, or many in each cell. 


\section{SYNOPSIS.}

Sub-order I. Coffeeæ. Orules and seed solitary in the cells. Calyx-tube adherent to the ovary.

\section{* Leaves (and leafike stipules) whorled; oxary adherent.}

Corolla rotate, 4-parted, valvate in the bud. Fruit 2-celled. Herbs........ Gartur. Carpels 2, one of them closed by partition. Flowers clustered....... SPERMACock. - both open on the inner face. Flowers clustered............. Borrents.

- 2-3, bony, and closed. Style 2-cleft. Albunen fleshy............ Dronis.

- 2, somewhat fleshy, closed. Style entire. Abumen horny...... Ersodea.

** Shmibs ; fmit dry; flowers in globular peduncled heads.

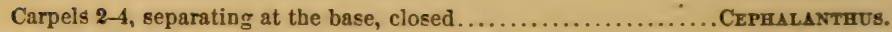
Flowers by pairs. Stamens 4. Berry 4-seeded. Mitchella.

Stb-order II. Cinchoneæ. Ovules and seeds numerous in the cells. Calyx-tube adherent to the ovary. Leaves opposite.

* Fruit capsular ; loculicidally dehiscent.

Herbs. Capsule often free from the calyx above. Seeds wingless.

OLDENLANDIA.

Sub-order III. Loganieæ. Ovules and seeds numerous in the cells. Calyx free from the ovary. Fruit capsular. Leaves opposite.

**Herbs.

Corolla short, 5-lobed. Styles 2 , united above ...Mrreola. - 4lobed.

single. Polyprexuy.

** Evergreen woody vines.

Corolla campanulate. Seeds winged.

Gelsemidar.

\section{Galium, L. Cleavers; Bedstraw.}

Calyx-limb minutely 4-toothed; corolla rotate, 4-cleft; stamens 4, short; styles 2; carpels 2, united, separating into two 1 -seeded indehiscent nutlets.-Herbs, with slender, 4-angled stems; verticels of 4,6 or 8 leaves, rarely of 5 . 
* Fruit baccate; peduncles 1-3-flowered ; leaves 4 in a whorl.

G. Hispidiur, Michx. Stem much branched, slightly roughened, hairy at the joints; leaves small, rigid, lanceolate-ovate, rough on the margins and veins beneath, acute; berry roughened, bluish black; stem $1^{\circ}-2^{\circ}$ long; root yellow; flower greenish white.

G. UNiflorum, Michx. Smooth; stems mostly simple, slender, erect; leaves linear, acute, rough on the margins, punctate beneath; berry smooth, black. Dry rich soil. Stems numerous, $1^{\circ}$ high; flowers white.

\section{** Frruit dry; peduncles commonly 3-many-flowered.}

G. TRIFIDUM, L. Stems slender, weak, smooth or roughangled, at length diffuse ; leaves 4-6 in a whorl, unequal, varying from linear to spatulate-lanceolate, obtuse, smooth, or rough on the margins and midrib, the upper ones often opposite; peduncles 1-3-flowered; corolla-lobes and stamens often 3 ; fruit smooth. (G. tinctorium, L.) Wet places. Stems $1^{\circ}-2^{\circ}$ long; flowers white.

G. CIRC zZANS, Michx. Stems erect, smooth or nearly so ; leaves large $\left(1^{\prime}-1 \frac{1^{\prime}}{2}\right), 4$ in a whorl, oval, mostly obtuse, 3-nerved, pubescent; peduncles forking, then spreading and spike-like; fruit bristly with hooked hairs, nearly sessile, nodding. Dry open woods. Stems several, sparingly branched, $1^{\circ}$ high; flowers purple.

\section{SPERMACOCE, L.}

Calyx 2-4-parted, persistent; corolla salver-shaped or funnel-shaped, 4-lobed, valvate in the bud; stamens 4, inserted on the throat of the corolla; stigma simple or 2-cleft; fruit composed of two 1-seeded carpels, separating: from the apex downward, one of them closed by the partition, the other open; seeds grooved on the inner face.-Low 
herbs; leaves obliquely straight-veined, their bases connected by the bristly-fringed sheathing stipules; flowers small, in axillary sessile clusters.

S. GLABRA, Michx. Stem 4-angled, smooth, erect; leaves lanceolate or oblong, acute, roughened on the margins and veins beneath; clusters globose, dense, manyflowered; corolla barely longer than the lanceolate calyxteeth, white woolly within; stamens and style included; fruit obovate. Stem $1^{\circ}-2^{\circ}$ high; perennial.

\section{BORRERIA.}

Like Spermacoce in character and habits, differing only in the carpels of the fruit separating from the apex downward, both opening lengthwise on the inner face.

B. Micrantha, Torr. and Gray. Annual; stem slender, erect, simple, branched above, 4-angled, smooth; leaves lanceolate, mostly obtuse, narrowed at the base, the upper surface and margins rough, the lateral veins obscure; clusters dense, globose, axillary and terminal; calyx-teeth 4 , subulate, longer than the very small corolla ; fruit ovoid, hairy. Plant $6^{\prime}-18^{\prime}$ high, pale green; leaves $1^{\prime}$ long.

\section{DIODIA, L.}

Differing from Spermacoce in having the two bony indehiscent carpels closed on the inner face.-Herbs ; corollatube often long and slender ; flowers axillary, solitary, and few ; leaves narrow.

D. Virginiana, L. Stem and leaves smooth, pubescent or hirsute; stem prostrate, 4-angled ; leaves fleshy lanceolate, acute, sessile; flowers single, or 2-6 clustered ; corolla hairy within, the tube long and slender; fruit ovoid, strongly ribbed, crowned with the $2-4$ linear or lanceolate calyx-teeth. Flowers white or purplish. 


\section{CEPHALANTHUS, L. Button-Bush.}

Calyx obconical, 4-toothed; corolla tubular, 4-cleft, imbricated in the bud; stamens 4; style slender, exserted; stigma capitate; fruit dry, obconical, separating from the base into 2-4 one-seeded carpels; seeds pendulous; albumen horny.-Aquatic shrubs, with oval or lanceolate leaves, short entire stipules, and white flowers collected into a globose long-peduncled head; receptacle hairy.

C. occidentalis, L. Smooth, or the young branches and lower surface of the ovate-oblong acute leaves pubescent; peduncles terminal, and in the upper axils. Ponds and marshes. Stem $4^{\circ}-12^{\circ}$ high; leaves petioled, $3^{\prime}-5^{\prime}$ long, sometimes 3 in a whorl; heads $1^{\prime}$ in diameter.

\section{MITCHELLA, L.}

Flowers by pairs, with their ovaries united; calyx 4-toothed; corolla funnel-shaped, 4-lobed, hairy within, valvate in the bud; stamens 4; style slender; stigmas 4; fruit composed of two 4-seeded fleshy drupes united, crowned with the 4-toothed calyx.-A smooth creeping evergreen shrub, with small broadly-ovate leaves, minute stipules, and fragrant white terminal flowers.

M. Repens, L. Shady woods. Stem $1^{\circ}-2^{\circ}$ long; leaves $6^{\prime \prime}-10^{\prime \prime}$ long, mostly somewhat cordate, shining above, on slender petioles; corolla $\frac{1}{2}$ long; fruit red.

\section{OLDENLANDIA, Plum. Bluets.}

Flowers tetramerous; calyx 4 -toothed, persistent; corolla funnel-shaped, salver-shaped, or wheel-shaped, 4-lobed, imbricated in the bud; stamens 4 ; stigma mostly 2-lobed; capsule roundish or obcordate, 2-celled, opening loculicidally at the apex, which is often free from the calyx; seeds 
few or many, wingless.-Chiefly small herbs, with opposite leares; stipules united with the petioles, sometimes fringed with bristles; flowers small, white or purplish.

* Corolla salcer-shaped, longer than the calyx, smooth; flowers dimorphous, some of them beuring exserted stamens and an included style. uhile others bear included stumens and an exserted style; peduncles axillary, solitary; capsule broad, free at the apex.

O. Cœrulea, Gray. Annual or biennial, smooth; stems tufted, forking; leaves lanceolate, those at the base spatulate, clustered; peduncles elongated, erect or spreading. (Houstonia cœrulea, L.; H. patens, Ell.) Moist hanks. Stems 3 '-6' high; corolla blue or white, yellow in the throat.

O. serpyllifolia, Gray. Perennial, smooth; stems filiform, prostrate, branching; leaves ovate or roundish, abruptly contracted in to a long and slender petiole ; peduncles elongated, terminal and in the forks of the stem. (Houstonia serpyllifolia, Michx.) High mountains. Stems $6^{\prime}-12^{\prime}$ long ; peduncles $1^{\prime}-2^{\prime}$ long.

** Corolla funnel-shaped; flowers diaciously dimorphous; capsule fiee at the apex; stem 4-angled; flowers in terminal cymes.

O. PUrpurea, Gray. Pubescent; stem branching, erect; leares orate or lanceolate-orate, sessile, 3-5-ribbed; calyxlobes longer than the capsule; corolla purple or nearly white, slightly hairy within ; capsule roundisb. (Houstonia purpurea, L.) Woods. Stems 8 '-12' high ; calyxlobes occasionally 3-4 times the length of the capsule.

O. Axgestifolia, Gray. Smooth; root woody; stems clustered, erect, branching abore; leares linear; cymes crowded, with the central flowers nearly sessile; corolla white, rery hairy within; capsule oroid, as long as the calyr-teeth. (Hedyotis stenophylla, Torr. and Gray.) Sandy pine-barrens. Stems $1^{\circ}-2^{\circ}$ high. Red River.-Marcy.

Var. filifolia. Stem shrubby at the base, diffusely branched; leaves filiform, remote; cymes scattered, 3-flow- 
ered, the slender pedicels equal and spreading; capsule obcordate, rather longer than the calyx-teeth, the upper half free. Stem slender, $6^{\prime}-10^{\prime}$ long; flower's and capsules very small._Marcy.

*** Conolla wheel-shaped, shorter than the calyx-lobes; flowers axillary and ter. minal, singls or clustered, sessile; stamens and style very short; capsule in. closed in the calyx-lube; perennial; stipules fringed.

O. Boscri. Stem smooth, diffuse, 4-angled; leaves linear; flower's single or 2-3 together; corolla white or purplish ; capsule ovoid; stem $6^{\prime}-10^{\prime}$ long.

**** Corolla funnel-form, 5-bobed, longer than the calyx-teeth; flower's axillary and terminal, pentamerous; capsule top-shaped, inc uded in the calyx-tube; stipules fringed; annual.

O. Haler. Stem diffuse, forking, weak; leaves ovaloblong, acute at each end, somewhat fleshy; flowers solitary, or in short 3-5-flowered cymes, white.

\section{MITREOLA, L. Mitrewort.}

Calyx 5-parted; corolla short, 5-lobed, valvate in the bud, the tube roundish, bearded in the throat; stamens 5, included; anthers ovate; styles 2, short, united above; stigma capitate; capsule 2-parted, mitre-shaped, manyseeded, the two lobes opening on the inner face near the apex; seeds oval, concave.-Smooth herbs, with opposite leaves, and small white flowers in terminal and axillary cymes, with the simple branches recurved in the bud.

M. Petiolata, Torr. and Gray. Stem branching; leaves thin, oblong, acute, narrowed into a petiole. (Ophiorhiza lanceolata, Ell.) Muddy banks. Stem 4-angled, $1^{\circ}-2^{\circ}$ high ; leaves $2^{\prime}-3^{\prime}$ long; annual.

M. sessilifolia, Torr. and Gray. Stem simple, 4-angled; leaves thick, ovate or roundish, strongly veined, sessile, rough on the margins; flower's and capsule very small. (Ophiorhiza mitreola, Michx.) Varies with lanceolate 
obscurely-veined leares, and larger flowers and fruit. Grassy swamps. Stem $6^{\prime}-18^{\prime}$ high; leaves $6^{\prime \prime}-10^{\prime \prime}$ long; plant pale green; annual.

\section{POLYPREMUM, L.}

Calyx deeply 4-parted, persistent; corolla wheel-shaped, bearded in the throat, 4-lobed, imbricated in the bud; stamens 4 ; style single, very short; stigma ovoid, entire; capsule ovoid, compressed, 2-celled, loculicidally 2-ralred, many-seeded.-A low smooth perennial herb, with 4-angled forking stems, linear acute leaves, their bases united by the membranaceous stipules, and solitary sessile white flowers in the forks of the stem.

P. PRocumbens, L. Waste places. Stems $6^{\prime}-10^{\prime}$, erect or prostrate, clustered; flowers very small, the corolla barely longer than the calyx-lobes.

\section{GELSEMIUM, Juss. Yellow Jess a Mine.}

Flower's dimorphous; calyx 5-parted, persistent; corolla funneI-shaped, 5-lobed; the lobes rounded, emarginate, spreading, quincuncial in the bud, the sinuses impressed; stamens 5, inserted near the base of the corolla; anthers oblong-sagittate, extrorse; styles united, filiform, partly persistent; stigmas 4, linear, spreading; capsule oblong, compressed, 2-celled, opening septicidally to the middle, and loculicidally at the apex, each valve tipped with the persistent base of the styles; seeds several, oval, flat, winged, obliquely imbricated in two rows.-A smooth, woody vine, with opposite evergreen leaves, minute stipules, and large yellow fragrant flowers, in axillary bracted and cluster-like racemes.

G. SEMPERTIRENS, Ait. On margins of swamps and river-banks. Stem twining, purplish; leaves lanceolate or orate, acute or subcordate at the base, short-petioled; racemes few-flowered; pedicels scaly ; corolla $1^{\prime}-1 \frac{1^{\prime}}{2}$ long. 


\section{Valerian FaMiLY. Order, Valerianacee.}

Herbs with opposite exstipulate leaves, and cymose flowers; calyx-tube adherent to the ovary; corolla tubular or funnel-shaped, mostly 5-lobed, imbricated in the bud; stamens distinct, fewer than the corolla-lobes, and inserted into its tube; ovary 3-celled, two of which are empty, the third containing a single suspended anatropous ovule; style slender; stigmas 1-3; fruit 1-3-celled, 1-seeded; albumen none.

\section{VALERIANA, Tourn. Valerian.}

Limb of the calyx composed of several plumose bristles, at first incurved, afterward spreading; corolla gibbous at the base, 5-lobed; stamens 3; fruit 1-celled, 1-seeded. Perennials.

V. Scandens, L. Smooth; stem climbing; leaves on slender petioles, ternately divided; leaflets ovate, entire; cymes paniculate, diffuse, axillary and terminal; corolla very short.

\section{FEDiA, Mœnch. Lamb Lettuce.}

Calyx-limb toothed or obsolete; corolla funnel-shaped, 5 -lobed; stamens 3 ; fruit 3-celled, two of the cells empty and sometimes confluent into one, the other 1-seeded.Annual herbs, with forking stems, opposite entire or lobed leaves, and white or purplish flowers in crowded bracted cymes.

F. Radiata, Michx. Leaves oblong, the upper ones clasping and toothed at the base; fruit mostly downy, ovoid, with a furrow between the parallel and contignous empty cells; flowers white; stem 6'-12' high. 


\section{COMPOSITE FAMILY. Order, CoMposite.}

Flower's clustered in a dense head (compound), surrounded by an involucre of many bracts (scales), with 5 united anthers, and the fruit an achenium; leaves alternate, or opposite, exstipulate, simple, yet often much divided; florets numerous, crowded, sessile on the receptacle, with or without pales (chaff); calyx adherent, the limb wanting or divided into bristles, hairs, etc. (pappus); corolla tubular, of 5 lobes, with a marginal vein, often ligulate or bilabiate; stamens 5, alternate with the lobes of the corolla; anthers cohering into a tube; ovary 1-celled, with 1 erect ovule; style single, with 2 stigmas at the summit; fruit dry, indehiscent, 1-seeded, often crowned with a pappus.

(The author has followed Dr. Chapman's analysis of this Order verbatim, finding it easy for the student, clear, and comprehensive.)

\section{ARTIFICIAL SYNOPSIS OF THE GENERA.}

\section{SUb-order I. Tubulifloræ. Corolla of the perfect} flowers tubular, equally 5- (rarely 3-4) -lobed. Ray-flowers, when present, ligulate, either pistillate or neutral.

\section{§1. Heads discoid.}

* Heads with the flowers all perfect.

Pappus none. Leaves resinous-dotted. Flowers yellow. Flateria. Pappus bristly or hairy.

Flowers ycllow.

Receptacle pointed...................................... BigELoVIA. Receptacle flat....................................... 1 and 33 in Sotidaeo.

Receptacle convex RUGKLIA. Flowers white, blue, or priple.

Receptacle chaffy.

Leaves opposite. Flowers white. Melanthera.

Leaves alternate. Flowers purple. . CARPHEPHORUS. 
Receptacle bristly.

Leaves spiny ........................................ Cirsiux.

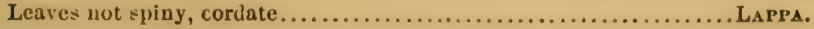

Receptacle naked.

Scales of the involucre in a single row........................ Cacalra.

Scales of the involucre in 2 or more rows.

Pappus double, the outer row very short.................. Vennonu.

Pappus single.

Achenia ribbed or striate.

Pappus plumose. Flowers cream-colored................ Kunnis.

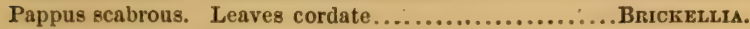

Pappus scabrous. Leaves not cordate.....................Lratris.

Achenia not ribbed, 5-angled

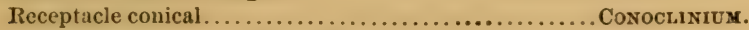

Receptacle flat. Stems climbling ..............................

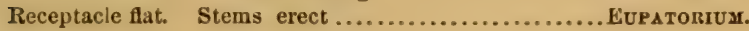

Pappus scaly.

Flowers blue or purple.

Pappus a cup-shaped border of united scales

Pappus slender, almost bristly.

Pappus deciduous. Heads large and single................ Sтокеsis.

Pappus persistent. Heads small, in 3-bracted clusters....ELEPHantopus.

Pappus of 5 oval almost bony scales. Leaves whorled... .... ScherolePis.

Flowers white.

Receptacle naked.

Leaves entire, linear or lanceolate .............................

Leaves entire, ovate or cordate...............................

Leaves pinnately lobed ............................... MrENOPAPPU.

Receptacle chaffy.

Achenium top-shaped. Scales of the pappus 5-6............ Marshallia.

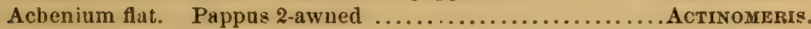

Flowers yellow. Pappus 2-4-awned.

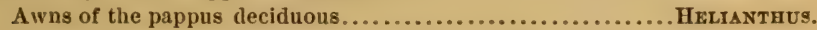

Awns of the pappus persistent, hispid upward................. Coneopsis.

Awns of the pappus persistent, kispid downward

BIDENS.

\section{** Heads with flowers variously imperfect.}

Marginal flowers pistillate. Central flowers perfect.

Pappus bristly.

Scales of the involucre in a single row..... ERecht hites.

Scales of the involucre in 2 or more rows.

Involucre persistent. Leaves sinuate-lobed....................

Involıcre persistent. Leaves entire. Anthers tailed............PLucura.

Involucre persistent. Leaves entire. Anthers tailless........ GNapHa i.IUM.

Involucre decidnous. Heads spiked .................. PtERocAULON.

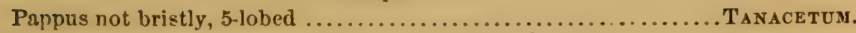

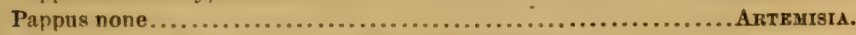

Marginal flowers pistillate. Central flowers staminate.

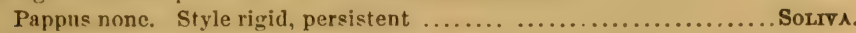

Pappus none. Style deciduous. Heads nodding..................... Iva.

Marginal flowers neutral. Central flowers perfect............... CENTaUREA. 
*** Heads diocions or monoecious.

Staminate and pistillate heads on the same plant.

Fruiting involucre 1-seeded, naked or tubercled................. A mвповг.

Fruiting involucre 2-seeded, armed with hooked spines. XANTHUUM.

Stamiuate and pistillate heads on separate plants.

Anthers tailed. Hoary herbs.

ANTENNARIA.

Anthers tailless. Smooth slurubs.

.BACCHARI8.

Rays pistillate.

§ 2. Heads radiate.

Flowers all fertile.

Receptacle naked.

Rays yellow. Leaves opposite.

Pappus none

Flatieria.

Pappus scaly

Pectis.

Rays yellow. Leaves alternate.

Scales of the involucre in 1 row.

SENECIO.

Scales of the involucre in 2 rows.

HELENTUM.

Scales of the involucre in several rows

INULA.

Rays wbite or purple.

Pappus none.

LEUCANTHEMUM.

Pappus bristly

Receptacle pitted.

Rays white or purple.

Pappus double.

DipLOPA PPU8.

Pappus single. Rays about 5. Achenia silky............. SERICOCARPUs.

Pappus single. Rays numerous. Pappus bristly................ Aster.

Pappus single. Rays numerous. Pappus scaly.................

Rays yellow.

Pappus double, of the ray and disk flowers alike.......... Chrysopsis.

Pappus double, of the ray flowers none............... Heterotheca.

Pappus single.

Leaves opposite. Heada large, single or corymbose...........ARNica.

Leaves alternate. Heads racemed or clustered............. SolrdaGo.

Leaves alternate. Heads panicled .................... Isopaprus.

Receptacle chaffy.

Involucre double, the outer 4-leaved, 4-angled

Tetragonotheca.

Involucre imbricated or spreading.

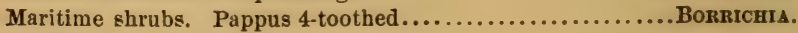

Herbs.

Receptacle conical or elongated.

Rays persistent. Corolla-lobes velvety .................. Zinsis.

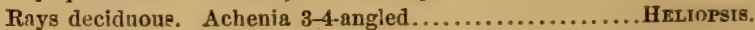

Rays decidnous. Achenia compressed............... SPILANTHEs.

Receptacle flat.

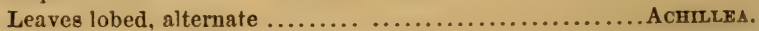

Leaves not lobed. Pappus 2-awned.................. Verbesina.

Leaves not lobed. Pappus none .............................

Flowers of the disk sterile.

Rays yellow. Pappus none.............................. Polymana.

Rays yellow. Pappus a toothed crown...................... 
Rays yellow. Pappus 2-toothed or awned. Achenia winged...... SiLPHiv

Rays yellow. Pappus 2-toothed or awned. Achenia wingless.. Berlandiera.

Rays white. Receptacle conical........................ PArtheniua.

Rays neutral (without pistils).

Receptacle naked, or nearly so.

Achenia villous. Pappus scaly, long-awned................ GAmLARDL.

Achenia smooth or the angles hairy. Pappus awnless .......... LEPTOPODA.

Receptacle deeply pitted.

Margins of the pits entire. Perennial..................... BALDWrnia.

Margins of the pits toothed. Annual..................... Actrospermum.

Receptacle chaffy thronghout.

Involucre double. Pappus 2-4-awned.

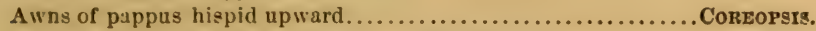

Awns of pappus hispid downward. Achenia beakless............. Bromens.

Awns of pappus hispid downward. Achenia beaked.............. Cosmos.

Involucre simple or imbricate.

Pappus a cup-shuped border, or none.

Chaff of the receptacle elongated, spine-pointed.............. EcHINACEA.

Chaff of the receptacle not elongated nor spine-pointed.......RUDBECKIA.

Pappns 2-4-awned.

Achenia winged. Leaves divided....................... LePachrs.

Achenia winged Leaves undivided..............................

Achenia wingless. Awns of the pappus decidnous.......... Heliantrus.

Achenia wingless. Awns of the pappus persietent....... Helianthella.

Receptacle chaffy. Achenia ribbed................................

Sub-order II. Labiatifloræ. Corolla of the perfect flowers 2-lipped; the outer lip 3-lobed, the inner 2-lobed.

Herb stemless. Scape 1-flowered. Flower nodding.............. ChaptaLra.

\section{SUb-order III. Ligulifloræ. Corolla of all the flowers} ligulate.

Pappus none. Achenia many-ribbed

APOGON.

Pappus scaly and bristly.

Scales of the pappus 5 , with 5 intermediate bristles............... Krigra.

Scales of the pappus and bristles numerous.................... CrNTHIA.

Pappus hairy.

Pappus tawny or dirty white.

Flowers erect, rose-colur. Leaves filiform............... Lyeodesmia.

Flowers erect, yellow. Achenia beakless.................. Hreracium.

Fluwers erect. yellow. Achenia long-beaked............. PXrRHopappus.

Flowers nodding, whitish or purplish...........................

Pappus clear white (except in one Mulgedium).

Achenia conspicuously beaked.

Acheuia rilubed. Stemless herbs .................... TARAXAcuM.

Achenia flat. Stems leafy.................................

Achenia beakless, or nearly so.

Flowers blue. Achenia slightly beaked

MULGEDIUM.

Flowers yellow. Achenia beakless

SoNcets. 


\section{SUb-order I. Tubulifioræ.}

Tribe I. Vernoniaceæ. Heads discoid; the flowers all tubular and perfect; branches of the style terete, filiform, hairy all over; the stigmatic lines only on the lower part. -Herbs, with alternate leaves and purple flowers. Pectis alone has pistillate rays and yellow flowers.

\section{VERNONIA, Schreb. IRON-WEED.}

Heads many-flowered, the flowers all equal and tubular; involucre shorter than the flowers, the scales closely imbricated in several rows; receptacle naked; achenia cylindrical, ribbed; pappus double, the exterior consisting of very short scale-like bristles, the interior of copious capillary bristles.-Perennial herbs, with alternate leaves, and corymbose purple flower's.

V. Noveboracensis, Willd. Stem more or less pubescent, branched above; leaves lanceolate, serrate, mostly roughish above, smooth or pubescent beneath; corymbs spreading, involucre hemispherical, the scales fringed, ovate, ending in a long filiform point, or simply acute. (V. tomentosa, Ell.; V. præalta, Willd.) River-banks and low ground. Stem $3^{\circ}-6^{\circ}$ high ; scales of the involucre purple. and usually covered with web-like hairs.

V. Fascicclata, Michx., var. Altissima, Torr. and Gray. Stem tall, and, like the lanceolate serrate leaves, smoothish; involucre small, hemispherical; the scales orate, acute or mucronate, fringed, appressed. (V. altissima, Nutt.) Low ground. Stem $6^{\circ}-10^{\circ}$ high ; leaves $6^{\prime}-12^{\prime}$ long.

V. Axgustifolia, Michx. Stem slender, smooth or hairy, very leafy; leaves linear or linear lanceolate, smoothish, or pubescent and roughish, the lowest ones sparingly denticulate, the upper entire, with the margins revolute; corymbs mostly unbel-like; involucre bell-shaped; the scales lanceolate, fringed, acute or conspicuously mucronate. (V. scaberrima, Nutt.) Dry pine-barrens. Stem $2^{\circ}-3^{\circ}$ high. 


\section{STOKESIA, L'Her.}

Heads many-flowered; the marginal flower's much larger, deeply split on the inside, and ray-like; involucre subglobose, bracted, the outer scales prolonged into a leafy bristly-fringed appendage, the inner ones lanceolate and entire; receptacle naked; achenia short, 3-4-angled, smooth ; pappus composed of 4-5 filiform chaffy deciduons scales.-A sparingly branched downy-stemmed perennial ; leaves smooth, lanceolate, entire, the upper ones sessile, and, like the bracts, fringed at the base, the lowest narrowed into a slender petiole; heads few or solitary, large, terminal; flowers blue.

S. CYANEA, L'Her. Wet pine-barrens. Stems $1^{\circ}-1 \frac{1}{2}^{\circ}$ high ; heads 1 ' wide.

\section{ELEPHAN'TOPUS, L. ELEPHANT'S-FOOT.}

Heads 3-5-flowered, crowded in terminal 3-bracted clusters; flowers all equal and similar; involucre compressed; scales 8 , in 2 rows, dry, oblong, acute, dotted; receptacle naked; corolla deeply split on one side, palmate; achenium oblong, ribbed, hairy; pappus bristly from a dilated base, double or single--Erect hairy corymbosebranched perennials, with aiternate ample leaves, and purple or white flowers.

E. tomentosus, L. Rough-hairy; stem nearly naked; radical leaves spreading, obovate-oblong, narrowed into a petiole; stem-leaves (1-2) small, lanceolate; bracts ovate or cordate, usually shorter than the heads; scales of the involucre very hairy. (E. nudicaulis, Ell.) Dry sandy soil. Stem $1^{\circ}-2^{\circ}$ high ; radical leaves $4^{\prime}-10^{\prime}$ long, $2^{\prime}$ wide, spreading on the ground; flowers pale purple.

Tribe II. Eupatoriaceæ. Heads discoid; the flowers all tubular and perfect; branches of the style usually elongated, club-shaped, minutely pubescent; the stigmatic lines obscure; flowers white, blue, or purple. 


\section{CELESTINA, Cass.}

Heads many-flowered; involucre nearly hemispherical, the scales numerous, imbricated; receptacle naked or chaffy; achenia 5-angled; pappus cup-shaped, truncate or more or less prominently tonthed; leaves opposite, toothed; heads in close corymbs; flowers blue or purple.

C. maritima, Torr. and Gray. Stem diffuse, somewhat shrubby at the base, smooth; leaves ovate, abruptly contracted into a slender petiole; corymbs few-flowered; receptacle naked; pappus a whitish truncated margin. Stem $1^{\circ}-2^{\circ}$ long; flower's blue.

\section{AGERATUM, L.}

Receptacle always naked; pappus composed of 5-10 distinct scales. Otherwise like Cœlestina.

A. Conyzordes, L. Leaves ovate, rhombic, or cordate, on rather long petioles; scales of the pappus 5, slightly serrate, awn-pointed from a broad base. Wet places. Pubescence and form of the leaves variable; flowers white or blue.

\section{CARPHEPHORUS, Cass. (Liatris, Ell.)}

Heads about 20-flowered; receptacle chaffy; pales narrow, 3-veined and rigid, shorter than the flowers; stem. simple, leafy, corymbous at top, with middle-sized head of purple flowers; achenia 10-ribbed; leaves alternate ; scales of the involucre imbricated in three rows, ovate or lanceolate, appressed.

C. Tomentoses, Torr. and Gray. Stem erect, downy; leaves cuneate-lanceolate, 3-ribbed, narrowed into a clasping petiole; cauline leaves lance-ovate; scales of the involucre lance-ovate, nearly smooth. Stem $2^{\circ}$ high, bear- 
ing a loose spreading corymb; pales linear; pappus purplish.

C. Corymbosus, Torr. and Gray. Stem stout, erect, hairy, single; lenves slightly hairy, obtuse, oblanceolate, tapering at the base; heads about 20,20-flowered in a dense corymbous cyme; scales smooth, oblong oval. Stem $3^{\circ}$ high; flowers purple.

\section{LIATRIS. BetTon SNaKeroot.}

Heads few to many (5-60) flowered; flowers all perfect, tubular; involucre oblong imbricated; receptacle naked; pappus abundant and bristly; achenia tapering to a slender base; styles much exserted.-Perennial herbs, erect stems, alternate leaves; flowers rose-color, sometimes white.

* Scales of the involucre colored, and petioled at their ends.

L. ELEGANs, Willd. Leaves glabrous, the radical oblanceolate, 3-5-veined, cauline, linear, the upper bract-like, spreading; spike or raceme dense; heads oblong-cylindrical, 4-5-flowered; scales of the involucre petal-like, purple; stem tomentose.

L. SQUARRosa. (Blawing Star.) Leaves linear, smooth or scabrous-pubescent; racemes flexuous, leafy; heads few, 20-40-flowered, sessile or nearly so ; involucre ovate-cylindrical; scales large, squarrous-spreading, outer larger, leafy, inner mucronate-acuminate, scarcely colored.

** Heads 3-i-flonored, in one-sided spikes or racemes ; pappus densely bearded.

L. Gracilis. Stem puibescent, slender, simple; leaves linear, 1-veined, the lower lanceolate, obtuse, all glabrous, ciliate at the base, long petioled; heads 3-7-flowered on divaricate, slender, hairy pedicels, in a long virgate raceme, rarely paniculate; scales few and appressed, shorter 
than the purple barbellate pappus. Plant $3^{\circ}-5^{\circ}$ high, grayish ; heads small ; fruit villous.

L. Acidota. Found on the Washita; mentioned but not described by Engelmann.

L. SPICATA. Leaves lance-linear, smooth, lower ones narrowed at the base; scales of involucre oblong, obtuse; flowers 8; pappus scabrous-plumose; heads numerous, with bright purple flowers.

L. scariosa, L. (Gay Feather.) Stem pubescent; leaves mostly pubescent, the lower large, lanceolate or oblong, the upper ones linear acute; heads large, 15-40flowered, roundish, sessile or pediceled; scales of involucre spatulate or obovate, rounded at the apex, usually with broad and colored margins, the outer ones with spreading tips.

Root not tuberous ; leaves obovate or oblong; heads fero-flowered, corymbed or panicled ; pappus minutely bearded.

L. odoratissima, Willd. (Deer's Tongue.) Stem herbaceous, smooth; leaves smooth and often glancous, obtuse, the lowest spatulate-obovate, 3-5-ribbed, the upper oral or oblong, small, sessile; heads 7 -8-flowered, disposed in an ample, spreading corymb or panicle. Stem $2^{\circ}-3^{\circ}$ high. Withering, it exhales an odor like vanilla. Abundant in the prairies around Houston.

\section{KUHNIA, L.}

Herb; leaves lanceolate or linear, dotted; achenium cylindrical, many-striate; heads 10-25-flowered; flouers all similar and perfect; scales of involucre few and loosely imbricated in 2-3 rows; pappus a single row of strongly plumose bristles.

K. ecpatoroides. Corymbs loose or crowded; stem 
$2^{\circ}-4^{\circ}$ high, branched, pubescent, somewhat viscid; leaves toothed or entire, pubescent, or smoothish beneath, the lower sometimes opposite.

\section{BRICKELLIA, Ell.}

Herbs with opposite leaves, three-ribbed and dotted; headls large, purple, in terminal corymbs; scales of involucre imbricated, outer ones shorter; receptacle flat, naked; corolla 5-toothed; achenia cylindrical, 10-striate; pappus a single row of bearded bristles. Perennial.

B. CoRdifolia, Ell. Heads large, from 30-40-flowered; achenia nearly smooth; stem erect, branching; leaves ovate, serrate, mostly cordate, petioled, the upper ones mostly alternate. Stem $2^{\circ}-4^{\circ}$ high; flowers conspicuous and gay.

\section{EUPATORIUM. THOROUGHWORT.}

Herbs, resinous dotted, opposite or whorled leaves; flover's purple and white; involucre bell-shaped or cylindrical; scales in a single row or imbricated in two or more rows; receptacle flat, naked; corolla 5-toothed; achenia 5 -angled, the sides smooth; pappus a single row of rough bristles; heads corymbed.

* Scales of the involucre purplish, scarious, obtuse, imbricated in several rows, the outer ones much shorter; leaves whorled; flowers purple.

E. Purpureum. Stem simple, tall, often dotted; leaves 3-6 in a whorl, varying from lanceolate to ovate, coarsely serrate, roughish; corymbs large, compound; heads 5-10-flowered. Stem $3^{\circ}-10^{\circ}$ high, solid or hollow, even or grooved, smooth or pubescent.

** Scales of the involucre green or white, imbricated in several rows; heads 5-10-flowered; leaves, achenia, etc., dotted with resinous glands; flowers white.

+Head 5-flowered; leaves undivided, sessile, or narrowed into a stalk-like base.

E. Hyssopifolium, L. Stem $2^{\circ}-3^{\circ}$ high ; leaves lanceo- 
late or ovate-lanceolate, serrate or toothed, 3-ribbed at the base, pubescent, opposite or alternate; scales of the involucre lanceolate, mucronate, shorter than the flowers.

E. cuneifolium. Leares $1^{\prime}$ long; scales of the inrolucre obtuse, shorter than the flowers; leaves obovateoblong, serrate or entire, 3-ribbed; stem $2^{\circ}-3^{\circ}$ high ; plant pubescent.

E. telcrifolium. Stem virgate, $2^{\circ}-3^{\circ}$ high; leaves $1^{\prime}-1 \frac{1}{2}^{\prime}$ long, the base rounded or truncate, ovate or oblongorate, coarsely serrate, the upper ones small; flowers in dense corymbs, depressed in the center; scales of the involucre lanceolate, shorter than the flowers.

t+ Leaves petioled.

E. Serotinum, Michx. Heads 12-15-flowered; scales of involucre linear-oblong, obtuse; achenia smooth; stem $3^{\circ}-6^{\circ}$; leaves $4^{\prime}-9^{\prime}$ long, ovate-lanceolate, acuminate, 3-ribbed, long-petioled.

*** Scales of the involucre green, equal, in a single row ; heads 8-30-flowered; luaves, achenia, etc., not resinous-dotted; leaves on slender petioles.

$\dagger$ Heads in a panicled raceme; leaves pinnately divided.

E. Fœniculaceun. Heads 3-5-flowered; scales of the involucre smooth, margined, notched at the apex, mucronate; achenia smooth; stem $3^{\circ}-8^{\circ}$ high ; flowers white leaves filiform, smooth.

\section{MIKANIA, Willd.}

Heads 4-flowered; scales of the involucre 4 ; receptacle naked, flat; anther's partly exserted ; corolla, achenia, etc., as in Eupatorium.-Chiefly climbing herbs, with opposite mostly cordate leaves, and whitish flowers.

M. Scandens, Willd. Smooth or pubescent; leaves on slender petioles, acuminate, toothed or entire; corymbs numerous, on short axillary branches or peduncles; scales 
of the involucre linear, acute; achenia minutely glandular; stem twining.

\section{CONOCLINIUM, DC.}

Heads many-flowered; scales of the involucre nearly equal, imbricated in 2-3 rows; receptacle conical, naked; corolla 5 -toothed; anthers included; achenia angled, smooth. -Perennial herbs, with opposite petioled serrate leaves, and heads of purple or blue flowers in a terminal corymb.

C. CaLestinum, DC. Smoothish; leaves deltoid-ovate, the lowest often cordate, acuminate, coarsely serrate; heads 30-60-flowered; flowers bluish-purple; stem $2^{\circ}$ high.

Tribe III. Asteroideæ. Heads discoid or radiate, the rays pistillate; branches of the style, in the perfect flower, flattened, linear or lanceolate, equally pubescent above on the outside; the conspicuous stigmatic lines terminating where the exterior pubescence commences.

\section{SERICOCARPUS, Nees.}

Heads 12-15-flowered; the ray-flowers about 5, white, pistillate; those of the disk tubular and perfect; involucre somewhat cylindrical or club-shaped; the scales cartilaginous, whitish, closely imbricated in several rows, with greenish and more or less spreading tips; receptacle pitted, toothed; achenia short, obpyramidal, silky ; pappus simple, composed of numerous capillary bristles.-Perennial herbs; leaves alternate; heads crowded in a dense corymb; diskflowers yellow.

S. TORTIFolius. Stem $1^{\circ}-2^{\circ}$ high; leaves $1^{\prime}$ long, obovate, rarely serrate, vertical; involucre top-shaped, scales oblong and spreading slightly at the tips; pappus copious, white. 


\section{ASTER, Tourn. Aster ; Starwort.}

Heads many-flowered, the rays (white, blue, or purple) in a single series, pistillate; scales of the involucre more or less imbricated, mostly with herbaceous or leafy tips; receptacle flat, pitted; achenia usually compressed; pappus a single row of numerous rough capillary bristles.-Perennial (rarely annual) herbs; leaves alternate; disk-flowers yellow, often changing to purple.

AsTER proper.-Scales of the involucre imbricated in various degrees, with herbaceous tips; rays numerous; achenia flattened; pappus of soft capillary bristles, not thickened upward.-Autumnal plants.

* Leaves uniform, small, sessile, entire, silky or silvery on both sides, mucronate ; scales of the irvolucre imbricated in 3-several rows; rays violet-purple.

A. SERICEUS, Vent. Stem with numerous branches, bearing the large heads (single or 3 in a cluster) at their summits; leaves oblong-lanceolate, silvery; scales of the involucre leafy and spreading; achenia smooth. Stem $10^{\prime}-20^{\prime}$ high ; leaves $\frac{1^{\prime}}{2}-1^{\prime}$ long; heads showy.

A. CONCOLOR, L. Stem mostly simple, slender, bearing toward the summit, the middle-sized heads in a long often compound raceme; leaves lanceolate, silky when young, the lowest ones oblong; scales of the obovoid involucre lanceolate, appressed, the subulate tips spreading; achenia silky; root sometimes tuberous. Stem $1^{\circ}-3^{\circ}$ high; leaves erect, $\frac{1^{\prime}}{2}-1^{\prime}$ long.

\section{+ Leaves all clasping and auricled at the base; heads large; scales of the involucre linear.}

A. PATEns, Ait. Stem pubescent, loosely panicled abore; leaves ovate-oblong, with very rough and wavy margins, those on the slender and spreading branchlets very small. -Var., phlogifolius. Leaves larger, thinner, and less 
roughened, contracted below the middle; heads often racemose on the short lateral branches. Stem $1^{\circ}-3^{\circ}$ high; leaves $1^{\prime}-2^{\prime}$ (in the var. $3^{\prime}-6^{\prime}$ ) long; heads showy.

** Leavis (and stem*) smooth, the lowest tapering into a petiole, the others sessile or clasping; heads middle-sized, showy; scales of the obovoid involucre whitish, the short green tips scarcely spreading; rays bright blue; achenia mostly smooth.

A. concinnes, Willd. Stem nearly smooth, somerwhat loosely corymbose ; the branches virgate, dichotomous-paniculate; leaves lanceolate, partly clasping, remotely and sharply serrate, with scabrous margins, those of the branchlets oblong, entire; scales of the involucre linear, acute, closely imbricated. Stem $2^{\circ}-3^{\circ}$ high; achenia pubescent.

Lonver leaves large, cordate, on long petioles; heads middle-sized or small, racemed or panicled; scales of the involucre somezohat membranaceous, with short green tips; rays blue or violet.

\section{+ Leaves entire, or nearly 80.}

A. undulatus, L. Pubescent; stem racemose-panicled above; leaves varying from lanceolate to broadly ovate, often wavy or slightly serrate on the margins, roughish on the upper surface, the lowest on long and slender petioles which are dilated and clasping at the base, the upper on broadly winged petioles or sessile and clasping; scales of the obovoid involucre linear, appressed, acute. Stem $2^{\circ}-3^{\circ}$ high; heads small; rays pale blue.

A. ASPERUlus, Torr. and Gray. Roughish; stem racemose-panicled above, or simple; lowest leaves oblong-ovate, obtuse or slightly cordate at the base, sparingly serrate, on slender (not clasping) petioles; the upper oblong, narrowed at the base, sessile or on short winged petioles; those of the branches minute; heads loosely racemed or panicled, small; scales of the hemispherical involucre lanceolate, acute. Stem $2^{\circ}$ high ; rays pale blue. 
1*** Leaves lineur or lanceolate, entire, sessile; radical leaves stipulate-lanceolate, serrate; heads small and numerous, racemed; scales of the incolucre in several rows, rigid, with spreading or recurved green tips.

A. MUltiflorus, Ait. Stem $1^{\circ}-2^{\circ}$, very leafy and much branched; leaves linear, obtuse at each end, often bristlypointed, spreading or recurved, the upper ones sessile or somewhat amplexicaul; scales of the involucre broadest at the apex, obtuse or short-pointed; heads densely racemose on the short and very leafy branches, or sometimes solitary at their summits; rays white; plant whitish-pubescent.

\section{ERIGERON, L. Fleabane.}

Heads mostly hemispherical, many-flowered; rays very numerous, pistillate; scales of the involucre nearly equal, in 1-2 rows; receptacle flat, naked; achenia compressed; pappus a single row of capillary bristles, or with an outer row of short chaffy scales or bristles.-Herbs; leaves alternate; rays white or purplish.

\section{* Pappus double.}

E. strigosum, Muhl. Annual, rough pubescent; stem slender, corymbose-panicled above ; leaves entire or sparingly serrate, the lowest oblong, tapering into a slender petiole, the upper lanceolate or linear, sessile, distant; heads small, corymbose-panicled; rays white or rose-color; outer pappus short and chaffy. Stem $2^{\circ}$ high.

** Pappus singie.

+ Annual; rays shorter than the disk.

E. Canadense, L. Hirsute or smooth; stem much branched; leaves linear-lanceolate; heads rery numerous, in panicled racemes, small, cylindrical ; rays white; diskflowers 4-toothed. Stem $1^{\circ}-3^{\circ}$ high. 
t+ Perennial; rays conspicuous.

E. Bellidifolium, Muhl. Hairy or villous; stem simple; lowest leaves spatulate or obovate, toothed above the middle, the upper oblong, sessile and entire; heads lurge, solitary or corymbose; rays broadly linear, bluish purple. Stem $1^{\circ}$ high, stoloniferous.

E. vernum, 'Torr. and Gray. Smonth or nearly so; stem simple, scape-like; radical leaves clustered, thick, spatulate or obovate, entire or slightly toothed, the others small and remote; heads corymbed; rays (about 30 ) white. (E. nudicaule, Michx.) Rhizoma thick; stem $1^{\circ}-2^{\circ}$ high.

\section{DIPLOPAPPUS, Cass.}

Heads many-flowered; rays 8-12, pistillate; scales of the involucre imbricated, without herbaceous tips ; receptacle flat, alveolate; pappus of capillary bristles in two rows, the outer row much shorter.-Perennial erect herbs; leaves alternate; heads single or corymbose; rays white or purple.

\section{* Rays purple.}

D. LiNariffolius, Hook. Stem rigid, simple, closely pubescent; leaves numerous, linear, spreading, the margins very rough; heads solitary or somewhat racemose; scales of the involucre imbricated in several rows, linear, appressed; achenia silky. Stem $1^{\circ}$ high ; leaves $1^{\prime}$ long.

\section{** Rays while.}

D. CoRnifolius, Darl. Stem pubescent ; leaves ellipti al, tapering at each end, hairy on the margins and veins beneath; heads few, on slender spreading peduncles; achenia smooth. Stem $1^{\circ}-2^{\circ}$ high ; leaves $2^{\prime}-4^{\prime}$ long.

D. amygdalinus, Torr. and Gray. Stem roughish and corymbose above; leaves oval or oblong, acute at each end, 
nearly smooth ; headls numerous, corymbed; scales of the involucre obtuse; achenia hairy. Stem $2^{\circ}-4^{\circ}$ high ; the branches spreading; leares $1 \frac{1}{2}-2^{\prime}$ long.

\section{BOL'TONIA, L'Her.}

Heads many-flowered; rays pistillate; scales of the hemispherical involucre imbricated in two rows, not longer than the disk ; receptacle hemispherical or conical, obscurely alveolate; achenia flattened, obovate, wing-margined; pappus composed of several short chaffy scales, that of the disk-flowers mostly with 2-4 longer awns.-Perennial herbs, resembling Asters.

B. Diffusa, Ell. Stem with long and slender branches; leaves linear, entire; heads small, terminal; achenia narnowly margined, hairy; pappus very short, 2-awned. Stem $3^{\circ}-4^{\circ}$ high ; rays purplish.

B. glastifolia, L'Her. Stem paniculate; leaves rigid, lanceolate, sparingly serrate, the upper ones linear, entire; heads rather large; achenia broadly margined; pappus of few short bristles, and 2-4 long awns. Stem $3^{\circ}-5^{\circ}$ high ; rays white.

\section{SOLIDAGO, I. GoLdeN RoD.}

Heads few or many flowered; rays 1-16, rarely wanting, pistillate; disk-flowers tubular, perfect; scales of the involucre imbricated, rarely with spreading tips; achenia terete, many-ribbed; receptacle flat; pappus simple, of numerous scabrous mostly capillary bristles.-Plant erect; leaves alternate; perennial; flowers yellow.

Chrysastrum.-Scales of the involucre with herbaceous spreading tips; bristles of the pappus unequal, some of them thickened upward; racemes short, forming a long and narrow leafy panicle. 
S. DISCOIDEA, Torr. and Gray. Stem $3^{\circ}-5^{\circ}$ high, simple or branched, pubescent or hairy; leaves ovate, acute, abruptly narrowed into a petiole, lower ones serrate; achenia smooth; racemes 3-6, large, 10-15-flowered heads; rays none; flowers yellowish white.

Virgaurea. Scales of the involucre appressed; rays mostly fewer than the disk-flowers, rarely wanting; racemes racemose-corymbose, or panicled.

* Racemes not 1-sided ; leaves feather-veined.

+ Racemes crowded in racemose or pyramidal terminal panicles, longer than the leaves; lowest leaves large, commonly tapering into a petiole, the uppermost small, sessile and entire.

S. PETIOLARIS, Ait. Minutely pubescent; stem mostly simple, straight, very leafy; leaves oblong-lanceolate or elliptical, acute, rough on the margins, all but the lowest entire, and nearly sessile; panicle racemose or oblong; heads large, 20-25-flowered; rays about 10, showy; scales of the involucre linear, pubescent, the outer ones more or less spreading; achenia smoothish. Stem $2^{\circ}-3^{\circ}$ high; leaves $1^{\prime}-2$ ' long.

S. Speciosa, Nutt. Stem stout, mostly simple, smooth below, pubescent above; leaves smooth, the lowest large ( $5^{\prime}-8^{\prime}$ long, $1 \frac{1^{\prime}}{2}-2^{\prime}$ wide), serrate, the upper ones lanceolate; panicle compact, pyramidal; heads rather large, crowded, 15-20-flowered; rays 6-8, showy; scales of the involucre lanceolate, obtuse; achenia smooth. - Varies, with the stem and lower surface of the broader $\left(2^{\prime}-3^{\prime}\right)$ leaves villous; the fewer, larger, and more scattered heads about 30-flowered; or every way smaller; the short racemes forming a narrow racemose panicle. The first variety only in the upper districts. Stem $3^{\circ}-5^{\circ}$ high, often purplish. 
Racemes 1-sided, mostly compound, spreading or recurved, often erect, commonly disposed in a pyramidal panicle.

Smooth species, growing in marshes; stems virgate; leaves very numerous, more or less fleshy, the lowest elongated and tapering into a marginal peliole, the upler small and passing inlo bracts; heads middle-sized; achenia pubescent.

S. Missouriensis. Stem $1^{\circ}-2^{\circ}$ high; leaves smooth and shining, the lower $3^{\prime \prime}-4^{\prime \prime}$ by $3^{\prime}-5$, gradually reducing upward into small bracts, lance-linear, tapering to each end, 3-veined; radical leaves oblong-lanceolate, petiolate; racemes small in a dense pyramidal or somewhat corymbous panicle; scales with greenish tips; heads small, 12-15-flowered; rays about 8 . On Witchita River.

Leaves very numerous, gradually diminishing in size umvard, veiny, sessile, or the lowest narrowed into a short petiole; heads small.

S. Ulyifolia, Muhl. Stem smooth, or softly pubescent above; leaves ovate-lanceolate, acuminate, serrate, smooth on the upper surface, paler and pubescent on the veins beneath; panicle loose, spreading; heads about 10-flowered; rays 4-5; sccules of the involucre acutish; achenia nearly smooth. Stem $2^{\circ}-3^{\circ}$ high ; leaves thin, $2^{\prime}-3^{\prime}$ long.

S. Elliotrir, Torr. and Gray. Smooth; stem mostly simple; leaves oblong-lanceolate or elliptical, sessile, acute, finely serrate, the upper often entire; racemes crowded, forming a pyramidal panicle; scales of the 13-20-

S. odorA, Ait. Stem $2^{\circ}-3^{\circ}$ high, mostly simple, pubescent in lines; leaves entire, linear-lanceolate or oblongovate, smooth, rough margins, dotted; panicle pyramidal, mostly one-sided; heads 5-7-flowered; rays 3, showy; achenia hairy; leaves $1^{\prime}-2$ ' long; plant anise-scented. Witchita Mountains.

\section{Leaves more or less prominently 3-ribbed.}

S. Canadensis, L. Stem $3^{\circ}-8^{\circ}$ high, pubescent and often rough; leaves acute or acuminate, serrate, lanceolate, rough above, pubescent beneath; panicle pyramidal, dense; heads small; rays very short; achenia pubescent. 


\section{BIGELOVIA, DC.}

Heads 3-4-flowered, the flowers all tubular and perfect; involucre cylindrical-club-shaped, as long as the flowers; the scales linear, rigid, appressed, somerwhat viscid; receptacle narrow, cuspidate; achenia terete, striate, hairy; pappus simple, of numerous scabrous capillary bristles; styles scarcely exserted.-A smooth erect perennial herb, with narrow obtuse and entire leaves, and small heads of yellow flowers, disposed in a compound corymb.

B. NUdATA, DC. Stem mostly simple, virgate; lowest leaves spatulate-lanceolate, obscurely 3-nerved, the others scattered, linear. Stem $2^{\circ}$ high.

\section{ISOPAPPUS, Torr. and Gray.}

Heacis several-flowered; rays 5-12, pistillate; involucre cylindrol-campanulate; the scales lanceolate-subulate, imbricat $:$ in 2-3 rows, appressed; receptacle alveolate; achenia terete, silky; pappus a single row of nearly equal capillary bristles. Biennials. Stems paniculate; leaves alternate, narrow; heads scattered, on slender peduncles; rays yellow.

I. DIVARICATUS, Torr. and Gray. Hispid and glandular; stem erect, the slender branches spreading; leaves linear-lanceolate, sparingly toothed; involucre soft-hairy; rays 5-S. Stem $1^{\circ}-4^{\circ}$ high ; panicle large; heads $15-20$ flowered.

\section{HETEROTHECA, Cass.}

Heads many-flowered; rays pistillate; scates of the involucre imbricated in few rows, linear; receptacle alveolate, bristly ; achenia of the rays oval, destitute of pappus, those of the disk-flowers obovate, compressed, hairy, with a double pappus, the outer one short and chaffy, the inner 
bristly.-Biennial rough-hairy branching herbs, with irregularly toothed or entire alternate leaves, and corymbosepanicled heads of yellow flowers.

H. SCABRA, DC. Leares oblong, toothed, commonly sessile or clasping, the lowest petioled, obtuse or somewhat cordate at the base; involucre thick, shorter than the brownish inner pappus. Stem rigid, $1^{\circ}-2^{\circ}$ high; leaves $1^{\prime}-2$ ' long.

\section{CHRYSOPSIS, Nutt.}

Pappus of the ray and disk flowers alike, double; the exteriur row chaffy, or of chaffy bristles, the interior longer, capillary; otherwise like Heterotheca.-Biennial or perennial hairy or silky herbs, with linear or oblong mostly entire leaves; heads mostly corymbed; flowers yellow.

* Leaves narrow, nerved, entive; achenia oblong-linear, narrowed at each end, pubescent; perennials.

C. Graminifolia, Nutt. Stem leafy, white with appressed silky shining hairs, as also the linear leaves; heads numerous, rather small, on slender and more or less glandular peduncles; involucre top-shaped, the linear scales glandular. Stem $1^{\circ}-2^{\circ}$ high ; lowest leaves $4^{\prime}-8^{\prime}$ long.

C. oligaxtha, Chapm. Stem nearly naked and glandular above, the lower part, like the linear or lanceolate leaves, silky with appressed shining hairs; heads 1-4, on long erect glandular peduncles, rather large ; involucre bellshaped, the scales glandular-pubescent. Stem $1^{\circ}$ high; stem-leaves clasping, those of the root elongated.

C. PINifolia, Ell. Smooth; stem rigid; leaves linear, crowded, rigid; corymb large; scales of the involucre woolly at the summit. Stem $1 \frac{1}{2}{ }^{\circ}-2^{\circ}$ high ; stem-leares $4^{\prime}-6^{\prime}$ long, the uppermost filiform; heads large; exterior pappus somewhat chaffy. 
** Leaves veiny, oblong or lanceolate; the lowest narrowed at the base, the upper sessile; achenia obovale, compressed.

C. Mariana, Nutt. Perennial; stem simple, covered with loose silky deciduous hairs; lowest leaves spatulate-oblong, entire or slightly serrate, the upper ones lanceolate, sessile, entire; corymb small, mostly simple and umbellate, cone-like in the bud; peduncles and involucre glandular. Stem $1^{\circ}-2^{\circ}$ high.

\section{BACCHARIS, L.}

Heads diœcious, many-flowered, the flowers all tubular; corolla of the sterile flowers 5-cleft; of the fertile ones filiform, nearly entire, without anthers; style exserted; scales of the oblong or hemispherical involucre imbricated in several rows; receptacle naked or somewhat chaffy; achenia ribbed; pappus of the sterile flowers capillary, in a single row, as long as the involucre; of the fertile flowers in 1 -several rows, commonly much longer than the involucre. -Smooth and resinous shrubs; leaves alternate; flowers white.

B. Halimifolia, L. Branches angled; leaves obovate, or oblong-obovate, toothed above the middle, the uppermost lanceolate, entire; heads peduncled, the terminal ones clustered; pappus of the fertile flowers $3-4$ times as long as the involucre.-Shrub, $2^{\circ}-12^{\circ}$ high.

B. Glomeruliflora, Pers. Branches angled; leaves wedge-oborate, coarsely-toothed, rigid, the uppermost obovate, entire; heads very numerous, in dense sessile axillary clusters; pappus of the fertile flowers twice as long as the involucre. $-S / \iota r u b, 6^{\circ}-12^{\circ}$ high.

B. ANGUstifolia, Michx. Branches numerons, angled; leaves linear, entire; heads single, or $2-4$ in a terminal cluster; achenia smooth.-Shrub, $4^{\circ}-8^{\circ}$ high; heads small. 


\section{PLUCHEA, Cass.}

Heads many-flowered; the central flowers mostly perfect, but sterile, with the corolla dilated and 5-cleft, the others pistillate, slender, slightly toothed; anthers bicandate; scales of the involucre imbricated; receptucle flat, mostly naked; achenia grooved or angled; pappus a single row of capillary slightly scabrous bristles.-Odorous mostly pubescent and glandular herbs, with alternate ovate or oblong serrate leaves; heads of purplish flowers corymbose.

P. BIfrons, DC. Stem simple, or sparingly branched; leaves oblong, acute, denticulate, strongly reticulated and rugose, cordate and clasping; heads clustered; involucre pubescent and viscid. Stem $1^{\circ}-2^{\circ}$ high ; flowers pale purple or white.

P. Fetida, DC. Minutely pubescent and glandular; leaves large, membranaceous, ovate-lanceolate, acuminate, serrate, tapering into a petiole; corymbs axillary anc terminal; heads rather small, numerous, on slender pedicels; involucre smoothish, often purplish. Stem $2^{\circ}-5^{\circ}$ high; leaves 5'-8' long, resinous-dotted; flowers purple.

\section{PTEROCAULON, Ell.}

Hecuds spiked; scales of the involucre lanceolate, imbricated in several rows, caducous; leaves lanceolate, tomentose and hoary beneath, the margins decurrent on ice stem ; receptacle hairy; achenia angled, pubescent; pul...us of numerous capillary bristles, longer than the invincre. Heads many-flowered, central flowers mostly perfect, hut sterile, with the corolla dilated and 5-cleft, the others pistillate.

P. PYcNostaCHYUM, Ell. Leaves wavy, smooth; stem $1^{\circ}-2^{\circ}$ high; spike thick, woolly; flowers white. 


\section{SILPHIUM, L.}

Heads many-flowered; the rays numerous, pistillate, fertile, in a single row; distc-flowers cylindrical, sterile; the style undivided; scales of the involucre leafy, imbricated in several rows, the innermost smallest, chaff-like; receptacle small, with linear acutish chaff; fertile achenia in 3-4 rows, round or obovate, flat, broadly winged, 2 -toothed or emarginate at the apex; the sterile ones slender; pappus none, or replesented by the two teeth of the achenia.-I'Ill resinous herbs, with alternate opposite or whorled leaves, and large heads of yellow flowers in corymbose panicles.

* Stems terete, nearly naked; leaves alternate. the lowest large, serrate or variously lobed, long-petioled, the others small and scattered.

S. LACiniatur, L. Stem hispid or smooth ; leaves very rough or hispid, on clasping petioles, pinnately parted; the divisions oblong or lanceolate, acute, lobed or toothed; heacls large, spicate or racemose; scales of the involucre ovate, tapering into a long and spreading point, ciliate; achenia round-obovate, emarginate.-Varies with the more numerous sessile and clasping leaves less deeply parted.Stem $6^{\circ}-8^{\circ}$ high; lowest leaves $1^{\circ}-2^{\circ}$ long; heads $1 \frac{1}{2}^{\prime}-2^{\prime}$ in diameter.

S. TEREBINThinacedy, L. Stem smooth, naked above; leaves rough-hairy, undivided, cordate-oval or oblong, coarsely serrate, on slender petioles; heads small, loosely panicled; scales of the involucre oval or obovate, obtuse, smooth; achenia obovate, emarginate or 2-toothed. Stem $4^{\circ}-8^{\circ}$ high; radical leaves $2^{\circ}$ long; heads $1^{\prime}$ wide.

S. compositum, Michx. Smooth; leaves cordate-ovate or reniform, angularly toothed or variously lobed, longpetioled; heads small, corymbosely panicled; scales of the involucre obovate or oblong, obtuse; achenia roundish, deeply emarginate; rays $6-10$. Stem $3^{\circ}-6^{\circ}$ high; leares $6^{\prime}-12^{\prime}$; heads $\frac{1}{2}^{\prime}$ in diameter. 
** Stems leafy ; leaves undirided, alternate, oppasite, or whorled. + Stems terete.

S. Asteriscus, L. Stem smooth or hirsute; leaves rough, opposite or alternate, or the lower ones sometimes 3 in a whorl, lanceolate or oblong, toothed, on short hirsute petioles; the upper ones sessile and commonly entire; heads somewhat corymbose, rather large; exterior scales of the involucre ovate, acute, short-ciliate, the interior oblong, obtuse; achenia broadly obovate, 2-toothed. Stem $2^{\circ}-4^{\circ}$ high ; leaves $3^{\prime}-5^{\prime}$ long; rays showy.

S. SCABERRIMUM, Ell. Stem rough-hairy; leaves mostly opposite, ovate, acute, serrate, rigid, very rough on both sides, on short petioles; heads corymbose; scales of the involucre ovate, ciliate; achenia nearly orbicular, broadly winged, deeply notched at the apex. Stem stout, $3^{\circ}-4^{\circ}$ high, becoming smoothish; leares $3^{\prime}-4^{\prime}$ long; heads larger than in the last.

t+ Stems square.

S. PERfoliatuy, L. Stem and branches smooth or hairy; leaves large, opposite, ovate or ovate-oblong, coarsely toothed, rough on both sides, or pubescent or hairy beneath, their bases, or winged petioles, united, the uppermost commonly entire, simply serrate; corymb trichotomous; the central heads long-peduncled; scales of the involucre orate, obtuse; achenia broadly obovate, emarginate. Stem $4^{\circ}-6^{\circ}$ high; leares $66^{\prime}-12^{\prime}$ long; heads large.

\section{BERLANDIERA, DC.}

Heads many-flowered; ray-flowers few, pistillate; those of the disk tubular, 5-toothed, sterile; scales of the involucre in three rows, the innermost largest, membranaceous, adherent to the fertile achenia; receptacle chaffy, the chaff dilated upward, obtuse, hooded, partly embracing the sterile achenia, the inner ones gradually narrower; fertile 
achenia in a single row, obovate, flattened, wingless, pubescent on the inner face, the apex entire--Perenuial duwny or hoary herbs, with alternate leaves, solitary or corymbose heads, and yellow rays.

B. tomentosa, Torr. and Gray. Stem leafy, hoarytomentose; leaves oblong-obovate, crenate, hoary beneath, closely pubescent above, the lowest tapering into a petiole, the upper cordate, sessile; heads at length numerous, corymbose-panicled. Stem $1^{\circ}-3^{\circ}$ high; leaves $2^{\prime}-3^{\prime}$ long.

\section{PARTHENIUM, L.}

Herbs; heads many-flowered; ray-flowers 5, in a single row, short obcordate, pistillate; disk-flowers tubular, 5-toothed, sterile; anthers slightly united; involucre scales oval; receptacle conical, chaffy, the chaff dilated upward; achenia compressed, thick-margined; flowers white; pappus of two roundish scales; alternate leaves.

P. Integrifolium, L. Stem $1^{\circ}-2^{\circ}$ high, erect, rough ; panicle dense, corymbose; involucre hoary; pappus awnlike; conspicuous rays; leaves undivided, oblong-ovate, serrate.

\section{IVA, L.}

Flowers tubular, marginal, with short corolla, pistillate, fertile; central ones 5-toothed, sterile; anther's nearly distinct; involucre scales $3-5$ in a single row, oval or obovate, distinct or partly united, or 6-9 and imbricated; chaff of the small receptacle linear or spatulate; heads few or many-flowered; achenia obovate; pappus none-Herbs or shrubs; leaves opposite or alternate, mostly fleshy; flowers small, nodding, axillary, white.

* Scales of the involucre 3-5, single row.

I. MicRocepHaLA, Nutt. Heads minute, 6-12 flowered; 
stem $1^{\circ}-2^{\circ}$ high, slender, much branched; annual, stiff hairs; involucre scales 4-5, obovate, ciliate; fertile foucer's $1-3$; leaves entire, narrow-linear.

** Scales of the invalucre 6-9, imbricated, in 2-4 ronos.

I. imbricata, Walt. Stem $1^{\circ}-2^{\circ}$ high; leaves fleshy, lanceolate, lower ones slightly serrate, upper ones alternate and entire; outer scales of the involucre orbicular, inner obovate, toothed-margined; fertile flowers $2-4$, the short corolla 5-parted. Somewhat shrubby; leaves $1^{\prime}$ long.

\section{AMBROSIA, Tourn.}

Heads monœcious, in racemes or spikes, the upper ones sterile, nodding, the lower pistillate and fertile; involucre of the sterile flowers hemispherical, composed of 7-12 united scales, 5-20 flowered; receptacle naked or with slender chaff; corolla 5-toothed; involucre of the fertile flowers 1-flowered, oroid or turbinate, entire, closed, pointed, commonly with a row of tubercles or spines near the apex ; corolla and stamens none; achenia globose or oroid; pappus none.-Herbs; leaves mostly pinnately lobed; fertile fluvers single or clustered at the base of the sterile spike, or in the axils of the upper leares, bracted; flowers whitish.

* Leaves undivided or 3-5-lobed, opposite; receptade naked.

A. TRIFIDA, L. Stem tall $\left(6^{\circ}-10^{\circ}\right), 4$-sided, rough-hairy; leaves rough, palmately $3-5$ lobed, with the lobes oratelanceolate and serrate, or all undirided; fruit oborste, 6 -toothed around the base of the conically beaked anex, clustered.

* Leaves pinnately lobed; the upper ones mostly alternate; receptacle commonly chaffy.

A. Crithmifolia, DC. Stem prostrate and shrubby at the base; the branches velvety pubescent; leaves bipinnatifid, thickish, softly pubescent; spikes fer, the terminal 
one elongited; fruit downy, unarmed. Sandy shores at Key West, forming large clusters.

A. ARTEMisi fFolia, L. Annual, erect, hairy or smoothish; leaves bipinnatifid, with linear lobes, the upper often entire; spikes single or panicled; fertile flowers single, clustered, or sometimes spiked; fruit nearly globose, armed with six short teeth. Stem $1^{\circ}-4^{\circ}$ high.

\section{XANTHiUM, Tourn. Cocklebur.}

Heads monœcious, spiked, the upper ones many-flowered, sterile, with the scules of the involucre separate, in a single row; the receptacle oblong, chaffy, and the short corolla 5 -toothed; the lower ones fertile, consisting of two pistillite fluwers, inclosed in a 2-celled oblong closed involucre, which is armed externally with numerous hooked spines or bristles, and terminated by one or two stout beaks; corolla filiform; ackenium oblong, solitary in each cell-_Coarse annual herbs; leaves alternate, lobed and petioled.

X. strumarium. Stem $1^{\circ}-4^{\circ}$ high, spineless, rough, brauched; leaves broadly cordate, large, lobed, the lobes toothed-acute, rough on both sides; fruit oval, pointed by two straight and smooth beaks.

\section{ECLIPTA, L.}

Annuals, rough, branching; heads small, axillary-peduncled; flowers white; receptacle flat, chaff bristly; achenia 3-4-angled, hairy at the apex; many-flowered, the ray-flowers short pistillate, in a single row; disk-flowers tubular, 4-toothed, perfect; pappus none; scales of the involucre 10-12 in two rows; white.

E. ERECTA. Stem $1^{\circ}-2^{\circ}$ high, erect or diffuse, terete, tumid below the joints; leaves oblong-lanceolate, acute, serrate, narrowed into a petiole, covered like the stems with hairs; peduncles $2-3$ together. 


\section{ZINNIA, L.}

Aunual herbs; heads many-flowered; ray-flowers pistillate, disk-flowers tubular, perfect, 5-lobed; ray-flowers oblong, rigid, persistent; leaves sessile, 3-ribbed; scales of involucre imbricated, oral or roundish ; chaff of the conical receptacle clasping the disk-flowers; achenia of the disk compressed, with a 1-2-awned pappus; those of the rays 3 -angled, destitute of pappus.

Z. Multiflora. Stem erect, $1^{\circ}-2^{\circ}$ high, hairy, branching; leaves oblong-lanceolate; rays red or purple; chaff of the receptacle obtuse; pappus of the disk-flowers 1-awned.

Z. GRANDiflora. Mentioned by Engelmann as found on the Red River and its tributaries; description not given.

\section{HELIOPSIS, Pers.}

Perennial herbs; heads many-flowered; ray-flowers pistillate; disk tubular, perfect, 5-toothed; achenia truncate; scales of the involucre in 2-3 rows; exterior leafy; chaff lanceolate, clasping the achenia; receptacle conical; pappus none; rays yellow.

H. Lexvis, Pers. Siem $2^{\circ}-5^{\circ}$ high, smooth, slender, branching; leaves ovate-lanceolate, acuminate, serrate, on slender petioles; scales of the involucre obtuse ; rays deciduous; peduncles elongated; leaves 3-ribbed at the base.

\section{ECHINACEA, Mœnch.}

Heads many-flowered; the ray-flowers pistillate, but sterile, drooping; those of the disk tubular and perfect; scales of the involucre lanceolate, imbricated in three or more rows, spreading; receptacle at length conical; chaff of the receptacle rigid, spine-pointed, longer than the disk- 
flowers; achenia short, 4-sided, crowned with a cup-shaped toothed pappus.-Perennial sparingly branched herbs, with alternate undivided 3-5-ribbed leaves, and large heads terminating the peduncle-like summit of the stem or branches; rays red, purple, or white.

\section{* Rays elongated, purple or white.}

E. angustifolia, DC. Hirsute; stem simple; leaves lanceolate, entire, 3-ribbed ; the lowest tapering in to a long petiole; scales of the involucre imbricated in 2-3 rows; rays $12-15$, narrow, pale purple. Stem $11^{\circ}-3^{\circ}$ high ; lowest leares $\frac{1}{2}^{\circ}$ long.

\section{RUDBECKIA, L.}

Heads many-flowered; the ray-flowers neutral; those of the disk tubular, perfect; scales of the involucre in about two rows, leafy, spreading; receptacle conical or cylindrical ; the chaff not rigid, and mostly shorter than the diskflowers; achenia smooth, angled, truncated; pappus a narrow border, or none.

* Disk ovate or globose.

+ Leaves undivided; stem simple or sparingly branched.

R. HIRTA, L. Hirsute; stem and branches naked at the summit; leaves 3 -ribbed, lanceolate or oblong, serrate, the upper ones sessile, the lowest narrowed into a petiole; disk roundish, purplish brown; chaff of the receptacle acute, hairy at the apex ; appendages of the style subulate. Stem rigid, $1^{\circ}-2^{\circ}$ high; rays longer or shorter than the involucre.

t+ Lreaves divided; stem paniculately or commbosely branched.

R. TRILOBA. Stem much branched, rough hairy; lower stem-leaves 3-lobed, the upper sessile, simple, entire; heads small, numerous; scales of involucre narrowlanceolate, shorter than the rays; disk almost black; chaff of receptacle awl-pointed, smooth, as long as the flowers. 


\section{LEPACHYS, Raf.}

Siales of the involucre few and small; chaff of the oblong or columnar receptacle truncate and thickened at the apex; achenia flattened and margined; pappus 2-toothed or none. Perennials. Leaves pinnately divided; rays large, drooping, yellow.

L. PInnata, Torr. and Gray. Rough with short appressed hairs; stem sparingly branched; divisions of the leaves $3-\%$, lanceolate, acute, serrate or entire ; disk yellowish, oval or oblong, shorter than the rays; pappus obscurely 2 -toothed. Stem $3^{\circ}-4^{\circ}$ high ; rays $2^{\prime}$ long.

\section{HELIANTHUS, L. SUNFLOWER.}

Heads many-flowered; the ray-flowers neutral; those of the disk tubular and perfect; scales of the involucre imbricated in three or more rows, with or without leafy spreading tips; receptacle flat or convex, chaffy; achenia 4-angled, usially compressed; pappus of 2 (rarely 3-4) caducous chaffy scales or awns.-Annual or perennial herbs, with opposite or alternate, commonly 3-ribbed, undivided leaves; heads solitary, terminating the stem or branches; disk yellow or dark purple; rays yellow.

* Annual ; disk dark purple; chaff of the recentacle 3-toothed; leaves on long and slender petioles; achenia pubescent.

H. PRecox, Gray and Engel. Rough with scattered rigid hairs, villons when young; stem erect, paniculately branched, somewhat spotted; leaves thin, coarsely serrate, acuminate, undulate, the lowest deltoid-ovate, cordate, opposite, the upper ones ovate-lanceolate; scales of the involucre lanceolate-subulate; rays 15-20. Stem $2^{\circ}-3^{\circ}$ high.

** Perennial : disk dark purple.

++ Rays conspicuous.

H. ANGUSTIFolius, L. Stem rough-hairy or smoothish, 
paniculately branched; leaves linear, elongated, entire, with the margins revolute, the lowest ones opposite; scales of the involucre lanceolate, acuminate; chaff of the receptacle 3 -toothed ; rays 12-18, showy.-Varies, with broader leares, and the disk at first yellow. Stem $2^{\circ}-6^{\circ}$ high; leaves $3 '-6$ ' long.

H. Heterophyllus, Nutt. Hirsute or hipsid; stem slender, mostly simple, naked above ; leaves opposite, thick, entire; the lower ones lanceolate or oblong, tapering into a petiole; the others linear, remote; scales of the involucre lanceolate, acuminate, ciliate; chaff of the receptacle 3 -toothed, the middle tooth cuspidate; rays 15-20, elongated. Stem $2^{\circ}-4^{\circ}$ high ; lowest leaves $2^{\prime}-6^{\prime}$ long; rays $11^{\prime}$ long.

H. Atrorubexs, L. Hirsute or hispid; stem sparingly branched and somewhat naked above; leaves opposite, oval, serrate, the lowest large and long-petioled; the upper small, sessile, distant; scales of the involucre oral or oblong, obtuse ; chaff of the receptacle acute ; rays about 12 ; achenic pubescent at the apex. Stem $2^{\circ}-5^{\circ}$ high ; lowest leaves $4^{\prime}-6^{\prime}$ long; heads rather small.

H. tomentosus. Stem $4^{\circ}-8^{\circ}$ high, stout, hirsute, branching; leaves all alternate, or lowest ones opposite, very rough above, tomentose beneath, slightly serrate, lowest ones large, ovate, on short-winged petioles; the upper ones oblong; heads large; scales of the involucre numerous, lanceolate, acuminate, villous, spreading; rays 15-20.

*** Perennial ; disk yellow ; heads small; leaves narrow.

H. Loxgrfolits, Pursh. Stem $3^{\circ}-4^{\circ}$, slender, branching; leaves lanceolate, sessile, entire, opposite, lowest contracting in slender petioles and serrate; heads few ; rays small ; scales of inrolucre ovate-lanceolate, as long as the disk. Leaves 6'-8' long. Resembles an aquatic Coreopsis. 


\section{ACTINOMERIS, Nutt.}

Heads many-flowered; the ray-flowers 4-14, neutral, or wanting; scales of the involucre in 1-3 rows, leafy ; receptacle convex or conical, chaffy, the chaft embracing the outer edge of the laterally compressed oborate mostly winged achenia ; pappus of two persistent awns.-Perennial herbs, with ovate or lanceolate serrate often decurrent leaves; flowers yellow or white.

* Stems tall, branching ; pappus 2-avoned.

A. helianthoides, Nutt. Stem $2^{\circ}-4^{\circ}$ high, hirsute, strongly winged ; leaves 3 ' long, ovate-lanceolate, alternate, sessile, hairy above, downy beneath; involucre-scales in 3-4 rows, broadly lanceolate, appressed; heads few ; rays 8-14, yellow; achenia winged, awns bristly; flowers in corymbs.

\section{COREOPSIS, L. TickseEd.}

Heads many-flowered; the ray-flowers commonly 8, neutral, rarely wanting; involucre double, each row of about 8 scales, the outer ones narrow and spreading, the inner membranaceous and appressed ; receptacle flat, chaffy ; chaff membranaceous, mostly deciduons with the achenia; achenia compressed, often winged, not narrowed nor beaked at the apex, awnless, or with a pappus of two upwardly hispid or serrulate awns or scales.-Herbs; leaves entire or pinnately divided; heads solitary or corymbose; disk dark purple or yellow; rays yellow, rarely rose-color.

\section{* Rays entire, or emarginate at the apex, yellono.}

+ Leaves petioled; achenia narroioly wedge-shaped, 2-toothed or aconed; scales of the invo'ucre equal, the outer ones separate.

C. ACREA, Ait. Stem smooth, much branched; leaves smooth or slightly pubescent, 5-7-parted, the divisions oblong or lanceolate, serrate, toothed or lobed, or all linear 
and entire; exterior scales of the involucre linear-spatulate ; achenia smoothish, with two short triangular teeth. (C. mitis, Michx.; C. arguta, Pursh.) Stem $2^{\circ}-4^{\circ}$ high; leaves polymorphous, the uppermost commonly undivided; rays showy.

+† Leaves petioled; achenia elliptical or obovate, emarginate, awnless; exterior scales of the irvolucre shorter than the interior.

C. Tripteris, L. Stem smooth, branching; leaves smooth, or rough above, the upper and lower ones entire, the middle ones 3- (rarely 5) -parted, with the divisions lanceolate and entire; exterior scales of the involucre $5-6$, obtuse, united at the base ; achenia elliptical, smooth, incurved, narrowly winged. Stem $3^{\circ}-6^{\circ}$ high.

$t^{++}$Leaves sessile, 3-parted to the base, seemingly 6 in a whorl, the divisions entire or variously divided; scales of the involucre equal, the exterior ones linear-oblong, united below; achenia oblong, narrowly winged, naked or minutely 2-toothed at the apex.

C. verticillata, L. Smooth ; stem branching, slender ; divisions of the pinnately or bipinnately divided leaves linear or filiform; disk yellow ; achenia minutely 2-toothed at the apex. Stem $1^{\circ}-3^{\circ}$ high.

+† Rays yellow; achenia nearly straight, oblong, 2-awned, the margins with a serrulate or pectinate wing ; exterior scales of the involucre shorter than the interior; disk dark purple.

C. Angustifolia, Ait. Stem $2^{\circ}-3^{\circ}$ high, slender, 4-angled, branched, smooth ; leaves linear, alternate or opposite, obtuse, entire, the lower ones spatulate-lanceolate; heads corymbose ; rays 3 -toothed, $\frac{1}{2}$ long; achenia-wings pectinately toothed.

+++ Rays purple or rose-color.

C. Rosea, Nutt. Smooth; stem low, branching; leaves opposite, linear; heads small; rays slightly 3-toothed; achenia wingless, unawned. Stem $S^{\prime}-12^{\prime}$ high; rays rosecolor. 


\section{BIDENS, L. BEGGAR-TICKS.}

Chiefly like Corenpsis, but the exterior involucre often long and leaf-like; the achenia compressed, or 3-4 angled (not narrowed at the apex), and crowned with 2-4 persistent downwardly barbed or hispid awns; leaves serrate, or pinnately divided, opposite; rays yellow or white, often wanting; disk yellow.

\section{* Achenia flattened, narrowly wedge-shaped.}

B. froxdosa, L. Stem tall, branched; leaves thin, longpetioled, piunately $3-5$-divided, the divisions ovate or ovatelanceolate, acuminate, sharply serrate; heads discoid; exterior scales of the inrolucre large, leafy; achenia 2 -a wned. Stem $2^{\circ}-5^{\circ}$ high ; margins of the achenia upwardly ciliate.

B. Chrysaxthemoides, Michx. Smooth; stem erect or ascending; leaves undivided, oblong-lanceolate, obscurely serrate, connate; heads radiate, showy; achenia $2-4$-awned; annual. Stem thick, $1^{\circ}-2^{\circ}$ high.

** Achenia 3-4-angled, linear; heads radiale; scales of the involucre nsarly equal.

B. Bipirxata, L. Stem tall, 4-angled, much branched; leaves bipinnate, the divisions small, ovate or lancenlate, acute; heads small; rays $2-3$, yellow; achenia $3-4$ awned; annual. Stem $2^{\circ}-5^{\circ}$ high.

\section{VERBESINA, L.}

Heads many-flowered; scales of the involucre in 2 rows, imbricated; ray-flowers few, sometimes none; receptacle flat, or somewhat convex, the chaff concare; achenia wingless, 2-awned, laterally compressed; stems winged by the decurrent lobed or serrated leares; heads corymbose; flowers white or yellow.

V. Siegrabeckia. Stem $4^{\circ}-6^{\circ}$ high, 4 -winged, branching; leaves lanceolate-ovate, acuminate, serrate, opposite, 
3-ribbed; rays 1-5, yellow; achenia wingless; corymbs trichotomous.

\section{GAILLARDIA, Foug.}

Heads many-flowered, the rays neutral, deciduons; scales of the involucre in 3 rows, acute, spreading above; receptacle convex or hemispherical, naked or fimbrillate; rays wedge-shaped, palmately 3-lobed; corolla of the disk with subulate lobes; achenia top-shaped, hairy; pappus of 6-10 membranaceous 1-nerved awned scales.-Pubescent branching herbs, with alternate leaves, and solitary heads of yellow or purple flowers terminating the branches.

G. LaNCEolata, Michx. Stem $\left(1^{\circ}-2^{\circ}\right)$ with long and slender branches; leaves narrow-lanceolate, mostly entire, sessile, the lowest narrowed at the base; rays yellow, sometimes wanting; disk-flowers purple; receptacle naked; scales of the pappus $7-9$.

\section{PALAFOXIA, Lagasca.}

Heads many-flowered, the ray-flower's pistillate or none; scales of the obconical involucre in 2 rows, membranaceous at the summit; receptacle flat, naked; achenia slender, 4-angled, tapering at the base ; pappus of 6-12 membranaceous denticulate scales, pointed by the prolonged rigid midrib.-Herbs or shrubs, with narrow entire leaves, and hearls of white or purple flowers in a terminal corymb.

P. integrifolia, Torr. and Gray. Stem ( $2^{\circ}$ high) branched above, smoothish; leaves lanceolate, rough, the lower ones often opposite; rays none; flowers purplish; scales of the pappus $8-9$, linear subulate.

\section{HYMENOPAPPUS, L'Her.}

Heads many-flowered, the flowers all tubular and perfect; 
scales of the involucre 6-12, oral or obovate, membrana. ceous, white; receptacle naked; corolla slender; achenica top-shaped, t-angled; pappus of 10-20 short obtuse thin scales.-Hoary or woolly herbs, with alteruate pinnately lobed or divided leares; heads corymbed; flowers commonly white.

H. scabios és, L'Her. Hoary-tomentose; stem corymbosely branched; leaves pinnatifid or the lowest bipinnatifid, with lanceolate or oblong divisions; scales of the inrolucre broadly obovate, longer than the disk; pappus minute. Stem $2^{\circ}$ high; leares at length smoothish abore.

\section{HELENIUM, L.}

Heals many-flowered, radiate, the rays pistillate, wedgeshaped, 3-5 cleft; scales of the involucre in 2 rows, the outer ones linear or subulate, spreading, the inner fewer and chaffy; receptacle naked, conrex, globose, or oblong; corolla of the disk 4-5-toothed; achenia top-shaped, furrowed, hairy; pappus of 5-8 membranaceous pointed or awned 1-nerred scales.-Erect branching herbs, with the stem winged by the alternate decurrent leares; heads terminating the branches; flowers mostly yellow.

\section{* Disk globose; corolla of the disk mastly 5-cleft.}

H. A tetcrisale, L. Smooth or minutely pubescent; leaves lanceolate or oblong, serrate, strongly decurrent; scalcs of the involucre linear-subulate; scales of the pappus orate-lanceolate, denticulate, awn-pointed; rays $3-\tilde{5}$ cleft, longer than the disk. Stem $2^{\circ}-4^{\circ}$ high; achenia hairy.

H. texcifolicy, Nutt. Smooth; stem slender, rery leafy; leaves narrow-linear, entire; heads on long and slender peduncles; scales of the inrolucre subulate; scales of the pappus orate, entire, abruptly awned; aclienia rillous. Stem $1^{\circ}-2^{\circ}$ high; branches erect. 


\section{LEPTOPODA, Nutt.}

Headls many-flowered, radiate, the rays neutral, 3-4-cleft ; clisk-flowers 4-5-toothed; scales of the involucre in 1-2 rows, spreading, the exterior leafy, numerous, the interior short and chaffy; receptacle conical or hemispherical, naked; achenia short, truncate at each end, striate; pappus of 6-12 scarious toothed or fimbriate scales.-Perennial herbs; stems mostly simple, naked above; leaves alternate; heads solitary; flowers yellow or purple.

* Stems commonly simple, dilated under the head; disk-flowers yellow; rays 20 or more.

+ Achenia smooth.

L. INCISA, Torr. and Gray. Smooth; leaves lanceolate, rather obtuse, sessile, not decurrent, sinuate-pinnatitid or incised; scales of the pappus lacerate, or slightly fimbriate at the summit; rays about 40 , in 2-3 rows.

t+ Achenia hairy on the angles.

L. Fimbriata, Torr. and Gray. Stem smooth, sometimes branching, the peduncle slightly pubescent; leaves linear-lanceolate, acute, entire or obscurely serrate, decurrent; scales of the pappus fimbriate. Stem $1^{\circ}-2^{\circ}$ high.

L. Puberula, Macbride. Closely pubescent; leaves somewhat fleshy, linear-lanceolate, sessile but not decurrent, denticulate, the lowest spatulate-lanceolate, toothed or pinnatifid; scales of the pappus obtuse, with slightly lacerated margins. Stem $2^{\circ}$ high.

\section{MARSHALLIA, Schreb.}

Heads many-flowered; the flowers all tubular and perfect; corvlla pubescent, with linear spreading lobes; scales of the involucre oblong-linear or lanceolate, in 1-2 rows; chaff of the convex or conical receptacle narrow-linear, 
rigid; achenia oblong, narrowed downward, 5-angled, mostly hairy; pappus of 5-6 orate or triangular acuminate entire membranaceous scales.-Perennial herbs, with simple and scape-like or branching stems, smooth entire 3-nerved alternate leaves, and a solitary head of white or purplish flower's terminating the stem or branches; anthers blue.

M. Lanceolata, Pursh. Stem naked above, simple, pubescent; leaves lanceolate, obtuse, the lowest spatulate; scales of the involucre oblong-linear, obtuse; achenia pubescent.-Var., PlatyPhylda, Curtis. Stem leafy to the middle; leaves longer and broader, the lowest $\left(\overline{5}^{\prime}-\sigma^{\prime}\right)$ on long and slender petioles. Stem $6^{\prime}-12^{\prime}$ high ; leaves $2^{\prime}-3^{\prime}$ long.

M. angustifolia, Pursh. Stem simple or branched, leafy below, puberulent above; leaves linear, acute, the lowest spatulate; scales of the involucre linear and acute; disk at length ovate or oblong; achenia with hairy angles. Stem $2^{\circ}-3^{\circ}$ high.

\section{MaRUTA, Cass. MaY-Weed.}

Heads many-flowered; the rays neutral; scales of the hemispherical involucre imbricated in few rows, shorter than the disk; receptacle conical, chaffy throughout, or only at the summit; achenia obovoid, ribbed, smooth; pappus none.-Branching annuals; leavès alternate, thrice pinnately divided; heads solitary, terminal; rays white.

M. cotula, DC. Stem $1^{\circ}$ high; divisions of the leaves linear; scales of the involucre with scarious margins; dish yellow.

\section{ACHILLEA, L. YARROW.}

Heads many-flowered, the rays pistillate, few and short; scales of the involucre imbricated; receptacle flat or elongated, chaffy; ashenia oblong, compressed, margined; 
pappus none.--Perennial herbs; leaves alternate, commonly pinnately divided; heads small, corymbose.

A. millefolium, L. Stems ( $1^{\circ}$ high) simple, pubescent, tufted; leaves linceolate, bipinnatifid, the division linear, 3-5-cleft; corymbs dense, compound; rays 4-5, white.

\section{TANACETUM, L. TANSY.}

Heads many-flowered, discoid, the flowers all fertile; the marginal ones chiefly pistillate, 3-5-toothed; scales of the involucre imbricated, dry; receptacle convex, naked; achenici angled or ribbed; pappus a narrow border, or none. - Herbs with alternate dissected leaves, and solitary or corymbose heads of yellow flowers.

T. vulgare, L. Stem smooth, erect; leaves bipinnately divided, the lobes serrate; heads corymbose, numerous; pappus 5-lobed. Stem $1^{\circ}-2^{\circ}$ high.

\section{ARTEMISIA, L. WORMWOOD.}

Heads few or many flowered, discoid; the central flowers perfect, 5-toothed (sometimes abortive), the marginal ones pistillate, 3 -toothed; scales of the involucre imbricated, mostly with scarious margins; receptacle convex, naked or villous; achenia obovoid; pappus none.-Aromatic herbs or shrubs; leaves alternate, pinnately divided; heads small, in panicled spikes or racemes.

A. Caudata, Michx. Smonth; stem slender, branching; lowest leaves 2-3-pinnately divided, the upper ones pinnate, with the divisions filiform; heads globular, in small racemes, forming an elongated panicle; receptacle naked; disk-flowers abortive.

\section{GNAPHALIUM, L. Everlasting.}

Heads many-flowered, discoid, the exterior and pistillate 
ones rery slender, mostly in several rows, the central ones perfect; scales of the involucre imbricated, appressed, scarious; receptacle flat, naked; achenia terete or more or less flattened; pappus a single row of capillary bristles.Woolly or downy her.bs; leaves alternate, undirided; heads in crowded spikes or corymbs; involucre colored.

G. Polycephalum, Michx. Stem woolly, white, branching abore; leaves linear, sessile, undulate, white beneath ; heads corymbose; scales of the involucre white, obtuse. Stem $2^{\circ}$ high; perfect flowers few.

G. PLRPCRECM, L. Woolly or tomentose and hoary throughout; stems branching at the base, ascending simple; lowest leaves spatulate-lanceolate, the upper ones linear; heads in crowded spikes. Stems $4^{\prime}-12^{\prime}$ high.

\section{ANTENNARIA, Gært. Everlastixg.}

Heads many-flowered, diøcious, discoid; the corolla of the sterile flowers 5-cleft, of the pistillate ones filiform; scales of the involucre imbricated, scarious, colored ; receptacle convex or flat; achenia nearly terete; pappus a single row of capillary bristles, which, in the staminate flowers, are thickened at the apex.-Perennial downy or woolly herbs, with alternate entire leaves, and corymbose rarely single heads.

A. MARGARITACEA, R. Br. Stem corymbose abore, woolly; leaves linear-lanceolate, with revolute margins, tomentose; heads corymbose; involucre white. Stem $1^{\circ}-2^{\circ}$ high.

A. Plantaginifolia, Hook. Stoloniferous ; stems scapelike; radical leaves spatulate or obovate, hoary, becoming smooth above, 3-ribbed, those of the stem few, linear or lanceolate; heads small, in a terminal cluster, sometimes single and larger; involucre white or purplish. Stem 6'-12' high. 


\section{ERECH'HITES, Raf. FireweEd.}

Heads many-flowered; discoid; the marginal flowers pistillate, very slender, 2-3-toothed; the others perfect, 4-5-toothed; scales of the cylindrical involucre in a single row, linear, acute, bracted; receptacle naked; achenia oblong, striate; pappus of copious soft hairs.-Erect annual herbs, with alternate simple leaves, and corymbose heads of greenish flowers.

E. HIERACIFOLIA, Raf. Stem mostly branched, smooth or hairy; leaves lanceolate, sessile, sharply serrate or toothed, the upper somewhat clasping; bracts subulate, minute; pappus white. (Senecio hieracifolius, L.) Stem $1^{\circ}-5^{\circ}$ high.

\section{CACALIA, L.}

Heads 5-many-flowered; the flowers all tubular and perfect, 5 cleft; scales of the involucre $5-30$, in a single row; receptacle flat, naked, or with a tubercular prominence in the center; achenia oblong, smooth ; pappus of numerous capillary bristles.-Perennial, mostly smooth and tall herbs, with alternate entire or lobed leaves, and corymbose heads of white flowers.

* Receptacle flat ; involucre about 12-beaved, 25-30-flowtred.

C. Suaveolens, L. Smooth; leaves ovate, hastate, acute, toothed-serrate, on winged petioles, the uppermost sessile; bracts filiform. Stem $3^{\circ}-5^{\circ}$ high.

** Receptacle tubercular in the center; scales of the involucre and flower's 5.

C. Reniformis, Muhl. Stem angled; leaves not glaucous, angularly toothed, on slender petioles, the lowest large, reniform, the upper ones roundish; corymb compound. Stem $4^{\circ}-9^{\circ}$ high ; radical leaves sometimes $2^{\circ}$ in diameter, the teeth mucronate.

C. atriplicifolia, L. Stem terete, corymbosely branch- 
ed above; leaves glaucous beneath, angularly lobed, the lobes mostly entire, mucronate, the lowest ones renifurm, the upper rhomboid; corymls compound. Stem $4^{\circ}-8^{\circ}$ high; leares smaller and thicker than the last.

\section{SENECIO, L. Groundsel; BttTer-TWeed.}

Heads many-flowered; the flowers all tubular and perfect, or with pistillate rays; scales of the involucre in a single row, often bracted; receptacle naked or alveolate; achenia not beaked nor winged; pappus of copious soft hairs.-Herbs, with entire or pinnately divided leaves; heads corymbose; flowers yellow; pubescence mostly webby and deciduous.

* Annual; heads radiate.

S. Lobatcs, Pers. Smooth; stem furrowed, hollow; leaves tender, lyrate-pinuatifid, with rounded toothed lobes, the earliest orbicular, long-petioled; rays about 12. Stem $1^{\circ}-3^{\circ}$ high; lobing of the leaves variable.

** Perennial ; heads radiate; lowest leaves petioled, undivided, the others pinnately lobed or toothed, the uppermast sessile.

S. AUREus, L. Smooth, or more or less woolly when young; stem ( $2^{\circ}$ high) slender; radical leaves long-petioled, round-cordate, crenate; the others lanceolate or oblonglanceolate, pinnatifid; rays 8-12; achenia smooth.

Var. BaLsamix. Radical leaves spatulate-lanceolate or oborate; lower part of the stem often densely woolly; achenia hairy.

\section{CENTAUREA, L. StaR-THistle.}

Herbs, with alternate leaves; heads solitary, manyflowered; marginal flowers large and sessile; receptacle bristly; involucre imbricated; achenia compressed; pap- 
pus sometimes wanting, when present of one or two rows of rough bristles.

C. Americana. Stem $2^{\circ}-4^{\circ}$ high, erect, sparingly branched; lower leaves oblong-ovate, repand-dentate, upper ones lanceolate, acute, sessile, glabrous; heads few or solitary, very large; ray-flower's twice longer than the disk; scales with pectinate-pinnate, reflexed appendage. Flowers large, showy pale-purple heads. Red River.Engelmann.

* Leaves sessile.

+ Scales of the involucre lipped with spreading spines.

C. Virginianum. Stem $2^{\circ}-3^{\circ}$ high, tall, branching, commonly hairy; leaves with scattered hairs above, pubescent or at length nearly smooth beneath, bristly ciliate on the margins, deeply pinnatifid; the lobes lanceolate, 2-3toothed, spiny; scales of the involucre unarmed, webby, riscid; flower's purple; heads $1^{\prime}$ in diameter.

SUB-ORDER II. Labiatifloræ, not represented in any floral report.

\section{Sub-order III. Ligulifloræ.}

Tribe VII. Cichoraceæ. Style cylindrical above and pubescent, like the rather obtuse branches; the stigmatic lines terminating below or near the middle of the branches.-Plants with milky juice; leaves alternate.

\section{KRIGIA, Schreb.}

Heads 15-30-flowered; scales of the involucre 6-15, somewhat in 2 rows, equal; receptacle naked; achenia topshaped, 5-angled; pappus donble, the outer of $\mathbf{5}$ broad chaffy scales, the inner of 5 rough bristles.-Small annual herbs, branching at the base, with naked peduncle-like stems, each terminated by a small head of yellow flowers; leaves chiefly radical, mostly lyrate or toothed. 
K. Caroliniana, Nutt. Stem short; scapes pubéscent or somewhat hispid near the apex; leaves linear-lanceolate, acute at each end, entire or sparingly toothed, or the upper nnes variously lobed; scapes $3^{\prime}-12$ ' high.

\section{HIERACIUM, Tourn.}

Heads many-flowered; scales of the involucre imbricated, or in 2 rows, the outer row short; receptacle nearly naked; achenia not beaked, commonly terete or spindle-shaped, ribbed; pappus a single row of persistent brownish-white hairs.-Perennial herbs, with alternate entire or toothed leaves, and single, corymbose, or panicled heads of yellow flowers. Involucre, in our species, in 2 rows, the outer short and bract-like.

H. scabrum, Michx. Stem stout, leafy, hirsute below, rough above; panicle somewhat corymbose; leaves oval, sessile, the lowest spatulate-oblong, hirsute; peduncies and involucre tomentose and glandular-hispid; achenia cylindrical. Stem $1^{\circ}-3^{\circ}$ high; heads large, many-flowered.

H. Gronovir, L. Stem leafy and hirsute below, naked and smoother above; leaves entire or denticulate, hirsute, the lowest spatulate-oblong, the upper small, sessile; panicle narrow, elongated; achenia narrowed upward. Stem $1^{\circ}-2^{\circ}$ high; lowest leaves spreading on the ground.

\section{NABALUS, Cass.}

Heads 5-20-flowered; involucre cylindrical, composed of 5-14 linear scales, and several short exterior ones; receptacle naked; achenia linear-oblong or cylindrical, furrowed, glabrous, not narrowed upward; pappus of numerous straw-colored or brownish bristly hairs.-Perennial herbs, with bitter tuberous roots, entire or varionsly lobed leaves, and nodding heads of yellowish white or purplish flowers, in short racemes or clusters. 
N. virgates, DC. Stem $2^{\circ}-4^{\circ}$, smooth, virgate, simple; leaves linceolate, acute, sessile, amplexicaul; upper leaves small, entire, the lowest pinnatifid on margined petioles; heads small clusters, racemed; involucre smooth, purplish, of 8 scales, 8-12-flowered; pappus straw-colored; flowers purplish.

\section{LYGODESMIA, Don.}

Heads solitary, 5-10-flowered; leaves linear or filiform; receptacle naked; achenia linear, elongated, smooth, striate, not narrowed upward; pappus of copious hairs, white, in several rows; flowers rose-color.-Perennial herbs.

L. APHYLLA, DC. Stem $1^{\circ}-2^{\circ}$, simple or forking; leaves filiform, elongated, on the lower part of the stem; the upper are remote, small, and bract-like; heads showy.

\section{PYRRHOPAPPUS, DC.}

Heads many-flowered; involucre donble, of numerous subulate scales, the inner ones erect and partially united, often with a callous appendage at the apex; receptacle flat, naked; achenia oblong, nearly terete, 5 -furrowed, the apex narrowed into a long filiform beak; pappus of copious soft reddish or brownish hairs._Smooth annual herbs; leaves oblong or lanceolate, commonly toothed or pinnatifid; heads solitary, terminating the naked stem or peduncle-like branches; flowers yellow.

P. Carolinianus, DC. Stem branching; leaves lanceolate, mostly toothed or pinnatifid; achenia shorter than the filiform beak. Stem $1^{\circ}-2^{\circ}$ high.

\section{LACTUCA, L. LetTUCE.}

Heads few or many-flowered; scales of the cylindrical involucre imbricated, the outer ones short; receptacle naked; achenia compressed parallel to the scales, smooth, 
abruptly narrowed into a filiform beak ; pappus of copious soft white hairs. - Tall herbs, with entire or pinnatifid leaves; heads paniculate; flowers white, purple, blue, or yellow.

L. Elongata, Muhl. Smooth or nearly so; stem tall $\left(4^{\circ}-8^{\circ}\right)$, simple or paniculate; leaves elongated, lanceolate, sessile or partly clasping, the upper ones mostly entire, the lower pinnatifid; panicle long, leafless; flowers yellow. -Var. integrifolia. Leaves all undivided, or the lowest pinnatifid; flowers yellow or purplish.-Var. GRAMINIFOLIA. Smaller $\left(2^{\circ}-3^{\circ}\right)$; leaves linear or linear-lanceolate, rather rigid, all entire, or the lowest ones sparingly toothed or pinnatifid; flowers purple.

\section{MULGEDIUM, Cass.}

Heads many-flowered; scales of the involucre imbricated, the outer ones short; receptacle naked; achenia smooth, laterally compressed, narrowed into a short beak, which is expanded into a ciliate disk at the apex; pappus of copious white or tawny hairs. - Tall herbs; leaves pinnatifid or undivided; flowers mostly blue.

* Pappus tawny.

M. LECCOPH AUM, DC. Smoothish ; stem panicled above; leaves numerous, irregularly pinnatifid, with coarselytoothed lobes, the terminal lobe 3 -angled, or in the upper leaves often linear and entire; racemes panicled. Stem $3^{\circ}-12^{\circ}$ high ; leares $6^{\prime}-12^{\prime}$ long; flowers pale blue.

\section{SONCHUS, L.}

Heads many-flowered; scales of the involucre imbricated; receptacle naked; achenia compressed, ribbed, not beaked nor narrowed at the apex; pappus. of copious soft white hairs. Annuals. Leaves entire or pinnatifid; heads somewhat umbelled; flowers yellow. 
S. oleracers, L. Smooth; stem branching; leaves pinnatifid, with spiny-toothed lobes, clasping, the lowest petioled; achenia transversely roughened. Stem $1^{\circ}-2^{\circ}$ high.

\section{LOBELIA FAMILY. Order, Lobeliacee.}

Chiefly herbs, with milky juice; leaves alternate, without stipules; flowers irregular; calyx 5 -lobed, the tube adherent to the 2-celled ovary; corolla unequally 5-lobed, valvate in the bud; the tube split on one side to the base; stamens 5, inserted on the calyx; the anthers, and commonly the filiments, united into a tube; style solitary; stigma 2-lobed, surrounded with a ring of hairs; fruit baccate and indehiscent, or capsular and 2-3-valved, manyseeded; seeds anatropous; embryo straight in fleshy albumen.-Acrid, poisonous plant.

\section{LOBELIA, L. LOBELIA.}

Corolla bilabiate, the upper lip small, erect or reflexed, 2-parted, the lower spreading, palmately 3 -cleft; the tube straight; anthers, or a part of them, bearded at the apex, curved; capsule 2-celled, 2-valved at the apex, manyseeded. Stems erect; leaves undivided, the serratures glandular; flowers blue, white, or scarlet, in terminal racemes or spikes.

\section{* Flowers scarlet.}

L. Cardinalis, L. (Cardinal-flower.) Smooth or slightly pubescent; stem stout, simple; leaves lanceolate, denticulate; bracts leafy; stamens and style much longer than the corolla; raceme many-flowered; flowers very elegant and showy. Perennial. Stem $2^{\circ}-4^{\circ}$ high. Common on the banks of Buffalo Bayou in the neighborhood of Houston. 
** Flowers blue and white.

† Sinuses of the calyx with deflexed appendages.

L. SyPHILITICA, L. Hairy; leaves thin, lanceolate, acute at each end, coarsely serrate; racemes leafy, many-flowered; caly $x$ hairy; the lanceolate denticulate lobes half as long as the large ( $1^{\prime}$ long) light-blue corolla. Perennial. Stem $1^{\circ}-3^{\circ}$ high. Buffalo Bayou.

L. Brevifolia, Nutt. Stem thick, virgate, angled, smooth or pubescent; leaves short $\left(4^{\prime \prime}-12^{\prime \prime}\right.$ long), fleshy, oblong-linear, obtuse, toothed, spreading or reflexed, the lowest wedge-shaped; calyx hirsute, the orate-lanceolate lobes strongly toothed, the 5 appendages obtuse; corolla pale blue. Stem $1^{\circ}-1 \frac{1}{2}^{\circ}$ high; leaves very numerous.

\section{$+\dagger$ Sinuses of the calyx without appendages.}

L. Inflata, L. Pubescent or hairy; stem leafy, branching from the base; leaves oblong, obtuse, toothed, sessile; racemes leafy below; corolla small.

L. Paludosa, Nutt. Smooth; stem mostly simple, nearly leafless; radical leaves fleshy, spatulate-lanceolate or linear, obtuse, crenulate, the others small, linear, and remote; racemes slender, loose; bracts minute; corolla small, white or pale blue. Stem $2^{\circ}-4^{\circ}$ high ; lowest leaves $3^{\prime}-9^{\prime}$ long; corolla $\frac{1}{2}^{\prime}$ long.

\section{6\%. GOODENIA FAMily. Order, Goodeniaces.}

$H e r b s$ or shrubs, with watery juice, alternate exstipulate leaves, and irregular flowers; caly $x$ tubular, 3-5-lobed or entire, more or less adherent to the 1-4-celled ovary; corolla irregular, unequally 5-lobed, induplicate in the bud; the tube split on one side, or 5-parted; stamens 5, free from the corolla, the filaments and anthers rarely united; style commonly single; stigma thick, surrounded with a 
cup-shaped mostly ciliate membrane; fruit capsular or drupaceous ; embryo straight, in the axis of fleshy albumen.

\section{Cairpanula faMily. Order, Campanulaced.}

Herbs, with milky juice, alternate leaves, and regular mostly blue flowers; calyx 3-5-lobed, adherent to the ovary; corolla 5 -lobed, valvate in the bud; stamens 5 , free from the corolla, the broad filaments and anthers distinct; style single, hairy above; stigmas 2 or more; capsule 2 -several-celled, many-seeded, splitting at the apex, or opening by lateral valves or holes; embryo straight in fleshy albumen.

\section{CAMPANULA, L. BELL-FLOWER.}

Calyx 5-lobed; corolla 5-lobed, mostly bell-shaped; filaments dilated at the base; stigmas 3 , slender; capsule short, 3-celled, opening by lateral valves; flowers spiked or panicled.

* Flowers panicled, on slender spreuding pedicels; corolla small $\left(3^{\prime \prime}-4^{\prime \prime}\right)$, bell-shaped.

C. AParinoides, Pursh. Stem weak, reclining, the angles, as also the margins and midrib of the linear nearly entire leares, hispid backward ; panicle few-flowered ; calyxlobes triangular; corolla white. (C. erinoides, Muhl.) Swamps among the mountains, Georgia, and northward. July and August. Stem $1^{\circ}-1 \frac{1}{2}^{\circ}$ high; lowest leaves narrowly obovate.

** Flowers spiked, single or 2-3 together; corolla large, somenohat wheel-shaped.

C. Americana, L. Stem tall, smooth or hairy, mostly simple; leaves ovate-lanceolate, acuminate, serrate; spike elongated, leafy; corolla $\left(1^{\prime}\right.$ wide) blue. Stem $2^{\circ}-4^{\circ}$ high ; spike $1^{\circ}-2^{\circ}$ long; style exserted.

SPECULARIA, Heist.

Calyx 3-5-lobed; corolla wheel-shaped, 5-lobed; stamens 
free, the filaments membranaceous, hairy, shorter than the anthers ; stigmas 3 ; capsule prismatic, 3 -celled, opening by 3 lateral valves. Low annuals. Flowers axillary; corolla blue.

S. PERfoliata, A. DC. Pubescent; stem angled, simple or branched; leaves round-cordate, crenate, clasping, the lowest narrowed at the base; flowers single or clustered, sessile, the lower ones apetalous. Stem $1^{\circ} \mathrm{high}$.

\section{HEATH FAMILY. Order, ERICACEx.}

Shrubs or small trees, rarely herbs, with undivided alternate exstipulate leaves, and regular flowers; calyx 4-5parted; corolla 4-5-parted or toothed, or 4-5-petalous, imbricated in the bud; stamens free from the corolla, and as many or twice as many as its divisions; anthers 2-celled, often variously awned, opening commonly by terminal pores; style 1; stigma entire or 3-lobed; fruit 3-10-celled; seeds anatropous, attached to a central placenta; embryo small, in fleshy albumen.

\section{SYNOPSIS.}

SUb-ORder I. Vaccinieæ. Calyx-tube adherent to the orary; corolla superior; anther-cells prolonged into a slender tube; fruit a berry.-Shrubs; corolla monopetalous. Berry 4-5-celled, or partially 8-10-celled by false partitions, many-seeded. . VACcINIUM.

Sub-order II. Ericineæ. Calyx free from the ovary. Corolla hypogynous. Fruit a capsule. Shrub or tree.

Tribe I. ANDromedex. Capsule loculicidally dehiscent.

* Anther-cells opening at the apex; corolla monopetalous.

Calyx valvate in the early bud. Capsule globular. Seeds pendulous.. ANDROMEDA. - valvate in the bud. — pyramidal. —ascending..OXYDENDRUM.

** Anthers inverted in the bud, opening by terminal pores; corolla 5.petalous. 


\section{Sub-order III. Monotropa. Indian-Pipe Family.}

Calyx of 4-5 scale-like or bract-like sepals; corolla 5-lobed

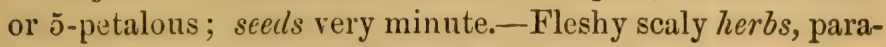
sitic on roots, and destitute of green foliage.

Corolla 4-5-petalous. Anthers kidney-shaped, opening across the top... Mомотrops.

\section{VACCINIUM, L. HuCKLeberry; Blueberry.}

Corolla cylindrical, urceolate, or campanulate, 4-5 toothed or pirted; stamens 8-10; anther's awnless, or 2-awned on the back; the cells prolonged into a tube, and opening at the apex; berry 4-5-celled, or by false partitions 8-10celled, many-seeded.-Shrubs; flowers nodding, solitary, clustered, or racemed, white or reddish ; pedicels 2-bracted.

Batodendron. Ovary more or less 10-celled by false partitions; corolla bell-shaped, 5-cleft; stamens 10, hairy; anthers 2-awned on the back; flower's in leafy racemes, seemingly axillary.

V. ARboreum, Michx. Arborescent, smoothish; leaves evergreen, oval or obovate, shining above, the veins beneath more or lass pubescent; corolla large, angled, white; anthers included; berry globose, black. Stem $8^{\circ}-15^{\circ}$ high ; flowers very numerous; berry mealy, ripening in the winter.

\section{ANDROMEDA, L.}

Calyx deeply 5-parted, valvate in the early bud; corolla 5 -toothed; stamens 10 ; anther-cells opening by a terminal pore; capsule 5-celled, 5-valved, many-seeded; seeds pendulous or spreading.-Shrubs; leaves alternate; flowers in literal and terminal racemes or clusters, nodding.

Flowers in umbel clusters; capsule more or less ribbed at the sutures, the ribs separating at maturity.

Corolla ovate, cylindrical, or somewhat bell-shaped; anthers or filaments awned; capsule ovate, truncate; shrubs smooth.

A. Mariana, L. Corolla large ( $\frac{1^{\prime}}{2}$ long), cylindrical, 
white; leaves oblong, obtuse or acute, entire, deciduous; caly $x$-lobes lanceolate acute, half the length of corolla; flowering sterins commonly leafless; filaments 2-awned. Stem $2^{\circ}-4^{\circ}$ high ; leares $2^{\prime}-3^{\prime}$ long.

\section{OXYDENDRUM, DC. Sour-Wood; Sorrel-tree.}

Calyx 5-parted; corolla ovate, 5-toothed; stamens 10 ; anther's awnless, opening by terminal chinks; the cells acuminate; capsule conical, 5-angled, 5-celled, manyseeded; seeds ascending.-A small tree, with deciduous oblong serrulate acuminate leaves, on slender petioles, and white flowers in long and slender 1-sided terminal panicled vacemes.

O. Arboreum, DC. Tree $15^{\circ}-40^{\circ}$ high ; leaves $4^{\prime}-6^{\prime}$ long, sour; corolla pubescent.

\section{CLETHRA, L.}

Calyx 5-parted, imbricated in the bud; corolla 5-petalous; stamens 10 ; anthers obcordate, inverted in the bud, opening by terminal pores; style slender, 3-cleft; capsule 3-celled, 3-ralved, many-seeded.-Shrubs or small trees; leaves alternate, oblong or oborate, serrate, deciduous; flower's white, in terminal racemes; stamens and style exserted.

C. alnifolia, L. Shrubby; branches and racemes. tomentose; leaves short-petioled, obovate or wedge-oblong, acute, smooth on both sides; racemes simple or panicled; style and filaments smooth; bracts partly persistent. (C. paniculata, Pursh.)-Varies, with the leaves hoary beneath, rongh above (C. tomentosa, Lam.), or on both sides (C. scabra, Pers.); style hairy; bracts caducous, $4^{0}-8^{\circ}$ high; leares 2 '-3' long; flowers fragrant.

\section{ARBUTUS.}

A. Texand, Buckley. Leares orate, acute, serrate, 
smooth $_{2}$ a little paler beneath; flowers capitate, subracemose; corolla campanulate, smooth, twice the length of the calyx ; filaments included, at base lanuginose, about $\frac{1}{3}$ the length of the corolla; calyx laciniate, ovate, acute; style long, cylindrical; berries round. Fruit ripe in November, of a deep scarlet or red color; trunk and branches very smooth, brownish red, the outer bark peeling off; wood very brittle.-Tree, 20-25 feet and 8-12 inches in diameter; leaves evergreen, $1 \frac{1}{2}-2 \frac{1}{2}$ inches long; petioles 1 inch long. Flowers in March; highly ornamental. Hills northwest of Austin. Rare.

\section{MONOTROPA, L. Indian Pipe.}

Calyx of 2-5 deciduous sepals; corolla 4-5-petalous, gibbous at the base, deciduous; stamens $8-10$; anthers reniform, opening across the apex; stigma broad, 4-5rayed; capsule oroid, 8-10-furrowed, 4-5-celled; seeds very numerous, minute. Stems low, fleshy, white or reddish, scaly ; flowers solitary or racemose, nodding; capsules erect; herbs parasitic on roots, or decayed vegetable matter.

§1. MохотворА, Nutt. Stem 1-flowered; sepals 2-4: petals 5; anthers opening by 2 chinks; style short and thick.

1. M. cniflora, L. Shady woods. Stem smooth, $4^{\prime}-10^{\prime}$ high, white, turning black in drying ; flower showy.

8 2. HYPopiTY, Dill. Stem several-flowered, the upper flower commonly with 5 petals and 10 stamens, the other's with 4 petals and 8 stamens; sepals as many as the petals; anthers opening by 2 unequal valves, the smaller one erect; style longer than the ovary.

2. M. Hypopitys, L. (M. Landginosa, Michx.) August. Stems $4^{\prime}-8^{\prime}$ high, pubescent, reddish.

70. GalaX Family. Order, Galacinee.

Calyx small, 5-sepalons, persistent; petals 5, hypogynous, oborate-spatulate, deciduous ; stamens hypogynous ; 
the filaments united into a 10-toothed tube, those opposite the petals sterile, the 5 alternate ones shorter and bearing a roundish 1-celled anther, which opens across the top; style short ; stigma 3-lobed; capsule ovoid, 3-celled, loculicidally 3 -valved; seeds numerous, fixed to the central placenta; embryo straight, in fleshy albumen.-A smooth perennial stemless herb, erect from a creeping scaly rhizoma; leaves all radical, evergreen, round-cordate, crenate, petioled; scape $\left(1^{\circ}-2^{\circ}\right.$ high) simple, bearing a long spiked raceme of small white flowers.

This order, with ane or two others not thus far found in Texas, have been placed here to assist the student, because they are well represented by the flora of the other Gulf States.

\section{HOLLY FAMily. Order, Aquifoliacex.}

Trees or shrubs, with alternate simple leaves, and small white or greenish flowers; calyx 4-9-toothed; corolla hypogynous, rotate, 4-9-parted, imbricated in the bud; slamens 4-9, alternate with the lobes of the corolla, and inserted on its base; anthers opening lengthwise; ovary free from the calyx, 4-9-celled; stigma lobed, nearly sessile; drupe berry-like, composed of 4-9 one-seeded nutlets; seeds anatropous, suspended; embryo minute, in fleshy albumen.

\section{ILEX, L. HolLy.}

Flowers perfect or diœciously polygamous, of 4-9 parts; drupe containing 4-9 nutlets; leaves evergreen or deciduous; fertile flowers commonly solitary on the young branches, the sterile ones mostly in sessile or peduncled clusters or cymes.

AQUIFoliom. Parts of the floner 4; ampe red; nutlets ribbed or veiny on the back; leaves evergreen.

I. opACA, Ait. (Holly.) Smooth ; leaves oral, concare, 
wavy and spiny on the margins; sterile flowers cymose, on slender peduncles; caly $x$-lobes acute.-A small tree.

I. Cassine, L. (Yaupon.) Leaves small $\left(\frac{1^{\prime}}{2}-1^{\prime}\right.$ long), oval or oblong, obtuse, crenate; chisters very numerous, nearly sessile; calyx-lobes minute, obtuse. Light sandy soil along the coast.-Shrub, $8^{\circ}-12^{\circ}$ high, slender, the short spreading branches often spine-like; fruit clustered, abundant.

Prinordes. Parts of the flower 4-6; drupe red or purple; nutlets 4-6, ribbed on the back; shrubs; leaves deciduous.

I. DECIDUA, Walt. Leaves lanceolate or oblong, obtusely serrate, pubescent on the veins beneath, tapering into a short petiole; flowers on short pedicels, in sessile clusters; calyx-teeth smooth, acute. (I. prinoides, Ait.) Varies, with the leaves smooth on both sides, and the flowers on longer pedicels. River swamps.-A large slırub; leaves thin, $1^{\prime}-2^{\prime}$ long; drupe red.

I. AMBigua. Branches slender; leaves oval or oblong, acute or somewhat acuminate, finely and sharply serrate, smooth on both sides, or rarely, like the branchlets, softly pubescent; pedicels of the sterile flowers clustered, longer than the petioles; those of the fertile ones very short, solitary ; calyx-teeth obtuse, ciliate ; leaves $1^{\prime}-4^{\prime}$ long.-Shrub or tree.

\section{STORAX FAMily. Order, Styracace.e.}

Trees or shrubs; leaves alternate, without stipules; flowers perfect; calyx 4-8-toothed, or entire, free, or adherent to the 2-5-celled orary ; corolla hypogynous, or inserted on the calyx, 4-8-lobed or 4-8-petalous; stamens inserted on the base of the corolla, twice as many as its divisions, or more numerous, separate, or monadelphous or polyadelphous at the base; style single; fruit capsular or drupaceous, 1-5-celled; seeds anatropous, mostly solitary 
in each cell; embryo nearly as long as the albumen; cotyledons flat; radicle slender.

\section{SYNOPSIS.}

Drupe drupaceous, 2-4-winged, 2-4-celled. Ovary wholly united with the calyz. HALESIA. Flowers in sessile clusters. Fruit baccate.................... SxMPLOCos.

\section{HALESIA, Ellis. SNowdrop Tree.}

Calyx obconical, slightly 4-8-toothed, adnate to the 3-4celled ovary ; corolla inserted on the calyx, 4-lobed or 4-petalous; stamens 8-16, separate or united below, free from the corolla; anthers linear; ovules 4 in each cell, 2 of them erect, and 2 pendulous ; drupe dry, 2-4-winged, 1-3seeded; seeds cylindrical.-Shrubs or small trees; leaves ample; flowers in short lateral racemes, appearing with the leaves, white, drooping.

* Ovary 3-celled; corolla 4-petalous ; stamens mostly 8, distinct; drupe 2-winged

H. DIPTERA, L. Leaves oval, coarsely serrate, pubescent, $4 '-5$ ' long; racemes 2-4-flowered, the flowers on long pedicels; corolla $1^{\prime}$ long; anthers spreading; drupe compressed, $1^{\prime}$ long. Rich woods, Florida and Georgia. March and April.

\section{SYMPLOCOS, Jacq.}

Calyx 5-cleft, more or less adherent to the 2-5-celled ovary; corolla 5-10-petalous; stamen.s 15 or more, monadelphous or polyadelphous, inserted at the base of the corolla; anthers roundish; ovules $2-4$ in each cell, suspended, anatropous; style slender; stigma entire or 3-5-parted; berry 1-5-seeded.-Trees or shrubs; leaves alternate, serrate; flowers axillary, in racemes or clusters.

S. TINCTORIA, L'Her. Leaves smooth, coriaceous, oblong, partly persistent; clusters sessile, 6-12-flowered; calyx smooth, top-shaped, the lobes obtuse; corolla yellow ; 
stamens in 5 sets; stigma entire; berry 1 -seeded.-A small tree; leaves $3^{\prime}-4^{\prime}$ long, sweetish; flowers very numerous.

\section{CYRILLA FAMiLY. Order, Cyrillacez.}

Trees or shrubs, with alternate evergreen leaves, without stipules, and perfect white flowers in lateral or terminal racemes; calyx of 4-5 sepals; petals 5-8, hypogynous, imbricated in the bud; stamens 5-10, inserted with the petals; anthers introrse, opening lengthwise; ovary 2-4celled, with a single suspended ovule in each cell ; stigma entire or 2-4-lobed; fruit 2-4-seeded; embryo straight in the axis of fleshy albumen; radicle superior.

\section{EBONY FAMILY. Order, Ebenacez.}

Trees or shrubs, with watery juice; leaves alternate, entire, without stipules; flowers polygamous, the sterile cymose, the fertile ones larger, solitary ; calyx free from the 3-12-celled ovary, peristent, 3-\%-lobed; corolla 3-7-lobed, imbricated in the bud, deciduous; stamens mostly 16 , inserted on the base of the corolla, often united by pairs, the filaments short and hairy; anthers introrse; ovules 1-2 in each cell, anatropous, suspended ; styles distinct, or united below; fruit baccate, roundish, few-seeded; the seeds large, compressed; embryo in the axis of hard albumen; radicle superior.

\section{DiOspyros, L. Persimmon.}

Calyx 4-6-lobed ; corolla bell-shaped, 4-6-cleft; stamens in the sterile flower mostly 16 ; in the fertile 8 , with the anthers sterile; styles 2 or 4 , united below ; ovules solitary in the cells; berry $4-8$-seeded.

D. Virginiana, L. Leaves ovate-oblong, mostly smooth, petioled; calyx 4-parted; corolla 4-cleft; styles 4, each 
2-lobed; ovary 8-celled. Woods and old fields.-A small tree; flowers greenish; berry eatable when fully ripe.

D. Texana, Scheele. Leaves obovate, obtuse, sessile or shortly petiolate, dark green above, paler below, and densely tomentose; corolla bell-shaped. clefts recurved; caly $x$ about $\frac{1}{2}$ length of corolla; sepals recurved; flowers aggregated or solitary. Flowers in March or April ; fruit ripe in August.-A small tree or large shrub, growing in clumps often; fruit dark brown or black when ripe; sweet and juicy; some like it, others think it insipid. Limestone hills, Central and Western 'Texas.

\section{\%. SAPODIlla FAMily. Order, Sapotaces.}

Trees or slirubs, with milky juice, alternate entire exstipulate short-petioled leaves, and regular perfect (small) flowers, commonly in sessile axillary clusters; calyx free from the 3-12-celled ovary, 4-8-parted, persistent; corolla hypogynous, 4-8-cleft, mostly with one or two appendages between each lobe; fertile stamens as many as the lobes of the corolla and opposite them, alternating with as many scale-like or petal-like sterile ones, inserted on the tube of the corolla; anther's extrorse; ovules anatropous, single, suspended from the central angle of each cell, or ascending from its base; fruit a drupe or berry; seedls few ; albumen fleshy or oily, or none; embryo straight.

Seeds without albumen. Sterile stamens entire. Ovary hairy........... BuMELIA.

\section{BUMELIA, Swartz.}

Calyx 5-parted; corolla 5-cleft, with two appendages between the lobes; stamens 5 , alternating with a petal-like sterile one; ovary 5-celled, hairy; berry ovoid, 1-seeded; leaves oblong, narrowed into a petiole, deciduous.-Shrubs, with hard wood, spiny; flowers white or greenish, clustered.

B. Lyciordes, Gært. Leaves 2 '-4' long, obovate-oblong, 
smooth ; corolla twice as long as the calyx; pedicels twice as long as the flower, shorter than the petioles.-A large shrub or small tree; berry oroid; flowers green.

B. Lanuginosa, Pers. Corolla white, twice as long as the calyx ; leaves 2 '-3' long, obovate-lanceolate or obovate, coriaceous, the lower surface, like the branchlets and manyflowered clusters, covered with a dense rusty villous pubescence; berry small, ovoid.-A tree or shrub.

\section{THEOPHRASTA FAMILY. Order, Theo-} PHRASTACEÆ.

Trees or shrubs, with watery juice; leaves coriaceous, often resinous-dotted, without stipules; flowers perfect, thick, white, orange, or red; calyx 5-parted; corolla 5-cleft, with a single appendage between the lobes; stamens 5 , fertile, opposite the lobes of the corolla; anthers extrorse, 2-celled, the thickened connective prolonged above the cells; ovary free, 1-celled, many-ovuled; placenta central, globose; stigma capitate; fruit globose; seeds few, inclosed in gelatinous pulp; embryo in the axis of copious albumen; radicle inferior.

\section{7\%. MYRSINE FAMILY. Order, Myrsinacee.}

Trees or shrubs, often glandular-dotted, with alternate exstipulate mostly entire leaves, and regular, often monœcious or diœecious, white or rose-colored flowers; calyx 4-6parted; corolla 4-6-cleft; stamens 4-6, opposite the lobes of the corolla; anthers 2-celled, introrse; ovary mostly free, 1-celled, smooth; ovules 1-many, imbedded in the cavities of the central placenta; style simple; fruit drupacenus, globose, somewhat fleshy, commonly 1-seeded; seeds roundish, concave at the base; embryo transverse, in hard albumen. 
78. Plantain family. Order, Plantaginacez.

Chiefly stemless herbs, with radical mostly ribbed leaves, and small whitish spiked or capitate flowers, borne on a naked scape; calyx of 4 imbricated sepals, with scarious margins; corolla salver-shaped, 4-parted, withering; stamens 2-4, included or exserted, inserted on the tube of the corolla, and alternate with its lobes; anthers 2-celled, deciduous; style slender; ovary free, 2-4-celled; capsule 2-celled, few-many-seeded, opening transversely; seeds attached to the deciduous partition; embryo straight in fleshy albumen.

\section{Plantago, L. Plantain.}

Characters same as the order.

* Flower perfect.

P. MAJOR, L. Leaves ovate or oval, smooth or pubescent, 5-7-ribbed, mostly toothed, narrowed into a broad concave petiole; scape pubescent; spike long-cylindrical, densely many-flowered; bracts ovate; capsule many-seeded. Low ground around dwellings. Scape $6^{\prime}-12^{\prime}$ high ; leaves $4^{\prime}-6$ ' long.

P. Larceolata, L. Leaves lanceolate, denticulate; acute, long-petioled, and 3-ribbed, pubescent; spikes dense, oblong or ovate; capsule 2-seeded. Spikes 1'-2' long; scapes $1^{\circ}-2^{\circ}$ high.

** Flowers diocious; annuals.

P. Virginica, L. Leaves lanceolate or oblong, entire or toothed; petioles short, 3-5-ribbed; stamens 4; capsule 2-4-seeded; spike cylindrical, densely-flowered; scupcs $1^{\prime}-1^{\circ}$; leaves $\frac{1^{\prime}}{2}-6^{\prime}$ long.

P. Heterophylla, Nutt. Smooth or pubescent; scrpe $2^{\prime}-6$ ' high, longer than the leaves; leaves somewhat fleshy, 
entire, or with scattered spreading teeth, linear; spikes linear, closely flowered, the lower flowers scattering; stamens 2 , exserted; capsule twice the length of calyx, manyseeded.-Torrey.

P. Gnaphaloines. On the Big Medicine River. Description not given.-Torrey.

\section{LEADWORT FAMILY. Order, Plumbaginacex.}

Calyx funnel-form or tubular, 5-toothed, plaited, persistent; corolla salver-shaped, こ-petalous, or 5-lobed; stamens 5 , opposite the lobes or petals, inserted on their claws or on the receptacle; styles 5, united or distinct; ovary 1-celled; ovule anatropous, solitary, suspended from the apex of the filiform cord rising from the base of the cell ; fruit capsular or utricular, variously dehiscent; embryo straight in mealy albumen.-Herbs or shrubs; leaves scattered, or radical and clustered.

\section{STATICE, L. MARSH Rosemary}

Perennial herbs, growing in saline marshes, with fleshy radical leaves and scape-like stems; calyx bracted, the limb scarious, 5-lobed; petals 5, united or distinct; stamens 5, inserted on the claws of the petals; style nearly or entirely separate; stigmas slender; utricle variously dehiscent.

S. Caroliniana, Walt. Scape $\frac{1}{2}^{\circ}-2^{\circ}$ high, scaly, and widely branched; leaves $3^{\prime}-6^{\prime}$ long, obovate or oblong, tapering into a long petiole; flowers mostly single, in 1-sided spreading spikes; calyx funnel-shaped, smooth, lobes of the scarious limb alternating with 5 smaller ones.

\section{PRIMROSE FAMILY. Order, Primulace.}

Stamens 4-5, opposite the lobes of the corolla, and inserted on its tube; corolla 4-5-lobed; calyx 4-5-lobed, per- 
sistent; ovary free or partly adherent to the calyx, 1-celled, many-ovuled; placenta central, globose; style single; capsule 1-celled, many-seeded, valvate or circumscissile; seeds anatropous or amphitropous; embryo straight in fleshy albumen.

\section{SYNOPSIS.}

Ovary free from the calyx.

+ Capsule opening by valves or teeth.

Corolla salver-shaped. Leaves pectinately dissected .Hotronia.

- wheel-shaped.

- opposite, entire.

Lrgimachis.

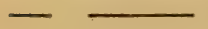

- radical.

DodecathroN.

++ Capsule opening transversely.

Parts of the flower 5. Leaves opposite. Stamens bearded

ANAgallis.

\section{4.}

alternate.

beardless.

. Centuncules.

** Ovary partly adherent to the calyx.

Stamens 5, with sterile filaments interposed. C'apsule valvate...

SAMOLUS.

\section{HOTTONIA, L.}

Calyx 5-parted; corolla 5-lobed, salver-shaped; stamens 5 ; style slender; capsule globose, at length splitting into 5 valves, which cohere at the base and apex; seeds anatropous, fixed by the base; flowering stems mostly clustered, nearly leafless, inflated, bearing at the joints whorls of small white flowers.-Aquatic perennial herbs, with pectinately dissected leaves.

H. INFLAta. Flowering stems 3-sereral in a terminal cluster, much inflated; upper stem-leaves crowded, with filiform divisions; bracts entire. Ponds and ditches.

\section{LYSIMACHIA, L. LOOSESTRIFE.}

Calyx 5-parted; corolla 5-lobed, wheel-shaped; stamens 5 ; filaments often monadelphous at the base, and commonly 
with the rudiment of a sterile one interposed; style slender; capsule globose, 5-10-valved, few-many-seeded; seeds amphitropous.-Perennial herbs, with entire opposite or whorled leaves, and axillary or racemose yellow flowers.

\section{* Flowers in terminal racemes or panicles.}

L. STRICTA, Ait. Leaves 2 ' long, very numerous, lanceolate, acute at both ends, dotted, opposite; flowers small; racemes long, leafy at the base; pedicels slender; corollalobes lanceolate-oblong, obtuse, entire, marked with dark lines; filaments monadelphous, unequal ; sterile ones none; capsule 5 -valved, $3-5$-seeded; stem $1^{\circ}-2$ : high.

** Flowers axillary.

L. QUADrifolia, L. Stem $2^{\circ}$ high, pubescent, simple; leaves 4-5 in a whorl, ovate-lanceolate, dotted, acute, sessile; peduncles filiform; corolla-lobes ovate-oblong, dotted; filaments monadelphous.

L. ciliata, L. Stem $1^{\circ}-2^{\circ}$ high, mostly branching, smooth; leaves lanceolate-ovate, cordate or rounded at the base, on ciliate petioles, opposite; corolla longer than the calyx, with broadly ovate or roundish denticulate lobes; peduncles opposite.

\section{DODECATHEON, L. AMERICAN Cowslip.}

Stemless herbs; leaves radical, clustered, spatulate or oblong; flower's umbellate, terminating the naked scape, white or purple; calyx 5-cleft, the lobes reflexed; corollatube very short, the 5-parted limb reflexed; stamens 5; the filaments monadelphous at the base; anthers long and linear, erect; capsule oblong-ovate, 5-valved at the apex, many-seeded; leaves spatulate or oblong, radical, clustered.

D. Meadia, I. Scape $1^{\circ}$ high ; leaves $4^{\prime}-6^{\prime}$ long. entire, or remotely crenate, smooth; flowers showy, nodding, in many-bracted umbels. Perennial. 


\section{ANAGALLIS, L. Pimpernel.}

Low herbs, with whorled or opposite leaves, and axillary peduncles; calyx 5-parted; corolla 5-parted, wheel-shaped, longer than the calyx ; stamens 5 ; filaments bearded; capsule globose, opening transversely, many-seeded.

A. ARvensis, L. Stem $6^{\prime}$ long, branching, spreading, 4-angled; leaves ovate, sessile; peduncles longer than the leaves, nodding in fruit; flowers red. Annual.

\section{'CENTUNCUIUS, L.}

Small annuals; leaves minute, nearly sessile, axillary, alternate; flowers white; calyx 4-parted; corolla 4-cleft, bell-shaped, shorter than the calyx; stamens 4, beardless; capsule globose, many-seeded, opening transversely.

C. Minimus. Stem 1'-5' long, ascending, branched, 3 -angled; leaves obovate, acute; flowers often clustered.

\section{SAMOLUS, L.}

Marsh herbs, smooth and somewhat fleshy; leaves alternate, entire; flowers small, white, in terminal racemes; calyx 5-cleft; the tube adherent to the base of the ovary; corolla 5-parted, salver-shaped, commonly with slender filaments interspersed; stamens 5, included; capsule 5-valved at the apex, many-seeded.

S. Floribundus, Kunth. Plant $66^{\prime}-12^{\prime}$ high, pale green, at length much branched; leaves obovate, the lowest tufted, spreading, the others scattered; racemes many-flowered; perlicels long, filiform, minutely bracted in the middle; capsule longer than the calyx, globose; flowers minute. Brackish marshes.

S. ebracteatus, Kunth. Stem $1^{\circ}-2^{\circ}$ high, simple or 
sparingly branched, naked above; leaves spatulate-obovate; pedicels bractless; racemes few-flowered; capsule shorter than the calyx; flowers conspictious. Saline marshes.

\section{BLADDERWORT FAMILY. Order, Lentibulacer.}

Aquatic or marsh herbs, with showy bilabiate flowers on scapes; corolla irregular, bilabiate, personate spurred; calyx 2-lipped, inferior; stamens 2, inserted on the upper lip of corolla; anther 1-celled; ovary 1-celled; style 1; capsule many-seeded; seeds minute; embryo straight and thick; albumen none.

\section{U'TRICULARIA, L. BLADDERW ORT.}

Lips of the calyx entire; throat of the corolla nearly closed by the projecting palate; the lips entire or slightly lobed, the lower one with an appressed or depending spur at the base.-Herbs, floating in still water by means of small air-bladders attached to the finely dissected leaves (or roots), or rooting in damp earth, with entire leaves, and few or no air-bladders; scapes or peduncles 1-many-flowered.

* Stem floating; upper leaves whorled, on inflated petioles, the others scattered and finely dissected; flowers yellow.

U. Inflata, Walt. Seape 5-10-flowered; corolla large ( ${ }^{\prime}{ }^{\prime}$ wide); the lower lip 3-lobed, twice as long as the appressed conical notched spur, the upper concave, nearly entire ; fruit nodding.-Var., MINor. Every way smaller; scape 2 -flowered. Ponds and ditches. Stem $2^{\circ}$ long; scape $6^{\prime}-12^{\prime}$ high.

** Stems floating ; leaves all scattered and finely dissected; flowers yellow.

U. VULGARIS, L. Leaves decompound ; scape scaly, 5-12flowered; throat of the corolla closed by the prominent palate; the lobes nearly entire, with reflexed margins, longer than the conical obtuse somewhat spreading spur; fruit nodding. Ponds and still water. Stem $2^{\circ}-3^{\circ}$ long; scapes 6'-12' high ; corolla $\frac{1^{\prime}}{2}$ wide. 


\section{PINGUiCUla, Tourn. ButTerwort.}

Calyx 3-lobed on the upper lip, lower 2-lobed; corolla somewhat 2-lipped, the upper lip 2-lobed, the lower 3-lobed, spurred at the base; palate hairy ; leaves all radical, clustered, entire, with the margins commonly involute; scape naked, commonly viscid. Stemless herbs.

* Flowers yellow.

P. LUTEA. Corolla $1^{\prime}-1 \frac{1}{2}$ ' wide, nodding, large, lobes rounded, 2-4-cleft; spur subulate; leaves oblong-obovate; scape 6 ' -12 ' high ; plant yellowish, clammy pubescent.

* Flowers purple, often changing to blue.

P. PuMila, Michx. Corolla-lobes obcordate; spur somewhat saclike, obtuse; leaves roundish or obovate; scape $2^{\prime}-6^{\prime}$ high ; corolla $\frac{1^{\prime}}{4}-\frac{3^{\prime}}{4}$ wide.

\section{BigNONIA FAMILY. Order, Bignoniacex.}

Herbs, shrubs, or trees, with simple or compound leaves, and regular or somewhat irregular showy flowers; calyx 2-lipped, כ̌-lobed, or truncate and entire; corolla tubular or bell-shaped, mostly 2-lipped; fertile stamens 2, or 4 and didynamous, inserted on the corolla ; anther-cells diverging; ovary 2-celled, many-ovuled, the base surrounded with a glandular disk; style filiform; stigma 2-lipped; capsule 2 -valved, 2 or 4 celled, many-seeded; embryo flat; albumen none.

\section{SYNOPSIS.}

Stb-order I. Bignonieæ. Trees, shrubs, or woody vines. Capsule 2-celled, the valves separating from the partition. Seeds flat, winged. Cotyledons notched at each end. Leaves opposite.

Valves of the capsule parallel with the partitions. Leaves compound......Bianomia. 
Sub-order. Sessameæ. Herbs. Capsule 4-celled. Seedls wingless. Cotyledons thick, entire.

Capsule woody, beaked. Leaves simple, allernate, or opposite...........MARTrNu,

\section{BIGNONIA, Tourn. Cross-vine.}

Calyx cup-shaped, truncate or slightly 5-toothed; corolla tubular-bell-shaped, 5-lobed; fertile stamens 4, didynamous; anthers smooth; valves of the capsule flattened parallel with the partition, and separating from it at maturity; seeds flat, winged.-Climbing woody vines; leaves opposite, compound.

B. CAPREOLATA, L. Leaves evergreen; the short petiole terminated by 2 cordate-oblong entire stalked leaflets, with a branched tendril between; pedicels clustered, axillary, elongated. Stem climbing high ; leaflets $3{ }^{\prime}-6$ ' long; corolla $2^{\prime}$ long, red without, yellow within; capsule $\frac{1}{2}^{\circ}$ long.

\section{TECOMA, Juss. TRUMPET-FLOWER.}

Calyx bell-shaped, 5-toothed; corolla funnel-shaped, 5 -lobed ; fertile stamens 4 , didynamous ; valves of the capsule convex, contrary to the partition; seeds winged.Shrubs or woody vines; leaves opposite, compound, deciduous.

T. Radicans, Juss. Stem climbing by rootlets; leaves pinnate, more or less pubescent; leaflets 9-11, ovate or ovate-lanceolate, acute or acuminate, serrate; racemes terminal, few-flowered (Bignonia radicans, L.) ; corolla $2^{\prime}-3$ ' long, scarlet without, yellow within ; capsule $4^{\prime}-5^{\prime}$ long.

\section{CATALPA, Scop.}

Calyx 2-lipped; corolla bell-shaped, somewhat 2-lipped, 5 -lobed; fertile stamens 2 ; valves of the cylindrical capsule contrary to the partition; seeds flat, with fimbriate wings. -Small trees; leaves simple, opposite; flowers in terminal panicles.

C. BIGNonioides, Walt. Leaves large, cordate, entire or 
angularly lobed, acuminate, long-petioled, pubescent; panicle trichotomous, many-flowered; calyx purple; corolla white, variegated with yellow and purple within, the lobes undulate; capsule slender, elongated, pendulous (C. cordifolia, Ell.); corolla $1^{\prime}$ long; capsule $1^{\circ}$ long.

\section{MARTYNIA, L. UNICORN-PLANT.}

Calyx 5-cleft, 2-3-bracted; corolla irregular, tubularbell-shaped, unequally 5-lobed; fertile stamens 2 or 4 ; capsule woody, falsely 4-celled, ending in two long recurved horns, and opening between them; seeds wingless.-Viscid branching annuals; leaves petioled, entire, roundish, the upper ones alternate; flowers racemed.

M. PRoвoscidea, Glox. Stem thick, at length prostrate; leaves round-cordate; corolla $11_{2}^{\prime}$ long, whitish, spotted with yellow and purple; capsule crested on one side, shorter than the beaks.

\section{BROOM-RAPE FAMILY. Order, Orobanchacf.x.}

Low, leafless, scaly herbs, parasitic on roots, with bilabiate didynamous flowers; calyx 4-5-toothed or parted; corolla withering-persistent, tubular, the upper lip 2-cleft or entire, the lower 3-lobed; stamens inserted on the tube of the corolla; anthers persistent; ovary free, 1-celled, with 2-4 parietal placentæ; style simple, curved at the apex; stigma thick, 2-lobed; capsule 2-valved, many-seeded; seeds very small, anatropous, with the minute embryo at the base of transparent albumen; flowers perfect or polygamous, solitary or spiked.

\section{SYNOPSIS.}

Flowers polygamous, spiked; the lower ones fertile, the upper sterile. Calyx 2-bracted, 5-toothed. Stem branching................................

Flowers perfect, spiked. Calyx 2-bracted, cleft on the lower side. Stem simple, thick, and fleshy. Conophous.

Flowers solitary, perfect. Calyx bractless, 5-cleft. Corolla nearly equally 5-lobed. APHXLLON. 


\section{EPIPHEGUS, Nutt. BEECH-DROPS.}

Flowers polygamous, the upper ones slender and sterile, the lower abbreviated and fertile; calyx 5 -toothed; capsule 2 -valved at the apex, with 2 placentæ on each valve. Stem smooth, slender, much branched, purplish; flowers small, in loose slender spikes; corolla purplish.

E. Virginiana, Bart. Stems $66^{\prime}-12^{\prime}$ high ; flowers scattered; corolla of the sterile flowers $4^{\prime \prime}-6^{\prime \prime}$ long, 4-toothed, curved.

\section{CONOPHOLIS, Wallr. SQUAW-ROOT.}

Flowers perfect, densely spiked; calyx 2-bracted, tubular, 4-toothed, cleft on the lower side; upper lip of the corolla arching, notched, the lower short, 3-toothed; stamens exserted; capsule 2 -valved, with 2 placentæ on each valve.A thick and fleshy whitish simple herb, covered with imbricated scales; flowers yellowish, spreading.

C. Americana, Wallr. (Orobanche, L.) Stems clustered from matted roots, $4^{\prime}-6^{\prime}$ high, $\frac{1^{\prime}}{2}$ thick.

\section{APHYLLON, Mitchell.}

Flowers solitary, perfect; calyx 5-cleft, bractless; corolla tubular, curved, nearly equally 5-lobed; stamens included; capsule 2-valved, with 4 equidistant placentæ. Stemless or nearly so; flowers purplish, on a long scape or peduncle.

A. Uniflonum, Torr. and Gray. Stem very short and scaly; peduncles 1 -several, $3^{\prime}-5$ 'high, pubescent; calyx-lobes lanceolate-subulate.

\section{FIG TORT FAMily. Order, Scrophulariacex.}

Chiefly herbs; leaves commonly opposite, without stipnles; calyx 4-5-cleft or parted; corolla 4-5-lobed, regular, 
or bilabiate, the lobes imbricated in the bud; fertile stamens 4 (sometimes 2, rarely 5), mostly didyuamous, inserted on the tube of the corolla; anther-cells often separate, opening lengthwise; ovary free, 2-celled, many-ovuled; placentce central; style simple or 2-cleft; capsule 2-celled, many- (rarely 1-few) -seeded; seeds anatropous; embryo small, in copious albumen.

\section{SYNOPSIS.}

Upper lip of the corolla exterior in the bud (except Mrmulus). Capsule commonly septicidally dehiscent.

* Stamens 5, all perfect. Corolla regular.

Corolla wheel-shaped. Filaments, or part of them,-bearded. Leaves alternate. VERBASCUM.

** Fertile stamens 4, the ffth sterile, or rudimentary. Flowers cymose. Leaves opposite.

Corolla globose or oblong; four of the lobes short and erect. Fifth stamen scale. like............................................. ScropHULARIA.

Corolla tubular, inflated, contracted at the throat. Fifth stamen shorter than the others. Seeds winged......................................... Chenone.

Corolla dilated upward. Fifth stamen as long as the others. Seeds wingless.

Pentstemon.

*** Fertile stamens 4; sterile ones none. Flowers axillary or racemed.

Corolla spurred at the base. Capsules toothed at the apex...............LENARIA. - large. Calyx tubular, 5-angled, 5-toothed ..................... MrмuLus.

- - short. _ - 5-parted; the three outer lobes much larger....... HERPEsTIS. ****: Fertile stamens 2 ; sterile ones 2 or none.

Calyx 5-parted. Sterile filaments entire, included. Capsule ovate or globose.

Gratiola.

Calyx 5-parted. Sterile filiments 2-cleft, exserted. Capsule oblong.....ILYSANTHBs.

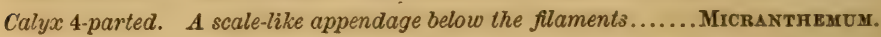

Upper lip of the corolla interior in the bud. Capsule commonly loculicidally dehiscent.

* Corolla regular or slightly 2-lipped ; the lobes nearly equal.

† Slamens 2, distant. Capsule mostly obcordate.

Style simple. Flowers in leafy racemes or spikes....................VERONICA. 
t† Stamens 4-5, equal. Peduncles axillary, 2 or more together.

Corolla bell-shaped, 5-cleft. Capsule loculicidal. Leaves alternate........ CAPRARIA.

t+† Slamens 4. Flowers racemed or spiked.

$\ddagger$ Anther's 2-celled. Stamens equal.

Corolla salver-shaped. Stamens didynamous. Flowers spiked.........BuchNERA. ¥¥ Anthers 2-celled. Stamens equal.

Corolla bell-shaped, yellow. Stamens included. . SETMERIA.

- tubular, orange. Stamens long-exserted.

MACRANTHERA.

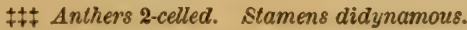

Anther's equal, awned at the base. Corolla funnel-shaped, yellow. Leaves mostly

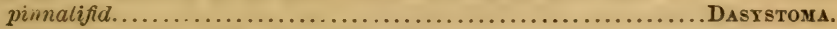

Anthers equal, pointed at the base. Corolla bell-shaped, purple. Leaves narrow, entire. Gerardia.

** Corolla tubular, 2-lipped ; the upper lip arching, and inclosing the 4 didynamous stamens.

+ Anther-cells unequal.

Anther-cells separate. Leaves alternate, the floral ones eolored.

t+ Anther-cells equal.

Calyx 10-12-ribhed, the upper teeth smaller. Capsule oblong, many-seeded. Leaves

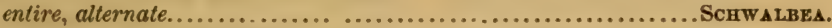

Capsule sword-shaped, few-seeded. Leaves pinnatifid. .Pedicularis.

\section{VERBASCUM, L. MUllein.}

Calyx 5-parted; corolla rotate, 5-lobed, the lobes nearly equal, roundish; stamens 5, declined, all, or a part of them, bearded; stigma simple; capsule globose, many-seeded.Tall biennial herbs; leaves alternate; flowers in racemes.

V. Blattaria, L. Stem smooth below, pubescent above, sparingly branched or simple; leaves smooth, oblong, acute, serrate or pinnately lobed, the lowest petioled, the upper clasping; racemes elongated, glandular, the flowers scattered; corolla bright or pale yellow ; filaments all bearded with purple hairs. Stem $2^{\circ}-3^{\circ}$ high. 


\section{SCROPHULARIA, L. FIGWORT.}

Calyx 5-parted; corolla globose or oblong, 5-cleft; the 4 upper lobes erect, with the two uppermost longer, the lowest spreading; stamens 4, declined; the fifth sterile and scale-like, placed near the orifice of the tube of the corolla; anther-cells transverse and confluent into one; capsule many-seeded.-Tall herbs, with opposite leaves, and greenish-purple flowers in loose cymes, forming a narrow panicle.

S. Noposa, L. Smooth; stem 4-sided; branches elongated, spreading; leaves ovate or oblong, or the uppermost lanceolate, acute, serrate, rounded or cordate at the base; flowers small. Stem $2^{\circ}-5^{\circ}$ high.

\section{CHELONE, Tourn. SNake-head.}

Calyx 5-parted or 5-sepalous, bracted; corolla inflatedtubular, contracted at the throat, bilabiate; the upper lip concave, emarginate; the lower obtusely 3-lobed, woolly in the throat; stamens 4 , with the filaments and cordate anthers woolly, and a fifth sterile one shorter than the others ; seeds imbricated, broadly winged.-Smooth perennial herbs, with opposite serrate leaves, and large white or purple flowers in short dense bracted spikes.

C. GLABra, L. Stem simple or branched, 4-sided; leaves lanceolate or oblong, acute or acuminate, on very short petioles; spike terminal, imbricated, nearly sessile, simple or branched; bracts and sepals ovate; corolla white or rose-color. September. Stem $2^{\circ}$ high; leaves $2^{\prime}-4^{\prime}$ long, sometimes pubescent beneath ; corolla $1^{\prime}-1 \frac{1}{2}^{\prime}$ long, concave beneath.

\section{PENTSTEMON, L'Her.}

Calyx 5-parted; corolla inflated-tubular, or somewhat 
bell-shaped, open at the throat, bilabiate; the upper lip rounded, concave, emarginate or 2-lobed; the lower lip 3-lobed; stamens 4, declined at the base, and a fifth sterile one as long as the others, and commonly bearded above; capsule 2-valved, many-seeded; seeds wingless.-Erect perennial herbs, with opposite leaves, and white or purple flowers in axillary and terminal cymes, forming a close or open narrow terminal panicle.

\section{* Leaves undivided.}

P. Pubescens, Solander. Pubescent or smooth; leaves lanceolate, acute, serrate or entire, sessile or clasping, the lowest ovate or oblong, tapering into a slender petiole; cymes spreading; few-flowered; tube of the corolla gradually dilated above the middle; the lower lip longer than the upper; sterile stamen bearded down one side; anthers smooth. Stem $2^{\circ}$ high; lowest leaves $3^{\prime}-5^{\prime}$ long; corolla $1^{\prime}$ long, pale purple.

P. Grandifloris. Found on the Red River by Marcy's Expedition.-Torrey.

\section{LINARIA, Juss. Toad-Flax.}

Calyx deeply 5-parted; corolla personate, spurred at the base; the upper lip emarginate or 2-lobed; the lower 3 -lobed; the throat commonly closed by the prominent palate; stamens 4, didynamous; capsule globose or ovoid, opening at the apex, with few or several tooth-like valves, many-seeded.-Herbs, with alternate or (on the radical branches) opposite or whorled leaves, and axillary or racemose flowers.

* Stems with prostrate branches at the base, which bear broader opposite or whorled leaves.

L. Canadensis, Spreng. Smooth ; stem erect, slender, mostly simple; leaves linear, flat, scattered, those on the radical branches oblong; racemes straight; pedicels erect, 
as long as the calyx; lobes of the small $\left(3^{\prime \prime}-4^{\prime \prime}\right)$ blue and white corolla rounded; spur filiform, curved, as long as the pedicels. (Antirrhinum Canadense, L.) Biennial. Stem $1^{\circ}-2^{\circ}$ high.

\section{MIMULUS, L. MONKET-FLOWER.}

Calyx tubular, 5-angled, sharply 5-toothed; corolla bilabiate; the upper lip 2-lobed, erect or reflexed; the lower 3-lobed, spreading; stamens 4, didynamous; anther-cells somewhat confluent; stigma ovate, 2-lipped; capsule loculicidally 2-valved, many-seeded.-Erect smooth perennial herbs, with opposite leaves, dan axillary purple flowers.

M. ALATus, Ait. Stem square, with winged angles; leaves oblong-ovate, acuminate, serrate, tapering at the base into a petiole; peduncles shorter than the flowers. Stem $2^{\circ}$ high ; leaves $2^{\prime}-5^{\prime}$ long; calyx-teeth small.

\section{HERPESTIS, Gærtn.}

Calyx 5-parted, the three outer lobes, especially the upper one, broader; corolla bell-shaped, 5-lobed or bilabiate, with the upper lip 2-lobed or emarginate, the lower 3-lobed; stamens 4, didynamous; anther-cells contiguous or divaricate; style dilated and flattened at the apex; capsule 2-valved, many-seeded.-Low herbs, with opposite leaves; flowers opposite, axillary, or in leafy terminal racemes.

* Stems 4-angled; leaves serrate; peduncles 2-bracted at the base; exterior calyxlobes oblong; corolla white.

H. Nigrescens, Benth. Smooth; stem erect, simple or branched; leaves oblong or oblong-obovate, rather obtuse, serrate above the middle; lower peduncles as long as the leaves, the upper much longer ; tube of the corolla striped with blue; the upper lip rounded. Stem $1^{\circ}-1 \frac{1}{2}^{\circ}$ high; leaves $1^{\prime}-2^{\prime}$ long. 
** Stems terete, succulent, creeping; leaves ovate or roundish, entire ; exterior calyxlobes cordate or ovate; peduncles 2 -bracted at the apex.

H. aMplexicaulis, Pursh. Stem villous, ascending from a creeping base; leaves smoothish, ovate, cordate and clasping, obtuse; peduncles shorter than the flowers; exterior calyx-lobes cordate; base of the ovary surrounded by a 12-toothed disk. (H. rotundifolia, Ell., not of Pursh.) Flowering stems $6^{\prime}-8^{\prime}$ high; leaves $11^{\prime}{ }^{\prime}$ long, crowded; flowers blue; plant odorous; perennial.

\section{GRATIOLA, L. HEDGE-HYSSOP.}

Calyx 5-parted, the lobes nearly equal, narrow ; corolla bilabiate, with the upper lip entire or emarginate, the lower 3-cleft; fertile stamens 2, included, the anterior ones sterile or wanting; stigma 2-lipped; capsule 4-valved, many-seeded.-Low perennial herbs, with opposite leaves, and solitary axillary white or yellow flowers; calyx mostly 2-bracted.

* Connective of the anthers dilated, the cells transverse; stems tender; flowers peduncled.

+ Sterile stamens minute or none.

G. Virginiana, L. Stem branching from the base, glandular-pubescent above ; leaves lanceolate, acute, sparingly serrate, sessile, the lower ones narrowed at the base ; peduncles slender, the upper ones longer than the leaves; corolla white, with the yellowish tube twice as long as the calyx ; capsule ovate, acute. Stem $66^{\prime}-12^{\prime}$ high ; leaves $1^{\prime}$ long; corolla 5" -6 " long, hairy within.

G. Floridana, Nutt. Stem simple or branched, smooth ; leaves lanceolate or oblong, obtuse, entire or nearly so, narrowed at the base, sessile, the lowest slightly petioled; peduncles filiform, longer than the leaves; lobes of the corolla emarginate, white; the slender yellowish tube three times as long as the calyx. Stem $1^{\circ}$ high; leaves $1^{\prime}$ long; corolla 8" long ; capsule globose. 


\section{$+\uparrow$ Sterile stamens manifest.}

G. QUadridentata, Michx. Pubescent and somewhat riscid; stem decumbent at the base, ascending, simple or branched; leaves lanceolate, sessile, 4-toothed; peduncles mostly longer than the leaves; corolla yellowish-white; capsule small, globose, much shorter than the linear unequal calyx-lobes; bracts minute. Stem $4^{\prime}-6^{\prime}$ high; leaves $\frac{1^{\prime}}{2}$ long; corolla $5^{\prime \prime}$ long.

G. AUReA, Muhl. Smooth; stem decumbent, creeping, the flowering branches ascending, 4-angled; leaves sessile, oblong-lanceolate, slightly serrate; peduncles as long as the leaves, or the upper ones longer; bracts as long as the calyx; corolla bright yellow. Stem $1^{\circ}-2^{\circ}$ long; leaves $\frac{1^{\prime}}{2}-1^{\prime}$ long; corolla $6^{\prime \prime}$ long.

\section{ILYSANTHES, Raf.}

Calyx 5-parted, bractless; corolla bilabiate; the upper lip short, erect, 2-cleft, the lower larger, spreading, 3-cleft; fertile stamens 2 , included, the two anterior ones sterile, 2-lobed, with one of the lobes tipped with a gland, the other smooth, acute; capsule ovate or oblong, as long as the calyx. - Smooth annuals, growing in wet or muddy places. Stems 4-angled; leaves opposite; peduncles axillary, often reflexed in fruit; flowers small, purplish.

I. Gratioloides, Benth. Stem ẻrect, at length diffusely branched; leaves lanceolate, oblong, or ovate, the lowest narrowed into a petiole, the upper sessile, acute, obscurely toothed or entire; lower peduncles mostly shorter than the leaves, the upper much longer, spreading; corolla pale blue, twice as long as the calyx; capsule oblong, acute, scarcely longer than the calyx. Stem $6^{\prime}-12^{\prime}$ long; leaves $\frac{1^{\prime}}{2}-1^{\prime}$ long ; corolla 3 " -4 " long.

I. ReFracta, Benth. Stem erect, very slender, forking; radical leaves tufted, oblong, obtuse, entire, narrowed at 
the base, the others remote, small, lanceolate, sessile; peduncles filiform, many times longer than the leaves, reflexed in fruit; corolla pale blue variegated with purple; capsule oblong linear, twice as long as the calyx. Stem $6^{\prime}-12^{\prime}$ high ; radical leaves $1^{\prime}$ long; corolla $3^{\prime \prime}-4^{\prime \prime}$ long.

\section{MICRANTHEMUM, Michx.}

Calyx 4-parted, or 4-cleft; corolla somewhat bilabiate, the upper lip shorter, entire, the lower 3-lobed, with the middle lobe longer; stamens 2, included; the filaments with a gland-like appendage at the base; anther-cells diverging; style short; stigma capitate; capsule 2-valved, few-seeded, the delicate partition vanishing at maturity; seeds oblong, reticulate.-A small smooth perennial herb, with diffuse creeping stems, roundish opposite entire leaves, and minute nearly sessile axillary white flowers.

M. onbicllatum, Michx. (M. emarginatum, Ell.; Hemianthus micranthemoides, Nutt.; Herpestis micrantha, Ell.? not of Pursh.) Stem 6'-12' long; leaves $3^{\prime \prime}-5^{\prime \prime}$ long, sometimes emarginate; corolla not longer than the minute $\left(\frac{1}{2}{ }^{\prime \prime}\right)$ calyx.

\section{VERONICA, L. SPEEDWELL.}

Calyx 4-5-parted; corolla wheel-shaped, or salver-shaped, 4-5-lobed; stamens 2, one each side of the upper lobe of the corolla; stigma capitate; capsule compressed and obcordate, or oblong and obtuse, septicidal or loculicidal; seeds few or many, flattened or concave on the inner face. -Chiefly herbs, with the stem-leaves opposite or whorled, the floral ones alternate; flowers small, axillary, racemed or spiked, blue or white.

* Leaves whorled; corolla tubular; capsule oblong.

V. Vinginica, L. Perennial, smooth or pubescent; stem tall, erect; leaves 4-7 in a whorl, lanceolate, serrate, short- 
petioled; flowers very numerous, crowded in axillary (whorled) and terminal spikes; stamens long-exserted; corolla white or purple. Stem $2^{\circ}-4^{\circ}$ high ; leaves $2^{\prime}-4^{\prime}$ long.

** Stem-leaves opposite; corolla wheel-8haped; capsule obcordate.

†† Flowers scattered, in leafy terminal racemes.

V. serpyllifolia, L. Perennial, smoothish; stem ascending, diffusely branched; leaves oval or roundish, crenate, short-petioled, the floral ones lanceolate and entire; pedicels as long as the calyx; corolla blue. Stem $4^{\prime}-6^{\prime}$ long; leaves $4^{\prime \prime}-6^{\prime \prime}$ long.

V. Peregrina, L. Annúal, smooth; stem erect, simple or branched; leaves sessile, oblong, toothed, the lowest narrowed into a petiole, the floral ones entire; peduncles shorter than the calyx; corolla white, minute. Stem $2^{\prime}-12$ ' high ; leaves $\frac{1}{2}^{\prime}-1^{\prime}$ long.

\section{CAPRARIA, L.}

Calyx 5-parted, equal; corolla bell-shaped, equally 5-lobed, smooth within ; stamens 4-5; anthers sagittate; style slender; stigma thick, ovate, at length 2-lobed; capsule coriaceous, ovate, septicidally 2 -valved, the valves 2 -cleft at the apex; seeds numerous, reticulate--Perennial herbs or shrubby plants; leaves alternate, serrate; peduncles axillary, single or by pairs, mostly 1 -flowered.

C. BIFLORA, L. Shrubby, smooth or pubescent; stem erect, branching; leaves lanceolate or oblong. sharply serrate, narrowed and entire below the middle; peduncles filiform, mostly by pairs, shorter than the leaves; calyxlobes linear; corolla deeply 5-cleft; stamens 5, included. Stem $2^{\circ}-3^{\circ}$ high ; leaves $1^{\prime}-1 \frac{1}{2}^{\prime}$ long; flowers white?

\section{BUCHNERA, L.}

Calyx tubular, 5-toothed; corolla salver-shaped, 5-lobed, 
the lobes wedge-obovate; stamens 4, didynamous, included; anthers 1-celled; style simple, club-shaped at the apex; capsule coriaceous, straight, loculicidally 2 -valved, the valves entire; seeds numerous, reticulate.-Rough herbs, turning black in withering; leaves opposite, toothed or entire, the uppermost small, and passing into the bracts of the manyflowered spike; flowers blue.

B. Elongata, Swartz. Rough with short rigid hairs; stem mostly simple; leaves entire or slightly toothed, 1-nerved or obscurely 3-nerved, the lowest obovate or obovate-oblong, obtuse; the lower stem-leaves narrowly lanceolate, the uppermost distant, acute; spikes interrupted, long-peduncled; flowers opposite or alternate. Low pinebarrens. Stem $1^{\circ}-2^{\circ}$ high ; corolla $4^{\prime \prime}-5^{\prime \prime}$ long.

\section{SEYMERIA, Pursh.}

Calyx 5-parted; corolla bell-shaped, 5-lobed, the lobes oblong; stamens 4, equal, the filaments woolly; anthers oblong, opening at the apex, awnless ; style simple, obtuse; capsule ovate, flattened above, loculicidally 2 -valved; seeds numerous, covered by the loose hyaline testa.-Chiefly annuals; stems erect, branching; leaves opposite, pinnately divided; flowers yellow, in terminal leafy-bracted racemes.

S. Tenuifolia, Pursh. Smooth or nearly so ; stem with elongated erect-spreading branches; leaves pinnate, the entire or lobed divisions filiform; capsule smooth, acute at the base, shorter than the pedicel. Low pine-barrens. Stem $2^{\circ}-4^{\circ}$ high.

S. pectinata, Pursh. Viscid-pubescent; stem with ascending branches; leaves pinnatifid, the entire obtuse divisions oblong-linear; capsule hairy, obtuse at the base, as long as the pedicel. Stem $6^{\prime}-18^{\prime}$ high. 


\section{MACRAN'THERA, Torr.}

Calyx 5-cleft, the lobes elongated; corolla cylindrical, 5 -toothed, the teeth reflexed; stamens 4, equal, long-exserted, woolly; anthers large, oblong, approximate; style simple, filiform, elongated; stigma minute, flat; capsule ovate, loculicidally 2-valved, many-seeded.-A tall biennial, with pinnatifid opposite leaves, and showy orange-colored flowers, in terminal leafy racemes.

M. FUCHSIoIdes, Torr. Smoothish; stem branching, 4-sided; earliest leaves ovate-oblong, entire, those of the stem lyrate-pinnatifid, with the lobes denticulate, the uppermost toothed-serrate; pedicels slender, recurved, the upper ones longer than the floral leaves; flowers erect; calyx-lobes lanceolate, denticulate, rather shorter than the corolla. Var. LECONTEI has the shorter and narrower lobes of the calyx entire. Stem $3^{\circ}-5^{\circ}$ high ; earliest leaves $6^{\prime}-8^{\prime}$ long, those of the stem $2^{\prime}-4^{\prime}$ long; corolla $9^{\prime \prime}-12^{\prime \prime}$ long. The plant turns black in drying.

\section{DASYSTOMA. (See page 454.)}

\section{GERARDIA, L.}

Calyx bell-shaped, 5-toothed, the teeth short, acute, entire; corolla tubular-bell-shaped, 5-lobed, the lobes rounded, spreading, the throat oblique; stamens 4, didynamous, the longer ones commonly woolly; anthers woolly, connivent in pairs, the cells diverging and pointed at the base; style slender, dilated, and flattened upward; capsule ovoid or globose, smooth, loculicidal; seeds numerous, angled, reticulated.-Chiefly slender branching annuals; leaves opposite, or rarely alternate, narrow, entire; flowers in the axils of the upper leaves, showy, purple; the tube of the corolla mostly dotted with red and yellow, often woolly at the throat.

\section{* Perennial.}

G. LiNifolia, Nutt. Smooth; branches elongated, erect; 
leaves erect, linear; peduncles as long as the leaves, or the uppermost longer; calyx truncate, with minute teeth; lobes of the corolla nearly equal, fringed on the margins; capsule large ( $3^{\prime \prime}$ wide), globose, one-third longer than the calyx. Stem $2^{\circ}-3^{\circ}$ high; leaves $1^{\prime}$ long; corolla $1^{\prime}$ long, pubescent.

++ Lobes of the corolla nearly equal, spreading.

$\ddagger$ Pedicels as long or twice as long as the calyx, shorter than the leaves.

G. APHYLLA, Nutt. Stem $2^{\circ}-3^{\circ}$ high, smooth, 4-angled sparingly branched near the summit; leaves minute, $1^{\prime \prime}$ long, subulate, appressed; flowers mostly alternate, on one side of the spreading branches; pedicel as long as the calyx; calyx-teeth minute, obtuse; corolla $\frac{1}{2}^{\prime}$ long, hairy within, the upper lobes reflexed; capsule globose, $2^{\prime \prime}$ long, twice as long as the calyx.

G. PARVIfolia. Stem rough, striate, $12^{\prime}-18^{\prime}$ high, the slender branches erect; leaves $4^{\prime \prime}-6^{\prime \prime}$ long, opposite or alternate, linear, very rough, rather obtuse; pedicels filiform, $2-4$ times as long as the minute floral leaves; calyx-teeth

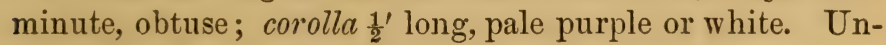
like the other species, this remains unchanged in drying.

\section{CASTILLEIA, L.}

Calyx tubular, compressed, cleft at the summit, the lobes entire or 2-cleft; tube of the corolla included in the calyx; the upper lip long, narrow, curved, laterally compressed, and inclosing the four didynamous stamens; the lower lip short, 3-lobed; anther-cells oblong-linear, unequal, the outer one fixed by the middle, the inner pendulous; capsule loculicidal, many-seeded.-Herbs, with alternate entire or incisely lobed leaves, the uppermost colored; flowers in leafy spikes or racemes.

C. Coccinea, Spreng. Stem hairy ; radical leaves clustered, nearly entire; those of the stem pinnatifid, with the 
lobes linear; the floral ones 3 -lobed, bright scarlet at the summit; corolla greenish yellow. Stem $1^{\circ}-1_{\frac{1}{2}}^{\circ}$ high.

\section{PEDICULARIS, L.}

Calyx tubular, more or less cleft at the apex, variously 2-5-toothed; corolla bilabiate; the upper lip compressed, curved and bearded at the apex, inclosing the 4 didynamous stamens; the lower lip 2-crested above, 3-lobed, with the lateral lobes larger and rounded; anthers transverse; capsule ovate or lanceolate, compressed, the upper portion empty.-Herbs, with finely and pinnately divided leaves; flowers in leafy racemes or spikes.

P. Canadensis, L. Stem simple, hairy $\left(6^{\prime}-9 \cdot\right.$ high $)$; leaves alternate, smooth, oblong or lanceolate, pinnatifid, the lobes oblong, simply or doubly crenate; spike dense, capitate, elongated in fruit; corolla pale yellow and purple; the upper lip hooked, 2-awned under the apex; capsule lanceolate, exserted. Stem bearing slender leafy and rooting runners; fruiting spike $3^{\prime}-5^{\prime}$ long. Perennial.

P. Lanceolata, Michx. Stem tall $\left(1^{\circ}-3^{\circ}\right)$, smooth, simple or sparingly branched; leaves nearly opposite, lanceolate, pinnately toothed, the teeth crenate; spike dense; corolla pale yellow, the upper lip curved, awnless, the lower erect; capsule ovate, scarcely exserted.

\section{ACANTHUS FAMILY. Order, ACanthacex.}

Chiefly herbs, with opposite (rarely alternate or clustered) undivided exstipulate leaves, and bracted, often showy flowers; calyx 5-parted; corolla more or less bilabiate, 5 -lobed, twisted in the bud; fertile stamens 2 or 4 , inserted on the tube of the corolla; anthers 2-celled; ovary free; style single; stigma entire or 2-lobed; capsule loculicidally 2-valved, 2-celled, 4-several-seeded, opening elastically; 
seeds anatropous, flat, rounded, without albumen, mostly supported by curved appendages of the placentæ; radicle inferior. Stems commonly swollen between the joints.

\section{SYNOPSIS.}

* Capsule oblong, bearing the seeds at the base; appendages of the placenta none.

spike borne on a closely-bracted scape. Leaves radical................ ELYTraria.

** Capsule club-shaped, bearing the seeds above the base appendaged.

Conolla nearly regular. Stamens 4. Flowers axillary, solitary or clustered.

Dipteracanthus.

Corolla bilabiate. Stamens 2. Cells of the anthers placed one lower than the other.

Flowers in long-peduncled axillary spikes.................... Dianthera.

Corolla bilabiate, resupinate. Stamens 2 . Cells of the anthers placed one behind the

other. Flowers in leafy-bracted heads or clusters................ DICLIPTERA.

\section{ELYTRARIA, Vahl.}

Calyx 4-5-parted, the lateral lobes narrower; corolla salver-shaped or bilabiate, 5-lobed; fertile stamens 2, the 2 anterior ones sterile; anther-cells parallel ; stigma 2-cleft; capsule sessile, about 8 -seeded, the seeds fixed near the base of the capsule, without appendages.-Low herbs; leaves all radical, clustered; scape covered with imbricated bracts; flowers spiked, 2-bracted.

E. virgata, Michx. Leaves oval or oblong, narrowed downward, entire or wavy on the margins, smooth or pubescent; bracts of the scape alternate, rigid, lanceolate, acuminate, clasping, those of the spike ovate; corolla white, salver-shaped, the lobes nearly equal ; capsule cylindrical. Scapes $6{ }^{\prime}-12^{\prime}$ high ; leaves $2^{\prime}-4^{\prime}$ long.

\section{DIPTERACANTHUS, Nees.}

Calyx 2-bracted, 5-parted, with linear or bristle-like lobes; corolla funnel-shaped, 5-lobed, the lobes equal, rounded; stamens 4, didynamous, included; anthers sagit- 
tate; style simple, or 2-cleft at the apex ; capsule narrowed below the middle, flattened contrary to the partition, 4-12-seeded; seeds borne above the middle, supported by curved appendages of the placentr. Herbs, with tumid joints ; leaves entire, opposite ; flowers axillary or clustered, nearly sessile; corolla white, blue, or purple. Perennial.

D. oblongifolius. Pubescent and somewhat hoary; stem 4-angled, erect from a creeping base, simple or sparingly branched; leaves nearly sessile, oval or obovate; flowers solitary or 2-3 in a cluster; calyx-lobes subulatesetaceous, as long as the oblong bracts, and tube of the spotted corolla; anther-cells pointed at the base; style simple; capsule 4 -seeded. Stem $6^{\prime}-12^{\prime}$ high ; leaves $\frac{1}{2}^{\prime}-1^{\prime}$ long; corolla $1^{\prime}$ long, rather exceeding the leaves.

\section{DIANTHERA, Gron.}

Calyx 5-parted ; corolla bilabiate, the upper lip emarginate, the lower 3-lobed, rugose or veiny in the middle, spreading; stamens 2 ; anther-cells separated, one placed lower down than the other; stigma simple, acute; capsule flattened, narrowed downward, bearing the seeds above the middle; seeds mostly 4, supported by the appendages of the placentæ.-Perennial smooth herbs, with opposite entire leaves, and short-bracted mostly alternate flowers in long-peduncled axillary spikes.

D. Americana, L. Stem tall, angled; leaves long, linear-lanceolate; spikes oblong, dense or somewhat capitate, on peduncles as long as the leaves. (Justicia ensiformis, Ell.? J. pedunculosa; Michx.) In slow-flowing streams. July and August. Stem $2^{\circ}$ high; leaves and peduncles $4^{\prime}-6^{\prime}$ long; spike $\frac{1}{2}^{\prime}$ long; flowers pale purple.

\section{DICLIPTERA, Juss.}

Herbs, with simple leaves; flowers purple, scarlet, or 
white, in axillary or terminal heads or spike-like cymes; calyx 5 -parted, mostly leafy-bracted; corolla bilabiate, mostJy reversed, the lower lip 3-lobed, the upper 2 -cleft or entire; stamens 2 ; anther-cells equal, one placed behind the other; capsule oblong or oval, bearing 2 or 4 seeds below the middle; the partitions at length free from the valves.

D. Brachiata, Spreng. Leaves thin, oblong-ovate, acuminate, abruptly contracted into a long and slender petiole; stem 6-angled, with numerous spreading branches; spikes solitary or 2-3 together, interrupted, unequal; bracts oblong, mucronate, narrowed at the base, at length inflated; corolla small, purple. Stem $1^{\circ}-2^{\circ}$ high; plant smooth or nearly so.

\section{DREJERA.}

D. PARtiflora, Buckley. Leaves opposite, lanceolate, shortly petiolate, acuminate, obtuse at base ; spikes terminal, naked; calyx deeply 5-cleft; segiments long-subulate; tube of corolla narrow, twice the length of the calyx; flowers opposite, sessile, shortly interrupted on the spikes. -Shrub, 3-4 feet high, with slender branches; the young branches and calyx glandular pubescent, the rest of the plant smooth ; petioles about 1 line long; flowers 6-8 lines long; bracts lanceolate, shorter than the calyx. Western Texas. June.

\section{VERVAIN FAMILY. Order, Verbenacex.}

Chiefly herbs or shrubs, with 4-angled mostly rough stems, and opposite and exstipulate leaves ; flowers spiked, capitate, or cymose; calyx 4-5-cleft or parted, free; corolla regular and salver-shaped, or more or less bilabiate, 4-5lobed; stamens 4-5, inserted on the tube of the corolla; anthers 2-celled; ovary entire, 1-8-celled, with 1 or (in Avicennia) 2 ovules in each cell; style simple, terminal; 
fruit dry or baccate, 1-8-celled, commonly separable into as many 1-seeded indehiscent nutlets; albumen scarce or none; embryo straight.

\section{SYNOPSIS.}

Tribe I. Verbeneæ. Ovule solitary, erect from the base of the cell, anatropous. Radicle pointing downward. Flowers in spikes or heads.

* Herbe ; fruit dry.

Stamens 4. Fruit of 2-celled nutlets, inclosed in the inflated calyx...... VERBENA.

4. - 2-celled nutlets. Flowers capitate.

I.IPPIA.

** Shrubs; fruit fleshy or pulpy.

Fruit of 2-celled nutlets. Flowers capitate

LANTANA.

Tribe II. Viteæ. Ovule solitary, suspended from the inner angle of the cell, amphitropous. Radicle pointing downward. Flowers in cymes. Fruit baccate.

Fruit of 4 separate 1-celled nutlets.

Shrubs

Callicarpa.

Tribe III. Phrymeæ. Ovule solitary, erect from the base of the 1-celled ovary, orthotropous. Radicle pointing upward. Cotyledons convolute around their axis. Flowers in elongated slender spikes. Fruit a caryopsis.

Corolla bilabiate. Stamens 4 , didynamous. Fruit reflexed............. Phrтм.

\section{VERBENA, L. VERVAIN.}

Herbs, with small flowers in lengthened slender spikes; leaves serrate or pinnately divided; calyx tubular, 5-ribbed, 5 -toothed; corolla salver-shaped, bearded in the throat, the limb somewhat bilabiate, 5-lobed; stamens 4, didynamous, included; stigma 2-lobed; ovary 4-celled; fruit of 4 separate 1 -seeded nutlets.

*Anthers of the longer stamens tipped with a gland-like appendage; flowers showy.

V. Aubletia, L. Hairy; stem creeping at the base, ascending, forking; leaves ovate-oblong, 3-cleft, with the 
lobes toothed, narrowed into a slender petiole, the lower ones smaller, rounded, toothed; spikes terminal and in the forks of the stem, long-peduncled, closely flowered; calyx long, slender, the unequal teeth subulate; corolla showy, purple. Stem $6^{\prime}-12^{\prime}$ high; corolla $\frac{1^{\prime}}{2}$ long.

** Anthers without appendages; flowers small.

+ Leaves undivided.

V. URTICIFolia, L. Rough-hairy; stem tall, branching; leaves ovate-oblong, acute or acuminate, mucronate-serrate, contracted at the base into a long petiole; spikes very long, filiform, axillary and terminal; flowers minute, white or pale blue. Low ground. Stem $2^{\circ}-5^{\circ}$ high; leaves very rough, $2^{\prime}-6$ ' long.

V. Hastata, L. Rough-hairy; stem branching; leaves oblong-lanceolate, acuminate, coarsely and sharply serrate, tapering into a long petiole, the lowest broader, and often hastate-lobed at the base; spikes linear, short, close-flowered; flowers violet. (V. paniculate, Lam.) Low ground. Stem $2^{\circ}-3^{\circ}$ high ; flowers larger than in V. urticifolia.

V. Angustrfolia, Michx. Rough-hairy; stem simple or branched above; leaves lanceolate or linear-lanceolate, rather obtuse, coarsely serrate, tapering from near the apex to the sessile base; spikes linear, terminal, close-flowered; flowers purple. Dry woods. Stem $6^{\prime}-12^{\prime}$ high ; flowering spikes $2^{\prime}-3^{\prime}$ long.

\section{LIPPIA, L.}

Herbs, with 4-angled stems, opposite or whorled, simple leaves; flowers in dense spikes or headș; calyx tubular, membranaceous, 2-4-toothed; corolla tubular-funnelformed, somewhat bilabiate, 5-cleft; stamens 4, didynamous, included ; ovary 2-celled, 2-ovuled; style short; stigma obliquely capitate; fruit of two 1-seeded separable nutlets. 
L. Nodiflora, Michx. Flowering stems $66^{\prime}-12^{\prime}$ high ; leaves 1 ' long, obovate, lanceolate or oblong, rough, tapering and entire below the middle, serrate above; stem creeping, finely pubescent, the flowering stems erect; heads dense, globose in flower, oblong or cylindrical in fruit, on axillary peduncles, which are 2-3 times as long as the leaves; flowers white or purple.

L. CUNeIFolia. Found on the Witchita by Torrey.

\section{LANTANA, L.}

Calyx minute, slightly 4 -toothed; corolla bilabiate, the upper lip notched or entire, the lower 3-lobed; stamens 4, didynamous, included; style short; stigma oblique; fruit fleshy or berry-like, of two mostly rugose or tuberculate 1-seeded nutlets, inclosed in the enlarged membranaceous calyx.—Shrubs, with simple rugose serrate leaves, and axillary peduncled capitate bracted flowers.

L. involucrata, L. Var., Floridana. Stem much branched, pubescent; leaves small $\left(\frac{1^{\prime}}{2}-1^{\prime}\right)$, oval or obovate, crenate, rounded at the apex, densely pubescent when young, at length rough above, contracted into a slender petiole; peduncles 2-3 times as long as the leaves, the upper ones corymbose; heads small; bracts ovate, as long as the tube of the small $\left(2^{\prime \prime}-3^{\prime \prime}\right)$ white (?) corolla; the outer ones empty and narrower, involucrate.

\section{CALlicarpa, L. French Mulberry.}

Shrubs with a glandular or scurfy mostly stellate pubescence; leaves undivided, serrate, petioled, opposite; flowers in axillary forked cymes; calyx 4-toothed, cupshaped, small; corolla 4-cleft, funnel-form ; stamens 4, equal, exserted; ovary 4-celled; style slender; stigma capitate; drupe baccate, of four separate 1-seeded nutlets. 
C. Americana, L. Branches and leaves scurfy; leaves ovate-oblong, acute at each end, crenate, serrate, rough above, hoary beneath, becoming smoothish; cymes manyflowered, as long as the petioles; corolla blue; drupe purple.-Shrub, $3^{\circ}-8^{\circ}$ high ; leaves $4^{\prime \prime}-6^{\prime \prime}$ long. On Buffalo Bayou.

\section{PHRYMA, L. LOPSEED.}

Perennial, branching pubescent herbs, with opposite, ovate or oblong, coarsely-serrate, long-petioled leaves, and small opposite purplish flowers, in a slender terminal spike; fruit reflexed, oblong, pointed by the persistent style; calyx tubular, bilabiate, the upper lip notched, the lower longer, 3-lobed; stamens 4, didynamous, included; style slender; stigma 2-cleft.

P. Leptostachya. Stem $1^{\circ}-3^{\circ}$ high, tumid above the joints; leaves 3 '-5' long.

\section{8\%. MINT FAMILY. Order, LABIate.}

Herbs or shrubs, with opposite 4-angled branches, and opposite exstipulate leaves; flowers opposite, solitary, or oftener in close axillary spiked or capitate cymes (whorls); calyx 3 -10-cleft or toothed; corolla more oi less bilabiate, 4-5-lobed; stamens inserted on the tube of the corolla, diandrous or didynamous; ovary 4-cleft or 4-parted, the lobes surrounding the base of the single style; ovule solitary, erect, anatropous; fruit of 1-4 one-seeded nutlets; albumen scarce or none; embryo straight or (in Scutellaria) curved; radicle short, inferior.-Plants commonly dotted with minute glands, which are filled with an aromatic volatile oil.

\section{SYNOPSIS.}

Tribe I. Ocimoideæ. Stamens 4, didynamous; the 
lower pair longer, reclining on the lower lobe of the corolla. Anthers 2-celled. Nutlets smooth, distinct.

Calyx-teeth nearly equal. Lowest lobes of the corolla longest, saccate, bent downward.

HYPTIS.

Tribe II. Satureiæ. Stamens 2 or 4, straight and spreading, or connivent under the upper lip; the upper pair shorter or abortive. Anthers 2-celled. Naitlets smooth, distinct.

* Corolla-lobes nearly equal. Stamens distinct.

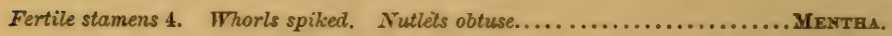

- 2. - axillary.

LxcopUs

** Corolla 2-lipped. Stamens straight, distinct, spreading.

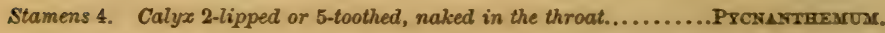
2 or 4.

Coutrossomi.

*** Corolla 2-lipped. Stamens ascending and spreading above, or connivent under the upper lip.

T Fertile stamens 4. Calyx 13-nerved.

Calyx 2-lipped. Flowers in cymes. Anthers awnless. Chiefly shrubs...CAuAsmrTzu. Anther-cells awned. Branching annuals.............. DICERANDRA.

Tribe III. Monardeæ. Stamens 2, ascending and parallel. Anthers 1-celled, or with 2 confluent cells. Calyx and corolla 2-lipped. Nutlets smooth, distinct.

Connective of the anther elongated, oblique; the upper cell fertile, the lower abortive or

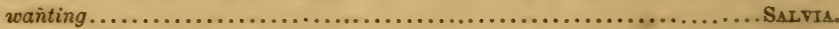

Anthers 2-celled, the cells confluent. Calyx-teeth equal...................

- 2-lipped, upper teeth awned....BLEPHTLA.

Tribe IV. Nepeteæ. Stamens 4, the upper pair longer. Nutlets smooth, distinct.

Stamens all ascending. Anther-cells parallel.................... CEDROAELLA.

Tribe V. Stachydeæ. Stamens 4, the lower pair longer, parallel, ascending. Upper lip of the corolle concare or keeled. Calyx 3-10-toothed or lobed. Nutlets smooth, distinct. 
* Calyx 2-lipped, closed in fruit.

Lips of the calyx entire; the upper one appendaged. F lowers single, opposite.

SCUTELLARLA.

** Calyx not 2-lipped; the teeth or lobes spineless.

Calyx 3-lobed. Flowers capitate, in crowded 4-flowered whorls........... MACBRIDEA.

*** Calyz not 2-lipped; the teeth rigid or spiny.

Calyx-teeth 10, nearly equal. Stamens included. Herbs woolly.......... MARRUBIUM.

5. Nutlets truncate, sharp-angled. Leaves undivided........... STACHYs.

Tribe VI. Ajugeæ. Stamens 4, ascending, parallel, exserted. Nutlets reticulated and pitted, their bases partially united within.

Lobes of the corolla and calyx nearly equal. Peduncles 1-3-flcwered. . ......I8ANTHU⿴.

** Stamens long-exserted, didynamous.

Lobes of the corolla nearly equal. Calyx 5-cleft. Flowers solitary......Trichostema.

\section{HYPTIS, Jacq.}

Calyx tubular, with 5 equal subulate teeth; corolla 5-lobed, the four upper lobes short, spreading or reflexed, the lowest longer, saccate, abruptly deflexed, thickened at the base; stamens 4, didynamous, included in the bud in the lower lobe of the corolla; nutlets smooth, ovoid.

H. Radiata, Willd. Herbaceous; stem erect, mostly simple, pubescent above; leaves orate-lanceolate, serrate or toothed, tapering into a petiole, smooth; heads peduncled, in the axils of the upper leaves, globose, surrounded by an involucre of several lanceolate whitish bracts, pubescent; corolla small, white, dotted with purple. Low ground. Stem $2^{\circ}-4^{\circ}$ high.

\section{MENTHA, L. Mint.}

Caly $x$ tubular, nearly equally 5 -toothed; corolla equally 4-lobed, the upper lobe notched or entire; stamens 4, equal, distant, straight; anther-cells parallel; style 2-cleft at the apex; nutlets smooth, obtuse.-Pungent aromatic 
herhs; whorls (in our species) approximate, forming a dense or interrupted terminal spike.

M. viridis, L. Stem and leaves smooth; leaves ovatelanceolate, unequally serrate, nearly sessile; bracts leafy, and like the calyx, smooth or hairy; spike cylindrical, interrupted below; calyx-teeth linear-subulate. (M. tenuis, Michx.) Damp soils. Stem $1^{\circ}-2^{\circ}$ high; flowers pale blue.

M. Rotundifolia, L. Soft-hairy; stem erect; leaves roundish, rugose, crenate, sessile, hoary beneath; spikes oblong, interrupted; bracts lanceolate; fruiting calyx roundish; the teeth short and acute. Stem $1^{\circ}-2^{\circ}$ high; corolla white.

\section{LYCOPUS, L.}

Calyx bell-shaped, equally 4-5-toothed, naked at the throat; corolla bell-shaped, exserted, equally 4-cleft; fertile stamens 2, exserted, the upper pair sterile, included or wanting; anther-cells parallel; style 2-cleft at the apex; nutlets 3-angled, truncate at the apex, narrowed at the base.-Marsh or aquatic herbs, with long runners at the base; leaves mostly toothed or pinnatifid; whorls dense, axillary; flowers small, sessile.

L. Virginicus, L. Stem smoothish; leaves ovate-lanceolate, toothed-serrate, acute or acuminate at each end, roughened above; calyx-teeth 4 , ovate, obtuse; corolla small, exserted; sterile stamens minute. Ponds and ditches. September. Stem $1^{\circ}-2^{\circ}$ high; leaves $1^{\prime}-2^{\prime}$ long; flowers white.

PYCNANTHEMUM, Michx. Horse-Mint.

Calyx tubular, 13-nerved, naked in the throat, equally 5-toothed, or slightly 2-lipped; corolla 2-lipped, the upper lip notched or entire, the lower 3-cleft; stamens 4, nearly equal, straight, spreading, commonly exserted; anther-cells parallel ; style 2-cleft at the apex ; nutlets smooth.-Peren- 
nial mostly pubescent or hoary herbs, with erect branching stems; floral leaves often white-tomentose; cymes mostly terminal, bracted; corolla small, white or purplish. -Plants aromatic and pungent.

\section{Calyx-teeth nearly equal.}

Calyx as long as the corolla; the teeth subulate and awn-pointed, live the rigid bracts; cymes dense-flowered.

P. ARISTatum, Michx. Tomentose and hoary, or sometimes hairy; stem branched; leaves ovate or oblong, acute, sparingly serrate, rounded at the base, short-petioled, the uppermost somewhat whitened; cymes mostly terminal; ovary bearded.--Var., HYssopifolium, Gray. Stem simple or corymbose above; leaves rigid, linear-oblong, obtuse, entire. Stem $1 \frac{1}{2}^{\circ}-3^{\circ}$ high; leaves $1^{\prime}-2^{\prime}$ long.

\section{COLLINSONIA, L. HORSE-BALM.}

Calyx obovate, enlarged and deflexed in fruit, 2-lipped, the upper lip flattened, truncate, 3-toothed, the lower 2-cleft; corolla funnel-shaped, 2-lipped, dilated at the throat; the four upper lobes equal, the lowest larger, declining, toothed or fimbriate; stamens 2 or 4, long-exserted, spreading; anther-cells diverging; nutlets smooth.-Strongseented perennial herbs; leaves large, coarsely serrate, dotted beneath ; flowers yellowish, solitary, opposite, in racemes or panicles; petioles tumid at the base.

\section{Fertile stamens 4.}

C. Anisata, Pursh. Viscid pubescent; stem $1^{\circ}-2^{\circ}$ high ; stout, simple or branched; leaves $4^{\prime}-8^{\prime}$ long, large, oval or ovate, mucronate-crenate, mostly rounded or cordate at the base, the uppermost sessile; corolla large, yellow; panicle many-flowered; bracts ovate; calyx-lobes large, ovate-lanceolate, nearly equal. 


\section{HEDEOMA, Pers.}

Herbs, with small leaves, and axillary few-flowered cymes; calyx tubular, somewhat gibbous under the base, equally 5 -toother or bilabiate, with the upper lip 3-toothed, the lower 2-cleft, hairy in the throat; corolla 2-lipped, the upper lip notched or entire, the lower 3-cleft; stamens 2, ascending; anther-cells diverging; nutlets smooth.

H. Pulegioides, Pers. Stem $1^{\circ}$ high, much-branched; leaves $1^{\prime}$ long, oblong-ovate, obtuse, sparingly serrate, pale beneath, contracted into a slender petiole; whorls 6 -flowered, shorter than the leaves; lower lip of the calyx hispid; corolla small, pale blue.-Annual, pubescent plants.

\section{CALAMINTHA, Benth.}

Herbs or shrubby plants, with white, scarlet, or purple flowers ; calyx tubular, 13-nerved, 2-lipped, the upper lip spreading, 3-toothed, the lower 2-cleft, bearded or naked in the throat; corolla 2-lipped, open at the throat, the upper lip notched or entire, the lower 3-lobed, the tube commonly exserted; stamens 4, didynamous, arching inward; anther-cells at length diverging; nutlets smooth.

Shrubs; cymes nearly sessile, axillary, few-flowered, often leafy-bracted; pedicels elongated; throat of the calyx bearded; flowers showy.

C. Coccrnea, Benth. Stem $2^{\circ}$ high, the onter bark loose and shreddy; leaves $\frac{1^{\prime}}{2}$ long, obovate-oblong, obtuse, entire or obscurely crenate, tapering into a short petiole; smooth or minutely pubescent; flowers solitary, or in 3-flowered bracted cymes; corolla large, scarlet.

\section{DICERANDRA, Benth.}

Calyx tubular, 13-nerved, 2-lipped, the upper lip entire or minutely 3 -toothed, the lower scarcely longer, 2 -eleft, the 
throat bearded; corolla 2-lipped, the upper lip erect, the lower spreading, 3-cleft; stamens 4, didynamous, spreading, exserted; anther-cells distinct, diverging, awned at the apex; nutlets smooth.-Smooth annuals, with narrow leaves; cymes loose, spreading, several-flowered, forming a leafy terminal raceme; flowers purple.

D. LiNearifolia, Benth. Stem mostly branching, erect; leaves linear or lanceolate, serrate or entire, obtuse, sessile; cymes peduncled, 3-9-flowered; calyx purple, declined in fruit. (Ceranthera linearifolia, Ell.) Dry sandy pinebarrens. October and November. Stem $1^{\circ}$ high; leaves 1 ' long; flowers very numerous, purple, dotted; style hairy.

\section{SALVIA, L. SAGE.}

Calyx tubular or bell-shaped, 2-lipped, the upper lip entire or 3 -toothed, the lower 2-cleft, beardless in the throat; corolla 2-lipped, the upper lip entire or notched, the lower spreading, 3-lobed, with the middle lobe larger, entire or notched; stamens 2 , short; anther-cells linear, widely separated by the elongated oblique connective, the upper one fertile, the lower imperfect or wanting; cymes in spikes, racemes or panicles.

* Opper lip of the calyx entire; lower anther-cell wanting.

S. Azurea, Lam. Smooth; stem simple or branched; leaves lanceolate or linear, obtuse, entire, or the lower ones serrate, tapering at the base; racemes elongated; whorls nearly sessile, $6-12$-flowered; caly $x$ longer than the pedicel, the teeth ovate, acute; corolla 2-3 times as long as the calyx. white or blue; style bearded. Dry light or sandy soil. July and Angust. Stem $2^{\circ}-4^{\circ}$ high; leaves $1 \frac{1^{\prime}}{2}-3^{\prime}$ long; corolla $6 "-8^{\prime \prime}$ long.

** Upper lip of the calyx broad, 3-toothed ; lower anther-cell pollen-bearing, but sterile.

S. LYRATA. Hairy; stem erect, sparingly branched; 
leaves chiefly radical, spreading, lyrate-pinnatifid, mostly discolored; stem-leaves 2 or 4 , smaller, the upper pair lanceolate and entire; raceme many-flowered; whorls 6 -flowered, distant in fruit, longer than the ovate-lanceolate bracts; upper lip of the bell-shaped calyx truncate, with short erect teeth ; corolla-tube elongated, widening upward, the middle lobe of the lower lip dilated and notched. Stem $1^{\circ}$ high ; leaves $3^{\prime}-6^{\prime}$ long, commonly purple beneath ; racemes in fruit $6^{\prime}-12^{\prime}$ long; corolla $9^{\prime \prime}-12^{\prime \prime}$ long, blue, whitespotted in the throat.

\section{MONARDA, L. HoRSE-MINT.}

Calyx tubular, elongated, 15-nerved, nearly equally 5 -toothed, bearded in the throat; corolla nearly equally 2-lipped, the upper lip notched or entire, the lower 3 -toothed; stamens 2 , ascending under the upper lip, and oftener exserted; anther-cells linear, diverging, confluent; nutlets smooth.-Herbs; leaves undivided; whorls large, dense-flowered; bracts colored.

\section{* Upper lip of the corolla linear, acute.}

M. DIDYMA, L. Stem smoothish; leaves orate-lanceoJate, acuminate, serrate, rounded at the base, petioled, smooth or hispid; whorls mostly solitary, terminal ; calyx smooth, incurved; corolla large, bright red. Mountains. August and September. Stem erect, $2^{\circ}$ high ; leaves $2^{\prime}-3^{\prime}$ long; bracts lanceolate, red; corolla $1^{\prime}$ long.

M. Fistulosa, L. Stem branching, more or less pubescent, commonly hairy at the joints; leaves petioled, oratelanceolate, acute, sharply serrate, mostly rounded or truncate at the base; whorls terminal; calyx slightly incurved, hispid in the throat; corolla slender, rose-color. (M. clinopodia, and M. mollis, L.) August and September. Stem $2^{\circ}-5^{\circ}$ high; leaves smoothish, tomentose, or hispid, $1^{\prime}-3^{\prime}$ long; bracts pale purple. 
** Tpper lip of the corolla broader, notched.

M. punctata, L. Closely and finely pubescent; Stem much branched; leaves lanceolate or oblong, acutish, slightly serrate, narrowed into a petiole; whorls lateral and terminal ; bracts ovate or oblong, purple; corolla yellowish, the lower lip dotted with brown, the upper keeled; stamens not exserted. Dry sandy soil. August-October. Stem $1^{\circ}-3^{\circ}$ high ; leaves $1^{\prime}-2^{\prime}$ long.

M. Gracilis, Pursh. Very smooth; whorls lateral and terminal; exterior bracts linear, ciliate; corolla short; leaves linear-lanceolate, acuminate, serrate. Mountains. Stem obtuse-angled; whorls small, naked; calyx pubescent, ciliate; corolla very slender, smooth, yellowishwhite.

\section{BLEPHILIA, Raf.}

Calyx ovate-tubular, 13-nerved, beardless in the throat, 2-lipped; the upper lip with three awned teeth, the lower 2-cleft. awnless or short-awned; anthers 1-celled. Otherwise like Monarda. Stem erect; whorls several, lateral and terminal, the upper ones crowded.

B. Hirsuta, Benth. Stem hirsute; leaves long-petioled, oblong-ovate, serrate, smooth or hirsute; whorls globose, distinct, or the upper ones crowded, the lower axillary; bracts linear-subulate, long-ciliate; corolla slightly pubescent. (Monarda hirsuta, Pursh.) Damp woods. July and August. Stem $2^{\circ}-3^{\circ}$ high, branching; leaves thin, 3'-4' long; corolla pale blue.

\section{CEDRONELLA, Mœnch.}

Calyx bell-shaped, nearly equally 5 -toothed, the mouth oblique; corolla dilated at the throat, 2-lipped, the upper lip straight, 2-cleft, the lower 3-cleft, with the middle lobe largest; stamens 4, ascending, the upper pair longest; anther-cells parallel - nutlets smooth; flowers in a terminal spike or raceme. 
C. cordata, Benth. Stem low, pubescent, bearing long runners; leaves long-petioled, cordate, crenate, smoothish, the floral ones ovate; raceme few-flowered, 1 -sided ; cymes 1-3-flowered; calyx and pale-blue corolla large. (Dracocephalum cordatum, Nutt.) May and June. Stem $\frac{1}{2}^{\circ}$ high, creeping at the base ; leaves $1^{\prime}$ long; corolla $1 \frac{1}{2}$ ' long. Plant pleasant-scented.

\section{BRUNELLA, Tourn. Self-heal.}

Calyx tubular-bell-shaped, 10-nerved, flat abore, 2-lipped, upper lip broad, truncated, 3-toothed, the lower 2-cleft; corolla-tube slightly inflated under the throat, 2-lipped, the upper lip roundish, arching, entire, the lower 3-lobed, with the middle lobe rounded, concave, crenate; stamens 4, exserted, the smooth filament prolonged above the anther; anther-cells spreading.-Herbs, with 6-flowered denselyspiked whorls; floral leaves orbicular, imbricated, persistent.

B. vULGARIs, L. Pubescent or smoothish; stem erect, mostly simple; leaves ovate or oblong, serrate, petioled; spikes oblong or cylindrical; flowers purple. Low grounds. Stem $6^{\prime}-12^{\prime}$ high ; spikes thick, lateral and terminal.

\section{SCUTELlaria, L. SkUllcap.}

Calyx bell-shaped, 2-lipped, entire and closed after flowering, the upper lip furnished with a helmet-shaped appendage on the back, and falling away at maturity, the lower persistent; corolla-tube recurved-ascending, dilated at the throat, 2-lipped, the upper lip arching, entire or notched, with the small lateral lobes united with its sides, the lowest lobe large and spreading; stamens 4, ascending; anthers ciliate, approximate by pairs, those on the shorter filaments 1-celled, on the longer ones 2-celled, cordate.Perennial mostly inodorous herbs; flowers opposite, soli- 
tary, in the axils of the upper, mostly bract-like leaves, rarely in lateral racemes; corolla blue or white.

\section{* Flowers in terminal racemes.}

+ Leaves cordate, ovate or oblong, crenate, petioled; the floral ones shorter than the flowers, entire.

S. PILOSA, Michx. Hairy; stem simple or sparingly branched; leaves distant, ovate, obtuse, coarsely crenate, the lowest rounded at the base, the upper ones abruptly short-petioled, the floral ones spatulate, obtuse; racemes short, few-flowered; corolla pale blue. Dry sandy soil. July and August. Stem $1^{\circ}-2^{\circ}$ high ; leaves $1^{\prime}-2^{\prime}$ long; corolla $8^{\prime \prime}-9^{\prime \prime}$ long.

†+ Upper and floral leaves alike, entire, nearly sessile; the lower broader, petioled, and mostly crenate.

S. INTEgrifolia, L. Pubescent throughout; stem mostly simple $\left(6^{\prime}-12^{\prime}\right.$ high $)$; leaves small $\left(\frac{1^{\prime}}{2}-1^{\prime}\right.$ long), lanceolate, obtuse, entire, tapering downward, sessile, the lowest ovate or obovate, short-petioled, crenate or entire, the lower floral ones sometimes longer than the flowers; racemes leafy, few-many-flowered. Dry sandy soil.

** Flowers solitary, in the axils of the upper leaves.

S. Parvula, Michx. Stem low, pubescent; leaves ovate or roundish, obtuse, mostly entire, nearly sessile, strongly veined; flowers small, peduncled; fibers of the root often bearing small tubers. Stem $6^{\prime}-9^{\prime}$ high ; leaves $4^{\prime \prime}-6^{\prime \prime}$ long ; corolla blue, $2^{\prime \prime}-3$ " long.

\section{MACBRIDEA, Ell.}

Caly $x$ tubular-bell-shaped, 3-lobed, the upper lobe lancullate, entire, the two lower ones oblong, notched or entire; corolla inflated, 2-lipped, the upper lip arching, concave, the lower broadly 3 -lobed, spreading; stamens 4, ascending under the upper lip; filaments hairy; anthers approximate by pairs, the cells diverging, hairy within, den- 
ticulate on the margins; nutlets smooth.-Erect mostly simple perennials; whorls crowded in a dense cone-like terminal head; corolla large, white or purple.

M. PUlchra, Ell. Smooth or hairy; leaves lanceolate, acute, serrulate, dotted, the lower ones narrowed into a petiole, the upper sessile, the floral ones ovate, acute; whorls 4 -flowered; calyx striate, the lobes entire; corolla purple, the tubes striped with purple and white, the upper lip entire. Pine-barren swamps. August and September. Stem $1^{\circ}-1 \frac{1}{2}^{\circ}$ high ; corolla $1 \frac{1}{2}^{\prime}$ loug.

\section{MARRUBIUM, L. HOREHOUND.}

Calyx tubular, 5-10-nerved, nearly equally 5-10-toother, the teeth spiny, mostly spreading in fruit; corolla-tube included in the calyx, 2-lipped, the upper lip erect, the lower 3-lobed, with the middle lobe largest ; stamens 4, included; anther-cells diverging; lobes of the style short, obtuse; nutlets obtuse at the apex.-Chiefly tomentose or woolly perennial herbs, with rugose leaves, and axillary whorls.

M. vULGARE, L. Woolly; stems branching at the base, ascending; leaves petioled, ovate or roundish, crenate, the floral ones smaller, but longer than the capitate manyflowered whorls ; calyx-teeth 10 , recurved-spreading; corol$l a$ small, white. Waste ground and roadsides. Stems $1^{\circ}-2^{\circ}$ high.

\section{LEONOTIS, R. Brown.}

Calyx tubular, 10-nerved, incurved, unequally 8-10-toothed, the teeth straight, spiny, the upper one largest; corolla slender, 2-lipped, the upper lip long, arching, entire, the lower very short, 3-cleft, spreading; stamens 4, ascending under the upper lip; anther-cells diverging; nutlets 3 -angled, truncate.-Tall herbs, with very large globose whorls in the axils of the upper leaves; flowers yellow or scarlet.

L. nepetæfolia, R. Br. Annual; stem tomentose, 
simple or branched; leaves remote, long-petioled, broadly orate, crenate, the floral ones lanceolate; whorls 1 -several ; calyx 8-toothed; corolla villous, scarlet. Waste grounds. June-August. Stem $1^{\circ}-6^{\circ}$ high; whorls $1^{\prime}-2^{\prime}$ in diameter ; corolla 1' long.

\section{STACHYS, L. HEDGE-NETTLE.}

Calyx tubular-bell-shaped, 5 or 10-nerved, 5-toothed, the teeth equal, or the upper one larger, more or less spiny (in our species), spreading in fruit; corolla hairy within, 2-lipped, the upper lip erect, the lower spreading, 3-lobed, with the middle lobe nuch larger; stamens 4, ascending; anthers 2-celled; nutlets not truncate.-Chiefly hairy or hispid herbs, with few-flowered whorls in terminal racemes.

\section{* Perennial.}

S. ASPERA, Michx. Stem erect, with the angles rough with recurved bristly hairs, rarely smoothish ; leaves shortpetioled, ovate-oblong or ovate-lanceolate, acute, serrate, rounded at the base, smooth, or sprinkled with hairs above, the floral ones longer than the calyx; whorls 6-10-flowered, the lower ones distant; calyx-teeth spine-pointed. (S. hispida, Pursh; S. tenuifolia, Willd.) Swamps. June-August. Stem $1 \frac{1}{2}^{\circ}-2^{\circ}$ high ; leaves $2^{\prime}-3^{\prime}$ long; corolla purple.

S. HYssopifolia, Michx. Smooth or nearly so; stem erect, slender; leaves sessile, lanceolate or linear, obtuse, entire or sparingly serrate; raceme short, of few 4-6-flowered whorls; calyx smooth, with spiny spreading teeth, $\frac{1}{3}-\frac{1}{2}$ as long as the smooth violet corolla. Wet pine-barrens. June-August. Stem $1^{\circ}-1 \frac{1}{2}^{\circ}$ high ; leaves $1^{\prime}-2^{\prime}$ long.

\section{ISANTHUS, Michx.}

Caly $x$ bell-shaped, 10-nerved, 5-cleft; corolla bell-shaped, equally 5-lobed; stamens 4, incurved-ascending, exserted; anthers 2-celled; nutlets obovoid, impressed-reticulated, 
laterally cohering at the base.-An annual pubescent and somewhat viscid branching herb, with lanceolate entire or sparingly toothed acute leaves, and small pale blue flowers, on 1-3-flowered axillary peduncles.

I. Ceeruleus, Michx. Dry soil. July-August. Stem terete, $1^{\circ}-1 \frac{1}{2}^{\circ}$ high ; leaves $1^{\prime}-1 \frac{1}{2}^{\prime}$ long, 3 -nerved below the middle.

\section{TRICHOSTEMA，L。 BLtE-CURLS.}

Calyx short, reversed, oblique, 5-toothed, the 3 lower teeth long, connate, the 2 upper ones very short; corclla slender, nearly equally 5-cleft; stamens 4, long-exserted, partly coiled; anther-cells diverging; nutlets pitted, united at the base.-Branching annuals, with entire leaves, and solitary blue flowers on lateral peduncles.

'T. ріснотомим, L. Pubescent and somewhat viscid, or nearly smooth; stem much branched, obscurely 4-angled; leaves oblong or lanceolate, obtuse, narrowed into a petiole. (T. lineare, Nutt., is a smoother form, with linear leaves.) Dry sandy soil. August and September. Stem $1^{\circ}-2^{\circ}$ high.

\section{BORAGE FAMILY. Order, Borraginacez.}

Herbs or sturubs, with terete or irregularly angled stems, and alternate entire exstipulate mostly rough-hairy leaves; flowers usually in 1-sided spikes or racemes, which are coiled in the bud; calyx free, 5-cleft or 5-parted, valvate in the bud, persistent; corolla regular, hypogynous, 5-lobed, imbricated or (in Myosotis) convolute in the bud; stamens 5 , equal, inserted on the tube of the corolla and alternate with its lobes; ovary 4-celled, with a single ovule in each cell; style single; fruit various; albumen scarce or none; cotyledons flat or folded; radicle superior.

SYNOPSIS.

Tribe I. Borrageæ. Ovary deeply 4-parted, inclos- 
ing the base of the simple style. Fruit of 1-4 one-seeded nutlets. Herbs.

* Throat of the corolla naked; nutlets not hispid.

+ Corolla irregular.

Corolla finnel-shaped, unequally lobed Eснгим. ++ Corolla regular.

Lobes of the corolla erect, acute. Nutlets smooth and stony. ONOSMODIUM. rounded.

or rugose.......... LITHOBPERM UM. Mrosotis.

** Throat of the corolla closed with scales; nutlets hispid.

Conolla funnel-formed. Nutlets depressed.

.Crnoglossum.

\section{ECHIUM, Tourn.}

Calyx 5-parted; corolla funnel-form, unequally 5-lobed, naked at the throat; stamens 5 , unequal, mostly exserted; style filiform; nutlets 4, closed at the base, uneven or rough.-Herbs, with alternate leaves, and blue or purple flowers in spiked often panicled racemes.

E. VULGARE, L. Hispid with bristly spreading hairs; stem simple, erect $\left(1^{\circ}-2^{\circ}\right.$ high $)$; leaves linear-lanceolate, sessile; flowers large, in short axillary racemose spikes; corolla purple, pubescent, twice as long as the lanceolate calyx-teeth, shorter than the stamens and style. JuneAugust. Biennial.

\section{ONOSMODIUM, Michx.}

Calyx 5-parted, the lobes linear and acute; corolla ovatetuoular, naked in the throat, with five acute, connivent lobes; anthers nearly sessile, sagittate, included; ovary 4-parted; style smooth, exserted; nutlets 1-4, ovoid, shining.-Erect hispid herbs, with entire somewhat ribbed sessile leaves, and greenish flowers in a terminal bracted raceme or spike. 
O. Virginianey, DC. Rough with appressed bristly hairs; stem slender, sparingly branched; leaves lanceolate or oblong-lanceolate, obtuse or acute; lobes of the corolla lanceolate-subulate, bristly; calyx-lobes 3-4 times as long as the white polished nutlets. (O. hispidum, Michx.) Dry pine-barrens. May and June. Stem $1^{\circ}-2^{\circ}$ high; leares $2^{\prime}$ long; corolla twice as long as the calyx ; racemes leafy. Perennial.

\section{LITHOSPERMUM, I. GROMWELL.}

Calyx 5-parted, the lobes equal; corolla funnel or salver form, obtusely 5-lobed, smooth, gibbous or hairy in the throat; anthers oblong, nearly sessile, iucluded; stigma capitate, somewhat 2-lobed; nutlets 1-4, orate, stony, truncate at the base.-Chiefly rough-hairy herbs, with red roots, alternate entire leaves, and variously colored flowers in leafy-bracted racemes or spikes.

\section{* Perennials ; nutlets smooth, white.}

L. HIRTUM, Lehm. Hispid with rigid glossy hairs; stem mostly simple, erect; leaves linear-lanceolate, obtuse, sessile, the lowest scale-like, the floral ones ovate-lanceolate; corolla large, yellow, the tube hairy at the base within, rather longer than the linear calyx-lobes; nutlets orate, polished. (Batschia Gmelini, Michx.) Dry pine-barrens. April and May. Stem $1^{\circ}-1 \frac{1}{2}^{\circ}$ high ; leares $1^{\prime}-2^{\prime}$ long; corolla $6^{\prime \prime}-8^{\prime \prime}$ long.

L. Canescens, Lehm. Stem villous, erect, nearly simple; leaves lanceolate, sessile, obtuse, somewhat silky with appressed glossy hairs, the lowest small and scale-like; corolla large, yellow, the tube $2-3$ times as long as the calyx. Dry soil. April and May. Stem $6{ }^{\prime}-12^{\prime}$ high; corolla smaller than in the preceding. 


\section{MERTENSIA, Roth.}

Calyx 5-parted; corolla funnel-shaped, 5-lobed, naked, or with 5 folds in the throat; stamens partly exserted; style filiform; nutlets somewhat fleshy, not flattened at the base.-Smooth or soft hairy perennial herbs, with entire leaves, and showy purplish-blue flowers in corymbed or panicled racemes, the upper ones bractless.

M. Virginica, DC. Smooth; stem erect, simple; leaves membranaceous, elliptical or obovate-oblong, the lower ones narrowed into a petiole; racemes corymbose; corolla large, naked and expanding at the throat, slightly lobed, the tube 4 times as long as the calyx, villous at the base within; filaments longer than the anthers. (Pulmonaria Virginica, L.) River-banks and along mountain streams. May. Stem $1^{\circ}-2^{\circ}$ high; leaves $2^{\prime}-3^{\prime}$ or the lowest $4^{\prime}-6^{\prime}$ long; corolla $1^{\prime}$ long, sometimes white.

\section{MYOSOTIS, L. FORGET-ME-NOT.}

Calyx 5-cleft; corolla salver-form, 5-lobed, convolute in the bud, the tube as long as the calyx, with 5 obtuse appendages in the throat; stamens very short, included; nutlets 4, elliptical, compressed, smooth, with a minute scar at the base.-Low hairy herbs, with entire alternate leaves, and small white or blue flowers in terminal bractless racemes.

M. verna, Nutt. Hirsute with rigid spreading hairs; stem erect (4'-8' high), branching above; leaves lanceolate, sessile, the lower ones spatulate, obtuse; calyx longer than the appressed pedicel, hispid, with the hairs near the base hooked, the teeth unequal, acute.-Var. MACROSPERMA is every way larger $\left(1^{\circ}-1 \frac{1}{2}^{\circ}\right.$ high;) calyx with all the hairs hooked, the lower teeth twice as long as the upper ones. Dry places. March and April. Annual. Corolla white or pale blue. 
M. SUffruticosa, Torr. Very hispid and canescent with spreading hairs; throws up several stems from a thick root or caudex; leaves linear-spatulate and obtuse; flowers on conspicuous pedicels; fructiferous calyx broadly ovate, nearly erect; the segments ovate-lanceolate and closed orer the firuit; nutlets truncate at the summit, very smooth and shining.

This plant was collected by Marcy on the Red River. Torrey declares it a genuine Eritrichium, and in the Flora of Marcy's Expedition calls it E. JAMESI, though in Ann. Lyc., N. York, 2, p. 225, he gives it the name above, $M$. suffruticosa.

\section{CYNOGLOSSUM, Tourn. HoUnd'S-TONGUE.}

Calyx 5-parted; corolla funnel-form, with the throat closed with 5 obtuse scales; racemes with the lower flowers commonly bracted, the upper ones bractless; stamens included; nutlets 4 , fixed near the apex to the base of the style, covered all over with barbed or hooked bristles.

C. Virginiced, L. Hispid; stem $2^{\circ}-3^{\circ}$ high, simple, stout, naked above; racemes single or corymbose, bractless; pedicels slender, recurved in fruit; leaves oval or oblong, the lowest petioled, the upper auriculate and amplexicaul; nutlets rounded anteriorly; corolla pale blue.

\section{WATERLEAF FAMILY. Order, HYDROPHYL- LACE巴.}

Herbs, with alternate or opposite palmately or pinnately divided leaves, and regular flowers, either solitary in the axils, or in 1-sided recurved spikes or racemes; calyx 5-parted, persistent, the lobes imbricated in the bud, and often with reflexed appendages in the sinuses; corolla obtusely 5-lobed, imbricated or convolute in the bud ; stamens 5 , inserted into the base of the corolla, and alternate with 
its lobes; anthers versatile; ovary free, 1-celled, with 2 parietal placentæ, each bearing 2 or more amphitropous ovules; style slender, 2-cleft; capsule globose or oblong, loculicidally 2-valved; seeds reticulated; embryo small, in the axis of the hard albumen.

\section{SYNOPSIS.}

* Lobes of the corolla convolute in the bud.

Calyx without appendages. Stamens exserted. Stems erect...... HYDROPHYLIOX. - appendaged at the sinuses. Stamens included. Slems prostrate.Nemorama.

** Lobes of the corolla imbricated in the bud.

Calyx without appendages. Capsule 4-many-seeded.

Pracelia.

\section{HYDROPHYLLUM, L. WATERLEAF.}

Calyx 5-parted, the lobes subulate, without appendages; corolla broadly tubular, 5-cleft, about as long as the calyx, with 5 linear appendages on the tube within, opposite the lobes; stamens and style exserted; anthers linear; ovary hispid; placentoe 2, thick and fleshy, connected with the pericarp at the base and apex, each 2-ovuled; style filiform, 2-cleft; capsule globose, 2-valved, 1-4-seeded.-Erect perennial mostly hairy herbs, with long-petioled pinnately or palmately divided leaves, and white or blue flowers in peduncled cymes, without bracts.

H. Virginicum, L. Stem leafless below, sprinkled, like the leaves, with rigid hairs; leaves pinnately divided into 5-7 ovate cleft or toothed lobes, paler beneath; peduncles forking, longer than the petioles; cymes dense; calyx-lobes linear, hispid; filaments slightly hairy. Low woods along the mountains. June. Stem $1^{\circ}-2^{\circ}$ high.

\section{NEMOPHILA, Nutt.}

Calyx 5-parted, with reflexed appendages in the sinuses; corolla tubular or short bell-shaped, with 10 scale-like ap- 
pendages at the base of the filaments; stamens included; anthers ovoid; ovary hispid, 2-12-ovuled; placentce large, lining the walls of the pericarp; style 2-parted; capsule globose, 1-2-seeded.-Tender prostrate annual herbs, with divided leaves, and solitary long-peduncled flowers opposite the leares.

N. Microcalyx, Fisch. and Meyer. Pubescent, or at length smoothish ; stem filiform, diffuse ; leaves thin, longpetioled, alternate, 3 -lobed, the lobes obovate or wedgeshaped, crenately toothed, the lowest ones mostly opposite, and 3-5-lobed; flowers minute, white, on slender spreading peduncles, which are shorter than the petioles; ovary 4-ovuled; capsule 1-2-seeded. Shady woods. April-June. Stem $3^{\prime}-1^{\circ}$ long; leaves $\frac{1^{\prime}}{2}-1^{\prime}$ long; corolla $1^{\prime \prime}$ long; seeds bony.

\section{PHACELIA, Juss.}

Calyx 5-parted, not appendaged in the sinuses; corolla bell-shaded, 5-lobed, imbricated in the bud; stamens included or exserted ; anthers ovoid or oblong ; ovary 2-manyovuled, the 2 narrow placentæ often projecting in ward, and forming an imperfect partition in fruit; style 2-cleft ; capsule 2-valved, 4-many-seeded.-Low chiefly annual herbs, with alternate mostly pinnately divided leaves, and white or blue flowers in one-sided racemes.

EuтосA. Ovules more than 4 ; corolla usually with minute appendages within, the lobes entire.

P. Parviflora, Pursh. Pubescent; stems several, spreading, branching ; leaves petioled, the lowest 3-7-lobed, the upper 3-parted; racemes loosely 5-15-flowered; pedicels slender, much longer than the calyx; calyx-lotes linear-oblong, bristly-ciliate; corolla small, pale-blue or white. Shady banks. April and May. Stems $3^{\prime}-8^{\prime}$ high ; corolla $3^{\prime \prime}-4^{\prime \prime}$ wide ; capsule few-seeded.

P. PUsilla, Buckley. Pubescent and somewhat glau- 
cous; stems ascending, branched; leaves sessile, pinnatifid, the segments obovate, abruptly acuminate; pedicels short or elongated; sepals linear-oblong, acute, two-thirds the length of the pale-blue or white corolla; stamens exserted. Prairies.-Buckley.

\section{HYDROLEA FAMILY. Order, Hydroleaceæ.}

Glandular-pubescent or bristly herbs, with entire alternate leaves; flowers regular, axillary and solitary or clustered, or in terminal corymbs or coiled bracted spikes; calyx 5-parted; corolla somewhat bell-shaped, 5-lobed, imbricated in the bud; stamens 5, inserted on the tube of the corolla, and alternate with its lobes, the filaments oftener hairy; styles 2 , separate; stigmas capitate; ovules numerous, anatropous; capsule many-seeded, more or less 2 -celled by the meeting of the two parietal placentæ, 2 or rarely 4 valved, opening through the middle of the cells, or at their margins; embryo straight, in fleshy albumen.

\section{HYDROLEA, L.}

Calyx 5-parted; corolla short, bell-shaped, 5-cleft, the lobes spreading; stamens somewhat exserted, with the filaments dilated at the base; anthers sagittate; styles 2 (rarely 3), separate; capsule globose, 2-celled, or imperfectly 4-celled by the introversion of the placentæ, 2-valved.-Herbs, growing in water or muddy places, with entire leaves, often with spines in their axils, and blue axillary or corymbose flowers.

H. QUADRIvalvis, Walt. Spiny; stem ascending from a creeping base, hispid, mostly simple; leaves lanceolate, acute, pubescent on the veins, tapering into a petiole; flowers axillary, the lower ones clustered, the upper solitary, short-peduncled; calyx-lobes linear, nearly as long as the corolla; stamens included; capsule almost 4-celled, by the introversion of the placentr, 2-valved. July and 
August. Stem $1^{\circ}-3^{\circ}$ long; leaves $3^{\prime}-4^{\prime}$ long. In ponds and ditches around Houston.

\section{POLEMONIUM FAMILY. Order, Polemoniaceæ.}

Chiefly herbs, with opposite or alternate leaves, and regular solitary or cymose flowers; calyx 5-cleft or 5-parted, with membranaceous-margined lobes, imbricated in the bud; corolla 5-lobed, convolute or imbricated in the bud; stamens 5, inserted on the tube of the corolla; ovary 3 -celled, with 3-many amphitropous ovules attached to the central placentæ; style 3-cleft; capsule 3-celled, loculicidally 3 -valved; seeds angular; embryo straight in the axis of copious albumen; cotyledons leafy ; radicle inferior.

\section{SYNOPSIS.}

Tribe I. Polemonieæ. Lcbes of the corolla convolute in the bud. Anther-cells parallel, opening lengthwise. Corolla salver-form. Filaments unequally inserted on the tube. Leares entire.

Paxox.

tubular-funnel-form. Filaments equally inserted near the throat of the corolla. Leaves pinnately divided........................ Grus.

short-bell-form. Filaments inserted on the throat of the corolla. Leaves pinnate .Polemontum.

Tribe II. Diapensieæ. Lobes of the corolla imbricated in the bud. Anther-cells opening transversely.

Anther-cells awned at the base. Leaves entire. Flowers solitary... Pу XIDAXTHERA.

\section{PHLOX, L.}

Calyx cylindrical or bell-shaped, 5-cleft; corolla salverform, with a long and slender tube, and obovate or roundish lobes; stamens 5, included, unequally inserted on the tube; style filiform; ovules solitary in the cells; capsule oroid, 1-3-seeded, the valves at length separating from the central placenta; seeds erect.-Mostly perennial herbs, with 
opposite or (the upper) alternate entire leaves, and showy purple or white flowers in terminal panicled cymes.

Stems herbaceous, erect or ascending.

* Style long, fliform ; calyx-teeth lanceolate-subulate, not awn-pointed ; lobes of the corolla entire.

P. GLABERrima, L. Smooth; stem erect or ascending, sparingly branched above; leaves lanceolate or linear, acute, the lower tapering to the base, the upper broader and rounded at the base; cymes usually 3 , terminal, fewflowered; calyx-lobes lanceolate, acute; corolla large, with the lobes wedge-obovate. July. Stem $1^{\circ}-2^{\circ}$ high; leaves $3^{\prime}-4^{\prime}$ long; pedicels as long as the calyx; corolla $1^{\prime}$ long, pale purple.

Style short, scarcely longer than the ovary; calyx-teeth linear-subulate, tapering into an awn-like point; lobes of the corolla often notched; stems pubescent.

P. PILOSA, L. Pubescent or villous; stem erect, mostly branching; leaves linear, or linear-lanceolate, spreading, distant, acute, the uppermost rounded at the base; cymes corymbose, loose-flowered; calyx-teeth $\frac{2}{3}$ as long as the tube of the corolla, prolonged into long and spreading bristle-like points, hairy. (P. aristata, Michx.) April and May. Stem rather slender, $1^{\circ}-1 \frac{1}{2}^{\circ}$ high ; leaves $2^{\prime}-4^{\prime}$ long; corolla $\frac{1}{2}$ long, purple. On the Trinity River.

P. Floridana, Benth. Stem erect, simple, closely pubescent; leaves uniform, linear-lanceolate, acute, spreading or recurved, the upper ones often alternate; cymes crowded or corymbose ; calyx-teeth spreading, somewhat bristle-pointed, glandular-pubescent, $\frac{1}{3}-\frac{1}{2}$ as long as the tube of the large corolla. Dry open woods, Middle Florida. May. Stem $1 \frac{1}{2}^{\circ}-2^{\circ}$ high ; leaves $2^{\prime}-3^{\prime}$ long; corolla $1^{\prime}$ broad, pale purple, the lobes round-obovate and entire.

Stems shrubby, tufted, creeping; leaves subulate, rigid, leafy in the axils; style short.

P. subulata, L. Pubescent; flowering stems erect; 
leaves very numerous, the upper ones linear and mostly alternate; calyx-teeth subulate, erect, spiny-pointed; lobes of the corolla notched or entire. (P. setacea, L.; P. Hentzii, Nutt.) April and May. Stems $4^{\prime}-12^{\prime}$ long; leaves $4^{\prime \prime}-6^{\prime \prime}$ long; corolla $\frac{1^{\prime}}{2}-1^{\prime}$ broad, purple or white.

P. Drumurondi, Hook., is an annual species, common in gardens.

\section{GILIA, Ruiz and Paron.}

Calyx tubular or bell-shaped, 5-cleft; corolla funnelshaped, 5-lobed; stamens inserted equally near the mouth of the corolla; ovules commonly numerous in the cells; capsule oblong or obovoid; seeds angled or compressed.Herbs, with finely divided leaves, and showy flowers.

G. coronopifolia, Pers. Stem tall, simple, pubescent or hairy, very leafy; leaves pinnately divided into many filiform very acute segments; flowers scarlet, crowded in a long compound raceme or narrow panicle ; corolla tubularfunnel-shaped, with the oval-oblong obtuse lobes about $\frac{1}{3}$ as long as the tube ; stamens exserted. (Cantua Floridana, Nutt.?) Dry sandy soil. July. Stem $2^{\circ}-4^{\circ}$ high; corolla $1^{\prime}$ long, yellow and spotted with red within. Biennial.

\section{CONVOLVULUS FAMILY. Order, Convolve- LACE正.}

Chiefly twining or prostrate herbs, with alternate exstipulate leaves, and regular mostly showy and fugaceous flowers; calyx 5-sepalous, imbricated ; corolla bell-shaped, funnel-shaped, or salver-form, 5-plaited or 5-lobed, convolute in the bud; stamens 5, inserted on the tube of the corolla; anthers 2-celled, sagittate; ovary free, single or double, 1-4-celled, with 1-2 erect anatropous ovules in each cell ; styles 1 or 2 , entire or 2 -cleft; stigmas capitate, ovate, or acute; capsule 2-6-seeded; embryo large, coiled or curved in mucilaginous albumen. 


\section{SYNOPSIS.}

Tribe I. Convolvuleæ. Ovary single. Embryo with leafy cotyledons. Capsule opening by valves. Flowers axillary, single or cymose.

* Style single; stigmas globose.

Capsule 4-celled, 4-seeded. Corolla (ved) salver-shaped. Stamens exserted.

QUAMOCLIT.

3-celled, the cells 2-seeded. Corolla bell-yormed

.Pharbitis.

** Style single; stigmas ovate or cylindrical.

Caporule imperfectly 2-celled, 4-seeded. Stigmas cylindrical. Calyx included in the membranaceous bracts. . Calystegia.

Slyles separate, 2-parted or 2-cleft Evolvuliss.

*** Styles 2, separate or partly united ; ovary 2-celled.

Styles separate or partly united, entire.

STYLISMa.

Tribe II. Cuscuteæ. Ovary single. Embryo destitute of cotyledons. Capsule closed.

Twining parasites, with scale-like leaves. Styles 2. Cuscuta.

\section{QUAMOCLIT, Tourn. Cypress-vine.}

Sepals 5; corolla salver-form, 5-plaited, with the tube elongated; stamens inserted at the base of the tube, dilated at the base, exserted; ovary 4-celled; style single; stigma globular, 2-lobed; capsule 4-valved, 4-seeded.-Twining annual herbs, with cordate entire or pinnatifid leaves, and red flowers, on axillary peduncles.

Q. Coccinea, Mœnch. Leaves petioled, cordate, acuminate, angled at the base; peduncles as long as the petioles, 3-5-flowered; sepals awned; corolla slightly lobed, scarlet. (Ipomøa coccinea, L.) Cultivated ground, in Middle and Upper Texas, and north ward. July and August. Corolla $1^{\prime}$ long, sometimes yellowish. 


\section{PHARBITIS, Chois. MorNING-GLORY.}

Sepals 5 ; corolla bell-shaped or funnel-shaped, 5-plaited; stamens dilated at the base, included; style simple; stigma globose ; capsule 3-4-celled, 3-4-valved, 6-8-seeded.-Twining herbs, with petioled cordate entire or lobed leaves, and single or cymose blue or purple flowers, on axillary bracted peduncles.

P. HISPIDA, Chois. Annual; stem glandular-roughened and hairy; leaves entire, round-cordate, acuminate; peduncles mostly longer than the leaves, 3-5-flowered; sepals ovate-lanceolate, acute, mostly hairy; corolla showy, blue, purple, or variegated. (Convolvulus purpureus, Linn.) Around dwellings. Introduced. June-September.

P. Nin, Chois. Annual, hairy; leaves membranaceous, broadly cordate, 3 -lobed, the lobes acuminate; peduncles shorter than the leaves, 2-3-flowered; sepals densely hispid, ending in a long subulate point; bracts linear; corolla purple. (Convolvulus Nil, L.) Cultivated ground. JulySeptember. Corolla 1 $\frac{1^{\prime}}{2}$ long.

\section{CALYSTEGIA, R. Brown.}

Sepals 5, included in the two large membranaceous bracts ; corolla bell-shaped; style single; stigmas 2 , oblong or cylindrical; capsule imperfectly 2-celled, 4-seeded. Leaves petioled, cordate or sagittate; peduncles 1 -flowered.

C. SEPIUM, R. Br. Smooth; stem twining; leaves broadly sagittate, acute, the wide lateral lobes obliquely truncated and often toothed; peduncles 4-angled, as long as the petioles; bracts cordate-ovate or oblong. strongly keeled on the backs; sepals acute; corolla white or rosecolor ; leaves $2^{\prime}-4^{\prime}$ long ; corolla $11_{2}^{\prime}-2^{\prime}$ long ; stigmas oblongovate; stamens dilated and flattened below. Perennial. 


\section{EVQLVULUS, L.}

Sepals 5 ; corolla bell-shaped or somewhat wheel-shaped, mostly hairy ; stamens included; styles 2, distinct, 2-cleft or 2-parted; stigma obtuse; capsule 2-celled, 4-seeded.-Small perennial herbs, with chiefly silky or hairy prostrate stems, entire leaves, and small flowers on axillary peduncles; capsules nodding.

* Common peduncles very short or none; the pedicels shorter than the leaves.

E. SERICEUS, Swartz. Silky with appressed hairs throughout, except the upper surface of the leaves; stem dividing at the base into numerous prostrate or ascending simple filiform branches; leaves sessile, linear, or linear-lanceolate, acute at each end, erect; peduncle almost wanting, 1 -flowered, rarely $2^{\prime \prime}-3$ "long and $2-3$-flowered ; sepals ovatelanceolate, acuminate, $\frac{1}{2}$ as long as the white wheel-shaped corolla.-Varies with shorter $\left(4^{\prime}-6^{\prime}\right.$ long) and more rigid stems, and oblong or elliptical and obtuse leaves. Damp soil. June-October. Stems $6^{\prime}-12^{\prime}$ long; leaves $6^{\prime \prime}-9^{\prime \prime}$ long; corolla $4^{\prime \prime}-5^{\prime \prime}$ in diameter.

** Peduncles longer than the leaves.

E. Glabriusculus, Chois. Stem creeping, simple, sprinkled with appressed hairs; leaves rigid, elliptical-oborate, mucronate, nearly sessile, smooth above, pubescent on the veins beneath; peduncles bristle-like, rather longer than the leares, 1-3-flowered; sepals ovate-lanceolate, acute, hairy, as long as the pedicel; corolla very small. Stem $1^{\circ}$ long; leaves $4^{\prime \prime}-6^{\prime \prime}$ long; corolla $2^{\prime \prime}$ wide.

\section{STYLISMA, Raf.}

Sepals 5 ; corolla bell-shaped, hairy; stamens included; styles 2, distinct or united below, entire; stigmas peltate; ovary 2-celled, 4-ovuled; capsule 1-4-seeded.-Perennial 
prostrate pubescent herbs, with entire leaves, and small flowers on axillary peduncles which are longer than the leaves.

S. Humistrata. Hairy and roughish; leaves petioled, oblong, slightly cordate, obtuse or emarginate at the apex, mucronate; peduncles filiform, 1-7-flowered; sepals ovate, acute, smooth, fringed on the margins; capsule smooth, nodding; bracts minute; corolla white; filaments hairy; styles united below.-Varies with linear or lanceolate, often acute, nearly sessile leaves, shorter and uniformly 1 -flowered peduncles, and more pubescent sepals. (Convolvulus humistratus, Walt.; C. tenellus, Ell.) Dry sandy pinebarrens. July-September. Stems $2^{\circ}-3^{\circ}$ long; leaves $1^{\prime}-3^{\prime}$ long; corolla 10" long; capsule ovate, commonly 1-seeded, crowned with a tuft of hairs when young.

S. Pickeringit, Gray. Stem $2^{\circ}-3^{\circ}$ long, soft-pubescent; leaves $12^{\prime \prime}-15^{\prime \prime}$ long, linear, obtuse, narrowed at the nearly sessile base; peduncles 1-3-flowered ; bracts linear, as long as the flower; sepals ovate-lanceolate, very hairy, longer than the pedicel; corolla small, white; styles united nearly to the apex; stamens slightly exserted; corolla 5 "long.

\section{CUSCUTA, Tourn. DODDER.}

Calyx 4-5-cleft, or 4-5-sepalous; corolla globular-urnshaped, bell-shaped, or somewhat tubular, 4-õ-cleft; stamens 4-5, with fimbriate mostly confluent scales at the base ; ovary 2-celled, 4-ovuled; styles 2 ; stigmas capitate (in our species) ; capsule 4-seeded; embryo filiform, coiled around fleshy albumen; cotyledons none--Twining parasites, germinating in the ground, but early decaying at the root; stems filiform, yellow or reddish, without leaves, or with minute scales in their place; flowers white, small, variously clustered. 
* Flowers pediceled, with few and distant bracts; culyx 4-5-cleft; corolla bellshaped, persistent at the base of the capsule.

C. ARvensis, Beyrich. Low ; flowers small, 5-parted, in loose umbel-like cymes; lobes of the corollia lanceolate, acuminate, spreading or reflexed, longer than the tube; scales ovate, often partly exserted; capsule globose, thin, yellowish. Fields and sterile soil, on small herbs. June and July. Stems $1^{\circ}$ high; flowers the smallest of our species.

C. Gronovir, Willd. Stem climbing high; flowers mostly 5-cleft, in loose paniculate cymes; lobes of the corolla ovate, obtuse, spreading, mostly shorter than the tube; scales large, confluent at the base; capsule globose, brown. (C. Americana, Pursh., DC.) Low shady places, on coarse herbs. August-October.

C. Neuropetala, Engelm. Stem branching; flowers rather large, 5-parted, in smooth umbel-like cymes; lobes of the calyx ovate-lanceolate, acute; lobes of the corolla ovate, acuminate, crenulate, 1 -nerved, spreading, as long as the tube; scales ovate, incurved, as long as the tube. Damp soil. May.

C. rostrata, Shuttl. Stem twining high ; flowers large, 5 -parted, in umbel-like cymes; lobes of the calyx ovate, obtuse; lobes of the corolla ovate, obtuse, spreading and at length reflexed, half as long as the tube; scales connate at the base; capsule large, acute. Shaded moist places on tall herbs, on the mountains.

** Flowers sessile, in compact clusters; calyx of $\mathbf{5}$ separate sepals, surrounded by several stmilar bracts; corolla persistent at the apex of the capsule.

93. NIGHTShADE FAMILY. Order, Solanacex.

Herbs or shrubs, with colorless juice, alternate leaves, and regular axillary or supra-axillary flowers ; calyx 4-\%cleft, or 4-7-toothed, persistent, often inflated in fruit; 
corolla 5-10-lobed, plaited and valvate, convolute, or imbricated in the bud; stamens 4-\%, inserted on the tube of the corolla; anthers 2-celled, opening lengthwise or by terminal pores; style and stigma single; fruit a 2-celled (rarely 3-5-celled) many-seeded capsule or berry; placenta adnate to the partition and projecting in to the cells; seeds campylotropous or amphitropous; embryo mostly slender and curved in fleshy albumen. Chiefly narcotic poisons.

\section{SYNOPSIS.}

\section{§ Fruit a berry.}

** Coro'la wheel-shaped or short bell-shaped.

+ Anthers connivent. Calyx unchanged in fruit.

Anthers opening by terminal pores.

Berry juicy Solanuar. lengthwise. CAPICUM.

t+ Anthers separate, opening lengthwise; fruiting calyx inflated.

Berry juicy. Calyx entire at the base. Phtsalis. - dry. 10-toothed at the base NICANDRA. Corolla funnel-form; fruit a capsule.

Calyx prismatic or terete, circumscissile. Capsule sipy DatURA.

\section{SOLANUM, L. Nightshade.}

Calyx 5-toothed or 5-cleft; corolla wheel-shaped, 5-lobed, valvate, with the margins turned inward; stamens 5 , inserted on the throat of the corolla, exserted; the filaments very short; anthers opening by 2 terminal pores, connivent; stigma obtuse; berry juicy, 2-celled, many-seeded.-Herbs or shrubs, often armed with prickles; leaves alternate or in pairs ; flowers opposite the axils, or above them.

* Unarmed ; cymes or racemes corymbed; corolla s-parted.

S. verbascifolitur, L. Shrubby, and hoary throughout with dense soft stellate hairs; leaves large, orate-oblong, acute at each end, entire; cymes on long and very stout peduncles, forking, compactly many-flowered; flowers globose-obovate in the bud; calyx-lobes ovate, acute; co- 
rolla-lobes oblong, obtuse; anthers oblong, twice as long as the slender filaments; ovary woolly. October-December. -Shrub $4^{\circ}-5^{\circ}$ high ; leaves $6^{\prime}-9^{\prime}$ long; corolla $\frac{1^{\prime}}{2}$ wide.

** Prickly ; flowers racemed ; corolla mostly angularly lobed.

S. Carolinense, L. Hirsute with stellate hairs; stems erect; leaves ovate-oblong, angularly lobed or toohted, abruptly contracted into a short petiole; the veins and petiole, like the stem, armed with straight yellow prickles; racemes simple, slender, 3-several-flowered; calyx-lobes acuminate.-Var. Floridana (S. Floridana, Dunal) is less hairy; stems ascending from a creeping base; leaves narrower, sinuate-lobed or toothed, with more numerous and stronger prickles. June-September. Stem $1^{\circ}-1_{\frac{1}{2}}^{\circ}$ high ; leaves $3^{\prime}-5^{\prime}$ long; corolla $9^{\prime \prime}-12^{\prime \prime}$ wide, blue or white. Perennial.

S. HIRsutum, Nutt., not of Dunal. Dwarf, hirsute; leaves broadly obovate, very obtuse, nearly entire, narrowed at the base, prickly on the midrib; racemes 3 -flowered; peduncles filiform; roots profusely creeping; stem a span high, beset with yellowish hairs; calyx, very rough ; flowers purple?

S. PSEUDO-CAPSICUM, L., the Jerusalem Cherry, is sometimes spontaneous near dwellings.

S. Tuberosum, L., is the Irish Potato, as it is here called; S. Melongena, L., the Egg-Plant; and S. LycoPERSICUM, L. (Lycopersicum esculentum, Mill.), the Tomato.

\section{CAPSICUM, Tourn. Red Pepper.}

Calyx cup-shaped, 5-7-toothed; corolla wheel-shaped, 5-7-cleft, plaited; stamens 5-7, inserted on the throat of the corolla, exserted; anthers connivent, opening lengthwise; stigma obtuse; berry juiceless, partly 2-3-celled, 
many-seeded.-Herbs or shrubs, with acrid juice, solitary flowers, and red berries.

C. FRUTescens, L. Shrubby, smooth ; stem branching; leaves oblong-ovate, obtuse, entire, acute or rounded at the base, petioled, often by pairs; calyx obscurely 5 -toothed, long-peduncled, erect; berry oblong, shorter than the peduncle. Stem $1^{\circ}-3^{\circ}$ high ; leaves $6^{\prime}$ long; berry $4^{\prime}-8^{\prime}$ long. (Bird Pepper, or Mexican Pepper.)

\section{PHYSALIS, L. GROUND-CHERRY.}

Calyx 5-toothed, inflated in fruit, and inclosing the juicy berry; corolla short-bell-shaped, plaited, 5-lobed or 5-angled; stamens 5, inserted on the tube of the corolla; anthers separate, opening lengthwise; stigma obtuse; seeds flat, kidney-shaped.-Diffusely branching herbs, with alternate petioled leaves, which are often by pairs, and solitary nodding flowers in their axils, or in the forks of the branches.

* Perennial; peduncles commonly longer than the petiole; corolla 8"-10" in diam. eter, spotted in the throat with brown or purple.

P. viscosa, L. Pubescent or hairy; root slender, elongated; stems erect, at length diffusely branched, angled; leaves ovate, entire or angularly toothed, acute or obtuse, rounded or cordate at the base; calyx hairy, with triangular-ovate lobes; corolla pubescent, yellow, with 5 large brown spots in the throat; style and filaments purple; anther's yellow; fruiting calyx oblong-ovate, sharply 5-angled, concave or truncate at the base; berry globose, viscid. (P. heterophylla, Nees; P. Pennsylvanica, L.) Dry light or sandy soil. July-October. Stems $\frac{1}{2}^{\circ}-2^{\circ}$ high, sometimes purple; the pubescence often viscid, jointed, or rough; leaves $1^{\prime}-2$ ' long, the uppermost rarely acute and unequal at the base; corolla obscurely lobed; fruiting calyx $1^{\prime}-1 \frac{1}{2}^{\prime}$ long. 
P. Lanceolata, Michx. Pubescent; leaves ovate-lanceolate or oblong, obtuse, but often attenuate at the apex, entire, wavy, or coarsely and obtusely toothed on the margins, acute and commonly very unequal at the base; calyx pubescent, the lobes long-acuminate from an ovate base; corolla 5-lobed, or somewhat 10-lobed or toothed, yellow in the throat; fruiting calyx ovate or globose-ovate, 5-angled. (P. Elliottii, Kunze; P. maritima, M. A. Curtis?) Dry sandy soil. July-October. Stem $1^{\circ}$ high, erect or diffuse; leaves $1^{\prime}-3^{\prime}$ long; fruiting calyx $1^{\prime}-1 \frac{1}{2}^{\prime}$ long, smooth or hairy.

** Annual; peduncles shorter than the petiole; corolla $4^{\prime \prime}-6$ " in diameter, yellow, spotted in the throat with green or brown.

P. Pubescens, L. Tomentose or villous with soft often viscid hairs, rarely smoothish; stem diffusely branched, 4-angled, with one side rounded; leaves long-petioled, mostly acute, obtusely toothed, wavy-margined, or entire, ovate, and mostly slightly cordate and unequal at the base; calyx-teeth subulate, twice as long as the tube; corolla bright yellow, 5 or somewhat 10-toothed, brown in the throat; filaments hairy; anthers purplish; fruiting calyx oblong-ovate, sharply 5-angled, truncate at the base. (P. hirsuti, Dunal; P. pruinosa, Ell.; P. obscura, Michx.) Fields and waste grounds, common. July-October. Stems $1^{\circ}-3^{\circ}$ long; leaves $1^{\prime}-2^{\prime}$ long.

\section{NICANDRA, Adans.}

Calyx 5-parted, inflated, 10-toothed at the base; corolla bell-shaped, plaited, obscurely 5-lobed; stamens 5 ; anthers separate, opening lengthwise; berry juiceless.-A smooth erect branching annual, with ovate-oblong toothed or lobed petioled leaves, and solitary axillary nodding purple flowers.

N. Physaloides, Gært. (Atropa physaloides, L.) Wastc and cultirated ground. July-September. 
Stem $1^{\circ}-3^{\circ}$ high, with angled branches; leaves $2^{\prime}-5^{\prime}$ long, decurrent on the petiole; corolla white in the throat; fruiting calyx 5 -angled, inclosing the globose berry.

\section{DATURA, L. JAMESTOWN-WEED; THORN-APPLE.}

Calyx tubular, terete or angled, 5-cleft, separating near the base, the upper portion deciduous; corolla funnelshaped, the limb plaited, 5 -lobed, convolute in the bud; stamens 5; anther's opening lengthwise; capsule spiny, imperfectly 4-celled, 4-valved, many-seeded.-Strong-scented poisonous herbs, with petioled oblong or ovate mostly toothed leaves, and large solitary flowers in the forks of the branches.

D. stramonidu, L. Smooth; stem stout, forking; leaves orate or oblong orate, acute, sinuate-toothed; corolla sharply 5-toothed, white, twice as long as the 5-angled calyx ; capsule erect.-Var., Tatula. Larger; leares often cordate; stem and corolla purplish.-Waste ground, very common. June-October. Stem $1^{\circ}-3^{\circ}$ high; leaves $4^{\prime}-8^{\prime}$ long; corolla $3^{\prime}-4^{\prime}$ long.

D. Metel, L. Pubescent; stem stout, branching; leaves orate, entire or slightly toothed; corolla white, 10-toothed; calyx loose, terete; capsule nodding. Stem $3^{\circ}-4^{\circ}$ high; leaves $6^{\prime}-8^{\prime}$ long; corolla $6^{\prime}$ long.

The Night-blooming Jessamine (Cestrum), Tobacco (Nicotiana), and Petunia, belong to the Nightshade Family.

\section{Gentian Family. Order, Gentianacex.}

Chiefly smooth and bitter herbs, with colorless juice, opposite entire partly sheathing exstipulate leaves, and regular often showy flowers; calyx 4-12-parted, or 4-12cleft ; corolla 4-12-lobed, convolute, rarely ralvate or imbricated in the bud, hypogynous; stamens alternate with the 
lobes of the corolla, and inserted on its tube; anthers 2-celled; ovary single, with numerous anatropous ovules; stigmas 1-2; capsule 1-celled, or imperfectly 2-4-celled by the introversion of the margins of the valves, septicidally 2-valved; placentce parietal; seeds numerous; embryo minute, in the axis of fleshy albumen.

\section{SYNOPSIS.}

* Corolla convolute, or (in Obolaria) imbricated in the bud; testa membranaceous; leaves sessiie.

Style conspicuous, deciduous. Stigma linear. Corolla wheel-shaped, 5-12-parted.

SABBATIA.

Style persistent. Stigma roundish. Corolla tubular, 4-5-parted..........Eustoma. Stigma sessile, flat persistent. Corolla bell or funnel-form, 4-5-lobed, mostly with plaited appendages between the lobes.......................... Gentiana.

Calyx and corolla 4-lobed. Sligma sessile. Leaves scale-like............BARTONIA. - 2-leaved. Corolla 4-lobed, imbricated in the bud............... Oвоц Corolla wheel-shaped, 4-parted, the lo'es with a large depressed gland in the middle.

Frasera.

** Corolla folded in the bud; flowers clustered on the petiole.

Leaves floating, cordate. Flowers clustered on the petiole. LIMNANTHEMUU.

\section{SABBATIA, Adans. American Centaury.}

Calyx 5-12-parted; corolla wheel-shaped, 5-12-parted, withering-persistent; stamens 5-12, inserted on the throat of the corolla; anthers sagittate, mostly recurved; style conspicuous; stigmas linear or oblong, twisted; capsule globose, 1-celled, 2-valved, many-seeded.-Annual or biennial branching herbs, with cymose or panicled white or purple showy flowers.

* Calyx and corolla mostly 5-parted.

+ Flowers in corymbose cymes, white, turning yellowish; branches oppasite.

S. MACROPHYLLA, Hook. Glaucous; stem terete, corymbosely branched abore; the branches opposite; leaves thick, erect, ovate-lanceolate, acute, clasping, 3-5-nerved ; cymes large, flat-topped ; corolla small, the lobes thrice as long as 
the very short bristle-like calyx-lobes. July and August. Stem rigid, hollow, $2^{\circ}-2 \frac{1}{2}^{\circ}$ high ; leaves $1 \frac{1}{2}^{\prime}-3^{\prime}$ long ; corolla $5^{\prime \prime}-66^{\prime \prime}$ wide.

t+ Flowers scattered, on long peduncles, white or purple; branches alternate.

S. stellaris, Pursh. Stem obscurely 4-angled, slender, paniculately branched, the branches elongated; leaves somewhat flesky, the lowest lanceolate or oblong, obtuse, the upper linear, acute; flowers on very long peduncles; lobes of the corolla oblong, longer than the filiform calyxlobes. Salt marshes. August and September. Stem $1^{\circ}-3^{\circ}$ high; leaves $1^{\prime}-2^{\prime}$ long; peduncles $1^{\prime}-4^{\prime}$ long; corolla $1 \frac{1^{\prime}}{2}$ wide.

** Calyx and corolla 7-12-parted; flowers purple.

S. Gentianoines, Ell. Stem erect, simple, slender; lowest leaves lanceolate or oblong, narrowed at the base, the others long, linear, sessile; flowers large, in axillary and terminal clusters, or terminal and solitary; corolla 8-10parted, 2-3 times as long as the subulate calyx-lobes; anthers straight. Low pine-barrens. July and August. Stem $1^{\circ}-2^{\circ}$ high ; leaves $1 \frac{1}{2}^{\prime}-3^{\prime}$ long; corolla $2^{\prime}$ wide.

\section{EUSTOMA, Don.}

Calyx bell-shaped, 4-5-parted, sharply 4-5-angled, the lobes subulate, keeled; corolla tubular, 4-5-lobed, membranaceous at the base, withering-persistent, the lobes erect, lanceolate-oblong, acute; stamens 4-5, partly exserted, inserted on the middle of the tube of the corolla; anthers sagittate, introrse, opening lengthwise; style conspicuous, erect, persistent; stigmas round-ovate, thick, at length spreading, with the margins revolute; capsule oblong, obtuse, 1-celled, the margins of the valres slightly inflexed; placento spongy, sutural; seeds minute, globose, sessile.Herbs, with oblong glaucous clasping leaves, and panicled showy purple or blue flowers. 
E. Russellianum. Stem $2^{\circ}$ high, square, glaucous, paniculately forking; leaves ovate-lanceulate, $4^{\prime}$ long, $2^{\prime}-3^{\prime}$ broad, amplexicaul; calyx bell-shaped, $\tilde{5}$-cleft ; corolla bellshaped, 5-cleft, withering-persistent, long-peduncled, terminating the branches, rich purplish blue, $4^{\prime}-5^{\prime}$ long; stamens $\tilde{5}$, slightly exserted, inserted on the middle of the tube of the corolla; anthers sagittate; capsule oblong, 1-celled; style erect, conspicuous; stigmas round-ovate, spreading; seeds minute. Around Independence, and in all the rich, black prairies from Washington County to Austin.

\section{Gentiana, Tourn. Gentian.}

Calyx 4-5-parted; corolla bell-shaped or funnel-shaped, 4-5-lobed, often with plaited toothed appendages between the lobes; stamens 4-5; stigmas 2, sessile, compressed, persistent; capsule 1-celled, 2-valved, many-seeded, the seeds sutural, or covering the inner face of the valves; flowers showy, solitary or clustered, axillary and terminal.

* Annual; corolla funnel-shaped, destitute of appendages; anthers versatile; capsule sessile; seeds wingless.

G. Angustifolia, Michx. Stem low, smooth, 1-flowered; leaves linear, fleshy; calyx-lobes linear, erect, half as long as the corolla; corolla large, bright blue, the lobes ovate, twice as long as the broad toothed appendages.-Varies with the corolla green without and white within.-Low pine-barrens. November and December. Stem $4^{\prime}-10^{\prime}$ high ; corolla $2^{\prime}$ long.

\section{BARTONIA, Muhl.}

Calyx 4-parted; corolla 4-parted; stamens 4; anthers small; stigmas sessile; capsule 1-celled, 2-valved, septicidal ; seeds covering the inner surface of the valves.-Small annual herbs, with erect filiform stems, scale-like subulate leaves, and white flowers. 
B. TENella. Stem $6^{\prime}-12^{\prime}$ high, branched; branches alternate, opposite or alternate, many-flowered; calyx-lobes subulate, as long as the tube of the greenish-white corolla; lobes of the corolla erect, acute; anthers globose; capsule oblong-lanceolate; leaves alternate or opposite.

\section{OBOLARIA, L.}

Low sparingly-branched perennial herb, with opposite wedge-obovate leaves, and single or clustered axillary and terminal purplish-flowers; calyx of 2 spatulate bract-like sepals ; corolla bell-formed, 4-cleft, imbricated in the bud; stamens 4; anthers round-cordate; style short; stigma 2-lipped; capsule ovoid, 1-celled; seeds numerous, covering the base.

O. Virginica, L. Plant smooth, purplish, $3^{\prime}-8^{\prime}$ high; branches generally 3 -flowered.

\section{LIMNANTHEMUM, Gmel.}

Perennial aquatic herhs, with floating circular or cordate spongy leaves, and white peduncled flowers clustered near the summit of the long petiole; calyx 5-parted; corolla wheel-shaped, 5-parted, the lobes infolded in the bud, ciliate, and glandular-crested at the base ; stamens 5 ; style short or none; stigma 2-lobed, persistent; capsule 1-celled, opening irregularly; seeds few or many; testa woody.

L. TraChyspermuM, Gray. Leaves $\left(3^{\prime}-5^{\prime}\right.$ wide) circular, crenate, rough and pitted beneath; petioles stout, dotted, elongated; seeds glandular roughened. Ponds in deep water. April-June.

95. DOGBANE FAMILY. Order, A Pocynacee.

Herbs or shrubs, with acrid milky juice, mostly opposite entire exstipulate leaves, and regular cymose or panicled 
flowers; calyx free, 5-parted, imbricated in the bud, persistent; corolla bell-shaped, funnel-shaped, or salver-form, 5-lobed, convolute in the bud; stamens 5, distinct, inserted on the tube of the corolla; anthers mostly sagittate, erect, introrse; pollen granular; ovaries 2 , distinct, their styles united; fruit few-many-seeded; seeds anatropous or amphitropous, naked, or bearing a tuft of down at the apex (comose); embryo straight in scarce albumen.

\section{SYNOPSIS.}

* Fruit a many-seeded follicle.

+ Seeds comase; leaves opposite.

Corolla bell-shaped, with scale-like appendages at the base of the lobes. Herbs.

APOCTNUM.

t+ Seeds naked; leaves opposite or alternate.

Corolla funnel-formed. Flowers panicled. Leaves alternate............Assowis.

\section{APOCYNUM, Tourn. Indian Hemp.}

Calyx 5-parted; corolla bell-shaped, 5-lobed, with scalelike appendages at the base of the lobes; stamens inserted on the base of the corolla ; anthers sagittate; stigma sessile, 2-lobed; follicles long and slender; seeds numerous, obovoid, comose.-Perennial erect branching herbs, with opposite oral or oblong mucronate petioled leaves, and small white flowers in lateral and terminal cymes.

A. Canvabinum, L. Stem smooth, with erect branches; leaves oval or oblong, mucronate, pubescent beneath; cymes terminal, close-flowered, shorter than the leares; calyx-lobes lanceolate, as long as the tube of the greenishwhite corolla ; lobes of the corolla erect. Stem $2^{\circ}-3^{\circ}$ high ; leaves 2 '-3' long; corolla $2^{\prime \prime}$ long.

\section{AMSONIA, Walt.}

Calyx small, 5-parted; corolla funnel-form, 5-lobed, 
bearded within; stamens inserted above the middle of the tube, anthers oblong, obtuse; stigma globose, surrounded by a cup-shaped membrane; follicles slender; seeds in a single row, terete, truncated at each end, naked.-Erect branching perennial herbs, with alternate leaves, and small pale-blue flowers in a terminal panicle.

A. ciliata, Walt. Stem hairy, at length much branched above; leaves rery numerous, linear or linear-lanceolate, acute at each end, fringed on the margins; corolla smooth. Dry sandy soil. April and May. Stem at length $2^{\circ}-3^{\circ}$ high ; leaves $1^{\prime}-2^{\prime}$ long; corolla pale blue or white; follicles more slender than those of the preceding.

A. SAlicifolia, Ph. Very glabrous and lance-elliptic, acuminate at each end, conspicuously petiolate; calyx-segments triangular acute; corolla-tube glabrous outside or more or less woolly; flowers blue.

\section{MilKWEed FAMily. Order, Asclepiadacez.}

Erect or twining herbs or shrubs, with milky juice, entire commonly opposite leaves without stipules, and umbellate or cymose flowers; caly $x$ 5-parted, persistent; corolla 5 -parted, mostly valvate in the bud, hypogynous, deciduous; stamens 5, inserted on the base of the corolla, the filaments united in a tube (gynostegium) which incloses the ovaries, and bears appendages of various forms, which are collectively termed the stamineal crown; anthers erect, 2-4-celled, expanding above into a thin membrane; pollen united in flattened waxy pear-shaped masses, which are equal in number to the cells of the anthers, and fixed to the fire angular processes of the stigna by a slender stalk, pendulous or horizontal; styles 2, the thick and fleshy stigma common to both; fruit a follicle; seeds anatropous, imbricated on the thick and at length free placenta, and commonly bearing at the hilum a tuft of hairs $($ coma $)$; embryo straight in thin albumen; cotyledons leafy. 


\section{SYNOPSIS.}

Tribe. Asclepiadeæ. Pollen-masses 10, fixed by pairs to the cleft processes of the flat or conical stigma, pendulous.

* Stamineal crown single, 5-leaved.

+ Lobes of the corolla reflexed or spreading.

Leaves of the crown inclosing a horn-like appendage................AscLEPIAs.

\section{ASClePias, L. Milkweed; Silkweed.}

Calyx 5-parted; corolla wheel-shaped, deeply 5-parted, reflexed; crown composed of 5 hooded leaves, each containing an incurved horn-like appendage; pollen-masses 10 , by pairs, each pair occupying the contiguous cells of adjacent anthers, and suspended by a slender stalk from the projecting angles of the stigma; follicle many-seeded; seeds obovate, flat, usually comose.-Perennial herbs, with mostly simple (not twining) stems, and opposite alternate or whorled leaves; flowers in lateral (between the leaves) and terminal umbels.

\section{Stems herbaceous; seeds comose.}

* Follicles spiny ; leaves opposite.

A. CoRnuti, Decaisne. Softly pubescent; stem stout, erect, obscurely 4-angled ; leaves oval-oblong, short-petioled, mucrotena, soon smooth above, the lowest somewhat cordate; umbels numerous, many-flowered, long-peduncled; corolla greenish purple, one-fourth as long as the pedicels; leaves of the crown pale purple, ovate, obtuse, longar than the incurved horn; follicle ovate-oblong, woolly, armed with soft spines. Stem $3^{\circ}-4^{\circ}$ high, sometimes branched; leaves $4^{\prime}-8^{\prime}$ long; pedicels $1^{\prime}-1 \frac{1}{2}^{\prime}$ long, purplish ; corolla $\mathrm{z}^{\prime}$ wide. 
** Follicles spineless.

$\uparrow$ Leaves opposite, oval or oblong, narrowed into a petiole.

A. Purpurascens, L. Stem smooth; leaves ovate-oblong, acute, short petioled, paler and pubescent beneath; umbels 1-2, terminal, peduncled, many-flowered; pedicels half as long as the peduncle, and twice as long as the darkpurple corolla; leaves of the crown oblong, abruptly contracted above, twice as long as the incurved horn and nearly sessile gynostegium. Thickets and borders of woods. June and July. Stem $2^{\circ}-3^{\circ}$ high; leaves $4^{\prime}-7^{\prime}$ long; pedicels $9^{\prime \prime}-15^{\prime \prime}$ long, pubescent.

A. INCARNata, L., var. PUlchra. Hairy; stem erect, branching; leaves oblong or oblong-lanceolate, acute, nearly sessile; umbels numerous, somewhat corymbose, long-peduncled, often compound; pedicels erect, much shorter than the peduncle; corolla small, reddish purple; leaves of the crown flesh-color, ovate, as long as the slender incurved horns, and twice as long as the short-stalked gynostegium. A. pulchra, Willd.) Swamps. June and July. Stem $3^{\circ}-4^{\circ}$ high ; leaves $4^{\prime}-6^{\prime}$ long.

+† Leaves opposite, lanceolate or linear, narrowed into a petiole.

A. cinerea, Walt. Stems erect, slender, pubescent in lines; leaves long, narrowly linear, distant, spreading ; umbols 3-6, commonly longer than the leaves, 5-7-flowered, the slender drooping pedicels longer than the peduncle; flowers small, purple without, ash-color within; leaves of the crown obliquely truncated, 2-toothed at the inner angle, shorter than the gynostegium, longer than the thick horn; follicle smooth, linear. Flat sandy pine-barrens. June-August. Stem $1^{\circ}-2^{\circ}$ high ; leaves $2^{\prime}-3^{\prime}$ long, $1^{\prime \prime}$ wide, somewhat glaucous, the uppermost often minute; corolla $3^{\prime \prime}-4$ " wide; follicle $3^{\prime}-4^{\prime}$ long.

A. PaUpercula, Michx. Stem smooth, tall; leaves elongated, linear or linear-lanceolate, acuminate, rough-mar- 
gined, the upper ones small and remote; umbels $2-5$, corymbose, 6-10-flowered; pedicels pubescent, about as long as the peduncle; corolla deep red; leaves of the crown oblong, erect, bright orange, more than twice as long as the subulate incurved horn and the short-stalked grnostegium; follicle lanceolate, minutely pubescent. June and July. Stem $2^{\circ}-4^{\circ}$ high ; leaves $6^{\prime}-12^{\prime}$ long ; corolla $3^{\prime \prime}-4^{\prime \prime}$ long. In marshes and low places.

t+† Upper and lower leaves mostly opposite, the middle ones whorled.

A. QUADRIfolia, Jacq. Somewhat pubescent; stem slender, simple ; leaves thin, ovate or ovate-lanceolate, acuminate, contracted into a petiole, pale beneath; umbels 2-5, many-flowered, the slender peduncle longer than the pedicels ; corolla pale pink; leaves of the crown white, oblong, obtuse, twice as long as the gynostegium and stout horn. June-August. Stem $1^{\circ}-1 \frac{1}{2}^{\circ}$ high; leaves $2^{\prime}-3^{\prime}$ long.

$\mathrm{t}_{++}+$Leaves alternate, or the lowest opposite.

A. tuberosa, L. Hirsute; stem erect or declining, widely branched above, very leafy; leaves varying from linear to oblong, acute, short-petioled; umbels numerous, corymbose; corolla yellowish orange; leaves of the crown bright orange, erect, oblong-lanceolate, twice as long as the gynostegium, and rather longer than the slender incurved horn. Light dry soil, common. June and July. Stem $1^{\circ}-2^{\circ}$ long. Red River.

A. Speciosa. Red River.-Torrey.

\section{ACERATES, Ell.}

Leaves of the crown destitute of a horn-like appendage. Otherwise like Asclepias.

* Leaves opposite.

A. viridiflora, Ell. Pubescent; stem stout, simple; 
leaves varying from oval or obovate to lanceolate, acute, obtuse, or emarginate, undulate, short-petioled; umbels lateral and terminal, nearly sessile, densely many-flowered; flowers small, greenish; leaves of the crown oblong, erect, as long as the sessile gynostegium. Dry sterile soil. June and July. Stem $1^{\circ}-1 \frac{1}{2}^{\circ}$ high; leaves $1 \frac{1}{2}^{\prime}-2 \frac{1}{2}^{\prime}$ long. Red River.-Torrey.

A. Connivens, Decaisne. Stem stout, simple, pubescent above; leaves nearly sessile, erect, mucronate, the lower ones approximate, oblong or oblong-obovate, the upper more distant, smaller and lanceolate ; umbels 3-6, 6-9-flowered, the stout peduncle and pedicels nearly equal, pubescent; flowers large, greenish ; leaves of the crown oblong, incurved, twice as long as the gynostegium, with their rounded summits connivent over it. June and July. Stem $1^{\circ}-2^{\circ}$ high ; leaves $1^{\prime}-2^{\prime}$ long, somewhat fleshy; corolla $8^{\prime \prime}-10^{\prime \prime}$ wide.

\section{** Leaves alternate.}

A. Paniculata, Decaisne. Closely pubescent; stem angular, often branching; leaves oblong or lance-oblong, acute or obtuse at each end, short-petioled; umbels corymbose, often compound ; corolla large, greenish, spreading or nearly erect; leaves of the crown oblong, obtuse, ascending, shorter than the nearly sessile gynostegium. (Podostigma viridis, Ell.) Dry pine-barrens. July. Stem $1^{\circ}-1 \frac{1}{2}^{\circ}$ high, leafy to the summit; leaves $3^{\prime}-4^{\prime}$ long; corolla $1^{\prime}$ wide.

A. Decumbens. Found in Northern Texas by Marcy's Expedition.

\section{9\%. OLIVE FAMILY. Order, Oleacex.}

Trees or shrubs, with opposite entire or pinnate exstipnlate leaves, and perfect polygamous or diœcious flowers; calyx 4 -toothed; corolla 4-lobed or 4-petalous, valvate in 
the bud, sometimes wanting; stamens $2-7$; ovary 2-celled, with 2 suspended anatropous ovules in each cell; style single or none ; fruit 1-2-seeded; embryo straight, in hard albumen.

\section{SYNOPSIS.}

Tribe I. Oleineæ. Fruit a drupe or berry. Flowers with both calyx and corolla. Leaves simple, entire.

Flowers polygamous. Corolla salver-formed with short lobes.............. OuEs. - perfect. _ _ wheel-shaped, with elongated lobes.... CHrosastrus.

Tribe II. Fraxineæ. Fruit a samara. Flowers diœcious, apetalous. Leaves pinnate.

Flowers in lateral and terminal panicles. Calyx minute or rarely wanting. Trees.

Frasinus.

ThIbe III. Forestiereæ. Fruit a drupe. Flowers diœcious or perfect, apetalous. Leaves simple.

Flowers mostly diocious, from scaly axillary buds. Shrubs.

Forestiena.

\section{OLEA, Tourn. OLIve.}

Calyx 4-toothed; corolla short-salver-form, 4-lobed; stamens 2 ; style short; stigma globose or 2-lobed; drupe mostly 1-seeded, oily.-Trees or shrubs, with opposite coriaceous entire leaves, and small white fragrant flowers, in axillary racemes or panicles.

O. Americana, L. Smooth; leaves oblong or obovateoblong, narrowed into a petiole ; racemes compound, shorter than the leaves; flowers polygamo-diœcious, bracted; drupe ovoid, dark purple. Light soil, near the coast. March and April.-A shrub or small tree, with whitish bark and evergreen leaves; drupe as large as a pea, bitter and astringent. 


\section{CHIONANTHUS, L. FRINGE-TREE.}

Calyx small, 4-cleft; corolla wheel-shaped, 4-parted, with long and linear lobes; stamens 2-4, included; style very short; stigma notched; drupe fleshy, 1 -seeded.-A shrub, with oblong entire deciduous leaves, and delicate white flowers in slender axillary panicles, appearing with the leaves.

C. Virginica, L. Light soil. April and May. Shrub $6^{\circ}-10^{\circ}$ high ; leaves smooth or pubescent, narrowed into a petiole; panicles longer than the leaves, leafy-bracted; flowers on slender drooping pedicels; corolla-lobes linear, $1^{\prime}$ long; drupe ovoid, purple. Near Houston on Buffalo Bayou.

\section{FRAXINUS, Tourn. AsH.}

Flowers diœecious and (in our species) apetalous; calyx 4-lobed or tonthed, minute, sometimes wanting; stamens 2-4; filaments shorter than the large anthers; stigma 2-cleft; fruit (samara) dry, winged above, 1-2-seeded ; cotyledons elliptical; radcile slender.-Trees; leaves petioled, odd-pinnate, deciduous.

* Fruit naked and terete or barely margined and 2-edged at the base, uinged ubove; leaflets 7-9, stalked.

F. Americana, L. (White Ash.) Branches and petioles smooth ; leaflets orate-oblong or lanceolate-oblong, acuminate, entire, or slightly serrate above, smooth on the upper surface, pubescent or glaucous beneath; fruit terete, striate, dilated at the apex into a cuneate-linear or lanceolate obtuse or notched wing.-A large tree; fruit $1 \frac{1^{\prime}}{2}$ long.

F. pubescens, Lam. (Red Ash.) Branchlets and petioles velrety-pubescent; leaflets oblong-ovate or orate-lanceolate, gradually acuminate, bright green above, pale and more or less pubescent beneath; fruit acute at the base, 
flattish and somewhat 2-edged, gradually dilated upward into a long lanceolate and often notched wing. (F. tomentosa, Michx.) Swamps. March and April.-A small tree.

F. viridis, Michx. (Green Ash.) Glabrous throughout; leaflets ovate or oblong-ovate, more or less toothed, smooth and green both sides; fruit as in Pubescens, of which it may be a variety. Swamps. March and April.A small tree.

Fruit winged all round the seed-bearing portion; leaflets 5-9, short-stalked.

F. quadrangulata, Michx. (Blue Ash.) Branchlets square, smooth ; leaflets oblong-ovate or oblong, acuminate, sharply serrate, when young pubescent beneath; fruit linear-oblong, obtuse at both ends. May.

F. Platycarpa, Michx. (Water Ash.) Brancnlets terete, smooth or pubescent; leaflets ovate or elliptical, serrate or almost entire, often pubescent beneath; fruit broadly winged, oblong-obovate or oblong with a tapering and acute base, sometimes 3-winged. (F. triptera and F. pauciflora, Nutt.) Deep river-swamps. March and April. -A small tree.

FORESTIERA, Poir. Adelia, Michx.

Flowers dinecious or polygamous, from axillary scaly buds; corolla none; calyx minute, 4-lobed; sterile-flowers single or 3 together in the axils of imbricated scaly bracts; stamens 3-7; fertile-flowers peduncled; styles slender; stigma capitate; ovary 2-celled; drupe ovoid, 1-seeded, black or blue._Shrubs ; leaves opposite, petioled, serrulate ; flowers minute, greenish, preceding the leaves.

F. porulosa, Poir. Leaves coriaceous, smooth at maturity, nearly sessile, ovate-lanceolate or oblong, obtuse, entire, punctate underneath, the margins entire and revolute ; drupe short-ovoid. Coast.-Michaux; Leitner. 
F. Ligustrina, Poir. More or less pubescent; the branchlets roughened with fine tubercles; leaves rather membranaceous, obovate or obovate-oblong, mostly obtuse, serrulate ( $1^{\prime}$ long), contracted at the base into a distinct petiole; drupe oval-oblong. Rocky banks.

\section{DASYSTOMA, Raf. FALSE FOXgLOVE. (See page 398.)}

Caly $x$ bell-shaped, 5-cleft, the lobes often toothed ; corolla tubularbell-shaped, woolly within, 5-lobed, the lobes rounded; stamens 4, didynamous; anthers oblong; the cells parallel and awned at the base ; style filiform, thickened and slightly 2-lobed at the apex ; capsule ovate, acute, loculicidally 2-valved, many-seeded.-Tall herbs, with opposite ovate or oblong mostly pinnately divided or lobed leaves, and large yellow flawers in a leafy raceme; filaments woolly.

D. QUERCIFolia, Benth. Smooth and glaucous; stem simple or branched; lowest leaves twice-pinnatifid, the others pinnatifid, or the uppermost lanceolate and entire ; calyx shorter than the pedicel, with lanceolate or subulate acute lobes. (Gerardia quercifolia, Pursh.) Rich woods and river-banks. Stem $3^{\circ}-6^{\circ}$ high. Lobes of the leaves toothed; corolla $2^{\prime}$ long, the tube more slender and with smaller lobes than the preceding.

D. PEdicularia, Benth. Smooth or somewhat pubescent ; leaves ovate-lanceolate, pinnatifid, the lobes finely toothed; flovers opposite; calyx shorter than the pedicel, the toothed lobes as long as the tube. (Gerardia pedicularia, L.) Dry sandy soil, chiefly in the upper districts. Stem $2^{\circ}$ high, much branched ; leaves about $2^{\prime}$ long, the lobes numerous and short; corolla $12^{\prime \prime}-15^{\prime \prime}$ long, with a rather slender tube and short lobes.

D. PeCtinata, Benth. Pubescent or somewhat villous; leaves lanceolate or ovate-lanceolate, finely pinnatifid and toothed, the earliest ones entire; flowers alternate, scattered on the outside of the ascending branches; calyx longer than the pedicel, the pinnatifid lobes longer than the tube. Dry sand-ridges in the pine-barrens. 


\section{Division III.-Apetalous Exogenous Plants.}

Floral envelope consisting of a calyx only, or altogether wanting.

98. BIRTHWORT FAMILY. Order, ARtstolochiacex.

Herbs or woody vines, with alternate petioled mostly cordate and entire leaves, and solitary peduncled dull-colored flowers; calyx adherent to the 6-celled ovary, tubular, valvate in the bud; stamens 6-12, more or less united with the styles; anthers adnate, extrorse; fruit 6-celled, fewmany-seeded; seed anatropous; embryo minute, at the base of fleshy albumen.

\section{ASARUM, Tourn. Asarabacca.}

Calyx regular, 3-lobed; stamens 12 , the filaments partly united with the style, and usually prolonged beyond the anther's ; capsule fleshy, globose, opening irregularly.-Aromatic perennial herbs, with creeping stems, long-petioled cordate or kidney-shaped leaves, and axillary peduncled flowers.

The Asarabacca grows in South-eastern Texas. Variety not described by the friend who found it.

99. FOUR-0'CLOCK FAMILY. Order, NyCTAGINACEE.

Herbs or shrubs, with tumid joints; leaves mostly opposite, simple, petioled, without stipules; caly $x$ colored and resembling a corolla, tubular-bell-shaped or funnel-shaped, free from the 1-celled and 1-ovuled ovary, plaited in the bud, contracted in the middle, with the upper portion de- 
ciduous; stamens 1-several, hypogynous; anthers 2-celled, roundish; ovule erect; style simple; stigma simple or branched; achenium inclosed in the indurated, mostly ribbed, often glandular base of the calys; embryo coiled or folded around copious mealy albumen; cotyledons leafy; radicle inferior.

\section{SYNOPSIS.}

* Flonvers surrounded by a calyx-like involucre.

Invalucre open, membranaceous, 5-lobed. Herbs .OXYBAPHU⿴.

** Flowers without an involucre.

* Flowers perfect. Embryo coiled. BoemraAvia.

\section{OXYBAPHUS, Vahl.}

Flowers perfect, 1-5 in a cluster, surrounded by an open cup-shaped 5-lobed involucre; calyx-tube very short, the bell-shaped limb 5-lobed, deciduous; stamens 3, exserted; style slender; stigma capitate; achenium inclosed in the indurated ribbed persistent base of the calyx._-Erect herbs, from thick perennial roots; leaves opposite; flowers terminal, purple or rose-color.

O. ANGustifolius, Sweet. Stem smoothish, branching above; leaves linear-lanceolate, smooth, obtuse at the sessile base, the upper ones distant, acute; flowers loosely panicled; involucre with rounded hairy lobes, at length enlarged and strongly nerved, 3-flowered; base of the calyx villous. Stem $3^{\circ}-4^{\circ}$ high; leaves $2^{\prime}$ long; calyx $4^{\prime \prime}-5^{\prime \prime}$ long, whitish, veiny.

O. NYCTAGINeus, Sweet. Nearly smooth, erect, with alternate or forked branches; leaves broadly ovate or oblong, subcordate, acute; peduncles solitary, axillary and terminal; involucre pubescent, 3-5-flowered; perennial. Red River.-Marcy.

O. coccineus. Roots ligneous, black and tortuous; stems 
$12^{\prime}-18^{\prime}$ high, slender, terete, paniculately branched above; leaves 2 '-3' long, mostly about a line wide, but sometimes 2 lines; inflorescence a loose cymose panicle; involucres sometimes solitary in upper axils and the pedicels recurved; perianth $\frac{3^{\prime}}{4}$ in length, funnel-form, with a long narrow tube; the limb of a bright crimson, 5 -lobed, with the lobes notched; stamens and styles exserted; fruit pubescent, strongly 5-ribbed and slightly rugose.-Torrey. Highlands between Nueces River, west to San Pedro.

O. aggregatus, Vahl. Mirabilis aggregata, Cav. Smith's Run, Western Texas.

O. albidus, O. HiRsutus, O. ANGUSTIFolius, are all found in Western Texas, but the writer has been informed of nothing concerning their distinctive characteristics.

\section{BOERHAAVIA, L.}

Flowers perfect; involucre none; calyx-tube cylindrical or obconical, 5-ribbed, the limb colored, funnel-shaped, 5-lobed, deciduous; stumens 1-4; anthers minute, roundish ; style slender; stigma obtuse; embryo folded.-Annual herbs, with diffuse branching stems, and opposite ovate or rounded leaves; flowers small, in solitary or panicled clusters.

B. ERECTA, L. Stems ascending, branched from the base, smooth, tumid at the joints; branches alternate; leaves ovate or roundish, acute or mucronate, often more or less cordate, wavy along the margins, whitened and minutely dotted with black beneath; clusters 3-5-flowered, in ample panicles; stamens 2 ; fruit smooth, obconical, truncate, strongly ribbed. July-September. Stem $1^{\circ}-3^{\circ}$ long; leaves rather thick, $2^{\prime}-3^{\prime}$ long; flowers small, purple.

B. Hirsuta, Willd. Stem diffuse, alternately branched, minutely pubescent, hirsute abore; leaves orate or oblongovate, mucronate, obtuse at the base, undulate, smooth, 
and similarly colored on both sides, ciliate on the margins; clusters 3-6-flowered, forming a loose spreading panicle; flowers minute; calyx-limb hairy at the apex; fruit obconical, rounded at the apex, with the ribs glandular-viscid. Stem stout, $2^{\circ}-3^{\circ}$ long; leaves $1^{\prime}-2^{\prime}$ long.

\section{POKEWEED FAMily. Order, Phytolaccacex.}

Calyx composed of 4-5 nearly equal sepals, more or less united at the base, unchanged in fruit; stamens hypogynous, as many as the sepals and alternate with them, or numerous, free or united at the base; sterile ones none; anthers 2-celled, introrse; ovary simple or compound; ovules amphitropous or campylotropous, solitary, erect; styles as many as the ovaries; fruit of 1-many carpels; albumen copious or none; embryo annular, rarely straight; radicle inferior.-Herbs or shrubs, with alternate entire leaves, and apetalous 3-bracted racemed or spiked flowers.

SYNOPSIS.

Stb-order I. Petiverieæ. Fruit simple. Cotyledons convolute. Leaves stipulate.

Fruit a berry. Embryo forming a ring around the albumen.............Rrvis..

Strorder II. Phytolacceæ. Fruit compound. Cotyledons flat. Leaves exstipulate.

Fruil a berry, composed of numerous carpels arranged in a circle......PвY тоLAcc..

\section{RIVINA, Plum.}

Calyx remotely 3-bracted, 4-parted, colored; stamens 4-8; anther's ovate or oblong; ovary simple; ovule solitary, amphitropous ; stigma capitate or many-cleft; berry nearly globose, at length dry; embryo forming a ring around the copious albumen; cotyledons somewhat leafy, convolute.- 
Shrubs, with alternate minutely stipulate petioled leaves, and small white or rose-colored flowers in axillary and terminal racemes; bracts deciduous.

R. HUMiLis, L. Closely pubescent; stem with spreading branches; leaves oblong-ovate, rounded at the base, tapering but obtuse at the summit, on long filiform petioles; racemes slender, longer than the leaves; calyx-lobes obovate, pale rose-color; berry rounded,- compressed.-Shrub $1^{\circ}-2^{\circ}$ high; leaves $1^{\prime}-3^{\prime}$ long; flowers and berries $1^{\prime \prime}-1 \frac{1}{2}{ }^{\prime \prime}$ long.

\section{PHYTOLACCA, Tourn. PoKeweed.}

Caly $x$ 3-bracted, 5-parted, the lobes petal-like, rounded; stamens 5-25, the filaments subulate; anthers elliptical; ovary compound; styles 5-12, short, distinct, recurved at the apex, stigmatic within ; fruit a depressed globose berry, containing 5-12 one-seeded indehiscent carpels united in a circle; embryo forming a ring around the central albumen; cotyledons linear.-Erect branching herbs, with entire petioled leaves; flowers in racemes opposite the leaves.

P. DECANDRA, L. Smooth; stem very stout $\left(2^{\circ}-12^{\circ}\right.$ high); leaves ovate-lanceolate, acute; racemes many-flowered, as long as the leaves; flowers white, turning purplish ; stamens, styles, and carpels 10 . Margins of fields and uncultivated ground. July-September. Root large; berry black. Perennial.

\section{GOOSEFOOT FAMILY. Order, Chenopodiace.e.}

Unsightly herbs, with exstipulate leaves, inconspicuous flowers, and the characters mostly of the preceding family; but the green calyx often becoming succulent in fruit, $\tilde{5}$ (rarely 1-2) stamens opposite the sepals, a solitary ovary forming an achenium or utricle in fruit, two short and spreading styles, a horizontal or vertical lenticular seed, 
and the embryo forming a ring around the albumen, or spirally coiled with little or no albumen.

\section{SYNOPSIS.}

Tribe I. Cyclolobeæ. Embryo curved in a ring around the albumen.

Calyx 3-5-parted, the lobes commonly keeled in fruit. Seeds horizontal, rarely

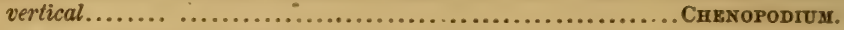

Bracts of the fertile flower united. Radicle superior. OBIONE.

Tribe II. Spirolobeæ. Embryo spirally coiled, with little or no albumen. Seeds horizontal.

Calyx 5-parted, not keeled. Leaves terete, fleshy. .Chenopodina. SALSOLA。

\section{CHENOPODIUM, L. Pigheed; Goosefoot.}

Calyx 5- (rarely 3-4) -parted, bractless, the lobes mostly keeled; stamens 5, the filaments filiform; styles 2-3, distinct, or united at the base; utricle depressed, inclosed in the globose or 5 -angled calyx ; seed horizontal (rarely vertical), lenticular; embryo forming a more or less perfect ring around the copious mealy albumen.-Glandular or powdery-coated herbs, with alternate leaves, and clusters of small greenish flowers disposed in panicled spikes.

\section{* Annuals.}

C. Boscianum, Moq. Stem erect, with angular branches; leaves small, spreading, lanceolate-linear, very acute, entire, or the lower ones somewhat toothed, more or less mealy and whitened beneath; spikes loose, leafy; seed acute on the margins, slightly roughened, shining, inclosed in the acute-angled calyx. (Carolina, Bosc.) Stem slender, $2^{\circ}$ high; leaves $5^{\prime \prime}-12^{\prime \prime}$ long, on petioles, $2^{\prime \prime}-3$ " long; calyx-lobes elliptical-ovate, acutish.

C. ALbur, L. Stem erect, branched, slightly furrowed; 
leaves ascending, rhombic-ovate, acute at the base, toothed, the upper ones lanceolate and entire, more or less coated with a white powder; spikes panicled, the small clusters scattered or crowded, nearly leafless; seed inclosed in the 5 -angled calyx, acute on the margins, smooth and shining. - Varies (C. viride, L.) with nearly entire and less mealy leaves, and the larger clusters more scattered. Cultivated grounds. July-September. Stem $2^{\circ}-6^{\circ}$ high ; petioles long and slender.

C. Murale, L. Stem ascending, branched; leaves longpetioled, ovate-rhombic, acute, unequally and sharply toothed, bright green on both sides; spikes slender, spreading, corymbose, scarcely exceeding the leaves; seed not shining, acute on the margins, nearly inclosed in the slightly angled calyx. Waste places. Stem $6^{\prime}-18^{\prime}$ high.

C. Botrys, L. Stem erect, branched; leaves oblong, somewhat pinnatifid-lobed, with the lobes obtuse and glandular-pubescent, the upper ones minute; racemes numerous, axillary, spreading, cymose ; seeds with rounded margins, not wholly included in the open and even calyx. Waste places. Stem $6^{\prime}-12^{\prime}$ high.

C. SubsPicalum. Diffuse and much branched, clothed with furfuraceous seales ; leaves petiolate, broadly rhombicorate, with one or two coarse teeth on each side. (Neither flower nor fruit described.)-Torrey (Marcy's Expedition).

\section{** Perennial.}

C. Anthelminticum, L. (Wormseed.) Stem stout, erect, branching; leaves oblong or lanceolate, acute at each end, sharply toothed; flowers in narrow panicles terminating the branches; seeds with obtuse margins, smooth and shining, included in the even calyx. Waste grounds. - Stem $2^{\circ}-3^{\circ}$ high. 


\section{OBIONE, Gærtn.}

Chiefly as Atriplex, both in character and habit; but the two indurated bracts more or less united, often toothed on the edges and crested on the sides, and the radicle superior.

O. arenaria, Moquin. Plant coated with silvery scales; stem branching from the base, ascending; lowest leaves opposite, obovate, entire, tapering into a petiole, the others alternate, nearly sessile, lanceolate or oblong, acute, wavy and slightly toothed; sterile flowers in close terminal spikes; the fertile ones in axillary clusters; bracts 3 -toothed at the summit, and with two mostly toothed knobs at the sides. (Atriplex arenaria, Nutt.) Drifting sands along the coast. July-September. Annual. Stem $1^{\circ}-2^{\circ}$ high; leaves $1^{\prime}-11^{\prime}$ long.

O. Canescens. On the Red River-Marcy.

\section{SALICORNIA, Tourn. SAMPHIRE.}

Flowers perfect, lodged in excarations of the thickened upper joints of the stem, spiked; calyx thin, with a denticulate border, at length spongy, and surrounded at the apex by a circular wing; stamens 1-2; styles united below; utricle included in the calyx ; embryo coiled, or bent into a ring.-Smooth and succulent saline plants, with jointed leafless stems ; flowers three together, the lateral ones sometimes sterile, minute.

S. HERBACEA, L. Annual; stem erect, much branched; the joints thickened upward, obtusely 2-toothed at the apex; spikes long, tapering to the summit.-Salt marshes along the coast, Georgia, and northward. August. Stem $6^{\prime}-12^{\prime}$ high.

CHENOPODINA, Moquin.

Flowers perfect, bracted; calyx 5-parted, fleshy, inflated 
and berry-like in fruit; stamens 5 ; stigmas 2-3, spreading; utricle depressed, inclosed in the calyx ; seed horizontal, lenticular; embryo flat-spiral, dividing the scanty albumen into 2 portions.-Smooth saline plants, with fleshy terete alternate leaves, and axillary clustered flowers.

C. Maritima, Moquin. Annual; stem diffusely much branched ; leaves linear, acute ; calyx-lobes obtuse, keeled ; stamens exserted. Low sandy places along the coast. September. Stem $1^{\circ}-3^{\circ}$ high ; leaves $1^{\prime}-2^{\prime}$ long ; flowers minute.

\section{SALSOLA, L. SALTWORT.}

Flowers perfect, 2-bracted; calyx 5-parted, the lobes at length transversely winged; stamens 5 , slightly united at the base; style slender; stigmas 2 ; utricle flattened at the apex, inclosed in the persistent calyx; embryo conicalspiral; albumen none.-Saline plants, with alternate and fleshy leaves and axillary flowers.

S. KALI, L. Smooth ; stem spreading, ascending; leaves subulate, spine-pointed, like the ovate bracts ; flowers solitary; calyx-lobes connivent, with the dilated, membranaceous wing rose-colored. (S. Caroliniana, Walt.) Sandy shores. August. Stem $1^{\circ}-1 \frac{1}{2}^{\circ}$ high. Annual.

\section{AMARANTH FAMILY. Order, Amarantacez.}

Chiefly herbs, with simple exstipulate leaves, and inconspicuous scarious-bracted flowers, which are commonly crowded in spikes or heads; sepals $3-5$, free, or united at the base, scarious, imbricated in the bud; stamens $3-5$, hypogynous, opposite the sepals, free, or united below, often with sterile filaments interposed; anthers 1-2-celled, in trorse ; ovary single, ovate, compressed, 1-many ovuled; stigmas 1-3; utricle closed or circumscissile; embryo coiled into a ring around the central albumen. 


\section{SYNOPSIS.}

Tribe I. Achyrantheæ. Anthers 2-celled. Ovary 1-ovuled. Leaves alternate. Stamens free. Sterile filaments none.

* Utricle circumscissile.

Flowers monocious. Stpals 3-5 Amarantur.

Tribe II. Gomphreneæ. Anthers 1-celled. Ovary 1-ovuled. Leaves opposite. Stamens below.

Calyx 5-cleft. Stamens wholly united. Anthers sessile. Sterile filaments entire.

Frotichus.

\section{CELOSIA, L.}

Flowers perfect, 3-bracted; sepals 5; stamens 5, united at the base into a cup; sterile filaments none; anthers 2-celled; style short or elongated; stigmas 2-3, recurred; utricle many-seeded, circumscissile.-Smooth herbs or shrubs, with alternate petioled leaves, and glossy flowers, crowded in axillary and terminal spikes or panicles.

C. Paniculata, L. Stem shrubby, erect; leaves deltoidovate, acute, abruptly petioled; spikes cylindrical, simple or branched, mostly shorter than the leaves; sepals oblong, rigid, several times longer than the bracts ; stigmas 3 ; utricle many-seeded. Leaves $2^{\prime}$ long; seeds minute, lenticular, shining.

\section{amarantUS, Tourn. Amaranth.}

Flowers polygamo-monœcious, 3-bracted ; sepals 5, rarely 3 , smooth, erect; stamens 5 or 3 , free; sterile filaments none; anthers oblong, 2-celled; style none ; stigmas 2-3, slender, spreading; utricle 1-seeded, ovate, $2-3$-toothed at the apex, circumscissile, commonly included in the calyx ; pericarp mostly membranaceous; radicle inferior.-Unsightly annual herbs, with erect or diffuse stems, alternate mostly 
petioled entire mucronate leaves, and greenish or purplish flowers, crowded in axillary and terminal spikes or clusters; bracts longer than the sepals.

* Flowers in small axillary clusters; sepals and stamens 3.

A. Albes, L. Stem erect, branching from the base, smooth; leaves small, long-petioled, oblong-obovate, very obtuse or emarginate, wavy at the margins ; clusters shorter than the petioles; sepals awl-pointed, much shorter than the subulate spine-pointed spreading bracts, and half as long as the rugose utricle. Cultivated grounds. MaySeptember. Stem $1^{\circ}$ high; leaves $\frac{1^{\prime}}{2}-1^{\prime}$ long.

* Flowers (green) crowded in terminal and axillary spikes; sepals and stamens 5; leuves long-petioled.

A. HYbridus, L. Smooth or nearly so ; stem erect, branching; leaves thin, ovate or ovate-oblong, obtuse, notched, or tapering at the apex, long-mucronate, the pale reins prominent beneath; spikes numerous, panicled, the terminal one elongated, the lower axillary ones short and roundish ; sepals oblong, acuminate, rather shorter than the subulate bracts, and equaling the slightly rugose utricle. Cultivated grounds. August and September. Stem $2^{\circ}-3^{\circ}$ high ; leaves $2^{\prime}-5^{\prime}$ long.

A. Spinosus, L. Smooth; stem stout, succulent, often purplish; leaves ovate or ovate-oblong, obtuse or emarginate, long-petioled, often blotched with purple, spiny in the axils; terminal spike elongated, bending, the lower axillary ones short and roundish; sepals, bracts, and rugose utricle nearly equal. Fields and waste places. July-October. Stem $1^{\circ}-3^{\circ}$ high.

\section{FRELICHIA, Mœnch.}

Flowers perfect, 3-bracted; calyx tubular, 5-cleft, inđurated and spiny-crested in fruit; stamens 5, united into a long tube; sterite filaments entire; anthers sessile; stigna 
capitate or many-cleft; utricle indehiscent, 1-seeded, included in the calyx; seed vertical; radicle ascending.Woolly or hairy annuals; leaves opposite; spikes opposite, and terminating the naked peduncle-like summit of the stem.

F. Floridana, Moquin. White-tomentose or woolly; stem erect, simple or branched; leaves varying from linear to oblong; spikes ovate or oblong, lengthening with age; bracts mostly blackish, shorter than the woolly calyx ; style short; stigma capitate; fruiting calyx round-ovate, compressed, toothed along the margins, and minutely tubercled at the base. Dry sandy places. July-September. Stem $\frac{1}{2}{ }^{\circ}-3^{\circ}$ high; spikes solitary, few, or numerous.

\section{BUCKWHEAT FAMILY. Order, Polygonacex.}

Herbs, shrubs, or (tropical) trees, with simple mostly alternate and stipulate leaves, and perfect or diœcious flowers; calyx 3-6-cleft, or 3-6-sepalous, persistent; stamens 4-12, inserted on the base of the calyx ; anthers 2-celled; ovary single, 1-celled, with the solitary orthotropous orule erect from the base of the cell ; styles $2-3$, distinct or partly united; fruit (achenium) lenticular or 3-angled, rarely ovoid; embryo mostly on the outside of mealy albumen; radicle pointing upward; stipules sheathing, annular, or wanting.

\section{SYNOPSIS.}

Sub-order I. Polygoneæ. Involucre none. Calyx 5-cleft or 5-sepalous. Stamens 4-9 (mostly 5-8). Ovules sessile. Embryo curved on the outside of the albumen, rarely straight in its center. Stipules sheathing.

* Calyx 5-sepalous, the inner sepals erect, mostly enlarged in fruit.

Calyx green, often grain-bearing. Stigma many-cleft................ RUMEx. - coralla-like.

Polygontlua.

** Calyx 5-sepalous, the sepals all erect, unchanged in fruit, free from the achenium. Sepals entire. Embryo curved on the outside of the albumen.......... PoLrGoxum. 
Sub-order II. Eriogoneæ. Flowers surrounded by an involucre. Calyx 6-parted. Stamens 9. Ovule sessile. Embryo included in scarce albumen. Stipules none.

Involucre toothed. Woolly or silky herbs. ERTOGONOM.

\section{RUMEX, L. Dock.}

Flowers perfect or diœcious; calyx herbaceous, 6-parted, the 3 outer lobes spreading or recurved, the inner ones (ralres) mostly enlarged in fruit, and inclosing the 3-angled achenium, often bearing grain-like prominences on the outside; stamens 6 ; anthers erect ; styles 3 ; stigmas manycleft; achenium 3 -angled; embryo curved on the outside of the albumen.-Herbs, with alternate leaves, smooth truncated sheaths, and small green flowers in racemed or panicled clusters.

\section{* Flowers perfect or polygamous. \\ + Valves entire.}

R. CRISPUS, L. Smooth; leaves lanceolate, wavy-crisped, acute at both ends, or the lowest truncate or slightly cordate at the base, and long-petioled, the uppermost linear; panicle leafy at the base; whorls crowded in fruit; valves broadly cordate, obtuse, one or all grain-bearing. Waste ground around dwellings. June and July. Stem $2^{\circ}-3^{\circ}$ high ; lowest leaves $1^{\circ}$ long. Perennial.

R. Floridanus, Meisner. Smooth ; stem stout, branching; leaves lanceolate, acute at each end; panicle naked, dense-flowered; pedicels about twice as long as the valves, thickened upward, reflexed in fruit; valves deltoid-ovate, obtusely pointed, each bearing a narrow grain, which is much narrower than the reticulate valve. Deep riverswamps. June. Stem $2^{\circ}-3^{\circ}$ high ; leaves $\frac{1}{2}^{\circ}-1 \frac{1}{2}^{\circ}$ long.

t+ Valves toothed or bristly on the margins.

R. maritimus, L. Pubescent; stem low, diffusely branched; leaves lanceolate, wavy-margined, the lower ones 
somewhat cordate or hastate at the base, the upper linear; whorls compactly crowded in leafy spikes; valves small, bristly on the margins, nearly covered by the large grain. (R. persicarioides, L.) Sea-shores. August and September. Stems $6^{\prime}-12^{\prime}$ high; spikes yellowish. Annual.

** Flowers dicecious; herbs with sour juice.

+ Calyx not enlarged in fruit.

R. Acetosella, L. Root creeping; stems low, erect or ascending; leaves oblong, lanceolate, or linear, entire or hastate-lobed; panicle slender, leafless; whorls scattered, few-flowered; valves ovate, grainless, appressed to the achenium. Old fields and sterile soil, common. June and July. Stems 6'-12' long; leaves and flowers small. Perennial.

t+ Inner calyx-lobes dilated in fruit.

R. Hastatulus, Baldw. Stems clustered, erect; leaves glaucous, lanceolate or linear, or the lowest oblong, entire or hastate-lobed; whorls few-flowered, scattered, or the upper ones crowded; valves round-cordate, entire, membranaceous, reticulated, red or white, grainless. Dry sands, along the coast. May and June. Stem $1^{\circ}-1 \frac{1}{2}^{\circ}$ high; leaves $1^{\prime}-2$ long, the upper ones mostly entire.

\section{POLYGONELLA, Michx.}

Flowers perfect or diœeciously polygamous; calyx corollalike, deeply 5-parted or 5-sepalous, the three inner sepals mostly enlarging and inclosing the 3 -angled achenium, glandless; stamens 8; anthers roundish; stigmas 3, capitate; embryo straight, or nearly so, in the center, or at one side of the mealy albumen.-Smooth and commonly glaucous herbs or shrubs, with slender branching stems, small alternate leaves, and small flowers in spiked racemes; sheaths smooth; bracts imbricated, top-shaped, mostly 1-flowered; pedicels nodding in fruit. 
Eupozygonella. Filaments all alike, subulate; stigmas nearly sessile; flowers diceciously polygamous; embryo in the center of the albumen.

P. GRacilis, Meisner. Annual; stem tall and slender, paniculately branched above; leaves remote, wedge-oblong, obtuse, often wanting; sheaths truncate, pointless; racemes slender, scattered, forming a large and spreading panicle on the sterile plant, more crowded on the fertile; bracts truncate; flower's white or pale rose-color, the fertile ones greenish; sepals all erect; valves oval or elliptical, unequal (the interior longer), shorter than the ovate-lanceolate acuminate achenium. (Polygonum gracile, Nutt.) Dry sandridges in the pine-barrens. September and October. Stem $2^{\circ}-5^{\circ}$ high ; leaves $1^{\prime}$ long; racemes linear, $1^{\prime}-3^{\prime}$ long.

P. articulata, Meisner. Annual; stem much branched, slender; leaves narrowly linear, obtnse, deciduous; sheaths truncate, pointless; racemes numervus, erect, slender; bracts truncate, open, the lowest ones pointed; flowers bright rose-color; sepals oval or roundish, nearly equal, unchanged in fruit; interior filaments rhombic-ovate at the base. Dry sandy soil. August. Stem $6^{\prime}-12^{\prime}$ high; leaves $4^{\prime}-8^{\prime}$ long; racemes $1^{\prime}$ long.

\section{POLYGONUM, L. KNOTWEED.}

Flowers perfect; calyx 5- (rarely 4) -parted, corolla-like, the lobes nearly equal, erect and unchanged in fruit; stamens $3-9$; anthers roundish ; styles $2-3$, distinct or partly united; stigmas entire; achenium 3-angled or lenticular, inclosed in the persistent calyx ; embryo curved on the outside of the albumen; radicle slender.-Herbs, with alternate, simple leaves, and sheathing stipules; flowers commonly white or rose-color, variously disposed.

AмBLтgonon. Flowers in closely-mracted spikes ; stamens 7 ; style 2-cleft ; achenium lenicular; cotyledons incumbent ; albumen mealy.

P. orientale, L. Hairy; stem tall, branching; leaves 
ovate, acuminate, petioled; sheaths loose, salver-form; spikes panicled, cylindrical, dense, nodding; bracts orate; flowers large, bright rose-color. June-September. Stem $3^{\circ}-5^{\circ}$ high ; spikes $2 \prime-3$ long.

Persicaris. Flowers in closely-bracted spikes; stamens 4-8; styles 2-3, or 2-3-cleft; achenium 3-angled or lenticular; cotyledons accumbent; albumen horny; sheaths cylindrical, truncate.

* Sheaths naked; style 2-clefl or 2-parted; ach enium lenticular.

P. INCARNatum, Ell. Stem smooth below, the summit of the branches, peduncles, and calyx sprinkled with glandular dots ; leaves lanceolate, long-acuminate, petioled, rough on the margins and veins; sheaths slender, appressed; spikes racemed, linear, nodding; bracts spreading, acute, longer than the pedicels; flowers small, flesh-color; stamens 6 ; style 2-parted; achenium orate, with the sides concare. Ponds and ditches. July-October. Stem $2^{\circ}-3^{\circ}$ high; leares $66^{\prime}-8^{\prime}$ long; spikes $1^{\prime}-2^{\prime}$ long. Annual.

** Sheaths fringed wilh bristly hairs; achenium 3-angled, or sometimes lenticular ; stamens mostly 8.

P. Persicaria, L. Stem smooth, branching from the base, erect or diffuse; leaves lanceolate or oblong, obtuse or acutish, the margins and veins roughened; sheaths short, nearly smooth, fringed with a few short bristles; spikes short, oblong, obtuse, dense-flowered; flowers rosecolor; stamens 6-7; style half 2-cleft; achenium lenticular or 3-angled, smooth and shining. Low places around dwellings and along roads. July. Stem $1^{\circ}-1 \frac{1}{2}^{\circ}$ high; leaves $2^{\prime}-4^{\prime}$ long, often with a dark triangular spot in the middle; spikes $\frac{1^{\prime}}{2}-1^{\prime}$ long. Annual.

P. setaceus, Baldw. Stem erect, sparingly branched, smooth below, the upper portion, like the peduncles and lanceolate glandless leaves, rough with appressed hairs; stipules appressed-hirsute, copiously fringed with long bristles; spikes filiform, by pairs, loose-flowered; flowers white, glandless; stamens 8 ; style 3-cleft; achenium 
3-angled. Low ground. July-September. Stem $2^{\circ}-3^{\circ}$ high; leaves $3^{\prime}-5^{\prime}$ long; spikes $1^{\prime}-2^{\prime}$ long. Perennial.

Avicularia. Howers axillary, single or 2-3 together; stamens 8, rarely feiver; stigmas 3, nearly sessile; achenium 3-angled; cotyledons incumbent ; albumen horny; sheaths scarious, 2-3-parted, lacerated; leaves small.

P. Aviculare, L. Stem prostrate, diffuse, short-jointed ; leaves sessile (1 $1 \frac{1}{2}$ long), oblong-linear or lanceolate, obtuse, longer than the 3-cleft sheaths; flowers clustered, nearly sessile, greenish white, longer than the dull achenium; stamens mostly 5 . Waste places and along roads, common. -Var., ERECTUM. (P. erectum, L.) Stem stouter, erect or ascending, leaves larger ( $1^{\prime}-1 \frac{1}{2}^{\prime}$ long), oblong. With the preceding.-Var., LitToRALE. (P. maritimum, L.; P. glaucum, Nutt.) Stem long $\left(1^{\circ}-2^{\circ}\right)$, prostrate, rigid, short-jointed; leaves small $\left(4^{\prime \prime}-6^{\prime \prime}\right)$, oblong-linear, glaucous, the uppermost imbricated and scarcely longer than the more conspicuous silvery sheaths; calyx reddish white, shorter than the smooth achenium. Sea-coast sands, and northward.

Ecrinocaulon. Flowers in terminal clusters; calyx 4-5-purted; stamens 6 or 8 ; styles 2-3 ; achenium lenticular or 3-angled; cotyledons accumbent ; stems weak, branching, armed on the angles, petioles, etc., with recurved prickles.

P. sagitratum, L. Leaves small, sagittate, acute, shortpetioled, smooth; peduncles elongated, smooth; flowers white, capitate; stamens 8 ; styles 3 ; achenium 3-angled. Wet places. June-October. Stem $1^{\circ}-3^{\circ}$ long; leares 1'-2' long. Annual.

\section{ERIOGONUM, Michx.}

Flowers perfect or polygamous, surrounded by an involucre; calyx deeply 6-cleft; stamens 9 ; ovary free, 3 -sided ; styles 3 ; stigmas capitate; achenium 3 -angled or 3-winged; embryo straight in the axis of the albumen, or more or less 
curred.-Downy or woolly herbs; leaves alternate, opposite or whorled; sheaths none; inflorescence rarious.

E. Loxgrfolium, Nutt. Stem erect, tomentose, corrmbose above, leafy below; lear's smooth or rillous abore, white-tomentose beneath, the lowest clustered, oblonglinear, long-tapering at the base, the upper scattered, the uppermost bract-like; inrolucre stalked, many-flowered, obtusely 5-toothed; calyx herbaceous, equal, woolly without. Sand-ridges. Stem $2^{\circ}-3^{\circ}$ high ; lowest leares $3^{\prime}-5^{\prime}$ long. Perennial.

E. tomextosty, Michx. Stem erect, tomentose, corymbose above, leafy throughout; leaves smooth abore, whitetomentose beneath, the lowest clustered, oborate-oblong, long-petioled, the others in whorls of $3-4$, elliptical, sessile; involucre sessile, obtusely 5-toothed; calyx white, unequal, woolly without. Dry pine-barrens. July-September. Stem $2^{\circ}-3^{\circ}$ high ; lowest leaves $4^{\prime}-6^{\prime}$ long; flowers very numerous on one side of the spreading branches. Perennial.

\section{LAUREL FAMILY. Order, Lacracee.}

Aromatic trees or shrubs (except Cassyta), with alternate simple minutely dotted leaves, without stipules, and perfect or polygamous clustered flowers ; calyx 6-9-parted, imbricated in 2 rows; stamens 6 or more, in 1-4 rows; anthers adnate, 2-4-celled, opening by lid-like ralres; ovary free, 1-celled, with a solitary anatropous suspended orule; style simple, thick; stigma obtuse; fruit a drupe or berry; seed without albumen; embryo large; radicle superior.

\section{SYYOPSIS.}

Tribe I. Laurineæ. Fruit naked. Trees or shrubs.

* Flowors perfect; stamens 12, the 3 inner ones sterile.

Anthers 4-celled, 4-valved. Trees with exergreen leaves. Penses. 
** Flovers diccious ; stamens 9, all fertile.

Anthers 4-celled.

2-celled. 4-celled.
SASSAFRAS. BENZOIN. Tetranthera.

PERSEA, Gærtn. Red Bay.

Flowers perfect; calyx deeply 6-parted, persistent ; stamens 12 , in 4 rows, the inner ones sterile and gland-like; filaments pubescent, the inner fertile ones biglandular; anthers 4-celled, those of the two outer rows introrse, of the inner row extrorse; stigma disk-like; drupe ovoid. - Trees or shrubs, with evergreen entire petioled leaves, and greenish or white flowers in axillary peduncled clusters or panicles.

P. Carolinensis, Nees. Branchlets smoothish; leaves oblong or lanceolate-oblong, smooth and deep green above, glacous beneath, obscurely veined; flowers silky, in cymose clusters, on peduncles shorter than the petioles; calyxlobes unequal, persistent; drupe blue. (Laurus Carolinensis, L.) Rich shady woods. July.-A tree, $20^{\circ}-40^{\circ}$ high; leaves $2^{\prime}-3^{\prime}$ long.

\section{SASSAFRAS, Nees.}

Involucre none; flowers diœciously polygamous; calyx 6-parted, spreading; stamens of the sterile flowers 9 , in 3 rows, all fertile, the 3 inner ones biglandular at the base, those of the fertile flowers 6, sterile; anthers linear, 4-celled, 4-valved, introrse; style subulate; stigma disk-like; drupes blue, on thick red pedicels.-Trees, with entire or 2-3-lobed deciduous leaves, and greenish flowers in clustered racemes, appearing before the leaves.

S. officinale, Nees. Leaves ovate, entire or 2-3-lobed, smooth or pubescent; racemes short, silky; flowers sometimes white. (Laurus Sassafras, L.) Dry open woods and old fields. March. - A small tree, with spicy bark. 
BENZOIN, Nees. SPICE-Bush.

Involucre 4-leaved; flowers diœciously polygamous ; calyx 6-parted; stamens of the sterile flowers 9 (more numerous and rudimentary in the fertile flowers), in 3 rows; filaments slender, the inner ones lobed and glandular at the base; anthers ovate, 2-celled, 2-valved, introrse; style short; drupe obovoid, red, the pedicels not thickened.-Shrubs, with entire deciduous leaves, and dull-yellow flowers in lateral sessile clusters, appearing before the leaves.

B. odoriferum, Nees. Branches slender, smooth; leaves oblong-obovate, acute at the base, paler and pubescent beneath, soon smooth; clusters numerous, smooth. (Laurus Benzoin, L.) Banks of streams and low woods. February and March.-A shrub, $6^{\circ}-10^{\circ}$ high, with spicy bark; leaves $3^{\prime}-5^{\prime}$ long.

\section{TETRANTHERA, Jacq.}

Involucre 2-4-leaved; flowers diœcious; calyx 6-parted, deciduous; stamens of the sterile flowers 9 , in 3 rows, those of the fertile flowers numerous and rudimentary; anthers 4-celled, 4-valved, introrse; stigma peltate; drupe globose.-Trees or shrubs, with entire leaves, and small flowers in clustered umbels.

T. geniculata, Nees. Branchlets smooth, zigzag, spreading; leaves small, oval or oblong, soon smooth, deciduous; involucre 2-4-flowered; flowers yellow, appearing before the leaves; drupe red. (Laurus geniculata, Walt.) Shallow pine-barren ponds. February and March.

\section{MEZEREUM FAMILY. Order, Thymelace}

Shrubs, with acrid juice, tough bark, simple entire dotless leaves, without stipules, and regular perfect flowers, with a tubular or bell-shaped 4-5-cleft rarely entire calyx; 
stamens commonly twice as many as the calyx-lobes, in 2 rows; anthers 2-celled, opening lengthwise; style simple; stigma capitate; drupe with a single suspended anatropous seed, containing little or no albumen; cotyledons planoconvex; radicle superior.

\section{DIRCA, L. LEATHERWOOD.}

Calyx bell-shaped, entire, or obscurely 4-toothed ; stamens 8, unequal, exserted ; style filiform; albumen none.-A low branching shrub, with alternate petioled oblong or obovate at length smooth and deciduous leaves, and light-yellow flowers from hairy buds, appearing before the leaves.

D. PALUSTRIS, L. Shady banks of streams. February and March.-Shrub, $2^{\circ}-3^{\circ}$ high, with pale spreading jointed branches; leaves $2^{\prime}$ long, silky when young; flowers three in a cluster, on short pedicels; drupe small, red.

\section{SANDALWOOD FAMily. Order, Santalacez.}

Herbs, shrubs, or trees, with simple entire exstipulate leaves; calyx tubular, 4-5-cleft, valvate in the bud, the tube coherent with the ovary; stamens 4-5, opposite the lobes, and inserted on the fleshy disk at their base; anthers introrse, opening lengthwise; ovary 1 -celled, with 2-4 anatropous ovules suspended from the apex of the free central placenta; style single; fruit 1-seeded; embryo small, at the apex of copious albumen; cotyledons cylindrical; radicle superior.

\section{SYNOPSIS. \\ * Flowers perfect.}

Anthers connected with the calyx-lobes by a tuft of hairs. Leaves alternate.

COMANDra.

** Flowers dicecious; shrubs.

Calyx-limb double, each 4-lobed. Stamens 4. Anthers free. Albumen fleshy. Leaves nearly opposite. Flowers terminal. Bucklexa (Torrey). 


\section{COMANDRA, Nutt.}

Flowers perfect; calyx bell-shaped, 5-cleft, the persistent lobes alternating with the lobes of the disk; stamens 5 ; anthers connected with the calyx-lobes by a tuft of hairs; stigma capitate; fruit nut-like, 1-seeded.-Smooth perennial herbs, with alteruate leaves, and small greenishwhite flowers, in axillary and terminal umbel-like peduncled clusters.

C. umbellata, Nutt. Stem branching above; leaves sessile, lanceolate or oblong; peduncles several, corymbose, 3-5-flowered, mostly longer than the leaves; style slender; fruiting calyx urn-shaped. (Thesium umbellatum, L.) Dry soil. April and May. Stem $8^{\prime}-10^{\prime}$ high ; leaves $\frac{1^{\prime}}{2}-1^{\prime}$ long.

\section{Mistletoe FAMily. Order, Lonanthacez.}

Parasitical shrubby plants, with evergreen almost veinless leaves, without stipules, and perfect or diœcious flowers; calyx of 2-8 sepals, distinct or united into a tube, valvate in the bud, sometimes wanting; stamens as many as the sepals and opposite them; ovary 1-celled, commonly with a single suspended ovule; style simple or none; fruit berry-like; seeds anatropous; embryo longer than the fleshy albumen.

\section{PHORADENDRON, Nutt. Mistletoe.}

Flowers diœcious, in short jointed spikes; calyx of the sterile flower globular, 2-4-lobed; anthers sessile at the base of the lobes, transversely 2-celled; caly $x$ of the fertile flower adnate to the ovary; stigma sessile; berry globose, pulpy, 1-seeded.-Evergreen shrubs, growing on the branches of rarious trees, with brittle jointed stems, thick, persistent leaves, and small flowers in axillary spikes. 
P. Flavescens, Nutt. (Viscum flavescens, Pursh.) April and May. Plant yellowish, $2^{\circ}-3^{\circ}$ long; branches opposite or whorled; leaves obovate, fleshy; spilies shorter thin the leaves; berry white, glutinous.

10\%. LIZARD'S-TAIL FAMILY. Order, Saururacex.

Perennial marsh herbs, with jointed stems, alternate entire leaves, with sheathing stipules, and perfect flowers in bracted spikes or racemes; caly $x$ and corolla none; stamens few or many, hypogynous; anthers introrse, opening lengthwise; ovaries 3-5, more or less united; ovules few, orthotropous, ascending; embryo minute, cordate, contained in a cavity at the apex of the albumen; fruit follicular, 1-fewseeded.

\section{SAURURUS, L. LIzaRD'S-TAIL.}

Stamens 4-8, with long club-shaped filaments; fruit somewhat fleshy, composed of 3-4 partly united 1-2-seeded carpels, pointed with as many stigmas; flowers white.

S. Cernuus, L. Stem erect, branching; leaves petioled, cordate-ovate, or oblong-ovate, acuminate; spikes white, terminal, nodding at the apex; flowers numerous, each from the axil of a small bract. Marshes and muddy banks. May-August. Rhizoma creeping; stem $1^{\circ}-2^{\circ}$ high ; spikes $4^{\prime}-6^{\prime}$ long.

108. HORN WORT FAMILY. Order, Ceratophyllacee.

Submerged aquatic herbs, with filiform jointed and branching stems, finely dissected whorled leaves, and small axillary monœcious flowers, destitute of floral envelopes, but surrounded by an involucre of 8-12 linear leaves; anthers 12-24, oblong, 2-3-toothed, sessile; ovary solitary, simple, with a single suspended orthotropous ovule; achenium compressed, pointed with the slender persistent st albumen none; cotyledons 4 ; plumule conspicuons. Consisting of the single genus 


\section{CERATOPHYLLUM, L. HoRNWORT.}

C. DeMersem, L. Leaves rigid, 6-9 in a whorl, once or twice forking, with the lobes spiny-toothed; achenium oval, compressed, tubercular-roughened on the sides, and armed near the base with 2 lateral widely-spreading slender spines. In still water. September and October. Stems $1^{\circ}-4^{\circ}$ long; leaves near the end of the branches much crowded.

109. STARWORT FAMILY. Order, Callitrichacex.

Small aquatic annuals, with opposite entire leaves, and solitary axillary polygamous flowers without floral envelopes; stamen mostly solitary, 2-bracted in the sterile flower; filament slender; anther reniform, the cells confluent; styles 2 , slender; stigmas acute; capsule 4-angled, 4-celled, with a single suspended anatropous seed in each cell, indehiscent; embryo straight, in copious fleshy albumen; radicle long, superior. Consisting of the single genus

\section{CALLITRICHE, L. WATER-STARTORT.}

C. VERNA, L. Leaves floating, obovate or spatulate, lower ones crowded. Fruit sessile, keeled on the back. Stems several, $6^{\prime}-12^{\prime}$ long; leaves $\frac{1}{2}$ long.

110. RIVER-WEED FAMILY. Order, Podostemaces.

Moss-like aquatic plants, with minute flowers, from a spathe-like involucre, and destitute of floral envelopes; stamens 5-12; anthers 2-celled; capsule 2-3-celled, and pointed by as many persistent styles; seeds numerous, on a thick central placenta, destitute of albumen. 


\section{PODOSTEMON, Michx. RIVER-WeED.}

Spathe 2-leaved; flower's pediceled; filaments elongated, borne on one side of the stalk of the ovary, united below, and bearing only a single anther; styles 2 , simple; capsule ribbed, 2-celled, 2-valved; seeds imbricated.-Submerged aquatic plants, attached to rocks and pebbles by disk-like expansions of the stem; leaves 2-ranked, divided into filıform segments.

P. CERATOPHYlud, Michx. Leaves rigid, sparingly divided, sheathing at the base; flowers solitary, on slender pedicels; capsule oval, 8-ribbed. Rocky places in rivers. July. Plant olive-green, $1^{\prime}-4^{\prime}$ long.

P. ABrotanoides, Nutt. Leaves much divided, with hair-like segments; flowers $2-3$ together, on short pedicels; capsule oblong, 10-ribbed. Gravelly places in rivers.Nuttall. Plant larger than the last.

\section{SPURGE FAMILY. Order, Euphorbiacez.}

Plants commonly with acrid milky juice, and moncecious or diocious often petalous flowers; calyx 2-8-lobed, mostly valvate in the bud, sometimes wanting; stigmas 2 -several, simple or divided; fruit of 2-several (mostly 3) 1-2-seeded carpels united around a central axis, separating at maturity, rarely 1-celled or indehiscent; seeds suspended, anatropous; embryo in fleshy albumen; cotyledons flat.

\section{SYNOPSIS.}

8 Omiles and seeds solitary in the cell; flowers monocious.

* Flowers without floral envelopes, inclosed in a common cup-shaped involucre.

Fertile flowers solitary in the 4-5-toothed involucre. Sterile flowers several, each reduced

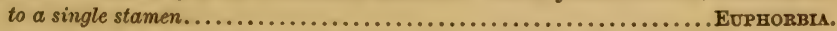

** F lowers in bracted spikes or racemes; the upper ones sterile, the lowest fertile.

+ Flowers apetalous.

I† Stigma and cells of the capsule 6-7.

Calyx 2-3-toothed. Anthers erect. Staminate flowers clustered............ STru.rNGrA.

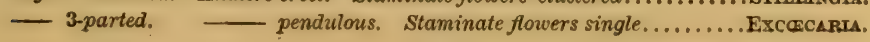


Stigmas many-parted. Flowers spiked. Bracts of the pistillate flowers leafy, toothed.

ACALYPEA.

Stigmas 3, simple. Flowers racemed. Bracts small and entire..............Tragu.

†† Staminate Howers (except CROTON MARITIMUX), or the pistillate flowers also furnished with petals.

Pistillate flowers apetalous, or with minute pelcls. Stamens 6 or more, distinct..Croton. apetalous. Capsule 1-celled. Stamens 5, distinct........ Свотомоғвrs. *** Flowers cymose or panicled, apetalous.

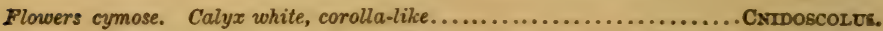

— in crowded panicles. Calyx herbaceous...................... RICrsus

8 Ovules, and commonly the seeds, 2 in the cells.

* Flowers moncecious, apetalous; ovary 3-celled; herbs.

Flowers axillary. Calyx 5-6-parted. Stamens 3, monadelphous.........PHrunawrios.

- spiked. L-parted.

4, distinct.............PACHYSANDRA.

** Flowers dicecious, apetalous; ovary 2-celled; shrubs.

Flowers in axillary clusters. Fruit drupaceous, 1-celled, 1-seeded .......... DRYPETEs

\section{EUPHORBIA, L. SpURge.}

Flowers monœcious, destitute of calyx and corolla, the single pistillate, and several monandrous staminate ones included in a cup-shaped or top-shaped 4-5-toothed involucre, which has commonly thick and often colored glands between the teeth; styles 3, 2-cleft; capsule exserted, 3-celled ; carpels 2-valved, 1-seeded.-A polymorphous genus of plants with acrid milky juice.

\section{\& Leaves without stipules.}

* Stem erect, umbellately branched above; involucres solitary, terminal and in the forks of the branches; leaves of the stem alternate, those of the branches opposite or whorled.

+ Glands of the involucre 5, with white petal-like appendages; leaves entire; perennials.

E. Corollata, L. Stem smooth or pubescent; branches 4-6, twice or thrice forking, mostly short and fustigiate; leavcs thick, oblong or oral, obtuse, pale and mostly liairy beneath; involucres pediceled; appendages of the (green) glands orbicular, showy; capsule and seed smooth. (E. 
paniculata, Ell.)-Var., ANgustifolia, Ell. Stems slender; branches mostly 3 , forking, elongated, spreading; leaves varying from linear to obovate; involucres small, scattered; appendages of the glands transversely oblong. Dry rich soil; the var. in sandy pine-barrens. July-September. Stem $1^{\circ}-2^{\circ}$ high.

E. marginata, Pursh. Leaves oblong-lanceolate, subcordate; umbel 3-rayed, once or twice dichotomons; involucre-leaves oblong, cordate, colored and membranaceous at the margin; inner segments of the floral involucre roundish; capsules hoary-pubescent. A handsome species, remarkable for the variegated leaves.

E. Helioscopa, I. (Sun Spurge.) Erect; floral leaves obovate, cauline, wedge-shaped, sharply serrate, smooth; umbel 5-rayed, then 3-rayed and forked; fruit smooth and even; seeds reticulated.-A large annual weed, remarkable for its symmetry. Stem smooth, erect, $8^{\prime}-16^{\prime}$ high ; leaves scattered, $\frac{2}{3}^{\prime}-1 \frac{1}{2}^{\prime}$ long, $\frac{2}{3}$ as broad at the rounded or retuse apex, tapering to the base; umbels subtended by a large involucre of 5 obovate leaves. Each of the 5 rays is pilous with scattered hairs, and subdivided into an umbellet of 3 rays with a 3 -leaved involucel, and these finally into 2 or more pedicellate fascicles.

t+ Glands of the involucre 5, without appendages.

$\ddagger$ Annuals.

E. Commutata, Engelm. Smooth; stems erect or ascending, umbellately or alternately branched; leaves thin, obovate, entire, the lower ones petioled, those of the branches round-kidney-shaped, sessile; involucres nearly sessile, shorter than the floral leaves; glands crescentshaped or 2-horned; capsule smooth, round-angled; secds ovoid, pitted. Stem $6^{\prime}-12^{\prime}$ high ; leaves $\frac{1^{\prime}}{2}-1^{\prime}$ long; plant pale green. 


\section{STILLINGIA, Gard.}

Flowers monœcious, apetalous, spiked; sterile flowers clustered, cup-shaped, 2-4-toothed or crenate; stamens $2-3$, exserted; anthers erect; fertile flowers few at the base of the spike; calyx 3-lobed; style short; stigmas 3, entire, spreading; capsule roundish, of three 1-celled, 1-seeded, 2-valved carpels.-Smooth herbs, shrubs, or trees, with milky juice; leaves alternate, stipulate; bracts with a fleshy gland on each side.

S. sylvatica, L. (Quen's Delight.) Herbaceous; stems clustered, erect or ascending from a thick woody root, umbellately branched; leares somewhat crowded, nearly sessile, thickish, varying from linear-lanceolate to oborate, obtuse or acute, crenate-serrulate; spikes yellowish, terminal, and in the forks of the stem, longer than the leares; glands cup-shaped; stamens 2; capsule roughish; seed globose. Light dry soil. April-September. Stems $1^{\circ}-3^{\circ}$ high ; leares $1^{\prime}-2^{\prime}$ long; spikes $2^{\prime}-3^{\prime}$ long.

S. Ligcstrisa, Michx. Shrubby; branches alternate, slender; leaves petioled, orate-lanceolate or oblong-orate, mostly obtuse, narrowed at the base, entire; stipules orate; spikes short, often by pairs, shorter than the leares, lateral and terminal; stamens 3 ; capsule and oral seed smooth. River-swamps. May-August. Shrub $6^{\circ}-12^{\circ}$ high; branches spreading; leaves $1^{\prime}-3$ ' long.

\section{ACALYPHA, L.}

Flowers monœcious, apetalous, in axillary and terminal spikes; staminate flowers clustered, minutely bracted; calyx 4-parted; stamens 8-16, with the filaments united at the base; anthers pendulous; pistillate flowers at the base of the staminate ones, or on separate spikes, surrounded by a leafy toothed bract; calyx 3-parted; styles 3, many-cleft; capsule roundish, of three 1-celled, 1-seeded, 2-ralred carpels.-Herbs with watery juice, and alternate serrate leaves. 
* Staminate and pistillate flowers on the same spike.

A. Virginica, L. Annual, smoothish or hairy; stem erect, branched; leaves thin, long-petioled, rhombic-ovate or oblong-ovate, acute, coarsely serrate above the middle; staminate spikes few-flowered, mostly shorter than the large 5-9-lobed bracts, with 1-3 pistillate flowers at the base; capsule pubescent. Stem $1^{\circ}-2^{\circ}$ high ; leaves, with the petiole, $4^{\prime}-5^{\prime}$ long. Near Austin.

** Staminate and pistillate flowers on separate spikes.

A. Caroliniana, Walt. Annual; stem erect, much branched, pubescent; leaves thin, smooth, cordate-ovate, sharply serrate, long-petioled; staminate spike lateral, small, the minute white flowers pediceled; pistillate spike terminal, stout, many-flowered; bracts cut into several subulate lobes; capsule bristly; seeds silvery, pitted. Cultivated ground. July-September. Stem $1^{\circ}-2^{\circ}$ high; leaves $2^{\prime}-3^{\prime}$ long.

\section{TRAGIA, Plum.}

Flowers monœcious, apetalous, in slender racemes; sterile flowers few or numerous, caducous; calyx 3-4-parted; stamens 2-4, with short and separate filaments;-fertile flowers few or solitary at the base of the raceme; calyx 5-8-parted; style 3-cleft; stigmas entire; capsule bristly, of three globose 1-celled, 1-seeded, 2-valved carpels.-Pubescent or bristly herbs, with watery juice; leaves alternate; racemes opposite the leaves and terminal; bracts small, entire, persistent; flowers minute, greenish.

T. URENS, L. Low, downy or hairy; stem at length much branched; leaves nearly sessile, varying from broadly ovate or oblong-orate, and serrate or toothed throughout, or only at the apex, to linear and entire, obtuse, paler beneath; racemes shorter than the leaves and few-flowered, or elongated and many-flowered. (T. linearifolia, Ell., the narrow-leared form.) Dry sandy soil. May-August. Stem $6^{\prime}-12^{\prime}$ high ; leares $1^{\prime}-2$ ' long. Perennial. 
T. URTicifolia, Michx. Bristly, with stinging hairs; stem erect, sparingly branched; leaves petioled, deltoidovate or oblong, coarsely serrate, truncate or cordate at the broad base, pale beneath; racemes shorter than the leaves, the sterile flowers somewhat crowded; capsule very bristly. Dry soil. June-September. Stem $1^{\circ}-2^{\circ}$ high; leaves $1^{\prime}-2$ ' long. Perennial.

T. Ramosa. Red River.-Marcy.

\section{CROTON, L.}

Flowers monœcious, in spikes or racemes; calyx of the sterile flowers 4-6-cleft or 4-6-parted; petals 4-6; stamens $5-20$, distinct; anthers erect, introrse; glands as many as the calyx-lobes and opposite them; fertile flowers at the base of the sterile spike; calyx 5-8-cleft or 5-8-parted; petals minute or wanting; styles 2-3, once-thrice 2-cleft; capsule of 3 (rarely 1-2) 1-celled, 1-seeded, 2-valved carpels; glands as many as the calyx-lobes or none.-Herbs or shrubs, with watery juice, stellate pubescence, and alternate petioled leaves; flowers terminal, and at the divisions of the stem.

* Styles very short; stigmas 18-20 ; petals none; stamens mostly 12 ; capsule 3 -celled.

C. maritimus, Walt. Herbaceous; whole plant corered with a rough scurfy stellate and somewhat hoary pubescence; stem stout, bushy, umbellately branched; leaves thick, long-petioled, ovate, obtuse, entire, rounded or slightly cordate at the base, hoary beneath; spikes longpeduncled, capitate, few-flowered, the sterile and fertile ones mostly separate; calyx 5 -cleft, with ovate-obtuse lobes; capsule much longer than the calyx; seeds ovoid, mottled. Drifting sands along the coast. July-October. Stem $2^{\circ}-3^{\circ}$ high ; leaves $2^{\prime}-3^{\prime}$ long ; flowers occasionally polygamous.

** Styles 3, twice 2-parted or 2-cleft; stigmas 12; petals of the sterile flowers 5-6, of the fertile none; stamens 8-15; capsule 3 -celled.

C. Balsamiferux, Willd. Shrubby; stem smooth, 
whitish ; branches stellate-pubescent, roughish ; leaves slender-petioled, ovate, acute, crenulate, sprinkled with rigid stellate hairs, hoary when young; spilies woolly, at length elongated; sterile flowers numerous, the fertile ones few; calyx of the sterile flower 5-parted, longer than the woollymargined petals; style twice 2-parted, the divisions long, filiform ; stamens about 15; capsule much longer than the calyx ; seed ovoid, smooth. - Shrub $1^{\circ}-2^{\circ}$ high ; leaves thin, $1^{\prime}-1 \frac{1^{\prime}}{2}$ long. Prairies around Houston.

C. arg Yrantheuum, Michx. Herbaccous, perennial, corered throughout with stellate silvery scales; stem erect, umbellately branched; leaves obovate or oblong, obtuse, entire, silvery beneath, narrowed into a petiole; racemes sessile, oblong, olstuse; the fertile flowers numerous and crowded; culyx 5-6-parted, with the lobes acute; stamens 10-12, hairy; styles long and slender, 4-cleft at the apex; capsule much longer than the calyx. Dry sandy pine-barrens.

C. Lindhemeri, Eng. and Gray. Shrubby, erect, trichotomously branched, clothed with a dense hoary tomentum; leaves oblong-lanceolate, rounded or subcordate at the base, acute, entire; lower petiole elongated; spikes terminal and in the forks, mixed or separate; sterile flowers many, sessile, fertile larger, 2 or 3 at the base or alone; calyx rery woolly ; pistillate flowers 7 or 8-parted; styles 3 , twice or thrice forked, red; ovary very villous; pistillate flowers a mass of rusty wool, $5^{\prime \prime}$ broad.-Shrub $2^{\circ}-4^{\circ}$ high ; leaves $2^{\prime}-3$ ' long.

*** Styles 2, 2-parted; stigmas 4; petals 5 in the sterile flowers, none in the fertile; stamens 5-10; capsule 1-2-celled.

C. мoxaxthograta, Michx. Annual; stem erect, twice or thrice umbellately branched, the spreading forking branches, like the leares and racemes, stellate-tomentose; lerres on slender petioles, ovate or oblong, entire, obtuse, whitish beneath; racemes in the forks of the branches, few-flowered; the sterile flowers corymbose; the fertile 
(1-2) nodding. Dry sterile soil. June-September. Stem $1^{\circ}$ high ; leaves $1^{\prime}$ long.

\section{CROTONOPSIS, Michx.}

Flower's monœcious, in terminal and axillary clusters; calyx of the sterile flowers 5-parted; petals and stamens 5; filaments separate, dilated upward; fertile flowers below the sterile; calyx 3-5-parted; petals none; petal-like glands 5, opposite the calyx-lobes; ovary 1 -celled, 1-ovuled ; stigmas 3, each 2-cleft; fruit globose, indehiscent, 1-seeded. -A low and slender branching annual; leaves linear or lanceolate, short-petioled, entire, green and hairy above, the lower surface, like the branches, covered with silvery scales; flowers minute.

C. Linearis, Michx. Dry sandy soil. August-September. Stem $6^{\prime}-12^{\prime}$ high, alternately branched or forking; leaves $\frac{1^{\prime}}{2}-1^{\prime}$ long, alternate or opposite.

\section{CNIDOSCOLUS, Pohl.}

Flowers monœcions, apetalous, cfmose; calyx corollalike; calyx of the sterile flower salver-shaped, 5-lobed; stamens 10 , the 5 inner ones with monadelphous filaments; fertile flowers intermingled with the sterile ones; calyx of 5 sepals, convolute in the bud; styles 3 , many-parted; capsule of three 1-celled, 1-seeded, 2-valved carpels.-Herbs or shrubs, with alternate leaves, and white flowers.

C. stimulosus, Gray. Herbaceous, bristly with stinging hairs; stem erect, simple or branched; leaves long-petioled, round-cordate in outline, palmately $3-5$-lobed or parted, the divisions toothed, pinnatifid, or somewhat bipinnatifid, often discolored; calyx showy; capsule oblong; seed oblong, smooth, spotted. (Jatropha stimulosa, Michx.) Dry pine-barrens. April-September. Stem $\frac{1}{2}^{\circ}-2^{\circ} \mathrm{high}$; flovers sometimes diœcious. Perennial. 


\section{RICINUS, Tourn. Castor-orl Plant.}

Flowers monœcious, apetalous, in a dense oblong panicle, the upper ones fertile ; calyx 3-5-parted ; corolla none; stamens numerous, the filaments much branched; anthercells distinct, pendulous; styles 3, 2-parted ; capsule spiny or bristly, of 3 oblong 1-celled, 1-seeded, 2-valved carpels. -Herbs, or (tropical) strubs or trees, with petioled peltate lobed leaves; panicles lateral and terminal.

R. communis, L. Stem large, glancous; leaves orbicular in outline, palmately $7-9$-lobed, the lobes oblong or ovate, acuminate, unequally serrate, smooth; petioles glandular; panicles in the forks of the stem, and opposite the leaves, dense, glaucous; capsules oblong, spiny. Waste places. June-October. Stem $3^{\circ}-10^{\circ}$ high; leaves $1^{\circ}$ in diameter; stipules large, deciduous; panicle 6'-12' long. Annual.

\section{PHYLLANTHUS, Swartz.}

Flowers monœcious, apetalous, axillary; calyx 5-6-parted ; stamens 3, monadelphous ; glands 5-6; ovary 3-celled, with two ovules in each cell; styles 3 , 2-cleft; capsule globose, of three 1-celled, 2-seeded, 2-ralred carpels.Smooth herbs, with 2-ranked leaves and branches; flowers small, greenish.

P. Carolinensis, Walt. Annual; branches erectspreading; leaves oblong, oval, or obovate, entire, shortpetioled; flowers mostly by pairs, one sterile, the other fertile, on short nodding pedicels; calyx 6 -parted, the lobes oblong, obtuse, strongly 1-nerved, membranous on the margins ; capsule smooth ; seed semicircular, 3-angled, striped with lines of minute raised points. Low ground. AugustSeptember. Stem $8^{\prime}-16^{\prime}$ high ; leaves $\frac{1^{\prime}}{2}-1^{\prime}$ long.

\section{PACHYSANDRA, Michx.}

Flowers monœcious, apetalous, spiked ; calyx bract-like, 
4-parted; sterile flowers numerous; stamens 4, with clubshaped exserted filaments; fertile flowers few, at the base of the sterile spike; ovary 3-celled, with two ovules in each cell; styles 3, thick, recurved; capsule of three 1-celled, 2 -seeded, 2-valved carpels.-A pubescent creeping perennial herb, with erect simple branches, bearing at the summit several large ovate toothed alternate abruptly long-petioled leaves, and near the base several thick bracted spikes.

P. Procumbens, Michx. February and March. Flowering stems $1^{\circ}$ high; leaves $3^{\prime}-4^{\prime}$ long, often discolored; flowers odorous.

\section{DRYPETES, Vahl.}

Flowers diœcious, apetalous, in axillary clusters; calyx 4-6-parted, lined in the center with a wavy-lobed disk; stamens 4-10, inserted under the disk; anther-cells distinct; ovary resting upon the disk, 2-celled, the cells 2-ovuled; styles 2 , short, spreading; fruit drupaceons, 1-2celled, 1-2-seeded.-Tropical trees or shrubs, with alternate coriaceous entire smooth petioled leaves, and minute many-bracted flowers.

D. Crocea, Poit. Branches smooth; leaves oblong, acute at each end, somewhat coriaceous, finely veined; clusters many-flowered, shorter than the petioles; calyx 4-parted, and like the ovary and slightly 4 -angled 1 -seeded drupe tomentose; stamens 4, exserted; styles thick, obtuse.-A small tree; leaves $3^{\prime}-4^{\prime}$ long, smooth and shining; flower's greenish-white.

D. GLAUCA, Vahl. Branches whitish, warty; leaves glaucous, oblong, obtuse or gland-pointed, coriaceous; clusters few-flowered, as long as the petioles; calyx 5-parted; stamens 10 ; drupes oval, tomentose. Leaves $2^{\prime}-3^{\prime}$ long.

112. CROWBERRY FAMILY. Order, EMpetracex.

Shrubs, with erergreen linear alternate or whorled leaves, 
without stipules, and small diœcious or polygamous flowers ; caly $x$ bract-like, of 2-3 sepals, imbricated; corolla of $2-3$ petals similar to the calyx, hypogynous; stamens $2-3$, alternate with the petals, exserted; anthers 2-celled, extrorse; ovary 2-9-celled, the cells 1-ovuled; style short or none; stigma lobed or incised; drupe berry-like, globose, of 2-9 one-seeded nutlets; seeds erect; embryo in the axis of copious fleshy albumen.

\section{CERATIOLA, Michx.}

Calyx bracted, of two fringed sepals; corolla 2-petaled; stamens 2 ; anther-cells globose; ovary resting on a fleshy disk, 2-celled, 2-ovuled; style short; stigma many-cleft; drupe 2-seeded.-A heath-like erect verticillately muchbranched shrub, with small linear shining whorled leaves, and axillary (whorled) reddish flowers.

C. ericordes, Michx. Dry barren sands. November. Silub $2^{\circ}-5^{\circ}$ high, the young branches pubescent; leaves 3 in a whorl, $4^{\prime \prime}-6^{\prime \prime}$ long, the margins revolute; petioles yellowish, appressed; drupe yellowish, somewhat persistent.

\section{BATIS FAMILY. Order, Batidacez.}

Represented only by

\section{BATIS, P. Browne.}

Flowers diøcious, in axillary fleshy conical spikes; bructs of the sterile flowers round-cordate, persistent; culy $x$ cup-shaped, somewhat compressed, unequally 2-lipped; petals 4, rhombic-ovate, clawed; stamens 4, alternate with the petals, partly exserted; anthers oblong, introrse; fertile flowers consolidated; bracts deciduous; calyx and corolla none; ovary 4-celled, with a single erect anitropous ovule in each cell; stigma sessile, broad, obscurely 2-lobed; drupe 4-seeded; seed oblong, without albumen; cotyledons fleshy; radicle inferior.-A smooth 
maritime shrub, with the habit of Salicornia; leaves opposite, fleshy, club-shaped, semi-terete; stipules none; petals white.

B. maritima, L. Salt marshes. June-September. Plant pale green, strong-scented; stems prostrate, $2^{\circ}-3^{\circ}$ long, the short branching flowering-stems erect; leaves $1^{\prime}$ long; spikes 3 "- 5 " long.

\section{NETTLE FAMILY. Order, URTICACEA.}

Herbs, with watery juice, often armed with stinging hairs; leaves undivided, stipulate; flowers monœcious or diœcious, apetalous, clustered, cymose, spiked, or panicled ; calyx of the sterile flower 4-5-parted or 4-5-sepalous; stamens as many as and opposite the sepals; filaments inflexed in the bud, expanding elastically ; anthers 2-celled, introrse; calyx of the fertile flower $2-4$-sepalous; ovary sessile, free, 1-celled, with a single erect orthotropous ovule; stigma simple or tufted; achenium commonly inclosed in the dry persistent calyx; embryo straight in the axis of fleshy albumen.

\section{SYNOPSIS.}

* Plants armed wilh stinging hairs.

Stamens 4. Stigma tufled. Achenium straight.....................UnтrcA.

** Plants destitute of stinging hairs.

+ Flowers in cymose clusters.

Clusters naked. Calyx-lobes unequal. Leaves opposite...................PILEA.

- involucrate. - equal.

Parietaria.

t+ Flovers in spiked clusters.

Stigmas subulate, leaves opposile or alternate.

. BøHMERIA.

\section{URTICA, Tourn. Nettle.}

Flowers monœcious or diœcions; calyx of the sterile flower 4-parted; stamens 4, inserted around the abortive 
ovary; calyx of the fertile flower 4-sepalous, unequal, the inner ones dilated in fruit, and inclosing the achenium; stigma sessile, tufted; achenium straight, ovate, smooth, compressed.-Herbs, with stinging hairs, opposite learcs, and greenish flowers, in panicled spikes or close clusters.

\section{* Flowers in panicled or simple spikes.}

U. GRACILIS, Ait. Stem tall, 4-angled, smoothish, slender; leaves. long-petioled, ovate-lanceolate, coarsely serrate, acnte, rounded at the base, 3-5-nerved, smoothish, the petioles bristly; spikes very slender, loosely panicled. (U. procera, Willd.) Low ground in the upper districts, and northward. July and Angust. Stem $3^{\circ}-4^{\circ}$ high, mostly simple; leaves thin, $4^{\prime}-6^{\prime}$ long. Perennial.

U. DIOICA, L. Hispid throughout; stem 4-angled, pubescent above, branching; leaves rather short-petioled, ovate, cordate, acuminate, coarsely serrate, pubescent beneath; spikes much branched; flowers often diœcious. Waste places. Introduced. June-August. Stem $2^{\circ}-3^{\circ}$ high ; leaves $3^{\prime}-4^{\prime}$ long, thicker than in the preceding and flowers larger. Perennial.

U. capitata, Willd. Stem 4-angled, roughish; leaves large, long-petioled, rough, oblong-ovate, slightly cordate, coarsely serrate, 3 -nerved, those on the branches alternate; spike solitary, leafy at the summit. Wet shaded places. July and August. Stem $3^{\circ}-5^{\circ}$ high.

** Flowers in simple clusters shorter than the petioles.

U. trexs, L. Stem 4-angled, hairy; leaves ovate, coarsely serrate, 5 -nerved, hairy; clusters by pairs in each axil, loose, peduncled. Damp soil. December-February. Stem $1^{\circ}$ high. Annual.

U. Chasradryordes, Pursh. Stem smooth; leaves small, nearly sessile, orate, coarsely serrate, hairy beneath, hairy and bristly above; clusters nearly sessile, globose, dense; calyx hairy. February and March. Stem 4'-6' high. 


\section{PILEA, Lindl.}

Flowers monœcious or diœcious; calyx of the sterile flower 3-4-parted; stamens 3-4; calyx of the fertile flowers 3 -lobed, the lobes unequal or nearly equal, commonly with an inflexed scale-like sterile stamen at the base of each; stigma sessile, tufted; achenium ovate, compressed, straight. -Low herbs, destitute of stiuging hairs; leaves opposite, long-petioled; flowers in axillary cymose clusters.

P. PtMild, Gray. Stem angular, simple, smooth, pellucid; leaves membranaceous, orate or elliptical, acuminate, coarsely serrate, 3 -nerred, slightly hairy above; cymes much shorter than the petiole. (Urtica pumila, I.) Wet shaded places. July-September. Stem $6^{\prime}-12^{\prime}$ high ; upper leares $1^{\prime}-2^{\prime}$ long, the lower not longer than the petiole Annuals.

P. HerriartoIdes, Lindl. Stems erect or creeping, branched, tender, pellucid; leaves small, round-obovate, entire, opaque, transversely marked on the upper surface with white raised lines; clusters shorter than the petiole; flowers minute. Shaded moist places. Norember. Stems $2^{\prime}-4^{\prime}$ long; leaves $1^{\prime \prime}-2^{\prime \prime}$ long, rather longer than the petiole; achenium rery minute, oblong, terete.

\section{PARIETARIA, Tourn. Pellitory.}

Flowers polygamous, in axillary cymose clusters, supported by a bract-like involucre; crly $x$ of the sterile flowers 4-5-sepalous; stamens 4-5, inserted around the abortive ovary; caly.x of the fertile flowers 4-parted; stigma tufted; ovary surrounded by four sterile or sometimes perfect stamens; achenium ovoid.-Weak downy herbs. without stinging hairs; leaves alternate, entire, long-petioled; flowers minute, greenish.

P. Pexssylvaxica, Muhl. Pubescent with straight hairs; stem simple or sparingly branched; leaves thin, ob- 
long-lanceolate, obtuse, roughened with minute elevated dots; clusters dense; flowers shorter than the involucre. Shaded rocks in the upper districts. May-July. Stem $4^{\prime}-12^{\prime}$ high ; leaves $6^{\prime \prime}-9^{\prime \prime}$ long. Annual.

\section{Befhmeria, Jacq. False Nettle.}

Flowers monœcious or diœcions, in spiked clusters; calyx of the sterile flowers 4-5-cleft; stamens 4-5; calyx of the fertile flowers tubular, 4-5-toothed or entire; stigma subulate, hairy; achenium elliptical, inclosed in the persistent calyx.-Rough herbs, with alternate or opposite petioled leaves.

B. CYlindrica, Willd. Pubescent and rough with straight and hooked hairs; leaves opposite and alternate, ovate and orate-lanceolate, acuminate, serrate, rounded and 3-nerved at the base, on long or short petioles; spikes axillary, mostly leafy at the summit, the fertile ones compactly flowered, short, the sterile interrupted, and sometimes longer than the leaves. Swampy thickets. JulySeptember. Stem $1^{\circ}-3^{\circ}$ high, mostly simple; leaves $2^{\prime}-5^{\prime}$ long. Perennial.

\section{HEMP FAMiLY. Order, Cannabinacez.}

Erect or twining herbs, with opposite incised or lobed and stipulate lenves, and diœcious flowers; sterile flowers racemose or panicled; calyx 5-sepalous; stamens 5, opposite the sepals, not inflexed in the bud; fertile flowers in bracted spikes; calyx 1-leaved, embracing the 1-celled ovary; ovule solitary, erect; stigmas 2 , subulate, pubescent; fruit indehiscent; albumen none; embryo coiled or curved.

\section{HUMULUS, L. Hop.}

Sterile flowers panicled; fertile flowers in short axillary and solitary spikes; bracts leafy, imbricated, 2-flowered, 
forming in fruit a membranaceous cone; calyx enlarged in fruit; embryo spirally coiled.-A rough perennial twining herb, with cordate 3-5-lobed leaves, and greenish-yellow flowers.

H. LUPULUS, L. Low grounds along the mountains. June and July. Stem $6^{\circ}-10^{\circ}$ high; leaves petioled, serrate; achenium covered with resinous yellowish odorous grains.

\section{MULBERRY FAMILY. Order, Moracex.}

Trees or shrubs, with milky juice, alternate leaves, with large deciduous stipules, and monœcious or diœcions flowers, crowded in spikes or heads, or inclosed in the fleshy receptacle; calyx of the sterile flowers $3-4$-lobed; stamens $3-4$, inserted on the hase of the calyx; filaments inflexed in the bud, elastic ; calyx of the fertile flowers $3-5$-sepalous; ovary 1-2-celled, 1-2-ovuled; styles 2 ; achenium 1-seeded; embryo curved, in fleshy albumen.

\section{MORUS, Tourn. MUlberRy.}

Flowers monœcious, spiked, the sterile and fertile flowers in separate spikes; calyx 4-parted; stamens 4; ovary 2-celled; styles filiform; achenium ovate, compresser, covered by the succulent berry-like calyx.-Trees, with rounded leaves, and axillary spikes.

M. RUbra, L. Leaves cordate-ovate, acuminate, serrate, petioled, rough above, white-tomentose beneath, on young shoots 3-5-lobed; stipules linear; sterile spikes slender, drooping; the fertile ones ovoid or oblong, resembling a blackberry in fruit. Rich woods. March.-A small tree.

M. A LBA, L. Leaves cordate-ovate, acute, serrate, oblique at the base, smooth and shining, sometimes lobed; fruit whitish. Introduced.-A small tree.

M. mсrophylla, Buckley. Leaves cordate-ovate or 3-lobed, serrate, teeth mucronate, smooth, veins and mar- 
gins slightly ciliate; stipules small, linear, membranaceous, caducous; fruit ripe last of May, black and sour, with little juice and deep sinuses between the achenia, which are a little compressed; styles divaricate and obtuse; leaves generally entire, 1-1 $\frac{1}{2}$ inches, and of about the same width; the lobed leaves are about $2 \frac{1}{2}$ inches long, the middle lobe prolonged and acuminate. Stem and branches smooth, with a light-gray bark.-A large shrub or small tree, 12-20 feet high, growing in clumps. Western Texas, on hills in vicinity of Austin.

\section{FICUS, Tourn. Fig.}

Flowers monœcious or diøcious, lining the inside of the fleshy closed receptacle; caly $x$ of the sterile flowers 3-parted; stamens 3 ; caly $x$ of the fertile flowers 5 -cleft, pediceled; styles lateral, slender; achenium fragile; embryo hooked.Trees or shrubs, with entire or lobed leaves, and large convolute stipules; flowers axillary.

Broussonetia Papyrifera, Vent., the Paper Mulberry of our yards, belongs to this family.

\section{1\%. ELM FAMILY. Order, Ulmaces.}

Trees, with watery juice, alternate undivided stipulate leaves, and perfect or polygamous apetalous flowers; calyx 4-9-lobed; stamens 4-9, inserted on the base of the calyx, erect in the bud; ovary 1-2-celled; ovules solitary, suspended; styles 2, spreading; fruit membranaceous or drupaceous; embryo straight or curved, without albumen; cotyledons leafy.

\section{SYNOPSIS.}

* Fruit dry ; anthers extrorse.

Flowers perfect. Ovary 2-celled. Fruit winged...................... Urmus.

__ polygamous. Ovary 1-celled. Fruit wingless.................... PLANERA.

** Fruit a drupe; anilkers introrse.

Flowers polygamous. Ovary 1-celled. Cotyledons curved........................ 


\section{ULMUS, L. ELM.}

Flowers perfect; calyx bell-shaped, 4-9-cleft; stamens 4-9, slender, exserted; anthers extrorse; ovary 2-celled; styles short; fruit 1-celled, 1-seeded, surrounded by a broad membranaceous wing; embryo straight.-Trees; leaves short-petioled, mostly oblique, doubly serrate, straightveined; stipules deciduous; flowers greenish or purplish, clustered, appearing before the leares.

U. FCLra, Michx. (Slippery Elm.) Branchlets pubescent; leaves thick, orate-oblong, acuminate, broadly serrate, slightly oblique at the base, very rough abore, pubescent beneath; calyx and short pedicels pubescent; fruit orbicular, pubescent on the sides, smooth on the margins, with the obtuse teeth erect; expanding buds rusty-tomentose. Rich woods. February, March.-A small tree; leares $4^{\prime}-8^{\prime}$ long; fruit $8^{\prime \prime}-9$ " wide; inner bark rery mucilaginous.

U. Americana, L. (Elm.) Branchlets and buds smooth; leaves thin, oborate-oblong, or oral, oblique at the base, sharply serrate, abruptly acuminate, smooth abore, pubescent, or at length smooth beneath; pedicels clustered, slender, smooth, like the calyx; fruit oral or oborate, downy on the margins, with the sharp teeth comnirent. Low grounds. February and March.-A large tree, with spreading branches; leares $2^{\prime}-4^{\prime}$ long; fruit $6^{\prime \prime}$ long.

U. ALATA, Michx. (Wha7ioo.) Branches corky-winged; leaves small, orate-lanceolate, acute, sharply serrate, commonly eren and rounded at the base, rough abore, pubescent beneath, nearly sessile; flowers clustered, on slender pedicels; fruit oral, downy on the margins. Rich soil.A small tree ; leaves $1^{\prime}-1 \frac{1^{\prime}}{2}$ long.

\section{PLANERA, Gmel. Plaxer-tree.}

Flowers polygamous, clustered; calyx bell-shaped, 4-5cleft; stamens 4-5; anthers extrorse; ovary 1-celled; 
styles short; fruit nut-like, coriaceous, wingless; embryo straight, without albumen.-Small trees, with the foliage of the Elm.

P. Aquatica, Gmel. Leaves ovate, short-petioled, acute, serrate, roughish; flowers in small, roundish clusters, appearing before the leaves; nut ovate, covered with warty scales. River-swamps. February and March.-A tree, $20^{\circ}-30^{\circ}$ high ; leaves $1^{\prime}-1 \frac{1}{2}^{\prime}$ long.

\section{CELTIS, Tourn. NeTtle-TREe.}

Flowers perfect or polygamous, apetalous; calyx of five sepals; stamens 5 ; anthers introrse ; ovary 1-celled; styles 2, slender, pubescent; drupe globose; embryo curved around scanty gelatinous albumen; cotyledons wrinkled.Trees; leaves petioled, commonly oblique at the base; flowers axillary, solitary or few in a cluster, greenish.

C. occidentalis, L. Young leaves and branchlets silky; leaves ( 2 ' long) orate, acuminate, sharply serrate, abruptly contracted at the base, soon smooth, ferruginous beneath; fertile flowers mostly solitary, on drooping peduncles; the sterile ones $2-4$ in a cluster; drupe dark purple, with a thin sweet pulp. Narch. A tree, $40^{\circ}-60^{\circ}$ high.-Var., INTEGRIrolis. (C. integrifolia, Nutt.) Leaves ovate or ovate-lanceolate $\left(2^{\prime}-3^{\prime}\right.$ long), acuminate, entire, rounded, or the lower ones cordate at the base, roughened with minute elevated points. Sandy soil. A small tree; branches and leaves 2-ranked.-Var., pumila. (C. pumila, Pursh.) Shrubby; leaves $\left(1^{\prime}-1 \frac{1}{2}^{\prime}\right.$ long) ovate, acute, serrate, obtuse at the base, pale beneath, very rough above; drupe glaucous. Shady woods. March and April. Stem $5^{\circ}-10^{\circ}$ high.

\section{Plane-TrEe FaMily. Order, Platanacex.}

Large trees, with alternate palmately-lobed petioled leaves, and monœcious flowers, in axillary long-peduncled 
globose heads; calyx and corolla none; anthers on short club-shaped filaments, numerous, 2-celled, adnate to the truncated connective; ovaries numerous, obconical, hairy at the base; ovules 1-2, orthotropous, pendulous; style subulate; nut 1-seeded; seed cylindrical ; embryo in the axis of scarce fleshy albumen; flowers intermixed with copious club-shaped scales. Consisting of scales.

\section{Platanus, L. Plane-tree; Sycamore.}

P. occidentalis, L. Leaves $\left(4^{\prime}-9^{\prime}\right.$ wide) round-cordate, angularly lobed and toothed, covered when young with dense whitish down, soon smooth; stipules toothed; heads pendulous ( $8^{\prime \prime}-12^{\prime \prime}$ in diameter). River-banks. March and April. A large tree, with the white bark separating in thin plates.

\section{WALNUT FAMILY. Order, JugLANDACEæ.}

Trees, with alternate odd-pinnate exstipulate leaves and monocious apetalous or minutely petaled flowers; sterile flowers in pendulous aments; calyx 2-6-parted, the stamens few or numerous; fertile flowers single or clustered; calyx 3-5-parted, the tube adherent to the incompletely 2-4-celled ovary ; fruit drupaceous, with a bony endocarp; seed 4-lobed, without albumen, orthotropous; cotyledons oily, 2-lobed; radicle short, superior

\section{CARYA, Nutt. Hickory; Pignet.}

Aments of the sterile flowers mostly three together, on a common peduncle, lateral; calyx unequally 3 -parted; stamens 3-6; fertile flowers terminal; calyx 4-parted; petals none; stigma large, 4-lobed; nut smooth, 4-6-angled, incompletely 4-celled; the coriaceous epicarp (husk) partly or completely 4-valved.-Trees, mostly with scaly buds; leaflets serrate; fruit roundish. 
* Epicarp very thick, 4-valved; seed thick, edible.

C. Alba, Nutt. (Shellbark Hickory.) Leaflets 5-7 (mostly 5), lanceolate-oblong, or the upper ones obovateoblong, acuminate, pubescent beneath ; fruit depressed-globose; nut roundish, thin-shelled, compressed, 4-angled, slightly pointed. Rich woods. March and April. A large tree, with shaggy and scaly bark.

C. SulCata, Nutt. Leaflets 7-9, obovate-oblong, acuminate, pubescent beneath ; fruit oval, 4-angled above; nut oblong, thick-shelled, conspicuously pointed, slightly compressed. Rich woods. March and April.-A large tree, with scaly bark.

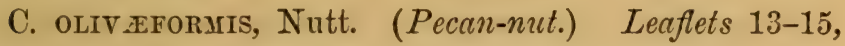
lanceolate-oblong, serrate falcate, acuminate; nut oliveshaped, smooth, thin-shelled, somewhat 4-angled. Riverbottoms.-A large tree, with smoothish bark.

** Epicarp partly 4-valved; seed thin; bark not scaly.

C. tomentosa, Nutt. (Hickory.) Leaflets "7-9 (mostly 7), large, oblong-obovate, acute, pubescent beneath; sterile aments tomentose; fruit large, globose; epicarp thick, coriaceous, parted nearly to the base; nut thick-shelled, oral, somewhat 6-angled. Rich soil. March and April.A large tree, with rough bark.

C. GLABra, Torr. (Pignut.) Leaflets 5-7 (mostly \%), orate-lanceolate, acuminate, smooth ; fruit obovate, obcordate, or pear-shaped; epicarp thin, parted to the middle, coriaceous; nut thick-shelled, sometimes angled. (C. porcina, Nutt.) Woods. March and April.-A large tree, with smoothish bark.

C. microcarpa, Nutt. Leaflets 5-7, oblong-lanceolate, smooth, glandular beneath, acuminate; aments smooth; fruit roundish; epicarp thin; nut thin-shelled, slightly 4-angled. April and May.-A large tree; fruit $\frac{3}{4}$ in diameter. 
C. MYRISTIC late, acuminate, smooth, the terminal one sessile; fruit oval, rugose, rough ; nut oval, slightly acuminate, furrowed, rery hard. Nuts resembling nutmegs.

C. amara, Nutt. (Bitter-nut.) Leaflets 9-11, oblonglanceolate, acute, smoothish; fruit globular ; epicarp thin, parted to the middle; nut thin-shelled, obcordate; seed much wrinkled. Low ground. March and April.-A tree of moderate dimensions, with smooth bark, and very bitter and astringent seeds.

C. AQUaticn, Nutt. Leaflets 9-13, lanceolate, acuminate, slightly serrate, smooth; fruit roundish, 4-ribbed; epicarp thin, 4-parted to the base; nut compressed, thinshelled, 4-angled; seed much wrinkled. River-swamps. March and April.-A small tree, with rough bark; seeds very bitter and astringent.

C. Buckleyir, Durand. Leaflets $7-9$, broad ovate, or ovate-lanceolate, sharply serrate, smooth on both sides, paler beneath, acute at apex, subobtuse or acute at base; staminate and pistillate catkins subpubescent; fruit globular, slightly 4-angled; shell thin, separating to the base.Tree, 3-4 feet in diameter, and 30-40 feet high; bark of trunk very thick, deeply and irregularly furrowed, not scaly; leaflets $6-8$ inches long, and 2-3 inches wide. Dry hills, among post-oak and black-jack, Texas.

\section{JUGLANS, L. Walnut ; Butternut.}

Sterile aments lateral, solitary ; calyx 5-6-parted ; stamens numerous; fertile flowers terminal; calyx 4-cleft; petals 4 , minute; stigmas 2 , long, recurved; fruit oblong or globose; epicarp indehiscent; nut incompletely 4-celled, furrowed or sculptured. - Trees, with naked buds; leaflets serrute.

J. NIGRA, L. (Black Walnut.) Leaflets 11-21, ovate- 
lanceolate, pubescent beneath, acuminate, slightly cordate at the base, or oblique; fruit globose, rough-dotted; nut furrowed. March and April. - A tree, $30^{\circ}-\tilde{2} 0^{\circ}$ high.

\section{OAK FAMILY. Order, Cupulifere.}

Trees or shrubs, with alternate entire or lobed straightveined stipulate leaves, and monœcions apetalous flowers; sterile flowers in pendulous slender or capitate aments; calyx scale-like, or regular and 4-6-lobed; stamens few; fertile flowers single or clustered, furnished with an involucre which incloses the fruit, or forms a cup at its base; ovary 2-7-celled, with 1-2 pendulous anatropous ovules in each cell; stigmas as many as the cells; fruit 1-celled, 1-seeded; albumen none; cotyleclons thick and fleshy; radicle superior.

\section{SYNOPSIS.}

* Fertile flowers single, or few in a cluster.

Nut solitary, with the base inclosed in a scaly involucre................ QuERcus.

- 1-3, inclosed in a 4-valved spiny involucre; sterile aments elongated, erect.

Castanea.

- 2-3-angled, inciosed in a somewhat spiny 4-valved involucre; sterile aments

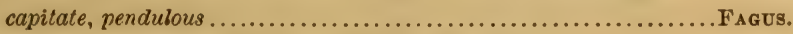

- solitary, bony, inclosed in a leafy lacerated involucre............ Conruus.

** Ferlile flower's spiked.

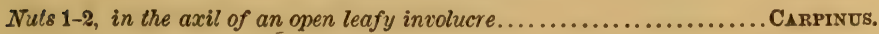

- solilary, inclosed in a membranaceous inflated involucre............ Ostria.

\section{QUERCUS, L. OAK.}

Sterile ament slender, bractless, pendulous; calyx unequally 6-8 parted; stamens 6-12, slender; anthers 2-celled; fertile flowers axillary, solitary, or few in a cluster; calyx 6-cleft or denticulate, adnate to the 3-4-celled ovary; ovules 2 in each cell; stigmas obtuse; nut (acorn) oblong or hemispherical, partly (rarely wholly) inclosed in the cup-shaped scaly involucre; cotyledons very thick, 
plano-convex.-Trees or shrubs, with simple entire or lobed leaves; stipules caducous.

\section{§ Fruit biennial.}

* Leaves entire, short-petioled; those on vigorous shoots often lobed or toothed.

Q. Phellos, L. (Willow Oak.) Leaves (2'-3' long) lanceolate or linear-lanceolate, bristle-awned, scurfy, like the branchlets, when young, becoming smooth on both sides; fruit small, sessile; cup flattish, inclosing the base of the hemispherical nut. Margins of swamps and streams. -A slender tree, $40^{\circ}-50^{\circ}$ high.

Var., La Unifolia. (Q. laurifolia, Michx.) Leaves larger ( $3^{\prime}-4^{\prime}$ long), oblong-lanceolate; cup deeper and more pointed at the base. Light uplands.-A tree, commonly larger than the preceding.

Var., ARENARIA. (Q. myrtifolia, Willd.?) Shrubby $\left(4^{\circ}-8^{\circ}\right.$ high); leaves small ( $\frac{1}{2}^{\prime}-1 \frac{1}{2}$ long), rigid, oblong or obovate, obtuse or barely pointed, with the margins revolute. Dry sand-ridges, along the coast.

Q. IMBRICARIa, Michx. (Shingle Oak.) Leaves lanceolateoblong, acute or obtuse at each end, mucronate, pale and downy beneath, deciduous; fruit middle-sized; cup narrowed at the base, inclosing one-half or one-third of the nearly hemispherical nut, the broad and whitish scales closely appressed. Mountains.-A tree, $40^{\circ}-50^{\circ}$ high; leaves 3 '-5' long.

Q. Cinerea, Michx. (High-ground Willow Oak.) Leaves perennial, oblong-lanceolate, obtuse or acute, mucronate, white-tomentose beneath; fruit small, sessile; cup shallow, narrowed at the base, pale, inclosing one-third of the hemispherical nut. Dry sandy pine-barrens.-A small tree, fruiting abundantly; leaves $2^{\prime}-3^{\prime}$ long, scurfy, like the branchlets, when young.

Var., Pumila, Michx. (Q. pumila, Walt.) Shrubby $\left(1^{\circ}-3^{\circ}\right.$ high $)$; branches slender; leaves lanceolate, wavy, at 
length smooth on both surfaces. Flat or dry pine-barrens. Roots creeping.

Q. virens, Ait. (Live Oak.) Branchlets tomentose; leaves coriaceous, perennial, oblong, obtuse, somewhat rugose, smooth and shining above, hoary-tomentose beneath, the margins revolute; fruit long-peduncled; cup topshaped, hoary, inclosing the base of the oblong chestnutbrown nut. Dry or wet soil.-Commonly a large tree, with spreading branches; leaves 2 ' -4 ' long.

** Leaves 3-lobed at the summit, bristle-aumed.

Q. AQUATICA, Catesb. (Water Oak.) Leaves perennial, short-petioled, obovate-oblong or wedge-shaped, smooth on both sides, obtusely 3-lobed at the summit, often entire, or on young shoots pinnatifid-toothed or lobed, mostly awnless when old; fruit small, mostly sessile; cup shallow, flat, inclosing the base of the hemispherical downy nut. Swamps and wet banks.-A small tree, with smooth bark; leaves $2^{\prime}-3^{\prime}$ long, with tufts of down in the axils of the veins when young.

Var., HYBRIDA. Smooth, with ash-colored branchlets; leaves oblong or wedge-oblong, entire, emarginate, or 3 -lobed at the summit, tapering or abruptly contracted into a short petiole; fruit very small, closely sessile; cup shallow, flattened, inclosing the base of the ovate nut.-A lofty tree; leaves $3^{\prime}-4^{\prime}$ long ; fruit $4^{\prime \prime}-5^{\prime \prime}$ long.

Q. NIGRA, L. (Black Jack.) Leaves short-petioled, coriaceous, broadly wedge-shaped, rounded at the base, mostly 3-lobed at the summit, bristle-awned, smooth above, rusty-pubescent beneath, deciduous; fruit middle-sized, on short and thick peduncles; cup top-shaped, with coarse truncate scales, inclosing one-third or one-half of the oblong-ovate nnt. (Q. ferruginea, Michx.) Dry gravelly or sandy soil.-A small tree; leaves 4 '-9' long.

*** Leaves long-petioled, sinuate-pinnatifi, bristle-awned, deciduous.

† Leaves smooth or nearly so.

Q. Catesbai, Michx. (Turkey Oak.) Leaves some- 
what coriaceous, broad, narrowed into a short petiole, deeply pinnatifid, the lobes very acute from a broad base, spreading, mostly falcate and entire; fruit rather large, short-peduncled; cup thick, turbinate, with broad obtuse scales, inclosing half of the ovoid nut; the upper scales inflexed and lining the inner edge of the cup. Dry pinebarrens.-A small tree; leaves $6^{\prime}-9^{\prime}$ long.

Q. TINCtoria, Bartr. (Black Oak.) Leaves obovate-oblong, with deep or shallow open sinuses, and about 6 sharply-toothed lobes, obtuse or truncate at the base, pubescent when young, at length only in the axils of the veins beneath; cup top-shaped, with broad scales, inclosing about half of the roundish depressed nut. (Q. discolor, Ait.) Dry woods.-A large tree, with the outer bark dark brown, the inner thick and yellow; leaves turning light brown after frost; nuts $6^{\prime \prime}-8^{\prime \prime}$ long.

Q. Coccines, Wang. (Scarlet Oak.) Leaves long petioled, oval or oblong, with deep and broad sinuses, and 6-8 entire or sparingly toothed lobes, truncate at the base, smooth and shining on both sides; cup top-shaped, with coarse scales, inclosing one-half or one-third of the ovoid nut. Dry woods, more abundant in the upper districts.-A large tree, not easily distinguished from the preceding, and probably only a form of it; leaves turning bright scarlet after frost.

Q. RUBRA, L. (Red Oak.) Leaves oblong, with open shallow sinuses, and 8-12 entire or sharply toothed lobes, smooth on both sides, paler beneath; fruit large; cup shallow, flat, with fine scales, inclosing the base of the ovate or oblong nut. Rocky woods.-A large tree; leaves turning dark red after frost; nut $1^{\prime}$ long.

Q. Georgiana, M. A. Curtis. Shrubby; leaves small, very smooth, somewhat obovate, wedge-shaped at the base, with deep or shallow open sinuses, and 3-5 triangularlanceolate entire acute or obtuse lobes; fruit short pedun- 
cled; cup smooth and shining, saucer-shaped, inclosing one-third of the oval-globose nut.-Shrub, $6^{\circ}-8^{\circ}$ high, growing in clusters; leaves $3^{\prime}-4^{\prime}$ long; fruit abundant; nut $\frac{1^{\prime}}{2}$ long.

t+ Leaves tomentose beneath.

Q. Falcata, Michx. (Spanish Oak.) Leaves oblong, rounded at the base, 3-5-lobed; the lobes entire or sparingly toothed at the apex, the terminal one commonly narnow and elongated; fruit rather small ; cup somewhat topshaped, with coarse scales, inclosing half of the globular nut.-Var. PAGODEFOLIA, Ell., has larger leaves, with 11-13 nearly opposite and spreading lobes. Dry woods.A large tree; leaves $4^{\prime}-5^{\prime}$ long, entire near the base; nut $\frac{1^{\prime}}{2}$ long.

\section{\$ Fruit annual ; leaves awnless, deciduous. \\ * Leaves sinuate-lobed.}

Q. овтusiloba, Michx. (Post Oak.) Leaves with 5-7 broad rounded or notched lobes separated by wide open sinuses, narrowed at the base into a short petiole, pubescent beneath; cup hemispherical, inclosing one-third or one-half of the oval nut. Cold clayey soil.-A tree, $40^{\circ}-50^{\circ}$ high; nut $\frac{1}{2}^{\prime}$ long; leaves $4^{\prime}-6^{\prime}$ long.

Var., PARVIFolia. Leaves smaller $\left(1 \frac{1}{2}^{\prime}-3^{\prime}\right.$ long $)$, oblong, obtuse, entire or sinuate-toothed, nearly smooth on both sides, rusty-pubescent, like the branchlets, when young; nut larger. Sand-ridges near the coast.-A shrub or small tree.

Q. ALBA, L. (White Oak.) Leaves oblong or obovateoblong, with " -9 mostly obtuse and entire narrow lobes separated by narrow sinuses, narrowed into a petiole, densely tomentose, like the branchlets, when young, at length smooth or glaucous beneath; fruit large, nearly sessile; cup hemispherical, inclosing one-third of the oblong-ovate mut. Damp woods.-A large tree, with white bark; leaves $4^{\prime}-6^{\prime}$ long; nut about $1^{\prime}$ long. 
Q. Macrociarpa, Michx. (Mossy-cup Oak:) Leaves thin, obovate-oblong, pubescent or pale beneath, acute at the base, short-petioled, slightly or strongly few-manylobed; the lobes rounded, entire or obtusely toothed; fruit large; scales of the cup thick, the upper ones produced into long awns; nut oroid, included, or half inclosed in the cup. Woods and river-banks.-A middle-sized tree ; leaves $6^{\prime}-15^{\prime}$ long; nut $1^{\prime}-11^{\prime}$ long.

Q. LYrata, Walt. (Over-cup Oak.) Leaves crowded at the end of the branchlets, obovate-oblong, acute at the base, 7-9-lobed, white-tomentose beneath, or at length smoothish, shining above, the lobes triangular, acute, and entire; fruit sessile; cup round-orate, with rugged scales, almost corering the roundish nut. Rirer-swamps.-A large tree; leaves $5^{\prime}-8^{\prime}$ long, short-petioled ; fruit $1^{\prime}$ long.

** Leaves toothed.

Q. Prinus, L. (Swamp Chestnut-Oak.) Leaves oblong or obovate-oblong, obtuse, with rounded teeth, smooth and shining abore, pale and pubescent beneath, acute at the base, short-petioled; fruit large, short-peduncled; cup hemispherical, rugged with tubercular scales, inclosing the base of the roundish or oblong-ovate nut. Low grounds.A large tree; nut about $1^{\prime}$ long.

Q. Castanea, Willd. (Chestnut Oak.) Leaves oblong, varying to lanceolate, acuminate, sharply toothed, with the points incurred, mostly acute at the base, smooth abore, paler and minutely pubescent or glaucous beneath; fruit small, sessile or short-peduncled; cup hemispherical, with flat scales, inclosing one-third of the oblong nut. Rocky woods.-A large or middle-sized tree; leaves $3^{\prime}-6^{\prime}$ long; nut $y^{\prime \prime}-9$ " long. Eastern Texas.

Q. PRINordes, Willd. (Chinquapin Oak.) Shrubby; leaves lanceolate-oblong, acute at each end, acutely toothed, smooth above, white tomentose beneath; fruit small, 
mostly sessile; cup hemispherical, with flat scales, inclosing about one-half of the round-ovate nut. (Q. chinquapin, Pursh.)-Shrub $2^{\circ}-6^{\circ}$ high ; leaves $3^{\prime}-4^{\prime}$ long; nut $8^{\prime \prime}-9^{\prime \prime}$ long. San Jacinto and eastward.

Q. Texaxa, Buckley. Leaves orate-oblong in outline, smooth, deeply sinuate-pinnatifid, with broad, divergent sinuses, $3-5$ on each side, lobes.1-3 toothed, teeth acute, setaceous; nut ovoid, oblong, acute; cup shallow, hemispherical, slightly turgid; scales acute, closely appressed; bark of trunk of a dark slate-color and slightly furrowed; limbs smooth; wood close-grained, white or of a light redcolor.-Tree, 1-3 feet in diameter, and 40-50 feet high. Hills in the vicinity of Austin.

Q. Durandi, Buckley. Leaves obovate or lanceolate, entire or slightly 3-lobed at the apex, with rudiments of one or more lobes at the margins, lobes very obtuse; when mature, smooth on both sides; acorn ovoid and often enlarged toward the apex; cup very shallow, scales acute, closely appressed; leaves $3-4$ inches long, 1-2 inches broad; acorns $\frac{1}{2}-\frac{5}{8}$ of an inch long, and about $\frac{1}{2}$ an inch wide, scarcely $\frac{1}{8}$ of an inch being included in the cup.-Tree, 2-3 feet in diameter, and 40-50 feet high; bark of trunk and branches light-gray, scaly, resembling the White Oak. Banks of streams, Middle and Southern Texas.

Q. San-Sabeana, Buckley. Leaves broad ovate, irregugarly and sparingly lobed, lobes very obtuse, upper surface smooth and bright green, beneath glaucous and subpubescent; acorn oblong-ovoid; cup shallow, $\frac{1}{3}$ the length of the acorn; bark of trunk and branches scaly and light gray.A large shrub or small tree, growing on limestone hills in Burnet and San Saba Counties, where it is called "Shin Oak." It often forms dense thickets.

\section{Castanea, Tourn. Chestnut.}

Sterile flowers in separate clusters, in long erect cylin- 
drical aments; calyx 5-6-parted; stamens 8-15; anthers 2-celled; fertile flowers 1-3, inclosed in the bell-shaped at length globose 4 -valved and very prickly involucre; calyx 5-6-lobed, superior; abortive stamens 5-12; ovary 3-6celled; ovules single or by pairs in each cell; stigmas $3-6$, bristle-like, spreading; nuts 1-3, roundish, compressed, or plano-convex; cotyledons very thick.-Trees or slirubs, with oblong petioled sharply-serrate and straight-reined leaves.

C. VESCA, L. (Chestnut.) Leaves oblong-lanceolate, acuminate, coarsely serrate, smooth on both sides; nuts mostly 3 , the middle one flattened, the 2 outer ones planoconvex, dark brown. Dry woods. April.-A large tree; leaves $6^{\prime}-7^{\prime}$ long.

C. PUMILA, Michx. (Chinquepin.) Leaves oblong, acute, or obtuse, finely serrate, hoary-tomentose beneath; nuts solitary, nearly globular. (C. nana, Muhl., a form with larger leaves and nuts.) Dry sandy soil. April-May.A large shrub or small tree; leaves, involucre, and nut smaller than those of the preceding.

\section{FAGUS, Tourn. BeEch.}

Sterile flowers capitate, on long and drooping peduncles, with deciduous bracts; calyx bell-shaped, 5-6-cleft; stamens 8-12; anthers 2-celled; fertile flowers solitary or by pairs, peduncled, surrounded with numerous linear bracts and a 4-lobed involucre; calyx of 4-5 subulate lobes; ovary 3 -celled, with two ovules in each cell; styles 3, filiform; muts commonly 2 , acutely 3 -angled, inclosed in the softspiny 4-valved involucre; cotyledons thick and fleshy.Trees, with whitish bark, and straight-veined leaves expanding with the flowers.

F. FERruginea, Ait. Leaves oblong-ovate or rhombic, acute, finely serrate, silky on both sides when young, when 
old only on the veins beneath; spines of the involucre short, recurved. Damp sandy soil. April.-A large tree, with widely spreading branches.

\section{CORYLUS, Tourn. HAZEL-NUT.}

Sterile flowers in cylindrical pendulous bracted aments; calyx 2-cleft, partly united with the bract; stamens 8; anthers 1-celled; fertile flowers clustered; ovary 2-celled, 2-ovuled; stigmas 2, filiform; involucre tubular at the base, leafy and lacerated at the summit, inclosing a single bony (edible) nut.-Shrubs, with broally cordate doubly serrate petioled leaves; flowers appearing before the leaves.

C. rostrata, Ait. (Beaked Hazel-nut.) Branchlets smooth; leaves ovate or oblong-ovate, slightly cordate, acuminate, finely serrate, rather thin, pubescent; involucre bristly, prolonged into a tube above the nut, 2-cleft and toothed at the summit; fruit nearly globular. Rich soil. March-April.-Shrub, $4^{\circ}-6^{\circ}$ high.

\section{CARPINUS, L. HoRNBEAM.}

Flowers destitute of floral envelopes, supported by scalelike bracts; sterile flowers in drooping cylindrical aments; stamens 8-14; filaments short; anthers 1-celled, hairy at the apex; fertile flowers spiked; bracts 2-flowered, deciduous; ovary 2-celled, 2-ovuled; stigmas 2 , filiform; nut solitary, angular, sessile in the axil of an open 3-lobed, leaflike in volucre.-Trees, with simple ovate or oblong straightveined decidnous leaves, folded in the bud ; flowers expanding before the leaves.

C. Americana, Michx. (Hornbeam.) Branchlets smooth and slender; leaves oblong-ovate, acute or slightly acuminate, sharply and doubly serrate, rounded at the base, more or less pubescent; fertile spikes terminal, long-peduncled, 
6-12-flowered; involucre unequally 3-lobed, the middle lobe longer and serrate on one side; nut small, ovate, compressed, 8-ribbed. Rich woods. March.-A small tree, with hard and close-grained wood.

\section{OSTRYA, Micheli. Hop HoRnbeAM.}

Sterile flowers in drooping cylindrical aments, each in the axil of a scale-like bract, destitute of a calyx ; stamens with the filaments irregularly united; fertile flowers in a short terminal crowded spike, each inclosed in a membranaceous involucre; ovary 2-celled, 2-oruled, bearded at the apex; stigmas 2, filiform; fruiting involncre inflated, nerved, hairy or bristly at the base, inclosing the solitary pointed nut.-Small trees, with ovate or oblong serrate short-petioled deciduous leaves; flowers appearing with the leaves.

O. Virginica, Willd. (Hop Hornbeam.) Leaves ovateoblong, sharply and simply serrate, acuminate, rounded or slightly cordate at the base, pubescent; fertile spike cone-like, short-peduncled; the imbricated involucres oblong, mucronate, bristly at the base. Rich woods. March. -A small tree, with hard and close-grained wood.

\section{WAX-MYRTLE FAMILY. Order, Myricacex.}

Chiefly shrubs, with simple alternate leaves, with or without stipules, and monœcions or diœcious flowers, disposed in aments, destitute of calyx or corolla, each in the axil of a simple bract; stamens 2-10; the short filaments free or partly united; anthers 2-celled; ovary solitary, 1-celled, surrounded at the base with a row of scales; ovule solitary, orthotropous or amphitropous; involucre none; stigmas 1-2, elongated; fruit a dry 1-seeded drupe; albumen none; catyledons fleshy; radicle superior. 


\section{SYNOPSIS.}

* Seed orthotropous; plants dotted with resinous glands.

Flowers diocious. Filaments united below. Leaves serrate or entire. Slipules

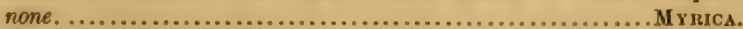

Flowers monacious. Filaments forking. Leaves pinnatifid. Stipules half-cor-

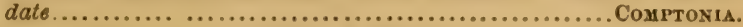

** Seeds amphitropous. Plant destitute of gland8.

Flowers diceious. Filaments distinct. Stigma solitary. Leaves entire. Stipules none

LEITNERIA.

\section{MYRICA, L. WAX-MYrTLE; BAYBerRy.}

Flowers in short axillary aments, diœcious, each in the axil of a scale-like bract; calyx and corolla none; stamens 2-10, with the filaments united below; ovary inclosed in a cup of 3-5 rounded scales; ovule orthotropous; stigmas 2 (rarely 4 ), flattened on the inner face, widely spreading; nut globose, covered with waxy grains.-Shrubs or small trees, dotted with minute resinous and odorous glands; branches clustered; leaves short-petioled, serrate or entire; stipules none.

M. Cerifera, L. (Wax-Myrtle; Bayberry.) Branchlets pubescent; leaves lanceolate or oblong-lanceolate, mostly obtuse, entire, or with a few sharp serratures near the apex, smooth, or pubescent on the reins beneath, tapering into a petiole; sterile aments very numerous, oblong; bracts wedge-shaped; stamens 4 ; fertile aments small; bracts rounded, obscurely 3 -lobed; scales of the ovary 4 , ciliate; stigmas 2 ; fruit abundant, white. Margins of swamps. March and April.-A shrub or small tree; leaves persistent along our southern limits, but northwardly deciduous, $1 \frac{1}{2}-4^{\prime}$ long.

M. INOdorA, Bartr. Smooth; leaves perennial, coriaceous, oblong, obtuse, very entire, tapering into a petiole, with the margins revolute; sterile aments oval or oblong, 
with the roundish bracts transversely ridged on the back; stamens about 10, monadelphous; fertile aments small, elongated in fruit; stigmas 2 or 4 ; scales of the ovary 5 ; nuts large, black, commonly solitary. Margins of pinebarien ponds and swamps. February-March.-A shrub or small tree, with whitish bark; leaves about $2^{\prime}$ long, sparingly dotted; nuts ovoid, $3^{\prime \prime}$ long.

\section{BIRCH FAMILY. Order, Betulacea.}

Trees or shrubs, with alternate simple straight-veined leaves, deciduous stipules, and monœcious amentaceous flowers, placed 2-3 together in the axil of a 3-lobed bract; stamens 4 ; filaments distinct; ovary 2-celled, with a single suspended anatropous ovule in each cell; stigmas 2, elongated; fruit a winged or angled 1-celled 1-seeded nut, forming, with the imbricated persistent bracts, a cone-like spike.

\section{BETULA, Tourn. BirCH.}

Sterile aments drooping; bracts 3 -flowered, 2-bracteolate, peltate; calyx scale-like; stamens short; anthers 1-celled; fertile aments oblong or cylindrical; bracts 3-flowered; calyx none; stigmas filiform; nut broadly winged; cotyledons oblong.-Trees or shrubs, with the outer bark often separable into thin papery sheets; leaves petioled, serrate; fruiting bracts membranaceous.

B. NigRA, L. (Black Birch.) Leaves rhombic-ovate, acute, doubly serrate, smooth above, hoary-tomentose beneath, like the short petioles and branchlets, becoming rusty or smoothish ; sterile aments long and drooping; the fertile ones oblong, short-peduncled, with the woolly bracts cleft into three linear-oblong nearly equal lobes. (B. rubra, Michx.) Banks of rivers. March.-A middle-sized tree, with reddish-brown bark, and long spreading branches. 


\section{ALNUS, Tourn. Alder.}

Sterile aments elongated, drooping; bracts peltate, 5-bracteolate, 1-3-flowered, calyx 4-parted or scale-like; stamens 4 ; anthers 2-celled; fertile aments short, erect; bracts fleshy, 2-flowered; calyx of four minute scales, adherent to the bracts; bracts of the fruiting aments woody, persistent; nut angled or winged.-Shrubs or small trees; leaves petioled, serrate, the stalked buds covered with a single scale; fertile aments racemed.

A. serrulata, Ait. Leaves obovate, obtuse or abruptly pointed, serrulate, commonly pubescent beneath, acute at the base, short-petioled; stipules oval, obtuse; fruiting aments ovoid, short-peduncled; fruit ovate, wingless. Banks of streams. January-March.—Shrub $3^{\circ}-12^{\circ}$ high ; leares $2^{\prime}-4^{\prime}$ long, thickish, and partly persistent at its southern limits; calyx of the sterile flowers 4-parted.

A. ViRIDIs, DC. Leaves oval, rounded at both ends, slightly oblique at the base, finely and sharply serrate, softly pubescent on the lower surface, or only on the veins and petiole; stipules ovate; calyx of the sterile flowers scale-like; fruiting aments ovoid, long-peduncled; fruit winged. April.-A low much-branched shrub; leaves $1^{\prime}-2^{\prime}$ long. Mountains.

\section{Willow FAMily. Order, Salicacez.}

Trees or shrubs, with soft wood, alternate simple stipulate leaves, and diœcious amentaceous flowers, destitute of calyx and corolla, each solitary in the axil of a simple bract; stamens 2-many; ovary 1-celled or imperfectly 2-celled, with numerous erect anatropous ovules in each cell; styles 2, very short, more or less united; stigmas 2-lobed; fruit a 2-valved many-seeded capsule; seeds minute, clothed with long silky hairs; albumen none; cotyledons elliptical, flattened; radicle pointing downward. 


\section{SALIX, Tourn. WILLOW.}

Bracts of the aments entire; flowers each with 1-2 small glands; stamens $2-6$, free, or their filaments cohering at the base; stigmas short, 2-lobed; leaves commonly narrow, short-petioled; stipules scale-like and deciduous, or leafy and persistent; buds covered with a single scale; aments mostly erect, appearing with or before the leaves.

Aments large cylindrical, on leafy peduncles or branchlets, appearing with the leaves; ovaries smooth and stalked.

S. NIGRA, Marshall. Leaves lanceolate, acute at each end, serrate, petioled, pubescent when young, becoming smoothish and green on both surfaces; stipules small and caducous, or sometimes lunate, toothed, and persistent; aments elongated, the fertile ones slender, loose-flowered; bracts deciduous; stamens $3-6$, hairy below ; capsule ovate, acuminate, pointed by the conspicuons style. (S. Houstoniana, Pursh.) Swamps and muddy banks of rivers. A shrub or small tree, with brittle branches; leaves 2 '-3' long, sometimes pubescent at maturity, like the branchlets; fertile aments $3^{\prime}-4^{\prime}$ long.

The Weeping Willow (S. Babylonica, Tourn.), and the Yellow Willow or Golden Osier (S. vitellina, Smith), are introduced species.

POPUlUS, Tourn. CotTonwood; Poplar; Aspen.

Bracts of the aments toothed or lobed; flowers from an oblique cup-shaped disk; stamens few or numerous, with the filaments free; stigmas elongated, 2-parted.-Trees; leaves ovate or roundish, on long and often laterally compressed petioles; buds covered with imbricated, often resinous-coated scales; aments slender, drooping, appearing before the leaves.

P. ANGUlata, Ait. Branches thick, smooth, and sharply 
angled; leaves large, smooth, deltoid-ovate, acute or slightly acuminate, truncate at the base, obtusely serrate with incurved teeth; the conspicuous veins and compressed petiole yellowish. Banks of rivers. March and April.-A large tree; leaves $6^{\prime}-8^{\prime}$ long, longer than the petiole.

\section{Sub-class II. Gymnospermæ.}

Oviles naked (not inclosed in an ovary), commonly supported by an open scale or leaf, and fertilized by the direct application of the pollen. Cotyledons often more than two.

\section{PINE FAMILY. Order, CoNifer止.}

Trees or shrubs, with branching stems, composed of glandular or disk-bearing woody tissue without ducts, resinous juice, linear or needle-shaped mostly persistent leaves, and monœcious or diœcious amentaceous flowers; calyx and corolla none; ovules orthotropous; fruit a cone or drupe; embryo in the axis of the albumen; cotyledons 2 or more.

\section{SYNOPSIS.}

SUb-ORder I. Abietineæ. Fertile flowers consisting of numerous bracted imbricated carpellary scales, bearing two collateral inverted ovules at their base, and forming a cone in fruit. Buds scaly.

Leaves 2-5 in a cluster, mostly elongated, sheathed at the base..............PINus.

Sub-order II. Cupressineæ. Fertile flowers consisting of few bractless mostly peltate carpellary scales, bearing one or several erect ovules at their base, becoming fleshy or indurated, and forming in fruit a drupe or cone. Buds naked.

Friit a drupe. Leaves minute, imbricated .....................Juniperers.

- a globular cone. with peltate scales. Leaves imbricated, persistent. . Cupressrs. 
Fruit a globular cone, with peltate scales. Leaves spreading on slender deciduous

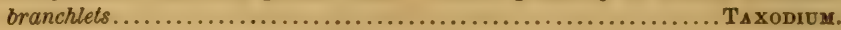

Fruit an oblong cone, with imbricated oblong scales. Leaves minute, imbricated on the flattened branches, persistent............................ TнбJA.

Sub-order III. Taxineæ. Fertile flower solitary, without a carpellary scale. Fruit a drupe. Buds scaly.

Drupe surrounded by a fleshy cup. Albumen homogeneous................ TAxus.

- naked. Albumen ruminated.......................... TоRREYA.

\section{PINUS, Tourn. Pine.}

Flowers monœcious; sterile aments spiked or clustered; stamens numerous on the axis, with very short filaments; anthers with a scale-like connective, 2-celled, opening lengthwise; fertile aments terminal, single or clustered; carpellury scales in the axils of deciduous bracts, each beuring two collateral inverted ovules at the base, indurated in fruit, and forming a cone, the apex commonly thickened, angular, and spiny; seeds nut-like, lodged in an excavation at the base of the scale, and furnished with a thin deciduous wing; embryo in the axis of oily albumen; cotyledons 3-12, linear.-Trees; leaves evergreen, needle-shaped, 2-5 in a cluster, their bases inclosed in a thin scarious sheath.

* Leaves two in each sheath.

P. Mrtrs, Michx. (Short-leaved Pine.) Leaves from a long sheath, crowded, very slender, concave on the inner face, dark green; cunes small, mostly solitary, oval or conical-oblong, the thin scales flattened at the apex, and armed with a weak incurved spine. (P. variabilis, Pursh.) Light clayey soil.-A large tree, with rough bark, and finegrained valuable wood; leaves $3{ }^{\prime}-5^{\prime}$ long, sometimes three in a sheath ; cones light-brown, about $1 \frac{1^{\prime}}{2}$ long, opening at maturity; wings of the seed reddish.

** Leaves three in each sheath.

P. Tæxi, L. (Loblolly or Old-field Pine.) Branches 
scaly; leaves from a long sheath, slender, elongated; cones large, solitary, oblong-conical, with the scales armed with a short and rigid straight spine. Light and mostly damp soil.-Commonly a lofty tree, with very thick and furrowed bark, and valuable but sparingly resinons wood, but in old fields low, with spreading branches ; leaves $6^{\prime}-10^{\prime}$ long, rarely 2 or 4 in a sheath, dark green ; cones $3^{\prime}-5^{\prime}$ long.

P. Australis, Michx. (Long-leaved or Yellow Pine.) Leaves very long, from long sheaths, crowded at the summit of the thick and very scaly branches; cones large, cylindrical or conical-oblong, the thick scales armed with a short recurved spine. (P. palustris, L., the prior but inappropriate name.) Sandy soil, constituting almost the entire growth of the Pine Barrens.-A lofty tree, with thinscaled bark, and very valuable resinous wood, dividing near the summit into few spreading branches; leaves $10^{\prime}-15^{\prime}$ long; leaf-bracts scarious, fimbriate ; cones $6^{\prime}-10^{\prime}$ long.

\section{JUNIPERUS, L. JUNIPER.}

Flowers mostly diœcious; aments lateral and terminal, small, few-flowered; stamens several ; anther-cells 3-6, inserted beneath the peltate scale, opening lengthwise; carpellary scales 3-6, 1-3-ovuled, partly united, fleshy, and forming in fruit a berry-like drupe containing 1-3 erect bony seeds ; cotyledons 2, oblong.-Trees, with subulate or scale-like persistent leaves.

J. Virginiana, L. (Red Cedar.) Branches terete; leaves opposite or by threes, minute, rhombic-ovate, closely imbricated, depressed on the back, those on young shoots subulate and spreading; drupes small, blue, 1-2-seeded. Dry, rocky, or even wet soil. March. - A small tree, with reddish, fine-grained, durable, and odorous wood, and spreading branches; leaves dark green. 


\section{TAXODIUM, Richard. Cypress; Bald Cypress.}

Flowers monœcious; sterile aments small, in a long drooping spiked panicle; scales peltate; anther-cells 2-5, opening lengthwise; fertile aments single or by pairs, with the peltate scales 2-ovuled; cone globular; scales very thick, angular, slender-stalked, separating at maturity; seeds 3 -angled, wingless; cotyledons 6-9, linear.-Trees, with distichous deciduous leaves.

T. DistichuM, Rich. Leaves alternate, opposite, or whorled, on very numerous short and slender deciduous branchlets, linear, acute, 2-ranked or imbricated. (Cupressus disticha, L.) Ponds and deep swamps. February and March.-A very large tree, with pale smoothish bark, light durable wood, and few fastigiate branches at the summit; leaves $4^{\prime \prime}-6^{\prime \prime}$ long; cones $\frac{3^{\prime}}{4}-1^{\prime}$ in diameter. Attached to the roots are hollow conical knobs called cypress-knees.

\section{THUJA, Tourn. ARbor Vite.}

Flowers monœcious; aments small, terminal; anthercells 4 , with a scale-like connective; carpellary scales imbricated in four rows, with two erect ovules at the base; cone oblong, the few scales imbricated, expanding at maturity, persistent; seed winged; cotyledons 2, oblong.Trees or shrubs, with scale-like imbricated persistent leaves.

T. occidentalis, L. (Arbor Vitar.) Branches flat, distichous; leaves ovate, obtuse, with a gland on the back, imbricated in four rows; cones oblong, nodding, with the outer scales oblong, obtuse; seeds broadly winged, emarginate at each end. Rocky banks on the mountains.-A small or middle-sized tree; cones $\frac{1^{\prime}}{2}$ long.

\section{CYCAS FAMILY. Order, CrCADACEE.}

Trees or shrubs, with simple trunks, increasing by a terminal bud, like the Palms, and composed of a large pith, 
mixed with woody bundles or plates, inclosed in a cylinder of woody fiber and spiral vessels; leaves pinnate, coiled in the bud, like Ferns; flowers diœcious, destitute of calyx and corolla; sterile flowers consisting of 1-celled anthers inserted under the peltate scales of a cone-like ament; fertile flowers consisting of naked ovules inserted under the scales like the sterile flowers, or on the margins of contracted leaves; seed nut-like; embryo in the axis of the albumen; radicle ending in a long spiral cord; cotyleclons 2.

\section{ZAMIA, L.}

Flowers in cone-like aments, with the peltate scales inserted on all sides of the common rachis; anthers numerous; ovules by pairs, pendnlous; seed roundish, drupelike.-Leaflets thickened at the base and articulated with the petioles, with numerous simple veins. 


\section{Class II.-Monocotyledonous or Endogenous Plants.}

Stems composed of cellular tissue and scattered bundles of woody fiber and vessels, destitute of proper pith, bark, or concentric laycrs, and increasing in diameter by the deposition of new fibrous buncles. Leaves mostly alternate, entire, and parallel-veined, commouly sheathing at the base, seldom falling off by an articulation. Floral envelopes usually by threes. Cotyledons single.

\section{PALM FAMILY. Order, Palmz.}

Chiefly trees, with a thick woody stem (caudex), growing by a terminal bud, pinnate or fan-shaped leaves, which are plaited in the bud, and a spadix of small perfect or polygamous flowers; sepals and petals 3 , free, or more or less united, persistent; stamens mostly 6, hypogynous or perigynous; anthers 2-celled, introrse; ovary 3-celled, commonly with a single erect orthotropous or anatropous orule in each cell; styles 3, mostly united; stigmas entire; fruit a drupe or berry; embryo cylindrical, placed in a cavity of the hard albumen, near the circumference of the seed. Stems erect or creeping; leaves long-petioled; spadix axillary.

\section{SABAL, Adans. Palmetto.}

Flowers perfect, sessile, bracted; calyx cup-shaped, 3-cleft; corolla 3 -petaled; stamens 6 , hypogynous, the filiments subulate, distinct; anther's cordate-orate, horizontal; ovary 3-celled; styles united, 3-angled; stignna capitate or obtuse; fruit a 1-seeded drupe; embryo dorsal; albumen homogeneous, horny. Stems simple or branched, erect or creeping; leaves fan-shaped, long-petioled, with the divi- 
sions 2-cleft at the apex and often with long thread-like filaments interposed; spadix long, branching, with sheathing spathes at the joints; flowers small, whitish, rigid; drupe oblong or ylobose; sheaths of the leaves commonly composed of dry interlaced fibers.

S. Palmetto, R. and S. (Cabbage Palmetto.) Stem erect, tall, simple, leafy at the summit; leaves large, cordate in outline, pinnatifid-fan-shaped, recurved at the summit, mostly shorter than the smooth concave petiole, the very numerous divisions deeply cleft, and with thread-like filaments at the sinuses; spadix smooth and spreading, commonly shorter than the leaves; petals slightly united at the base; style thick; drupe globose. (Chamærops Palmetto, Michx.) Sandy soil along the coast. June. Stem $20^{\circ}-40^{\circ}$ high ; leaves $5^{\circ}-8^{\circ}$ long, their bases long-persistent; drupe black, $4^{\prime \prime}-5^{\prime \prime}$ in diameter.

\section{CHAM FROPS, L.}

Flowers polygamous, bracted; calyx 3-cleft; corolla 3 -petaled; stamens 6-9, with the filaments connate at the base; anthers oblong; ovaries 3 , more or less united; stigmas acute, stigmatic on the inner face; drupes 1-3, oneseeded; embryo dorsal, in horny somewhat ruminated albumen.-Low palms, with fan-like, long-petioled leaves, destitute of thread-like filaments; sheaths soon dry and net-like; spadix dense-flowered, branching; spathe 2-4leaved; flowers yellowish; drupe globose or ovoid.

C. Hystrix, Fraser. (Blue Palmetto.) Stem short, proliferous; leaves circular in outline, with numerous 2-4toothed divisions, on triangular rough-edged petioles; sheaths persistent, composed of oblique fibers interworen with numerous erect strong spines; spadix small, shortpeduncled; spathes about 4, oblong, woolly, acutely 2-lipped; petals oroid; drupe ovoid. Low shady woods. June and July. Stem $2^{\circ}-3^{\circ}$ long, erect or creeping; leares 
somewhat glaucous, $3^{\circ}-4^{\circ}$ high; spadix $6^{\prime}-12^{\prime}$ long; partial spathes none; drupe $6^{\prime \prime}-9^{\prime \prime}$ long.

\section{2\%. ARUM FAMILY. Order, ARACEX.}

Acrid chiefly stemless herbs, from tuberous or creeping rootstocks, with entire or divided often veiny leaves, and perfect or monœcious flowers, borne on a spadix, and commonly inclosed in a spathe; calyx and corolla wanting, or the former with scale-like sepals; stamens short, hypogynous; anthers extrorse, commonly sunk in the thick connective; ovary 1-several-celled, with 1-several ovules in each cell; stigma sessile; fruit fleshy, indehiscent ; embryo straight; albumen mealy or fleshy, sometimes wanting.

\section{SYNOPSIS.}

* Calyx and corolla none; spadix inclosed in a spathe; flowers monocious.

+ Fertile flowers numerous; spadix free.

Spatha thin, convolute at the base, arching above. Spadix barren above. Leaves 3-seve-

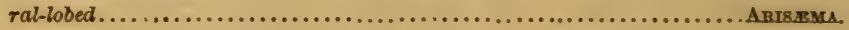

Spatha green, thick, convolute throughout, wavy on the margin. Spadix flowering

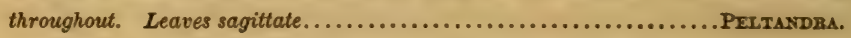
t+ Fertile flowers solitary; spadix adnate to the spatha.

Free-floating aquatics. Fertile flowers solitary..................... Prsm.

** Calyx manifest; flowers perfect.

+ Spadix naked.

Spadix attached to the side of the flattened leaf-like scape. ACOREs.

\section{ARISAMA, Mart. INDIAN TURNIP.}

Spathe convolute below, dilated and commonly arched above, withering; spadix covered below with monœcious flowers (the lower ones fertile), elongated and naked above; calyx and corolla none; stamens 4 in a whorl, very short; anther-cells 2-4, opening at the top; ovary 1-celled, with 5-6 erect orthotropous ovules; stigma sessile; fruit a 
1-few-seeded scarlet berry; embryo in the axis of mealy albumen; root tuberous; petioles of the commonly divided and veiny leaves elongated and sheathing the scape; fruitclusters naked.

A. Dracontium, Schott. (Dragon-root.) Leaf solitary, pedately 9-13-foliolate; lecuflets petioled, entire, lanceolate or oblong, acuminate; spathe tubular (green), concave and erect above, much shorter than the very slender spadix. (Arum Dracontium, L.) Rich woods. March and April. -Plant $1^{\circ}-1 \frac{1}{2}^{\circ}$ high ; berries numerous on the flat rachis, 1-3-seeded.

\section{PELTANDRA, Raf. Arrow Arum.}

Spathe elongated, fleshy, convolute throughout, wavy on the margins, curved at the apex, persistent at the base; spadix long, wholly covered by the monœcious flowers; calyx and corolla none; anther-cells 5-6, imbedded in the thick peltate connective, opening by a terminal pore; ovary 1-celled, with several orthotropous ovules; berry 1-3-seeded; seed gelatinous, without albumen; embryo large; plumule conspicuous, curved.-A fleshy stemless marsh herb, from a creeping rhizoma ; leaves sagittate, with the petiole sheathing the base of the thick scape; fruitclusters inclosed in the fleshy persistent base of the spathe.

P. VirginicA, Raf. Leaves several, oblong, acute, finely veined, and with 2-3 intramarginal nerves, the lobes obtuse; scapes shorter than the leaves recurved in fruit; spathe lanceolate, acute, longer than the cylindrical spadix, both early decaying above the fertile flowers; berries green, in a globose cluster, 1-seeded. (Arum Virginicum, L.) Marshes and wet places. April and May._Plant $1^{\circ}$ high ; spathes $2^{\prime}-4^{\prime}$ long.

\section{PISTIA, L.}

Spathe tubular at the base, spreading above, united with the spadix ; flowers few, monœcious, the upper ones stami- 
nate and supported by a cup-shaped involucre, the fertile solitary ; calyx and corolla none; anther-cells 3-8, opening transversely; ovary 1-celled, with several erect orthotropous ovules; style thick ; stigma disk-like ; berry few-manyseeded; embryo at the apex of the albumen.-Small freefloating aquatic herbs, with fibrous roots, and entire clustered spreading leaves, with the flowers in their axils.

P. SPAтHLlata, Michx. Leaves arranged in a circle, round-oborate, abruptly contracted into a short petiole, with the nerres projecting beneath (lamelliform); roots numerous, elongated; spathe short-peduncled, white. In still water. Leares 1 '-2' long.

\section{acorus, L. Calames ; Steet Flag.}

Scape flattened, leaf-like, with the lateral sessile spadix covered with the perfect flowers; spathe none; sepals and stamens 6 ; corolla nowe; filaments slender; anthers kidney-shaped, 1-celled, opening transrersely; ovary 2-3celled, with several orthotropous suspended orules in each cell ; stigma minute; fruit dry, gelatinous within, 1-fewseeded; embryo in the axis of the albumen.-Perennial herbs, from a creeping aromatic rhizoma ; leaves erect, long, flattened, 2-edged; scape leaf-like, elongated abore the spadix.

A. Calaurs, L. Wet places. April. Rhizoma rather slender, pungent; leaves $1^{\circ}-2^{\circ}$ high, linear-lanceolate; scape narrower than the leaves; spadix cylindrical, yellowish, $2^{\prime}-3^{\prime}$ long, spreading.

\section{DUCKWEED FAMILY. Order, LeMNACEx.}

Minute aquatic floating plants, with lenticular proliferous stems (fronds), and usually simple roots pendent from beneath; flowers monœcious, mostly from a marginal cleft of the stem ; spathe membranaceous, pitcher-shaped, bursting into two unequal lobes, soon vanishing, commonly.inclosing 
two sterile flowers, which are reduced to single slender filaments bearing a 2-celled anther, and a single sessile 1-celled ovary, which forms in fruit a 1-7-seeded utricle; embryo straight, in the axis of fleshy albumen.

\section{LEMNA, L. DECKWEED.}

Spathes marginal, 3-flowered; anthers opening transversely; stigma funnel-form; ovules erect from the base of the cell, anatropous or half-anatropous; stems increasing by lateral buds; roots terminating in a calyptre-like appendage. The flowers of these plants are seldom seen.

L. MINor, L. Stems pale, round-oborate, flattened, single or variously clustered; root single; ovule solitary, halfanatropous; seed horizontal. Pools, ditches, etc.; common near the coast. Stems $1^{\prime \prime}-2^{\prime \prime}$ long.

L. POLYRHIZA, L. Stems roundish or obovate, flat and pale above, convex and dark purple beneath, clustered; roots numerous, clustered; ovules 2 . Ponds; less common than the preceding. Stems $2^{\prime \prime}-4^{\prime \prime}$ long.

\section{CAT-TAIL FAMILY. Order, Typhaces.}

Simple-stemmed marsh herbs, with elongated strap-shaped nerved leaves, and monœcious flowers, on a globular or cylindrical spadix, destitute of floral envelopes, but enveloped in copious pappus-like hairs or scales; spathe bractlike or none; anthers single or 2-4 together, on long and slender filaments; ovary 1-celled, with a single suspended anatropous ovule; style slender; fruit nut-like; embryo straight in copious albumen; sterile spadix placed above the fertile, continuous or distant.

\section{TYPHA, Tourn. CAT-TAIL.}

Flowers densely crowded on a long cylindrical terminal spadix, enveloped in copious pappus-like hairs; the sterile 
ones sessile on the upper part of the spadix, the fertile on slender stalks; style filiform ; stigma lateral; embryo cylindrical, in the axis of fleshy albumen. Stems straight, from a thick rhizoma, clothed below with the sheathing bases of the elongated linear leaves; spathes bract-like and deciduous, or none.

T. LATifolia, L. Stem terete, jointed below; leaves nearly as long as the stem, erect, flat, reticulated and somewhat glaucous; sterile and fertile portions of the spadix contiguous, cylindrical. Margins of ponds and rivers. July and August. Stem $4^{\circ}-6^{\circ}$ high, scape-like above; leaves about $1^{\prime}$ wide; spadix about $1^{\circ}$ long. - $\mathrm{T}$. angustifolia, L., if found within our limits, may be known by narrower leaves which are channeled near the base, and by the interval which separates the sterile and fertile portions of the spadix.

\section{SPARGANIUM, L B BuR-REED.}

Flowers densely crowded in globular heads, surrounded by several scales like a calyx; the upper heads sterile, naked, the lower fertile and commonly bracted; ovary sessile, pointed by the short persistent style; stigma lateral; fruit nut-like; embryo cylindrical, in the axis of fleshy albumen.-Marsh or aquatic plants, with erect stems, and long strap-shaped sessile leaves, the lowest ones sheathing; heads of flowers scattered.

S. RAMosur, Huds.? Leaves flat, obtuse, the upper ones gradually shorter, concave and clasping at the base, the lower sheathing and elongated; heads 5-9, disposed in axillary and terminal interrupted spikes, the lowest one larger and pistillate, the others wholly staminate; scales wedge-shaped; stigma subulate, simple. (S. Americanum, El1.) Lagoons and ditches. July. Stem $2^{\circ}-3^{\circ}$ high; leaves as long as the stem, $8^{\prime \prime}-12^{\prime \prime}$ wide; heads of fertile flowers $8^{\prime \prime}-10^{\prime \prime}$ in diameter. 


\section{PONDWEED FAMILY. Order, NaIAdacee.}

Aquatic herbs, with slender jointed leafy immersed stems, and perfect monœcious or diœcious flowers, destitute of floral envelopes, or with a scale-like calyx; stamens 1-4; anthers 1-4-celled; ovary 1-celled, forming a 1-seeded achenium in fruit; stigmas 1-4; seed without albumen; embryo straight, curved, or coiled; leaves sheathing, or with sheathing stipules; flowers commonly inclosed in a spathe.

\section{SYNOPSIS.}

- Flovers moncecious or dicecious.

Stigma 2-4. Flowers naked. Leaves opposite or whorled................ NArAs. - 2. - inclosed in a spathe. Leaves alternate.............Zostren. _ single peltate. Ovaries 4 , from a cup-like involucre........ Z Z NNICHELLIA. ** Elowers perfect.

Fruit long-peduncled, umbellate. Calyx and corolla none...............RuPPIA. sessile, spiked. Calyx 4-leaved......................... Ротамовкто..

\section{NAIAS, L.}

Flowers monœcious or diœcious, axillary, sessile, destitute of calyx and corolla; sterile flower monandrous, inclosed in a spathe; anther 4-celled, opening at the apex, the filament lengthening; fertile flower naked, the sessile ovary pointed with the slender style; stigmas 2-4, subulate; ovule erect; achenium minute; embryo straight; radicle inferior. Stems filiform, forking; leaves opposite or whorled, linear, dilated into a short sheath at the base; flowers solitary, minute.

N. FLEXILIs, Rostk. Stem immersed $\left(1^{\circ}-2^{\circ}\right.$ long) ; leaves 3 in a whorl, narrow-linear, membranaceous, spreading, minutely denticulate on the margins, the lower ones often remote; stigmas $3-4$; achenium elliptical, acute, smooth, yellowish. (Caulinia flexilis, Willd.) In ponds and still water. July and August, Leaves about $1^{\prime}$ long. 
Var. ? FUSIformis. Stem $\left(6^{\prime}-12^{\prime}\right.$ long) almost capillary, very leafy throughout; leaves opposite, approximate, spreauing or recurved $\left(z^{\prime \prime}-t^{\prime \prime}\right.$ long); achenium narrowly spiudleshaped, finely reticulated, brownish. Brackish water along the coast. July and August.

\section{Zostera, L. Eel Grass.}

Flowers monœcious, naked, the sterile and fertile ones alternately arranged on the anterior edge of a flattened membranaceons spadix, and inclosed in the sheath-like base of the leaves; anthers oblong, 1-celled, filled with fine filaments instead of pollen-grains; ovary fixed near the apex, containing a single pendulous orthotropous ovule, and pointed with the subulate persistent style; stigmas 2 , capillary; utricle bursting irregularly; seeds striate ; cotyledons inflexed-curved, received in a longitudinal cleft of the embryo--Marine herbs, with creeping stems, and narrowly linear obtuse and elongated sheathing leaves.

Z. MaRina, L. Stem slender, terete, jointed; leaves thin and tender, faintly 3-5-nerved; flowers in two rows on the linear spadix. Deep salt-water cores. August and September.

\section{ZANNICHELLIA, L.}

Flowers monœcious, axillary; sterile flower consisting of a solitary naked filament bearing a 2-4-celled anther; fertile flower from the same axil, composed of $2-6$ sessile 1-celled ovaries, surrounded by a cup-shaped in rolucre, and pointed with the slender style; stigma obliquely peltate; ovule suspended, orthotropous; achenium oblong, stalkcd; embryo slender, coiled.-Submerged aquatic plants, with filiform branching stems, and very narrow and entire alternate leaves, with sheathing stipules.

Z. Palustris, L. Stems tufted, filiform, alternately branched; leaves narrowly linear, entire, acute, 1-nerved; 
anther 2-celled, on a long and slender filament; achenia 3-6 in a cluster, commonly raised on a short common peduncle, each stalked, linear-oblong, somewhat compressed and curved, smooth and wingless, about one-third longer than the persistent style. Fresh or brackish water. MayAugust. Stems $1^{\circ}-3^{\circ}$ long; leaves $1^{\prime}-2^{\prime}$ long.

\section{RUPPIA, L. Ditch Grass.}

Flowers perfect, naked, two or more on a slender spadix, inclosed in the spathe-like sheaths of the leaves, but soon long-exserted ; stamens 2 , closely sessile ; anther-cells large, distinct; ovaries 4, sessile, containing a single suspended campylotropous ovule; stigma peltate; achenium stalked, obliquely ovate; embryo pointed by the short plumule.Salt-water herbs, with filiform branching stems, and alternate linear or bristle-like sheathing leaves.

R. MARItima, L. In shallow water, along the coast. May-August. Stems immersed, $1^{\circ}-3^{\circ}$ long, mostly creeping at the base; leaves filiform, $1^{\prime}-3^{\prime}$ long, with dilated membranaceous sheaths; fruiting peduncles $1^{\prime}-4^{\prime}$ long; achenium pointed.

\section{POTAMOGETON, Touru. Pondweed.}

Flowers perfect, spiked; sepals 4, roundish, ralvate in the bud; stamens 4, opposite the sepals; filaments short; anthers 2-celled; ovaries 4, sessile; ovules ascending, camjylotropous; style short or none; stigma peltate; achenia 1-4, compressed; embryo curred or coiled.-Aquatic herbs, with immersed slender and jointed stems; leaves stipulate, alternate and opposite, either all immersed and commonly membranaceous, or the upper ones floating and more rigid; spikes peduncled, axillary and terminal.

* Leaves all immersed and alike.

+ Leaves lanceolate or cordate; stipules free, sheathing.

P. Perfoliatus, L. Stem terete, branching, very leafy; 
leaves ovate, cordate, clasping, obtuse, many-nerved, those at the branches and peduncles opposite; spikes lateral and terminal, oblong, densely many-flowered, on stout peduncles $2-3$ times as long as the leares; achenium obliquely obovate, rounded on the back, short-pointed. Fresh or brackish water. July-September. Stems $1^{\circ}-2^{\circ}$ long; leaves $6^{\prime \prime}-8^{\prime \prime}$ long.

P. Lucens, L.? Stems sparingly branched; leaves lanceolate, acute, contracted and sessile at the base, pellucid, 5-9-nerved, wavy on the margins; stipules (white) connate, rounded on the back; spikes cylindrical, many-flowered, on stout peduncles shorter than the leares; achenium (immature) oval, compressed, rounded on the back, shortpointed. Fresh water. August. Stems $2^{\circ}-3^{\circ}$ long; leares $2^{\prime}-3^{\prime}$ long, equaling the spikes.

** Leaves of two forms; the immersed ones thin and pellucid, the floating ones longpetioled and somewhat coriaceous.

P. FLUitans, Roth. Stem simple; leaves many-nerved, the floating ones varying from oblong-lanceolate to orate, acute at each end, or obtuse or cordate at the base, the others large, oblong, gradually or abruptly short-petioled, undulate; stipules connate and keeled on the back; peduncles stout, thickened upward; spikes long, cylindrical, dense-flowered; achenium smooth, 1-3-keeled on the back. Fresh-water ponds and streams. June-August. Leaves 2'-9' long.

P. Natans, L., probably occurs within our limits, but I have not seen specimens. It may be known by longerpetioled $\left(4^{\prime}-12^{\prime}\right)$ leaves, more slender peduncles, and rounded stipules and achenia.

P. heterophyllts, Schreber. Stem slender, branching; floating leaves small, thin, elliptical or oblong-linear, on filiform petioles; immersed leaves long, sessile, linear or lanceolate; stipules connate, 2-ribbed; peduncles thickened upward; spikes narrowly cylindrical; achenium smooth, 
slightly keeled on the back. Shallow ponds. July. Floating leaves $1^{\prime}-2^{\prime}$ long; immersed leaves $4^{\prime}-6^{\prime}$ long.

131. WATER-PLANTAIN FAMILY. Order, Alismacex.

Marsh herbs, usually with creeping runners or rootstocks, nerved and reticulated sheathing leaves, and scape-like stems, bearing the perfect or monœcious flowers in spikes or whorled racemes; sepals and petals 3, or the latter sometimes wanting; stamens few or numerous; anthers 2-celled; ovaries 3 or many, with 1-2 anatropous or campylotropous erect ovules; style short or none; achenium coriaceous, 1-2-seeded; embryo straight or curved, without albumen.

\section{SYNOPSIS.}

SUb-order I. Juncagineæ. Sepals and petals (when present) greenish. Ovule anatropous. Embryo straight.

Leaves rush-like. Flowers in spiked racemes...................TRIGLOcuIN.

Sub-order II. Alismeæ. Petals white, deciduous. Ovule campylotropous. Embryo curved or hooked.

Flowers perfect. Achenia whorled. Racemes compound.................. AuIsM. .SAgittaria.

\section{TRIGLOCHIN, L.}

Flowers perfect, in a spiked raceme; sepals 3 ; petals 3 , and greenish, like the sepals, or none; anthers 3-6, nearly sessile, oval; ovaries $3-6$, united around a central axis, from which they separate at maturity, 1-ovuled; stigmas plumose; embryo straight; leaves rush-like, fleshy, 2-ranked; flowers small, bractless.

T. Triandrum, Michx. Leaves erect, linear-subulate, semi-terete, dilated at the base and sheathing the base of the terete scape; flowers very numerous, on short pedicels; 
sepals oval, deciduous; petals none; anthers and oraries 3 ; fruit globose-triangular, pointless, when dry 3 winged by the compressed 3-ribbed achenia ; embryo oblong. Sult marshes along the coast. August-September. Scape and leares $\frac{1}{2}^{\circ}-1^{\circ}$ high.

\section{Alisma, L. Water Plantain.}

Flowers perfect in a whorled panicle; sepals 3 ; petals 3 , involute in the bud, deciduous; stamens $6-12$; ovaries numerous in a simple whorl; style short; achenium 1-seeded, 2-3-keeled on the back; roots fibrous; leares mostly oval or cordate, nerved, shorter than the scape; flowers white.

A. Plantago, L. Leaves long-petioled, orate or oblong, acute, rounded or cordate at the base, 3-9-nerred; panicle large, lax, the whorled branches and elongated filiform peclicels bracted at the base; achenia obtuse, 15-20 in a whorl. (A. trivialis, and A. parriflora, Pursh.) Ditches and margins of ponds. July and August. Leares $2^{\prime}-4^{\prime}$ long ; panicle $1^{\circ}-2^{\circ}$ long:

\section{ECHINODORUS, Richard.}

Flowers perfect, mostly in whorled racemes; sepals 3; petals 3 , imbricated in the bud, withering; stamens few or numerous; ovaries few or many, imbricated, forming ribbed achenia in fruit, usually beaked with the persistent style.-Herbs, with petioled nerved leaves; heads mostly bur-like.

E. Parvelts, Engelm. Small ; leaves lanceolate or spatulate, mostly acute, finely nerred and somewhat pinnatelyveined, commonly shorter than the single or clustered 1-6flowered scapes; flowers mostly clustered or umbelled, on long bracted pedicels which are recurred in fruit; stamens 9 ; achenia few, shorter than the ovate sepals, obovate, 
flattened at the sides, and surrounded with 5 prominent ribs, beakless. Margins of shallow ponds. July and August. Scapes $1^{\prime}-4^{\prime}$ high ; achenia black and shining.

E. Radicans, Engelm. Leaves large, long-petioled, orate, cordate or truncate at the base, obtuse, 7-9-ribbed; scape elongated, prostrate, rooting and proliferous; whorls several, remote; peclicels slender, spreading, or recurved; stamens about 20 ; style shorter than the ovary ; heads globose, longer than the many-nerved sepals; achenia very numerous, short-beaked, ribbed, and slightly denticulate on the back. (Alisma radicans, Nutt.) Swamps. July-September. Scape $2^{\circ}-4^{\circ}$ long; leaves $3^{\prime}-8^{\prime}$ long; flowers $8^{\prime \prime}-12^{\prime \prime}$ wide.

\section{SAGITTARIA, L. ARrow Grass.}

Flowers monœcious, in a whorled raceme, the upper ones sterile; sepals 3, persistent; petals 3 , imbricated in the bud, withering; stamens few or many; vvaries crowded in a globular head; achenia flat, membranaceous, winged. -Marsh or aquatic herbs, with scape-like stems, and variously-shaped nerved and reticulated sheathing leaves, which are often without a blade; flowers white, commonly 3 in a whorl from the axils of persistent bracts.

\section{* Filaments long and slender.}

S. fazcata, Pursh. Tall ; leaves erect, rigid, broadly lanceolate, acute at each end, pinnately nerved, on long and stout petioles; scape longer than the leares, often branching above; pedicels of the sterile flowers slender, longer than those of the fertile ones; bracts and sepals ovate, obtuse, granular-roughened; stamens numerous with hairy filiments ; achenia obliquely oborate, wing-keeled, strongly beaked. (S. lancifolia, Michx.) Lakes and rivers. JuneSeptember. Scape $2^{\circ}-5^{\circ}$ high ; leaves $1^{\circ}-2^{\circ}$ long; flowers $1^{\prime}-1 \frac{1}{2}^{\prime}$ wide. 
** Filaments short, thickened at the base.

S. SIMPlex, Pursh. Scape slender, commonly prostrate in fruit, simple or branched; leaves linear or lanceolate, acute at each end, 3-nerved, erect, the earliest mostly destitute of a blade; bracts membranaceous ; flowers small, all on long filiform pedicels ; stamens 10-12, hairy at the base; achenia obovate, wing-keeled, beakless. (S. graminea, Michx.) Shallow ponds in the pine-barrens. May-October. Scape $10^{\prime}-15^{\prime}$ high, usually longer the leaves.

\section{FROG'S-BI'T FAMILY. Order, HydrocharI-} DACEA.

Aquatic herbs, with monœcious or diœcious flowers, from a membranaceous spathe; sepals and petals 2 , or the latter wanting, distinct in the sterile flower, united into a tube in the fertile, and coherent with the 1-9-celled ovary; stamens $3-12$; ovules numerous, ascending, orthotropous; stigmas 3-9; fruit indehiscent, many-seeded; embryo straight, without albumen.

\section{SYNOPSIS.}

* Ovary 1-celled; stigmas 3.

Flowers dicecious. Spathe peduncled. Stamens 3. Leaves long, linear. VALIISNERIA. * Cells of the ovary and stigmas 6-9.

Flowers monacious. Stamens 6-9, monadelphous. Leaves cordate, petioled. .LIMnoвrux.

\section{VALLISNERIA, Micheli. TAPE Grass.}

Flowers diœcious; sterile flowers numerous, minute, crowded on a spadix, which is inclosed in an ovate 3-leaved short-stalked spathe; calyx 3-parted; corolla none; stamens 3; fertile flowers solitary, inclosed in a tubular spathe, and borne on a very long and mostly spiral scape; sepals and small petals 3 , united and coherent with the cylindrical 1-celled many-ovuled ovary; stigmas 3 , each 
2-lobed; seeds numerous, fixed to three parietal placentæ. - Aquatic herbs, with creeping stems, and elongated strapshaped leaves. Fertilization effected mostly as in Anacharis.

V. Spiralis, L. Slow-flowing streams and ponds. July-September. Plant creeping, proliferous; leaves strap-shaped, obtuse, 5-9-nerved, sharply serrulate, $1^{\circ}-3^{\circ}$ long, 6 "'-12" wide; scape of the sterile flowers $1^{\prime}-4^{\prime}$ long, of the fertile ones $2^{\circ}-5^{\circ}$ long; fruit $1^{\prime}-3^{\prime}$ loug, often curred. Perennial.

\section{BURMANNIA FAMILY. Order, BURMaNnI-} ACE正.

Small herbs, with filiform stems, scale-like leaves, and regular perfect flowers; sepals and petals united to form a tubular unequally 6 -cleft corolla-like perianth, with the tube coherent with the 1 or 3 -celled many-ovuled ovary; stamens 3 or 6 , inserted on the tube of the perianth; anther-cells separate, 2-lobed, opening crosswise; style slender; stigmas 3, dilated; placenta 3, central or parietal; capsule many-seeded; seeds minute, with a loose or reticulated testa.

\section{BURMANNIA, L.}

Tube of the perianth mostly 3-angled or 3 -winged, 6 -cleft, withering-persistent, the three interior lobes smaller; stamens 3 , very short, inserted opposite the interior lobes of the perianth ; ovary 3-celled, with three thick 2-lobed central placentæ; stigmas globose, dilated or 2-lobed; capsule splitting at the apex into 3 valves; radical leaves crowded and grass-like, or none; those of the stem minute, scalelike; flowers racemose or clustered.

\section{APTERIA, Nutt.}

Perianth terete, tubular-bell-shaped, 6-cleft, with the 3 
interior lobes smaller; stamens 3, very short, opposite the interior lobes of the perianth, the filaments flat and orbicular at the apex; anthers closely adhering to the globose stigmas; ovary 1-celled, with three 2-winged parietal placentæ; capsule oborate, splitting from the base into three valves, which remain attached to the apex of the persistent placentæ; seeds ovoid.-A small perennial herb, with subulate bract-like leaves, and scattered nodding flowers.

A. Setacea, Nutt. Deep shady woods, along the margins of swamps. September and October. Stem erect or ascending, purple, filiform, simple or branched, $2^{\prime}-8^{\prime}$ high ; leaves scattered; flowers few, distant, on nodding pedicels; perianth white, $5^{\prime \prime}$ long.

\section{ORCHIS FAMILY. Order, ORCHIDACE正.}

Perennial herbs, with simple stems, from thick fibrous or tuberous roots, nerved leaves, and irregular often showy flowers ; perianth 6-parted, united below with the 1-celled ovary, the three outer divisions (calyx) and commonly two of the inner ones (petals) similar in form, but the third posterior, or, by the twisting of the ovary, anterior one (labellum or lip), differs from the others in form, and often bears a spur or prominence at the base beneath; stamens 3 , united with the style into a column, one or (in Cypripedium) two only bearing a 2-celled anther; pollen-grains cohering in 2,4 , or 8 waxy or powdery masses (pollinia); capsule with three parietal placentæ, splitting at the sicles into three valves; seeds very numerous, minute, covered with a loose membranaceous testa; albumen none.-Plants mostly smooth and more or less succulent; leaves almost always alternate, sheathing and entire; stems leafy or scape-like; flowers bracted, solitary, spiked, or racemed, and remarkable for their various and singular forms. 


\section{SYNOPSIS.}

Anther solitary, fixed to the apex of the column like a lid, deciduous.

Tribe I. Malaxideæ. Pollen in smooth waxy masses, without stalks or connecting tissue. Roots tuberous.

* Stems leafy.

Lip cordate or sagittate. Column minutely 2-toothed at the apex..... Mrcrostruis. - entire. Culumn elongated, incurved, margined at the apex............ LIPARIs.

** Stems sheathed.

Spur of the lip shorl and adnate to the ovary. Root branching, toothed.

Corallorhiza.

Tribe II. Neottieæ. Anther attached to the back of the column, parallel with the stigma, the cells approximate. Pollen powdery.

* Pollen-masses 2.

Lip nearly entire, clasping the column, obtuse................... SPrranthes.

- 2-cleft. Stem with a pair of ovate opposite leaves...................ristrer.

\section{MICROSTYLIS, Nutt. Adder's Mouth.}

Sepals oblong, spreading; petals filiform; lip cordate or sagittate, entire or nearly so, sessile; column minute, 2-toothed at the apex; anther lid-like; pollen-masses 4, collateral, united by pairs at the apex.-Low herbs, from bulbous roots; stem 1-2-leaved, sheathed below; flowers racemed or spiked, minute, greenish.

M. ophiog lossoides, Nutt. Leaf solitary near the middle of the 5-angled stem, ovate, clasping; raceme short, with the unexpanded flowers crowded in a globular head, elongated in fruit; pedicels slender, much longer than the fluwers; lip auricled at the base, 3-toothed at the apex. (Malaxis ophioglossoides, Muhl.) Low shady woods. July and August. Stem $4^{\prime}-8^{\prime}$ high ; leaf $1^{\prime}-2^{\prime}$ long; flowers $\frac{1}{2}$ " wide. 


\section{LIPARIS, Richard. TWAYBLADE.}

Sepals spreading; petals linear or filiform, spreading or reflexed ; lip entire, flat, often with two tubercles above the base; column long, semi-terete, incurred, margined at the apex; pollen-masses 4, collibteral, united by pairs at the apex.-Low herbs, from bulbous roots; leaves 2 , sheathing the base of the scape-like stem; flowers racemed, greenish or purplish.

Li. Lilirfolia, Richard. Leaves elliptical, obtuse, sheathed at the base; scape 3-angled, 10-20-flowerer, longer than the leaves; sepals linear, whitish; petals filiform, reflexed, yellowish; lip large, wedge-oborate, concave, abruptly pointed, brownish purple. (Malaxis liliifolia, Swartz.) Low shady woods and banks. June and July. Scape $5^{\prime}-10^{\prime}$ high ; leaves $2^{\prime}-4^{\prime}$ long; lip $\frac{1^{\prime}}{2}$ long.

\section{CORALLORHIZA, Haller. Coral-Root.}

Sepals and petals alike, oblong or lanceolate, connirent; lip clasping the base of the straight 2 -edged column, spreading and concave above, 2-ridged near the base, spurless, or with the spur adnate to the ovary; anther lid-like; pollenmasses 4, incumbent.-Low dull-colored leafless herbs, with coral-like roots, sheathed stems, and racemose flowers.

C. odontorhizA, Nutt. Root pinuately branched and toothed; stem tumid at the base, slender above; sheaths 3, elongated; racemes 10-15-flowered; sepals and the rather shorter spotted petals erect, lanceolate, obtuse; lip entire, longer than the sepals, distinctly clawed, the spreading limb oval, concave, 3-nerred, with two tooth-like ridges in the throat, white spotted with purple; the margins crenulate below the middle and involute above; margins of the column thickened and incurred at the base; capsule oval, nodding. Shady woods. February and March. Stem $8^{\prime}-16^{\prime}$ high ; lip $4^{\prime \prime}$ long. 


\section{SPIRANTHES, Richard. 'TWISTED ORCHIS.}

Sepals and petals nearly equal, the lateral sepals diverging, dilated at the base, the upper one connivent with the petals; lip clawed, concave, furnished with two callosities near the base, clasping the short column below; stigma ovate, beaked; anther attached to the back of the column; pollen-masses 2, obovate, 2-cleft, fixed to a common gland of the stigma, powdery. Root composed of few clustered tubers or fleshy fibers; stem leafy at the base, sheathed abore; flower's small, white, in a regular 1-sided or spirally twisted spike. Near Houston.

\section{* Flowers on all sides of the untwisted spike.}

S. Cennua, Richard. Stem smooth below, the upper portion and thick crowded spike pubescent; lowest leaves long, linear-lanceolate, the others bract-like and sheathing; bracts ovate-lanceolate, acuminate, longer than the capsule; flowers recurved; lip longer than the sepals, contracted above the middle, wavy at the recurved obtuse apex, 2-toothed at the base. Grassy swamps and meadows. October. Stem $6^{\prime}-12^{\prime}$ high; leaves $4^{\prime}-8^{\prime}$ long; flowers yellowish white, $3^{\prime \prime}-4^{\prime \prime}$ long. All the coast prairies.

** Spikes twisted, bringing the flowers into a single straight or spiral row.

S. BREVIfolia, n. sp. Stem pubescent above; leaves all bract-like and sheathing, or the lowest expanding into a short $\left(1^{\prime}-2^{\prime}\right)$ lanceolate or linear early withering blade; flowers all on one side of the rachis or sparingly spiral, horizontal, pubescent; bracts ovate, acute, scarcely longer than the ovary; sepals and petals equal; lip oblong or elliptical, very entire, wavy on the margins, recurved at the acute or obtuse apex, and with two tooth-like prominences at the base. Open grassy swamps in the pine-barrens. October and November. Root of 3 fleshy fibers; stem $1^{\circ}$ high ; flowers 10-20, 3"-4" long, white. 
S. GRACILIS, Bigelow. Stem very slender, smooth throughout, scape-like; lowest leaves (early withering) lanceolate or elliptical, spreading; spike very slender; flowers minute, on one side of the rachis or sparingly spiral, smooth; bracts ovate-lanceolate, clasping, shorter than the capsule; lip finely crenulate on the margins, recurved and acute at the apex, with two raised ear-like prominences at the base; anther's 4-cleft. April and May. Stem sheathed, 6'-12' high; lowest leaves $1^{\prime}-2^{\prime}$ long; flowers $1^{\prime \prime}$ long. In the pine woods near Houston.

\section{LISTERA, R. Br.}

Sepals and petals alike, spreading or reflexed; lip longer than the sepals, 2-cleft; column short; stigma with a rounded beak; anther orate, attached to the dorsal summit of the column; pollen-masses 2, powdery. Stems low, from clustered fibers, bearing two opposite sessile leaves, and a loose raceme of small greenish flowers.

L. Australis, Lindl. Leaves ovate or oblong-ovate, closely sessile; raceme smoothish, few-several-flowered; bracts minute; lip linear, 3-4 times as long as the sepals, deeply 2-cleft, the divisions filiform; column very short. Wet shady woods. July. Stem $4^{\prime}-8^{\prime}$ high; leaves $\frac{1}{2}^{\prime}-1^{\prime}$ long.

\section{CANNA FAMILY. Order, CanNacex.}

Perennial herb.s, destitute of aroma, with alternate sheathing leaves, the rery numerous nerves parallel, and diverging from the strong midrib, and superior irregular monandrous flowers; sepals 3 ; corolla 6 -parted, the three exterior divisions alike, the three interior ones rery unequal and often variously imperfect; stamen and stigma mostly petal-like; anther 1-celled; ovary 1-3-celled, with 1-miny anatropous or campylotropous ovules; embryo straight or hooked, in hard albumen; rhizoma often tuberous, and abounding in starch. 


\section{THALIA, L.}

Calyx minute; corolla tubular, the three exterior divisions similar and equal, the interior unequal, the anterior one broad and hooded, the interior lateral one elongated and clawed, the exterior lateral one furnished with two bristles on one side, and partly adnate to the slender stamen on the other; style thick, spiral; stigma perforated, 2-lipped, the lower lip long and pendent; capsule utricular, 1-celled, 1-seeded; seed oroid, erect, campylotropous; embryo hooked, in hard albumen.-Stemless her's from fibrous roots; scape elongated; petioles terete. uilated and sheathing at the base; flower's in bracted panicled spikes, commonly two together, and included in a 2-valved spathe.

T. Dealbata, Roscoe. Plant duster orer with a minute white powder, otherwise smooth; leaves distichous, longpetioled, cordate-orate, acute; scape terete, reed-like; panicle erect, dense, smooth, the branches not longer than the lanceolate decidnous bracts at their base; spikes erect; valves of the spathe unequal, ovate, coriaceous; flowers small, purple. Ponds and marshes. June-September. Scape $3^{\circ}-5^{\circ}$ high ; leares $6^{\prime}-9^{\prime}$ long, on petioles $1^{\circ}-2^{\circ}$ long.

\section{AMARYLLiS FAMily. Order, Amaryllidacex.}

Chiefly stemless smooth and succulent herbs, with linear leaves, and smooth (not scurfy or woolly) often showy flowers; sepals and petals united to form a 6-parted corolla-like perianth, imbricated in the bud, the tube adnate to the 3 -celled ovary; stamens 6 ; anther' introrse; ovules anatropous, attached to the central placentæ; style single; fruit 1-3-celled, valrular or indehiscent; embryo straight in fleshy albumen, the radicle resting on the umbilicus. 


\section{SYNOPSIS.}

* Root bulbous.

Tube of the perianth elongated. Stamens connected with a cup-shaped crovon. Stig-

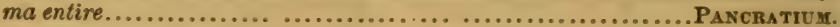

T'ube of the perianth elongated, crownless. Stigma entire............. Crixu.

** Root tuberous.

Capsule 3-valved. Flowers spiked. Leaves thick and fleshy............... A GAvE.

circumscissile. Flowers umbelled. Leaves grass-like.

HYPOXYs.

\section{PANCRATIUM, L.}

Perianth corolla-like, 6-parted, the narrow divisions spreading, the tube slender and elongated; stamens united below with a cup-shaped or funnel-shaped variously toothed crown, exserted; anthers versatile, linear; style elongated, declining; stigma entire; capsule membranaceous, 3 -celled; seeds often bulb-like; scape from a coated bulb, compressed or 2-edged, bearing the large and fragrant leafy-bracted flowers in a cluster at the apex; leaves strapshaped.

\$ PancRatrum. Tube of the perianth dilated and funnel-shaped at the apex; crovn almost wholly adnate to the tube, the border divided into six 2-cleft teeth, alternating with the stamens; capsule many-seeded, loculicidally 3-valved.

P. MaRitimum, L. Leaves glaucons, erect, longer than the slightly compressed many-flowered scape; divisions of the perianth linear-lanceolate, shorter than the slender $\left(3^{\prime}-4^{\prime}\right)$ tube, greenish without; stamens short. (P. Carolinianum, L.) July-September. Scape $1^{\circ}-1 \frac{1}{2}^{\circ}$ high. Marshes on the coast.

P. Coronarium, Leconte. Bulb without runners; leaves linear-strap-shaped, flat above, half-cylindrical near the base; scape solitary, green, 2-edged, 4-flowered; divisions of the perianth linear, spreading, white; crown large, funnel-shaped, with six truncate lobes at the stamens, and sereral fine teeth at the sinuses. Scape and leares $2^{\circ}$ long. Prairies of Gulf coast. 
P. occidentale, Leconte. Bulb without runners; leaves linear-strap-shaped, obtuse, concave, and, like the 2-edged, 6-flowered scape, glaucous; divisions of the perianth white, linear, spreading and recurved at the apex; crown funnelshaped, with six toothed lobes alternating with the filaments; capsule many-seeded. Stern and leaves $2^{\circ}$ long. Upland prairies and hills in Burleson County.

\section{CRINUM, L.}

Tube of the perianth crownless at the apex. Otherwise like Pancratium both in character and habit.

C. Americanum, L. Leaves strap-shaped, concave, obtuse, remotely denticulate, spreading; scape compressed, with rounded edges, 2-4-flowered; bracts lanceolate recurved; ovaries sessile, with a linear bractlet at the base of each; flower's large, fragrant; leaves of the perianth white, lanceolate, shorter than the green tube; filaments and style purple above; stigma truncate, entire; ovules 3 in each cell, erect ; capsule globose, membranaceous, indehiscent, 1-6-seeded, pointed with the long persistent tube of the perianth; seed large, corm-like; embryo oblong, in the axis of copious fleshy albumen; radicle inferior. MaySeptember. Scape $1^{\circ}-2^{\circ}$ high ; perianth $6^{\prime}-8^{\prime}$ long. On the banks of Buffalo Bayou.

\section{AGAVE, L.}

Perianth corolla-like, funnel-shaped, 6-parted, persistent; stamens exserted; anthers linear, versatile; style filiform, exserted ; stigma 3-angled or 3-lobed ; capsule coriaceous, 3-lobed, 3-celled, loculicidally 3-ralved, many-seeded; seeds flat, black and shining, attached to the central placentæ; scape bracted; leaves fleshy, spiny or cartilaginous on the margins; flowers in simple or panicled spikes, bracted. South-western Texas. 
A. Virgixica, L. Leaves lanceolate, thick and rigid, spine-pointed, denticulate on the margins; scape simple, smooth; flower's small, yellowish, scattered in a simple spike; perianth strongly nerred; filaments and style spotted. Sterile soil. July. Scape $3^{\circ}-5^{\circ}$ high; leares $66^{\prime}-12$ ' long; capsule globose, 3-lobed.

\section{HYPOXYS, L. Star Grass.}

Perianth 6-parted, persistent, the spreading divisions colored within; stamens short, unequal; anthers erect; ovary 3-celled, with the numerous amphitropous orules attached to the central placentæ in two rows; style short and thick; stigmas 3 ; capsule top-shaped, many-seeded, opening transversely near the summit, the upper portion, with the withered perianth, falling off like a lid; seeds globular, with a beak-like projection near the base; radicle inferior.-Low pubescent herbs, from a tuberons root, with grass-like leaves, and a naked scape, bearing the few yellow flowers in a terminal bracted umbel.

H. eRECTA, L. Hairy; leaves linear, channeled; scapes 1-4, filiform, 2-4-flowered; bracts subulate, much shorter than the slender unequal pedicels; dirisions of the perianth oblong, greenish and hairy without, rellow within; capsule 8-celled. Varies with the more rigid leares nearly smooth, the 2-3-flowered scape flattened, and the bristle-like bracts longer than the nearly sessile almost woolly perianth. Low ground. March and April. Scapes 2'-9' long; leares at length much louger than the scape; flowers $\mathrm{S}^{\prime \prime}$ wide.

H. JUXCEA, Smith. Sparingly hairy; leaves filiform ; scapes 1-3, filiform, 1-2-flowered; bracts tristle-like, shorter than the villous pedicels; dirisions of the periantho oblong. the three exterior ones greenish and hairy without; partitions of the capsule ranishing at maturity; seeds black, minutely pitted. (H. filifolia, Ell.) Low pine-har- 
rens. March and April. Scape $4^{\prime}-9^{\prime}$ long, at length procumbent ; flowers $9 "-12^{\prime \prime}$ wide.

\section{3\%. BLOODWORT FAMILY. Order, HжMono- RACE正。}

Perennial fibrous-rooted herbs, with leafy or scape-like stems, mostly equitant and sivord-shaped leaves, and regular woolly or scurfy flowers; perianth tubular, 6 -cleft, more or less cohering with the 3 -celled ovary ; stamens 3 or 6 ; anther's adnate, introrse, 2-celled; ovules mostly few, anatropous or amphitropous, attached to the central placentæ; styles 3, united, decidnous, or persistent and separating; stigma entire; capsule inclosed in the persistent perianth, loculicidally 3 -valved at the apex; embryo small, in hard albumen.

\section{PINE-APPLE FAMily. Oider, Bromeliacex.}

Chiefly scurfy epiphytes, with fibrous roots, rigid leaves, and regular conspicuously bracted mostly spiked flowers; perianth free, or more or less adnate to the 3 -celled ovary, 6 -parted, imbricated, the three outer divisions calyx-like; stamens 6 ; anther's 2-celled, introrse; ovules numerous, anatropous, erect or pendulous; placentce central; style single; stigmas 3 ; fruit berry-like, or 3-celled, 3-valved capsule; seeds stalked; embryo small, at the base of copious mealy albumen.

\section{TILLANDSIA, L. Long Moss; Air-plant.}

Sepals rigid; petals imbricated and tube-like below, spreading above; stamens filiform, hypogynous; ovary free; style slender; capsule linear or linear-oblong, cartilaginous, septicidally 3 -valved, each valve separating into 2 plates; seeds erect, club-shaped, pointed, raised on a long and hairy stalk; raclical leaves mostly crowded, imbricated; petals fugacious. 
* Stem rigid, erect; flowers spiked, blue.

+ Leaves broad at the base, gradually narrowed upward.

'T. Utriculata, Leconte. Leaves scurfy and glaucous, subulate and recurved at the summit, very much dilated, concare and imbricated at the base, shorter than the rigid mostly branching stem, the uppermost small and sheathing; flowers scattered; sepals oblong-linear, obtuse, longer than the oblong pubescent membranaceous bracts, much shorter than the capsule; petals pale blue, twice as long as the sepals, slightly spreading at the apex; stamens exserted. June and July. Stem $2^{\circ}-3^{\circ}$ high. The dilated and imbricated bases of the leares form a kind of cup which commonly contains a considerable quantity of water.

* Leaves linear or filiform, from an abruptly dilated base.

** Stems filiform, pendent; flowers solitary, green.

T. CsNeordes, L. (Long Moss.) Scurfy and hoary; stems $\left(1^{\circ}-2^{\circ}\right.$ long) branching; leaves 2 -ranked, linear-awlshaped, recurred; flowers sessile at the summit of the branches, small ; sepals longer than the bracts, half as long as the linear recurved green petals. Humid situations. June-September.

\section{IRIS FAMILY. Order, IRIDACEx.}

Herbs, with linear or sword-shaped equitant nerved leaves, and fugacious often showy flowers from a 2-leared spathe; perianth 6-parted, the dirisions spreading and equal, or the inner ones smaller, convolute in the bud; stamens 3 , distinct or united; anthers extrorse ; ovary adnate to the tube of the perianth, 3 -celled; the numerous anatropous ovules fixed to the central placentæ; style single; stigmas 3 ; capsule loculicidally 3 -ralred; embryo in the axis of fleshy albumen. 


\section{SYNOPSIS.}

Stigmas petal-like, covering the stamens. Capsule angular.................. Inrs Stigmas filiform. Capsule globular. Stem flat................. SisXrinchrom. Stigmas filiform, 2-parted. Stem terete..................................

\section{IRIS, L. Blue FlaG ; Flower-de-Luce.}

Perianth corolla-like, 6-parted, the exterior divisions recurved, and often crested or bearded within, the interior mostly smaller and erect; stamens 3, opposite the outer divisions of the perianth, concealed by the dilated petallike 2-lipped spreading stigmas; style 3 -angled; capsule $3-6$-angled; seed numerous, flattened, packed in 2 rows in the cells.-Perennial herbs, with creeping or tuberous rootstocks, simple or branched stems, linear or sword-shaped leaves, and showy flowers from a scarious spathe.

* Stems tall, leafy; divisions of the perianth unequal.

I. VERSICOLOR, L. Stem nearly terete, simple or branched ; leaves sword-shaped ; flowers terminal, single or spiked, crestless; perianth pale blue, variegated with white, yellow, and purple, the inflated tube shorter than the obtusely 3 -angled ovary; stigmas 2-toothed at the base, with the lips entire, or slightly crenate ; capsule oblong, obtusely 3 -angled. Wet places. April and May. Stem $1 \frac{1}{2}^{\circ}-2^{\circ}$ high ; lowest leares $1 \frac{1}{2}^{\circ}-2^{\circ}$ long, $1^{\prime}-1 \frac{1}{2}^{\prime}$ wide; perianth $2^{\prime}$ long.

\section{SISYRINCHIUM, L. BLUE-Eyed Grass.}

Perianth corolla-like, 6-parted, the divisions nearly equal, spreading; stamens 3 , monadelphous; anthers sagittate; style short; stigmas 3 , simple, filiform and inrolute; capsule and seeds roundish.-Grass-like herbs, with fibrous roots, and scape-like, 2-edged stems; flowers small, in an umbellate cluster, successively dereloped from a rigid 2-leaved spathe.

S. Bermediana, L. Leaves linear, erect; stem simple or sparingly branched, naked or 1-2-leaved, more or less 
broadly 2-winged; leaves of the spathe equal and shorter than the flowers, or the lower one much longer than the flowers ; perianth blue, yellow in the center; the divisions notched and bristle-awned at the apex. (S. mucronatum, Michx.) Prairies. July and August. Stem 6'-18' high; leaves mostly shorter than the stem; flowers 4-6 in a spathe, $\frac{t^{\prime}}{2}$ wide, opening in the evening.

\section{NEMASTYLIS, Nutt.}

Perianth 6-parted, the divisions nearly equal and spreading ; stamens 3, distinct, with the subulate filaments much shorter than the elongated linear anthers; style short, 3-lobed, with the lobes 2-parted, each division produced into filiform radiating stigmas; capsule oblong, truncated. - Herbs, with coated bulbous roots, linear plicate leaves, and very fugacious flowers from a 2-leaved spathe.

N. calestina, Nutt. Bulb small, roundish; radical leaves few, elongated, sheathing, those of the stem diminishing upward, the uppermost bract-like; flowers mostly solitary, terminal ; divisions of the perianth oblong-obovate; capsule obtusely 3-angled; seeds angular, brown. (Ixia cœlestina, Bartram.) Pine-barrens. May and June. Stem $1 \frac{1}{2}^{\circ}-2^{\circ}$ high ; flowers bright blue.

N. Gemirfora. Flower's on pedicels shorter than the spalhe, the sepals 1 ' long, obovate-spatulate, bluish purple, the azure petrils about half as large. A handsome flower, $15^{\prime}-200^{\prime}$ high; leaves of the same length, $3^{\prime \prime}$ to $5^{\prime \prime}$ wide, tapering at each end. Woods below Houston.

N. Acuta. Head-waters of the Trinity.-Marcy.

\section{YAII FAMILY. Order, Dioscoreacee.}

Twining lierbs, with tuberous roots, ribbed and reticulated leaves, and small regular diœcious flowers, in axillary spikes or panicles; perianth 6-parted, the tube (in the fer- 
tile flower) adherent to the 3-celled ovary; stamens 6 ; anther's 2.celled, introrse; ovules anatropous, 1-2 in each cell; styles 3, more or less unied below; fruit mostly capsular, 3-6-seeded ; embryo minute, in hard albumen.

\section{DIOSCOREA, Plum. YaM.}

Tube of the perianth 3-winged; stamens inserted at the base of the limb; capsule 6-seeded, membranaceous, 3 -winged, opening septicidally through the wings; seeds flat, broadly winged; leaves petioled, mostly cordate and entire; petioles tumid at the base.

D. villosi. L. Stem smooth $\left(10^{\circ}-15^{\circ}\right.$ long $)$; leaves alternate, opposite, or whorled, broadly cordate, acuminate, 7-9-nerved, smooth, or pubescent beneath, mostly longer than the slender petiole; flowers very small, whitish, the sterile ones in scattered clusters on the very slender branches of the axillary panicles, the fertile in a simple spike; stigmas notched at the apex; capsule oral or obovate, strongly 3 -winged, nodding. (D. quaternata, Walt.) Margins of swamps. July.

\section{SMILAX FAMILY. Order, SMilace.s.}

Herbs or climbing shrubs, not essentially distinct from the Lily Family, but with ribbed and veiny reticulated leaves, and separate styles or stigmas; leaves not sheathing, often bearing tendrils; fruit baccate.

\section{Sub-order I. Eusmilaceæ. (Smilax Family.)} Flowers diœcious, in axillary and umbel-like clusters. Anthers 1-celled. Stigmas 1-3, sessile or nearly so. Ovules 1-2 in each rell of the ovary, orthotropons, suspended.'Tendril-beating vines. Flower's small. Leares alternate. 
SUb-ORDER II. Trilliaceæ. (T'rillium Family.) Flowers perfect, terminal. Anther's 2-celled. Styles or stigmas 3. Ovules several in each cell of the ovary, anatropous, horizontal. - Erect herbs. Leaves whorled.

Exterior leaves of the perianth calyx-like, persistent. Stem 1-flowered. Leaves 3 in

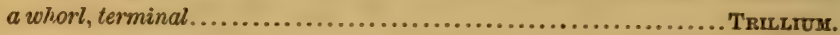

Leaves of the perianth alike, deciduous. Stem few-flowered. Leaves 3-7 in a whorl, lateral and terminal.

MEDEOLA.

\section{SMILAX, Tourn. China Brier.}

Flowers diøcious; perianth bell-shaped, 6-leaved, the leaves nearly equal and alike, deciduous; stamens 6, inserted on the base of the perianth; anthers erect, 1-celled; ovary free from the perianth, 1-3-celled, with a single orthotropous pendulous ovule in each cell; stigmas 1-3 (mostly 3), sessile or nearly so, slender, spreading, or recurved; berry 1-3-celled, 1-3-seeded; sceds globular or angled; embryo minute, in horny albumen.-Woody and commonly thorny or prickly vines, climbing by means of a pair of tendrils attached to the petioles; leaves alternate, ribbed, and reticulate-veined, mostly smooth and shining; flowers small, greenish, in stalked axillary clusters.

* Peduncles not longer than the petioles.

+ Berries red.

S. Walteri, Pursh. Stem low, armed with a few scattered prickles near the base, otherwise unarmed; branches obscurely 4-angled; leaves decidnous, membranaceous, varying from oblong-lanceolate to oval, mucronate, acute, rounded or rarely slightly cordate at the base, 5-ribbed; peduncles flattened, as long as the petioles and pedicels; perianth rather large ( $3^{\prime \prime}$ long), brownish; stigmas 3 ; berry (acuminate, Walt.) globular, 3 -seeded. (S. caduca, Ell.) Pine-barren ponds and swamps. March and April. 
Rhizoma creeping; stem seldom more than $6^{\circ}$ long; leaves $2^{\prime}-4^{\prime}$ long.

\section{†† Berries black.}

S. auriculata, Walt. Stem commonly low and straggling, slender, armed with short prickles; branches flexuous, 4-angled; leaves evergreen, rigid, small, strongly 3-ribbed, varying from lanceolate to ovate, entire or hastate--3-lobed, acute at each end; peduncles shorter than the pedicels, many-flowered; stigmas 2-3; berry small, globular 2-3seeded. (S. ovata, Pursh? Ell.) Dry sand-ridges along the coast. May and June. Stem trailing, or covering small bushes; leaves $1^{\prime}-2^{\prime}$ long, strongly reticulated; flowers small, very fragrant.

S. Rotundifolia, L. Stem climbing high, armed with scattered prickles; branchlets 4-angled; leaves thin, ovate or round-ovate, entire, abruptly pointed, mostly rounded or slightly cordate at the base; peduncles few-flowered, rather longer than the pedicels, flattened; berry globular, 3-seeded, blue-black. (S. caduca, L.; S. quadrangularis, Muhl.) Swamps. June. Plant yellowish green; leaves $2^{\prime}-4^{\prime}$ long.

\section{COPROSMANTHUS, Torr.}

Cells of the ovary 2-ovuled; stems herbaceous, unarmed; peduncles and petioles elongated; berry blue-black. Otherwise like Smilax.

C. HerbaCeus, Kunth. Stem erect $\left(1^{\circ}-3^{\circ}\right.$ high $)$, mostly simple, leafy above; leaves few, oblong or oval, mucronate, pubescent, 5-nerved, the upper ones whorled, the lower bract-like; peduncles few $\left(3^{\prime}-4^{\prime}\right.$ long), below the leaves; berry 2-3-seeded. (Smilax herbacea, L.) Dry fertile soil. June. Flowers fetid.

C. PEDUNCUlaris, Kunth. Stems curving or climbing $\left(3^{\circ}-5^{\circ}\right.$ long), branched, leafy; leaves alternate, round-cordate, acuminate, smooth; peduncles numerous, axillary (4'-6'long); berry 6 -seeded. (Smilax peduncularis, Muhl.) June, Flowers fetid. 


\section{'TRILLIUM, L.}

F'lowers perfect; perianth 6-leared, the three exterior leaves calyx-like, persistent, the interior withering; stamens 6 , inserted at the base of the perianth; filaments short; anthers adnate, linear, 2-celled; ovary 6-ribbed, 3-celled, with numerous anatropous horizontal orules in each cell; styles or stigmas 3, slender, stigmatic within, recurred, persistent; fruit a roundish 6 -sided many-seeded purple herry.-Low perennial herbs, with tuberous rootstocks, and simple stems, which are sheathed at the base, and terminated with a whorl of three broad leaves and a single sessile or peduncled showy flower.

\section{* Flowers on erect or declining peduncle.}

T. erythrocarpuir, Michx. Stem solitary; leaves ovate, lung-acuminate, rounded at the base, short-petioled; peduncle $\left(1^{\prime}-2^{\prime}\right.$ long) erect, longer than the widely-spreacing flower; petals oblong, acutish, wary, much longer than the lanceolate sepals, white, striped with purple at the base; stigmas slender, longer than the anthers; berry red. Rich shady woods. April and May. Stem $1^{\circ}$ high; leares 3 '-5' long; flowers $9^{\prime \prime}-12^{\prime \prime}$ long.

T. Texanum, Buckley. Leaves ovate-oblong, obtuse, sessile, smooth above, subpubescent beneath, longer than the peduncle; petals white, orate-lanceolate, acute, nearly equal or shorter than the sepals; sepals oblong-orate, oltuse.Plant six to nine inches high; leaves $1 \frac{1}{2}-2$ inches long, 5 lines wide; peduncle 6 lines long; sepals 6 lines long and 2 lines wide. Such is the size of a medium specimen. Flowers in March. Banks of streams and low grounds, Panola County, Texas.

\section{MEDEOLA, Gron.}

Flowers perfect; leaves of the perianth 6 , similar, deciduous; stamens 6, erect, hypogynous; anthers linear- 
oblong, fixed near the base, introrse ; ovary globose, 3-cell(d, with six anatropous ovules in each cell; styles 3 , slender, recurved, stigmatic within; berry globose.

M. Virginica, L. Rhizoma horizontal, tuberons; stem simple, slender, clothed with loose deciduons wool, bracted below, bearing above the middle a whorl of 6-8 oblonglanceolate acute leaves, and at the summit a smaller whorl of 3-4 ovate leaves, which surround the $2-8$ small greenish nodding flowers; styles red. Shady banks. June. Stem $2^{\circ}$ high.

\section{ROXBURGHIA FAMILY. Order, RoxbURghiacex.}

Herbs or twining shrubs, with petioled parallel-nerved reticulated leaves, and perfect axillary racemose flowers; perianth 4-leaved or 4-parted; stamens 4, hypogynous; anthers 2-celled, introrse; ovary free, or united with the base of the perianth, 1-celled; stigma sessile; ovules few or numerous, anatropous; placenta parietal; capsule 2-valved; seeds fixed to hairy or fibrillous cords, erect or pendulous; embryo minute or slender, in fleshy albumen.

\section{CROOMIA, Torr.}

Perianth deeply 4-parted, persistent, the spreading nerveless oval divisions imbricated in the bud; filaments separate, thick, erect, inserted on the base of the periunth opposite its lobes; anthers short, oblique, with the connective minute or wanting; ovary globose-orate, sessile; stigma 2-lobed; ovules 4-6; fruit follicular, beak-pointed, at length 2-ralved; seeds 1-4, obovate, suspended from the apex of the nerve-like at length free placenta, nearly corfred by the fibers of the cord; cmbryo minute, oborateA low perennial herb, from a slender creeping rhizoma; stem simple, sheathed at the base, leafy at the summit; leaves 4-6, alternate, oblong-cordate, 5-9-ribbed; peduncles 
few-flowered; flowers small, greenish, on jointed nodding pedicels, which are thickened upward.

\section{LILY FAMILY. Order, Liliaces.}

Chiefly herbs, with sessile or sheathing parallel-nerved leaves, and perfect flowers ; perianth corolla-like, 6- (rarely 4) -leaved or lobed, free from the 2-3-celled ovary; stamens 6 (rarely 4), hypogynous or perigynous; anthers introrse; styles united; stigmas 3, distinct or united; fruit a capsule or berry, few-many-seeded; seeds anatropous or amphitropous; embryo small, in fleshy or hard albumen.

\section{SYNOPSIS.}

Tribe I. Asparageæ. Fruit a berry. Divisions of the perianth more or less united. Leaves broad.

Flowers in terminal raceme. Perianth spreading. Stems leafy........ Sumscnva.

Tribe II. Asphodeleæ. Fruit a capsule. Divisions of the perianth united at the base. Stems scape-like. Leaves linear, rarely lanceolate.

* Root a coated bulb.

Fhowers umbelled, from a scarious spathe. Seeds smooth and black........ Alurux. in racemes, blue or purple. Seeds roundish black................ Scmu. ** Palm-like arborescent plants; seeds black.

Stigma 3 , nearly sessile. Capsule dry or pulpy. Leaves spiny-pointed...... Yuccs.

\section{SMILACINA, Desf. Solomon's Seal.}

Perianth 4 or 6 parted, spreading, deciduous; stamens 4 or 6 , inserted on the base of the perianth ; anthers ovate; ovary 2-3-celled, with two orules in each cell ; style short and thick; stigma obscurely 3-lobed; berry globular, 1-2-seeded. Stems simple, erect, leafy; flowers small, white, in a terminal raceme or panicle. 
\$ SMulacina. Divisions of the perianth and stamens 6 ; ovary 3 celled.

S. RAcejrosa, Desf. Pubescent; rhizoma thick; stem flexuons, curving and leafy ahove; leaves numerous, 2-ranked, oblong, acuminate, nearly sessile, strongly ribbed; flowers numerous, in a close raceme or panicle; berry red, spotted. Rich soil. June and July. Stem $1^{\circ}-2^{\circ}$ high ; leaves $3^{\prime}-5^{\prime}$ long.

\section{ALLIUM, L. ONION.}

Perianth 6-parted, spreading, persistent; stamens 6, inserted on the base of the perianth; filaments subulate, the interior ones more or less dilated at the base; ovary 3-celled; style filiform ; stigma entire ; capsule loculicidally 3 -valved; seeds anatropous or campylotropous, single or few in each cell, angled, black.-Strong-scented stemless herbs, with bulbous roots, and a naked scape, ending in an umbel of small flowers, from a 2-3-leaved spathe; flowers sometimes changed into bulblets.

* Ovules 2 in each cell.

A. cernutu, Roth. Leaves linear, channeled; scape angled; umbel many-flowered, nodding; leaves of the perianth acute; stamens exserted; ovary 6 -toothed. July. Scape $1^{\circ}-1 \frac{1}{2}^{\circ}$ high ; flowers rose-color, on slender pedicels.

A. Canadense, Kalm. Leaves narrowly linear, concave ; scape terete ; umbel erect, bearing a cluster of bulblets, intermingled with a few stalked rose-colored flowers; spathe 1-2-leaved; lerves of the perianth obtuse, as long as the stamens; ovary 6 -toothed. June. Scape $1^{\circ}$ high; outer coats of the bulb white and scarious.

A. mutabile, Michx. Leaves very narrow, concave; scape terete; umbel erect, many-flowered; spathe 3 leared; leaves of the perianth acute, as long as the stamens. white changing to rose-color. Dry sandy soil. May and June. 
Scape $1^{\circ}$ high ; outer coats of the bulb composed of a network of fine fibers.

** Ocules several in each cell.

A. striatur, Jack. Leaves linear, concare; umbel erect, 3-10-flowered; spathe 2-leaved; perianth longer than the stamens, white, the exterior leares green on the keel. Low pine-barrens. March and April. Scape 6'-12' high ; pedicels $1^{\prime}-2$ ' long; flowers 5" long; leaves streaked on the back.

\section{SCILLA, L. Squill.}

Perianth 6-parted, petals and sepals similar, spreading blue or purple; filaments 6 , subulate or filiform, smooth, hypogynous; style filiform-clavellate; capsule free, 3-celled, 3 -ralved, obtusely 3 -angled; cells with one or sereral roundish black seeds; bulb coated, bearing several linear leaves, and a scape with a raceme.

S. ESCUlenta. (Quamash.) Leaves linear, flaccid and recurved, tapering at both ends, shorter than the scape; bracts solitary, subulate, scarious, longer than the pedicels, about the length of the flower; filament filiform; stigma 3-toothed. Bulb nutritious, about 1' in diameter, resembling a small onion. Scape $1^{\circ}-2^{\circ}$ high; leaves as long, grass-like; raceme $2^{\prime}-3^{\prime}$ long. Head-waters of Trinity River.-Torrey.

\section{YUCCA, L. Spanish Bayonet.}

Perianth cup-shaped, corolla-like, 6-leaved; sepals and petals nearly alike, late-deciduous; stamens 6 , with thick granular club-shaped filaments; anthers small, oval; ovary 3-celled, 3-sided, grooved at the angles ; stigmas 3, nearly sessile, oblong, concave, 2-cleft; ovules numerous, in two rows, the rows separated by a false partition ; capsule oblong, 6-celled, pulpy and indehiscent, or dry and loculi- 
cidally 3-valved at the apex; seeds numerous, flat, horizontal, smooth and black.-Plants, with thick palm-like leafy stems (caudex), numerous rigid and spine-pointed leaves, and white showy panicled flowers.

* Slem short; capsule dry, 3-ralved.

Y. filanentosa, L. (Bear Grass.) Stem short and leafy; leaves rather rigid, spreading or recurved, varying from linear to broad-lanceolate, green or glancous, with thread-like filaments on the margins; scape elongated, branching and pubescent above; ienes of the perianth orate-lanceolate, white tinged with yellow or purple; capsule with 3 rounded angles, loculicidal at the apex, and at length separating at the inflexed sutures into three 2-celled carpels. (Y. puberula and Y. glaucescens, Haw.) Light or sandy soil. June. Stem rarely more than a foot above the ground; leares $1^{\circ}-2^{\circ}$ long; scape $4^{\circ}-6^{\circ}$ high.

** Stem tall ; capsule pulpy, 6-angled, indehiscent.

Y. Aloifolia, L. Stem mostly branching, leafy above; leaves linear-lanceolate, very rigid, strongly spine-pointed, rery rough on the margins, the lower ones reflexed; panicle short, smooth, densely flowered, nearly sessile; divisions of the perianth orate-lanceolate, white tinged with purple. (Y. Draconis, L. ; Y. serrulata, Haw.) Sands along the coast. May and June. Stem $4^{\circ}-8^{\circ}$ high; leaves and panicle $1^{\circ}-1 \frac{1}{2}^{\circ}$ long.

Y. LoNGifolia, Buckley. Stem erect, 8-15 feet high; leaves smooth, ensiform-lanceolate, rigid, sharply acuminate, crowded on the stem, lower ones reflexed often when dead with their points in the ground; panicles rery large, terminal; flowers campanulate; sepals orate-acute; bracts orate-lancerlate, acute; margin membranaceous; capsule oblong, cylindrical, obtuse at summit and base. Leaves

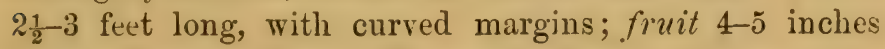
long. Western Texas. Flowers in March. Ornamental. 


\section{COLChiCUM FAMily. Order, Melanthacee.}

Perennial herbs, with parallel-nerved leaces, and regular flowers; perianth of 6 nearly equal divisions, free from or coherent with the base of the 3-celled ovary; stamens 6 , inserted on the base of the perianth ; anthers extrorse (except in Tofieldia); styles 3 , distinct or more or less united; fruit a capsule or berry; seeds anatropous; embryo minute in copious albumen.

\section{SYNOPSIS.}

Sub-order. Melanthieæ. (The Colchicus FasILY.) Perianth spreading, the divisions mostly distinct, often clawed, withering-persistent. Styles separate. Fruit a 3-celled capsule. Stems leafy at the base, simple or branched. Flowers in racemes or panicles, sometimes polygamous or diœcious.

Stamens 6. Anthers erect. Bracts short....................... ToriELdis.

\section{TOFIELDIA, Hudson.}

Flowers perfect; leaves of the perianth spreading, sessile, oblong or oborate; filaments subulate; anthers innate or introrse, 2-celled; styles subulate; stigmas terminal ; capsule 3-angled, septicidally 3-partible, many-seederl; seecls oblong. Stems simple, scape-like, from creeping rootstocks; leaves linear, 2-edged, equitant; flowers small, whitish, in spikes or racemes; pedicels commonly minutely 3-bracted under the flower.

\$1. TOFIELdia proper. Racemes simple, the flocers successively open from the brise uproard (centripetal); anthers introrse; seeds without appendages. Smooth herbs.

T. GLABRA, Nutt. Stem leafy at the base, and sparingly above; leaves linear; racemes densely flowered; stamens slightly exserted; styles very short. (T. glaberrima, Macbride.) Low pine-barrens. October. Stem $1^{\circ}-2^{\circ}$ high; raceme $2^{\prime}-4^{\prime}$ long; flowers white. 
82. Tиintra. Rucemes compound, the flowers successively opening from the apex downward (centrifugal); anther's innate; steds with tail-like appendages at each end. Pubescent herbs.

T. PUBENs, Ait. Stem and pedicels rough-puberulent; leaves long, linear; racemes ( $3^{\prime}-6$ ' long) loosely flowered; pedicels mostly three in a cluster, longer than the greenish white flowers; capsule as long as the perianth. September. Stem $1^{\circ}-1 \frac{1}{2}^{\circ}$ high ; leaves $6^{\prime}-12^{\prime}$ long.

T. gltitinosa, Willd. Stem and pedicels clammy-pubescent; leaves short, linear-sword-shaped; racemes ( $1^{\prime}$ long) dense-flowered; pedicels $3-5$ in a cluster, shorter than the yellowish flowers; capsule longer than the perianth. June. Stem $1^{\circ}-1 \frac{1}{2}^{\circ}$ high ; leaves $4^{\prime}-6^{\prime}$ long.

\section{RUSH FAMILY. Order, JUNCACEA.}

Tough grass-like herbs, with naked or leafy and jointed stems, flat or terete leaves, and regular cymose-clustered or panicled flowers; perianth of six nearly equal calyx-like persistent divisions; stamens 3 or 6 , inserted on the base of the sepals; anthers 2-celled, introrse, fixed at the base; ovary free from the perianth, 1-3-celled, 3-many-ovuled; style singie; stigmas oommonly 3 , hairy; capsule septicidally 3 -ralved; seeds anatropous; embryo minute at the base of the albumen.

\section{SYNOPSIS.}

Cansule 1-celled, 3-seeded. Leaves mostly hairy. Luzula.

- many-seeded, the placenta separating into the partitions. Smooth herbs, with alternate leaves..........................................

\section{LUZULA, DC. WOOD-RESII.}

Sepals flat; stamens 6 ; style rery short; stigmas filiform, villous; capsule 1-celled, 3-valred, 3-seeded; seeds erect from the base of the cell.-Perennial herbs, with flat mostly hairy leaves, and umbellate or spiked flowers. 
I. CAMPESTRIS, DC. Stem leafy; leaves linear, hairy; flowers in dense ovoid umbellate spikes; capsule roundish; seeds with a conical appendage at the base. (Juncus campestris, L.) Dry woods and banks. March and April. Stems clustered, $1^{\circ}$ high.

\section{JUNCUS, L. RUSH.}

Outer sepals keeled; stamens 3 or 6 ; style very short; stigmas villous; capsule 3 -celled, or imperfectly 3-celled, the partitions adherent to the valves, and bearing the placentæ at their inner edges; secds numerous, often appendaged, horizontal. Chiefly perennial. Leaves alternate, often knotted by cross partitions; flowers mostly green, clustered, cymose, or panicled.

\$1. Stems scape-like, jointless, sheathed or leafy at the base; stamens 6 or (in $J$. effusus) sometimes 3.

* Panicles lateral: stem sheathed at the base.

J. Effesus, L. Stem soft and spongy; sheaths dark brown; panicle diffuse or contracted; flowers single; sepals lanceolate, as long as the oborate obtuse obscurely 3 -angled light-brown capsule. Bogs and swamps. May-September. Stems tufted, $2^{\circ}-4^{\circ}$ high.

** Panicles lateral; stem leafy at the base; leaves lerete, pungent.

J. setaceus, Rostk. Stem and leaves slender; sheaths light brown; panicle simple, few-flowered; flowers single; sepals rigid, lanceolate-orate, rather longer than the globose pointed green capsule. Low grounds and swamps. May-July. Stems growing in small tufts, $1^{\circ}-3^{\circ}$ high; capsule coriaceous.

J. Maritimus, Lam. Stem and leaves stout and rigil, hard-pointed; panicle compound; flowers small, 4-8 in a cluster; sepals lanceolate, as long as the small oborate obtuse dark-brown capsule. (J. acutus, Muhl.) Brackish marshes along the coast. April and May. Stem $4^{\circ}-5^{\circ}$ high. 


\section{Panicles torminal, forking; leaves channeled or grooved, the upper ones forming an involucre under the panicle.}

J. TExurs, Willd. Slems tough, not tumid at the base, soveral-leaved; leaves narrowly linear, channeled; involucre longer thin the panicle; flowers single; scpals lanceolate, very acute, one-third longer than the oroid capsule. Low grounds. May and June. Stem 6'-12' high; panicle sm:ll, the flowers mostly on one side of the branches; capsule light green.

J. Dichотомus, Ell. Stem tumid at the base, 1-3-leaved; leaves filiform, nearly terete, slightly grooved on the inner side; involucre mostly shorter than the cymose panicle; flowers single; sepals rigid, ovate-lanceolate, very acute, as lung as the globose dark-green capsule. Low grounds. May and June. Stem $1^{\circ}-3^{\circ}$ high; panicle dense or elongated.

J. Filipexdulus, Buckley. Stems erect, slender, 1-2leaved; leaves numerous at the root; flowers terminal; fuscicles 6-12-fluwered; bracts orate, broadly membranaceous. acuminite, or long subulate; leaves of the perigynium 6, equal, lanceolate or ovate, broadly membranaceous, subulate; capsale 3-angled; style short; stigmas 3 -twisted and brown pubescent. In the Western part of Llano County, along streams, in dense tufts, with weak single stems, and long slender thread-like branches (hence the specific name), terminated by 1-4 sub-hemispherical heads of flowers, which when later with mature fruit are of a light strawcolor. Seeds ovate, with reddish-brown points; heads of flovers about 5 lines in diameter; radical leaves $3-5$ inches long.

§2. Stems jointed, leafy; clusters or panicles terminal.

- Leaves terete or somewhat fattened, knotted; stamens 3.

J. scirpoides, Lam. Rigid; stem stout, erect; leaves terete, panicle erect, contracted, the few large globose green or brownish heads composed of several more or less 
distinct smaller ones; sepals lanceolate-subulate, as long as the lanceolate taper-pointed 3 -angled capsule; seed ovoid, reticulated, without appendages. (J. echinatus, Ell.) Varies with the smaller more numerous and crowded heads conspicuously lobed by the more distinct clusters, and with broader and shorter sepals and capsules. Sandy swamps. July-September. Stem $2^{\circ}$ high, from a thick and creeping rhizoma; heads $4^{\prime \prime}-\gamma^{\prime \prime}$ in diameter.

J. Acuminatus, Michx. Stem erect, terete, like the slender leaves; punicle mostly simple, erect; heads $\left(2^{\prime \prime}-3^{\prime}\right.$ long) 3-8-flowered; sepals linear-lanceolate, half as long as the lanceolate-oblong abruptly pointed 3-angled lightbrown capsule; seeds with a short appendage at each end. Sandy wet places. July-September. Stem $8^{\prime}-15^{\prime}$ high; root fibrous; capsule $2^{\prime \prime}$ long.

\section{** Leaves knotless, concave or flattened.}

J. Bufonius, L. Annual; stems low, $2^{\prime}-\delta^{\prime}$ high, tufted, often branched; leaves very narrow; panicles forking; flowers solitary or 3-6 in a cluster; sepals whitish, lanceolate, acute, longer than the oblong obtuse pale capsule. April, May.

\section{PICKEREL-WEED FAMILY. Order, Poxte-} DERTACE

Perennial aquatic or marshy herbs, with perfect mostly irregular flowers from a 1-leared spathe ; perianth corollalike, unequally 6-cleft or 6-parted, imbricated in the bud, withering-persistent; stamens 3-6, more or less unequal, and unequally inserted on the throat of the perianth; anthers 2-celled, erect, introrse; orary free; style single; stigma 3-6-lobed; capsule 1-3-celled, 1-many-seeded; seeds anatropous; embryo slender in mealy albumen. 


\section{PON'tederia, L. Wampee; Pickerel-weed.}

Perianth funnel-shaped, 2-lipped, with the upper lip 3-lobed, the lower 3-parted, the curred tube fleshy and coiled in fruit; stamens 6 , unequally inserted, the three lower ones exserted, the three upper short and often imperfect; anthers oval, blue; ovary 3-celled, two of the cells empty, the other with a single suspended ovule; style slender; capsule (utricle) 1-seeded; rhizoma thick and creeping. Stem erect, bearing above the middle a single short-petioled leaf, and at the summit a hairy spike of blue flowers, from a 1-leaved spathe; radical leaves longpetioled, sheathing.

P. CoRdata, L. Stem and terete petioles erect $\left(2^{\circ}-3^{\circ}\right.$ high); leaves $\left(3^{\prime}-8^{\prime}\right.$ long) varying from round-cordate to lance-oblong, obtuse, finely nerved; spite dense, cylindrical $\left(2^{\prime}-4^{\prime}\right.$ long), the peduncle inclosed in the convolute spathe; upper lobe of the hairy perianth spotted with yellow, the tube 6-ribbed. (P. lancifolia, Muhl., and P. angustifolia, Pursh, are narrow-leaved forms.) Miry margins of ponds and rivers. July-September.

\section{SCHOLLERA, Schreb.}

Perianth salver-form, nearly equally 6-lobed, the tube elongated and filiform; stamens 3 , nearly equal ; filaments subulate; anthers sagittate-oblong, yellow; style long and slender; capsule oblong, 1-celled, loculicidally 3-valved, with three parietal placentæ many-seeded.-A small aquatic herb, with slender branching stems, linear sessile leaves, and a small terminal yellow flower.

S. GRAMInEA, Willd. Stem submerged, forking; leaves thin, pellucid; flowers expanding at the surface of the water; spathe convolute; lobes of the perianth linear, spreading. (Leptanthus, Mich.) In flowing water. July 
and August. Stems $1^{\circ}-2^{\circ}$ long; leaves $3^{\prime}-6^{\prime}$ long; tube of the perianth $1 \frac{1^{\prime}}{2}$ long.

\section{4\%. SPIDERWORT FAMILY. Order, CoMMELY- NACEE.}

Herbs, with chiefly fibrous roots, jointed and leafy stems, and perfect or somewhat polygamous often irregular flowers; perianth of three herbaceous or colored persistent sepals, and three fugacious petals ; stamens 6 , hypogynous, perfect, or a part of them sterile; anther's 2-celled, often of two forms; styles single; stigma entire; ovary free from the perianth, $2-3$-celled, with 1 -several orthotropous ovules in each cell; capsule loculicidally 2-3-ralved, 1-severulseeded; embryo pulley-shaped, placed in a carity of the albumen opposite the hilum.-Plants somewhat succulent; stems often branching; sheaths of the leaves entire or open.

\section{COMMELYNA, Dill. DaY-Flower.}

Flowers irregular; sepals mostly colored; petals fingacious, two of them kidney-shaped and long-cliwed, the other smaller; stamens unequal, three of them fertile, the others with 4-lobed sterile anthers; filaments beardless; capsule 1-3-celled, the cells 1-2-seeded, or one of them frequently empty. Stems branching; leaves flat, oblong, or lanceolate, on sheathing petioles, the floral ones cordate and spathe-like, folded, and inclosing the few-flowered peduncle; flowers blue.

C. Comuuris, L.? Stem smooth, filiform, and creeping; leaves (short 1'-2' long), ovate-lanceolate, obtuse; sheaths fringed at the throat; spathes nearly crescent-shaped, obtuse at the base, lateral and terminal; peduncles by pairs, one of them bearing $\delta-4$ small fertile flowers, which are included in the spathe, the other long-exserted, filiform, 1-flowered; odd petal lanceolate, sessile; seeds reticulate. Low grounds. July-September. Stem $1^{\circ}-2^{\circ}$ long. Annual. 
C. Virginica, L. Pubescent; stem erect; sheaths hairy; leaves $\left(4^{\prime}-6^{\prime}\right.$ long) oblong-lanceolate, acuminate, thin, rough above; spathe (when opened) round ovate, contracted at the base ; sterile peduncle included ; petals large, the odd one lanceolate; capsule 2-3-seeded. (C. erceta, Ell.) Varies (C. angustifolia, Michx.) with the stems smooth, ascending; leaves narrowly lanceolate, rather rigid, and, like the sheath, nearly smooth ; flowers smaller; seeds pulverulent. Light or sundy soil. May-September. Stem $1^{\circ}-2^{\circ}$ high. The spathes contain a viscid secretion until the seeds mature. Perennial.

C. Axgustifolia. Stem erect, slender; lcaves lancelinear, acute, rough, the sheaths fringed with brown hair; spathes crowded, short-stalked, conspicuously arcuate (hawk-bill-shaped), narrowed at the base; sterile peduncle included; petals nearly equal, the odt nne smaller; seeds transversely oblong. Perennial. Red River.-Marcy.

\section{TRADESCANTIA, L. SPIDERwort.}

Flowers regular; sepals herbaceous; petals similar, ovate, fugacious; stamens all fertile, the filaments hairy; anthers kidney-shaped; ovary 3-celled, with two ovules in each cell; capsule $2-3$-celled, the cells 1-2-seeded.-Perennial herls with narrow keeled leaves, both the floral ones and those of the stem ; flowers in umbel-like clusters, axillary and terminal, expanding in the morning; fruiting pedicels recurved.

T. Virginica, L. Smooth, or villous with glandless hairs; leaves linear, broadest at the base, mostly purpleveined; clusters axillary and terminal, sessile, manyflowered; flowers closely packed in 2 rows in the 1 ud, each with an orate scarious bract at the base; petals blue, like the style and densely bearded filaments, twice as long as the lanceolate-ovate sepals. Dry sandy soil. March-May. Stems $\frac{1}{2}^{\circ}-2^{\circ}$ high ; flowers $1^{\prime}$ in diameter. 
T. PIlosa, Lehm. Stem often branched, and, like the sheaths, villous or nearly smooth ; leaves oblong, narrowed at the base, pubescent on both sides; clusters axillary and terminal, sessile, dense, many-flowered; the pecticels and oblong sepals villous with glandular hairs; seeds transversely oblong, pitted on the back; petals blue. Light soil. May-July. Stem $1^{\circ}-1 \frac{1}{2}^{\circ}$ high ; leaves $1^{\prime}-1^{\frac{1}{2}}$ wide; flowers $8^{\prime}$ in diameter.

T. Rosea, Vent. Stem simple, slender, smooth; leaves linear-]anceolate, fringed on the margins; clusters solitary or by pairs, on long $\left(3^{\prime}-6^{\prime}\right)$ terminal peduncles, few-flowered; petals bright rose-color, three times as long as the ovate-lanceolate sepals. Light fertile soil. June-August. Stem $6^{\prime}-S^{\prime}$ high ; flowers $\frac{1}{2}^{\prime}$ in diameter.

\section{MAYACA FAMILY. Order, MaYacacez.}

Creeping moss-like marsh herbs, with very numerous narrow and pellucid leaves, and solitary axillary flowers. Represented only by

\section{MAYACA, Aublet.}

Flowers regular, perfect; sepals 3, lanceolate, herbaceous, persistent; petals 3, obovate, deciduous or withering-persistent; stamens 3 , free, inserted on the base of the sepals, persistent; anthers erect, spoon-shaped, imperfectly 2-celled, emarginate at the apex, introrse; ovary 1-celled; ovules few, orthotropous, fixed to three parietal placentæ; style single, terminal, persistent; stigma minutely 3 -lobed; capsule rugose, 3 -valved, the valves bearing the placentæ in the middle; seeds globose, furrowed and pitted, pointed at the apex; embryo minute at the apex of the albumen. Stems branching, tender; leaves alternate, linear, emarginate; flowers white or purple. 


\section{YELLOW-EYED GRASS FAMILY. Order, XYRIDACE.E.}

Perennial stemless marsh herbs, with fibrous roots, swordshaped equitant leaves, and perfect irregular fugacious flowers, collected in a dense imbricate-bracted spike; sepals 3 ; the two lateral ones glumaceous, keeled, persistent, the inner one hyaline, infolding, in the bud, the petals and caducous stamens; petals 3, rounded, distinct, or united by their long claws; stamens 3 , and inserted on the summit of the claws of the petals, or 6 , and the alternate ones sterile, hypogynous, and commonly bearded with jointed hairs; anthers erect, 2-celled, extrorse; ovary free, 1-3celled; style single, 3-parted; capsule 3-valved, manyseeded; seeds minute, orthotropous; embryo minute, at the apex of the albumen. Scape commonly twisted or spiral, 2-edged near the summit, with a spathe-like sheath at the base; spikes mostly solitary.

\section{XYRIS, L. Yellow-eied Grass.}

Petals distinct; stamens 6, the alternate ones hypogynous, sterile, commonly bearded at the summit, and slightly cohering with the claws of the contiguous petals; stigmas entire; capsule 1-celled, 3-valved, the valves bearing the placentæ in the middle; seeds very numerous, finely ribbed ; spikes oroid or oblong; bracts coriaceous or somewhat crustaceous, rounded, closely imbricated, convex and discolored on the back, the lower ones empty; keel of the lateral sepals mostly winged and varionsly lacerated; flowers yellow.

Sheath of the scape longer than the leaves. Biennials?

X. BRevifolia, Michx. Scape nearly terete, smooth; leaves narrowly linear, smooth on the edges; spike globose, light brown, few-flowered; bracts soon lacerated at the 
apex; lateral sepals lanceolate, rigid, crenulate on the wingless keel; petals obovate, rounded; sterile filaments sparingly bearded. Low sandy pine-barrens. April and May. Plant light brown; scape $66^{\prime}-12^{\prime}$ high, clustered leaves $1^{\prime}-3^{\prime}$ long; spike $2^{\prime \prime}-3$ "long; petals :' lung.

\section{PIPEIVORT FAMILY. Order, Eriocaulonaceze.}

Perennial chiefly stemless marsh herbs, with narrow tufted leaves, and minute monœcious or diøcious flowers, collected in a dense hairy chaffy-bracted head.-STAMINATE FLOWERS: sepals 2-3; corolla tubular, bilabiate or 3-toothed, or sometimes wanting; stamens 2-6; anthers introrse.-Pistillate Flowers: sepals and petals 2-3; ovary 2-3-celled, with a single orthotropous ovule in each cell ; style 2-3-parted; capsule loculicidally 2-3-valved, 1-3-seeded; embryo minute at the apex of the albumen.Leaves concave and partly clasping at the base ; scape furrowed and commonly twisted, with a spathe-like sheath at the base; exterior scales broader, empty, and involucrate; flowers fringed with white club-shaperl hairs; corolla white.

\section{SYNOPSIS.}

Stamens 4. Anthers 2-celled. Style 2-parted. Corolla 2-lipped.......Errocsulox. - 3. - 2-celled. - 3.parted, the lobes entire....... P.epalantrus. 3. 1-celled. -2-3-parted, the lobes, entire, or 2-cleft.

LAChNocaULON.

\section{ERIOCAULON, L. PIPEWORT.}

Flowers monœcious, each in the axil of a scale-like bract; sepals 2-3; corolla of the staminate flowers tubular, 2-lipped or 3-lobed, of the pistillate flower's 2-3-petalous; stamens 4 or 6 ; anthers 2-celled; style 2-3-parted; stigmas 2-3; capsule 2-3-celled, 1-3-seeded ; scapes single or numerous, mostly from a short and villous rootstock; lobes of the corolla furnished with a blackish gland on the inner face, 
commonly bearded with club-shaped hairs. The following species are all tetrandrous, with a 2-parted style and a 3 -celled capsule.

E. DeCANGlLaRe, L. Leaves mostly rigid, varying from lanceolate to linear-subulate, concave, obtuse ; scapes commonly several from a thick and creeping rootstock, stout, smooth, 10-12-furrowed; head ( $2{ }^{\prime \prime}-7^{\prime \prime}$ in diameter) compact, hemispherical, at length globose; scales of the involucre numerous, small, oblong, acutish, closely imbricated, straw-colored, or light chestnut, passing into the linearspatulate acuminate bearded bracts, which are longer than the flower. (E. gnaphalodes, Ell., not of Michx.) Boggy places. July-September. Scapes $2^{\circ}-3^{\circ}$ high ; leares $4^{\prime}-12^{\prime}$ long, $2^{\prime \prime}-6$ " wide.

E. GNaPH.ALodes, Michx. Leaves lanceolate-subulate, flat, very acute, rigid, or the immersed ones thin and pellucid; scapes few or single, slender, 9-11-furrowed; head hemispherical $\left(4^{\prime \prime}-8^{\prime \prime}\right.$ wide); scales of the involucre few, oblong or roundish, very obtuse, turning lead-color; bracts shorter than the flower, spatulate, their broad and bearded summit obtuse or more or less mucronate-pointed, turning blackish. (E. compressum, Lam.) Siwamps and shallow ponds. April-June. Scapes $1 \frac{1}{2}^{\circ}-2^{\circ}$ high; leaves $2^{\prime}-6^{\prime}$ long, concave at the base.

\section{PAEPALANTHUS, Martius.}

Flowers monœcious.-Staminate flowers: sepals 3; corolla tubular, 3-toothed; stamens 3 ; anthers 2-celled.Pistillate flowers: sepals and petals 3 ; style 3-parted, the divisions entire; stigmas 3 ; capsule 3 -celled.-Habit of the preceding.

P. Flavidulus, Kunth. Leaves short $\left(1^{\prime}-2^{\prime}\right.$ long), subulate, smooth, or sparingly pubescent; scapes numerous, filiform, 5-furrowed, and like the sheaths hairy; heads hemispherical, yellowish-white; scales of the involucre ob- 
long, acute, smooth and shining; flowers slender, pediceled; sepals linear, acute; corolla of the staminate flowers funnelshaped, of the pistillate flowers composed of 3 slender petals, cohering above the ovary; stamens and styles exserted. (Eriocaulon flavidulum, Michx.) Low sandy pine-barrens. April and May. Scapes 6'-12' high.

\section{LACHNOCAULON, Kunth.}

Flowers monœcious.-STAMinate fLowers: sepals 3, equal; corolla none; stamens 3 , with the filaments united below into a club-shaped tube; anthers 1-celled.-PistiLLATE FLOWERS: sepals 3, equal; corolla none, or reduced to tufted hairs ; style club-shaped, 2-3-parted, the divisions entire or 2-cleft; stigmas 2-6; capsule 2-3-celled. Habit of the two preceding. Bracts and sepals blackish, fringed with club-shaped hairs.

L. Michauxir, Kunth. Leaves linear (1'-2' long), hairy, becoming smoothish; scapes slender, hairy, 4-furrowed ( $1^{\circ}$ high); heads globose; bracts and sepals spatulate, obtuse, fringed with white hairs; divisions of the style 3, each 2-cleft. (Eriocaulon villosum, Michx.) Low grassy pine-barrens. May and June, growing in tufts. Heads $2^{\prime \prime}$ wide.

\section{SEDGE FAMily. Order, Cyperacex.}

Slender herbs, with simple solid mostly 3-angled stems (culms), and grass-like leaves, with closed sheaths; flowers spiked, each in the axil of a single (rarely 2-4) scale-like bract (scale) ; perianth composed of hypogynous scales or bristles, or none; ovary 1-celled, with a single erect anatropous ovule, forming in fruit a lenticular or 3 -angled achenium (nut), which is often crowned with the persistent jointed base of the style (tubercle); stamens 1-12; anthers erect; style 2-3-cleft or parted; embryo minute at the base of the albumen. 


\section{SYNOPSIS.}

Tribe I. Cypereæ. Flowers perfect. Spikelets 1many-flowered. Scales one to each flower, imbricated in 2 rows. Perianth bristly, or none.

- Perianth none; nut beakless.

Spikelets few-many-flowered. Inflorescence terminal................. CrPerus. -1-flowered. Inflorescence terminal, capitate................ KYLLiNgIA.

** Perianth bristly; nut beaked.

Spikes lateral and terminal. Spikelets many-flowered Düichrom.

TRIBE II. Lipocarpheæ. Flowers perfect. Spikes many-flowered. Scales 2-4 to each flower, the exterior ones imbricated in many rows. Perianth none.

Inner scale 1. Involucre mostly 1-leaved, erect.................. HEMICARPHA. Inner scales 2. Leaves of the involucre 2 or more, spreading...........LIPOCARPHA.

Tribe III. Scirpeæ. Flowers perfect. Spikes commonly many-flowered. Scales one to each flower, imbricated in several (rarely 2) rows, all fruitful, or the lowest empty. Perianth bristly, hairy, or wanting.

* Perianth of 3 bristles, alternating with 3 stalked scales.

Nut pointed. Scales of the clustered axillary and terminal spikes awned.. FUIRENA.

** Perianth bristly, occasionally wanting.

Nut tubercled. Culms leafless, sheathed at the base, bearing one terminal spike.

ELEOCHARIS.

Tubercle none. Culms mostly leafy at the base or throughout. Spikes commuly few or many. Perianth of $3-6$ bristles...............................

Perianth of numerous long and woolly hairs.................. EropHorux.

*** Perianth none; style tumid at the base.

+ Scales imbricated in several rovos; spikes terete.

Slyles deciduous. Stigmas 2. Nut lenticular or globose............ FimBristruis. 3. - 3-angled ................. Trichelostrus. persistent at the base. Stigmas 3. Nut 3 -angled... ............ IsolEPIs.

t+ Scales imbricated in 2 ronss; spike compressed.

Style 3-clett, jointed to the 3-angled nut Abilgandia. 
Tribe IV. Rhynchosporeæ. Flowers perfect or polygamous. Spitielets commonly few-flowered. Scales one to each flower, imbricated in few-sereral rows, the lower ones empty, the upper mostly sterile. Perianth bristly, or none.

* Perianth bristly (occasionally wanting in Rhynchospora).

Style 2-cleft, dilated and persislent at the base. Nut lenticular or globose.

RHYNCHOSPORA.

Style entire or minutely 2-cleft, the lower persistent at the base. Nut flat.

Ceratoschares.

** Perianth none.

Spikes fero-flowered, only the uppermost flower perfect. Nut globose...... CLADIUM.

Tribe V. Sclerieæ. Flowers monœcious. Sterile spike many-flowered. Scales one to each flower, imbricated in furrows. Fertile spike 1-flowered, with two or more scales. Perianth none.

Style 3-cleft, deciduous. Nut bony, globose or 3-angled............... ScLeria.

Tribe VI. Cariceæ. Flower's monœcious, rery rarely dicecions; sterile and fertile flowers on the same spike, or on separate spikes. Scales one to each flower, imbricated in few-many rows. Nut inclosed in a sac. Perianth none.

Bristles within the sac none. Spikes axillary and terminal..

CAREX.

\section{CYPERUS, L.}

Spikelets 2-manr-flowered, commonly flat or compressed ; scales imbricated in two opposite rows, often decurrent on the jointed rachis, deciduous; perianth none; stamens 1-3 ; style 2-3-cleft, deciduous; nut lenticular or 3-angled; culms 3-angled (rarely. terete), jointless, leafy or occasionally sheathed at the base; spikelets numerous (rarely 1-2), disposed in single or umbellate heads or spikes, and surrounded with a leafy involucre; rays sheathed. 
5 1. Prcreus. Style 2-cleft; nut lenticular; spikes more or less umbelled. Annuals; spikelets lineur or linear-obiong, flut, many-(10-40)-flowered; rachis narrowly margined; scales compressed-keeled, 5-nerved.

* Spikelets clustered on the common rachis.

C. Flavescens, L. Umbel sessile or of 2-4 rays, shorter than the spikelets; spikelets 3 -several in a cluster, oblonglinear, acute, spreading, 20-30-flowered; scales yellowish brown, ovate, obtuse, appressed; rachis margined; stamens 3 ; nut orbicular, black, smooth and shining; culms clustered, 4'-10' high ; leaves and 3-leaved involucre narrowly linear. (C. fusciculatus, Ell.?)

C. DiAndrus, Torr. Umbel of 2-5 short and unequal rays, the longer ones longer than the spikelets; spikelets lanceolate-oblong, acute, brownish or dark brown, spreading; scales ovate, obtuse, appressed, green on the keel; rachis margined; strmens 2 ; nut oblung-oborate, roughish, dull gray. Wet places. August. Culms 4'-10' high; involucre 3-leaved. 'Ihis and the preceding are probably only diandrous forms of C. flavescens.

** Spikelets scattered on the common rachis (spiked.)

C. Flavicoyus, Michx. Umbel compound, many-raved; spikclets very numerous, crowded, linear, acute, 12-30flowered; scales loosely imbricated, yellowish, round-obovate, emarginate, with broad and scarions margins, at length spreading; rachis broadly margined; stamens 3; mut obovate, black, smooth and shining. barly shorter than the scale; culms thick, obtuse angled; $1^{\circ}-3^{\circ}$ high ; leaves broadly linear, glaucous beneath, as long as the culm. Low grounds and ditches. May-September. Involucre 3-5-leaved; spikelets $6^{\prime \prime}-9^{\prime \prime}$ long.

C. Microdontus, Torr. Umbel of 4-8 rays, simple or somewhat compound; spikelets numerous, crowded, linear, acute, 15-25-flowered, pale brown; scales thin, ovate, acute, closely imbricated; racthis slightly margined; stcmens 2 ; nut linear-oblong or somewhat club-shaped, short- 
pointed, grayish and minutely pitted; culms filiform, 3 -angled, 6'-12' high ; leaves and elongated involucre very narrow. Margins of ponds and streams, Red River. JulySeptember. Rays 1'-2' lung; spikelets $4^{\prime \prime}-7^{\prime \prime}$ long.Marcy.

\$ 2. Crpenos proper. Style 3-cleft; nut 3-angled; joints of the rachis winged by the adnate decurrent scales, rarely wingless.

SPICATI. Umbel simple or compound; spikelets few-many-flowered, distinct, spreading, forming loose or compact spikes at the summit of the rays; scales rigid, 7-11. nerved; joints of the rachis commonly conspicuously winged; stamens 3.

* Spikelets approximate or crowded on all sides of the commón rachis, forming oblong or cylindrical spikes.

C. strigosus, L. Umbel large, 4-8-rayed, simple or compound, much shorter than the involucre; involucels bristly, shorter than the dense oblong spikes; spikelets yellowish, linear, acute, compressed, 6-10-flowered; scales somewhat scattered on the very slender rachis, oblong-lanceolate, acute, closely appressed, much longer than the linear-oblong acute minutely dotted dull nut; culms $\left(1^{\circ}-3^{\circ}\right.$ high $)$ tumid at the base, as long as the broadly linear leaves. Swamps and damp soil. July-September. Rays $4^{\prime}-6^{\prime}$ long; spikelets $\frac{1^{\prime}}{2}-3^{\prime}$ long; sheath of the rays bristlepointed. Wichita Mountains.

C. Schwernitzir, Torr. Culm $8{ }^{\prime}-12^{\prime}$ high, triquetrous, rough on the angles; leaves shorter than the stem, about a line wide; umbel simple, erect, 4-6-rayed; rays elongated, unequal; sheaths truncate, entire; involucre 3-5-leaved, longer than the leaves, scabrous on the margin; spikelets 6-7, alternate, approximate, in cylindric clusters, 6-8-flowered, with a small, setaceous bract at the base of each; scales membranaceous on the margin; stamens 3 ; style 3 -cleft, scarcely longer than the smooth achenia. Northern Texas.

C. Michauxianus, Schultes. Umbel compound, 4-6rayed; rays short with the sheaths pointed; spikes loose, mostly shorter than the leafy involucels; spikelets spreal- 
ing or reflexed, linear-subulate, terete, 10-12-flowered; scales scattered on the short-jointed broadly-winged rachis, oblong, obtuse, faintly-nerved, appressed ; nut oblong, compressed-3-angled; culns slender, obtuse-angled; involucre 4-6-leaved. (C. speciosus, Vahl.?) Swamps and ditches. August and September. Culm $2^{\circ}-3^{\circ}$ high; spikelets $6 "-8^{\prime \prime}$ long, flexuous in fruit. Annual.

Gromerati. Cmbel simple or compound; spicielets many-flowered, compressed, numerous in cluster, forming more or less dense heads at the summit of the common and partial rays; rachis wingless; stamens solitary.

* Umbel compound; spikelets ovate or oblong, flat; scales 3-nerved, concave on the back, acute; nut minute, lanceolate or oblong.

C. vegetus, Willd. Umbel often decompound, manyrayed, widely spreading; involucre 4-leaved, many times longer than the umbel; spikelets short ( $1 \frac{1}{2}{ }^{\prime \prime}-2^{\prime \prime}$ long), ovate, $10-15$-flowered, very numerous in the heads; scales lanceolate, incurved, spreading at the apex; nut minute, linear-lanceolate, slender-pointed; culms slender $\left(2^{\circ}-3^{\circ}\right.$ high), obtuse-angled or nearly terete; leaves narrow, rigid, rough on the margins near the summit. Low pine-barrens and margins of ponds. September. Culms tumid at the base; leaves of the involucre horizontal; heads light brown. Perennial.

C. Drummondi, Torr. Umbel compound, of 4-6 primary rays, and as many smaller ones, shorter than the 4-leaved involucre; spikelets (10-20 in a cluster) oblong or oblong-linear, 40-50 flowered; scales yellowish, ovate, straight, free at the apex ; nut oblong, pointed, abruptly contracted at the base, minutely wrinkled; culms $\left(6^{\prime}-15^{\prime}\right.$ high) obtuse-angled, very rough, longer than the narrow leares. Sandy swamps. September. Annual.

CAPITATI. Umbel simple or sessile; spilielets inserted on all sides of the common rachis, forming clusters or heads; joints of the rarhis mostly winged; scales rigid, 5-11. nerved; stamens 3.

* Spikelets few in loose clusters.

C. Filiformits, Swartz. Cluster's sessile ; spikelets 6-12, 
erect, terete, subulate, 6-12-flowered; scales scattered, appressed, oblong, mucronate, finely-nerved; rachis very slender, flexuous ; nut oblung, acute; culms tufted, fili. form, acute-angled, longer than the bristle-like leaves; $i \mathrm{n}$ volucre 2-leaved, the lower one elongated and erect. Culms $4^{\prime}-10^{\prime}$ high, tumid at the base; spikelets $4^{\prime \prime}-6^{\prime \prime}$ long. Perennial.

** Spikelets numerous in compact globular or oblong heads.

$\uparrow$ Perennials; culms tumid or tuberous at the base.

C. Retrofractus, Tort. Umbel of about 8 slender $\left(2^{\prime}-6^{\prime}\right.$ long) rays, longer than the involucre; heads obovate; spikelets subulate, reflexed, terete; scales 4-5, the two lower ones orate and empty, the upper lanceolate, acute; nut linear-oblong; culm tall $\left(2^{\circ}-4^{\circ}\right)$, downy and roughish, like the broadly linear leaves. (Mariseus retrofractus, Vahl.) Barren sandy soil. July-September. Leaves much shorter than the culm.

\section{KYLLINGIA, L.}

Spikelets compressed, mostly 1-flowered; scales commonly 4, imbricated in two rows, the two lower ones small and empty, the third perfect, the fourth imperfect; perianth none; stamens 1-3 ; style elongated, 2-cleft; nut lenticular ; culms jointless, 3 -angled, leafy at the base ; involucre 3-5-leaved; spikelets collected in single or clustered sessile heads. Plants odorous.

K. Pumila, Michx. Heads (green) mostly 3, globose or ovate; spikelets 1-flowered, ovate-lanceolate, acute at each end; scales 3, the lowest minute, the middle one orate, compressed, mucronate, mostly serrulate on the keel, inclosing the upper one; nut oborate; stamens 2; culms weak, acute-angled; leaves and 3-4-leared involucre linear. Wet places. July-September. Culms tufted, $4^{\prime}-10^{\prime}$ high. Annuals. 
K. Movocephala, L. " Heads single, globose, compact; spikelets 1-flowered, monandrous, ovate, acuminate, the 2 superior scales striate, nearly smooth on the sides, serrulate-ciliate on the keel, the 2 inferior minute; nut somewhat orbicular; involucre 3-leaved, one of the leaves erect, the others horizontal." (Torr.)-Rhizoma creeping; culms $1^{\circ}$ high ; head greenish, generally inclined; leaves abruptly pointed. Low moist lands.

\section{DULICHIUM, Richard.}

Spikelets linear, compressed, many-flowered; scales inbricated in 2 rows, decurrent on the joints of the rachis; perianth composed of 6-9 down wardly hispid rigid bristles; stamens 3 ; style 2-cleft ; nut lanceolate, compressed, longbeaked. Perennial. Culms terete, jointed, leafy ; leaves numerous, 3-ranked, linear or lanceolate, short and spreading; spikes numerous, solitary in the upper axils, simple or the lower compound; spikelets 8-14, 2-ranked, spreading, 6-10-flowered ; scales lanceolate, many-nerved, closely imbricated; bristles nearly twice as long as the compressed or concare nut.

D. spathaceum, Richard. Ponds and ditches. AugustSeptember. Culms $1^{\circ}-2^{\circ}$ high ; leaves $1^{\prime}-3^{\prime}$ long; spikelets $6^{\prime \prime}-12^{\prime \prime}$ long; peduncles of the lower spikes longer than the sheaths.

\section{LIPOCARPHA, R. Br.}

Spikes many-flowered, terete; scales spatulate, imbricated in many rows, deciduous, the lowest empty ; interior scales 2 , parallel to the exterior ones, membranaceous, inclosing the flower and nut; stamens 1-2 ; style 2-3-cleft; nut compressed, 3-ingled; culms jointless, leafy at the base ; spikes in a terminal cluster; involucre leafy.

L. Macclata, Torr. Annual; culms clustered, terete; leaves much shorter than the culm, linear, concave, smooth; 
involucre 2 6-leared, spreading or recurred; spikes small, ovate, 3-9 in a cluster; scales spotted; scales of the perianth very thin, the nerres at length free and bristle-like below; uut oblong, contracted into a short neck. (Kyllingia maculata, Michx.) Springy or miry places. JulySeptember. Culms 4'-8' high ; spikes $1^{\prime \prime}-2^{\prime \prime}$ long, green.

\section{FUIRENA, Rottb.}

Spikes many-flowered; scales imbricated in many rows, awned at the apex; perianth consisting of three petal-like stalked scales alternating with as many bristles; stamens 3 ; style 3-cleft; nut 3-anglerl, raised on a stalk, and pointed with the persistent base of the style; culms terete, jointed; spikes single or clustered, lateral and terminal; scales hairy.

F. ScIRPoIdes, Vahl. Rhizoma thick and creeping; culms slender; leaves reduced to pointed sheaths, smooth; spikes 1-3, terminal, orate, supported by a small bract-like involucre; scales oborate, 9-nerved, pointed with a short erect awn; stalks of the oral barely pointed petal-like scales longer than the hispid bristles. Wet sandy places, near the coast. May-September. Culms $1^{\circ}$ high.

F. squarrosa, Michx. Culms clustered, smooth, or pubescent near the summit; leares flat, linear or linear-lanceolate, the margins, like the lower sheaths, hairy; spikes oblong, in lateral and terminal clusters ; scales oblong-obovate, with the long pale awn recurred; petal-like scales orate, acute; bristles as long as the stalk of the oborate nut.-Var., HISPIDA. (F. hispida, Ell.) Leares, sheathe, and upper portion of the culm bristly-hairy; petal-like scales acuminate; bristles nearly as long as the nut. Swamps. July-September. Culms $\frac{1}{2}^{\circ}-2^{\circ}$ high; leares 2 '-5' long. The terminal cluster occasionally compound. Perennial. 


\section{ELEOCHARIS, R. Br. SPIKe-Rush.}

Spikes many- (rarely 2-4)-flowered; scales imbricated on all sides of the rachis, or somewhat 2-ranked, the lowest usu:llly empty, bract-like, and persistent ; perianth of 3-8 bearded bristles, occasionally wanting ; stumens 1-3; style 2-3-cleft; nut compressed, biconvex, or 3-ingled, crowned with the persistert jointed base of the style (tubercled). Commonly perennials, with creeping rootstocks. Culms jointless, leafless, sheathed at the base, bearing at the apex a single spike.

\$1. ELEocharis proper. Spikes many-flowered; scales imbricated in several rows.

* Spikes cylindrical, scarcely thicker than the soft cellular culms; nut biconvex, pitted or wrinkled in longitudinal lines.

+ Scales rounded, thick and faintly nerved; style 3 cleft; bristles 6, sparingly bearded or smoothish, as long as the nut. (Limnochloa, Nees.)

E. Equisetordes, Torr. Culms stout, terete, knotted by cross partitions, roughish; scales pale, round-orate, obtuse or the upper acute, scarious on the margins; bristles hispid ; nut pale brown, obscurely wrinkled, shining, crowned with a sessile conical-beaked acute tubercle. (Scirpus equisetoides, Ell.) Ponds. July-September. Culms $1^{\circ}-2^{\circ}$ high, $3^{\prime \prime}$ in diameter; sheaths brown ; spikes $1^{\prime}$ long. Perennial.

E. Quadrangulata, R. Br. Culms unequally 4-sided, with the angles acute; scales pale, roundish, very obtuse, scarious on the margins ; bristles slender, bearded, unequal ; nut broadly obovate, finely pitted, dull white; tubercle ovate or conical, free around the base, much shorter than the nut. (Scirpus quadrangulatus, Michx.) Ponds and ditches. July-September. Culm $2^{\circ}-3^{\circ}$ high, $1^{\prime \prime}-2^{\prime \prime}$ in diameter; sheaths purplish; spikes 1' long. Perenuial.

\footnotetext{
** Spikes thicker than the culm; style 3-cleft ; nut 3-angled.

+ Bristles 6, as long as the nut and tubercle; nut longitudinally furrowed and pitted.
}

E. tuberculosi, R. Br. Culms somewhat compressed, tough and wiry; spikes pale, ovate or oblong, acute; 
scales oblong, rigid, 1-nerved; nut obovate, as large as the ovate compressed 3-angled tubercle; bristles rigid, hispid. -Varies with larger spikes and pubescent bristles. (Scirpus tuberculosus, Michx.) Wet places, chiefly along the coast. March-September. Culms $6^{\prime}-12^{\prime}$ high ; spikes $3^{\prime \prime}-4^{\prime \prime}$ long $\left(6^{\prime \prime}-8^{\prime \prime}\right.$ in the var.). Nut shining. Perennial.

E. Simplex, Torr. Culms unequally 3 -sided, acuteangled; spikes short, ovate, acute; scales ovate-oblong, whitish, with brownish sides; nut obovate, flat on the inner face, twice as long as the conical-beaked compressed acute tubercle; bristles rigid. (E. tortilis, Schult.; Scirpus simplex, Ell.) Miry places along streams. May-September. Culms $1^{\circ}-1 \frac{1}{2}^{\circ}$ high, very slender, twisted when dry; spikes $2^{\prime \prime}-3$ " long, angular, few-flowered. Perennial.

E. Microformis, Buckley. Culms erect, setaceous, cespitose, 1-2 inches high, smooth; spikes ovate, obtuse or subacute, 10-12-scaled; scales ovate, acute or subobtuse, reddish brown ; keal green ; achenia smooth, shining, pyriform, setæ 6, equal to the seed in length. Mature achenia black and shining, crowned with a broad white tubercle, with a short point in the centre. Northern Texas. June.

\section{†† Culms terete or compressed, more or less spongy.}

E. oвTusa, Schultes. Culms tufted, terete, thick and spongy; spikes ovate or oblong, obtuse, many-flowered; scales thin, oblong, obtuse, commonly brown on the sides, green on the keel, with broad and white margins; style 2-3-cleft; nut (light brown) oborate, lenticular, smooth and shining, scarcely wider than the short compressed acute tubercle; bristles 6 , rigid, twice the length of the nut. (Scirpus capitatus, Ell.) Muddy margins of ponds and streams. Common. June-September. Culms 6'-18' high; spikes $2^{\prime \prime}-4^{\prime \prime}$ long. 
5 2. CH.s TOCYPERUs. Spiles fero-flowered, compressed; scales membranaceous, imbricated in $2-3$ rows; style 3 -cleft; culms capillary.

E. ACICUlaris, R. Br. Culms $\left(2^{\prime}-12^{\prime}\right.$ high) angled; spikes ovate, 5-6-flowered, acute; scales oblong, with reddish sides; nut oblong, white, nearly terete, longitudinally ribbed and pitted, pointed with the conical or depressed tubercle; bristles 3-4, shorter than the nut, sometimes wanting. (Scirpus trichodes, Muhl.) Margins of ponds. June-September.

E. PYGM.e.1, Torr. Culms short (1'-2' high), grooved on one side; spikes ovate, 3-6-flowered; scales whitish, ovate; nut ovate, pale, prominently 3 -angled, smooth and shining, narrowed above in to the minute tubercle; bristles 6, longer thin the nut, sometimes wanting. (Scirpus capillaceus, Ell.) Muddy or sandy banks near the coast. April-July. Rhizoma very slender, bearing minute tuberlike buds ; spikes $1^{\prime \prime}-2^{\prime \prime}$ long.

\section{SCIRPUS, L. Bulrush.}

Spikes terete, single, or oftener in clusters or umbels, which are subtended by a 1-many-leaved involucre; scales imbricated in several rows; nut obtuse, or pointed by the persistent jointless base of the style; tubercle none; culms jointed and leafy, or leafy or sheathed only at the base. Otherwise like Eleocharis. Perennial.

\footnotetext{
\$Culms jointless; leaves or sheaths radical.

* Spike solitary, terminal.
}

S. C.espitoscs, L. Culms tufted $\left(6^{\prime}-10^{\prime}\right.$ high), terete, wiry; sheaths numerous, rigid, imbricated, the uppermost ending in a short leaf; spike 3-8-flowered; involucre 2-leared, as long as the spike, pointed ; nut oblong, compressed-3-angled, ahruptly pointed, half as long as the smooth capillary bristles. Mountains. July. Rhizoma thick and creeping; spike $1^{\prime \prime}-2^{\prime \prime}$ long. 
** Spikes 2-many, apparently lateral; the 1-ieaved involucre erect and continuous with the culm.

+ Spikes in sessile clusters.

S. PUNGexs, Vahl. Culms stout, acutely 3-angled, two of the sides concare, leafy at the base; leaves channeled, sharply keeled; involucre slender $\left(3^{\prime}-4^{\prime}\right.$ long); spities $3-6$, light brown, oblong; scales membranaceous, oral, 2-cleft, mucronate-awned, slightly ciliate; anthers slender-pointed; style 2 -cleft; nut round-obovate, plano-convex or lenticular, as long as the 3-5 hispid bristles. (S. Americanus, Pers.) Sandy marshes along the coast. June-September. Culm $2^{\circ}-3^{\circ}$ high; leaves $2-3$, mostly shorter than the culm; spikes $4^{\prime \prime}-6^{\prime \prime}$ long.

S. OLxeyi, Gray. Culms stout, with three-winged angles, and three deeply channeled sides, leafless, or the sheaths ending in short pointed leares ; involucre short ( $1 \frac{1^{\prime}}{2}-1^{\prime}$ long) rigid; spikes " $7-13$, short, ovate, dark brown; scales smooth, orbicular, 2-cleft, mucronate ; anthers obtuse; style 2-cleft; mut round-obovate, plano-convex, as long as the 6 hispid bristles. Brackish marshes. June-September. Culms $2^{\circ}-4^{\circ}$ high ; leaves $2^{\prime}-4^{\prime}$ long; spikes $2^{\prime \prime}$ long.

8 Culms jointed, leafy throughout; umbel terminal; involucre 2-several-leaved, spreading.

* Bristles hispid dononward.

S. Poly phyluds, Vahl. Culm obtuse-angled, smooth; leaves long, rough on the margins; umbel decompound, spreading; spikes small, 3-8 in a cluster, orate, yellowishbrown; scales ovate, mucronate, keeled ; bristles 6 , slender, hispid near the summit, mostly tortuons, 2-3 times as long as the pale compressed-3-angled pointed nut. (S. exaltatus, Pursh.) Shady swamps. July. Culm $2^{\circ}-5^{\circ}$ high; spikes $1^{\prime \prime}$ long.

\section{ERIOPHORUM, L. CotTon Grass.}

Spikes many-flowered; scales imbricated in many rows; perianth composed of numerous (rarely 6) smooth and flat 
hairs, much longer than the scale, and forming a woolly or silky tuft; stamens commonly 3 ; style 3 -cleft, deciduous; mut 3-angled or lenticular. Perennials, with leafy culms, in our species, and clustered or umbelled spikes.

E. Virginicus, L. Culm nearly terete, rigid; leaves narrowly linear, elongated; spikes densely clustered, nearly sessile, erect; involucre 2-3-leaved; wool reddish, thrice the length of the brownish scales; nut compressed-3-angled, acute. Bogs and swamps. June-August. Culm $2^{\circ}-3^{\circ}$ high ; leaves $10^{\prime}-18^{\prime}$ long.

\section{FIMBRISTYLIS, Vahl.}

Spikes many-flowered; scales imbricated in several rows; perianth none; stamens $1-3$; style 2-cleft, commonly flat and fringed on the margins, tumid at the base, deciduous; nut lenticular. Culms jointless, leafy at the base; involucre 1-several-leaved; spikes terminal, umbellate or clustered.

* Spikes umbelled.

F. Spadicea, Vahl. Perennial; culms clustered, nearly terete, rigid $\left(2^{\circ}-3^{\circ}\right.$ high $)$; leaves long, linear or filiform, concave, rough on the margins; umbel simple or compound, erect; involucre 2-3-leaved; spikes ovate or oblong, dark brown; scales smooth, rigid, rounded; nut obovate, acute, slightly furrowed and pitted. (Scirpus castaneus, Michx.; S. ferrugineus, Ell.) Salt marshes. AugustOctober.

\section{TRICHELOSTYLIS, Lestib.}

Spikes terete, many-flowered; scales imbricated in few (4-8) rows; perianth none; style 3-cleft, tumid at the base, deciduous; nut 3 -angled. Culms jointless, leafy at the base; spikes umbelled.

T. actumnalis. Culms slender, flat, 2-edged, $6^{\prime}-12^{\prime}$ high, tufted; involucre 2-leaved, mostly shorter than the 
simple compound or decompound umbel; spikes linearlanceolate; scales ovate-lanceolate, mucronate, imbricated in 4 rows; stamens 2 ; nut white, obovate, obtuse, often warty. (Scirpus autumnalis, L.) Low grounds. Very common. July-October. Annual.

\section{ISOLEPIS, R. Br.}

Spikes few-many-flowered; scales imbricated in fewseveral rows; perianth none; style 3-cleft, the tumid base persistent at the apex of the 3-angled nut. All annuals (in our species), with filiform or bristle-form culms and leaves; spikes umbelled or clustered; leaves radical.

* Spikes umbelled. (Scales pubescent.)

I. CAPILlaris, R. and S. Culm $\left(4^{\prime}-6^{\prime}\right.$ high $)$ smooth, furrowed, and, like the rough-edged leaves, bristle-like; spikes $3-4$, in a single umbel, oblong, 6-8-flowered; scales oblong, obtuse, strongly keeled, brown on the sides, imbricated in 4 rows; nut obovate, obtuse, nearly equal-sided, transversely wrinkled; stamens 2. (Scirpus capillaris, L.) Moist sandy places. June-September. Sheaths of the leaves bearded at the throat; involucre $2-3$-leaved, scarcely longer than the umbel.

I. coarctata, Torr. Culms $\left(1^{\circ} \mathrm{high}\right)$ terete, filiform; leaves bristle-form, smooth, with the sheaths bearded; umbel compound, contracted; spikes ( $3^{\prime \prime}$ long) linearoblong, 10-15-flowered; scales ovate, acutish, imbricated in 4 rows; nut flat on the inner face, obtuse-angled in front, obscurely dotted. (Scirpus coarctatus, Ell.) Dry sandy soil, near the coast. September and October. Rays of the umbel $\frac{1^{\prime}}{2}$ long.

\section{RHYNCHOSPORA, Vahl. BEAK-RUSH.}

Spikes 1-several-flowered; scales imbricated in few rows, the lowest empty, the upper usually bearing imperfect 
flowers; perianth of 3-6 (rarely 12-20) hispid or plumose bristles, occasionally wanting; stamens mostly 3 ; style 2-cleft; nut lenticular or globose, crowned with the dilated and persistent base long as the nut.-Var., GLOBULARIS. Smaller $\left(6^{\prime}-15^{\prime}\right.$ high $)$; corymbs reduced to few globoseovate dark-brown clustered spikes; nuts smaller, and deeper furrowed. Low ground. June and July.

R. PUnctata, Ell. Culms ( $1^{\circ}-2^{\circ}$ high $)$ slender, 3 -angled; leaves short, linear-lanceolate; corymbs $3-4$, cluster-like, the lateral ones simple, distant, and long-peduncled; spikes orate; nut obovate, compressed, with transverse pitted furrows, rather shorter tha! the 6 slightly hispid bristles; tubercle conical, compressed, shorter than the nut. May and June.

* Nut smooth and evsn; bristles hispld upward.

R. ciliata, Vahl. Culms blunt-angled $\left(1^{\circ}-2^{\circ}\right.$ high); leaves short, glancous, linear-lanceolate, obtuse, fringed on the margins; corymbs mostly solitary, capitate; spikes light brown, ovate; nut oval, lenticular, minutely roughened; tubercle flat, conical; bristles $6, \frac{1}{3}$ the length of the nut; stamens 3. Wet pine-barrens. June-August. Leaves 2 '-4' long; lateral corymb (when present) remote.

\section{** Nut smooth and evien; bristles hispid dononward.}

R. ALbA, Vahl. Culms $\left(1^{\circ}-2^{\circ}\right.$ high $)$ slender, 3 -angled above; leaves narrowly linear or setaceous; corymbs mostly 2, capitate, white, turning brownish, the lower one longpeduncled; spikes ovate-lanceolate, 1-flowered; nut obovate, lenticular, twice as long as the compressed subulate tribercle; bristles 10-20, rigid, as long as the nut and tubercle, ciliate at the base. Wet springy places. August and September.

\section{CERATOSCHCENUS, Nees. Horned Rush.}

Spikes few-flowered; scales loosely imbricated, the lower ones empty, the upper with staminate or abortive flowers; 
periunth of 4-6 bristles, which are dilated and connate at the base; stamens 3 ; style elongated, entire or slightly 2-cleft at the apex; nut compressed, crowned with the persistent and hispid lower half of the style. Peremnials. Culms jointed, leafy; spikes scattered in an open corymb, or clustered in a globose head.

C. cornicllates, Nees. Culms stout $\left(3^{\circ}-4^{\circ}\right.$ high $)$, 3 -angled; leaves flat, scabrous on the edges $\left(6^{\prime \prime}-10^{\prime \prime}\right.$ wide); corymbs 3-5, erect, compound; spikes brown, ovate-lanceolate; style very long, the lower and persistent portion upwardly scabrous; nut narrowly obovate, smooth, the sides concave and minutely dotted; bristles 5-6, rigid, smoothish, half as long as the nut; tubercle subulate, $3-4$ times the length of the nut. (Rhynchospora longirostris, Ell.) Ponds and ditches. "July-September. Leaves $1^{\circ}-2^{\circ}$ long; nut and tubercle nearly $1^{\prime}$ long.

\section{CLADIUM, Browne.}

Spikes ovate, 1-2-flowered; scales loosely imbricated, the lower ones empty; perianth none; stamens 2; style 2-3cleft, the divisions often $2-3$-cleft, deciduous ; nut globoseovate, the pericarp thickened and corky near the apex; tubercle none. Culnis tall; spikes disposed in axillary and terminal cyme-like panicles.

C. Effesty, Torr. (Saw-grass.) Culms $\left(4^{\circ}-8^{\circ}\right.$ high) nearly terete; leaves linear, elongated, saw-edged; panicles numerous, diffuse; spikes small, 3-4 in a cluster, deep brown; scales about 6 , the uppermost bearing a perfect flower, the next below staminiferous, the others empty; nut ovate, pointed, wrinkled. - (Schœnus effusus, Swartz.) Fresh or brackish marshes along the coast. July and August.

\section{SCLERIA, L. NUT-RUSH.}

Flowers monœcions; sterile spike fen-many-flowered; scales loosely imbricated in 2-3 rows; fertile flowers soli- 
tary, separate or at the base of the sterile spike; stamens 1-3; style 3-cleft; nut globose or ovate, stony or bony.Chiefly perennials, with creeping rootstocks, and triangular leafy culms ; spikes clustered, lateral and terminal.

\$ Sclenia proper. Nut supported by an annular or 3-6.lobed disk.

* Nuts reticulated; disk of 3 fluttened lobes; stamens 2.

S. LAXA, Torr. Culms weak, rough on the angles; lecuves linear, obtuse; spikes sepurate, the axillary ones on a long and drooping peduncle; nut globose, wrinkled and somewhat hairy, obscurely pitted; lobes of the disk appressed to the nut. (S. reticularis, Ell.) Damp pine-barrens. August-October. Culms $1^{\circ}-1 \frac{1}{2}^{\circ}$ long; nut $1 \frac{1}{2}^{\prime \prime}-2^{\prime \prime}$ in diameter.

** Nut warty ; disk bearing 3-6 globular lobes; stamens 3.

S. Elliottir. Culms stout $\left(\frac{1}{2}^{\circ}-1^{\circ}\right.$ high), densely roughfringed on the angles throughout; leaves 3-4, broadly linear $\left(2^{\prime \prime}-3^{\prime \prime}\right.$ wide), closely fringed on the margins and midrib beneath; sheaths pubescent; clusters 2 , the lateral one remote, on a short erect peduncle; sterile spike small, few-flowered; nut globose, deeply wrinkled or pitted, and with slender warty projections at the base; lobes of the disk 3, globose, 2-lobed. (S. hirtella, Ell., Michx. ? not of Swartz.) Low pine-barrens.

§ HYPO PORUM. Disk none; nut concave and often pitted at the sides of the triangular base.

* Clusters of spikes (small) numerous, scattered near the summit of the culm, forming an interrupted compound spike; bracts mostly short.

S. FILIFormis, Swartz. Glancous; culms slender $\left(1 \frac{1}{2}^{\circ}-2^{0}\right.$ high), smooth; leaves narrowly linear, rough on the margins and keel, ciliate at the throat; clusters 3-4, erect, few-flowered, the lowest remote, leafy-bracted ; scales lanceolate, rough-pointed; stamens 3 ; nut oborate, obscurely 3 -angled, smooth and glassy, concave at the base, not pitted. October. 
S. Michauxir. Culms $\left(6^{\prime}-12^{\prime}\right.$ high) smooth; leaves linear, and, like the sheaths, hairy ; clusters 4- $t$, nodding; scales bristle-awned; nut globose-3-angled, very minute, pointed, smooth, not pitted at the base. (S. interrupta, Michx., not of Richard.) Low pine-barrens. July and August.

\section{CAREX, L. SEDGE.}

Flowers monœcious, rarely diœcious, spiked; sterile and fertile flowers in the same spike (androgynous), or in separate spikes; scales imbricated in few-many rows; stamons $2-3$; style $2-3$-cleft, exserted from a sac (perigynium) which incloses the ovary and the lenticular biconvex or 3 -angled nut.-Perennials, with grass-like leaves; spikes fiom the axils of scale-like or leaf-like bracts, simple or compound.

§ VIGNeA. Stigmas two; nut lenticular, or more or less compressed.

* Spikes with the upper flowers sterile, the lower fertile.

+ Spikes indefinite, disposed in a close panicle.

¥ Perigymia shrot-stalked, truncate at the base.

C. CRUs-Convi, Shuttleworth. Panicle very large, the lower branches long and distinct, the upper short and crowded; perigynia plano-convex, ovate, strongly nerved, dilated at the base, tapering into a long and slender ronghedged deeply 2-cleft beak, thrice the length of the ovatemucronate scale. River swamps. May. Culms thick and spongy, sharp-angled, and, like the broad $\left(\frac{1}{2}^{\prime}-3^{\prime}{ }^{\prime}\right.$ wide) leavıs, gla:ıcous ; panicle $4^{\prime}-9^{\prime}$ long. oblong or spike-like ; pərigynia widely spreading, brown at maturity.

C. Muhlenbergir, Schk. Spikes 5-8, ovoid, approximate, or crowded in an oblong head; perigynia roundovate, plano-convex, strongly nerved, with a short and broad rough-edged 2-cleft beak, barely longer than the o rate short-pointed scale. Dry sterile soil. Culms $12^{\prime}-18^{\prime}$ 
high, rigid, rough above, twice as long as the narrow leaves; head or spike 1' long; bracts bristle-form, longer than the spikes. Cache Creek.-Marcy.

** Spikes with the lower flowers sterile, the upper fertile.

C. STElltlata, Good. Spikes 3-5, obovoid, distinct, the uppermost club-shaped at the base; perigynia ovate, rounded at the base, tapering into a short and rough 2-cleft beak, finely nerved, spreading and finally recurved, jather longer than the ovate pointed scale. (C. scirpoides, Schk.) Shady river-swamps. Culms $6^{\prime}-12^{\prime}$ high, weak; leaves narrow and tender; spikes small.

Var., STERILIS. Sterile and fertile spikes on separate culms, or some of them either sterile or fertile on the same culm, otherwise like the preceding, and growing in similar places. (C. sterilis, Willà.)

Var., coxferta. Culms taller $\left(2^{\circ}\right.$ high $)$ and stouter; spikes larger and more crowded; perigynia round-orate, twice as long as the broadly ovate barely pointed scale. Pine-barren swamps.

C. Straminea, Schk. Spikes 3-6, distinct, ovoid; perigynia ovate or round-ovate, broadly winged, abruptly narrowed into a short 2-cleft beak, somewhat tawny and spreading at maturity, longer than the ovate-lanceolate scale.

Var., Festucacea. Spikes 6-8, pale, obovoid or somewhat club-shaped, scattered; perigynia ovate, less broadly mirgined, tapering into a more slender beak, erect and pale green at maturity. (C. festucacea, Schk.; C. fœnea, Torr., etc., a form with more rigid culms, and more crowded and glaucous spikes.) Swamps, very common. Culms $1^{\circ}-2^{\circ}$ high; leaves narrowly linear, shorter than the culm. Trinity River. 
8 CAREX proper. Stigmas 3; nut 3-angled; spikes 2 or more.

* Spikes monacious; terminal spikes sterile below, fertile above; the others chiefly fertile.

$\uparrow$ Perigymia leafless.

¥ Spikes remote, linear or cylindrical, rather loosely flowered, on long and mostly drooping peduncles; bracts long and leaf-like; perigynia smooth, someiohat inflated, few and faintly nerved.

C. oxrlepis, Torr. and Hook. Spikes 4-5, linear, all on long bristle-like partly included nodding peduncles, distant; perigynia oblong, acute-angled, emarginate at the pointed apex, longer than the lanceolate rough-pointed white scale. Low ground. Culms slender, $11^{\circ}-2^{\circ}$ high, the lower part, like the leares and sheaths, pubsscent.

C. Gracillima, Schw. Spikes 3-5, distant, linear, on slender and nodding peduncles; perigynia oblong, obtuse, entire and oblique at the orifice, about twice as long as the oblong obtuse short-awned scale. Wet lands. Culm $1^{\circ}-2^{\circ}$ high ; spikes $1^{\prime}-1 \frac{1^{\prime}}{2}$ long, thicker than those of the preceding; sheaths smooth.

Spikes cylindrical or oblong, densely many-flowered; perigymia ovate or roundish.

C. Cherokeexsis, Schk. Sterile spikes 2-4, slender; fertile spikes $5-15$, often $2-3$ from the same sheath, oblong or cylindrical, sterile at the summit, all on long and nodding peduncles; perigynia whitish, oblong, compressed-3-angled, short-beaked, with the orifice membranaceous and obliquely 2-cleft, longer than the oblong acute scale; stigmas elongated.-Plant whitish; culms $1^{\circ}-2^{\circ}$ high, smooth, like the linear leaves.

\section{GRASS FAMILY. Order, Graminex.}

Chiefly herbs; stem (culm) mostly hollow and with closed joints; leaves alternate, 2-ranked, narrow and entire; sheaths open or split on one side, and usually prolonged into a membranaceous or fringed appendage (ligula) at the base of the blade; flowers in spiked or panicled 
spikelets, consisting of 2-ranked imbricated bracts or scales, of which the exterior or lower ones, subtending one or more flowers, are called glumes, and the two inner ones, inclosing the 1-celled 1-ovuled ovary, and 1-11 (commonly 3) hypogynous stamens, are called palece; perianth none, or composed of 1-3 minute hypogynous scales (squamula); anthers versatile, 2-celled; styles $2-3$, with hairy or plumose stigmas; fruit a caryopsis (grain); embryo placed on the outside and near the base of mealy albumen; root fibrous.

\section{SYNOPSIS.}

Tribe I. Oryzeæ. Spikelets 1-flowered, mostly imperfect. Glumes none. Palea 2. Stamens 1-11.

Flowers perfect, compressed-panicled. Palea unequal, ciliate............. LeEnsia. - monocious; the pistillate and staminate ones in the same panicle..Zizania. in separate spikes.

HYDRocHLA. dicecious, in terminal spikes. Monanthochloe.

Tribe II. Agrostideæ. Spikelets 1-flowered, or with the pedicel of a second flower above. Glumes 2 . Palea mostly 2, the lower one often awned. Stamens 1-3. Spikelets in open or closely spiked panicles.

\section{* Glumes united at the base, strongly compressed-keeled.}

Lower palea awned on the back, the upper wanting. Flowers spiked. . Alopecurus.

** Glumes distinct, concare or keeled ; palea membranaceous ; grain free ; spikelets in open or contracted panicles.

Flowers awnless. Seed loose in the globose or obovoid pericarp ........ Srononouts. Palece shorter than the rearly equal glumes, the lower awned on the back, the upper sometimes wanting ...................................................

Lower glume smaller than the upper one. Palea bearded at the base, the lower one mucronate or awn-pointed. Stamens $3 \ldots \ldots \ldots \ldots \ldots \ldots \ldots$ MUHLENBERGIA.

*** Palece raised on a hairy stalk; the lower one awned, indurated, and involute, closely investing the grain.

Lower palea with a single contorted awn jointed with its apex. Panicle short. 
Tribe III. Chlorideæ. Spikelets 2-several-flowered in 1-sided spikes. Rachis jointed. Upper flower's imperfect. Glumes and palece 2. Spikes racemed or digitate, rarely single.

\section{* Spikelets 2-3-flowered, only the lowest flower perfect.}

Spikelets linear, scatlered. Lower palea and rudiment auned. Spikes racemed. GYMNOPOGON.

roundish, crowded. mucronate. Spikes digitate. EustacHYs.

Lower palea awnless. Culms creeping. Slikies digitate.............. Cxnodon.

** Spikelets mostly several-flowered the lower flowers perfect.

Spikes digitale. Upper glumes awned. Palea pointed......... Dactrloctenrom. Glumes and palea awnless... .................... ELEusine. racemed, long and slender. Glumes awnless. .LEPTOCHLOA.

'T'ribe IV. Festucaceæ. Spikelets panicled, fewmany-flowered, the upper flowers imperfect. Glumes 2. Palece 2, membranaceous or rarely indurated, awnless, or the lower one with a straight awn at or near the apex. Stamens 1-3.

* Grain smooth, free frm the palea; lower Nowers perfect.

† Lower palea 3-5-tosthed or awned.

Spikelets 5-7-flowered. Lower palea slightly 2-cleft, the 3 hairy nerves percurrent. TRICUSPIS.

t+ Lower palea entire, awnless or awn-pointed.

$\ddagger$ Glumes unlike, the lower one linear, the upper obovate.

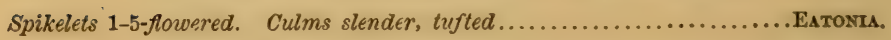

¥‡ Glumes alike; lower palea round:d on the back, not keeled.

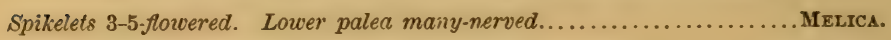
spikelets 5-many-fowered. Lower palea strongly 7-nerved............ GLrceria. Spikelsts lonsely many-flowered. Culms woody ................... Anundinaria. Spikelets dicecious. Lower palea rigid..................... Brizoprnum.

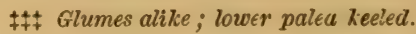

Palece falling avry tirethor, the lower one 5-nerved, and with cobwebby hairs at

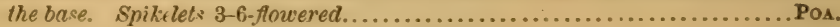
Lower palea falling before the upper one, 3-nerved, not hairy.......... Eratarosris. aun-pointed. Panicle contracted, composed of 1-sided clusters.

Dictruis. 
** Grain adherent to the upper palea, downy at the arex.

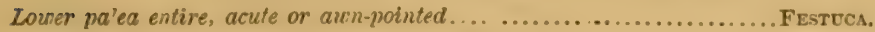
- 2 -clefl, aroned between the teeth........................... Brosrus.

*** Gruin free, smooth; lowest flo:vers of the spike'ets imperfect.

Spikelets broad and flat, many-flowered. Falea coriaceous............ Uxrou.

T'ribe V. Hordeaceæ. Spikelets 2-several-flowered, sessile, on opposite sides of the jointed rachis, spiked. Glumes 1-2, rarely wanting. Palece 2.

Spikelets 2-4 at each joint of the rachis. Glumes 2, placed side by side before the

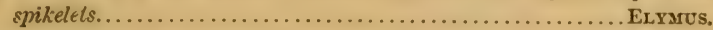

$2-3$ at each joint of the rachis. Glumes none........... Grмnostichuм.

Trube VI. Avenaceæ. Spikelets panicled, 2-sereralflowered, the terminal flowers mostly imperfect. Rach is or base of the flowers often bearded. Lower palea with a twisted, bent, or straight awn on the back, or below the apex.

Spikelets 2-several-flowered. Lower palea thin, compressed-keeled, bearing a bent awn below the 2 cleft apex........................... TrisetcM.

2-flowered, the lower flower staminate, and bearing a long bont aicn

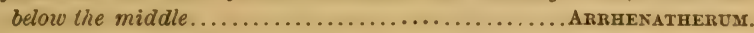

Tribe VII. Phalarideæ. Spikelets in spike-like panicles, 3-flower d, the upper or midale flower perfect, the two lateral ones imperfect or mere rudiments. Glumes 2. Palece 2, indurated in fruit.

Lateral flowers rudimentary. Perfect flowers triandrous............... PhaLaris.

T'ribe VIII. Paniceæ. Spikelets 2-flowered. Glumes 2, or the lower wanting. Lower fower imperfect, either staminate or neutral, with the lower palea membranaceous and similar to the upper glume, the upper one mostly wanting. Palea of the perfect flower coriaceous. Grain mostly grooved or flattened on the outside. Flowers in spikes or panicles.

* Lower glume and upper palece of the sterile flocer wanting (the spikelet appearing like a single flower, with 2 glumes and 2 palea).

Spikel:ts alike, plano-conver, in 1-sided spikes. Paspalua. 
** Glumes 2, the lower one oflen minute, rarely wanting.

Spikelets single, without a bristly or spiny involucre................. PAsicuss. - - single, or few in a cluster, inclosed in an indurated and spiny involucre; spikelets spilied....................................... Spikes and spikelets as in Roltbollia, but the flower's as in Panicum.. Stenotaphrum.

Tribe IX. Rottbœlliaceæ. Spikelets 1-2-flowered, by pairs, imbedded in an excavation of the thick and jointed rachis, one stalked and imperfect, the other sessile and perfect; or the upper spikelets all staminate and the lower pistillate. Lower glume coriaceous or cartilaginous. Palece awnless.

Spikelets 2 on each joint, one stalked and sterile, the other sessile and perfect.

ROTTBCELLA.

2 on each joinl, the one at the top of the joint sterile, the other at the

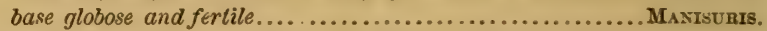

Upper spikelets by pairs, all staminate; the lonver ones single, and pistillate.

Tripsacum.

TRIBE X. Andropogoneæ. Spikelets 2-3 on each joint of the slender hairy or plumose rachis. Glumes more rigid than the thin-awned paleæ.

Spikelets 2 on each joint of the plumose or hairy rachis, one sessile and perfect, the other stalked and imperfect or rudimentary......... ANDROPOGON.

- 2 on each joint of the rachis, both fertile and surrounded by a hairy involucre ..................................... Erranthus.

panicled, 2-3 together, the latter ones rudimentary............. Sorghum.

LEERSIA, Swartz. False Rice.

Perennial aquatic or marsh grasses, with the leaves and sheaths roughened with minute recurved points, the 1-flowered (whitish) spikelets crowded in 1-sided panicled racemes; pedicels jointed; glumes none; palece 2, chartaceous, strongly compressed, fringed on the keel, the lower one much wider; stamens 1-6; stigmas 2 ; grain compressed.

L. onyzordes, Swartz. Panicle large, diffuse; spikelets oblong, flat, loosely imbricated; stamens 3. Ditches and swamps. July and August. Cuim $3^{\circ}-4^{\circ}$ long, commonly 
prostrute at the base; leaves spreading; base of the panicle mostly inclosed in the sheath of the subtending leaf; spikelets strongly fringed, about $3^{\prime \prime}$ long.

L. Virginica, Willd. Panicle nearly simple, the lower branches spreading; spikelets small, concave, sparingly fringed, closely imbricated; stamens 1-2. (L. imbricata, Lanı.?) Swamps and margins of streams. July and August. More slender than the last, and with spikelets half as large.

\section{ZIZANIA, Gron. Wild Rice.}

Rank water-grasses, with broad flat leaves, and large diffuse panicles of monœcious 1-flowered spikelets, on clubshaped jointed pedicels; glumes none, or reduced to a cup-shaped ring at the base of the spikelet; palece 2, membraniceous, the lower one rough-awned in the pistillate spikelet; stamens 6 ; stigmas elongated, brush-shaped; grain cylindrical, free.

Z. AqUatica, L. Lower portion of the panicle staminate and widely spreading, the upper pistillate and erect, with straight branches; awn straight, elongated; styles 2; grain linear. Deep marshes and ponds. July. Culms $4^{\circ}-8^{\circ}$ high; leaves rough beneath; panicle $1^{\circ}-2^{\circ}$ long.

\section{ALOPECURUS, L. Foxtail Grass.}

Flat-leaved grasses, with the 1-flowered spikelets closely crowded in a simple spike-like cylindrical panicle; glumes 2 , compressed, boat-shaped, sharply keeled, united below, awnless; lower palece compressed, awned on the back below the middle, the upper wanting; stamens 3 ; styles 2 , rarely united below; grain free, smooth and lenticular.

A. Gericulatus, L. Low ; culms ascending, bent at the lower joints; awn longer than the obtuse hairy glume. Wet cultivated grounds. April. Culms $66^{\prime}-12^{\prime}$ high; 
leaves $2^{\prime}-4$ ' long, with the sheaths shorter than the joints; spikes $1^{\prime}-1 \frac{1}{2}{ }^{\prime}$ long.

\section{SPOROBOLUS, Brown. Drop-SEed Grass.}

Tough wiry and tufted or creeping perennial grasses, with narrow leaves, and 1-flowered awnless spikelets, disposed in open, or crowded in spiked panicles; glumes 2, membranaceous, unequal, the lower one shorter; palece 2, mostly longer than the glumes, and of the same texture; stamens 3 ; styles 2 ; grain oval or globose, loose in the thin membranaceous pericarp, deciduous ; panicles ex serted.

\section{* Panicles open.}

S. Jurceus, Kunth. (Wire Grass.) Panicle narrow, the short and spreading branches whorled; spikelets on one side of the branches, short-stalked; glumes smooth, the upper one acute, 2-3 times longer than the lower, and about equal to the obtuse paleæ; culms $\left(1^{\circ}-2^{\circ}\right.$ high) erect; leaves chiefly radical, filiform and elongated, involute, those of the culm short and remote. (Agrostis juncea, Michx.) Dry pine-barrens, common. April and May, and often in October.

\section{** Panicles spiked.}

S. Virginicus, Kunth. Culms creeping, short-jointed, the short and mostly clustered branches erect; leares 2-ranked, soon convolute, short and rigid; panicle small, lanceolate; glumes nearly equal, acute, rather longer than the paleæ. (Agrostis Virginica, L.) Saline marshes and banks along the coast. July and August. Flowering stems 6 '-12' high; leaves '2'-4' long; panicle $1^{\prime}-2$ ' long, pale or purple.

\section{Agrostis, L. Bent Grass.}

Tufted usually tender grasses, with flat and narrow leaves; the small 1-flowered spikelets racemose on the hairlike clustered branches of the open panicle, on thickened 
pedicels; glumes 2, nearly equal, longer than the palex; palece 2 , the lower one commonly awned on the back, 3-5nerved, the upper 2-nerved, occasionally minute or wanting; stamens 1-3; styles or stigmas 2; grain free.

\$1. TRICHODIUM. Upper palea minute or wanting, the lower awnless, shorter than the unequal acute rough-keeled glumes.

A. SCABra, Willd. Culms slender, erect; leaves short; branches of the panicle long, hair-like, hispid, bearing the purple spikelets near their summits. ('T. laxiflorum, Ell.) Sterile soil. June and July. Panicle usually as long as the culm. Annuals.

§2. Agrostis proper. Upper palea manifest, the lower commonly awned on the back.

A. rUPestris, All. Culms slender, erect; panicle small, oblong, with erect smooth branches; glumes lanceolate, nearly equal, rough-keeled; lower palea one-third shorter than the glumes, short-awned below the middle, the upper one minute. July. Culms $1^{\circ}$ high.

\section{POLYPogon, Desf. Beard Grass.}

Flat-leaved chiefly annual grasses, with the 1-flowered spikelets stalked, and crowded in close clusters into a terminal spiked panicle; glumes 2, equal, awned, and much longer than the paleæ, of which the lower one is truncated and toothed at the apex, and often short-awned; stamens 3 ; stigmas 2 ; grain elliptical, free.

P. Maritiuus, Willd. Culms simple $\left(6^{\prime}-8^{\prime}\right.$ high $)$; glumes pubescent, hispid on the keel, one-third as long as the slender awns; lower palea 4-toothed, unawned. (Phleum pratense, Ell., Herb.) Sea-shore.

\section{MUHlendergia, Schreb. Drop-seed Grass.}

Spikelets 1-flowered; glumes persistent, pointed or awned, equal, or the lower one smaller; palece 2, sessile in the 
glumes, commonly hairy at the base, deciduous with the inclosed grain, the lower one 3-nerved and mucronate or awned at the apex; stamens 3.

Mchundergia proper. Spikelets commonly much crowcied, in lateral and terminal panicles, short-stalked; culms branching ; leaves flat.

M. Willdenovir, Trin. Culms sparingly brauched, erect; panicles linear; spikelets scattered; palea twice as long as the nearly equal short-pointed glumes, the lower one with an awn 3-4 times as long as the spikelet. (Agrostis tenuiflora, Willd.) Dry rocky soil. July and August. Culms $3^{\circ}$ high.

M. Diffusa, Schreb. Culms diffusely branched, low; panicles long and slender; glumes very small, the upper one truncated; awn of the palea twice as long as the spikelet. Shaded waste places. August and September. Culms $1^{\circ}-1 \frac{1}{2}^{\circ}$ high.

\section{STIPA, L. Feather Grass.}

Perennial grasses, with convolute leaves, and loose pamcles of 1 -flowered spikelets, with rery long awns; glumes 2 , membranaceous, nearly equal, awnless and persistent; palece coriaceous, involute, raised on an obconical bearded stalk, the lower one with a twisted or contorted awn jointed with its apex; stamens 3 ; grain terete, inclosed in the paleæ.

S. Avenaces, L. Culms $\left(1^{\circ}-2^{\circ}\right.$ high) clustered; leaves narrowly linear, rough, the lowest elongated; awn pubescent, bent in the middle, many times longer than the darkbrown palea. Dry soil. April.

\section{ARISTIDA, L. Wire Grass.}

Dry and harsh perennial grasses, growing in barren soil, with narrow leaves, racemose or spiked-panicled 1-flowered spikelets nearly as in Stipa, but the lower palea ending in a triple awn, which is continuous with its apex; upper palea minute; grain linear. 
* Glumes unequal, the upper one shorter.

A. Purpurascens, Poir. Culms $\left(1_{\frac{1}{2}}^{\circ}-2^{\circ}\right.$ high) slender, sparingly branched; sheaths smooth; glumes sometimes nearly equal, purple; lower palea ( $3^{\prime \prime}$ long) $\frac{1}{2}-\frac{1}{3}$ as long as the nearly equal awns. Dry soil. August. Panicle slender, $1^{\circ}$ long, with the branches appressed.

\section{** Glumes equal, or the upper one longer.}

A. Gracilis, Ell. Culms much branched at the base, very slender; leaves flat; panicle very narrow, with distant appressed branches; middle awn rather longer than the rough and spotted lower palea, the lateral ones much shorter; glumes nearly equal. Dry gravelly soil. August. Culms (with the panicle) $6^{\prime}-12^{\prime}$ high; spikelets purple.

A. SPICIFORMIS, Ell. Culms simple, rigid, erect $\left(1^{\circ}-1_{2}^{\circ}\right.$ high); leaves rigid, erect, convolute, smooth; panicle spiked; glumes much shorter than the long $\left(1^{\prime}\right)$ very slender paleæ, the upper one twice as long as the lower; awns nearly equal, widely spreading, the middle one as long as the paleæ. Low pine-barrens. August and September. Panicles $2^{\prime}-4^{\prime}$ long, at length twisted.

A. tuberculosa, Nutt. Culms rigid, branching $\left(1^{\circ}-1 \frac{1}{2}^{\circ}\right.$ high); leaves flat; glumes nearly equal, longer than the paleæ, bristle-awned; awns ( $2^{\prime}$ long) equal, jointed with the paleæ, twisted below, then widely spreading, several times longer than the paleæ. Dry ridges. September. Panicle simple.

\section{GYMNOPOGON, Beauv.}

Low perennial grasses, with short and crowded distichous spreading leaves; spikelets appressed, scattered on the straight and at length reflexed branches of the simple panicle, consisting of one perfect flower, and the awn-like pedicel of a second flower above; glumes 2 , subulate, hispidserrulate; palece 2 , shorter than the glumes, the lower one awned under the apex; stamens 3 . 
G. Racemosus, Beauv. Culms $\left(1^{\circ}\right.$ high) rigid; leaves lanceolate $\left(1 \frac{1}{2}^{\prime}-2^{\prime} \mathrm{long}\right)$; branches of the panicle bearing the linear spikelets from the base to the summit; awn 2-3 times the length of the paleæ and the pedicel of the sterile flower. (Andropogon ambiguus, Michx.) Var. Filiformis has narrower leaves, the spikelets borne above the middle of the branches, and the awns and sterile pedicel shorter than the paleæ. Dry sandy soil. September and October.

\section{EUS'TACHYS, Desv.}

Chiefly tropical grasses, with compressed culms and sheaths, distichous flat or folded obtuse leaves, and digitate rarely single spikes; spikelets $2-3$-flowered, imbricated or crowded in 2 rows on one side of the triangular rachis; the lowest flower perfect and sessile, the upper ones staminate or neutral, and stalked; glumes 2, membranaceous, persistent, the upper (exterior) one short-awned; palece coriaceons, the lower one boat-shaped, mucronate-awned under the apex, the upper (mostly wanting in the sterile flowers) unawned; stamens 3 ; grain free.

E. PETr Aa, Desv. Culms $\left(1^{\circ}-2^{\circ}\right.$ high) clustered, erect; leaves glancous; spikes $3-5$; spikelets 2-flowered; glumes hispid, the upper oblong, deeply emarginate; lower palea dark brown, hairy on the keel and margins, bearded at the base; sterile flower neutral, club-shaped, awnless. Damp soil along the coast. May-August. Leaves $3^{\prime}-5^{\prime}$ long; spikes erect; spikelets roundish. Perennial.

\section{CYNODON, Richard. BERMUda Grass.}

Diffusely creeping grasses, with short and erect flowering stems, and flat leaves; spikes digitate, 1-sided; spikelets crowded, awnless, 2-flowered, the lower flower perfect, the upper an awn-like pedicel; glumes 2, membranaceous, nearly equal; palece 2 , membranaceous, the lower one larger and keeled; stamens 3 ; grain free. 
C. Dactrlon, Pers. Spikes 3-5, filiform, purple; glumes rough-keeled; patea longer than the glumes, the lower one boat-shaped, and hairy on the keel; anthers and stigmas purple. (Digitaria Dactylon, Ell.) Waste places. Culms perenuial ; leaves $2^{\prime}-4^{\prime}$ long; spikes $1^{\prime}-2^{\prime}$ long, filiform.

\section{DACTYLOCTENIUM, Willd. Crowroot Grass.}

Annual creeping or spreading branching grasses, with flat leaves and digitate rarely single spikes; spikelets 2-sereral-flowered, crowded on one side of the flattened rachis; the uppermost flower imperfect; glumes 2, compressed-keeled, membranaceous, the upper (exterior) awnpointed; palece 2 , boat-shaped, pointed; stamens 3 ; stigmas plumose, with branching hairs; grain roundish, rugose, free.

D. Aggrptiacus, Willd. Culms ascending from a creeping base; leaves fringed; spikes commonly 4, awn-pointed; spikelets 3 -flowered. (Eleusine? cruciata, Ell.) Cnltivated ground, common. Culms numerous, $1^{\circ}$ high ; spikes $1^{\prime}-2^{\prime}$ long.

\section{ELEUSINE, Gært.}

Characters chiefly of Dactyloctenium, but the narrower glumes and palece obtuse and awnless; stigmas plumose, with simple hairs; spikelets closely imbricated. Low annuals. .

E. Indica, Gært. Cultivated ground, very common. Culms $\left(6^{\prime}-18^{\prime}\right.$ high) flattened; leaves flat; spikes 2-several, the lower ones sometimes scattered $\left(2^{\prime}-4^{\prime}\right.$ long); spikelets 6 -flowered.

\section{LEPTOCHLOA, Beanv.}

Flat-leaved grasses, with the numerous spikes disposed in a terminal raceme; spikelets sessile, loose on one side of the elongated filiform rachis, 3-many-flowered; glumes 2, 
membranaceous, unequal, keeled; palece 2, membranaceous, the lower one longer than the upper, 3-nerved, awned or unawned; stamens 3 ; grain oblong, free.

\section{LEPTOChLOA proper. Lower palea unawned.}

L. mucrosata, Kunth. Culms $2^{\circ}-3^{\circ}$ high ; sheaths of the broad $\left(4^{\prime \prime}-6^{\prime \prime}\right.$ wide) rough leaves hairy; spikes numerous, in an elongated raceme, $2^{\prime}-4^{\prime}$ long, spreading; spikelets minute, 3-4-flowered; glumes mucronate, longer or shorter than the flowers; lower palea smooth, enarginate. (Eleusine mucronata, Michx.) Cultivated fields. AngustSeptember.

\section{TRICUSPIS, Beauv.}

Perennial grasses, with tall, erect, simple culms, from a thick and scaly rootstock, elongated rigid leaves, and orate or lanceolate 5-\%-flowered stalked spikelets, disposed in a simple or compound open panicle; glumes 2 , smooth, emarginate, shorter than the crowded flowers; palece 2, 2-cleft, the lower one shortly 3 -awned by the percurrent hairy nerves, bearded at the base ; stamens 3 ; grain obovate-oblong, free.

T. Sesslerioides, Torr. Panicle ample and diffuse, or contracted and erect, bearded in the axils ; spikelets terete, lanceolate, mostly purple; lower palea with two awn-like teeth similar to the three short awns. (Poa quinquifida, Pursh.) Dry soil. Angust and September. Culms $3^{\circ}-5^{\circ}$ high; sheaths often hairy.

\section{EATONIA, Raf.}

Slender erect and tufted grasses, with narrow ieaves, and small smooth (not hairy) spikelets of pale flowers in a racemose or spicate panicle; spikelets awnless, $2-5$-flowered, the uppermost flower usually an awn-like peciicel; glumes membranaceous, shorter than the flowers, the lower one 
linear and 1-nerved, the upper obovate, 3-nerved; palece mequal, the lower one obtuse; stamens 3 ; grain linearoblong.

E. Pennsylvanica, Gray. Panicle slender, loose, the 2-3-flowered spikelets scattered on the slender branches; glumes slightly roughened on the back, the upper one obovate, obtuse, or abruptly short-pointed; lower palea obtuse; leaves flat, with the sheaths smooth, rough, or soft-downy. (Aira mollis, Ell.) Upper districts. April. Culms $1^{\circ}-2^{\circ}$. Perennial.

\section{MELICA, L.}

Perennial grasses, with flat leaves, and 3-5-flowered spikelets of large flowers in a simple panicle; flower's awnless, the upper ones imperfect; glumes membranaceous, unequal, convex, obtuse, scarious on the margins, manynerved; palece similar to the glumes, the upper one smaller, concave on the back; stamens 3 ; grain free.

M. sutica, Walt. Culms $1^{\circ}-2^{\circ}$ high; leaves and sheaths smooth or rough-pubescent; panicle loose, of few nodding racemose spikelets ; upper flowers imperfect, truncate-obovate; palea ronghish. (M. glabra, Michx.) Dry open woods. April. Witchita River.

\section{GLYCERIA, Brown.}

Sinooth perennial marsh or water grasses, with flat leaves, nearly eniire sheaths, and terete or tumid manyflowered spikelets disposed in a simple or compound panicle; rachis jointed; glumes membranaceous, obtuse, persistent; palece nearly equal, somewhat chartaceous, obtuse, early falling away with the separating joints of the rachis, the lower one naked, convex, 7-nerved; stamens 2-3; grain free, oblong.

G. Nervata, Trin. Culms erect; panicle diffuse, the capillary branches at length drooping; spikelets purplish, 
very numerous, orate-oblong, 5-6-flowered, nearly terete ; lower palea oblong, obtuse, \%-nerved. (Poa parviflora, Pursh.) Wet swamps. July. Culms $2^{\circ}-3^{\circ}$ high; spikelets $2^{\prime \prime}$ long.

G. PAllidA, Trin. Cuims erect or ascending; panicle narrow, nearly siniple, with the capillary branches erect; spikelets pale, oblong-linear, 5-9-flowered, nearly terete; lower palea oblong, minutely 5-toothed, 7-nerved. Shallow water. July. Culms $1^{\circ}-3^{\circ}$ long; spikelets $\frac{1}{2}$ long.

\section{ARUNDINARIA, Michx. Cane or Reed.}

Tall woody grasses, with clustered spreading branches, broad and flat persistent leaves, and racemose or panicled many-flowered spikelets; glumes unequal, concare, membranaceous, awn-pointed; palece rather loosely imbricated on the bearded and jointed rachis, nearly equal, the lowest one ovate-lanceolate, concare, many-nerved, awn-pointed, the upper strongly 2-keeled; stamens 3 ; stigmas 3 ; grain oblong, free.

A. gigantea. (Cane.) Culms arborescent, $10^{\circ}-20^{\circ}$ high, rigid, simple the first year, branching the second, afterward at indefinite periods fruiting, and soon after decaying; leaves lanceolate ( $1^{\prime}-2^{\prime}$ wide), acuminate, smoothish; panicles lateral, composed of few simple racemes; spikelets purple, erect ; lower palea lanceolate-orate, pubescent, fringed ( $8^{\prime \prime}$ long), awn-pointed. (Arundinaria macrosperma, Michx.) Banks of the rivers. February.

A. тECTA, Muhl. (Reed.) Culms slender, $2^{\circ}-10^{\circ}$ high, branching; leaves linear-lanceolate, acuminate, roughish, the sheaths bearded at the throat; spikelets solitary, or in a simple raceme at the summit of the branches, or frequently on leafless radical culms; lower palea (6" long) orate-lanceolate, smooth, fringed on the margins, awn-pointed. (Arundo tecta, Walt.) Swamps. Felvuary and Marnh. 


\section{BRIZOPYRUM, Link.}

A low and rigid perennial dicecious grass, growing in saline marshes, with linear-subulate involute distichous leaves, and many-flowered compressed spikelets, crowded in a nearly simple spike; glumes and palece smooth, somewhat coriaceous, obtuse, compressed, not keeled, the lower ones several-nerved; stamens 3 ; stigmas 2 ; grain oblong, free.

B. SPICATUM, Hook. Rootstocks long and creeping; culins $1^{\circ}$ high ; leaves spreading, rigid ; $2^{\prime}-4^{\prime}$ long, smooth, like the imbricated sheaths; spikelets oblong, 17-15-flowered. (Unioli spicata, Ell.) Low sandy shores and marshes. August and September.

\section{POA, L. Meadow Grass.}

Grasses with tufted culms, smooth flat and tender leaves, and compressed few-flowered spikelets in loose or contracted panicles; glumes unequal, shorter than the flowers; lower palea nearly membranaceous, keeled, scarious on the margins, awnless, 5 -nerved, the three more prominent nerves mostly hairy or woolly below ; upper palea 2-toothed, falling at maturity with the lower one; stamens 2-3; stigmas plumose; grain free.

\section{* Branches of the panicle single, or by pairs.}

P. ANvua, L. Annual ; culms tender, spreading, $6^{\prime}-10^{\prime}$ high ; leaves linear, $3^{\prime}-6^{\prime}$ long, $1 \frac{1}{2}^{\prime \prime}$ wide; panicle ovate, the smooth branches at length reflexed; spikelets ovate, about 5-flowered; glumes obtuse or emarginate, half as long as the sparsely hairy obtuse flowers. February and March.

P. COMPREssa, L. Culms $s^{\circ}$ ascending from a creeping base, geniculate, and, like the sheaths, compressed; panicle contracted, 1-sided, the short erect branches $2-4$ in a clus- 
ter; spikelets 4-8-flowered; lower palea rather obtuse, hairy below, faintly nerred. With the preceding. May. Culms $1^{\circ}$ high; leaves bluish green.

\section{ERAGROS'TIS, Beauv.}

Spikelets few-many-flowered, compressed; lower palea 3-nerved, not hairy nor woolly, the upper one remaining after the rest of the flower has fallen. Otherwise as in Poa. Culms often branched; leaves and sheaths smooth or hairy.

* Culms prostrate and creeping, diffusely branched.

E. Reptans, Nees. Culms filiform, the flowering branches erect $\left(4^{\prime}-6^{\prime}\right.$ high), leaves short $\left(1^{\prime}-2^{\prime}\right.$ long $)$, linear; sheaths downy at the base; panicle small ( $2^{\prime}-3^{\prime}$ long), ovate or oblong, often contracted; spikelets linear, 10-30flowered, nearly sessile, imperfectly diœcious; palece acute. (Poa reptans, Michx.) Low sandy places. August and September. Plant pale green. Annual.

** Culms branching, erect or ascending; annuals.

E. MEgastachya, Link. Culms prostrate and geniculate at the base, ascending; leaves linear; sheaths smooth; panicle oblong or pyramidal, contracted or spreading; spikelets oblong or at length linear $\left(3^{\prime \prime}-5^{\prime \prime}\right.$ long), 10-30flowered, often lead-color ; lower paled ovate, obtuse. (Briza Eragrostis, E.) July and August.

E. CILIARIs, Link. Culms slender, prostrate or ascending, geniculate; leaves ( $2^{\prime}-3$ 'long) linear, smooth; sheaths smooth, bearded at the throat; panicle spiked, cylindrical, the minute ( $\left(2^{\prime \prime}\right.$ long) ovate spilielets densely crowded on the short appressed branches, 5-\%-flowered; lower palea obtuse, mucronate, rough or ciliate on the back; the upper one fringed on the margins with long bristly hairs.Varies with the culms nearly erect, open lanceolate or ob- 
long panicle, distinct pale spikelets, and flowers more scattered on the smooth rachis. Culms $66^{\prime}-12^{\prime}$ long; spikelets purple.

E. Purshir, Schrad. Culms slender, ascending, geniculate near the base, $6^{\prime}-12^{\prime}$ long; leaves narrowly linear, with the sheaths bearded at the throat; panicle $3^{\prime}-6^{\prime}$ long, the lowest of the widely spreading branches whorled; spikelets linear, 5-10-flowered, purple or pale, the lateral ones appressed, and mostly longer than their pedicels; lower palea orate, 3-nerved. (Poa pectinata, and P. tenella, of authors. June-September.

\section{DACTYLIS, L. ORChard Grass.}

Perennial grasses, with simple culms, keeled leaves, and 2-7-flowered spikelets crowded in a 1-sided glomerate panicle; glumes and lower palec herbaceous, keeled, awnpointed, rough-ciliate on the keel, the latter 5-nerved; stamens 3 ; grain free.

D. glomerata, L. May and June. Culms $2^{\circ}-3^{\circ}$ high ; leaves and sheaths scabrous; spikelets in close clusters at the end of the short branches, 2-4-flowered; glumes and flowers lanceolate.

\section{FestuCA, L. Fescue Grass.}

Grasses with flat or setaceous leaves, and panicled 3-many-flowered mostly awned spikelets; rachis jointed as in Glyceria ; glumes unequal, mostly keeled; palece nearly coriaceous, the lower one naked, rounded on the back, $3-5$ nerved, acute or bristle-awned, the upper commonly adhering at maturity to the inclosed grain ; stamens 1-3.

* Flowers awned; panicle contracted; annuals.

F. Myurus, L. Culms erect, very slender, concealed in the sheaths of the bristle-like leaves; panicle elongated, linear, 1-sided, partly included in the sheath of the uppermost 
leaf, the scattered branches appressed ; spikelets compressed, 6-flowered; awn 3-4 times the length of the subulate sparsely hairy palea; stamens 1 . Dry sandy soil. March and April. Culms 6'-12' high ; panicle pale, $4^{\prime}-6^{\prime}$ long.

F. TENeLLA, Willd. Culms $\left(2^{\prime}-12^{\prime}\right.$ high $)$ erect or ascending; leaves narrowly linear or filiform; panicle long-peduncled, simple, spiked, or the branches slightly spreading, mostly purple; spikelets crowded, compressed, oblong, 8-12-flowered; awn not longer than the subulate hispid palea. Dry saudy soil. February-April. Witchita Mountains.

F. Duridscela, L. Culms erect, $1^{\circ}-1 \frac{1}{2}^{\circ}$ high; leaves filiform ; panicle simple, 1-sided, mostly bending, spreading; spikelets oblong, about 6 -flowered; awn shorter than the smooth lanceolate palea. April-May.

** Flowers avonless; panicle spreading ; perennials.

F. nutans, Willd. Culms $2^{\circ}-4^{\circ}$ high, and, like the broadly linear leaves, rough, or the latter hairy; panicle 1-sided, simple, erect or bending, the branches mostly by pairs, remote, bearing few ovate 5-6-flowered spikelets near their summits, at length reflexed; glumes rough on the back, acute; lower palea ovate, barely pointed. Rich woods and banks. August. Head-waters of Trinity River.

\section{BROMUS, L. Brome Grass.}

Grasses with flat leaves, and long-stalked spikelets in loose panicles; spikelets large, 3-many-flowered; glumes membranaceous, unequal, commonly keeled; lower palea usually awned under the apex, convex on the back, about 7 -nerred at the base; stamens 3 ; grain flattened and groored on the inner face, and adherent to the upper palea.

B. ciliatus, L. ; var., Purgans, Gray. Perennial ; panicle diffuse, the slender drooping branches mostly by pairs; 
spikelets lanceolate after flowering, 10-12-flowered; lower glume 1-nerved, the upper 3-nerved; lower palea convex on the back, 7-nerved, hairy, about as long as the awn; culms $2^{\circ}-4^{\circ}$ high ; leaves and sheaths smooth or downy. Riverbanks and rich soil. June.

B. Secalinus, L. (Cheat or Chess.) Annual; panicle spreading, with clustered, at length drooping branches; spikelets ( $\left(\frac{1}{2}-1^{\prime}\right.$ long) 8-10-flowered, oblong-ovate; lower glume 5-nerved, the upper 7 -nerved; palece smooth, the lower one convex, 7 -nerved, awnless or short-awned; culms $1^{\circ}-2^{\circ}$ high; leaves and sheaths smooth or downy.

\section{UNIOLA, L.}

Tough perennial grasses, with erect culms, from creeping rootstocks, and mostly broad, flat, many-flowered spikelets, in erect or drooping panicles, with one or more of the lower flowers glume-like and neutral, and the upper imperfect; glumes lanceolate, compressed-keeled; lower palea rather rigid, strongly compressed-keeled, nerved, awnless, much larger than the 2-keeled upper one; grain free; stamens 1-3.

\section{* Spikelets long-pediceled, drooping; flowers appressed.}

U. Latifolia, Michx. Culms $2^{\circ}-3^{\circ}$ high; leaves flat, lanceolate $\left(\frac{1}{2}-1^{\prime}\right.$ wide) ; panicle loose, drooping; spikelets green, oblong, acute, 10-15-flowered ; lower palea one-third longer than the upper, fringed on the keel, acutish ; stamen 1. Banks of rivers. July and August. Spikelets $12^{\prime \prime}-15^{\prime \prime}$ long.

\section{ELYMUS, L. LyMe Grass.}

Coarse flat-leaved perennial grasses, with rigid erect culms, bearing a single spike of 2-7-flowered spikelets, arranged 2-4 in a cluster at each joint of the zigzag rachis; glumes 2, placed side by side before the spikelets, coriaceous, un- 
equal-sided, mostly awned; palece of the same texture as

- the glumes, the lower convex on the back, tapering into a rigid awn, the upper inclosing the linear hairy-tipped grain ; stamens 3 ; stigmas 2.

E. Virginicus, L. Spile dense, erect (3' long), the base usually included in the dilated sheath of the uppermost leaf ; spikelets $2-3$ in a cluster, 2-3-flowered, smoothish, short-auned; glumes lanceolate, strongly nerved. River-banks. July and August. Culms $2^{\circ}-3^{\circ}$ high ; leaves rough; sheaths smooth.

E. Canadensis, L. Chlm erect, $3^{\circ}-5^{\circ}$ high; leaves lance-linear, flat, smooth, dark green, or often glaucous; spike rather loose and spreading, $4^{\prime}-8^{\prime}$ long, generally nodding; rachis hairy; spikelets more or less hairy, in twos and threes, 3-6-flowered; awns of the flowers usually enrred, longer $\left(7^{\prime \prime}-17^{\prime \prime}\right)$ than those of the glumes.-A tall grass, looking like rye, with long recurved, waving spikes. Red River.

\section{HORDEUM. BaRLEY.}

Spikelets 3 at each joint of the rachis, 1-flowered, the lateral ones sometimes abortire; glumes 2 , subulate, nearly equal, awned; palece 2, lower lance-orate, long-awned, upper obtusely acuminate; caryopsis adhering to the paleæ.

H. Jubatus, L. (Squirrel-tail Grass.) Culm slender, round, smooth, simple, about $2^{\circ}$ high ; leaves broad-linear, $4^{\prime}-6^{\prime}$ long, rough-edged, otherwise smooth, as well as the sheaths; spikes $2^{\prime}-3$ ' long; spikclets with the lateral flowers neuter; glumes and palece produced into fine, smooth awns, 6 times as long $\left(2^{\prime}\right)$ as the flowers; abortive flower's on short pedicels. Marshy places. Northern Texas. June.

H. pesilluas, Nutt. Culm 4'-6', decumbent or geniculate at the base; leaves about $1 \frac{1^{\prime}}{2}$ long, rather obtuse, glancous, striate; upper sheath turned, embracing the spike; 
spike linear, about $1 \frac{1^{\prime}}{2}$ long: glumes by threes, collateral, imbricated, lateral; abortive flower's awnless; awn of the central sessile perfect flower as long as those of the involucre, twice the length $\left(\gamma^{\prime \prime}\right)$ of the pales; glumes all awned, the inner setaceous from the base. Northern Texas.

\section{GYMNOSTICHUM, Schreb.}

Spikelets 2-3 on each joint of the rachis, raised on a short and thick. stalk; glumes none, or a single awn-like rudiment. Otherwise as in Elymus.

G. Hrstrix, Schreb. Spike erect, 3'-6' long, lax-flowered; spitielets yellowish, 3-4-flowered, smooth or roughhairy, long-awned; leaves and sheaths smoothish. (Elymus Hystrix, L.) July. Culms $2^{\circ}-3^{\circ}$ high; ractiis 2-edged.

\section{TRISETUM, Pers.}

Spikelets 2-several-flowered; lower palea compressedkeeled, usually bearing a bent awn below the 2-cleft or 2-pointed apex; spikelets in open or spiked panicles.

T. Paldstre, Torr. Smooth; culms weak $\left(1^{\circ}-1 \frac{1}{2}^{\circ}\right.$ long); leaves flat, linear; panicle long and narrow, loose; spikelets 2-3-flowered; the lower flower awnless, the upper with a spreading awn and an awn-like rudiment at the base, or rarely both flowers awnless. (Aira pallens, Muhl.; A. triflora, Ell.?) Swamps. March and April. Panicle pale, $4^{\prime}-8^{\prime}$ long.

\section{ARRHENATHERUM, Beauv.}

Tall grasses, with flat leaves, and spreading panicles with clustered or whorled branches; spikelets 2-flowered, with the awn-like rudiment of a third flower, the lower one staminate, the upper perfect; glumes membranaceous, concare, the upper one as long as the flowers; palea herbaceous, the lower one of the perfect flowers slightly awned 
near the apex, that of the staminate flower bearing a long bent awn below the middle; stamens 3 .

A. Avenaceum, Beauv. Culms smooth, $2^{\circ}-3^{\circ}$ high; leaves broadly linear; panicle narrow, whitish, $8^{\prime}-10^{\prime}$ long; glumes scarious. May. Perennial.

\section{PHALARIS, L.}

Spikelets crowded in a densely spiked panicle, 3 -flowered; the two lower flowers reduced to hairy scales; the upper perfect, consisting of 2 boat-shaped awnless, at length coriaceous paleæ, the lower one longer and inclosing the upper, and two nearly equal broadly keeled glumes which are longer than the flower; stamens 3 ; styles elongated; grain inclosed in the paleæ.

P. interyedia, Bosc. Culms ascending, slender, $6^{\prime}-12^{\prime}$ high; leaves short, with the uppermost sheath inflated; spike $\left(\frac{1^{\prime}}{2}-1^{\prime}\right.$ long) oval, compact; glumes lanceolate, slenderpointed, broadly keeled, twice as long as the hairy ovate flower. (P. Americana, Ell. ; P. microstachya, DC.) Sandy places along the coast. April and May. Leaves broadly linear, 1'-2' long, somewhat glaucous; spike white or purplish. Annual.

Var., ANGUsta. (P. angusta, Nees.) $\quad C u l m$ stout $\left(2^{\circ}-3^{\circ}\right.$ high ; spike cylindrical ( $2^{\prime}-4^{\prime}$ long), somewhat interrupted at the base; glumes short-pointed, rather narrowly keeled, $\frac{1}{3}$ longer than the ovate hairy flower. Leaves not glaucous, $4^{\prime}-10^{\prime}$ long. Annual.

\section{PASPALUM, L.}

Spikelets spiked or somewhat racemed, apparently 1-flowered, awnless, borne in 1-4 rows on one side of the flattened or triangular jointless rachis; glumes 2, membranaceous, nearly equal; palece 2, ovate or roundish, coriaceous, the lower one larger, concave, and partly inclosing the flattened. 
upper one; stamens 3 ; grain included in the indurated paleæ. Such is the apparent structure of the spikelet, but theoretically it is 2-flowered, as in Panicum, with the lower glume and upper palea of the lower flower undeveloped.

* Spikes racemed; spikelets partly inclosed by the recurved margins of the broadlywinged membranaceous rachis.

P. Walteri, Schultes. Smooth; spikes 3-7\%, the lowest ones included in the sheath of the uppermost leaf; spikelets in two rows, orate, smooth; glumes obtuse, 5-nerved. (P. vaginatum, Ell.) July and August. Culms decumbent, creeping, $1^{\circ}-3^{\circ}$ long; leaves linear, short.

** Spikes mostly by pairs, divaricate; spikelels ovate-lanceolate, acute, 2-rowed on the slender wingless rachis; glumes smooth, longer than the pa'ex.

P. vaginatum, Swartz. Peduncles single, terminal, spikes (rarely 3 or 4 ) short $\left(1^{\prime}-1 \frac{1}{2}^{\prime}\right.$ long), erect or horizontal; glumes rugose, 5-nerved, rather longer than the acute flower; culms diffuscly creeping, short-jointed, the flowering branches $\left(4^{\prime}-10^{\prime}\right.$ long) erect; leaves $\left(1^{\prime}-3^{\prime}\right.$ long) subulate-convolute, their dilated imbricated sheaths persistent. (P. furcatum, Fluegge.) Saline swamps. August and September. Culms $2^{\circ}-4^{\circ}$ long; sheaths compressed, bearded at the throat. Perennial.

*** Spikes solifary, or few and racemose; spikelets ovale or roundish, in 2-4 rows; rachis mostly fattened and flexuous; glumes and palece nearly equal.

P. LæVE, Michx. Spikes 3-5, long $\left(3^{\prime}-4^{\prime}\right)$ and slender; spikelets single, in 2 rows, orbicular, wider than the flexuous rachis; glumes smooth and even, 5-nerved; culms simple, erect $\left(3^{\circ}-4^{\circ}\right.$ high $)$; leaves (deep green) and sheaths smooth, or the latter hairy. Dry woods. July and August. Spikelets $1 \frac{1}{2}$ "long, larger and thicker than the last. Perennial.

P. undelatum, Poir. Spikes 2-12, spreading $\left(2^{\prime}-3^{\prime}\right.$ long); spikelets small (1" long), oval or roundish, crowded in $3-4$ rows under the broad and flat rachis; glumes smooth, 
5-nerved; palece of the neutral flower often rugose; culms erect or ascending, mostly branching; leaves deep green, broadly linear, flat, mostly fringed on the margins or near the base, and, like the smooth or hairy sheaths, often purple. (P. purpurascens, Ell.; P. plicatulum, Michx.; P. confertum, Leconte; P. Boscianum, Fluegge.) September. Culms $\frac{1}{2}^{\circ}-3^{\circ}$ high. Annual.

\section{PANICUM, L. Panic Grass.}

Inflorescence spiked, racemose or panicled; spikelets 2-flowered, naked (no involucre); glumes 2, herbaceous, the upper one usually as long as the flowers, the lower smaller, often minute, or occasionally wanting; lower flower staminate or neutral, of 1-2 paleæ; the upper palea, when present, small and hyaline, the lower herbaceous and resembling the upper glume; upper flower perfect, coriaceous, awnless, inclosing the free grain; stamens 3.

81. Digitanila. Inflorescence spiked; spikelets 2-3 together, imbricated on one side of a filform rachis; lower flower of one palea, and neutral; glumes shorter than the flowers; annuals.

P. sanguinale, L. (Crab Grass.) Culms ascending from a diffusely creeping base; leaves thin, spreading, the lower part, like the sheaths, hairy; spikes 5-10, spreading; spikelets oblong, pointed; glumes hairy on the margins, the upper half as long as the flowers, the lower minute, or in var. villosem (Digitaria rillosa, Ell., a smaller and more hairy form) wanting. May-October.

P. FILIForme, L. Culms erect, sparingly branched $\left(2^{\circ}-\right.$ $3^{\circ}$ high); leaves linear, erect, and, like the sheaths, hairy; spikes 2-5, alternate, erect, filiform; spikelets oblong, acute, scattered; upper glume half as long as the acute blackish palea, the lower wanting. Dry sandy soil, common. August and September. 
\$2. Paxicum proper. Glumes 2 , unequal, awnless; spikelets in panicles or racemes.

* Spikelets crowoded in simple or panicled racemes.

+ Sterile flowers of two palea, staminate or neutral.

P. Curtisir. 'Panicle slender, spike-like ( $66^{\prime}-8^{\prime}$ long), the appressed lower branches remote; spikelets ovate-lanceolate; glumes slightly keeled, the upper 5-nerved, twice as long as the lower one, and rather shorter than the acutish flower; sterile flower 3 -androus; culms and smooth lincarlanceolate leaves rigid; sheaths smooth or hairy. Ponds and swamps. Culms $3^{\circ}-4^{\circ}$ high, often rooting at the lower joints.

** Spikelets mostly in pairs, on short appressed pedicels scattered on the ullimate branches of the usually ample open panicle.

+ Sterile flower of one palea, neutral.

P. Proliferua, Lam. Smooth; culms thick and succulent, ascending, branched, genticulate; panicles lateral and terminal, diffuse; spikelets lanceolate-ovate, acute, somewhat crowded on the straight branches; upper glume 7-nerved, 3-4 times as long as the lower; perfect flower pointed. (P. geniculatum, Muhl.) Wet places near the coast. September. Culms $1^{\circ}-3^{\circ}$ long. Annual.

P. nivergens, Mubl. Culms slender, fragile, sparingly branched; leaves subulate, rough on the upper surface and margins; the smooth sheaths longer than the joints; panicle diffuse, bearded at the axils; spikelets small, spindle-shaped, solitary at the summit of very long $\left(2^{\prime}-4^{\prime}\right)$ and rough peduncles; lower glume minute; perfect flower lanceolate-oblong, acute, nearly as long as the upper glume and neutral palea. (P. autumnale, Bosc.) Dry sandy soil. August. Culms $1^{\circ}$ high; leaves $2^{\prime}-4^{\prime}$ long. Perennial.

P. PaUCIflorum, Ell. Panicle expanding, few-flowered; flowers very large; leaves narrow-lanceolate, ciliate at the base; sheaths hairy. May. Culm 12'-18' high, roughish and branching at the joints; leaves $3^{\prime}-4^{\prime}$ long, $3^{\prime \prime}-4^{\prime \prime}$ wide, smooth above; spikelets oval, the lower glume very small. 
P. Texanum, Buckley. Culms erect or subdecumbent, smooth; sheaths shorter than the internodes, subpubescent and hairy at their motiths; upper portion of the internodes and joints pubescent; leares $6-10$ inches long and 8-10 lines broad, long acuminate, under surface subpubescent; panicle compressed, $5-8$ lines long and 5-7 lines broad; rays alternate, erect; lower glume ovate-acute, $\frac{1}{2}$ shorter than the floret, 5-nerved; upper one 7 -nerved, acute, hyaline, between the nerves subpubescent, longer than and covering the floret. Several stems grow from the same root. Stems sparingly branched; seeds numerous and aggregated. Austin, Texas, where it is cut for hay, of which horses and cattle are very fond. It grows thick in. cultivated fields, and yields from 1-2 tons of hay per acre. It is a very valuable grass for the South.

\section{CENCHRUS, L. CocksPUR.}

Prostrate or creeping grasses, with the spikelets of Panicum proper, but inclosed, 1-several together, in spiny or bristly, at length indurated and deciduous involucres, the latter burr-like, and arranged in a terminal spike; stamens 3 ; styles united below.

C. echinatus, L. Spikes cylindrical, composed of 20 or more globular involucres $\left(3^{\prime}-4^{\prime}\right.$ long); involucre downy, spiny above, and with a row of rigid barbed bristles above the base, 3-5-flowered; culms ascending. Fields and waste grounds. July-September. Culms $1^{\circ}-2^{\circ}$ long; involucre purplish. Annual.

C. TRIBUloIdes, L. Involucres whitish, 10-15 in a spike, wedge-shaped at the base, armed above with stout compressed broadly subulate erect or spreading spines; bristles none; spikelets mostly by pairs. Sands along the coast. July-October. Culms prostrate, $1^{\circ}-2^{\circ}$ long; leaves linear; spikes $1^{\prime}-2$ ' long. Annual. 


\section{STENOTAPHRUM, Trin.}

A creeping and branching grass, with the awnless spikelets sunk in excarations of the continuous flattened rachis; spikelets by pairs, one pediceled and imperfect, the other sessile, and with the structure of Panicum.

S. Auericanum, Schrank. (Rottbœllia dimidiata, Ell.) Damp sandy places along the coast. June-September. Smooth throughout. Culms flattened, creeping, the branches nearly opposite; flowering culms erect, $66^{\prime}-12^{\prime}$ high; leaves $2^{\prime}-6^{\prime}$ long, linear, obtuse, flat or folded, contracted at the base; spikes lateral and terminal, peduncled, $2^{\prime}-5^{\prime}$ long; sterile spikelet neutral or rudimentary; fertıle spikelet sessile, the upper glume 7 -nerved, 3 times the length of the lower one; palea of the sterile flower coriaceous, like those of the perfect one. Perennial.

\section{ROTTBELLIA, Brown.}

Erect perennial mostly tall grasses, with flat or channeled leaves and spiked inflorescence; spikes nearly terete, jointed; spikelets awnless, borne by pairs at the base of each joint, one imperfect, on a coriaceous and closely appressed pedicel, the other sessile, imbedded in an excavation of the joint, 2-flowered; glumes 2 , the exterior one flat, coriaceous, with a hinge-like depression at the base, the interior boat-shaped, membranaceous; palece hyaline, 1-2 in the staminate or neutral lower flower, and 2 in the upper and perfect flower; stamens 3 ; styles 2 ; grain compressed, free; spikes solitary on lateral and terminal peduncles or branches.

R. Rugosa, Nutt. Culms compressed; peduncles or branches clustered, short, included in the sheaths of the elongated upper leaves; spikes spreading, slightly compressed; sessile spikelet shorter than the joint; lower 
glume lanceolate, transversely rugose; sterile flower neutral. Pine-barren swamps and ponds. September. Culms $2^{\circ}-4^{\circ}$ high ; spikes green, $11_{2}^{\prime}-2^{\prime}$ long, $1^{\prime \prime}$ in diameter.

\section{MANISURIS, L.}

Annual grasses, with branching culms, flat leaves, and spiked inflorescence; spikes lateral and terminal, clustered, jointed, the short peduncles inclosed in spathe-like sheaths; spikelets 1-flowered, placed one at each end of the joints of the spike, the upper neutral, compressed, of two nearly equal hispid membranaceous glumes, the lower perfect, globose; glumes coriaceous, concave, the lower reticulated, the upper smooth; palece 2 , hyaline; stamens 3 ; grain inclùded.

M. grandlaris, Swartz. Leaves linear-lanceolate, and, like the sheaths, hairy; spikes $6^{\prime \prime}-10^{\prime \prime}$ long; spikelets minute, turning black. Fields and pastures. August and September. Culms $1^{\circ}-2^{\circ}$ high.

\section{TRIPSACUM, L. GaMa Grass.}

A tall perennial grass, with solid culms, broad and flat leaves, and spiked inflorescence; spikelets awnless, monœcious, in jointed spikes, the upper ones staminate, the lower fertile, 2-flowered; staminate flowers by pairs on each short triangular joint of the slender rachis, 3-androus; glumes 2, coriaceous; palece hyaline; pistillate spikelets single, imbedded in a deep excavation of the thick and polished joints; the outer glume cartilaginons, concave, the inner membranaceous, boat-shaped; lower flower neutral, the upper pistillate, both with hyaline paleæ; anthers opening by terminal pores; stigmas elongated; grain free.

T. DaCtyloides, L. Rich soil. Angust and September. Culms erect, from tufted creeping rootstocks, $3^{\circ}-5^{\circ} \mathrm{high}$; 
leaves $1^{\prime}$ wide; spikes $4{ }^{\prime}-\delta^{\prime}$ long, on long lateral and terminal peduncles, $2-4$ in a cluster or sometimes solitary. ('I. monostachyum, Willd.)

\section{ANDROPOGON, L. Broom Grass.}

Coarse perennial grasses, with branching erect culms, long and harsh leaves, and spiked inflorescence; spikes lateral and terminal, jointed; spikelets by pairs on each joint of the slender commonly hairy or plumose rachis, one of then pediceled and staminate, neutral, or rudimentary, the other sessile, 2-flowered, the lower flower consisting of one palea, and neutral; the upper of 2 paleæ, mostly perfect, shorter than the herbaceous or chartaceous glumes, the lower one mostly awned at the apex; stamens 1-3; grain free.

ANDROPOGON proper. Upper flower perfect.

* Peduncle solitary, bearing a single spike.

A. Nuttallir. Culms $\left(3^{\circ}-4^{\circ}\right.$ high) straight, smooth, like the long linear leaves; spikes rigid, long-peduncled, the rachis and pedicel of the sterile flower fringed with closely appressed white hairs; spikelets awnless; glumes hispid above; sterile flower of 2 paleæ, 3 -androus. (Rottbœllia ciliata, Nutt.) Low pine-barrens. September. Spikes 3 '-6' long.

A. oligostachyus. Culms rigid, erect; leaves linear, smooth, glancous; spikes $3-4$, on short mostly included peduncles, hoary with short spreading hairs; lower glume pubescent, $\frac{1}{2}-\frac{1}{3}$ as long as the contorted awn; sterile flower neutral, short-awned. Dry sand-ridges. August and September. Culm $2^{\circ}-3^{\circ}$ high ; spikes $2^{\prime}-3^{\prime}$ long.

** Peduncles clustered, each bearing a single spike.

A. scoparies, Michx. Leaves smooth or rongh-hairy; spikes numerous, on exserted peduncles, the slender flexuous rachis, and pedicel of the awned or awnless staminate 
or nentral sterile flower fringed with spreading hairs; perfect flower half as long as the awn, the glumes often roughened with elevated points. Dry sterile soil. Angust and September. Culms $2^{\circ}-3^{\circ}$ high ; spikes $1^{\prime}-2^{\prime}$ long.

*** Peduncles or branches mostly clustered, bearing 2-4 rigid (green) digitate spikes; rachis and p.dicel of the triandrous awnless sterile flower finged with scattered hairs, and short-bearded at the base.

A. Furcatus, Muhl. Culm stout, rigid, $3^{\circ}-5^{\circ}$ high; leaves rough, fringed at the base; peduncles or branches commonly several at each upper joint; spikelets appressed; glumes hispid on the nerves, half as long as the bent awn. Open woods. September. Spikes compressed, $2^{\prime}-3^{\prime}$ long.

**** Pedincles or branches 1-several from each upper joint. of len included in the dilated sheaths; spikelets slender, hoary with long silky spreading hairs; sterile flower reduced to an awn-like glume at the apex of the very slender pedicel, or obsolete; stamen 1.

A. tetrastachyus, Ell. Culms $3^{\circ}-4^{\circ}$ high ; leaves and sheaths very hairy; branches short, the lower ones by pairs, the upper single; spikes 4 ; glumes bristly-serrulate, one-fourth as long as the straight awn; pedicel of the awnlike sterile flower barely exceeding the fertile flower.Var., Distachyus. Leaves and sheaths less hairy or smoothish ; spikes by pairs, more rigid, on long-exserted branches; pedicel of the sterile flower much longer than the smoother glumes. Low pine-barrens. September.

A. Macrourus, Michx. Spikes by pairs, exceedingly numerous, crowded in a large and close panicle; awns 3-4 times the length of the glumes; sterile flower an awnlike glume.-Varies, with the whole plant glaucous and more slender, branches and spikes more scattered. Low barren soils. September. Culms $2^{\circ}-5^{\circ}$ high.

\section{ERIANTHUS, Michx.}

Tall. reed-like grass, with long and flat leaves, and panicled inflorescence; spikelets by pairs on the slender 
branches, alike, one pediceled, the other sessile, both with a haily involucre at the base; lower flower of one paleal, neutral ; the upper of two paleæ, perfect, shorter than the membranaceous nearly equal glumes, the lower one awned; stamens $2-3$.

E. A LOPECUROIdes, Ell. Culms $4^{\circ}-10^{\circ}$ high ; sheaths of the broad $\left(6^{\prime \prime}-12^{\prime \prime}\right)$ very rough leaves woolly above, rough below ; panicle $\left(1^{\circ}-2^{\circ}\right.$ long) woolly, expanding, pyramidal; hairs of the involucre copious, twice as long as the sparsely hairy glumes; awn straight.

\section{SORGHUM, Pers.}

Spikelets 2-3 together on the slender branches of the loose panicle, the lateral ones sterile or a mere pedicel, the middle or terminal one fertile; glumes coriaceous or indurated, closely bearded, sometimes awnless. Otherwise like Andropogon.

S. Avenaceum. Panicle erect; glumes yellowish, lanceolate, the lower one hairy; one palea to each flower, linear, ciliate; awn rough, slender, twice as long as the glumes; sterile flowers reduced to one or two slender hairy pedicels. (Andropogon arenaceus, Mich.; A. ciliatus, Ell.) Dry sandy soil. September. Culms $\left(2^{\circ}-4^{\circ} \mathrm{high}\right)$ and leaves smooth ; panicle oblong, $6^{\prime}-12^{\prime}$ long. Perennial.

S. nutans, Gray. Panicle long and narrow, nodding; glumes dark brown, the upper sparingly, the lower densely hairy; palece of the upper flower 2, unequal; awn 4 times the length of the glumes, bent in the middle, rough above, twisted and hairy below; sterile spikelets mostly rudiments. (A. nutans, L.) Dry barren soil. September. Culns $2^{\circ}-4^{\circ}$ high ; panicle $1^{\circ}-2^{\circ}$ long. Perennial.

\section{MONANTHOCHLÖ̈, Engelm.}

A low maritime branching grass, with rery short rigid crowded leaves, and diøcious flowers in solitary terminal 
sessile spikes; glumes none; spikes short, 3-5-flowered, the lowest flower, or the two lower ones, neutral, of 1-2 palex, the uppermost abortive, the intermediate ones, composed of two paleæ, triandrous in the staminate, digynous in the pistillate spike; palece convolute, scarious and obtuse at the apex, the lower one rigid, ovate-lanceolate, 9-12-nerved above, the upper rather longer, 2-keeled or 2-winged on the back; squamula none; anthers longer than the short filaments, 2-lobed at each end; ovary lanceolate-linear, 3-angled; styles 2; stigmas elongated, plumose with simple hairs; grain 3 -angled, free.

M. LitToralis, Engelm. Low sandy shores. Culms much branched, $5^{\prime}-8^{\prime}$ high, smooth and somewhat woody, erect, or at length prostrate and rooting; leaves $3^{\prime \prime}$ long, very rigid, obtuse, many-nerved, rough on the margins, mostly crowded at the summit of the short branches, and inclosing the short $\left(3^{\prime \prime}-4^{\prime \prime}\right)$ sessile spikes; flower's pediceled. 


\section{SERIES II.}

\section{CRYPTOGAMOUS OR FLOWERLESS PLANTS.}

VEGETABLES destitute of proper flowers, and producing, in the place of seeds, minute homogeneous bodies (spores) containing no embryo.

\section{Class III.-Acrogens.}

Plants with a distinct stem, growing from the apex only, containing woody fiber and vessels.

154. HORSETAIL FAMILY. Order, Equisetacez.

\section{EQUISETUM, L. Scouring Rush.}

Character same as that of the order. Plants leafless, simple stem or with whorled branches; stems striate-sulcate, jointed, fistular between and separable at the joints; sheaths dentate, crowning each internode; fructification terminal, spiked or cone-like, composed of 6 -sided peltate scales arranged spirally, bearing beneath 4- 7 spore-cases which open laterally; spores globular, furnished at the base with 4 club-shaped elaters (elastic filaments) involving them spirally, or open when discharged.

E. LeVIGATUM. Tall, erect, simple or somewhat branched; sheaths elongated, appressed, green with black border, of about 22 leaves; sheaths of the branches about 8-leared, with subulate persistent points; stems $15^{\prime}-2^{\circ}$ high.

E. LImosum. Stems somewhat branched, erect, striatesulcate; branches from the middle joints, simple, short, 5-sided, smooth; spike oblong-ovoid; sheaths appressed. Stem $2^{\circ}$ high. Banks of Buffalo Bayou. 


\section{FERN FAMILY. Order, FILICES.}

Stem a creeping horizontal rhizoma, sometimes erect and arborescent; leaves (fronds) variously divided, circinate vernation, and raised on a foot-stalk or stipe; fructification borne on the back or margin of the fronds; spore-case sometimes covered by a membrane, called the indusium or involucre, and containing numerous minute spores or seeds.

\section{POLYPODIUM, L. PoLYPODY.}

Fruit-dots round, naked, mostly at the ends of the free or reticulated veins; rootstocks creeping; sterile and fertile fronds alike.

§1. PoLYPodruM proper. Veinsfree.

P. vUlGaRe, L. Fronds evergreen, smooth on both sides, oblong, simply and deeply pinnatifid; the divisions linear-oblong, obtuse, slightly-toothed; fruit-dots large. Mossy rocks, etc., in shady woods. Fronds $4^{\prime}-10^{\prime}$ high.

§2. Marginaria, Bory. Veins obscure, sometimes reticulating near the margin; stipe and lower surface of the frond covered with chaffy scales.

P. INCANUm, Swartz. Fronds evergreen, coriaceous, beneath thickly beset with peltate chaffy scales, smooth and green above, pinnately parted; the divisions oblong, obtuse, entire; fruit-dots near the margin. On trunks of trees. Rootstock chaffy, creeping; fronds $3^{\prime}-8^{\prime}$ high.

\section{PTERIS, L.}

Sporangia borne on a transverse marginal receptacle connecting the ends of the reins; indusium continuous, formed of the membranaceous margin of the frond, at first reflexed, at length pushed back and disclosing the ripened fructification; fronds 1-3-pinnate or decompound.

P. AQuilina, I. (Brake.) Fronds large, glabrous or 
somewhat hairy beneath, broadly triangular, tripinnate; pimmles oblong or linear, entire or hastate or pinnately parted; ultimate segments obtuse, oblong or linear, the terminal ones often elongated, the margin reflexed or revolute; veins simple or forked; indusium narrow, ciliated. Common everywhere. Stipe stout, $6^{\prime}-2^{\circ}$ high; frond $1^{\circ}-2^{\circ}$ long.

Var. CAUDATA (P. caudata, L.), with very narrow segments, the terminal ones elongated, and both surfaces of the frond glabrous or even glaucous, occurs along the Gulf coast.

\section{PELLAEA, Link.}

Fruit-dlots oblong or linear at the ends of the veins, confluent in a broad marginal line of fructification; indusium as in Pteris; veins free, forked or pinnate; fronds mostly 1-3-pinuate, smooth, mostly coriaceous.

P. ATRopurPUREA, Link. Fronds tufted, coriaceous, ovate-lanceolate, pinnate or below bipinnate; pinnce opposite, rather distant, the lower ones stalked; pinnules sessile, oblong or linear-oblong, truncate or subcordate at the base, obtuse or rarely somewhat mucronate; indusium formed of the reflexed and little-changed margin, at length pushed back and showing a broad marginal band of ripened sporangia. (Pteris atropurpurea, L. ; Allosorus, Kunze, Gray.) Mostly on lime-rock. Frond $2^{\prime}-12^{\prime}$ high; stipe and rachis black and shining, smooth or somewhat rusty-pubescent.

\section{CHEILAN'THES, Swartz.}

Fruit-dots at the thickened ends of the reins, distinct or at length confluent, corered by the continuous or interrupted reflexed margin of the lobes; veins free; fronds 1-3-pinnate; pinnules with a midrib, often hairy or woolly.

C. vestit., Swartz. Fronds broadly lanceolate, like the 27 
stalks hirsute with rusty hairs, bipinnate; pinnce trianguJar-ovate; pinnules oblong, obtuse, more or less incised; the ends of the lobes reflexed to form separate herbaceous involucres. Fronds 4'-8' long, becoming smooth above.

\section{ADIAN'TUM, L. Maidenhair.}

Indusium orbicular or transversely elongated, formed of a reflexed and altered portion of the margin of the frond, bearing the sporangia on its under side at the ends of the veins; midrib none or eccentric; veins forking, mostly free; stipe and ractis commonly black and shining.

A. Capillus-Vexeris, I. Frond ovate-lanceolite, 2-3pinnate; pinnules very delicate, oblique, broadly wedgeshaped or sometimes rhomboid, rather long-stalked, the upper margin deeply incised and fruit-bearing or sterile and dentate; stipe slender, ebeneous; rachis almost capillary, flexuous. Mostly pendent from limestone cliffs. Austin and west to the San Antonio. Fronds $1^{\circ}-3^{\circ}$ long. Found also in Buffalo Bayou.

\section{ASPLENIUM, L.}

Fruit-dots oblong or linear, oblique to the midrib, the indusium attached by one margin to the mostly free reins, rarely curved, or double and attached to both sides of the vein.

Asplenicu proper. Indusia straight, atlached by their whole length to the upper side of the vein; rarely some of them double, and placed back to back.

* Fronds pinnatifid or simply pinnate.

A. Ebenety, Aiton. Stipe and rachis purplish black and shining; fronds linear-lanceolate or spatulate, acuminate, pinnate; pinnce numerons, sessile, linear-oblong, aturicled on one or both sides of the base, serrate or nearly. entire, those below the middle of the frond gradually shorter 
and deflexed; fruit-dots 10-13 on a pinnal. Fronds $6{ }^{\prime}-1 S^{\prime}$ high, 1'-3' wide; stipe very short.

\section{** Frondò 2-3-pinnate or pinnalifid.}

A. moxtaxu, Willd. Fronds smail, ovate-lanceolate, pinnate; pinnce few, petioled, ovate or triangular; the louer ones pinnatifid; the upper ones incised; divixions toothed or serrate; fruit-dots very short, the basal ones often with a double indusium. Mountains, North and West 'Texas. Fronds 2 '-5' high, with a winged greenish rachis, and a stipe nearly as long as the frond.

\section{WATER-FERNS. Order, HydRopteridEs.}

Aquatic herbs, with the sporangia of two forms, borne at the base of the leaves and bursting irregularly.

\section{ISOETES, L.}

Plants composed of fibrous roots and filiform cellular leaves, without any apparent stem; sporangia sunk in an excavation of the dilated base of the leaves, plano-convex, membranaceous, filled with transverse threads and minute poudery spores; those of the central leares filled with larger spores.

I. FLACCIDA, Shuttlw. Immersed; leaves very long $\left(1 \frac{1}{2}^{\circ}-2^{\circ}\right)$, slender, flaccid, yellowish-green; spores very small, minutely pulverulent, not reticulated. In lakes and clear streams.

\section{AZOLLA, L.}

Minute florting plants, with pendent roots, pinnately branching stems, and thick imbricated cellular leaves; sporangia of two kinds, oroid, sessile on the under side of the branches, and covered with a thin numbrane; the smaller kind opening transrersels, containing sereral angular grains, attached to a central columu, the liuger 
bursting irregularly and containing numerous globulur stalked spores.

A. Carolisiaxa, Willd. On still water, chiefly near the coast. Plant reddish, circular in outline, $\frac{1^{\prime}}{2}-1^{\prime}$ in diameter; leaves orate, obtuse, rounded and roughened on the back. 


\title{
GLOSSARY.
}

\author{
ABBREVIATIONS AND SIGNS.
}

\begin{tabular}{ll|ll} 
Adans., & Adanson. & Gr., & Gray. \\
Ait., & Aiton. & Hoff., & Hoffman. \\
Arn., & Arnott. & Hook., & Hooker. \\
Aubl., & Aublet. & Jacq., & Jacquin. \\
Baldw., & Baldwin. & Juss., & Jussien. \\
Benth., & Bentham. & L., & Linnæus. \\
Bigel., & Bigelow. & Lam., & Lamark. \\
Boerh., & Boerhasve. & L'Herit., & L'Heritier. \\
Buckl., & Buckley. & Lindl., & Lindley. \\
Cass., & Cassini. & Marsh., & Marshall. \\
Catesb. & Catesby. & Michx., & Michaux. \\
Dari., & Darlington. & Mill., & Miller. \\
DC., & De Candolle. & Neck., & Necker. \\
Dill., & Dillenius. & Nutt., & Nuttall. \\
Ehrh., & Ehrhart. & Torr., & Torrey. \\
Ell., & Elliot. & Tourn., & Tournefort. \\
Endl., & Endlicher. & Walt., & Walter. \\
Engl., & Engelmann. & Willd., & Willdenow.
\end{tabular}

- Length in feet, as $3^{\circ}, 4^{\circ}$.

' Length in inches, as $2^{\prime}, 3^{\prime}$.

"Length in lines (1-12th of an inch), as $2 ", 4$ ".

A, prefixed to a word, signifies without ; as apetalous, without petals.

Abbrevialed ; shortened.

Abortive; nnt fully developed.

Accrete; grown together.

Accumbent; lying un something else.

Achenium ; 28.

Achlamydeous; without floral enrelopes.

Acute ; pointed.

Adhereut; growing fast to another body.

Adnate : growing fast to.

Adventitious; growing out of the usual position.

Estivation; the mode in which the sepals or petals are applied to each other.

Agrregate ; crowded together.

Alternate ; scattered, one after another.
Amentaceous ; bearing aments.

Amplexicanl ; stem clasping.

Anatropal ; $2 \%$.

Andrœecium ; 1.

Androgynous ; containing both starainate and pistillate fiowers.

Angiospermous ; seeds in a pod.

Angustifolius ; narrow-leaved.

Anomalous ; out of the regular order.

Anterior ; that part of the axilla"v flower farthest remuved from th.s main axil.

Apiculate; tipped with a short, abruje point.

Apocarpous : 9 .

Appendage ; something added to a part. A ppressed; pressed to.

Arborescent ; tree-like.

Areolate; having the surface divided into little spaces. 
Aril; an extra covering over the seed, 35 .

Aristate ; with an awn or beard.

Armed; furnistied with prickles, thorns, etc.

Articulated ; jointed.

Ascending ; 41.

Asperate; rough.

Assurgent; curved outward and upward.

Attenuated ; narrow and sharp-pointed.

Auriculate ; eur-bearing.

Awn; a rigid bristle.

Axillary ; being in the axil.

Axil placenta ; 13.

Axis; the central line of a body.

Baccate ; berry-like.

Bunner; same as vexillnm.

Barb ; stiff, hooked hair.

Basilar ; belonging to the base.

Bearded : tuft of hair.

Bibracteolate; consisting of two bracts.

Bicolor; two colors.

Bicrenale ; double crenate.

Bicuspidated; with two points or cusps.

J3identate : two tceth.

Biennial ; two years.

Bifid ; two-cleft.

Bifoliate; two leaves.

Bifurcate; two-forked, or merely forked.

Biglandular ; two glands.

Bilabiate ; two-lipped.

Biovulate ; two ovules.

Biserrate; twice serrate.

Biternate; twice ternate.

Bivalved : two valves.

Brachiate; with opposite spreading branches.

Bryology ; science of Mosses.

Lulbiferous; bearing bulbs.

Cæspitose ; growing in tufts.

Calceolate ; slipper-shaped.

Caliculate; accessories to the calyx.

Callous : thickened.

Calyciflora ; plants with the other parts if the fiowers on the calyx.

Campylotropal ; 27.

Carialiculate ; channeled.

Cunescent ; grayish white.

Capitate; head-shaped.

Capreolate ; bearing tendrils.

Carpels ; 3.

Cartilaginous ; stiff, strong.

Caruncle; appendage of the hilum.

Caryopsis; 30.

Caudate ; tailed.

('aule-cent; belonging to the stem.

Cauliculus; a small stem.

Centrifigal (growth of radicle) ; 43.

Centripetal (growth of radicle); 42 .

Cernus ; nodding.

Chalaza; 20.

Chartaceous ; paper-like textire.

Chromogen ; producing color.

Ciliate; fringed with hairs.

Cincrous; ash-gray.
Circinate : rollel inward at the apex.

Circumscissile ; 33.

Cirthose ; tendril-like.

Clusping ; inclosing by its base.

Clavate; club-shaped.

Clawed; raised on a claw.

Coarctate ; contracted, drawn together.

Cocci ; carpels of tue fruit, when away from the a:ill.

Coccus; a berry (plural, cocci ; 1-secded carpels of separable fruits).

Cochleate ; coiled like a short spiral sliell.

Coherent; growing together.

Comose ; hair-like.

Cone ; scaly fruit of pine, etc.

Corenchyma ; cone-like cells.

Confluent ; running together.

Conjugate : juind by pair's.

Connivent ; converging together.

Cordate ; heart-shayed.

Coriaceous ; leather-lik".

Corneous; hard like horn.

Corniculate ; bearing a horn or spur.

Corrugated; wrinkled.

Cortex; bark.

Cortical ; belonging to the bark.

Costate ; ribbed.

Crenate; having sharp notches on the edge.

Crenulate ; slightly crenate.

Crested; bearing an elevated ridge.

Crown; au appendage to the corolla.

Crowned; bearing anything at the apex.

Crustaceous ; hard, thin, and brittle.

Cucullate ; rolled up into a hood shape.

Culm; hollow stems of grasses.

Cuneate; wedge-slıped.

Cupule; a little cup.

Cuspidate ; sharp, stiff point.

Cyaneous ; bluish.

Cyathiform ; cup-shaped.

Cymbiform; boat-shaped.

Cymose ; in a cyme.

Deca; ten.

Decaridrous; ten stamens.

Deciduous; falling off at the end of the season.

Declinate; bent downward.

Decompounded; much divided.

Decumbent; prostrate, but ascending at the summit.

Decurrent; with the edges extending below the main point of attachment.

Decussate ; pairs of leaves that cross each other at right angles.

Deflected ; turned away.

Deflexed ; bent dowuward.

Dehiscent ; opening regularly.

Deliquescent ; same as sulvent.

Deltoid; triangular.

Dendroid ; tree-like in form.

Denticulate ; slightly toothed.

Dennded ; naked.

Depauperate; less developed than usual.

Depressed ; flattened horizontally.

Didynamous; having four stameus, two longer than the other two. 
Diffuse ; looseiy spreadiur.

Digitate ; with five or mort: leatlets.

I) inorphous ; of two forms.

Jissereted ; divided into mauy lobes.

Dissepiment ; 11.

Distichous; two-ranked, placed in opposite sides of the axis.

Divalicate ; widely spreading.

Doreal ; $\tilde{\tau}$.

Downy; with short hairs.

Darau.en ; hard wood.

Eared; auriculated.

Echinate ; with rigid prickles.

Eficte; sterile. exhausted.

Llaters ; epiral elastic threads accompanying certaill spores.

Elciugricel ; lengthened.

Emarginate ; notched at the apex.

Funersed; raised out of water.

Endochrome; the coloring-matter of plunts.

Endopleura ; inner corering or integument.

Entire ; even-erlgerl.

Ephemeral ; lasting but a day.

Epigynots ; $\left.\mathrm{u}_{3}\right)$ un the ovary.

Epipetalous; un the petals.

Epiphytes; air plants.

Episperm; the skin of the seed.

Equilateral ; equal-sideci.

Equitant: two leaves, with their bases clusped one within the other, and their eicles fucing, $8 \mathrm{~s}$ in the Iris.

Erose ; margins scalloped irregularly.

Exustome; the opening of the outer coat of the seed.

Ex-erted; projecting beyond.

Exstipulate : without stipules.

Exirurse; lurised outward.

Frenla : starch.

Fulcare ; sythe-shaped, curved.

False dissepiment; 12.

Farinucents ; flonr-ike in texture.

Fariions ; mealy on the surface.

F ascicled; collected in a cluster.

Fustigiate; rising to the eame level.

Favose; honey-combed.

Ferruginous; iron-colored.

filamentose ; composed of, or bearing ihreads.

Filiform; thrend-like.

Fimbriate ; margin cut into a fringe.

Fistular: hollow like an onion leaf.

Flabelliform ; fan-shaped.

Flagelliform; whip-shaped, lon! and supple.

Flexuous; I ent outward and inward, zigzag.

Floccose ; bcaring tufts of deciduous hairs.

Foliaceous ; leaf-like.

Fuliolate; bearing leaflets.

- Frutex, or Frutescent ; woody, as Crape Myrtie, or Lilac.

Fuguceous ; soon disappcaring.

Fulvous ; tawny.

Funiculus; a little rope.
Furcate; forked.

1. urfuraceous ; scurfy.

fuscons ; gravish or blackish brown.

Fusiform ; spiud.e-raped.

Galca, Galeate; rescmbling a shicld.

Gamopetalous; petals unired.

Gamophylions; sepals united.

Geminate; by pairs.

Gemmation; stale of budding.

Geniculate ; bent, as the knce.

Gibbous ; puffed vut.

Glabrous ; smooth.

Gladiate; sword-shaped.

Glands: small knols or excrescences.

Glatucous; covered with minute whitish powcler.

Glomerate ; collected into close heads.

Glumaceous: bearing glumes.

Glumes ; scale-like bracts of Grasses and sedues.

Granular; covered with grains.

Gymnobase; a process of the torus, on and around which the carpels are surpended.

Gymıœcium; 2.

Gymnos (Greek prefix); naked.

Gymnospermous ; naked seeds, 22.

Gynopusre: a produced torus, bearine the ovary on its summit.

Gyrous; strongly bent to and fro.

Hahit; the general appearance of a piaut.

Habitat: natire sitnation of a plaut.

Hairy : furuished with hairs.

ilalveri; one half apparently deficient.

Ilastate or Halbert-shaped; dilated at the base into two spreading lobes.

Hearl-shaped; ovate, with a sinus at the base.

Iiermaphrodite; stamens and pistils both present.

Heterocephalous; heads of two sorts in the same plant, some staminate und some pistillate flowers.

Heterogamous; flowers of two sorts in the same head.

IXilum; 22.

Hirsute ; beset with coarse hairs.

Hispid : witb rigid hairs.

IIoary ; gruyish white.

Hyaline; thin and nearly transparent.

Hybrid; a cross between two species.

Hyperborean; inhabiting northern regions.

Hypocrateriform; salver-form.

Icosandrous ; more than ten stamens.

Incised; cut like a gash.

Included; inclosed within.

Incrassate; thickened.

Incumbent; leaniug upon, 40.

Induplicate; folded in ward.

Intlusium; the shield of the sorus of the fern.

Inferior ovary ; 15.

Inflated; as if blown nis.

Infra-axillary; below the axil. 
Infundibuliform; funnel-shaped.

Inserted, or insertion ; referring to the point of junction.

Integument ; a covering.

Introrse; turned inward.

Inverted; turned upside-down.

Involute; rolled inward.

Jagged ; irregularly notched.

Joints; rings at regular intervals along stems.

Jugum, a pair; bijugus, two pairs ; trijugne, three pairs.

Keel ; a sharp, longitudinal ridge on the back of an organ.

Kidney-shaped; wider than heartshaped.

Knot; swelling joint.

Labellum; the odd petal of the orchis. Labiate; lip-shaped.

Laciniate; slashed with deep incisions.

Lactescence ; milkiness.

Lacunous; with large depressions or pits.

Lacustrine; growing in lakes.

Lamellate; formed in thin plates.

Lanceolate ; lance-shaped.

Lanuginous; woolly.

Lenticulate; shaped like a double convex lens.

Ligulate; strap-shaped.

Linear; long and narrow.

Lobe; one of the parts of a divided body.

Loculicidal, 32.

Locusta; a spikelet of the Grasses.

Loment; a jointed legume.

Lunate; crescent-shaped.

Lyrate pinnatifid; with the upper lubes larger than the lower.

Macros (in Greek compounds); long or large.

Maculate; spotted.

Marcescent; withering.

Marginal; belonging to the border.

Marginate; having the border different.

Medulla ; pith.

Membranaceous; thin and pellucid.

Mericarp; one of the carpels of a cremocarp of an Umbellifer.

Micropyle, 19.

Moniliform ; bearing short joints, like a string of beads.

Monos (in Greek compounds); one only.

Mucro; a sharp, small, abrupt point.

Mucronate; tipped with a short, slender point.

Multifid; many cleft.

Muricate; beset with hard, wart-like pointe.

Muriform; like a wall of brickwork.

Muscology; a treatise on Mosses.

Muticous; pointless, not pointed.

Natant ; Rwimming nnder water.

Naturalized; growing spontaneously, but not native.
Navicular: boat-shaped.

Necklace-form; same as moniliform.

Nectary ; any honey-bearing part.

Nervation; arrangements of the nerves in the leaves.

Neutral; flowers without stamens and pistils.

Nodding; bent over.

Node; a joint of the stem.

Nodose ; knotty.

Normal ; ordinary structure.

Nuciform; nut-like.

Nucleus; kernel, 16.

$\mathrm{Ob}$; reversed.

Obcompressed; flattened back and front.

Oblanceolate; inversely heart-shaped.

Oblique; unequal-sided.

Obovate; egg-shaped, narrow end down. ward.

Obsolete; ohscure, or wanting.

Obtuse; blunt.

Ocroleucous; cream-color, pale yellow.

Octandrous; having eight sides.

Oligandria ; with few stamens.

Oligos (in Greek composition); few.

Olivaceous; olive - green, brownish green.

Olie-sided; borne on one side of the axis.

Opaque ; dull.

Opposite; placed directly against each other.

Orbicular; circular.

Orthotropal ; 24.

Oval; longer than broad.

Ovary ; 4.

Ovate : egg-shaped.

Ovoid; a solid with an oval outline.

Ovule; 5.

Palate; prominence at the throat of some bilabiate flowers.

Paleaceous; chaffy, having pales.

Palmate; hand-shaped.

Papillose; studded with minute wartlike prominences.

Pappns ; the limb of the calyx of a composite flower.

Parietal; the inner lining of the fruit; on the wall.

Parted; deeply divided into parts.

Partial; pertaining to the parts of a compound organ.

Pectinate; finely pinnatifid, combed.

Pedate; shaped like a bird's foot.

Pediceled; raised on a pedicel.

Peduncled; raised on a peduncle.

Peltate; fixed to the sialk at a point within the margin : shield-shaped.

Peri (Greek) ; around.

Peripheric; 38.

Perisperm ; same as albumen.

Petaloid; with the form or texture of . petals.

Pliyllotasy ; leaf-arrangements.

Pileus ; cap of some Fungals.

Pitted; with depressions.

Placenta; 8. 
Pollinia: the pollen masses of Milkweed.

Posterior ; next the axis.

Precocious; Howering before the leaves.

Primine ; 18.

Procumbent ; resting on the ground.

Produced; extending more than usual.

Proliferous; where clusters of flowers arike from another cluster.

Pruinous ; powdered, as if frosted.

Psendo (in Greek composition); spurious.

Puberulent; minntely downy.

Pubescent; downy with short hairs.

Pulverulent ; covered with fine powder.

Punctate; marked with minute dots.

Pungent; sharp-pointed, piercing.

Putamen; the bony nucleus of a drupe.

Pyramidal; form of a cone or pyramid.

Pyrifurm; pear-shaped.

Pyxis; a pericarp with a lid.

Quadri (in composition); four.

Quadrifoliate; four-leaved.

Quadrijugate; four pairs of leaflets.

Quinate; growing in fives.

Quincuncial; when the pieces are five in number, of which two are exterior.

Quinque (in compositiou); five.

Quintuple ; fivefold.

Race; a permanent variety.

Rachis: axis of the inflorescence.

Radiate; diverging from a conmon center.

Radiant; outer flowers enlarged.

Radical; near or belongiug to the ruot.

Ramial; of a branch.

Raphe ; 25.

Reiurved; bent (not rolled) backward.

Reflexed : curved backward.

Refructed; bent sucidenly, as if broken.

Regma ; fruit, as of Geranium.

Regular; of uniform shape and size.

Reniform; kidney-shaped.

Repand; wavy.

Repent; creeping.

Reruspinate; upside-down.

Retrorse; backward, downward.

Revolute; rolled backward.

Rhombic ; in the figure of a rhomb.

Rosirate ; beaked.

Rosulate; (leaves) arranged around the base of the stem.

Rotate; wheel-shaped.

Rubicund; rosy-red.

Rugous ; wrinkled.

Ruminated (albumen); full of chinks, as if composed of folds.

Runcinate; hooded backward.

Sacente: bag-like.

Sasittate ; airow-shaped.

Samara ; 22.

Scalorous; rongh.

Scalariform ; ladder-shaped.

Scales; rerluced leaves, or any small and thin appendages.

Scaly ; beset with scales.
Scarions; very thin and colorless.

Scorbiculate; pitted with little depres. sions.

Scurfy ; covered with minute scales.

Secund; one-sided.

Secundine : 17 .

Serrate; with the margin cut like a saiv.

Serrulate : finely serrate.

Sessile; not raised on a stalk.

Sheath; the base of a leaf when wrapped round the stem.

Semicordate; half of cordate.

Semilunar; halfmoon-shaped.

Septicidal ; 31.

Sericeous ; silky.

Setous; bearing bristles.

Sinuate; with the margins cut into rounded incisions which are separated by rounded lobes.

Specific; pertaining to the species.

Spiny; armed with spines.

Spur; an appendage of the calyx or corolla.

Squarrous ; spreading widely, as the scales of the Composites.

Stellate ; radiating from a common center.

Sterile; not fruitful.

Stipe; the stalk of the ovary, etc.

Strap-shaped ; flat, narrow, and straight. strict ; erect and very straight.

Strigous; with sharp, close, rigid hairs.

Strophiolate; having an appendago about the hilum.

Suberous: corky in texture.

Subulate; awl-shaped.

Succulent; very juicy and cellular.

Suffrutescent; woody at the base only.

Sulcate; furrowed.

Superaxillary ; situated above the axil.

Superior ovary ; 14.

Supra-decompound; very much divided. Syconus (fruit); as the Fig.

Syn (in Greek compounds); union.

Syncarpous; 10.

Tawny; fulvons, dull yellowish brown. Taxonomy ; science of classification.

Tegmen; the inner seed-coat.

Terete; cylindrical.

T'erminal; situated at the end of the apex.

Ternate; of three leaflets, three in a whorl

Tesselated; checkered, as a pavement.

Testa; the outer seed-coat.

Tetra (in Greek composition) ; four.

Tetragonal ; four corners.

Tetragynous ; four pistils.

Tetrumerous ; in parts of four.

Throat; the orifice of a tubular corolla.

Tomentose ; clothed with hair ; velvety.

Torose or Torulose; knotty, knobby.

Torus ; same as Receptacle.

Tricoccous (fiuit); with three onesoeded carpels.

Triald ; split halfway in to three parts.

Trifoliate; with three leaflets,

Trigynous; three-styled. 
Trilohed : three lobes.

Trimerous ; three-parted.

Tripartible; separable into tbree parts.

Triquetrons; three-angled.

Triternate; thrice ternate.

Tubercle ; a wart-like appendage.

Tuberous ; like a tuber.

Tubuiar ; shaped like a tube.

Tumid ; swelled, thickened.

Turbinate; a cone with point downward.

Turion; a young shoot.

I'wining; rising by coiling around a support.

Unmbilicate; with sharp depression at the end.

Enarmed; no stings, prickles, etc.

Uncinate; hooked at the end.

Endulate ; way.

Unguiculate ; clawed.

Uni (in compounds); one.

Unifoliate; with one leaf.

Uniform ; with one form.

Unilateral ; one-sided.

Unilocular; one-celled.

Univalved ; one valve.

Urceolate ; irn-shaped.

Utricular ; formed like a utricle.

Valves; the pieces of which a seed-ves. sel is composed.

Varicose ; irregularly swollen.

Ventral ; 6 .

Ventricous ; swelling ont on one side

Verrucous ; covered with warts.

Vertex ; the summit.

Vespertine; appearing in the erening.

Villous; clothed with long, weak hair.

Vimineous ; with long, flexible shoots.

Virgate: wand-like, long and slender.

Vitta, Vittæ ; minute oil-tubes in the fruit-coat of the Umbelliferæ.

Viviparous; seeds germinating on the plant.

Volva: membrane inclosing the young Fungus.

Waxy ; like beeswax.

Whorl; a circle of similar organs.

Winged ; furnished with wings.

Woolly ; clothed with long hairs. 


\section{INDEX TO PART II.}

WHEkE two or more pages are given, and onc is in heavy-faced figures, it indicates that at that place the subject is more lilly treated.

\begin{tabular}{|c|c|}
\hline & \\
\hline Abictenc:e. . & Amelanchier.......... \\
\hline 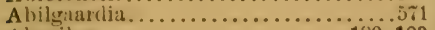 & American Centaury.. \\
\hline Abutilun .................. 180, 183 & Anuericun Cowslip.... \\
\hline Acacia, False.....................223 & American Ivy............... \\
\hline Acalypha.................. 480, 482 & Ammannia................. \\
\hline haces............. 131, 132, 400 & Amorplia............... \\
\hline Acanthus Family................ 400 & 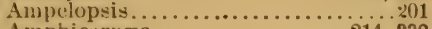 \\
\hline cer........................ & Amphicarpæa................. \\
\hline raceқ............129, 130, & 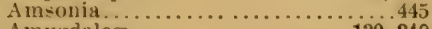 \\
\hline es......................... & 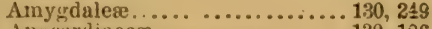 \\
\hline$\ldots \ldots \ldots \ldots \ldots$ & ex............. \\
\hline athea............... & s............... \\
\hline$n 1 \ldots \ldots \ldots \ldots \ldots \ldots$ & n............. \\
\hline$\ldots \ldots \ldots \ldots \ldots \ldots \ldots \ldots$ & $\ldots \ldots \ldots \ldots \ldots \ldots$ \\
\hline$n \rightarrow \ldots \ldots \ldots \ldots \ldots \ldots$ & .............. \\
\hline$\ldots \ldots \ldots \ldots \ldots \ldots \ldots$ & $\ldots \ldots \ldots \ldots$ \\
\hline$\ldots \ldots \ldots \ldots \ldots \ldots$ & exe...$\ldots \ldots$ \\
\hline is .............. 319 & $\ldots \ldots \ldots \ldots \ldots 1: 3$ \\
\hline $\operatorname{aum} \ldots \ldots \ldots \ldots \ldots$ & x $\ldots \ldots \ldots \ldots \ldots$ \\
\hline outh $\ldots \ldots \ldots \ldots \ldots$ & 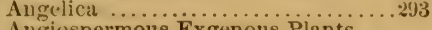 \\
\hline 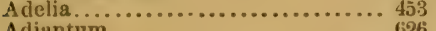 & Angiospermous Exgt \\
\hline .............. & \\
\hline$\ldots \ldots \ldots \ldots$ & \\
\hline mеæ........... & 8 \\
\hline$\ldots \ldots \ldots \ldots \ldots$ & n... \\
\hline ............... & 3 \\
\hline$\ldots \ldots \ldots \ldots$ & A \\
\hline .............. & .... \\
\hline$a \ldots \ldots \ldots \ldots$ & 5 \\
\hline$\cdots \ldots \ldots \ldots$ & A \\
\hline s............ 591, & 11. \\
\hline ( $\ldots \ldots \ldots \ldots \ldots$ & $11 .$. \\
\hline nn. & \\
\hline la $\ldots \ldots \ldots$. & 35 \\
\hline …........ & e... \\
\hline .53 & 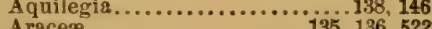 \\
\hline $\begin{array}{c}\cdots \ldots \ldots \ldots \\
\cdots \ldots \ldots \ldots\end{array}$ & $\begin{array}{l}\ldots \ldots \\
\ldots \ldots \\
\ldots\end{array}$ \\
\hline$\ldots \ldots \ldots \ldots \ldots \ldots 54,555$ & $\ldots \ldots \ldots \ldots \ldots \ldots, 131,301$ \\
\hline t & itæ $\ldots$ \\
\hline 591,5 & I \\
\hline ........ 139 & a.. \\
\hline$\ldots \ldots 173,176$ & Arc \\
\hline$\ldots \ldots \ldots 172$ & 176 \\
\hline$\ldots \ldots 134,463$ & .155 \\
\hline .464 & .522 \\
\hline h Family.... & $.591,598$ \\
\hline 4 & lochiaceæ.... \\
\hline acex & 320 \\
\hline Family.... & rhenatherum... \\
\hline & \\
\hline
\end{tabular}




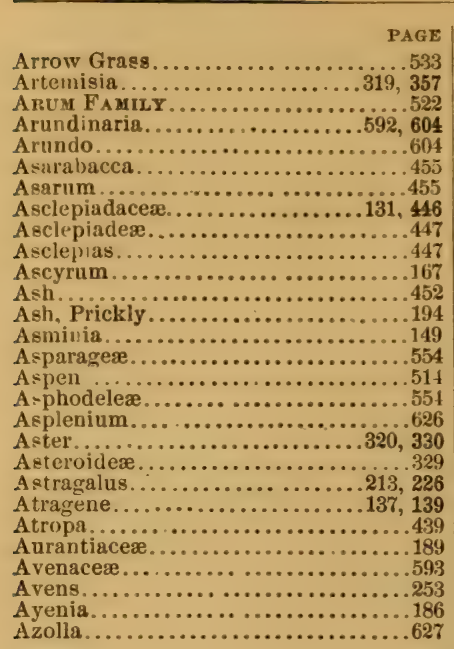

Baccharis 320,339

Bald winia............................321

Balm, Horse .....................411

Balsam Family..........................

Balsaminaceæ..................... 193

Balsam-Tree Family................169

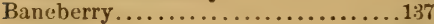

Baptisia....................214, 240

Barherry ...........................

Barherry Family....................151

Barley... .....................6. 610

Bartonia.....................441, 443

Basswood........................ 188

Batidaceæ....................129, 489

Batis..............................489

Batis Family .......................489

Bat-chis..........................422

Bayberry...........................511

B('an, Kidney........................236

Beak Rush.......................58t

Bear Grass........................ 557

Bedstraw............................ 310

Beech...........................508

Beech Drops ........................387

Beggar-Ticks....................... 352

Bell Flower.............................. 367

Benzoin....................473, 474

Berberidaceæ...............128, 129, 151

Berberis..........................151

Berchemia...............................

Rerlandiera ...................... 342

Betula.

Betnlacese.....................13:, 512

B1dens........................319, 321, 352

Bignonia..........................384, 385

Biqnoniaceæ...................132, 384

Bignonia Family......................384

Bignoniex....................... 384

Bigrelovia.......................3:8, 337

Birch........................ 512
PAGE

Birch Family.................. 512

Birthwort Family.................... 455

Bitter Cress.......................... 159

Bitter Nut . . . . . . . . . . . . . . 500

Black Jack.............................. 503

Bladderwort...............................

Bladderwort Family....................383

Blazing star.......................325

Blephilia...................... 408,415

Bluodwort Family.................... 545

Blueberry..................................

Blue Curls................................ 420

Bluets ...................................

Boehmeria.............................. 490

Boerhaavia.................... 456,457

Boltonia .......................320, 334

Bonnets .........................154

Borage Family.......................420

Borrageæ.......................4

Borraginaceæ....................132, 420

Borreria....................310, 312

Borrichia..............................

Brake..............................624

Bramble............................254

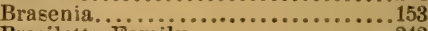

Brasiletto Family....................242

Brickellia.........................319, 327

Brier ...........................254

Brier, China......................550

Briza.........................6 $6 t^{\circ}$

Brizoprrum......................592, 605

Bromeliaces...................136, 545

Broom Grass...........................619

Broom-Kape Family................ 386

Bromus .......................... 593,608

Broussonetia ....................... 495

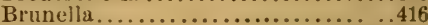

Buchnera........................389, 396

Buckleya ........................4

Buckeye .........................208

Buckthorn ........................203

Buckthorn, Carolina................204

Buckthorn Family.................202

Buckwheat Family.................. 466

Bugbane..........................137

Bulrush................................. 581

Bnmelia........................ 376

Bupleurum............................ 293

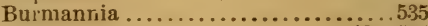

Burmanniacex....................186, 595

Burmannia Family................. $5: 5$

Bur Reed............................526

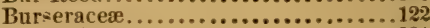

Bush Clover......................231

Buttercup........................... 143

Butternnt............................ 500

Button Bush.......................313

Button Suakeroot...........295, 296, 325

Butter Weed...................... 360

Byronia......................... 283,284

Byttneriacer......................129, 186

Byttneria Family.................. 186

Cabombacex.................12S, 153

Cacalia..........................319, 359

Cactaceæ........................131, 272

Cactus Family .................... 272

Cæsalpinieæ ...................215, 242

Calamintha.................. 408,412 


\begin{tabular}{|c|c|}
\hline PAGE & PAGE \\
\hline Calamus. & Chærophyllum . \\
\hline $.404,406$ & Chamæeps.... \\
\hline allirrhoē. & Chapmannia \\
\hline allitricha & Chaptalia... \\
\hline $.13 \mathrm{~s}, 145$ & Cheat..... \\
\hline alycanthacea. & Cheilanthus. \\
\hline alycocarpum. & ('helone... \\
\hline alyotegia.. & Chenopodiacex \\
\hline amelliacese... & Clienopodina. \\
\hline Camellia Family & Chenopodium \\
\hline Campanula...... & Cherry, Ground. \\
\hline Campanulaceæ: & Cherry, Jerusalen \\
\hline Campanula Fami & Cherry Laurel... \\
\hline Canavalia...... & Cherry, Plum.. \\
\hline Cane ....... & Chess ........ \\
\hline tanella.. & Clıestıut.. \\
\hline annabinaceæ. & Chestuut, Horse \\
\hline annaceæ....... & Crickweed..... \\
\hline Canna Family.. & Chicoracea. \\
\hline Cantua ......... & China Brier. \\
\hline Caper Family. & China Tree. \\
\hline Cappariciaceæ. & China, Wild. \\
\hline Capraria........ & Chinqnapin. \\
\hline Caprifoliaceæ.. & Chionanthus. \\
\hline 436,437 & Chloridex... \\
\hline Cardamine ...... & Chrysobalaneæ. \\
\hline Cardinal Flower. & Chrysobalanus. \\
\hline Cardiospermum. & Chrysogon \\
\hline Carex.... & Chrysopler \\
\hline Сariceæ & Chrysopsis \\
\hline Carolina Allspic & Cicuta.... \\
\hline arolina Buckth & Cimicifuga \\
\hline arphephorus.. & Cimicifuge \\
\hline Carpinus....... & C'inchoneæ. \\
\hline$\therefore 297$ & .....215, 242 \\
\hline . 498 & Cirsium.. \\
\hline $128,130,171$ & $8,129,161$ \\
\hline ...215, 244 & Cistus Family \\
\hline 501,507 & Cladastris.... \\
\hline 399 & $\ldots .572,586$ \\
\hline Oil Plaut & Claytonia. \\
\hline 384,385 & Clea \\
\hline tch Fly. & Clematideæ. \\
\hline .525 & 137,139 \\
\hline I Family & Cleo \\
\hline 527 & Clethra.. \\
\hline$\ldots \ldots 151$ & Clitoria. \\
\hline$. .202,203$ & Clover. \\
\hline$\ldots .51 \%$ & 231 \\
\hline $.408,415$ & Clusia. \\
\hline 130,204 & 169 \\
\hline .205 & $.480,486$ \\
\hline .464 & Cocculus. \\
\hline .134 & ebur. \\
\hline $.495,497$ & Cocl \\
\hline nchrus.... & $\ldots 319,324$ \\
\hline .319 & $\ldots 310$ \\
\hline American. & Colchicum Family \\
\hline 1,237 & nsonia........ \\
\hline, 313 & .202 \\
\hline era... & .146 \\
\hline 177 & $. .475,476$ \\
\hline $.4 \times 9$ & Commelyna. \\
\hline 3,477 & Commelynaces \\
\hline$\ldots \ldots 479$ & Compositæ. \\
\hline toschœuns......... & Composite Family.. \\
\hline .............273 & Comptonia.......... \\
\hline $\begin{array}{l}\text { Centunculus . . . . . . . . . . . } \\
\text { Cestrum. }\end{array}$ & $\begin{array}{l}\text { Conifere........... } \\
\text { Conioselinum..... }\end{array}$ \\
\hline
\end{tabular}




\begin{tabular}{|c|c|}
\hline PAGE & $P A G E$ \\
\hline onoclinium.. & Dalea... \\
\hline Dnopholis... & Dasystoma. \\
\hline onvolvulaceæ & Datura... \\
\hline onvolvulese... & Dancus... \\
\hline nvoivulus. & Day Flower \\
\hline onvolvulus Fan & Deer Grass. \\
\hline myza..... & Deer's Tong \\
\hline $\begin{array}{l}\text { prusmanthus } \\
\text { orsllorhiza... }\end{array}$ & Delphinum.. \\
\hline $\begin{array}{l}\text { orullorhiza... } \\
\text { oral Root.... }\end{array}$ & Desmanthus \\
\hline oral hoot.... & $\begin{array}{l}\text { Desmodum. } \\
\text { Diamorpha.. }\end{array}$ \\
\hline reopsis..... & Diapensiege. \\
\hline 134,302 & Dianthera.. \\
\hline rn-cuckle... & Dicerandra. \\
\hline rnel........ & 1)icliptera. \\
\hline ..303 & Dicotyledon \\
\hline$\ldots 157$ & Di \\
\hline urylus....... & Diodia ... \\
\hline osmos........ & Dioscurea .. \\
\hline tion $\ldots . . .$. & Dioscoreace \\
\hline otton Grass... & Diospyros.. \\
\hline of tonwood.... & 320,333 \\
\hline $\begin{array}{l}\text { owslip, A merican } \\
\text { ranc's Bill......... }\end{array}$ & eracin \\
\hline $.292,294$ & \\
\hline $30.292,294$ & $\begin{array}{l}\text { Discanthera. } \\
\text { Discoplenra. }\end{array}$ \\
\hline $\begin{array}{l}50,135,286 \\
\ldots .251,257\end{array}$ & Disphyll \\
\hline ss Family. & Ditch Gra \\
\hline $.542,543$ & Dock.. \\
\hline .553 & .434 \\
\hline ….385 & 80,381 \\
\hline $.212,215$ & 207 \\
\hline $.487,484$ & 444 \\
\hline 180,186 & \\
\hline Fan:ily. & $\mathrm{Fa}$ \\
\hline Family.. & 214,239 \\
\hline $129,130,157$ & 160 \\
\hline .157 & 416 \\
\hline$\ldots . .136,623$ & $52: 3$ \\
\hline ......292 & \\
\hline .....133, 283 & 129,165 \\
\hline$\ldots 2 / i 3$ & 480,488 \\
\hline .515 & d. \\
\hline & ckweed Fa \\
\hline$\ldots \ldots 150$ & ulichium ... \\
\hline $\begin{array}{l}\ldots .133,501 \\
\ldots \ldots .3251\end{array}$ & \\
\hline …2.2-2 & 375 \\
\hline 431434 & 375 \\
\hline (1) & 346 \\
\hline .149 & \\
\hline e Famil & 531,532 \\
\hline, 518 & \\
\hline y... & 345 \\
\hline & \\
\hline 600 & 437 \\
\hline. .421 , & 256 \\
\hline & \\
\hline$=7$ & 301,602 \\
\hline & 571,579 \\
\hline 572 & 323 \\
\hline .518 & t's Foo \\
\hline & \\
\hline 9,375 & Eim Family. \\
\hline & $\begin{array}{l}\text { Elodea........... } \\
\text { Elymus.......... }\end{array}$ \\
\hline & ia..... \\
\hline & dogetracere \\
\hline
\end{tabular}




\begin{tabular}{|c|c|}
\hline PAGE & $P A G_{i}$ \\
\hline lobium & Foxalove, $\mathrm{Fa}$ \\
\hline 386,387 & Fox Grape. \\
\hline Equisetacere & Foxtail Grass. \\
\hline $\begin{array}{l}\text { Eipuisetum . } \\
\text { E: } a=11-1 \text { is . . }\end{array}$ & $\begin{array}{l}\text { Fratraria...... } \\
\text { Franga!a .. }\end{array}$ \\
\hline Ereciliars. & Frasera..... \\
\hline rianthus. & Fraxinex..... \\
\hline , 132. 368 & $\begin{array}{l}\text { Fraxmus } \\
\text { French Mulberry }\end{array}$ \\
\hline 320,332 & Fringe Trce.... \\
\hline Eifocaulom. & Frcelicinia.... \\
\hline ijocanlonace & Frog's-Bit Far \\
\hline $\begin{array}{l}\text { Eriogunese ... } \\
\text { Erforonum .. }\end{array}$ & $\begin{array}{l}\text { Fuirena...... } \\
\text { Fumariaceæ }\end{array}$ \\
\hline Eriophorum..... & Fumitory Fami \\
\hline Ernodea........ & Gaillardia. \\
\hline Eroclium ... & Galacineæ... \\
\hline Eryngium. & Galactia...... \\
\hline Erythrina.. & Galax Family \\
\hline Escallonier ... & Galium....... \\
\hline Eschscinolizia & Gay Feather. \\
\hline $\begin{array}{l}\text { Euonymus....... } \\
\text { Eupatorium .... }\end{array}$ & $\begin{array}{l}\text { Gelsemium.. } \\
\text { Gentian. }\end{array}$ \\
\hline $\begin{array}{l}\text { Eupatoriam ... } \\
\text { Eupatoriacea... }\end{array}$ & Gentiana..... \\
\hline Enphorbia.... & Gentianaceæ. \\
\hline Euphorbiaces. & Gentis \\
\hline Eassmilacea . & Geraniacese . \\
\hline Eustachys. & Geran1um. \\
\hline Enstoma & Geranium Fami \\
\hline Eveniug Primr & Gerardia..... \\
\hline Evcrhating ... & Geum.... \\
\hline Evolvilus......... & Gilial.... \\
\hline $\begin{array}{l}\text { Excocaria } \\
\text { Exogenous pia }\end{array}$ & Gillenia \\
\hline Exogenous Plan & Giuseng Family \\
\hline 508 & Glottidium \\
\hline .223 & Glyceria.. \\
\hline False Foxglove. & Graphalium. \\
\hline e Mitrew & Goat's Rue. \\
\hline False Nettle.. & Golden Rod. \\
\hline False Rice... & Gomphre \\
\hline False Rue....... & Goos \\
\hline Fedia........... & Goodenia Family \\
\hline $\begin{array}{l}\text { Fern Family... } \\
\text { Fest uca........ }\end{array}$ & Gouseberry. \\
\hline $\begin{array}{l}\text { Festuca........ } \\
\text { Festucacese... }\end{array}$ & $\begin{array}{l}G(x)=e f o o t . . . . \\
\text { G(nosefoot Family }\end{array}$ \\
\hline Feverwort.... & Gossypium \\
\hline Ficus........ & Gourd Family.. \\
\hline 495 & Graminex. \\
\hline 390 & Grape Fumily.. \\
\hline rt Fitmily & Grape Vine.... \\
\hline $6: 4$ & Grass, \\
\hline Fimbristylis.. & Grass, Beard. . \\
\hline Fireweed. & Grass, Beut. \\
\hline Flag, Blue.. & Grass, Be \\
\hline …..... 31821 & Gruss, Bluc-eyed.. \\
\hline $\begin{array}{l}\ldots .318,: 320 \\
\ldots . . . .159\end{array}$ & Grass, Brome \\
\hline $\begin{array}{l}\text { Flax Family.... } \\
\text { Flax, Perenniai. }\end{array}$ & $\begin{array}{l}\text { Grass, Broom... } \\
\text { Grass, Cotton. }\end{array}$ \\
\hline Flax, Wild. & Grass, Crab. \\
\hline .332 & Gra-s, Crowfoot. \\
\hline Flower de Luce & Grase, Deer \\
\hline 27,137 & Gra-s. Dropseed \\
\hline $\begin{array}{l}\text { lerlens Plants. } \\
\text { stiera. }\end{array}$ & Grass Family.. \\
\hline estiera ...... & Grass, Feather. \\
\hline & Gra-s, Fescue. \\
\hline our-o'clock Fami & 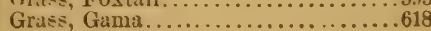 \\
\hline
\end{tabular}




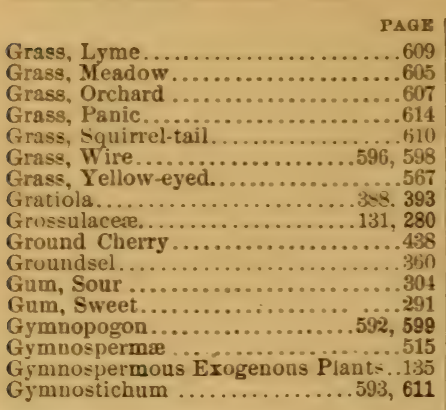

Hæmodoraceæ....................5 545

Halesia.............................

Haloragea . . . . . . . . . . . . . . . . 134

Hamamelacex.........131, 133, 134, 290

Ham:amelis.......................291

Hazel Nut.............................509

H:ızel, Witch.....................291

Hazel, Witch, Family................290

Haw ......................273, 309

Hawthorn........................25

Heart's Ease.......................163

Heath Family.................... 368

Hedeoma ....................... 41 2

Hedge Hyssop......................393

Hedqe Mislard ...................... 160

Hedge Nettle...................419

Hedioti $=\ldots \ldots \ldots \ldots \ldots \ldots \ldots \ldots \ldots \ldots . .314$

Hedysareæ ......................213

Hedysarum ..........................232

Helenium......................320, 354

Helianthella.......................321

Helianthemum..................164

Helianthus.................319, 321, 348

Heliopsis......................320, 346

Helleborinex.............................

Helosciadium.......................293

Hemicarpha .................57

Hemlock, Water...................297

Hemp Family................... 493

Hemp, Indian..................... 445

Hepatica....................137, 142

Heracleum ...........................293

Heron's Bill....................... 192

Herpestis...................398. 392, 395

Heterotheca..................320, 337

Hibiscer........................... 180

Hibiseus.................... 180, 185

Hickory.......................... 498

Hiera

Hofimanseggia...................... 242

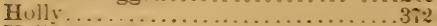

Holly Family .......................

Honey Lomist . . . . . . . . . . . . . . . . . 2 2

Honeysuckle $\ldots \ldots \ldots \ldots \ldots \ldots \ldots \ldots \ldots . . .6 \ldots$

Honeysuckle Family................306

IInopesia ....................215, 24j

Hop ...........................493

Hop Horubeam..................... 510

Hop Tree..............................195

Hop Vine........................194

Hordeacex ..........................593

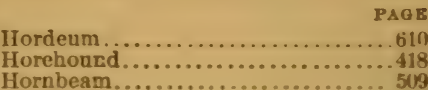

Horned Rush................... 585

Hornwort......................... tix

Hornwort Family ...............477

Horse Balm ......................... 411

Horse Chestnut ................... zus

Horse Mint ...................... 410,414

Horsetail Family.................ti2:3

Hosackia ..........................212

Hottonia ..........................

Hound's Tongue..........................424

Houston ......................... 262

Houstonia...................................

Huckieberry ............................. 369

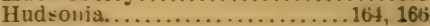

Humulus.............................. 493

Hydrangea.................2si, 289

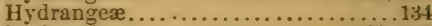

Hydrastis ..................138, 147

Hydrocaridaceæ...............135, 534

Hydrochlos....................591

Hydrocotyle ...............292, 283, 294

Hydroles......................427

Hydroleacer .....................132, 427

Hydrolea Family .................. 427

Hydrophyllacex................ 132, 424

Hydrophyllnm ....................425

Hydropterides.................136, 627

Hymenopappus................ 319, 353

Вуреricaceæ...........12\%, $128,129,167$

Hypericum .................... 16\%, 168

Hypobrychia ...................262

Hypoxys.................... 542,544

Hyptis.....................4 408,409

Hyssop................................

Ilex............................. $3 \tau_{2}$

Illicebraceæ................ 129, 134,172

Illicum.......................... 148

Ilysanthes ...................388, 394

Impatiens...................... 193

Indian Hemp........................445

Indian Mallow...................... 183

Indian Pipe...........................

Indian-Pipe Family ...............369

Indian Turnip.......................5 522

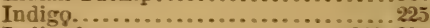

Indigofera .............................. 213,225

Inula........................... 320

Ipomea............................. 581

Iridacere ........................136. 546

Iris. .......................... 547

Iris Family.........................

Irónweed........................... 322

Isantlus ........................ 409,419

Isoetes......................627

Isolepis............................ 5i1. 581

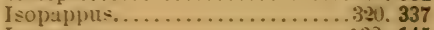

Isopyrum ....................... 139. 145

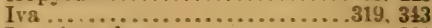

Ivv American...........................

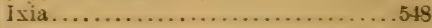

Jamestown Weed.................44n

Jatropha...............................486

Jersey Tea.......................... 0.3

Jerusalem Cherry...................437 


\begin{tabular}{|c|c|}
\hline PAQE & PAGE \\
\hline $.316,440$ & 404,405 \\
\hline ewel wred & Licquidamber \\
\hline Juglandacex. & Ligulifloræ. \\
\hline Juglana ...... & Ligusticum. \\
\hline Juncacer. & Listeria... \\
\hline Incaginex & Lithospermum. \\
\hline $.55 G, \approx 50$ & Liver-leaf .... \\
\hline Juniper . & Lizard's Tail. \\
\hline Juniperus. & Lizard's-Tail Fam \\
\hline Jussiæa . & Loasacer........ \\
\hline Justicia. & Loasa Family. \\
\hline Kidney Bean & $\begin{array}{l}\text { Lobelin........ } \\
\text { Lobelia Famil }\end{array}$ \\
\hline Knotweed... & Lobeliaceæ..... \\
\hline Kosteletzkya & Loblolly....... \\
\hline Firameria ... & Locust... \\
\hline Krameriaceæ & Locust, Honey.. \\
\hline Krigia ........ & Loganiex...... \\
\hline Kutinia.. & Lonicera.. \\
\hline $.571,576,578$ & Loosestrife. \\
\hline & Loosestrife Fam \\
\hline $\begin{array}{l}\text { Labiatæ...... } \\
\text { Labiatifloræ. }\end{array}$ & Lopseed......... \\
\hline $\begin{array}{l}\ldots . . .321,361 \\
\ldots . .568,570\end{array}$ & Loranthaceæ. . \\
\hline Lachnocaulon & Loteæ...... \\
\hline Lactuca....... & Ludwigia. \\
\hline $\begin{array}{l}\text { Lamb Lettuce } \\
\text { Lantana }\end{array}$ & Lupine .. \\
\hline$\ldots \ldots .404,406$ & Lupinus... \\
\hline Lappa.... & Luzula .... \\
\hline Larkspur. & Lycopersicum \\
\hline Lathyrus.. & Lycopodiaceæ. \\
\hline Lauraceæ. & Lycopus...... \\
\hline Laurel, Cherr & Lygodesmir. \\
\hline Laurel Family & Lysimachia... \\
\hline Laurineæ. & Lythraceæ... \\
\hline Laurus....... & Ly thrum.... \\
\hline Leadwort Fa: & \\
\hline Leatherwood. & Macbridea. \\
\hline Lechea. . & Macranthera.... \\
\hline $.591,594$ & Madder Family. \\
\hline $.128,129,130,211$ & Magnolia....... \\
\hline Leitneria. & $.127,147$ \\
\hline Lemna & Magnolia Family. \\
\hline 5,524 & Magnolieæ....... \\
\hline Lentibulaceæ & Maiden \\
\hline .418 & Malaxideæ.. \\
\hline 348 & Mallow.. \\
\hline Jepidium. & Mallow Family. \\
\hline .563 & $.179,180$ \\
\hline Leptocanlis. & Malvaceæ. \\
\hline Leptochloa.. & Malvastrum. \\
\hline Leptopoda. & Malver.. \\
\hline Lespedeza.. & Mammilaria. \\
\hline Lettuce..... & Manisuris......... \\
\hline Lam & Maple. \\
\hline themum. & Maple Family...... \\
\hline $.319,324,325$ & Mariscus .......... \\
\hline .....136, 554 & Marrubium... \\
\hline Lily Family. & Marshallia \\
\hline Ogeech & Marsh Marigold.... \\
\hline Limnanthemum. & Marsh Pennywort...... \\
\hline Limnobium & Marsh Rosemary...... \\
\hline Linacere & Martynia. \\
\hline 385,391 & $.321,356$ \\
\hline Linden... & Maxallis. \\
\hline Linden Family. & Mayaca. \\
\hline Linum. & Mayacaceæ... \\
\hline Liparis & Mayaca Family \\
\hline Lipocarpha... & May Pop. \\
\hline Lipocarphere .....................571 & May Weed.............................. 356 \\
\hline
\end{tabular}




\begin{tabular}{|c|c|}
\hline$\triangle \mathrm{GE}$ & PAGE \\
\hline ow $\mathrm{I}$ & ulgedinm \\
\hline & .389 \\
\hline 50,552 & $\therefore 01$ \\
\hline $.212,216$ & \\
\hline $.136,558$ & Yyosotis.. \\
\hline & .136 .143 \\
\hline & Myrerostylis \\
\hline 130,260 & ly rica. \\
\hline & .133 .510 \\
\hline$\therefore 159$ & Myriophyllum \\
\hline $.592,603$ & 37 \\
\hline otus & Iyrsine Fam \\
\hline $.1<7$ & Iyriacex.. \\
\hline $\begin{array}{l}\text { (uispermacea... } \\
\text { (-ui-jermum.... }\end{array}$ & Misrtie Family \\
\hline . 4us. 409 & $321,3 \notin 2$ \\
\hline .25 & aiadacere \\
\hline 421,423 & faias........ \\
\hline …. 155 & a-turtium. \\
\hline .....4i4 & esrundo .... \\
\hline $.3 \times, 395$ & 127,153 \\
\hline 319,328 & $\ldots \ldots 153$ \\
\hline$\ldots 2 \div 6$ & $54 \div, 34 S$ \\
\hline .447 & phila. \\
\hline Fami & .537 \\
\hline & \\
\hline .209 & .215 \\
\hline $.22:$ & \\
\hline $.215,246$ & $\mathrm{~F}=$ \\
\hline Fanily & .90 \\
\hline 215,246 & 419 \\
\hline $.388,392$ & e Tre \\
\hline & Neviusia... \\
\hline .407 & 451,459 \\
\hline 410,4 & \\
\hline$\ldots 4$ & \\
\hline 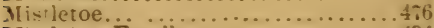 & $4: 3$ \\
\hline Famil & \\
\hline .310 .313 & $5=6$ \\
\hline & 134,45 \\
\hline .31 & \\
\hline $.208,315$ & hreaceæ \\
\hline wort, False & Xy=sa.......... \\
\hline$\cdots . .252$ & \\
\hline ....181, 1 & \\
\hline & 196,197 \\
\hline$\therefore 59$ & \\
\hline 408,414 & $441, \pm 44$ \\
\hline & .407 \\
\hline .3. & hera \\
\hline & \\
\hline Plan & nlanoiit. \\
\hline$t \leqslant .13$ & \\
\hline$\ldots$ & $13 \div 450$ \\
\hline & leinete. \\
\hline & \\
\hline $\mathrm{Fam}$ & Family. \\
\hline$\ldots 133,134,494$ & $130,1: 4$ \\
\hline Giory & \\
\hline .494 & nodium \\
\hline .545 & \\
\hline .801 & \\
\hline & Family \\
\hline & e, Mock \\
\hline lenthe!gia. & Orchidacez. \\
\hline & \\
\hline 4 & Uic in: \\
\hline & Urobanche... \\
\hline
\end{tabular}




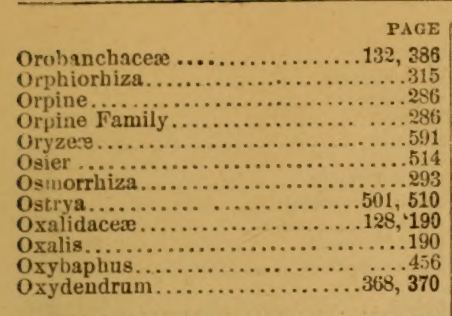

Pachysandra .... ..........480, 487

Prepalanthus...................5is', 569

Palafoxia........................ 319,353

Yalmæe...........................

Palmetto..................... 520, 521

Palm Family.................... 5:0

Pancratium.......................5 542

Paniceæ..........................593

Panicum ...................... 594, 614

Papqveraceæ.................128, 155

Papaw............................ 149

Papilionaceæ....................2!

Parietaria.......................490, 492

Parnassia Family..................166

Parnassiacea.........................166

Paronychia...................172, 173

Parsley Family.......................292

Parthenium.............................. 343

Paspalum........................593, 612

Passiflora............................

Passifloraceæ...............130, 134, 282

Passion Flower....................2 3

Passion-Flower Family.............2s2

Pavonia........................180, 134

Peach .......................252

Pear .............................. .259

Pear, Prickly..................277

Pecan Nut............................ 499

Pectis ............................320

Pedicularis .......................359, 400

Pelargonium.......................192

Pellæa...............................625

Pellitory ........................492

Peltandra.....................522, 523

Penny wort. . . . . . . . . . . . . . . . . . 293

Penthorum...........................286

Pentstemon ......................338, 390

Pepper Grass . ...........................161

Pepuer, Red.....................437

Persea ........................472

Persimmon........................375

Petalostemon................212.220

Petiverieæ.....................134, 158

Pernnia.........................440

Phacelia..........................425, 126

Phænogamous Plants.........127, 137

Phalarideæ.......................... 598

Phalaris...................598, 612

Pla rbitis ...........................431, 432

Phaseolus ...................214, 236

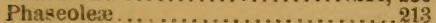

Philadelphus.................287, 290

Phleum.............................. 597

Pblox............................428

Phoradendron ......................476

Phryma.
PAGE

Phryme:e ......................132

Phyllanthus.....................480, 487

Physalis....................... 436, 438

Phytolacca..................458, 459

Phytolaccacea'....................135, 458

Pickerel Weed....................5.5

Pickerel-Weed Family................562

Pignut ......................498, 499

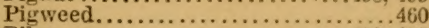

Pilea....................... 490,402

Pimpernel........................... 382

Pine...........................510

Piuc-Apple Family ...................545

Pine Family......................515

Pink Family.............................

Pinguicula......................... 384

Pirus......................... 515, 516

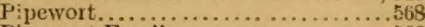

Pipewort Family..................... 568

Piscidia .............................

Pistia...........................522, 523

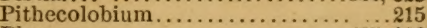

Planera ... ..................... 495, 496

Planer Tree......................496

Plane Tree..................... 498

Plane-Tree Family.................497

Plantaginaceæ.............131, 132, 378

Plantago...........................

Plantain ....................... 378

Plantain Family .........................

Piantain, Water..................5:39

Platanacex.......................13:, 497

Platanus.........................498

Piuchea........................... 319,340

Plum........................251

Plumbauinaceæ..............129, 131, 3 i

Plum-Cherry....................251

Poa..........592, 602, 604, 600, 606, 607

Podophyllum.....................151

Podostemaceæ.................133, 478

Podostemon ........................ 479

Podostigma........................ 450

Poison Oak.........................196, 197

Pokeweed..........................459

Pokeweed Family..................... 458

Polanisia......................... 1ti2

Polemoniaceæ....................... $132, \leq 28$

Polemonieæ....................... 428

Polemonium.......................... $4: 8$

Polemonium Family............... 428

Polycarpon....................172, 175

Polygalaceæ ..................128, 129, 209

Polygalia.........................2013

Polygonaceæ.......................... $131, \leq 66$

Polygoner........................ 455

Polygonella......................46, $46 \mathrm{~s}$

Polygonum.....................465

Polymnia...............................

Polypetalous Exogenous Plants..127, 137

Polypodium........................624

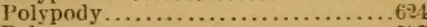

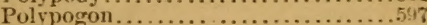

Polypremum ................... 310,316

Polytrenia ................................301

Pomeæ......................... 181 , 251

Pond Lily ...............................154

Pondweed ..........................529

Pondweed Family........................

Pontedaria......................... 563 


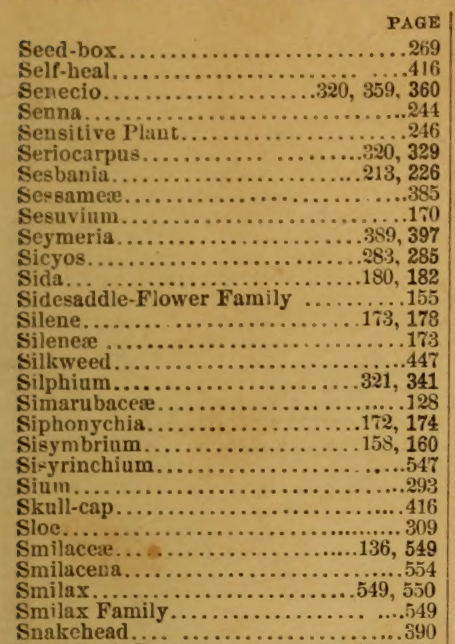

Snakeroot, Button..............295, 296, 325

Snowberry........................306

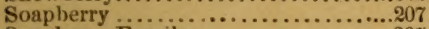

Soapberry Family...................207

Soapwort............................... 178

Solanacere....................132, 435

Solanum ............................ 436

Solidago..................318, 320, 334

Soliva........................................

Solomon's Seal....................554

Sonchus............................. 321,364

Sophora.......................214, 242

Sophoreæ..........................214, 242

Sorghum.................... 594, 621

Sorrel................................ 190

Sorrel Tree.............................

Sour Gum.............................. 304

Sour Wood..........................

Spauish Bayonet.......................

Sparganium ..........................

Spatter Dock.........................

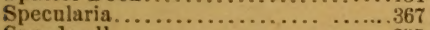

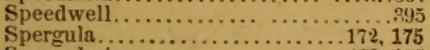

Spergularia .................. 172, 175

Spermacoce ........................310, 311

Spice Bush ............................. 474

Spider Flower.......................

Spiderwort............................

spiderwort Family.................564

Spikenard...............................

Spike Rush............................

Spilanthus .......................... $3_{20}$

Spindle Tree.........................205

Spiræa.......................250.252

Spiranthes..........................

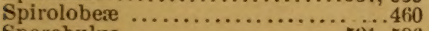

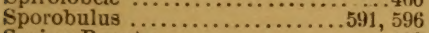

Spring Beauty .......................

Spurge..............................

Spurge Family................ 479

Spurrey ........................... 175

Squaw Root ......................... 387

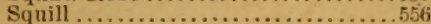

Stachydeæ......................... 408

Stachys .......................409, 119

Staft 'Tree ......................205

Staff-Tree Family $\ldots \ldots \ldots \ldots \ldots \ldots \ldots \ldots . .204$

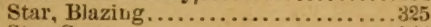

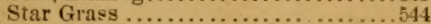

Starwort............................ 177, 330

Statice. ................................... 35

Stellaria ................................ 177

Stenotaphrum ..................... 594,617

Stillingia $\ldots \ldots \ldots \ldots \ldots \ldots \ldots \ldots \ldots, 479,482$

Stipa .......................... 591,588

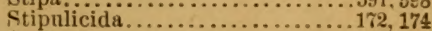

Stokesia............................ 319

Stone-Crop...........................28

Storax Family .................

Stork's Bill............................. 192

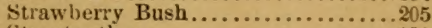

Streptanthus............................... 161

Stylisma.....................431, 433

Stylosanthes............................ 213,280

Styracaceæ...............131, 133, 373

Sugar Maple ..........................

Sumach........................ 196, 197

Sumach Family ........................ 196

Summer Grape...................20

Sundew ............................. 16 i

Sundew Family .....................

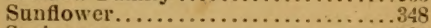

Surianaceæ....................... $: 85$

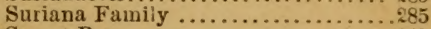

Sweet Bay ........................... 148

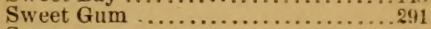

Sycamore .................................. 498

Symplocos ........................... 774

Symphoricarpus........................

Syringa $\ldots \ldots \ldots \ldots \ldots \ldots \ldots \ldots \ldots \ldots \ldots \ldots \ldots \ldots \ldots$

Talinum..................... 17\%, 171

Tanacetum .......................... 319,35

Tansy .......................... 357

Tape Grass . . . . . . . . . . . . . . . 534

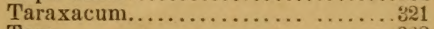

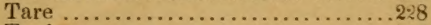

Taxineæ............................. 516

Taxodium ........................ 516,518

Taxus.......................... 516

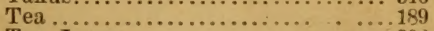

Tea, Jersey...............................

Tecom $九 \ldots \ldots \ldots \ldots \ldots \ldots \ldots \ldots \ldots \ldots \ldots \ldots \ldots \ldots \ldots \ldots \ldots, 385$

Tephrosia..........................213, 224

Tetragonotheca...................... 320

Tetran thera ......................47. 474

Thalia .............................

Thalictrum........................ 137,142

Thaspium......................293, 299

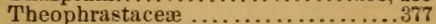

Theophrasta Family ................. 37

Thermopsis ............................214

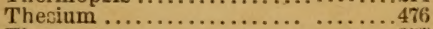

Thorn.............................. 257

Thorn Apple ................... 440

Thoroughwort.................... 327

Thuja $\ldots \ldots \ldots \ldots \ldots \ldots \ldots \ldots \ldots \ldots \ldots \ldots \ldots \ldots \ldots, 518$

Thymelaceæ.................. 134, $47 \AA$ 
PAGE
PA

Tiarella.

287,288

Tickseed.

Tiedemannia

This

tiliacex ............................... 187

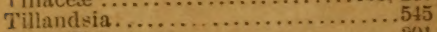

Toad Flax ........................... 391

Tobacco .......................... 440

'T'ofieldia. ... .....................

Tomato ............................. $44^{4}$

Toothache Tree .....................

Torreya .......................... 516

Touch-mc-pot....................

Tradescantia ................... 565

T'ragia .....................480, 483

Trautvetteria......................... 1372

Trichelostylis .................. 571 , 583

Trichostema................409, 420

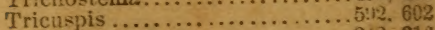

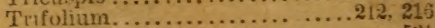

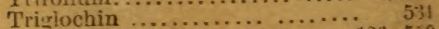

Trilliacese ....................

Trilitum .............................. 552

Trillium Fainily................ 5 ,

Triosteum..................... 306, 308

Tripsacum...................... 594,818

Trisetum ..................... 593. 611

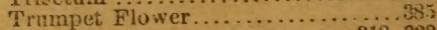

Tubntiflorie..................... 318,32

Turneracese : Turnera Family...... 282

Turuip, Indian ... ........ . . 5:2

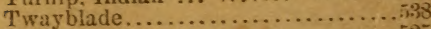

Typha. ......................... 525

Typhaceæ...........................

Ulmacer

$131,135,495$

Uimus

495,495

Umbelliferse

$130,29 ?$

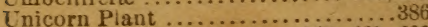

Univla ..................,93, 605, 603

Urenere ..............................

Urtica.

Urticacex

Uiricularia.

134,490

Vrccinieæ.

133,368

Vaccinium

368,369

Valerian

Valeriana.

.317

Valerianacere

Valerian Fainily ........................ 317

Vallisneria

Yerbascum

Verbena

Verbenacca

Verbener.

Verbesina

Vernonia

Vernoniacere.

Veronica.

Vervain.

Vervain Family...................... 403

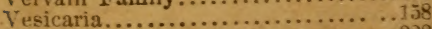

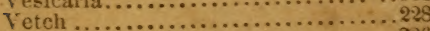

Vetch, iilik.......................2

Viburnum ......................... 306

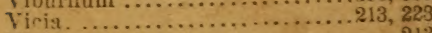

Ticice

$21:$

Vigna...

214,236
PAGE

Violacere ................... 129, 163

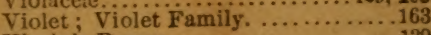

Virgin's Bower......................... 139

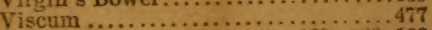

Vitacere................................ 120,188

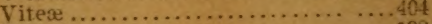

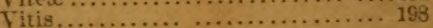

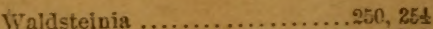

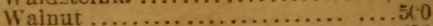

Walnut Family....................... 498

Waltheria. ......................... 187

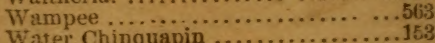

Water Chinquapin .................. 153
Water Cress $\ldots \ldots \ldots \ldots \ldots \ldots \ldots \ldots \ldots$
158

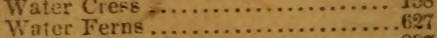

Water Hemlock......................207

Waterleai ..........................425

Waterleaf Family. ................... 424

W ater Lily .............................

Water-Lily Family.....................

Water Millfoil ........................

Water Plantain........................

Water.Plnntris: Family.............. 531

Water-Shield...................15:

Water-Shield Framily ................. 15:

Wax Myrtle... $\ldots \ldots \ldots \ldots \ldots \ldots \ldots \ldots \ldots \ldots \ldots \ldots \ldots$

Wax-Myrtle Fanily................. 510

Whahoo .........................496

Whitlow Grass.....................

Wild China........................ 208

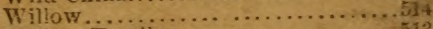

Willow Family......................

Willow Herb.......................

Wind Flower........................

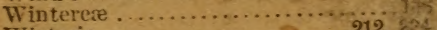

Wistaria ..................212, 6s

Witch Eazel.......................

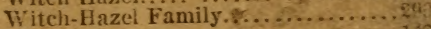

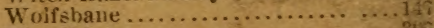

Woodbilie.......................

Wood Rush .................... ty

Wood Sorrel ......................

Wood-Sorrel Family...................

Wormseed.........................

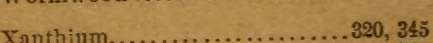

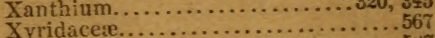

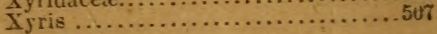

Yam .......................... 549

Yam Family........................ 548

Yarrow ............................ 356

Yaupon ..........................

Yellow-eyed Grass Family ............56i

Yellow Root.................... 147

Yellow Water-Lily ................

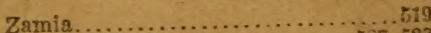

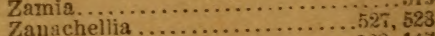

Zanthorhiza........................ 128,14

Zanthoxylum ......................... 194

Zinnia............................ 340

Zizania .............................. 595

Zizia............................ 2913

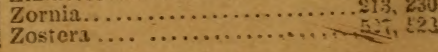

